The Anciversity of Thoronto Chemical Sibrany

Presented to

The Aniversity of Tovonto Silvary

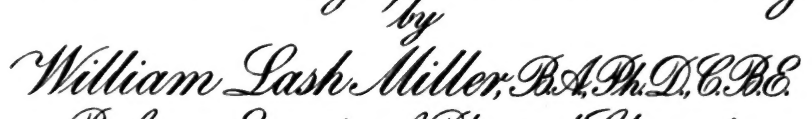
Professon Omeritus of Physical Chomistry fore

A Departmontal Libramy to be under the controb of the Professors Chemistry accos ding to the conditions setout in aletter from the Librarian of the Olniversity dated March 21." 1938. 
.

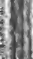

3)

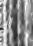



Digitized by the Internet Archive in 2007 with funding from Microsoft Corporation 


\section{THE BRITISH SCIENCE GUILD}

FOUNDED IN 1905 BY THE LATE

Sir NORMAN LOCKYER, K.C.B., F.R.S.

\section{President:}

The Rt. Hon. Lond Montagu of Bfaulieu, K.c.I.e., C.s .i ., v .D ., D .L .

Past Presidents :

The Rt. Hon. Viscount Haldane, K.T., o.m., P.c., F.R.s., 1905-1913.

The Rt. Hon. Sir William Mather, P.c., LI..D., 1913-1917.

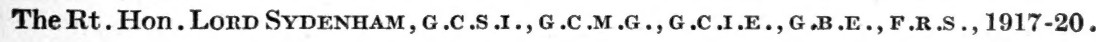

Trustees :

The Rt. Hon. Lorn Avebury .

The Rt. Hon. Lord BLyTH .

Sir Charles Macara, bart. Mr. Robert Mond.

Vice-Chairmen of Committees :

Sir Hugh Bell, bart , c.b. The Hon. Sir John Cockburn, K.c.m.g .

Sir Richard Gregory.

Hon. Treasurer: The Rt. Hon. Lord Avebury .

Hon. Assistant Treasurer: LADY Lockyer.

Hon. Legal Advisers :

Messrs. Ashurst, Morris, Crisp \& Co.

Hon. Secretary :

Lt.Col. W.A.J. O'Meara, c.M.g., late R.E.(Vice-President).

Secretary: Miss A. D. L. LACEY.

\section{Executive Committee.}

The President .

The Vice-Chairmen of Committees .

The Hon. Treasurer.

The Hon. Assistant Treasurer.

The Hon. Secretary.

The Rt. Hon. Lord Bledisloe, K.B.E. (Vice-President) .

Sir William H. Bragg, K.B.e.,F.r.s .

Sir Robert Waley Cohen, K.B.e.

Sir Robert HadField, Bart ., F.r.s .

Sir Lynden Macassey, K.B.e., K.c.

Sir Philit Magnus, Bart., m.P.

Mr. Robert Mond.

Sir Arthur W. Mayo-Robson, K.B.e. C.B., C.v.o., D.SC .
Professor C. S. Myers, F.r.S.

Sir Arthur Newsholme, K.c.B .

The Rt. Hon. Sir Gilbert Parker, BART., P.C. (Vice-President).

Mr.J.J. Robrnson (Managing Editor of the Journal of the Guild).

Col. Sir Ronald Ross, K.c.в., K.C.M.G., F.R.S .

Lady Shaw .

DR. D. Sommerville.

Mr. Carmichael Thomas.

Dr. Ethel N. Thomas.

Dr. R. M. WALMSLey .

Mrs. Carrington Wilde.

Col. Sir John S. Young, c.v .o.

Offices:

6, JOHN ST ., ADELPHI, LONDON, W.C.2 .

Telephone: Regent 5089. 


\section{Aims and Objects of the Guild.}

T

He British Schence Gurld is not a scientific society, an institute of industry, or an educational association, but a national organisation in which the interests of science, industry and education are represented. and their activities co-ordinated for the common good. No technical qualifications are required for membership; and the rate of subscription cannot prevent anyone from joining the Guild, and thus giving practical support to its work.

Though the Guild has been in existence since 1905, the objects for which it was founded have only recently been recognis $d$ as essential points of a national programme. As stated in 1905, they are as follows:

(1) To bring together as members of the Guild all those throughout the Empire interested in science and scientific method, in order, by joint action, to convince the people, by means of publications and meetings, of the necessity of applying the methods of science to all branches of human endeavour, and thus to further the progress and increase the welfare of the Empire.

(2) To bring before the Government the scientific aspects of all matters affecting the national welfare.

(3) To promote and extend the application of scientific principles to industrial and general purposes.

(4) To promote scientific education by encouraging the support of universities and other institutions where the bounds of science are extended, or whəre new applications of science are devised.

The attention lately given to science and industry in relation to the State shows that these objects are at last being accepted, and that widespread sympathy exists with the aims of the Guild.

In order to take advantage of this new attitude, in the interests of national welfare, the Guild should be represented in all parts of the Empire by members who will bring its aims before the public by individual efforts, or through local committees combining the activities of science, industry and education.

\section{Outline of Activities.}

The Guild, soon after its formation, constituted Committees to enquire into various matters which were at that date (1905) held to be of importance; it has since then, from time to time, constituted additional Committees to deal with new subjects and questions as these have come into prominence. 
These Committees, on which many distinguished representatives of industry as well as of science and education have served, have investigated, inter alia, the following matters:-

Awards for Medical Discovery.

Agricultural Research in the United Kingdom.

The British Chemical Industries .

The British Dye Industry .

The Conservation of Natural Sources of Energy .

The Co-ordination of Charitable Effort.

The Design and Manufacture of Microscopes.

Explosives.

Fisheries Development.

The Introduction of the Metric System.

Medical Research, and many other Medical Questions.

The Patent Law (Proposed Amendments).

The Prevention of the Pollution of Rivers.

The Provision of Glass and other Laboratory Ware.

Technical Optics, and the Manufacture of Optical Instruments.

The Synchronisation of Clocks.

Veterinary Research.

The Utilisation of Science in Public Departments .

Many very valuable reports have been prepared by these Committees and placed in the hands of Ministers in charge of the Government Departments particularly concerned with the matters and questions dealt with in them.

Recommendations contained in the Reports of the Committees of the Guild have also been widely acted upon outside Government Departments, and there is evidence that the value of the work which the Guild has done, and is doing, is becoming more widely appreciated as time proceeds. However, in order that the Guild shall carry, in connection with the work it has taken up, full weight in responsible quarters, and that its activities may be rendered more effective, an increase in its membership is essential.

In 1918 and 1919 the Guild organised highly successful Exhibitions of British Scientific Products, which were of much assistance in promoting the interests of British science and industry at a critical period.

Applications for Membership should be made to the Secretary, British Science Guild, 6, John St.,Adelphi,London, W.C.2. The rates of subscription are:

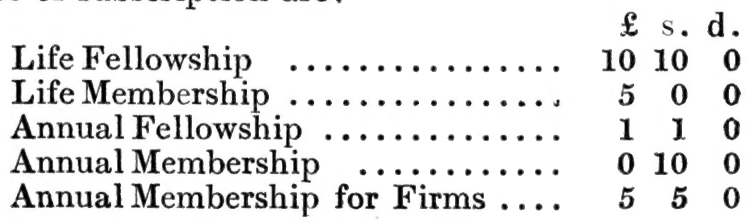





\section{A CATALOGUE OF BRITISH SCIENTIFIC AND TECHNICAL BOOKS}





\section{a CATAlogue}

$\mathrm{OF}$

\section{BRITISH SCIENTIFIC}

\section{AND TECHNICAL BOOKS}

Covering every Branch of Science and Technology carefully Classified and Indexed

Prepared by a Committee of the British Science Guild.

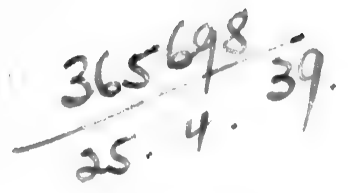

\footnotetext{
, BRITISH ,SCIENCE GUILD

6, John Street, Adelphi, London, W.C. 2.
} 


$$
\begin{aligned}
& 2 \\
& 7407 \\
& 6788 \\
& 1921 \\
& \text { cop. } 3
\end{aligned}
$$


"The Committee responsible for the preparation of the Catalogue of British Scientific and Technical Books consists of the following members of the British Science Guild :-

Sir Richard Gregory (Chairman).

Sir Edward Brabrook, C.B.

Mr. C. I. Bryant.

Dr. J. W. Evans, F.R.S.

Mr. L. W. Fulcher.

Mr. J. S. Highfield.

Mr. E. Wyndham Hulme.

Lady Lockyer.

Dr. H. Forster Morley.

Mr. P. Passenger.

Mr. J. J. Robinson.

Mr. Alan A. Campbell Swinton, F.R.S.

Mr. Carmichael 'Thomas.

Mrs. Willson.

Col. Sir John S. Young, C.V.O.

Lt.-Col. W. A. J. O'Meara, C.M.G. (Hon. Secretary of the British Science Guild). 


\section{PREFACE.}

W HEN the first British Scientific Products Exhibition was organised by the British Science Guild, in the year 1918, one of the stalls was devoted to a display of scientific and technical books. So much interest was taken in this exhibit that it was repeated in the following year, and a selected list of such books was published in the Catalogue of this Exhibition. Similar lists have been issued by the Science Masters' Association and the Association of Science Teachers, but the Guild's list was intended to be of service to industry rather than to education. It provided a handy guide to the chief existing British books on science and technology and proved of decided value to manufacturers seeking suitable works upon the particular subjects with which they were concerned.

The list was reprinted and widely circulated by the well-known scientific and technical booksellers, Messrs. A. and F. Denny, and the many inquiries for it, or for a more complete Catalogue of British books on science and technology, led the British Science Guild to undertake the preparation and publication of such a Catalogue. The work was entrusted to a special committee which had at the outset to decide whether an attempt should be made to establish a standard of merit by which to determine inclusion or exclusion of books in the Catalogue, or whether all titles within the scope of the Catalogue should be admitted. The conclusion reached was that it would be more satisfactory to make the Catalogue a complete record of scientific and technical books other than those intended for primary schools, and elementary volumes of like nature, in the current lists of publishers in the United Kingdom, and obtainable through booksellers in the usual way.

The Committee was fortunate in having among its members Mr. P. Passenger, who not only possesses wide 
knowledge and long experience in the handling of books on science and technology, but is also keenly interested in the cataloguing of them. Mr. Passenger undertook the task of making on a uniform plan a card catalogue of the full details of such books in the lists of British publishers; and the Committee is much indebted to him for the care and attention he devoted to this work. In order to secure uniformity in the bibliographic particulars, it was necessary to invite the assistance of publishers, and the Comnittee is glad to acknowledge that this aid was readily given. It has thus been possible to state, for each volume in the Catalogue, the author's name, title of book, size of page, number of pages, date of last edition, name of publisher, and price at the tinie (April, 1921) when the Catalogue was sent to the printers.

The volume contains more than six thousand titles, and their satisfactory classification required careful consideration. About fifty main groups were eventually decided upon and these were divided into nearly five hundred sub-classes. Even when a scheme of classification had been formed it was frequently difficult to determine under which head to place a book, but the Committee was fortunately able to secure additional assistance in accomplishing this task and desires to express grateful thanks for it. Prof. J. H. Ashworth, F.R.S., classified the titles of biological books, Miss M. S. Aslin those on agriculture, Prof. H. Wildon Carr dealt with books on philosophy and Miss M. Punnett and Prof. T. P. Nunn with those on mathematics. Other titles were classified by members of the Committee.

The classification adopted is such that, so far as practicable, related subjects are placed near one another; and under each head or sub-head the titles are arranged alphabetically according to author's names. It is thus possible to see at a glance the volumes available in any branch of science and technology. Following this natural order, there is an aphabetical list of authors' names, and a subject index, which should be of service in 


\section{Preface.}

furnishing an easy guide to a book or group of books upon a particular subject. For the preparation of this subject index, the Committee gladly expresses its obligations to Mr. G. S. Sweeting.

As to what are the best books available is often a matter of individual preference, and the Committee has made no attempt to exercise selective functions in this matter. With the present complete Catalogue, however, to show at a glance the actual works now obtainable, it is much easier to ask an authority upon a specific subject to indicate what he considers the most suitable books for particular needs or purposes-whether educational or industrial-than it would be in the absence of this list, and the Guild would no doubt furnish such information to any of its members who may desire guidance of this kind.

The British Science Guild believes that in producing this Catalogue it is promoting the use of knowledge and thereby furthering the development of education, science and industry. The books themselves represent worthy British scientific products and the Catalogue should be a means of extending their use not only at home but also in parts of the Empire overseas and in countries not yet familiar with what we have to offer in scientific and technical literature. If support to this enterprise is sufficiently encouraging, the Guild hopes to issue a revised edition of the Catalogue annually and thus keep up-to-date a publication which should prove of value to workers in many fields.

R. A. Gregory. 



\section{CLASSIFIED LIST OF CONTENTS.}

\section{SCIENCE IN GENERAL.}

i. General and Popular Science .. $\quad . . \quad \ldots \quad \ldots \quad 1$

ii. Biographies of Men of Science, etc... ... ..

iii. History of Science, Fducation, Learning, Commerce .. ... . . .

\section{PHILOSOPHY.}

i. General and Historical .. 6

ii. Metaphysies ... $\quad . . \quad \ldots \quad 8$

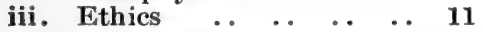

iv. Aesthetics.. $\quad \ldots \quad \ldots \quad \ldots \quad 12$

v. Logic.. $\quad . \quad \ldots \quad \ldots \quad \ldots \quad 13$

\section{PSYGHOLOGY.}

i. General and Historical .. 15

ii. Experimental and Physiological Psychology ..

iii. Mental Development and Child Study ... $\quad . . \quad \ldots \quad 18$

iv. The Animal Mind .. $\quad . .19$

v. The Abnormal and Psycho-

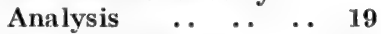

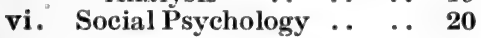

\section{MATHEMATICS.}

i. Collected Papers . . . 21

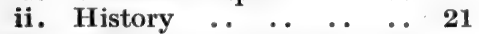

iii. Philosophy and Pedagogy $\begin{array}{llll}\text { of Mathematics } & . & \ldots & 22\end{array}$

iv. Examination Papers $\quad \ldots \quad \mathbf{2 2}$

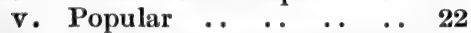

vi. General Pure Mathematics 22

vii. Functions ...

viii. Vectors and Quaternions 23

ix. Applied MathematicsDynamics, Physics, etc.

x. Practical Applied Mathematics (Elementary) . .

xi. Algebra: a. Elementary b. Higher Algebra, Theory of Equations and Quantics ... .. c. Determinants, Theory of Graphs, etc. . . xii. Calculus: a. Elementary

b. Differential and Integral ... ... c. Differential Equations, etc... .. ..

xiii. Higher Geometry, Pure and Analytical, and Differential Geometry

xiv. Pure Geometry: a. Elementary $\quad . \quad \ldots \quad \ldots \quad 30$

b. Conic Sections $\quad$. 31

c. Solid Geometry $\quad$. $\quad 32$

d. Projective Geometry 32

xv. Analytical Geometry .. 32

xvi. Practical Geometry and Graphics .. $\quad . . \quad \ldots \quad 33$

$\begin{array}{lllll}\text { xvii. Mensuration } & . & \ldots & \ldots & 33\end{array}$

xviii. Euclid ..

xix. Non-Euclidean Geometry $\mathbf{3 4}$

xx. Trigonometry:a.Elementary $\quad \ldots \quad \ldots \quad \ldots \quad \ldots \quad 34$ b. Plane and Spherical 35

xxi. Arithmetic .. $\quad . . \quad \ldots \quad 36$

xxii. Logarithms and Slide Rule 37

xxiii. Mathematical and Physi-

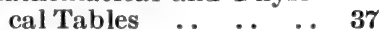

$\begin{array}{llllll}\text { xxiv . Statistics .. } & \ldots & \ldots & \ldots & 38\end{array}$

MEGHANICS.

i. General . .

ii. Staties and Dynamies .. 40

iii. Hydrostaties and Hydro$\begin{array}{lllll}\text { dynamics } & . & . & . & 42\end{array}$

iv. Applied Mechanics .. .. 42

v. Mechanism .. . . . . 43

vi. Strength and Elasticity of Materials $\quad \ldots \quad \ldots \quad 43$

vii. Mathematical Theory of Elasticity $\ldots$. $\quad \ldots \quad \mathbf{4 4}$

viii. Theory and Design of Structures $\quad \ldots \quad \ldots \quad \ldots 44$

ix. Gyrostatics $\ldots$. .

x. Measurements, Weights and Calculations .. . . 45

MACHINE DRAWING, DESIGN, DRAUGHTSMANSHIP.

i. General .. .. .. .

ii. Geometrical Drawing and Designing, Hand-Lettering $\ldots \ldots \ldots \ldots$ 
GIVIL ENGINEERING.

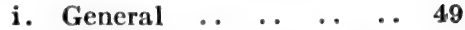

ii. Estimates, Formulæ, etc. 50

iii: "Surveying: Land and Mine .. .. ... .. 50

iiia. Tables and Calculations .. 52

iv. Roadmaking .. $\quad . . \quad \ldots \quad 52$

v. Railways and Tramways: Permanent Way and Working .. .. ..

vi. Hydraulies. Hydraulic Engineering. Harbours. River and Canal Engineering $\quad . . \quad \ldots \quad \ldots \quad 53$

vii. Irrigation $\quad \ldots \quad \ldots \quad \ldots \quad 55$

viii. Shore Protection. Land Reclamation .. . 55

ix. Hydraulic Motors $\quad$. 56

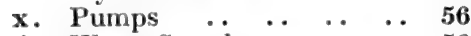

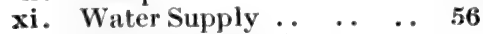

xii. Water Purification .. .. 57

xiii. Municipal Engineering: Sanitary Science and Plumbing $\quad . . \quad \ldots \quad . .57$

xiv. Illumination . . $\quad \ldots \quad \ldots \quad 59$

xv. Heating and Ventilating Buildings $\quad . .6 \quad \ldots \quad . .60$

xvi. Refuse Disposal . . . 60

\section{BUILDING CONSTRUCTION.}

i. General $\ldots$..

ii. Estimates, Quantities, Supervision, Repairs ..

iii. Building Law. Arbitration $\ldots$.. $\quad . . \quad$.

iv . Building Materials .. ..

v. Carpentry, Woodwork and Allied Trades

vi. Cob and Pisé Work ... ..

vii. Bricks and Tiles, Artificial and Masonry Stone

viii. Cement. Concrete ..

ix. Re-inforced Concrete .. 66

$\mathbf{x}$. Iron and Steel Construc$\begin{array}{llllll}\text { tion } & \ldots & \ldots & \ldots & . & 67\end{array}$

xi. Miscellaneous .. $\quad . . \quad \ldots \quad 68$

xii. Town Planning $\quad \ldots \quad \ldots \quad 98$

xiii. House Decoration, Paints etc. D...

NAVAL ARCHITECTURE AND SHIPBUILDING.

i. General $\ldots$..

ii. Miscellaneous .. $\quad \ldots \quad \ldots \quad 71$
MECHANICAL ENGINEERING.

i. General $\ldots \quad \ldots \quad \ldots 7_{2}$

ii. Power 'Transmission, Gear-

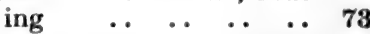

iii. Compressed Air Power Transmission $\quad \ldots \quad \ldots \quad 74$

iv. Lubrication ..

v. Lifting and Conveving .. 74

vi. Foundry Work. .. . . 74

vii. Machine Tools .. ... .. 75

viii. Wood Working Machinery 77

ix. Welding, etc. ... .. $\ldots 77$

x. Sheet Metal Work .. ..

xi. Metals:

a. Forging $\quad \ldots \quad \ldots \quad \ldots \quad 77$

b. Coating $\quad \ldots \quad \ldots \quad \ldots r$

c. Gold and Silversmith's

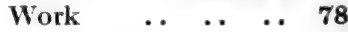

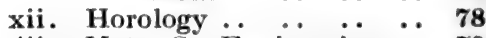

xiii. Motor Car Engineering .. 79

xiv. Motor Cycles .. . . . . 80

xv. Heat Engines and Steam Fingines: Design, Construction, Testing, etc.

xvi. Refrigeration .. .....

xvii. Stationary and Portable Steam Engines $\quad . \quad \ldots \quad 82$

xviii. Locomotive Engineering

xix. Valves and Valve Gearing

$\mathbf{x x}$. Steam Boilers: Construction and Management. .

xxi. Marine Engines .. ..

xxii. Internal Combustion Fngines $\quad \ldots \quad \ldots \quad \ldots \quad \ldots \quad 87$

xxiii. Turbines: Steam and Gas 89

xxiv. Engineering Reference Books \& Miscellaneous

AERONAUTICS.

i. Historical and General ..

ii. Theory and Practice of Flight $\ldots \ldots \ldots c$

iii. Design and Construction 93

iv. Airserews and Aerofoils ... 93

v. Aero Engines .... $\ldots . \quad \ldots 94$

vi. Aerial Navigation ..

vii. Reference Books for Aviators .. .. .. .. ..

viii. Balloons, Dirigibles, etc

PHYSICS.

i. Collected Works and Historical ...

ii. General Works...

a. Heat $\quad \ldots \quad \ldots \quad \ldots \theta$

b. Thermodynamics $\quad . \quad 99$

c. High Temperatures $\ldots 90$ 
d. Gases $\ldots$.. $\quad \ldots \quad \ldots 100$

e. Light $\ldots$. . $\quad \ldots \quad \ldots 100$

f. Physiological Optics and Optical Instruments 101

g. Colour : Spectra .. .. 102

h. Sound ....$\quad \ldots \quad \ldots 102$

i. Properties of Matter .. 103

j. Molecular Physics. . . 103

iii. Relativity .. . . .. 104

iv. Current in Gases .. .. 104

v. X-Rays and Radio-Activity $\ldots \ldots \ldots 104$

vi. Magnetism and Electricity .. . . . . . . 106

\section{ELEGTRIGAL ENGINEERING.}

i. General Treatises .. $\quad$.. 109

ii. Electric Generation: Power Plant

. 111

iii. Switchboards and Accessories .. . . . . . . 111

iv. Electric Generators and Motors : General .. .. 111

v. Continuous Current, and Machinery .. .. . 112

vi. Alternating Current, and Machinery .. .. .. 112

vii. Transformers... $\quad . . \quad \ldots 113$

viii. Transmission $\ldots$.. $\quad \ldots 114$

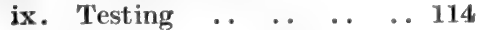

x. Electrical Measurements and Instruments ... . . 115

xi. Induction Coils and Batteries .. $\ldots \ldots \ldots \quad \ldots 115$

xii. Electric Wiring and Fitting $\quad \ldots \quad \ldots \quad \ldots \quad \ldots 116$

xiii. Electric Light and Illumination ... .. . . . 116

xiv. Electric Bells .. .. .. 117

xv. Electric Traction .. .. 117

xvi. Electrical Application to the Motor Car . . $\quad$. 118

xvii. Electro-Plating .. .. 118

xviii. Electric Welding .. . . 119

xix. Telephony and Telegraphy 119

xx. Wireless Telegraphy and Telephony .. $\quad . . \quad \ldots 120$

\section{CHEMISTRY.}

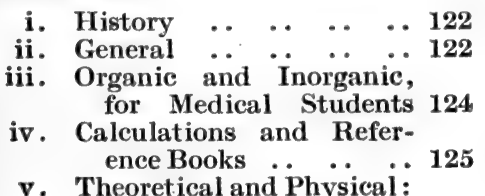
a. Theoretical $\ldots \quad \ldots 126$ b. Physical Chemistry 127

c. Colloids ...

d. Catalysis.. $\quad \ldots \quad \ldots 128$

e. Ferments $\quad$. $\quad \ldots 128$

f. Electrolysis . . . 128

vi. Inorganic Chemistry . 129

vii. Laboratory Work and Arts 130

viii. Organic Chemistry .. .. 130

ix. Analytical Chemistry:

a. General .. . . . 132

b. Qualitative Analysis 133

c. Quantitative Analysis ... . . . . 133

d. Volumetric Analysis $\mathbf{1 3 4}$

x. Biological and Physiolog-

ical Chemistry .. $\quad . \quad 134$

xi . Plant Constituents .. .. 135

\section{APPLIED AND INDUSTRIAL CHEMISTRY .}

i. General, including Chemical Engineering .. .. 136

ii. Water ... ... .. 137

iii. Fermentation. Brewing. Alcohol ... .. . . 137

iv. Sugar and its Manufacture 138

v. Cocoa and Chocolate .. 139

vi. Foods. Flour, and Bread making, etc. .. .. 139

vii. Glues, Agglutinants, Casein, etc... . . . . . 139

viii. Drugs and Disinfectants. . 139

ix. Oils, Fats, Waxes, Soap Manufacture. Margarine 139

x. Pigments, Paints, Varnishes, Resins, etc. . . 141

xi. Rubber, Gutta Percha, ete. .. .. .. .. 142

xii. Fuels. Smoke Prevention, etc. .. . . . . $\quad 142$

xiii. Liquid Fuels and their Use $\quad \ldots \quad \ldots \quad \ldots \quad \ldots 143$

xiv. Producer Gas. Acetylene $\mathbf{1 4 3}$

xv. Petroleum and Mineral Oils $\quad \ldots \quad \ldots \quad \ldots \quad \ldots 143$

xvi. Coal. Briquetting, etc. 144 xvii. Gas Manufacture: Coal Tar and its Products $\mathbf{1 4 5}$

xviii. Chemistry and Analysis of Gas $\quad \ldots \quad \ldots \quad \ldots \quad \ldots 146$

xix. Distribution of Gas _. 146

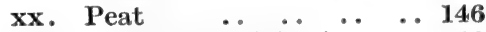

xxi. Dyestuffs and Dyeing .. 146

xxii. Ink Manufacture .

xxiii. Paper Making .. . 148

xxiv. Leather Manufacture and Tanning ... 
xxv. Glass, Pottery and Ceramics .. ... ... . 149

xxvi. Explosives and their Manufacture ... ... 150

xxvii. Acids, Alkalies, Salt, etc. 150 xxviii. Utilisation of Waste Products; Wood Products 151

xxix. Miscellaneous Chemical Manufactures .. .. 151

\section{METALLURGY.}

i. General and Miscellaneous $\mathbf{1 . 5 3}$

ii. Iron and Steel ... . . $\quad . \quad 153$

iii. Non-Ferrous Metals and Alloys .. $\quad . . \quad \ldots \quad \ldots 154$

iv. Electro-Metallurgy .. 155

v. Analysis and Assaying .. 156

vi . Metallography .. ... .. 156

vii. Heat Treatment of Metals 155

viii. Foundry Work .. .. 157

\section{MILITARY SGIENCE AND} ENGINEERING. . . 158

\section{ASTRONOMY.}

i. Historical and Biographical $\quad . \quad \ldots \quad \ldots \quad \ldots 159$

ii. General and Comprehensive Treatises $\quad \ldots \quad \ldots 159$

iii. The Moon .. $\quad \ldots \quad \ldots \quad \ldots 160$

iv. Solar and Stellar .. . 160

v. Astronomical Atlases .. 161

METEOROLOGY $\quad \ldots \quad \ldots \quad \ldots 162$

\section{MINERALOGY.}

i. General ..

ii. Crystallography $\ldots$. $\mathbf{1 6 4}$

iii. Economic Mineralogy .. 164

\section{GEOLOGY .}

i. General $\ldots$..

ii. History $\ldots$..

iii. Seismology and Findogenetic Structures $\quad \ldots 167$

iv. Land Forms and Exogenetic Structures $\quad \ldots \quad \ldots 167$

v. Petrology .. $\quad \ldots \quad \ldots, \ldots 168$ vi. Stratigraphy $\ldots$. $\quad \ldots 168$ vii. Geological Maps $\quad$. . . 168 viii. Topographical Geology .. 169

ix. Economic Geology ... .. 169

PALFONTOLOGY.

i. General .. $\quad \ldots \quad \ldots \quad \ldots 170$

ii. Palæobotany $\ldots$.. $\quad$.. 170
MINING.

i. General $\ldots$..

ii. Coal Mining ..

iii. Blasting, Ventilation, and Compressed Air .. 172

iv. Electricity applied to Mining ... .. . . . 173

v. Mining for Gold, Diamonds, $\begin{array}{llllll}\text { etc. } & \ldots & \ldots & \ldots & \ldots & 178\end{array}$

vi. Ore Dressing $\quad . \quad \ldots \quad \ldots \quad$. 174

\section{GEOGRAPHY .}

i. Teaching of Geography $\ldots 175$

ii. Historical Geography .. 175

iii. Physiography ... $\quad \ldots \quad \ldots 175$

iv. Physical Geography 176

v. Map Work .. .. .. 176

vi. Commercial and Economic ... .. .. $\quad .176$

vii. General: The World .. 177

viii. ,, British Empire 178

ix. Descriptive Regional .. 178

x. Miscellaneous .. $\quad . . \quad \ldots \quad 179$

\section{NAVIGATION AND SEAMAN - SHIP.}

i. Navigation and Nautical Astronomy ... .. . . 180

ii. Examination Guides to Navigation and Seamanship $\ldots . . . \quad \ldots \quad . .181$

iii. Compass Work $\ldots 181$ iv. Nautical Tables and

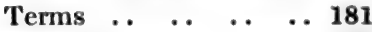

v. Seamanship $\ldots$. $\quad \ldots 182$

vi. Marine Signalling $\ldots \quad$.. 182 vii. Charts, Tides, Oceanography ... $\quad . . \quad \ldots \quad \ldots 182$

\section{BIOLOGY .}

i. General ..

ii. Nature Study ..

iii. Natural History .. .. 185

iv. Zoology and Morphology 185

v. Insects, Spiders, Ticks .. 187

vi. Other Invertebrates .. 180

vii. Vertebrates:

a. General .. $\quad \ldots \quad \ldots 191$

b. Fishes $\ldots \ldots \ldots 191$

c. Batrachians and Reptiles ... $\quad . . \quad \ldots \quad \ldots 192$

d. Birds $\quad$.. $\quad$.. $\quad$.. 192

e. Mammals .. . . 198

viii. Geographical Distribu-

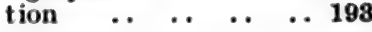


ix. Fvolution, Variation, Heredity, Geneties, Sex,

Origin of Life $\quad \ldots \quad \ldots 193$

x. Cytology .. $\quad \ldots \quad \ldots \quad \ldots 196$

xi. Microscopy $\quad \ldots \quad \ldots \quad \ldots 196$

xii. Anthropology .. $\quad . \quad \ldots 197$

BOTANY .

i. General $\ldots$. $\quad \ldots \quad \ldots 198$

ii. Morphology, Physiology,

$$
\text { etc. } \quad \ldots \quad \ldots \quad \ldots 201
$$

iii. Geographic Distribution 203

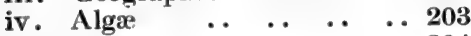

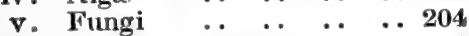

vi. Ferns and Mosses ..

vii. Flora $\quad \ldots \quad \ldots \quad \ldots \quad \ldots 205$

FORESTRY $\quad \ldots \quad \ldots \quad \ldots \quad \ldots 208$

\section{AGRICULTURE.}

i. General .. .. $\quad \ldots \quad \ldots 211$

ii. Botany, including Poisonous Plants, Plant Diseases and Pests . . . 212

iii. Chemistry.. $\quad \ldots \quad \ldots \quad \ldots 213$

iv. Geology .. $\quad$.. $\quad$.. $\quad$.. 214

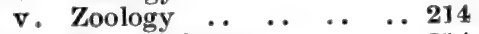

vi. Bacteriology $\ldots$. .. 214

vii. Economies ..

viii. Engineering . .

ix. History $\ldots$. $\quad \ldots \quad \ldots 215$

x. Animal Husbandry:
a. Dairying .. ..215
b. Livestock $\quad$. . . 216
c. Nutrition $\quad$. $\quad .2217$

xi. Field Crops $\quad \ldots \quad \ldots \quad \ldots 218$

xii. Soils and Fertilisers _. 220

ANATOMY.

i. General : Practical, Surgi-

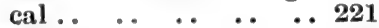

ii. Embryology $\quad \ldots \quad \ldots 2^{2}$

iii. Histology $\ldots$. $\quad \ldots 223$

iv. Osteology; Neurology ; Glands . . $\quad . . \quad \ldots \quad \ldots 223$

v. Surface Anatomy $\ldots$. $^{224}$

vi. Artistic Anatomy .. .. 224

vii. Comparative Anatomy .. 224

\section{PHYSIOLOGY.}

i. General and Practical .. 225

ii. Chemical Physiology .. 227

iii. Nerves; Brain; Special Senses $\ldots \quad \ldots \quad \ldots \quad \ldots 227$

iv. Secretions; Muscles; Electro Physiology . . .. 227

v. Sexual Physiology, etc. 228
BAGTERIOLOGY $\ldots \ldots$. . 229

\section{MEDICINE.}

\section{A. Historical, Biographical,}

etc. ..

B. Hygiene, Public Health,

Medical Jurisprudence,

Toxicology .

i. Hygiene $\ldots$. $\quad \ldots \quad \ldots 232$

ii. Public Health .. $\quad . . \quad$.. 234

iii. Water Analysis .. .. 234

iv. Food Analysis and Inspection $\quad \ldots \quad \ldots \quad \ldots 235$

v. Epidemics, Medical Geography, and Climatology $\ldots \quad \ldots \quad \ldots \quad \ldots 236$

vi. Tropical Hygiene .. $\quad .2236$

vii. Sanitary Law .. $\quad$. . . 237

viii. Medical Jurisprudence .. 237

ix. Toxicology $\quad \ldots \quad \ldots \quad$.. 238

c. Pathology .

i. Pathological Anatomy, Histology, Laboratory

Methods .. .. . 239

ii. Examination of the Urine 239

iii. Post Mortem Examina-

tion $\quad \ldots \quad \ldots \quad \ldots \quad \ldots 239$

iv. General Pathology $\quad$.. 239

v. Special Pathology $\quad \ldots 240$

vi. Hæmatology .. $\quad \ldots \quad \ldots 241$

D. Practice of Medicine.

i. General Treatises .. .. 241

ii. Clinical Medicine and

Diagnosis . . . . . 243

iii. Infectious Diseases :
a. General Fevers

b. General Infectious

Diseases .. $\quad . \quad \ldots 245$

c. Beri-beri $\quad \ldots \quad \ldots 245$

d. Cerebro-Spinal

Fever.. $\quad . \quad \ldots \quad .2245$

e. Cholera .. $\quad . . \quad \ldots 245$

f. Diphtheria $\ldots \quad \ldots 245$

g. Dysentery, Malarial

Diseases $\ldots \quad \ldots \quad \ldots 245$

h. Plague $\ldots \quad \ldots \quad \ldots 246$.

i. Small-Pox $\quad \ldots \quad \ldots 246$

j. Tetanus $\ldots$. .. 246

k. Typhoid Fever .. 246

1. Venereal Diseases;

Syphilis; Gonorrhea 246

m. Yellow Fever . 248

iv. Diseases due to Parasites 248

v. Constitutional Diseases:

a. Cancer $\ldots \quad \ldots \quad \ldots 248$

b. Rheumatism; Gout 249 


\section{Contents.}

vi. Tuberculosis ..

vii. Diseases of the Nervous System :

a. General, including

Alcoholism ....251

b. Diseases of the Brain and Spinal Cord .. 252

c. Neurasthenia and other Special Disorders of the Nervous System ..

d. Nervous Disorders caused by war .. . . 252 e. Mental Disorders, Insanity, Psychiatry 253

viii. Diseases of the Blood, Lymphatics, and Glands 254

ix. Diseases of the Heart and Circulatory Svstem .. 254

$x$. Diseases of the Respiratory System .. . . 255

xi. Diseases of the Digestive System and of the Stomach $\quad . \quad \ldots \quad \ldots 256$

xii. Diseases of the Liver and Gall Bladder . . . 256

xiii. Diseases of the Intestines $\mathbf{2 5 7}$

xiv. Diseases of the Rectum and Peritoneum .. . . 257

xv. Diseases of the GenitoUrinary System ... .. 257

xvi. Diseases of the Kidneys .. 257

xvii. Diseases of the Bladder .. 258

xviii. Diseases of the Abdomen 258

xix. Tropical Medicine .. $\quad . .258$

xx. Occupational Diseases .. 259

\section{SURGERY.}

i. General Treatises .. $\ldots 260$

ii. Operative Surgery .. . . 261

iii. Diagnosis (including $\mathbf{X}$ -

Ray Diagnosis) .. . . 262

iv. Surgical Therapeutics and Pathology $\quad . \quad \ldots \quad . .262$

v. Anaestheties ..

vi. Asersis and Antisepsis .. 263

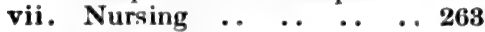

viii. Fractures .. $\quad \ldots \quad \ldots \quad \ldots 263$

ix. Minor Surgery; Bandaging; Emergencies ․ 263

x. War Surgery: Gunshot Wounds .. .. .. 264

xi. Regional Surgery :

a. Nead and Neck $\ldots 265$

b. Lungs and Heart .. 265

c. Abdomen $\quad$. $\quad .2265$

d. Amputations .. .. 266 e. Genito-Urinary Or-

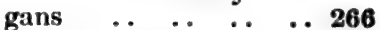

xii. Surgical Diseases :
a. Hernia $\ldots 2 . \quad \ldots 266$
b. Tumours $\quad \ldots \quad \ldots 267$

c. Diseases of the Locomotive System ..267

xiii. Orthopædic Surgery $\quad \ldots 267$

xiv. Deformities and their Surgical Treatment .. 268

\section{OPHTHALMOLOGY.}

i. General Treatises and Operative Ophthalmology .. .. .. .. 269

ii. Examination of the Eye: Ophthalmoscopy ..2 270

iii. Diseases of the Conjunctiva $\ldots . . . \quad \ldots \quad \ldots 270$

iv. Diseases of the Lens: Cataract $\ldots$. $\quad \ldots \mathbf{2 7 0}$

v. Diseases of the Optic Nerve $\quad . \quad \ldots \quad \ldots 270$

vi. Paralysis of the Eyc .. 271

vii. Wounds and Injuries .. 271

viii. Glaucoma $\ldots . . . \quad \ldots 271$

ix. Colour Blindness ... .. 271

x. Refraction and Optical Defects ... .. .. .. 271

xi. Therapeutics, Spectacles, etc...$\quad \ldots \quad \ldots \quad \ldots 271$

\section{OTOLOGY, RHINOLOGY,} LARYNGOLOGY.

i. General Treatises .. .. 278

ii. Diseases of the Ear.. .. 273

iii. Diseases of the Nose .. 274

iv. Diseases of the Throai .. 274

GYNACOLOGY, OBSTETRICS, etc.

i. Diseases of Women.. .. 275

ii. Gynacology :

a. Pathology $\quad \ldots \quad \ldots 275$

b. General .. .. .. 275

c. Diagnosis, Operations, Therapeutics.. 276

d. Disorders, Diseases 276

e. Cancer of the Breast 276

iii. Obstetrics :
a. General : Labour .. 276
b. Midwifery $\ldots$. $^{277}$
c. Popular .. $\quad . . \quad \ldots 278$ 
DISEASES AND HYGIENE OF CHILDREN.

i. Gencral : Nutrition, etc. 279

ii. Diagnosis; Diseases ; Treatment .. $\quad . \quad \ldots 280$

\section{DENTISTRY .}

i. General $\ldots$. $\quad \ldots \quad \ldots 282$

ii. Anatomy and Physiology 282

iil. Medicine and Diseases .. 282

iv. Operative Dentistry .. 282

v. Mechanical and Metallurgy 283

vi. Materia Medica and Therapeutics $\ldots 2 . \quad \ldots 283$

\section{DERMATOLOGY (SKIN}

DISEASES) . . $\quad \ldots \quad \ldots \quad \ldots \quad \ldots 284$

THERAPEUTICS.

i. General Treatises .. .. 285

ii. Prescribing $\quad \ldots \quad$.. $\quad$.. 286

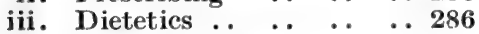

iv. Mineral Waters .. . 287

v. Massage and Movement

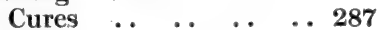

vi. Serum Therapy and Immunisation ... .. .. 287

vii. Vaccination: Salvarsan .. 288

viii. Tuberculin .., . . 288

ix. Climatotherapy, etc. .. 289

x. X-Rays, Radium, Thermotherapy .. $\quad . .28289$

xi. Electro-Therapy .. $\quad .289$

xii. Psycho-Therapeutics: Hypnotism .. .. .. 290

PHARMAGY AND MATERIA MEDICA.

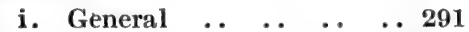

ii. Pharmacopieias $\ldots 2.291$

ii1. Materia Medica .. .. 292

iv. Pharmacology .. .. .. 292

NURSING.

General and Medical .. 294

VETERINARY.

i. Physiology and Anatomy 295

ii. Medicine and Surgery .. 295

iii. Therapeuties, Toxicology, etc. $\quad . \quad \ldots \quad \ldots \quad \ldots 296$

iv. General ..
TEXTILES.

i. Historical and Economic 297

ii. Raw Materials .. .. 297

iii. Spinning and Doubling:

a. Cotton .. .. $\quad .297$

b. Woollen and

Worsted .. .. .. 298

c. Jute, Flax, Silk ..298

iv. Weaving and Sizing ..298

v. Dyeing and Printing .. 299

vi. Bleaching and Finishing 299

vii. Designing, Testing, Research .. . . . . . 300

viii. General Manufacture .. 300

ix. Textile Machinery .. . . 301

x. Calculations, Reference Books, etc. .. .. .. 301

xi. Lace, Embroidery, etc... 302

xii. Boot and Shoe Manufacture ... $\quad . . \quad \ldots 302$

xiii. Leather Work . . . . . 302

GRAPHIG ARTS.

i. Printing and its Allied Branches .. .. . 304

ii. The Book and Bookbinding $\quad . .6 . .6305$

iii. Paper and Stationery .. 305

iv. Miscellaneous .. $\quad . . \quad \ldots 305$

\section{PHOTOGRAPHY.}

i. Photography $\ldots$. $\quad \ldots 307$

ii. Photo-Micrography .. 308

iii. Cinematography $\quad . \quad$.. 309

\section{SGIENTIFIG MANAGEMENT,} etc.

i. Scientific and Works Management .. . 310

ii. Industrial Organisation.. 310

iii. Estimating and Costing. . 311

DICTIONARIES OF TEGH-

NIGAL TERMS IN ENGLISH

AND OTHER LANGUAGES 312

LIST OF PUBLISHERS . . . 315

INDEX OF AUTHORS, COL -

LABORATORS, AND TRANS-

$\begin{array}{lllllll}\text { LATORS } & . & . & . & . & . & 319\end{array}$

INDEX OF SUB.JECTS .. . . 365 


\section{BIBLIOGRAPHIGAL DETAILS.}

Books that are out of print are not given, but where a new edition is in course of preparation, it is so mentioned.

Where no edition is mentioned, the title refers to the first, as the only edition. A further edition generally means that the text of the book has been revised and brought up to the date given.

An "impression" is a reprint of the original, or last edition, without alteration.

Difficulty arises in some instances as to the date given. Certain publishers give the date of the reprint of a book and not that of the original publication; but all the dates given in this Catalogue are those of books obtainable when the Catalogue went to Press.

Where two dates are given, that in parenthesis is the date of the last edition, the following date being the year the same edition was reprinted.

Some important books appear to be old, but in various cases essentials do not alter.

The sizes of books are designated in the usual way, and a list is given below of the equivalent measurement in inches.

With very few exceptions, all books are bound in cloth covers.

The number of pages given to each book generally includes the prefatory matter.

\section{SIZES OF BOOKS.}

The following are the approximate sizes in inches:-

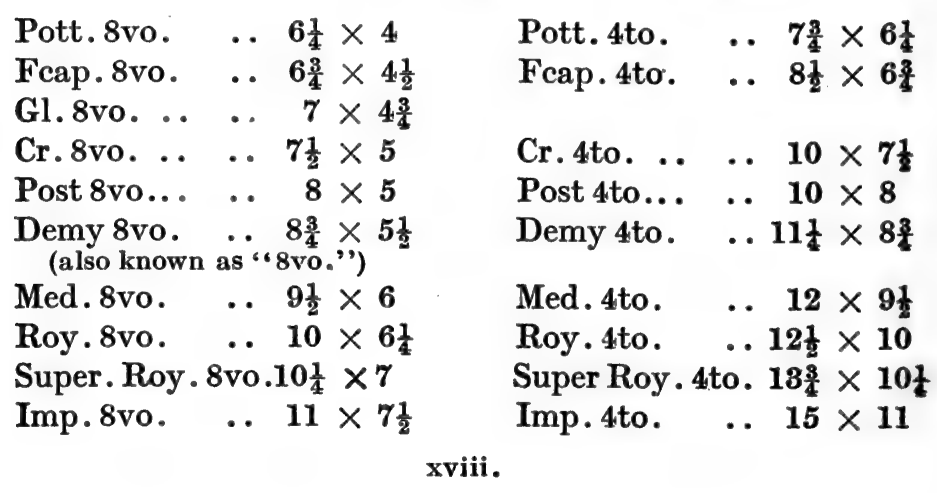




\section{SCIENCE IN GENERAL.}

\section{i. GENERAL AND POPULAR SGIENGE.}

Aliotta, A. The Idealistic Reaction Against Science. Translated by A. McCaskill. 8vo. Pp. 496 . 1914. Macmillan. 15s.

Allbutt, Sir T. C. Science and Medieval Thought. Harveian Oration. 1900. Cr. 8vo. Pp. 116. 1901. Cambridge University Press. 3s.6d.

Amos, S. Science of Law. 9th edn. Cr. 8vo. Pp. 437. 1909. Kegan Paul. 7s, 6d.

Armstrong, H. E. The Teaching of Scientific Method and other Papers on Education. 2nd edn. Cr. 8vo. Pp.531. 1910. Macmillan. 6s.6d

Briggs, w. (edited by). General Elementary Science. 3rd edn. 10th imp. Cr. 8vo. Pp. 412. 1920. 5s. Key, 2s. 3d. University Tutorial Press.

Clough, W. T. and Dunstan, A. E. Elementary Science for Pupil Teachers. Physics and Chemistry. $\mathrm{Cr}$. 8vo. Pp. 191. 1907. Methuen. 3s. $6 d$.

-Elementary Experimental Science. Physies and Chemistry. 18th edn. Cr. 8vo. Pp.266. 1919. Methuen. $4 s$.

Co-ordination of Scientific Publication, The . Faraday Society Report. 1918. Demy 8vo. Pp. 30. 1918. Faraday Society. 3s.

Darwin, Sir G. H. Scientific Papers. 5 vols. Roy. 8vo. Cambridge University Press.

Vol. 1.-Oceanic Tides and Lunar Disturbance of Gravity. Pp.477. 1907. 20s. Vol. 2.-Tidal Friction and Cosmogony. Pp. 532. 1908. 20s. Vol. 3.-Figures of Equilibrium of Rotating Liquid and Geophysical Investigations.
Pp. 542. 1910. 20s. Vol. 4.Periodic Orbits and Miscellaneous Papers. Pp.609. 1911. 20s. Vol. 5.-Memoirs by Sir F. Darwin and E. W. Brown, Lectures on Mill's Lunar Theory, etc. Pp. 137. 1916. 10s.

Dearle, N. B. Industrial Training: with special reference to the Conditions prevailing in London. Demy 8vo. Pp. 609. 1914. King. $10 s, 6 d$.

Donnan, F. G. (Translated by). International Language and Science. Considerations on the Introduction of an International Language into Science. Demy 8vo. Pp.95. 1910. Constable. $2 s$.

Dunn, J. T., and Mundella, V. A. General Elementary Science. An Introductory Course for Students in Schools and Technical Colleges. 2nd edn. Cr. 8vo. Pp. 333 . 1905. Methuen. 5s.

Fairweather, W. C. Foreign and Colonial Patent Laws. Demy 8vo. Pp.291. 1910. Constable.10s.6d.

Gibson, C. R. Scientific Ideas of To-Day. Cr.8vo. Pp. 342. 1920. Seeley. 7s.6d.

Glazebrook, Sir R. T. Science and Industry. Rede Lecture 1917. Cr. 8vo. Pp. 51. 1917. Cambridge University Press. 1s. $6 d$.

Gregory, Sir R.A. Discovery; or, The Spirit and Service of Science. Cr. 8vo. Pp. 347. 1918. Macmillan. $7 s .6 d$.

Griffiths, E. D. Housecraft Science. Cr.8vo. Pp.192. 1917. Methuen. $3 s, 6 d$.

Hodson, F. (edited by). Broad Lines in Science Teaching. 2nd edn. Demy 8vo. Pp. 267. 1911. Christophers. 6s. 


\section{Science in General}

Huxley, T. H. Science and Education. Gl. 8vo. Pp. 451. Macmillan. $6 s$.

Science and Hebrew Tradition. Gl. 8vo. Pp. 372. Macmillan. 6s.

Science and Christian Tradition. Gl. 8vo. Pp. 419. Macmillan. $6 s$.

-Method and Results. Gl. 8vo. Pp. 430. Macmillan. 6s.

Illingworth, S. R. The Co-operation of Science and Industry. Pocket size. Pp.91. 1914. Griffin. 1s. $6 d$.

Joly, N. Man before Metals. 6th edn. Cr. 8vo. Pp. 372. 1904 . Kegan Paul. 7s. 6d.

Lodge, Sir O.J. Life and Matter. 2nd edn. Cr. 8vo. Pp. 200. 1912. Williams and Norgate. $2 s, 6 d$.

Mivart, St. G. The Groundwork of Science. A Study of Epistemology. Large Cr. 8vo. Pp. 331 . 1898. Murray. 7s. 6d.

Moulton, Lord. Science and War. Rede Lecture 1919. Cr. 8vo. Pp. 60. 1919. Cambridge University Press. 2s. 6d.

Peddie, R. A. Engineering and Metallurgical Books 1907-1911. British and American. Cr. 8vo. Pp: 216. 1912. Grafton. 7s.6d.

Poincaré, H. Science and Method. Translated by F. Maitland. Large Cr. 8vo. Pp. 288. N.D. Nelson. 6s.

Rignano, F. Essays in Scientific Synthesis. Translated by W.J. Greenstreet. Demy 8vo. Pp. 254 . 1918. Allen and Unwin. 8s. 6d.

Seward, A. C. (edited by). Science and the Nation. Essays by Cambridge Graduates. Cr. 8vo. Pp. 350. 1917. Cambridge University Press. 5s.

Soddy, F. Science and Life. Aberdeen Addresses. Demy 8vo. Pp. 241. 1920. Murray. 10s.6d.

Strong, T. B. (edited by). Lectures on the Method of Science, delivered in Oxford, 1905, at the request of the Delegates for the Extension of University Teaching . 8vo. Pp. 250. 1906. Oxford: Clarendon Press. 7s. $6 d$.
Swan, K. R. The Law and Commercial Usage of Patents, Designs and Trade Marks. Ex. Cr. 8vo. Pp.402. 1908. Constable. 7s.6d.

Thomson, J. A. The Introduction to Science. Fcap. 8vo. Pp. 256. 1911. Williams and Norgate. $2 s .6 d$.

- - The System of Animate Nature. The Gifford Lectures 1915-1916. 2 vols. Demy 8vo. Pp.699. 1920. Williams and Norgate. $30 s$.

Turnbull, A. (edited by). The Life of Matter: An Inquiry and Adventure. Demy 8vo. Pp. 324. 1919. Williams \& Norgate. $7 s, 6 d$.

Westaway, F. W. Science and Theology. Their Common Aims: and Methods. Roy. 8vo. Pp. 359. 1920. Blackie. 15s.

- Scientific Method: its Philosophy and its Practice. New edn. Super Cr.8vo. Pp.426. 1919. Blackie. $10 s .6 d$.

Whitehead, A. N. The Organisation of Thought, Educational and Scientific. New imp. in preparation. Williams \& Norgate.

Year Book of the Scientific and Learned Societies of Great Brit ain and Ireland. A Record of the Work done in Science, Literature and Art during the Session 19101920 , by numerous Societies and Government Institutions, compiled from Official Sources. 37th Annual Iscue. Demy 8vo. Pp. 362 . Jan., 1921. Griffin, 15s.

\section{ii. BIOGRAPHIES OF MEN OF SGIENGE, etc.}

Bower, F . O. Joseph Dalton Hooker (Pioneers of Progress). Cr. 8vo. Pp. 64. 1919. S.P.C.K. 2s.

Bridges, J. H. The Life and Work of Roger Bacon. Cr. 8vo. Pp. 174. 1914. Williams \& Norgate. $3 s$.

Bryant, W. W. Galileo. (Pioneers of Progress). Cr. 8vo. Pp. 64. 1918. S.P.C.K. $2 s$.

Crowther, J. A. Michael Faraday. (Pioneers of Progress). Cr. 8vo. Pp. 64. 1918. S.P.C.K. 2s. 
Darwin, Sir F. (edited by). Charles Darwin: His Life told in an Autobiographical Chapter, and in a selected Series of his Published Letters. 2nd edn. Cr. 8vo. Pp. 348. 1908. Murray. 7s.6d.

Davis, A. Thomas H. Huxley . Small Cr. 8vo. Pp. 288. Dent. $3 s .6 d$.

Duncan, D. The Life and Letters of Herbert Spencer. Demy 8vo. Pp. 621. 1911. Williams \& Norgate. $6 s$.

Forbes, G. Memories of Sir David Gill, Man and Astronomer. Demy 8vo. Pp. 418. 1916. Murray. $12 s$.

Fox, R. H. William Hunter: Anatomist, Physician, Obstetrician (1718-1783). 8vo. Pp.83. 1901. Lewis. 4s. $6 d$.

Godlee, Sir R. J. A Review of the Life and Work of John Hunter. Demy 8vo. Pp.48. 1913. Bale \& Danielsson. 2s, $6 d$.

Gray, A. Lord Kelvin. Small Cr. 8vo. Pp. 317. Dent. 3s.6d.

Heath, Sir T. L. Archimedes. (Pioneers of Progress). Cr. 8vo. Pp. 64. 1920. S.P.C.K. 2s。

Hogben, L. T. Alfred Russel Wallace. The Story of a Great Discoverer. (Pioneers of Progress). Cr. 8vo. Pp.64. 1918. S.P.C.K. $2 s$.

Hooker, Sir J. D. A Sketch of the Life and Labour of Sir William Hooker. Roy.8vo. Pp.90. 1903. Oxford: Clarendon Press. Paper Cover. 3s. 6d.

Huxley, L. The Life and Letters of Sir Joseph Hooker. 2 vols. Demy 8vo. Pp. 546., 569. 1918. Murray. 36s.

Life and Letters of $\mathbf{T}$. H. Huxley. 3 vols. G1. 8vo. Macmillan. 18s.

Jackson, B. D. George Bentham. Small Cr. 8vo. Pp. 292. Dent. $3 s .6 d$.

Koenigsberger, L. Hermann von Helmholtz. Translated by F. A. Welby. 8vo. Pp. 458. 1906. Oxford: Clarendon Press. $16 s$.
Leupp, F. E. George Westinghouse: His Life and Achievements. Demy 8vo. Pp. 315. 1919. Murray. $15 s$.

Little, A. G. (edited by). Roger Bacon. Essays on the occasion of the commemoration of the Seventh Centenary of his birth. 8vo. Pp. 434. 1914. Oxford: Clarendon Press. $16 s$.

Lodge, Sir O.J. Pioneers of Science. Cr. 8vo. Pp. 404. 1893. Macmillan. $6 s$.

Lyddeker, R. Sir William $\mathbf{H}$. Flower. Small Cr. 8vo. Pp. 189. Dent. 3s. 6d.

Macpherson, H. Herschel. (Pioneers of Progress). Cr. 8vo. Pp. 80. 1919. S.P.C.K. $2 s$.

Miall, L.C. The Early Naturalists: Their Lives and Work (1530-1789). 8vo. Pp.408. 1912. Macmillan. $10 \mathrm{~s}$.

Millington, J. P. John Dalton. Small Cr. 8vo. Pp. 224. Dent. $3 s, 6 d$.

Mottelay, P. F. The Life and Work of Sir Hiram S. Maxim. Cr. 8vo. Pp. 258. 1920. Lane. 7s, 6d.

Peacock, D. H. Joseph Priestley. (Pioneers of Progress). Cr. 8vo. Pp. 64. 1919. S.P.C.K. 2s.

Pearson, K. The Life, Letters, and Labours of Francis Galton. Vol. I. 1822-1853. Cr. 4to. Pp. 258. 1914. Cambridge University Press. $30 s$.

Ramsay, Sir W. Life and Letters of Joseph Black, M.D. Demy 8vo. Pp. 160. 1918. Constable.6s.6d.

Schuster, Sir A., and Shipley, Sir A.E. Britain's Heritage of Science. 2nd edn. Pp.349. 1920. Constable. $14 s$.

Smiles, S. Lives of the Engineers; from the Earliest Period to the Death of the Stephensons. 5 vols. Cr. 8vo. 1904.

Brindley, Vermuyden, Myddleton, Perry-Early Engineers. Pp. 380. 


\section{Science in General}

Sineaton and Rennie-Harbours, Lighthouses, and Bridges. Pp. 459 .

Metcalfe and Telford-History of Roads. Pp. 412.

Boulton and Watt-The Steam Fingine. Pp. 481 .

George and Robert StephensonThe Locomotive. Pp. 466 .

Murray. 5s. each.

Men of Invention and Industry.

7th imf. Cr.8vo. Pp.3ro. 1901.

Murray. 58.

- Industrial Biography: Ironworkers and Tool-makers. Cr. 8vo. Pp. 353. 1901. Murray. 5s.

Tatlow, J. Fifty Years of Railway Life. Demy 8vo. Pp. 223. 1920.

Transport, Ltd. $10 s$.

Thompson, J. S. and H. G. Silvanus Phillips Thompson. His Life and Letters. Demy 8vo. Pp. 372. 1920. Fisher Unwin. $21 s$.

Thomson, J. A. Herbert Spencer. Small Cr. 8vo. Pp. 284. Dent. $3 s .6 d$.

Thorpe, Sir T. E. Joseph Priestley. Sinall Cr. 8vo. Pp. 228. Dent. $3 s .6 d$.

Turner, A. L. Sir William Turner. Professor of Anatomy, and Principal and Vice-Chancellor of the University of Edinburgh. A Chapter in Medical History. Demy 8vo. P'p. 531. 1919. Blackwood. 18s.

Tyndall, J. Faraday as a Discoverer. 5th edn. Cr.8vo. Pp. 208. 1894. Longmans. $4 s$.

Vallery-Radot, R. The Life of Pasteur. Demy 8vo. Pp. 505. 1919. Constable. $10 s .6 d$.

\section{ii. HISTORY OF SCIENCE- EDUCATION-LEARNING, COMMERCE, etc.}

Adamson, J. W. A Short History of Education. Demy 8vo. Pp. 370. 1919. Cambridge I'niversity Press. 12s. 6d.

- Pioneers of Modern Education in the Seventeenth Century. Cr. 8vo. Pp. 307. 1905. Cambridge University Press. 6s.
Albee, E. A History of English Utilitarianism. Med.8vo. Pp.427. 1902. Allen and Unwin. 12s. 6d.

Avebury, Lord. A Short History of Coins and Currency. Fcap. 8vo. Pp. 138. 1903. Murray. 2s.6d.

Barnard, F. P. The CastingCounter and the counting-Board. A Chapter in the History of Numismaties and Early Arithmetic. Demy 4to. Pp. 358. 1917. Oxford: Clarendon Press. 63s.

Benn, A. W. The History of English Rationalism in the Nineteenth Century. 2 Vols. 8vo. Pp. 478., 546. 1906. Longmans. 22s. 6d.

Compayré, G. The History of Pedagogy. Translated, with Introduction, Notes, and Index by W. H. Payne, 9th edn. Cr. 8vo. Pp. 598. 1918. Allen and Unwin. 7s.6d.

Cressy, E. Discoveries and Inventions of the Twentieth Century. 8vo. Pp. 416. 1915. Routledge. $10 s .6 d$.

Critchell, J. T., and Raymond, J. History of the Frozen Meat Trade. Demy 8vo. Pp. 460. 1912. Constable. 12s. $6 d$.

De Montmorency, J. E. G. State Intervention in English Education. A Short History from the Farliest Times to 1833. Cr. 8vo. Pp. 398. 1902. Cambridge University Press. 7s. $6 d$.

Draper, J. W. History of the Conflict between Religion and Science. 25th edn. Cr.8vo. Pp.395. 1910. Kegan Paul. $7 s, 6 d$.

-A History of the Intellectual Development of Europe. 2 Vols. Small Post 8vo. Pp. 438. 1914. Bell. 12s.

Fletcher, Sir B. F. A History of Architecture on the Comparative Method. 5th edn. Demy 8vo. Pp. 788. 1920. Batsford. 25s.

Gardner, P. A History of Ancient Coinage. 700-300 B.C. 8vo. Pp. 480. 1918. Oxford: Clarendon Press. 18s. 
Kerr, J. Scottish Education, School and University, from Early Times to 1908. With an Addendum, 1908-1913. Demy 8vo. Pp. 458. 1913. Cambridge University Press. $4 s .6 d$.

Kirkup, T. A History of Socialism. 5th edn, revised and edited by E.R. Pease. Cr. 8vo. Pp. 490. 1913. Black. $7 s .6 d$.

Laurie, S. S. Studies in the History of Educational Opinion from the Renaissance. New Imp. Cr. 8vo. Pp. 267. 1905. Cambridge University Press. $7 s, 6 d$.

Leach, A. F. Educational Charters and Documents, 598 to 1099 . Cr. 8vo. Pp. 582. 1909. Cambridge University Press. $12 s, 6 d$.

Leonard, E. M. The Early History of English Poor Relief. Demy 8vo. Pp. 418. 1900. Cambridge University Press. $10 s$.

Lewes, G. H. A Biographical History of Philosophy from Thales to Comte. 8vo. Pp.656. 1911. Routledge. $6 s$.

Libby, W. An Introduction to the History of Science. Cr. 8vo. Pp. 288. 1918. Harrap. 6s.

Mark, H. T. An Outline of the History of Educational Theories in England. 2nd edn. Cr. 8vo. Pp. 139. 1906. Allen and Unwin. 3s.

Merz, J. T. A History of European Thought in the Nineteenth Century. 4 Vols. Post 8vo. Vol. 1. 3rd imp. Pp. 472. 1907. 10s.6d. Vol. 2. 2nd imp. Pp.820. 1912. 15s. Vol. 3. Pp.639. 1912. 15s. Vol. 4. Pp. 847. 1914. 20s. Blackwood.

Page, W. (edited by). Commerce and Industry. 2 Vols. Imp. 8vo. 1919. Vol.1. A Historical Review of the Economic Conditions of the British Empire from the Peace of Paris in 1815 to the Declaration of War in 1914, based on Parliamen. tary Debates. Pp. 508. 32s. Vol. 2. Tables of Statistics for the British Empire from 1815. Pp. 259. 24s. Constable.

Simpson, F.M. A History of Architectural Development. 3 Vols. 8vo. Vol.1. New imp. in preparation. 16s. Vol.2 Pp.420.1913. 12s.6d. Vol. 3. Pp. 376. 1913. 12s. 6d. Longmans.

Thomson, J.A. Progress of Science in the Century. Cr. 8vo. Pp. 536. 1908. Chambers. 5s.

Webb, S. and B. The History of Trade Unionism. Revised Edition, extended to 1920. 8vo. Pp. 802. 1920. Longmans. $21 s$.

Wood, Sir H. T. A History of the Royal Society of Arts. Med. 8vo. Pp. 558. 1913. Murray. 15s.

Woodward, W. H. Studies in Education during the Age of the Renaissance. 1400-1600. Cr. 8vo. Pp.356. 1906. Cambridge University Press. $6 s$. 


\section{PHILOSOPHY.}

\section{i. GENERAL AND HISTORICAL.}

Adam, J. The Vitality of Platonism and other Essays. Demy 8vo. Pp. 250. 1911. Cambridge University Press. 9s.

Adam, Mrs. J. Plato:-Moral and Political Ideals. Roy. 16mo. Pp. 164. 1913. Cambridge University Press. 2s. 6d.

Adamson, R. The Development of Greek Philosophy, edited by W. R. Sorley and R. P. Hardie. Demy 8vo. Pp. 337. 1911. Blackwood. $10 s, 6 d$.

Arnold, E. V. Roman Stoicism. Demy 8vo. Pp. 480. 1911. Cambridge University Press. 12s. $6 d$.

Beare, J. I. Greek Theories of Elementary Cognition from Alcmaeon to Aristotle. 8vo. Pp. 362. 1906. Oxford: Clarendon Press. 12s. 6d.

Benn, A. W. The Greek Philosophers. 2nd edn. Demy 8vo. Pp. 619. 1914. Murray. 21s.

-History of Ancient Philosophy. Cr.8vo. Pp.160. Watts. 3s.6d.

- History of Modern Philosophy. Cr.8vo. Pp. 160. Watts. 3s.6d.

Bevan, J. O. Handbook of the History and Development of Philosophy. Cr. 8vo. Pp. 241. 1916. Chapman and Hall. 5s.

Bonar, J. Philosophy and Political Economy in some of Their Historical Relations. 2nd edn. Med. 8vo. Pp.410. 1909. Allen and Unwin. 12s. 6d.

Boutroux, E. Historical Studies in Philosophy. Translated by F. Rothwell. 8vo. Pp. 346. 1912. Macmillan. 10s. 6d.

Burnet, J. Greek Philosophy, Part 1. Thales to Plato. 2nd imp. 8vo. Pp. 370. 1920. Macmillan. 12s. $6 d$.

- Early Greek Philosophy. 3rd edn. Square Demy 8vo. Pp. 384. 1020. Black. $30 s$.
Burns, C. D. The Growth of Modern Philosophy. Cr. 8vo. Pp. 270. N.D. Sampson, Low. 6s.

Crozier, J. B. History of Intellectual Development on the lines of Modern Evolution. 8vo. Vol. 1. Pp. 564. 1912. 14s. Vol. 3. Pp. 360. 1901. 10s. 6d. Longmans.

Dewey, J. Reconstruction in Philosophy. Cr. 8vo. Pp. 230. 1921. University of London Press. $7 s .6 d$.

De Wulf, M. History of Mediæval Philosophy. 8vo. Pp. 500. 1009. Longmans. $11 \mathrm{~s}$.

Douglas, A. H. The Philosophy and Psychology of Pietro Pomponazzi. Demy 8vo. Pp. 328. 1910. Cambridge University Press. 7s. $6 d$.

Douglas, C. The Ethics of John Stuart Mill. Post 8vo. Pp. 360. 1897. Blackwood. 6s.

- John Stuart Mill : A Study of His Philosophy. Cr. 8vo. Pp. 289. 1895. Blackwood. 4s, $6 d$.

Erdmann, J. E. The History of Philosophy. Translated and Edited by W. S. Hough. 3 Vols. Med. 8vo. Vol.1. Ancient and Medieval Philosophy. 4th edn. Pp. 719. 1915. Vol. 2. Modern Philosophy. 6th edn. Pp. 719. 1915. Vol. 3. Modern Philosophy since Hegel. 5th edn. Pp. 356. 1913. Allen and Unwin. 15s. each Vol.

Figgis, J. N. Studies of Political Thought from Gerson to Grotius. 1414-1625. 2nd edn. Cr. 8vo. Pp. 266. 1916. Cambridge University Press. 6s.

Flint, R. Philosophy as Scientia Scientiarum. A History of Classifications of the Sciences. Pp. 350 . 1904. Blackwood. 10s. 6d.

Historical Philosophy in France and French Belgium and Switzerland. 8vo. Pp. 734. 1893. Blackwood. 21s. 
Fraser, A. C. Biographia Philosophica. Demy 8vo. Pp. 349 . 1904. Blackwood. 6s.

Gomperz, T. Greek Thinkers: a History of Ancient Philosophy . Demy 8vo. 4 Vols. Vol. 1. The Beginnings. From Metaphysics to Positive Science. The Age of Enlightenment. Translated by $\mathrm{L}$. Magnus. Pp.610. 1906. Vol. 2. Socrates and the Socratics. Plato. Translated by G. G. Berry. Vol. 3. Plato. Translated by G. G. Berry. Vol.4. Aristotle and $\mathrm{H}$ is Successors. Translated by G. G. Berry. Murray. 18s, each.

Hobhouse, L. T. Development and Purpose. An Essay towards A Philosophy of Evolution. 8vo. Pp.405. 1913. Macmillan. 12s.6d.

Hoffding, H. A History of Modern Philosophy. A Sketch of the History of Philosophy from the close of the Renaissance to our own day. Translated by B. E. Meyer. 2 Vols. 8vo. Pp.550.,610. 1915. Macmillan. 18s. each.

-A Brief History of Modern Philosophy. Translated by C. F. Sanders. Cr.8vo. Pp. 336. 1919. Macmillan. 12s.

The Problems of Philosophy. Translated by G. M. Fisher and a Preface by W. James. G1. 8vo. Pp. 220. 1913. Macmillan. 7s.

The Philosophy of Religion. Translated by B. E. Meyer. 8vo. Pp. 408. 1914. Macmillan. 15s.

-Modern Philosophers: Lectures; and Lectures on Bergson. Translated by A. C. Mason. Cr. 8vo. Pp.332. 191.). Macmillan. 6s.6d.

Janet, P. and Séailles, G. A History of the Problems of Philosophy. Translated by A. Monahan. Edited by $H$. Jones. 2 Vols. Demy 8vo. 1902. Vol. 1. Psychology. Pp. 420. Vol.2. Physics, Metaphysics, Theodicy. Pp.390. Macmillan. 10s, each Vol.

Keary, C. F . The Pursuit of Reason. Demy 8vo. Pp. 464. 1910. Cambridge University Press. $10 s$.
Kelvin, Lord, and Tait, P. G. Elements of Natural Philosophy. 2nd edn. Demy 8vo. Pp. 299. 1912. Cambridge University Press. $12 s$.

A Treatise on Natural Philosophy. Demy 8vo. Part 1. Pp. 515. 1912. 20s. Part 2. Pp.552. 1905. 20s. Cambridge University Press.

Külpe, O. The Philosophy of the Present in Germany. Translated by M. Lyall and G. T. W. Patrick. Cr. 8vo. Pp. 256. 1913. Allen and Unwin. $5 s$.

Introduction to Philosophy: A Handbook for Students of Psychology, Logic, Ethics, Aesthetics, and General Philosophy. Translated by W. B. Pillsbury and E. B. Titchener. 4th edn. Demy 8vo. Pp. 256. 1915. Allen and Unwin. $6 s$.

Lindsay, J. A Philosophical System of Theistic Idealism. Demy 8vo. Pp. 543. 1917. Blackwood. 15s. Studies in European Philosophy. Demy 8vo. Pp. 391. 1909. Blackwood. 10s. $6 d$.

Lloyd, A. H. The Will to Doubt: An Essay in Philosophy for the General Thinker. Cr. 8vo. Pp. 285. 1907. Allen and Unwin. 5s.

Mayor, J. B. A Sketch of Ancient Philosophy from Thales to Cicero. 5th imp. Feap. 8vo. Pp. 269. 1912. Cambridge University Press. $4 s .6 d$.

Mercier, Cardinal. Manual of Modern Scholastic Philosophy. Translated by T. L. and S. A. Parker. 2nd edn. 2 Vols. 8vo. Pp.600., 567. 1919. Kegan Paul. $12 s .6 d$ per Vol.

Merz, J. T. A Fragment on the Human Mind. Demy 8vo. Pp. 324. 1919. Blackwood. 12s.6d.

Pringle-Pattison, A. S. Scottish Philosophy. A Comparison of the Scottish and German Answers to Hume. 4th edn. Cr. 8vo. Pp. 238. 1907. Blackwood. 5s.

Radhakrishnan, S. The Reign of Religion in Contemporary Philosophy. Demy 8vo. Pp.475. 1920. Macmillan. 12s. 
Rappoport, S. Primer of Philosophy. Fcap. 8vo. Pp. 118. 1916 . Murray. 1s. 6d.

Ritchie, D. G. Natural Rights: A Criticism of Some Political and Ethical Conceptions. 3rd edn. Med.8vo. Pp. 304. 1916. Allen and Unwin. 12s.6d.

Studies in Political and Social Ethics. Cr. 8vo. Pp. 238. 1908. Allen and Lnwin. $5 s$.

Robertson, J. M. A Short History of Freethought. 2 Vols. Demy 8vo. Pp. 1,043. Watts. $15 \mathrm{~s}$.

A Short History of Morals. Demy 8vo. Pp.460. 1920. Watts. 18s.

Ruggiero, G. De. Modern Philosophy. Translated from the Italian by A. H. Hannay and R. G. Collingwood. Demy 8vo. Pp. 402. 1921. Allen and Cnwin. $16 s$.

Salter, W. M. First Steps in Philosophy-Physical and Ethical. 2nd edn. Cr. 8vo. Pp. 143. Allen and Unwin 3s. 6 $d$.

Seth, J. English Philosophers and school of Philosophy. Large $\mathrm{Cr}$. 8vo. Pp. 372. Dent. 7s.6d.

Sidgwick, H. Philosophy : Its Scope and Relations. 8vo. Pp. 270. 1902. Macmillan. 8s.

Sorley, W. R. A History of English Philosophy. Demy 8vo. Pp. 396. 1920. Cambridge Lniversity Press. $20 s$.

Stace, W.T. A Critical History of Greek Philosophy. Cr. 8vo. Pp. 400. 1920. Nacmillan. 7s.6d.

Stephen, D. J. Studies in Early Indian Thought. Cr. 8vo. Pp. 183. 1918. Cambridge Ĺniversity P'ress. 6s.

Stephen, Sir L. A History of English Thought in the Eighteenth Century. 2 Vols. Demy 8vo. Pp. 466., 469. 1902. Murray. 28s.

Stewart, H. L. Questions of the Day in Philosophy and Psychology. Demy 8vo. Pp. 296. 1912. Arnold. 10s.6d.
Stockl, A. Handbook of the History of Philusophy. 8vo. Pp. 4.52. 1911. Longmans. 10s. $6 d$.

Thomson, J. A. K. The Greek Tradition: Essays in the Reconstruction of Ancient Thought. $\mathrm{Cr}$. 8vo. Pp. 224. 1915. Allen and Unwin. 6s.

Walker, L. J. Theories of Knowledge, Absolutism, Pragmatism, Realism. 2nd edn. Cr. 8vo. Pp. 746. 1919. Longmans. $11 s$.

Webb, C. C. J. History of Philosophy. Feap. 8vo. Pp. 256. 1919. Williams and Norgate. 2s.6d.

Weber, A. History of Philosophy. Translated by F. Thilly. 8vo. Pp. 642. 1919. Longmans. $16 s$.

Whitehead, A. N. An Enquiry Concerning the Principles of Naturat Knowledge. Demy 8vo. Pp. 212. 1919. Cambridge University Press. $14 . s$.

The Concept of Nature: Tarner Lectures delivered in Trinity College, November, 1919. Demy 8vo. Pp.212. 1920. Cambridge University Press. $14 s$.

Whittaker, T. The Neo-Platonists. 2nd edn., with Supplement on the Commentaries of Proclus. Demy 8vo. Pp. 334. 1914. Cambridge University Press. $14 s$.

Zeller, E. Outlines of the History of Greek Philosophy. Translated by S. F. Alleyne and E. Abbott. Cr. 8vo. Pp. 380. 1914. Longmans. $12 s$.

\section{ii. METAPHYSICS.}

Alexander, S. Space, Time and Deity (Gifford Lectures, 1916-1918). 2 Vols. 8vo. Pp. 362., 450. 1920. Macmillan. 36s.

Arnold, R. B. Scientific Fact and Metaphysical Reality. 8vo. Pp. 384. 1904. Macmillan. 10s.

Aveling, F. On the Consciousness of the Universal and the Individual. A Contribution to the Phenomenology of the Thought Processes. Cr.8vo. Pp.265.1912. Macmillan. 5s. 
Baldwin, J. M. Thought and Things: A Study of the Development and Meaning of Thought, or Genetic Logic. 3 Vols. Med. 8vo. Vol. 1. Functional Logic, or Genetic Theory of Knowledge. Pp. 273. 1906. Vol.2. Experimental Logic, or Genetic Theory of Thought. Pp. 436. 1908. Vol.3. Interest and Art, being Real Logic. Pp. 284. 1911. Allen and Unwin. 12s. $6 d$. each.

Balsillie, D. An Examination of Professor Bergson's Philosophy. Cr.8vo. Pp.228. 1912. Williams and Norgate. $5 s$.

Bergson, H. Matter and Memory. Translated by N.M. Paul and W. S. Palmer. 3rd edn. Med. 8vo. Pp. 339. 1919. Allen and Unwin. $12 s .6 d$.

Time and Free Will : An Essay on the Immediate Data of Consciousness. Translated by F. L. Pogson. 3rd edn. Med. 8vo. Pp. 252. 1913. Allen and Unwin. 12s.6d. Creative Evolution. Translated by A. Mitchell. 6th imp. 8vo. Pp. 440. 1920. Macmillan. $12 s .6 d$.

Mind Energy: Lectures and Essays. Translated by H. W. Carr. Demy 8vo. Pp. 222. 1920. Macmillan. 10s.

Bosanquet, B. The Philosophical Theory of the State. 3rd edn. Demy 8vo. Pp. 382. 1920. Macmillan. 15s.

-The Value and Destiny of the Individual (Gifford Lectures for 1912). 8vo. Pp. 363. 1913. Macmillan. 12s. $6 d$.

-Implication and Linear Inference. Cr. 8vo. Pp. 190. 1920. Macmillan. 7s.6d.

Bradley, F.H. Essays on Truth and Reality. 8vo. Pp. 496. 1914. Oxford : Clarendon Press. 12s. 6d. _-Appearance and Reality : A Metaphysical Essay. 6th imp. Med. 8vo. Pp. 628. 1916. Allen and Unwin. 12s. $6 d$.

Broad, C. D. Perception, Physics, and Reality. An enquiry into the information that Physical Science can supply about the Real.
Demy 8vo. Pp. 400. 1914. Cambridge University Press. 12s.

Bury, J. B. The Idea of Progress. An Inquiry into its Origin and Growth. 8vo. Pp. 393. 1920. Macmillan. 14s.

Caldwell, W. Pragmatism and Idealism. Demy 8vo. Pp. 268. 1913. Black. $7 s, 6 d$.

Carr, H. W. The Philosophy of Change. A Study of the Funda. mental Principle of the Philosophy of Bergson. 8vo. Pp. 228. 1914. Macmillan. $7 s, 6 d$.

The Philosophy of Benedetto Croce: The Problem of Art and History. 8vo. Pp. 225. 1917. Macmillan. $7 s, 6 d$.

Croce, B. What Is Living and What is Dead of the Philosophy of Hegel. Translated by D. Ainslie. 8vo. Pp. 235. 1915. Macmillan. $10 s$.

Deussen, P. Elements of Metaphysics. A Guide for Lectures and Private Use. 'Translated by C.M. Duff. 2nd imp. Cr.8vo. Pp.362. 1909. Maemillan. $7 s$.

Driesch, H. The Problem of Individuality. 8vo. Pp. 94. 1914. Macmillan. 4s, $6 d$.

The History and Theory of Vitalism. Translated by C. K. Ogden. Cr. 8vo. Pp. 247. 1914. Macmillan. 6s, $6 d$.

The Science and Philosophy of the Organism. The Gifford Lectures, 1907-1908. 2 Vols. Demy 8vo. Pp. 329., 381. 1908. Black. 10s. 6d. each.

Fuller, B. A. G. The Problem of Evil in Plotinus. Cr. 8vo. Pp. 356. 1912. Cambridge University Press. $7 s .6 d$.

Gibson, J. Locke's Theory of Knowledge and Its Historical Relations. Demy 8vo. Pp. 352. 1917. Cambridge University Press. $10 s .6 d$.

Gibson, W. R. B. Rudolf Eucken's Philosophy of Life. 3rd edn. Cr. 8vo. Pp. 188. 1915. Black. 4.s. $6 d$. 


\section{Philosophy}

Gibson, W. R. B. Rudolf Eucken's The Meaning and Value of Life. 4th imp. Cr. 8vo. Pp. 155. 1916. Black. 4s.6d.

Gunn, J. A. Bergson and $\mathrm{His}$ Philosophy. Cr. 8vo. Pp. 212. 1920. Methuen. $6 s$.

Haldane, E. S., and Ross, G.R. T . The Philosophical Works of Descartes. Rendered into English. 2 Vols. Demy 8vo. Vol. 1. Pp. 462. 1911. 12s. 6d. Vol. 2. Pp. 388. 1012. 14s. Cambridge University Press.

Hartmann, E. Philosophy of the Unconscious. Translated by W.C. Coupland. 2nd edn. 3 Vols. Post 8vo. Pp. 404., 374., 368. 1903. Kegan Paul. 37s. 6d.

Hegel, G.W. F. The Phenomonology of Mind. Translated, with an Introduction and Notes, by J. B. Baillie. 2 Vols. Demy 8vo. Pp. 823. 1907. Allen and Unwin. $25 s$.

Hobhouse, L. T. Mind in Evolution. 2nd edn. 8vo. Pp. 500. 1915. Macmillan. 12s. 6d.

- The Theory of Knowledge. A Contribution to some problems of Logic and Metaphysics. 2nd edn. Demy 8vo. Pp. 647. 1896. Methuen. $15 s$.

_-Morals in Evolution: A Study in Comparative Ethics. 3rd edn. Demy 8vo. Pp. 664. 1915. Chapman and Hall. 10s, $6 d$.

Holt, E. B. The Concept of Consciousness. Demy 8vo. Pp. 343. 1914. Allen and Unwin. 12s.6d.

Huxley, T.H. Hume, with Helps to the Study of Berkeley. G1. 8vo. Pp. 320. Macmillan. 6s.

Jevons, F. B. Philosophy: what is it? 2nd edn. Cr. 8vo. Pp. 142. 1920. Cambridge University Press. 48 .

Kitchin, D. B. Bergson for Beginners : A Summary of His Philosophy. and edn. Cr. 8vo. Pp. 309. 1914. Allen and Unwin. $6 s$.
Lossky, N. O. The Intuitive Basis of Knowledge. An Epistemological Enquiry. Translated by N. A. Duddington. 8vo. Pp.450. 1919. Macmillan. $16 s$.

Mackenzie, J. S. Outlines of Metaphysics. 2nd edn. New imp. Cr. 8vo. Pp. 191. 1916. Macmillan, 5s.

-Elements of Constructive Philosophy. 2nd imp. Demy 8vo. Pp. 487. 1919. Allen and Unwin. $15 s$.

McTaggart, J. McT. E. The Nature of Existence. Vol. 1. Roy. 8vo. Pp. 331. 1921. Cambridge University Press. 22s. 6d.

-A Commentary on Hegel's Logic. Demy 8vo. Pp. 328. 1910. Cambridge University Press. $12 s$. -Studies in Hegelian Cosmology. 2nd edn. Demy 8vo. Pp. 812. 1918. Cambridge University Press. $8 s$.

- Studies in the Hegelian Dialectic. Demy 8vo. Pp. 275. 1896. Cambridge University Press. 88 .

Pearson, N. Some Problems of Existence. Demy 8vo. Pp. 176. 1907. Arnold. $7 s .6 d$.

Richardson, C. A. Spiritual PluraL ism and Recent Philosophy. Demy 8vo. Pp. 358. 1919. Cambridge University Press. 148.

Rickaby, J. First Principles of Knowledge. Cr. 8vo. Pp. 428. 1919. Longmans. $8 s$.

_-General Metaphysics. New edn. Cr. 8vo. 1921. Longmans. 88 .

Ruhe, A., and Paul, N. M. Henri Bergson: An Account of his life and philosophy. Ex. Cr. 8vo. Pp. 253. 1914. Macmillan. 6s.6d.

Russell, B. A Critical Exposition of the Philosophy of Leibniz. Demy 8vo. Pp. 327. 1900. Cambridge University Press. Os.

-Introduction to Mathematical Philosophy. Demy 8vo. Pp. 208. 1919. Allen and Unwin. 10s. 6d.

Slessor, H. H. The Nature of Being. An Essay in Ontology. Demy 8vo. Pp. 224. 1919. Allen and Unwin. $10 s, 6 d$. 
Spencer, H. The Principles of Biology. 2 Vols. 48 vo. Williams and Norgate. 18s. each Vol. -First Principles (A System of Synthetic Philosophy). 8vo. Williams and Norgate. $5 s$.

Stebbing, L. S. Pragmatism and French Voluntarism. Cr. 8vo. Pp.180. 1914. Cambridge University Press. 2s.6d.

Stewart, J. M'K. A Critical Exposition of Bergșon's Philosophy. 2nd edn. 8vo. Pp. 305. 1913. Macmillan. 6s, 6d.

Taylor, A. E. Elements of Metaphysics. 5th edn. Demy 8vo. Pp.436. 1920. Methuen. 12s.6d.

Varisco, B. The Great Problems. Translated by R. C. Lodge. Med. 8vo. Pp. 370. 1914. Allen and Unwin. $12 s .6 d$.

Ward, J. The Realm of Ends, or Pluralism and Theism. Gifford Lectures, 1907-10. 2nd edn., with some replies to criticisms. Demy 8vo. Pp. 506. 1913. Cambridge University Press. $21 s$.

Westermarck, E. The Origin and Development of the Moral Ideas. 2nd edn. 2 Vols. 8vo. Pp.740., 884. 1912. Macmillan. 14s. each Vol.

Widgery, A. G. Rudolf Eucken's Life's Basis and Life's Ideals. The Fundamentals of a New Philosophy of Life. 2nd edn. Demy 8vo. Pp. 337. 1918. Black. 10s.6d.

Williams, M. V. Six Essays on the Platonic Theory of Knowledge. Cr. 8vo. Pp. 142. 1908. Cambridge University Press. 3s.

Wodehouse, $\mathbf{H}$. The Presentation of Reality. Cr. 8vo. Pp. 174. 1910. Cambridge University Press. $3 s$.

\section{iii. ETHICS.}

Benett, W. Justice and Happiness. 8vo. Pp. 140. 1911. Oxford: Clarendon Press. 3s.6d.

Bosanquet, B. Some Suggestions in Ethics. 2nd edn. Cr. 8vo. Pp. 262. 1919. Macmillan. 6s.
Croce, B. Philosophy of the Practical. Economic and Ethic. Translated by D. Ainslie. 8vo. Pp. 628. 1913. Macmillan. 14s.

D'Arcy, C. F. A Short Study of Ethics. 2nd edn. Cr, 8vo. Pp. 305. 1912. Macmillan. 6s, 6d.

Duprat, L. Morals: The PsychoSociological Bases of Ethics. Translated from the French by W.J. Greenstreet. Cr. 8vo. Scott Pub. Co. $7 s .6 d$.

Johnston, G. A. An Introduction to Ethics for Training Colleges. Cr. 8vo. Pp. 264. 1915. Macmillan. 3s. $6 d$.

Jones, E. E. C. A Primer of Ethics. Fcap. 8vo. Pp. 101. 1909. Murray. 1s. $6 d$.

Mackenzie, J. S. Lectures on Humanism, with Special reference to its Bearings on Sociology. Cr. 8vo. Pp. 243. 1907. Allen and Unwin. $5 s$.

A Manual of Ethies. 5th edn. 11th imp. Cr. 8vo. Pp. 512. 1919. University Tutorial Press. $9 s .6 d$.

Outlines of Social Philosophy. Demy 8vo. Pp. 280. 1918. Allen and Unwin. 10s. $6 d$.

Moore, G. E. Ethics. Fcap. 8vo. Pp. 256. 1912. Williams and Norgate. $2 s .6 d$.

Muirhead, J. H. Chapters from Aristotle's Ethics. Cr.8vo. Pp. 319. 1900. Murray. 9s .

-The Elements of Ethics. Cr. 8vo. Pp. 296. 1919. Murray. 4s. $6 d$.

- -German Philosophy in Relation to the War. Cr. 8vo. Pp. 110. 1917. Murray. 4s.6d.

Rickaby, J. Moral Philosophy, Ethies and Natural Law. 4th edn. Cr. 8vo. Pp. 396. 1921. Longmans. $8 s$.

Rogers, R. A. P. A Short History of Ethics-Greek and Modern. 2nd imp. Cr. 8vo. Pp. 325. 1913. Macmillan. $1 s, 6 d$. 


\section{Philosophy}

Ryland, F. Ethics: An Introductory Manual for the Use of University Students. 3rd edn. Cr. 8vo. Pp. 220. 1914. Bell. 3s.6d.

Schopenhauer, A. The Basis of Morality. Translated by A. B. Bullock. 2nd edn. Cr. 8vo. Pp. 288. 1915. Allen and Unwin. $5 s$.

Seth, J. A Study of Ethical Principles. 14th edn. Post 8vo. Pp. 491. 1918. Blackwood, 8s. 6d.

Sidgwick, H. Outlines of the History of Ethies for English Readers. 5th edn. New imp. Cr. 8vo. Pp. 254. 1915. Macmillan. $4 s$.

— The Methods of Ethics. 7th edn. 8vo. Pp. 556. 1913. Macmillan. $10 s .6 d$

- Practical Ethies: A Collection of Addresses and Essays. 2nd edn. Cr. 8vo. Pp. 260. 1909. Allen and Unwin. $5 s$.

Sorley, W. R. Recent Tendencies in Ethies. Cr. 8vo. Pp. 146. 1904. Blackwood. 2s. 6d.

The Ethics of Naturalism. 2nd edn. Cr. 8vo. Pp. 352. 1904. Blackwood. $6 s$.

The Moral Life and Moral Worth. Roy. 16mo. Pp. 147. 1911. Cambridge University Press. 2s.6d. Ioral Values and the Idea of God. Gifford Lectures, 1914-15. 2nd edn. Demy 8vo. Pp. 554. 1921. Cambridge University Press. 22s. 6d.

Spencer, H. The Principles of Ethics. Vol. 1. Pt. 1. The Data of Fithics; Pt. 2. The Inductions of Ethics: Pt. 3. The Ethics of Individual Life. 8vo. 15s. Vol. 2. Pt.4. Justice; Pt.5. Negative Beneficence; Pt . 6. Positive Beneficence. 8vo. 12s. 6d. Williams and Norgate.

Taylor, A. E. The Problem of Conduct. A Study in the Phenomenology of Ethies. 8vo. Pp. 509. 1901. Macmillan. 12s. 6d.

Urwick, E. J. A Philosophy of Social Progress. 2nd edn. Cr. 8vo. Pp. 25t. 1920. Methuen. 7s. 6d.
Walston, Sir C. Truth. An Essay in Moral Reconstruction. Cr. 8vo. Pp.248. 1919. Cambridge University Press. 5s.

Ward, S. The Ways of Life: $A$ Study in Ethies. Cr. 8vo. Pp. 126. 1920. Oxford University Press. 6s. 6d.

Whittaker, T. The Theory of Abstract Ethics. Cr. 8vo. Pp. 136. 1916. Cambridge University Press. 4s, 6d.

Wundt, W. M. Ethics. 3 Vols. Demy 8vo. Vol.1. Introduction: The Facts of the Moral Life. Translated by J. H. Gulliver and E. B. Titchener. 3rd edn. Pp. 339. 1908. Vol. 2. Ethical Systems : The Development of Moral Theories of the Universe. Translated by M. F. Washburn. 3rd edn. Pp. 196. 1917. Vol. 3. Principles of Morality. Translated by M. F. Washburn. Pp.308. 19i4. Allen and Unwin. $7 s, 6 d$. each.

\section{iv. AESTHETICS}

Bosanquet, B. Three Lectures on Aesthetic. Ex. Cr. 8vo. Pp. 128. 1915. Macmillan. 4s.6d.

The History of Aesthetic. 4th edn. Med. 8vo. Pp. 502. 1917. Allen and Unwin. 12s. 6d.

Clay, F. The Origin of the Sense of Beauty. Large Post 8vo. Pp. 302. 1908. Murray. 7s. 6d.

Cook, Sir T. A. The Curves of Life. An Account of Spiral Formations and their Application to Growth in Nature, to Science, and to Art. Roy. 8vo. Pp.502. 1914. Constable. 12s. 6d.

Croce, B. Aesthetic as Science of Expression and General Linguistic. Translated from the Italian by $D$. Ainslie. 8vo. Pp. 436. 1009 . Macmillan. 12s. 6d.

Knight, W. The Philosophy of the Beautiful. 2 Parts. Cr. 8vo. Vol. 1. Pp. 288. 1916. Vol. 2. Pp. 281. 1914. Murray. 4s. 6d. each. 


\section{Philosophy}

Lee, V. The Beautiful. Roy. $16 \mathrm{mo}$. Pp. 166. 1913. Cambridge University Press. 2s. 6d.

Rand, B. Shaftesbury's Second Characters, or the Language of Forms. Demy 8vo. Pp. 210. 1914. Cambridge University Press. $9 s$.

Sweet, H, The History of Language . 5th edn. Post 8vo. Pp. 148. 1920. Dent. 1s.9d.

Tucker, T. G. Introduction to the Natural History of Language. Demy 8vo. Pp. 465. 1908. Blackie. 10s. $6 d$.

Türck, H. The Man of Genuis. Translated by G. J. Tamson. Demy 8vo. Pp. 483. 1914. Black. 12s, $6 d$.

Whitney, W. D. Life and Growth of Language. 7th edn. Cr. 8vo. Pp. 336. 1902. Kegan Paul. 7s, $6 d$.

\section{v. LOGIC.}

Adamson, R. A Short History of Logic. Edited by W. R. Sorley. Cr. 8vo. Pp. 276. 1911. Blackwood. $7 s .6 d$.

Bain, A. Logic. 2 Pts. 3rd edn. Part 1. Deduction. Pp. 300. 1910. 5s.6d. Part 2. Induction. Pp. 466. 1912. 7s, 6d. Longmans.

Bartlett, F. C. Exercises in Logic. Cr.8vo. Pp.156. 1913. 4s. Key. Pp. 142, 1914. 3s. University Tutorial Press.

Bosanquet, B. Essentials of Logic. 8th imp. Cr. 8vo. Pp. 177. 1920. Macmillan. $4 s$.

Glarke, R. F. Logic. New edn. Cr. 8vo. 1921. Longmans. 8s.

Goffey, P. The Science of Logic: an Inquiry into the Principles of Accurate Thought and Scientific Method. 2 Vols. 2nd imp. 8vo. 1918. Vol. 1. Conception, Judgment, and Inference. Pp. 466. 10s. Vol.2. Method, Science, and Certitude. Pp. 368. 10s. Longmans.
Croce, B. Logic as the Science of the Pure Concept. Translated by D. Ainslie. 8vo. Pp.640. 1917. Macmillan. $14 s$.

Gibson, W. R. B., and Klein, A. The Problem of Logic. Demy 8vo. Pp. 500. 1914. Black. 15s.

Holman, H., and Irvine, M. G. W. Questions on Logic with Illustrative Examples. 6th imp. Cr. 8vo. Pp. 130. 1916. 4s. Key. 4th imp. Pp. 121. 1914. 3s. University Tutorial Press.

Jevons, W. S. Elementary Lessons in Logic, Deductive and Inductive. New imp. Pott.8vo. Pp. 352. 1920. Macmillan. 4s.

-Pure Logic: and other Minor Works. Edited by R. Adamson and H. A. Jevons. 8vo. Pp. 314. 1890. Macmillan. 10s.6d. The Principles of Science: Treatise on Logic and Scientific Method. New imp. 8vo. Pp.830. 1920. Macmillan. 12s.6d.

Studies in Deductive Logic. 2nd edn. Cr. 8vo. Pp. 332. 1908. Macmillan. $7 s$.

Jones, E. E. C. A New Law of Thought and its Logical Bearings. Cr. 8vo. Pp. 86. 1911. Cambridge University Press. 3s. $6 d$. -A Primer of Logic. Fcap. 8vo. Pp. 188. 1913. Murray. $2 s$.

Keynes, J . N. Studies and Exercises in Formal Logic, including a generalization of Logical processes in their application to complex inferences. 4th edn. 8vo. Pp. 572. 1906. Macmillan. 12s. $6 d$.

Mellone, S. H. An Introductory Text-book of Logic. 11th edn. Cr. 8vo. Pp. 414. 1919. Blackwood. $7 s, 6 d$.

Mill, J.S. A System of Logic. Cr 。 8vo. Pp. 638. 1919. Longmans. $7 s, 6 d$.

Minto, W. Logic, Inductive and Deductive. 9th imp. Cr. 8vo. Pp. 373. 1915. Murray. 5s.

Read, C. Logic. Deductive and Inductive. 4th edn. Cr. 8voPp. 433. 1920. Simpkin, Mar . shall. 7s. $6 d$. 
Russell, B. Mysticism and Logic, and other Essays. 3rd imp. 8vo. Pp. 342. 1919. Longmans. 8s.6d.

Russell, L. J. An Introduction to Logic: from the Standpoint of Education. Cr. 8vo. Pp. 150. 1921. Macmillan. 3s. 6d.

Schiller, F. C. S. Formal Logic: A Scientific and Social Problem. 8vo. Pp. 441. 1912. Macmillan. 10s.

Sidgwick, A. The Application of Logic. Cr. 8vo. Pp. 332. 1910. Macmillan. 6s, 6d.

Fallacies: a View of Logic from the Practical Side. 3rd edn. Cr. 8vo. Pp. 391. 1901. Kegan Paul. 7s.6d.

Elementary Logic. Cr. 8vo. Pp. 260. 1914. Cambridge University Press. $4 s$.

Sturt, H. The Principles of Understanding. An Introduction to Logic from the standpoint of Personal Idealism. Cr.8vo. Pp.313. 1915. Cambridge University Press. $7 s$.

Venn, J. The Principles of Empirical or Inductive Logic. 2nd edn. 8vo. Pp. 624. 1907. Macmillan. 18s. Symbolic Logic. 2nd edn. Cr. 8vo. Pp. 578. 1894. Macmillan. 12s. $6 d$.
Venn, J. The Logic of Chance. 8rd. edn. Cr.8vo. Pp. 540. 1888. Macmillan. 12s. 6d.

Welton, J. A Manual of Logic. 2 vols. Cr. 8vo. Vol. 1. Deductive Logic. 2nd edn. 5th imp. Pp. 457. 1912. 10s. 6d. Vol.2. Fallacies, Deductive and Inductive. 6th imp. Pp. 330. 1916. 8s. 6d. University Tutorial Press.

-Groundwork of Logic. 2nd imp. Cr. 8vo. Pp. 368. 1920. University Tutorial Press. 5s.

and Monahan, A. J. Intermediate Logic. 4th imp. Cr. 8vo. Pp. 530. 1920. University Tutorial Press. 10s. 6d.

Windelband, W., and Ruge, $A$. (edited by). Encyclopredia of the Philosophical Sciences. Vol. 1. Logic. By various Authors. Translated by B. E. Meyer. 8vo. Pp. 280. 1913. Macmillan. 10s.

Wolf, A. Exercises in Logic and Scientific Method. Fcap 8vo. Pp. 78. 1919. Allen and Unwin. 3s. -The Existential Import of Categorical Prediction. Studies in Logic. Cr. 8vo. Pp. 176. 1905. Cambridge University Press. 4s. 


\section{PSYCHOLOGY.}

\section{i. GENERAL AND HISTORICAL.}

Bain, A. Mind and Body: the Theories of their Relation. 11th edn. Cr. 8vo. Pp. 196. 1910. Kegan Paul. 7s. 6d.

The Senses and the Intellect. 4th edn. 8vo, Pp. 736. 1894. Longmans. 17s. $6 d$.

Mental and Moral Science: A Compendium of Psychology and Ethics. Cr. 8vo. Pp. 788. 1884. Longmans. 12s.

The Emotions and the Will. 4th edn. 8vo. Pp. 638. 1899. Longmans. 17s. $6 d$.

Baldwin, J. M. History of Psychology. 2 vols. Cr. 8vo. Pp. 323. 1913. Watts. $7 s$.

Ballard, P. B. Obliviscence and Reminiscence. Roy. 8vo. Pp. 40. 1913. Cambridge University Press. $4 s$.

Bernstein. The Five Senses of Man . 8th edn. Cr. 8vo. Pp. 321. 1910. Kegan Paul. 7s. 6d.

Binet, A. The Mind and the Brain. Cr. 8vo. Pp. 292. 1907. Kegan Paul. 7s.6d.

Bligh, S. M. Applications of Psychology to Everyday Life. 3 vols. Pott. 8vo. The Desire for Qualities. Pp. 344. 1911. 3s.6d. The Direction of Desire. 4th imp. Pp. 372. 1919. 3s.6d. The Ability to Converse. Pp. 340. 1912. 5s. Oxford University Press.

Brackenbury, L. A Primer of Psychology. Fcap. 8vo. Pp. 139. 1919. Murray. 2s.

Brett, G. S. A History of Psychology: Ancient and Patristic. Demy 8vo. Pp. 388. 1912. Allen and Unwin. 12s. 6d.
Bridger, A. E. Minds in Distress : A Psychological Study of the Masculine and Feminine Mind in Health and Disorder. 2nd. edn. Cr. 8vo. Pp. 193. 1913. Methuen. 5s.

Brunt, D. The Combination of Observations. Demy 8vo. Pp. 230. 1917. Cambridge University Press. $10 s$.

Drever, $\mathbf{J}$. Instinct in Man : a Contribution to the Psychology of Education. 2nd edn. Demy 8vo. Pp.303 1921 . Cambridge University Press. 10s.6d.

Fuller, Sir B. The Science of Ourselves. Demy 8vo. Pp. 338. 1921. Frowde and Hodder. $16 s$.

Glover, W. Know Your Own Mind. A little book of Practical Psychology. Fcap. 8vo. Pp. 211. 1914. Cambridge University Press. $3 s$.

Granger, F.S. Psychology : A Short Account of the Human Mind. 4th edn. Cr. 8vo. Pp. 243. 1909 . Methuen. 5s.

Hayward, F. H. The Psychology of Educational Administration and Criticism. Cr. 8vo. Pp. 608. Herbert Russell. $7 s .6 d$.

Hoffding, H. Outlines of Psychology. Translated by M. E. Lowndes. New imp. Cr. 8vo. Pp. 376. 1912. Macmillan. $7 s$.

Jones, A. J. Character in the Making. Cr. 8vo. Pp. 144. 1913. Murray. 2s. $6 d$.

Loveday, T., and Green, J. A. An Introduction to Psychology, for the use of Students of Education. 3rd imp. Cr. 8vo. Pp. 272. 1915. Oxford: Clarendon Press. 6s.

McDougall, W. Psychology: the Study of Behaviour. Fcap. 8vo. Pp. 250. 1920. Williams and Norgate. $2 s .6 d$. 


\section{Psychology}

McDougall, W. Body and Mind: A History and a Defence of Animism. 4th edn. Demy 8vo. Pp.404. 1911. Methuen, 12s, $6 \mathrm{~d}$.

MacNamara, N. C. Instinct and Intelligence. $\mathrm{Cr}$. 8vo. Pp. 216. 1915. Frowde \& Hodder, $7 s, 6 d$.

Maher, M. Psychology, Empirical and Rational. 9th edn. Cr. 8vo. Pp. 632. 1919. Longmans. $11 s$.

McQueen, E. N. The Distribution of Attention. Roy. 8vo. Pp. 150. 1917. Cambridge University Press. 58 .

Marett, R. R. Psychology and Folk Lore. Cr. 8vo. Pp. 284. 1920. Methuen. is. $6 d$.

Marshall, H.R. Consciousness. 8vo. Pp. 700. 1909. Macmillan. 17s.

Maudsley, H. Organic to Human: Psychological and Sociological. 8vo. Pp. 394. 1916. Macmillan. $12 s$.

Mellone, S. H. Elements of Psychology. 4th edn. Cr.8vo. Pp.503. 1919. Blackwood. $7 s, 6 d$.

Merrington, E. M. The Problem of Personality. A Critical and Constructive Study in the Light of Recent Thought. Cr. 8vo. Pp. 239. 1916. Macmillan. 6s.

Mitchell, W. Structure and Growth of the Mind. 8vo. Pp.548. 1907. Macmillan. 12s. 6d.

Morgan, C. Lloyd. Psychology for Teachers. 2nd edn. 3rd imp. Cr. 8vo. Pp. 307. 1906. Arnold. $5 s$.

An Introduction to Comparative Psychology. Cr. 8vo. Scott Pub. Co. $7 s .6 d$.

-Instinct and Experience. 2nd edn. Cr. 8vo. Pp. 318. 1912. Methuen. 6s.

Parsons, J.H. Mind and the Nation : A Précis of Applied Psychology. Demy 8vo. Pp.154. 1918. Paper Covers. Bale and Danielsson. 7s. $6 d$.

Pearson, N. The Soul and Its Story . Demy 8vo. Pp. 336. 1913. Arnold. 10s . $6 d$.
Pillsbury, W. B. Attention. Med. 8vo. Pp. 346. 1908. Allen and Unwin. $12 s .6 d$.

Ribot, T. The Psychology of the Emotions. Cr. 8vo. Scott Pub. Co. $7 s, 6 d$.

Ryland, F. Psychology: An Introductory Manual for the use of Students. 10th edn. Cr. 8vo. Pp. 286. 1908. Bell. 4s. 6d.

- Questions on Psychology, Metaphysics and Ethics. Cr. 8vo. Pp. 143. 1887. Allen \& Unwin. 3s. $6 d$.

Shand, A. F. The Foundations of Character: being A Study of the Tendencies of the Emotions and Sentiments. 2nd edn. 8vo. Pp. 614. 1920. Macmillan. 20s.

Spencer, $H$. The Principles of Psychology. 2 vols. 8vo. Williams \& Norgate. $36 s$.

Stout, G. F. The Groundwork of Psychology, 6th imp. Cr. 8vo. Pp. 256.1919. University Tutorial Press. 6s. 6d.

-A Manual of Psychology. 3rd edn. 8th imp. Cr. 8vo, Pp. 788. 1920. University Tutorial Press. 12s. 6d.

Strong, C. A. The Origin of Consciousness : an Attempt to Conceive the $\mathrm{Mind}$ as a Product of Evolution. 2nd imp. 8vo. Pp. 338. (1918). 1920. Macmillan. 12s.

Sully, J. Outlines of Psychology . New edn. Cr.8vo. Pp.510. 1912. Longmans. $10 s .6 d$.

— The Teacher's Handbook of Psychology. 5th edn. Cr. 8vo. Pp. 626. 1919. Longmans. 7s.6d. The Human Mind: A Textbook of Psychology. 2 vols. 8vo. Pp. 520., 406. 1892. Longmans. $21 s$.

My Life and Friends. A Psychologist's Memories. Demy 8vo. Pp. 344. 1918. Fisher Unwin, 12s, 6d.

Varisco, B. Know Thyself. Translated by G. Salvadori. Med. 8vo. Pp. 327. 1915. Allen \& Unwin. $12 s, 6 d$. 


\section{Psychology}

Villa, G. Contemporary Psychology . Translated by H. Manacorda. Med. 8vo. Pp. 396. 1903. Allen \& Unwin. 12s. $6 d$.

Walker, G. E. Hereditary Characters and their Modes of Transmission. Demy 8vo. Pp. 252. 1910. E. Arnold. $10 s$.

Ward, J. Psychological Principles. and edn. Roy. 8vo. Pp. 492. 1920. Cambridge University Press. $26 s$.

Watt, H. J. The Psychology of Sound. Roy.8vo. Pp.250. 1917. Cambridge University Press. $10 s .6 d$ - The Economy and Training of Memory. 4th imp. Small Cr. 8vo. Pp. 136. 1915. Arnold. $2 s$.

Webb, E. Character and Intelligence. Roy. 8vo. Pp. $109 . \quad 1915$. Cambridge University Press, 6s, $6 d$

Wingfield-Stratford, E. The Reconstruction of Mind. An Open Way of Mind Training. Cr. 8vo. Pp. 246. 1921. Books, Ltd. 6s.

Wohlgemuth, A. On the After Effect of Seen Movement. Roy. 8vo. Pp. 126. 1912. Cambridge University Press. 5s.

- Pleasure-Un-Pleasure: an experimental investigation on the feeling-elements. Roy. 8vo. Pp. 260. 1919. Cambridge University Press. 14 s.

Wundt, W. M. Lectures on Human and Animal Psychology. Translated by J. E. Creighton and E. B. Titchener. 5th edn. Demy 8vo. Pp. 459. 1912. Allen \& Unwin. $10 s .6 d$.

An Introduction to Psychology. Translated by R. Pintner. Cr. 8vo. Pp. 198. 1912. Allen \& Unwin. $4 s, 6 d$.

\section{ii. EXPERIMENTAL AND PHYSIOLOGICAL PSYCHOLOGY .}

Baines, A. E. The Origin and Problem of Life. A Psycho-Physiological Study. Cr.8vo. Pp. 110. 1921. Routledge. 3s. $6 d$.

Ballard, P. B. Mental Tests. Cr. 8vo. Pp. 245. 1920. Hodder \& Stoughton. $6 s$.
Brown, W. Psychology and Psycho. therapy. Cr. 8vo. Pp. 208. 1921. Arnold. $8 s .6 d$.

and Thomson, G. H. The Essentials of Mental Measurement. Roy. 8vo. Pp. 226. 1921. Cambridge University Press. 21s.

Gowers, Sir W. R. Subjective Sensations of Sight and Sound Abiotrophy. 8vo. Pp. 250. 1904. Churchill. $6 s$.

Külpe, O. Outlines of Psychology: Based upon the Results of Experimental Investigation. 3rd edn. Demy 8vo. Pp.460. 1909. Allen \& Unwin. 12s. $6 d$.

McDougall, W. Physiological Psychology. 5th edn. Pott. 8vo. Pp. 172. 1918. Dent. 1s.9d.

Macnaughten-Jones, H. Ambidexterity and Mental Culture. Fcap. 8vo. Pp. 102. 1914. Heinemann. $2 s .6 d$.

Mercier, C. Criminal Responsibility: from the point of view of Psychology. 8vo. Pp. 232. 1905. Oxford: Clarendon Press. $10 s$.

Muscio, B. Lectures on Industrial Psychology. 2nd edn. Cr. 8vo. Pp. 300. 1920. Routledge.6s.6d.

Myers, C. S. An Introduction to Experimental Psychology. Roy. 16mo. Pp. 168. 1914. Cambridge University Press. $2 s, 6 d$.

- A Text-book of Experimental Psychology. 2nd edn. Demy 8vo. 2 Parts. 1911. Part 1. Text-book. Pp. 358. 9s. Part 2. Laboratory Exercises. Pp. 114. 6s. Cambridge University Press. The Two Parts, 13s. $6 d$.

Schulze, F. Experimental Psychology and Pedagogy, for Teachers, Normal Colleges, and Universities. Translated by R. Pintner. Demy 8vo. Pp. 364. 1907. Allen \& Unwin. $15 s$.

Scripture, E. W. The New Psychology. Cr. 8vo. Scott Pub. Co. $7 s, 6 d$. 
Storring, G. Mental Pathology in its Relation to Normal Psychology. Translated by T. Loveday. Demy 8vo. Pp. 298. 1907. Allen \& Unwin. $10 s .6 d$.

Stout, G. F. Analytic Psychology . 2 vols. 4th edn. Med. 8vo. Pp. 289., 314. 1918. Allen \& Unwin. $21 s$.

Stratton, G. M. Theophrastus and the Greek Physiological Psychology before Aristotle. Demy 8vo. Pp. 227. 1917. Allen \& Unwin. $8 s, 6 d$.

Tansley, A. G. The New Psychology and its Relation to Life. Demy 8 vo. Pp. 283. 1920. Allen \& Unwin. $10 s .6 d$.

Traube, M. R., and Stockbridge, F. P. Measure Your Mind. The Mentimeter and How to Use It. Large Cr. 8vo. Pp. 353. 1920. Harrap. 10s. 6d.

Valentine, C. W. An Introduction to Experimental Psychology, in Relation to Education. 2nd imp. Cr. 8vo. Pp. 204. 1916. University ${ }_{r}^{-T u t o r i a l ~ P r e s s . ~ 3 s . ~} 6 d$.

Weininger, $O$. Sex and Character. Translated from the German. New imp. Demy 8vo. Pp. 356. 1919. Heinemann. 12s, 6d.

Wundt, W. M. Principles of Physiological Psychology. Translated by E. B. Titchener. Vol. 1. The Bodily Substrate of the Mental Life. 2nd edn. Demy 8vo. Pp. 347. 1910. Allen \& Unwin. 12s.

Ziehen, T. Introduction to Physiological Psychology. Translated by C. C. Van Liew and O. W. Beyer. Cr. 8vo. Pp. 280. 1918. Allen \& Unwin. 6s.

\section{iii. MENTAL DEVELOPMENT} AND CHILD STUDY.

Bradby, M. K. The Logic of the Unconscious Mind. Demy svo. Pp. 330. 1920. Frowde \& Hodder. $16 s$.

Claparède, E. Experimental Pedagogy and the Psychology of the Child. Translated by M. Louch and H. Holman. 4thedn. Cr.8vo. Pp. 340. 1911. Arnold. 5s.
Dell, J. A. The Gateways of Knowledge. An Introduction to the Study of the Senses. Cr. 8vo. Pp. 183. 1912. Cambridge University Press. 3s. 6d.

Dexter, S. G. F., and Garlick, A. H. Psychology in the Schoolroom. Cr. 8vo. Pp. 425. 1913. Longmans. 5s. $6 d$.

Drummond, $M$. The Dawn of Mind. An Introduction to Child Psychology. Cr. 8vo. Pp. 191. 1918. Arnold. 3s.6d.

Drummond, W. B. The Child: its Nature and Nurture. Cr. 8vo. Pp. 223. Dent. 48.

- An Introduction to Child Study. 3rd imp. Cr.8vo. Pp. 348. 1007. Arnold. 6s.

Dumville, B. Fundamentals of Psychology. A brief account of the Nature and Development of Mental Processes for Teachers. 3rd imp. Cr. 8vo. Pp. 392. 1917. University Tutorial Press. 6s. 6d.

Child Mind: An Introduction to Psychology for Teachers. Cr. 8vo. Pp. 222. 1919. University Tutorial Press. $4 s$.

Keatinge, M. W. Suggestion in Education. 2nd edn. Cr. 8vo. Pp. 205. 1911. Black. 6s.

Kimmins, C. W. C hildren's Dreams . Cr. 8vo. Pp. 126. 1920. Longmans. 5s.

Macdonald, G. The Child's Inheritance. Its Scient ific and Imaginative Meaning: or an Enquiry into the Science of the Imagination. Demy 8vo. Pp. 339. 1910. Murray. $15 s$.

Meredith, C. M. The Bearings of Modern Psychology on Educational Theory and Practice. Cr. 8vo. Pp. 140. 1916. Constable. 3s.6d.

Mott, F. W. Nature and Nurture in Mental Development. Cr. 8vo. Pp. 151. 1914. Murray. 6s.

Mumford, E. E. R. The Dawn of Character in the Child. 7 th imp. Cr. 8vo. Pp. 226. 1920. Longmans. 5s. $6 d$. 
Myers, C. S. Mind and Work. The Psychological Factors in Industry and Commerce. Cr. 8vo. Pp. 216. 1920. University of London Press . $6 s$.

Reaney, M. J. The Psychology of the Organized Group Game, with special reference to its place in the Play System and its educational value. Roy. 8vo. Pp. 82, 1916. Cambridge University Press. $6 s$.

Sandiford, P. The Mental and Physical Life of School Children. Cr. 8vo. Pp. 358. 1919. Longmans. $7 s, 6 d$.

Slaughter, J. W. The Adolescent. 3rd.edn. Cr.8vo. Pp.100. 1919. Allen \& Unwin. $3 s, 6 d$.

Sully, J. Studies of Childhood, 8vo. Pp. 536. 1919. Longmans, 15s.

West, M. Education and Psychology. Cr. 8vo. Pp. 350. 1914. Longmans. $8 s .6 d$.

\section{iv. THE ANIMAL MIND.}

Binet, A., and Feré, C. Animal Magnetism. 5th edn. Cr. 8vo. Pp. 392. 1905. Kegan Paul. $7 s .6 d$.

Morgan, C. Lloyd. Animal Behaviour. 2nd edn. Cr. 8vo. Pp. 352. 1920. E. Arnold. 8s.6d.

Newland, C. B. What Is Instinct? Some Thoughts on Telepathy and Sub-consciousness in Animals. Cr. 8vo. Pp. 217. 1916. Murray. $7 s, 6 d$.

Romanes, G. J. Animal Intelligence. 9th edn. Cr. 8vo. Pp. 532. 1910. Kegan Paul. 7s.6d.

Smith, E. M. The Investigation of Mind in Animals. Cr. 8vo. Pp. 206. 1915. Cambridge University Press. 5s, 6d.

\section{v. THE ABNORMAL AND PSYCHO - ANALYSIS.}

Bousfield, P. The Elements of Practical Psycho-Analysis. Demy 8vo. Pp. 288. 1920. Kegan Paul. $10 s .6 d$.

Bradby, M. K. Psycho-Analysis and Its Place in Life. 2nd imp. Demy 8vo. Pp. 278. 1920. Frowde \& Hodder. 10s. 6d.
Freud, S. On Dreams. Translated from the German by M. D. Eder. Cr. 8vo. Pp. 144. Heinemann. 3s. $6 d$.

The Psychopathology of Every day Life. Translated by A. A. Brill. 6th imp. Demy 8vo. Pp. 342. 1920. Fisher Unwin. $12 s .6 d$.

Totem and Taboo: Resemblances between the Psychic Lives of Savages and Neurotics. Translated by A. A. Brill. 8vo. Pp. 280. 1919. Kegan Paul. 10s. $6 d$.

The Interpretation of Dreams. Translated by A. A. Brill. Demy 8vo. Pp. 410. 1920. Allen \& Unwin. 16s.

Wit and Its Relation to the Unconscious. New imp. in the Press. Fisher Unwin.

Hirsch, W. Genius and Degeneration. A Psychological Study. Demy 8vo. Pp.342. 1896. Heinemann. $17 s$.

Jones, E. Papers on Psycho-Analysis. 2nd edn. Roy. 8vo. Pp. 726. 1920. Baillière. $30 s$.

Jung, C. G. Collected Papers on Analytical Psychology. Authorised Translation. Edited by C. E. Long. 2nd edn. Demy 8vo. Pp. 520. 1917. Ballière. 18s.

-Studies in Word-Association. Experiments in the Diagnosis of Psychopathological conditions applied to normal and abnormal persons. Translated by M. D. Eder. Roy. 8vo. Pp. 575. 1918. Heinemann. 25s .

Leri, A. Commotions and Emotions of War. Edited by Sir J. Collie. Cr. 8vo. Pp. 262. 1919. University of London Press. $7 s .6 d$.

Long, C. E. Collected Papers on the Psychology of Fantasy. Demy 8vo. Pp.228. 1920. Baillière. 10s.6d.

Low, B. Psycho-Analysis: A Brief Account of the Freudian Theory. 2nd edn. Cr. 8vo. Pp. 191. 1920. Allen \& Unwin. $6 s$.

Nicoll, M. Dream Psychology. 2nd edn. Cr. 8vo. Pp. 209. 1920. Frowde \& Hodder. $7 s$. 
Ribot, T. Diseases of Memory : an Essay in the Positive Psychology. sth edn. Cr.8vo. Pp. 209. 1906. Kegan Paul. 7s. 6d.

Rivers, W. H. R. Instinct and the Unconscious . A Contribution to \& Biological Theory of the PsychoNeuroses. Demy 8vo. Pp. 260. 1920. Cambridge University Press. $16 s$.

Sully, J. Illusions: a Psychological Study. 4th edn. Cr. 8vo. Pp. 402. 1905. Kegan Paul 7s. 6d.

- An Essay on Laughter: its Forms, its Cause, its Development, and its Value. 8vo. Pp.458.1902. Longmans. $6 s$.

Watts, F. Abnormal Psychology and its Educational Applications. Cr. 8vo. Pp. 119. 1920. Allen \& Unwin. $7 s .6 d$.

Echo Personalities: A Short Study of the Contributions of Abnormal Psychology towards the Solution of some of the Problems of Normal Education. Cr. 8vo. Pp. 11. 1918. Allen \& Cnwin. 4s. $6 d$.

\section{vi. SOCIAL PSYCHOLOGY.}

Conway, Sir M. The Crowd in Peace and War. Cr.8vo. Pp 340. 1915. Longmans. $7 s, 6 d$.

Le Bon, G. The Crowd: A Study of the Popular Mind. 12th imp. 8vo. Pp. 239. 1920. Fisher Cnwin. 7s. $6 d$.
McDougall, W. An Introduction to Social Psychology. 15th edn. Cr. 8vo. Pp. 483. 1920. Methuen. 8s. 6d.

- The Group Mind: A Sketch of the Principles of Collective Psychology with some attempt to Apply them to the Interpretation of National Life and Character. Roy. 8vo. Pp. 320. 1920. Cam. bridge University Press. 21s.

Spencer, $\mathbf{H}$. The Principles of Sociology. Vol. 1. Pt. 1. The Data of Sociology; Pt. 2. The Induction of Sociology ; Pt. 3. Domestic Institutions. 8vo. 21s. Vol. 2. Pt. 4. Ceremonial Institutions; Pt. 5. Political Institutions. 8vo. 18s. Vol. 3. Pt.6. Ecclesiastical Institutions; Pt. 7. Professional Institutions; Pt. 8. Industrial Institutions. 8vo. 16s. Williams and Norgate.

Study of Sociology. 22nd edn. Cr. 8vo. Pp. 408. 1908. Kegan Paul. 78. 6d.

Trotter, W. Instincts of the Herd in Peace and War. 2nd edn. Med. 8vo. Pp. 264. 1920. Fisher Unwin. $8 s .6 d$.

Wallas, G. The Great Society: A Psychological Analysis. New imp. Demy 8vo. Pp. 395. 1920. Macmillan. $10 s$.

Wundt, W. M. Elements of Folk Psychology : Outlines of A Psychological History of the Development of Mankind. Translated by E. L. Schaub. Med.8vo. Pp. 305. 1900. Allen \& Unwin. 15s. 


\section{MATHEMATICS.}

\section{i. COLLECTED PAPERS.}

Andrews, T. The Scientific Papers of the late Thomas Andrews. With a Memoir by Profs. Tait and Crum Brown. 8vo. Pp. 578. 1889. Macmillan. $18 s$.

Barrow, I. Mathematical Works. Edited by W. Whewell. Demy 8vo. Pp. 339. 1860. Cambridge University Press. $7 s, 6 d$.

Cayley, A. Collected Mathematical Papers. Demy 4to. 1889-1899. Vols. I to XIII. Pp. 600 approx. each vol. 31s. 6d, each. Index. Pp. 147. 1898. 16s. Cambridge University Press.

Clifford, W. K. Mathematical Papers. Fdited by R. Tucker. Introduction by H.J.S. Smith. 8vo. Pp. 740. 1882. Macmillan. 30s.

Hopkinson, J. Original Papers. Edited by B. Hopkinson. 2 vols. Demy 8vo. 1901. Vol. 1. Technical Papers, Memoir. Pp. 360. Vol .2. Scientific Papers. Pp. 394. Cambridge University Press. $13 s$. $6 d$. each.

Kelvin, Lord. Mathematical and Physical Papers. 6 vols. Demy 8vo. Cambridge University Press. Vol. 1. Mainly 1841-53. Pp. 573. 1882. 21s. Vol. 2. Mainly 1853-56. Pp. 418. 1884. 17s. 6d. Vol. 3. Elasticity, Heat, ElectroMagnetism. Pp.540. 1890. 21s. Vol.4. Hydrodynamies and General Dynamics. Pp.579. 1910. 21s. Vol.5. Thermodynamics, Cosmical and Geological Physics, Molecular and Crystalline Theory, Electrodynamics. Pp. 617. 1911. 21s. Vol. 6. Voltaic Theory, Radioactivity, Electrons, Navigation and Tides, Miscellaneous. Pp. 386. 1911. $11 s$.
Knott, C. G. (edited by). The Napier Tercentenary Memorial Volume; Papers contributed to the congress held at Edinburgh in July, 1914. 4to. Pp. 454. 1915. Longmans. $21 s$.

Reynolds, O. Papers on Mechanical and Physical Subjects. 3 vols. Roy.8vo. Vol. 1. Pp.431. 1900. 20s. Vol.2. Pp.338. 1880.27s. 6d. Vol.3. Pp.271. 1903. 15s. Cambridge University Press .

Smith, H. J. S. Collected Mathematical Papers. Edited with a Mathematical Introduction by $\boldsymbol{J}$. W. L. Glaisher. 2 vols. 4to. Vol. 1. Pp. 690. Vol. 2. Pp. 728. Oxford: Clarendon Press. 63s.

Sylvester, J. J. Collected Mathematical Papers. Edited by H.F. Baker. 4 vols. Roy. 8vo. Vol. 1. Pp. 662. 1904. Vol.2. Pp. 747. 1908. Vol. 3. Pp. 703. 1909. Vol. 4. Pp. 783. 1912. Cambridge University Press. $21 s$. each.

Tait, P.G. Scientific Papers. 2 vols. Demy 4to. Vol. 1. Pp. 514. 1898. Vol. 2. Pp. 500. 1900. Cambridge University Press. 30s. each.

\section{ii. HISTORY.}

Allman, G.J. Greek Geometry from Thales to Euclid. 8vo. Pp. 250. 1889. Longmans. 15s. $6 d$.

Ball, W. W. R. A Short Account of the History of Mathematics. 6th edn. Large Cr. 8vo. Pp. 546. 1915. Macmillan. 12s. 6d.

Cunnington, S. The Story of Arithmetic: A Short History of its Origin and Development. Cr. 8vo. Pp. 254. 1904. Allen \& Unwin. 3s. $6 d$. 


\section{Mathematics}

Frankland, W. B. Theories of Parallelism: an historical critique. Demy 8vo. Pp.88.1910. Cambridge University Press. 5s.6d.

Heath, T. L. Diophantus of Alexandria, a Study in the History of Greek Algebra. 2nd edn. Roy. 8vo. Pp. 396. 1910. Cambridge University Press. 15s.

- The Works of Archimedes. Edited in modern notation. Demy 8vo. Pp. 502. 1897. Cambridge University Press. 17s. 6d.

- The Method of Archimedes. A Supplement to the above. Cr. 8vo. Pp. 51. 1912. Cambridge University Press. 3s.

Hobson, E. W. "Squaring the Circle." A History of the Problem. Demy 8vo. Pp. 66. 1913. Cambridge University Press. 3s. 6d

Knott, C. G. The Life and Scientific Work of Peter Guthrie Tait. Demy 4to. Pp. 390. 1911. Cambridge University Press. 15s.

\section{iii. PHILOSOPHY AND PEDAGOGY OF MATHEMATICS.}

Berkeley, H. Mysticism in Modern Mathematics. 8vo. Pp. 276. 1910. Oxford: Clarendon Press. $8 s$.

Branford, B. Mathematical Educa. tion, including the Teaching of Arithmetic. Cr. 8vo. Pp. 404. 1908. Oxford: Clarendon Press. $5 s$.

Jaeger, F. M. Lectures on the Principle of Symmetry and its application in all Natural Sciences. Roy. 8vo. Pp. 346. 1919. Cambridge University Press. $20 s$.

Nunn, T. P. The Teaching of Algebra, including Trigonometry. New edn. Cr. 8vo. Pp. 632. 1919. Longmans. $9 s$.

Thomson, J.B. The Art of Teaching Arithmetic. 2nd edn. Cr. 8vo. Pp. 304. 1921. Longmans. 6s.

Whitehead, A. N. Introduction to Mathematics. Fcap. 8vo. Pp. 256. 1911. Williams \& Norgate. $2 s .6 d$.
Whitehead, A. N. and Russell, B. Principia Mathematica. Roy. 8vo. Vol. 1. Pp. 679. 1910. 25s. Vol. 2. Pp. 796. 1912. 30s. Vol. 3. Pp. 501. 1913. 25s. Cambridge University Press.

Young, J. W. A. Monographs on Topics of Modern Mathematics Relevant to the Elementary Field. New edn. 8vo. Pp. 424. 1915. Longmans. $15 s$.

The Teaching of Mathematics in the Elementary and Secondary School. New edn. Cr. 8vo. Pp. 378. 1919. Longmans, $7 s .6 d$.

iv. EXAMINATION PAPERS.

Fawdry, R. C. Problem Papers in Mathematics on the lines of the Examinations by the Civil Service Commission. With Answers. Cr. 8vo. Pp. 224. 1915. Macmillan. $5 s$.

Milne, R. M. (edited by). Mathematical Papers for admission into the Royal Military Academy and the Royal Military College; and Papers in Elementary Engineering for Naval Cadetships and Royal Air Force, for the years 1911-1920, with Answers. Cr. 8vo. 1921. Macmillan. 10s. 6d.

Radford, E. M. Mathematical Problem Papers. 2nd edn. Cr. 8vo. Pp. 210. 1914. 6s. Solutions. Pp.566. 1914. 12s.6d. Cambridge University Press.

Wolstenholme, J. Mathematical Problems, on subjects included in the First and Second Divisions of Cambridge Mathematical Tripos. 3rd edn. 8vo. Pp. 512. 1891. Macmillan. 18s.

\section{v. POPULAR.}

Ball, W. W.R. Mathematical Recreations and Essays. 7th edn. Ex. cr. 8vo. Pp. 508. 1919. Macmillan. 10s. $6 d$.

\section{vi. GENERAL PURE MATHEMATICS.}

Bowley, A. L. A General Course of Pure Mathematics from Indices to Solid Analytical Geometry. 8vo. Pp. 284. 1913. Oxford: Clarendon Press. $7 s, 6 d$. 


\section{Mathematics}

Hardy, G. H. A Course of Pure Mathematics. 2nd edn. Demy 8vo. Pp. 156. 1914. Cambridge Univèrsity Press. $14 s$.

Whittaker, E. T., and Watson, G. N. A Course of Modern Analysis. An Introduction to the General Theory of Infinite Processes, and of Analytic Functions; with an account of the Principal Transcendental Functions. 3rd edn. Roy. 8vo. Pp. 608. 1920. Cambridge University Press. $40 \mathrm{~s}$.

\section{vii. FUNCTIONS.}

Baker, H. F. An Introduction to the Theory of Multiply-Periodic Functions. Roy. 8vo. Pp. 351. 1907. Cambridge University Press. $17 s$.

Abel's Theorem and the Allied Theory, including the Theory of the Theta Functions. Roy. 8vo. Pp. 704. 1897. Cambridge University Press. $30 s$.

Bôcher, M. An Introduction to the Study of Integral Equations. 2nd edn. Demy 8vo. Pp.71.1914. Cambridge University Press. $3 s$.

Dixon, A.C. The Elementary Properties of the Elliptic Functions. Gl. 8vo. Pp. 150. 1894. Macmillan. $5 s$.

Forsyth, A. R. Lectures Introductory to the Theory of Functions of Two Complex Variables. Roy. 8vo. Pp. 297. 1914. Cambridge University Press. 15s.

- Theory of Functions of a Complex Variable. 3rd edn. Roy.8vo. Pp. 879. 1918. Cambridge University Press. $33 s$.

Gray, A., and Mathews, G. B. A Treatise on Bessel Functions and their Applications to Physics. 8vo. New imp.in the Press. Macmillan. $14 s$.

Greenhill, Sir A. G. The Applications of Elliptic Functions. 8vo. Pp. 370. 1892. Macmillan. 14s.

Hardy, G. H., and Riesz, M. The General Theory of Dirichlet's Series. Demy 8vo. Pp. 86. 1915. Cambridge University Press. $4 s$.
Hardy, G. H. Orders of Infinity . The Infinitärcalcül of Paul du Bois-Reymond. Demy 8vo. Pp. 70. 1910. Cambridge University Press. 3s.

Hobson, E. W. The Theory of Functions of A Real Variable and the Theory of Fourier's Series. Vol. 1. 2nd edn. Roy.8vo. Pp.688. 1921. Cambridge University Press. $45 s$.

Macrobert, T. M. Functions of a Complex Variable. 8vo. Pp. 312. 1917. Macmillan. 12s.

Watson, G. N. Complex Integration and Cauchy's Theorem. Demy 8vo. Pp. 88. 1914. Cambridge Uni versity Press. 3s.6d.

Young, W. H., and G. C. The Theory of Sets of Points. Demy 8vo. Pp. 328. 1906. Cambridge University Press. 128.

\section{viii. VEGTORS AND QUATERNIONS.}

Hamilton, Sir W. R. Elements of Quaternions. Edited by C.J.Joly. 2 vols. Vol. 1. Pp. 622. 1899. Vol. 2. Pp. 558. 1901. Long: mans. 30s.6d. each. vol.

Hayward, R. B. The Algebra of CoPlanar Vectors and Trigonometry. Cr. 8vo. Pp. 376. 1892. Macmillan. $8 s, 6 d$.

Henrici, O., and Turner, G. C. Vectors and Rotors: with Applica. tions. Cr. 8vo. Pp. 220. 1910. Arnold. $5 s$.

Joly, C.J. A Manual of Quaternions . 8vo. Pp. 348. 1892. Macmillan. $12 s .6 d$.

Kelland, P., and Tait, P. G . Introduction to Quaternions: with numerous Examples. 3rd edn. Cr. 8vo. Pp. 226. 1904. Macmillan. $8 s .6 d$.

McAulay, A. Utility of Quaternions in Physics. 8vo. Pp. 122. 1893. Macmillan. 6s, $6 d$.

Silberstein, I. Projective Vector Algebra. An Algebra of Vectors, independent of the Axioms of Congruence and of Parallels. Demy 8vo. Pp.76.1919. Bell.7s.6d. Vectorial Mechanics. 8vo. Pp. 206. 1913. Macmillan. 10s. 


\section{Mathematics}

Silberstein, L. Filements of Vector Algebra. C'r. 8vo. Pp, 48. 1919. Longmans. $5 s .6 \mathrm{~d}$.

Weatherburn, C. E. Elementary Vector Analysis: with Application to Geometry and Physics. Demy 8vo. Pp. 211 . 1921. Bell. 12s.

iX . APPLIED MATHEMATICS DYNAMICS, PHYSICS, etc.

Havelock, T. H. The Propagation of Disturbances in Dispersive Media. Demy 8vo. Pp 96. 1914. Cambridge University Press. $4 s .6 d$.

Ibbetson, W. J. The Mathematical Theory of Perfectly Elastic Solids. with A Short Account of Viscuous Fluids. 8vo. Pp. 582. 1887. Macmillan. $21 \mathrm{~s}$.

Leathem, J. G. The Elementary Theory of the Symmetrical Optical Instrument. Demy 8vo. Pp. 82. 1908. Cambridge Lniversity Press. $3 s$.

Newton, Sir I. The First Three Sections of Newton's Principia, with Notes, Illustrations, and Problems. Edited by P. Frost. 3rd edn. 8vo. Pp. 308. 1900. Macmillan. $14 s$.

Tarleton, F. A. An Introduction to the Mathematical Theory of Attraction. 2 vols. Cr. 8vo. Vol. 1. Pp. 302. 1899. 10s.6d. Vol. 2. Pp. 220. 1913. 6s. Longmans.

\section{PRACTICAL APPLIED MATHEMATICS (ELEMENTARY).}

Bates, E. L., and Charlesworth, F. Practical Mathematic's and Geometry. A Text-book for Students in Technical and Trade Schools, etc. Cr.8vo. 1919. Part 1. Preliminary Course. Pp. 230. 2s. 6d. Part 2. Elementary Course, Pp. 220. 2s. 6d. Part 3. Advanced Course. Pp. 320. 5s. Parts 1, 2 and 3 together. 8s. Batsford.

Practical Mathenatics. Comprising a complete Course of Instruction for Technical sturlents and Practical Men. Znd edn. Cr. 8vo. Pp. 520. 1917. Batsford. 5s.
Brodetsky, S. A First Course in Nomography. 8vo. Pp.147. 1920. Bell. 10s. $6 d$.

Castle, F. Workshop Mathematics. 2 Parts. Gl. 8vo. Pp. 178., 208. 1919. 1920. Macmillan. 1s.9d. each.

Practical Mathematies for Beginners. New imp. G1. 8vo. Pp. 410. 1920. 3s. 6d. Key. 6s. 6d. Macmillan.

- Manual of Practical Mathematics. G1. 8vo. Pp. 634. 1919. Macmillan. $7 s$.

- Elementary Practical Mathematies for Technical Sturlents. New imp. G1. 8vo. Pp. H4. 1919. Macmillan. 4s.

Cocks, O. H., and Glover, F. P. Mathematies of Business and Commerce. Cr. 8vo. Pp. 25. 1920. Hodder \& Stoughton. 4s.6d.

Cracknell, A. G. Practical Mathematics: with Tables of Logs and Antilogs. C'r.8vo. Pp.398. 1920. Longmans. is. 6d.

Dobbs, W..J. Weighing and Measuring. A Short Course of Practical Exercises in Elementary Mathematies and Physies. Cr. 8vo. Pp. 184. 1910. Mèthuen. 3s. $6 d$.

Forrest, S. N. Mathematics for Technical Students. Junior Course. Cr.8vo. Pp. 268. 1920. Arnold. 7s. $6 \mathrm{~d}$.

Gates, S. B. Pure Mathematics for Engineers. Cr. 8vo. 2 vols. Pp. 202., 190. 1920. Hodder \& Stoughton. 4s.6d. each.

Gibb, D. A Course in Interpolation and Numerical Integration for the Mathematical Laboratory. Pp.90. 191. Bell. 3s. 6d.

Haler, P. J., and Stuart, A. H. A Course in Mathematics for Technical Students. Cr.8vo. Part 1. 2nd edn. 3rd imp. Pp. 204. 1919. 3s. Part 2. Pp. 371. 1920. 6s. Cniversity Tutorial Press.

Harvey, F. W. Everyman's Mathematics. Cr. 8vo. Pp. 142, 1920. Methuen. $4 s$. 


\section{Mathematics}

Hovenden, F. Practical Mathematics for Engineers. Cr. 8vo. Pp. 144. 1907. Jas. Munro. 3s. 6d.

Hudson, H. P. Ruler and Compasses. Cr. 8vo. Pp. 150. 1916. Longmans. $6 s$. $6 d$.

Knott, C. G., and Mackay, J. S. Practical Mathematics. Revised new edn. Cr. 8vo. Pp.639. N.D. Chambers. 6s.

Larard, C. E., and Golding, H. A. Practical Calculations for Engineers. Vol. 1. 4th edn. Cr. 8vo. Pp. 399. 1918. 5s. Vol. 2. In preparation. Griffin .

M'Lachlan, N.W. Practical Mathematics for Students attending Evening and Day Technical Classes. Cr. 8vo. Pp. 184. 1913. Longmans. 3s. $6 d$.

Mann, H. L. A Text-book on Practical Mathematics for Advanced Technical Students. 8vo. Pp. 500. 1915. Longmans. 10s.6d.

Mellor, J. W. Higher Mathematics for Students of Chemistry and Physics with special reference to Practical Work. 4th edn. 8vo. Pp. 682. 1920. Longmans. $21 s$.

Millis, C. T. Technical Arithmetic and Geometry. For Use in Technical Institutes and Workshops. 3rd edn. Cr. 8vo. Pp. 316. 1919. Methuen. 5s.

Partington, J. R. Higher Mathematics for Chemical Students. 2nd edn. Cr. 8vo. Pp. 272. 1920. Methuen. 6s.

Percival, A. S. Practical Integration for the Use of Engineers, etc. Cr. 8vo. Pp. 122. 1909. Macmillan. 3s.

Perry, J. Elementary Practical Mathematics. 8vo. Pp. 350. 1913. Macmillan. $7 s$.

Rose, W. N. Mathematics for Engineers. 2 vols. Demy 8 vo. Vol. 1. 2nd edn. Pp. 520. 1920. 10s, 6d. Vol. 2. Pp. 433. 1920. 13s. 6d. Chapman \& Hall.
Sandon, F. Everyday Mathematics. Cr. 8vo. Pp. 272. 1920. Hodder \& Stoughton. $4 s, 6 d$.

Saxelby, F. M. An Introduction to Practical Mathematics. 7 th imp. Cr. 8vo. Pp. 228. 1919. Longmans. $4 s$.

_- A Course in Practical Mathematics. Stages ii and iii. 8vo. Pp. 484. 1913. Longmans. 12s.

Sprague, E.H. Elementary Mathe. matics for Engineers. Cr. 8vo. Pp. 236. 1916. Scott, Greenwood, 5s .

Stern, H. A., and Topham, W. H. Practical Mathematics. 2nd edn. Cr. 8vo. Pp. 418. 1920. Bell. $6 s$.

Turner, G. G. Graphical Methods in Applied Mathematics. Cr. 8vo. Pp. 398. 1909. Macmillan. 7s.

Usherwood, T. S., and Trimble, C. J.A. Practical Mathematics for Technical Students. Cr.8vo. Part 1. Pp.378. 1919. 4s. Part 2. Pp. 576. 1916. 8s.6d. Macmillan.

\section{xi AlgeBra.}

\section{a. Elementary.}

Baker, W. M., and Bourne, A. A. Elementary Algebra, with or with. out Answers. 17th edn. Cr. 8vo. Pp. 560. 1919. 6s. Key to ditto. 3rd edn. Pp. 252. 1919. 12s. Bell.

Barnard, S., and Child, J.M. A New Algebra. With or without Answers. Cr. 8vo. Vol. 1. Pp. 320. 1919. 4s, 6d. Key, 7s, 6d. Vol. 2. Pp. 431. 1919. 5s. Key. 10s. Macmillan.

Borchardt, W. G. Elementary Algebra, with Answers. 7th edn. Cr. 8vo. Pp. 562. 1918. 5s. Key Complete. Cr. 8vo. Pp.511. 1912. 10s. Rivington.

Briggs, W., and Bryan, G. H. The Tutorial Algebra. Advanced Course. 4th edn. 11th imp. Cr.8vo. Pp.655. 1919. 9s.6d. Key. כs. University Tutorial Press. 
Briggs, W., and Bryan, G. H. A Middle Algebra (from the Tutorial Algebra). 4th imp. Cr. 8vo. Pp. 364. 1916. University Tutorial Press. 5s.

Buck, R. C. A Manual of Algebra. Designed to meet the Requirements of Sailors and Others. 2nd edn. Cr. 8vo. Pp. 166. 1906. Griffin. 3s. $6 d$.

Chrystal, G. Introduction to Algebra. 3rd edn. Cr. 8vo. Pp. 412. 1914. Black. 6s.

Cracknell, A. G. School Algebra. With Answers. 2nd imp. Cr. 8vo. Pp.654. 1919. University Tutorial Press. $7 s, 6 d$.

Davison, C. Algebra for Secondary Schools. Cr. 8vo. Pp.632. 1918. $10 s$. , or in 2 Vols. 6s. Bd. each. Cambridge University Press.

- Higher Algebra for Colleges and Secondary Schools. Demy 8vo. Pp. 328. 1918. Cambridge University Press. 8s. 6d.

Deakin, R. Elementary Algebra (formerly entitled The New Matriculation Algebra). 4th edn. 11th imp. Cr. 8vo. Pp. 416. 1914. 4s. 6d. Key. 6s. 6d. University Tutorial Press.

Eastwood, G.S., and Fielden, J.R. Algebra for Engineering Students. Cr. 8vo. Pp. 208. 1919. Arnold. 7s. $6 d$.

French, C. H., and Osborn, G. Elementary Algebra. Cr. 8vo. Pp. 514. 1908. Cambridge University Press. 5s.

Gibson, G. A. Elementary Treatise on Graphs. Cr. 8vo. Pp. 244. 1919. Macmillan. 4s. $6 d$.

Godfrey, C., and Siddons, A. W. Elementary Algebra. Cr. 8vo. Pp. 638. 1920. Cambridge University Press. $8 s$.

Hall, H. S. A School Algebra, with Answers. Cr.8vo. Pp.624. 1919. 5s. 6d. Key to ditto. Pp. 672. 1919. 12s. Macmillan.

and Knight, S. R. Eilemen. tary Algebra for Schools, with Answers. 8th edn. GI. 8vo. Pp.
524. 1919. 5s. Key, for Teachers only. Pp. 464. 1919. 10 . Macmillan.

Higher Algebra. 4th edn. Cr. 8vo. Pp. 570. 1919. 8s. 6d. Key to ditto. Pp. 380. 1020 . 12s. 6d. Macmillan.

Nunn, T. P. Exercises in Algebra, including Trigonometry. Cr. 8vo. Part 1., with Answers. Pp. 368. 1918. 78. 6d. without Answers. 6s. 6d. Part 2, with Answers. Pp. 564. 1914. 8s.6d., without Answers. $7 s .6 d$. Longmans.

O'Dea, J. J. The New Explicit Algebra in Theory and Practice. Cr. 8vo. Pp. 748. 8s. 6d. Also in two Parts. Part 1, 3s.6d. Part 2, 5s. 6d. Longmans.

Ross, P. Elementary Algebra for the use of Higher Grade and Secondary Schools, with Answers. New imp. Cr.8vo. Pp.504. 1919. 7s. 6d. Also in two parts. 4s. 6d. each. Longmans.

Smith, C. A Treatise on Algebra. 5th edn. Cr. 8vo. Pp. 664. 1920. 8s. 6d. Key to ditto. Pp. 322. 1914. 12s. 6d. Macmillan.

Smith, J. H. Elementary Algebra, with Answers. Cr. 8vo. Pp. 478. 1919. 5s. Key. Cr. 8vo. Pp. 424. 1908. 10s. Longmans.

\section{b. Higher Algebra, Theory of Equations and Quantics.}

Burnside, W. S., and Panton, A. W. The Theory of Equations: with an Introduction to the Theory of Binary Algebraic Forms. 2 Vols. 8vo. Vol. 1. 8th edn. Pp. 300. 1018. Vol.2. 6th edn. Pp. 308 . 1916. Longmans. 15s. 6d. each Vol.

Chrystal, G. Algebra, an Elementary Text-book for the Higher Classes of Secondary Schools and Colleges. Post 8vo. Part 1. 5th edn. Pp. 571. 1910. 12s.6d. Part 2. 2nd edn. Pp.616. 1919. 12s. 6d. Black.

Dickson, L. E. Linear Algebras. Demy 8vo. Pp. 82. 1914. Cambridge University Press. $3 s .6 d$. 


\section{Mathematics}

Elliott, E. B. Algebra of Quantics, an introduction, having as its primary object the explanation of the leading principles of invariant Algebra. 2nd edn. 8vo. Pp. 432. 1913. Oxford: Clarendon Press. $15 s$.

Klein, F. Lectures on the Icosahedron, and the Solutions of Equations of the Fifth Degree. Translated by G. G. Morrice. 2nd edn. 8vo. Pp. 305. 1913. Kegan Paul. 10 s. $6 d$.

Macaulay, F. S. The Algebraic Theory of Modular Systems. Demy 8vo. Pp. 126. 1916. Cambridge University Press. 5s.6 $d$.

Mathews, G. B. Algebraic Equations. 2nd edn. Demy 8vo. Pp. 72. 1915. Cambridge University Press. 3s.

Milne, W. P. Higher Algebra. Cr. 8vo. Pp. 598. 1913. Arnold. $8 s, 6 d$.

-Homogeneous Co-ordinates. $\mathrm{Cr}$. 8vo. Pp. 176. 1910. Arnold. 6s.

Whitehead, A. N. A Treatise on Universal Algebra. Vol. 1. Roy. 8vo. Pp. 612. 1898. Cambridge University Press. 24s.

\section{c. Determinants, Theory of Groups, etc.}

Burnside, W. Theory of Groups of Finite Order. 2nd edn. Demy 8vo. Pp. 526. 1911. Cambridge University Press. 17s. 6d.

Gampbell, J. E. Theory of Continuous Groups, an Introductory Treatise on Lie's Theory of Finite Continuous Transformation Groups . 8vo. Pp. 436. 1903. Oxford: Clarendon Press. 14s.

Gullis, G. E. Matrices and Determinoids. Roy.8vo. Vol.1. Pp. 442. 1914. 24s. Vol.2. Pp. 580. 1918. 42s. Cambridge University Press.

Grace, J. H., and Young, A. The Algebra of Invariants. Demy 8 vo. Pp. 384. 1903. Cambridge University Press. $12 s .6 d$.
Hilton, H. Homogeneous Linear Substitutions. A collection for the benefit of the Mathematical Student of those properties of the Homogeneous Linear Substitution, with real or complex co-efficients of which frequent use is made in the Theory of Groups and the Theory of Bilinear Forms and Invariant Factors. 8vo. Pp. 192. 1914. Oxford: Clarendon Press. 12s.6d.

-Theory of Groups of Finite Order, an Introduction which aims at introducing the reader to more advanced treatises and original papers on Groups of Finite Orders . 8vo. Pp. 24.8. 1908. Oxford: Clarendon Press. $14 s$.

MacMahon, P. A. An Introduction to Combinatory Analysis. 8vo. 1920. Cambridge University Press. $7 s .6 d$.

Combinatory Analysis. 2 Vols. Roy.8vo. Vol.1. Pp.329. 1915. 20s. Vol. 2. Pp. 359. 1916. 18s. Cambridge University Press.

Muir, Sir T. Theory of Determinants in the Historical Order of Development. 8vo. Vol. 1. Part 1. General Determinants up to $\mathbf{1 8 4 1}$. Vol. 1. Part 2. Special Determinants up to 1841. Pp. 504. 1906. 21s. Vol.2. The Period 1841 to 1860. Pp.492. 1911. 21s. Vol. 3. The Period 1861 to 1880 . Pp. 530. 1920. 35s. Macmillan.

Scott, R. F. The Theory of Determinants and their Applications. 2nd edn., revised by G.B. Mathews. Demy 8vo. Pp. 299. 1904. Cambridge University Press. $12 s$.

Wright, J. E. Invariants of Quadratic Differential Forms. Demy 8vo. Pp. 98. 1908. Cambridge University Press. $3 s$.

\section{xii. GAlGULUS .}

\section{a. Elementary .}

Andrews, E. S., and Heywood, H. B. The Calculus for Engineers. Cr. 8vo. Pp. 284. 1914. Scott, Greenwood. $5 s$. 
Baker, W. M. The Calculus for Beginners. 4th edn. Cr. 8vo. Pp. 166. 1919. Bell. 3s.6d.

Barker, A. H. Graphical Calculus. 5th imp. Cr. 8vo. Pp. 208. 1914. Longmans. 5s. $6 d$.

Blaine, R. G. The Calculus and Its Applications. A Practical Treatise for Engineering Students. Cr. 8vo. Pp. 332. 1919. Constable. $\tilde{s}$.

Carey, F. S. Infinitesimal Calculus. New imp. 8vo. Pp. 366. 1919. 16s. also in two parts. Part 1. 7s. 6d. Part 2. 10s. 6d. Longmans.

Carslaw, H. S. An Introduction to the Infinitesimal Calculus. Notes for the use of Science and Engineering Students. 2nd edn. 8vo. Pp. 154. 1919. Longmans. $6 s .6 d$.

Caunt, G. W. Introduction to the Infinitesimal Calculus, with Applications to Mechanics and Physies. 8vo. Pp. 588. 1914. Oxford: Clarendon Press. $10 s$.

Gibson, G. A. Elementary Treatise on the Calculus. Cr. 8vo. Pp. 552. 1919. Macmillan. 8s,6d.

Graham, J. An Elementary Treatise on the Calculus, for Engineering Students. 4th edn. Cr. 8vo. Pp. 355. 1914. Spon. 8s.6d.

Lamb, H. An Elementary Course of Infinitesimal Calculus. 3rd edn. Demy 8vo. Pp. 54t. 1919. Cam. bridge University Press. 22s. 6d.

Larkman, A. E. The Calculus, for Marine Engineers. Demy 8vo. Pp. 92. 1918. James Brown. 4s. $6 d$.

McNeile, A. M., and J. D. A School Calculus. Med. 8vo. Pp. 375. 1911. Murray. 9s.

Mayo, C.H.P. Elementary Calculus. Cr. 8vo. Pp. 404. 1919. Rivington. $10 s$.

Mercer, J. W. The Calculus for Beginners. Cr. 8vo. Pp. 464. 1919. Cambridge University Press. 8s. $6 d$.
Milne, W. P., and Westcott, G. J. B. A First Course in the Calculus. Cr.8vo. Part 1. 2nd edn. Pp. 196. 1919. 4s. Part 2. Trigonometric and Logarithmic Functions of X, etc. Pp. 260. 1920. 5s. 2 Parts in 1 Vol. 8s.6d. Bell.

Murray, D. A. A First Course in the Infinitesimal Calculus. Cr. 8vo. Pp. 458. 1918. Longmans. 8s.6d.

Perry, J. The Calculus for Engineers. 13th imp. Cr. 8vo. Pp. 390. Arnold. 8s.6d.

Smith, R. H. The Calculus for Engineers and Physicists, Integration and Differentiation, with Applications to Technical Problems : and Classified Reference List of Integrals. 2nd edn. Cr. 8vo. Pp. 222. 1908. Griffin. $9 s$.

Thompson, S. P. Calculus Made Easy. 2nd edn. Gl.8vo. Pp.314. 1919. Macmillan. $3 s$.

\section{b. Differential and Integral.}

Davison, C. Differential Calculus. Cr. 8vo. Pp. 309. 1919. Bell. 6s. $6 d$.

Edwards, J. Differential Calculus for Beginners. Gl. 8vo. Pp.272. 1919. Macmillan. 5s.

The Differential Calculus: with Applications and numerous Examples. 3rd edn. 8vo. Pp. 546. 1918. Macmillan. 17s.

-The Integral Calculus for Beginners. Gl. 8vo. Pp. 322. 1919. Macmillan. $5 s$.

Hardy, G. H. The Integration of Functions of a Single Variable. 2nd edn. Demy 8vo. Pp. 75. 1916. Cambridge University Press. $4 s$.

Leathem, J. G. Volume and Surface Integrals used in Physics. 2nd edn. Demy 8vo. Pp. 54. 1913. Cambridge University Press. $3 s$.

Lodge, A. Integral Calculus for Beginners. 2nd edn. Cr. 8vo. Pp. 203. 1911. Bell. 5s. Differential Calculus for Beginners. 4th edn. Cr. 8vo. Pp. 299. 1913. Bell. 5s. 


\section{Mathematics}

Love, A. E. H. Elements of the Differential and Integral Calculus. Cr. 8vo. Pp. 222. 1918. Cambridge University Press. 6s. 6d.

Murray, D. A. Differential and Integral Calculus. Cr. 8vo. Pp. 510. 1918. Longmans. 9s.

Prasad, G. A Text Book of Integral Calculus. 8vo. Pp. 252. 1910. Longmans. $9 s$.

A Text-Book of Differential Calculus. 8vo. Pp. 124. 1909. Longmans. $8 s$.

Stoney, J. An Introduction to the Differential and Integral Calculus: for the use of Engineering and Technical Students. Cr. 8vo. Pp. 146. 1919. Pitman. 3s. 6d.

Taylor, F. G. An Introduction to the Differential and Integral Calculus and Differential Equations. Сr. 8vo. Pp. 592. 1916. Longmans. 10s. $6 d$.

Todhunter, I. A Treatise on the Differential Calculus. Cr. 8vo. Pp. 428. 1919. 12s.6d. Key to ditto. Cr.8vo. Pp. 160. 1920. 12s. 6d. Macmillan.

- A Treatise on the Integral Calculus. Cr. 8vo. Pp. 416. 1916. 12s, 6d. Key to ditto. Cr. 8vo. Pp. 138. 1913. 12s.6d. Macmillan.

Wansbrough, W. D. A.B.C. of the Differential Calculus. 3rd edn. Cr.8vo. Pp.148. 1912. Technical Pub. Co. 4s. $9 d$.

Williamson, B. An Elementary Treatise on the Integral Calculus. Cr. 8vo. Pp. 538. 1918. Longmans. $12 s, 6 d$.

An Elementary Treatise on the Differential Calculus: containing the Theory of Plane Curves. Cr. 8vo. Pp. 488. 1920. Longmans. 12s. $6 d$.

Young, W. H. The Fundamental Theorems of the Differential Calculus. Demy 8vo. Pp. 82. 1910. Cambridge University Press. $3 s$.

\section{c. Differential Equations, etc.}

Bateman, H. Differential Equa. tions. 8vo. Pp. 318. 1918. Longmans. $10 s .6 d$.

Forsyth, A. R. A Treatise on Differential Equations. 4th edn. 8vo. Pp.602. 1914. 17s. Solutions of the Examples. 8vo. Pp. 249. 1918. 10s. Macmillan.

'Theory of Differential Equations. Demy 8vo. Part 1. Exact Equations and Pfaff's Problem. Pp. 352. 1899. 10s. Part 2. Ordinary Equations, not linear. 2 Vols. Pp. 356., 401. 1900. 27s. Part 3. Ordinary Linear Equations. Pp. 550. 1902. 16s. Part 4. Partial Differential Equations. 2 Vols. Pp. 488., 609. 1906. 31s,6d. Cambridge University Press.

Murray, D. A. An Introductory Course in Differential Equations. 14th imp. Cr. 8vo. Pp. 252. 1919. Longmans. 6s. 6d.

Page, J. M. Ordinary Differential Equations. Cr. 8vo. Pp. 246. 1897. Macmillan. 6s, 6d.

Piaggio, H. T. H. An Elementary Treatise on Differential Equations and their Applications. Demy 8vo. Pp. 257. 1920. Bell. 12s.

Xiii. HIGHER GEOMETRY, PURE AND ANALYTICAL, AND DIFFERENTIAL GEOMETRY.

Basset, A. B. A Treatise on the Geometry of Surfaces. 8vo. Pp. 291. 1910. Bell. 12s. 6d.

An Elementary Treatise on Cubic and Quartic Curves. 8vo. Pp. 255. 1901. Bell. 12s.6d.

Besant, W. H. Notes on Roulettes and Glissettes. 2nd edn. Cr. 8vo. Pp. 99. 1890. Bell. 5s.

Coolidge, J.L. A Treatise on the Circle and the Sphere. 8vo. Pp. 604. 1916. Oxford: Clarendon Press. 21s. 


\section{Mathematics}

Ferrers, N. M. An Elementary Treatise on Trilinear Co-ordinates, the Method of Reciprocal Polars, and the Theory of Projectors. 4th edn. Cr. 8vo. Pp. 198. 1890. Macmillan. 6s.6d.

Forsyth, A. R. Lectures on the Differential Geometry of Curves and Surfaces. Roy. 8vo. Pp. 550. 1912. Cambridge University Press. $40 s$.

Fowler, R. H. The Elementary Differential Geometry of Plane Curves. Demy 8vo. Pp. 114. 1920. Cambridge University Press. $6 s .6 d$.

Frost, P. An Elementary Treatise on Curve Tracing. 4th edn. Revised by R. J. T. Bell. 8vo. Pp. 226. 1918. Macmillan. 12s.6d.

Hatton, J.L.S. The Theory of the Imaginary in Geometry. Roy. 8vo. Pp. 224. 1920. Cambridge University Press. $19 \mathrm{~s}$.

Henderson, A. The Twenty-Seven Lines upon the Cubic Surface. Demy 8vo. Pp. 108. 1911. Cambridge University Press. 5s.6d.

Hime, H. W. L. Anharmonic Coordinates. 8vo. Pp.142. 1910. Longmans. $7 s .6 d$.

Hudson, R. W. H. T. Kummer's Quartic Surface. Demy 8vo. Pp. 230. 1905. Cambridge University Press. $10 s$.

Jessop, C. M. Quartic Surfaces with Singular Points. Demy 8vo. Pp. 234. 1916. Cambridge University Press. 12s.

-A Treatise on the Line Complex. Demy 8vo. Pp. 379. 1903 . Cambridge University Press. 12s.6d.

Thompson, A. W. H. A New Analysis of Plane Geometry, Finite and Differential. Demy 8vo. Pp. 136. 1914. Cambridge University Press. 7s.

Whitehead, A. N. The Axioms of Descriptive Geometry. Demy 8vo. Pp. 82. 1914. Cambridge University Press. 3s.
Wood, P.W. The Twisted Cubic, with some account of the Metrical Properties of the Cubical Hyperbola. Demy 8vo. Pp. 88. 1913. Cambridge University Press. $3 s$.

\section{xiv. PURE GEOMETRY.}

\section{a. Elementary.}

Askwith, E. H. A Course of Pure Geometry. Containing a complete Geometrical Treatment of the Properties of the Conic Sections. New edn. Demy 8vo. Pp. 295. 1917. Cambridge University Press. 7s, 6d.

Baker, W. M., and Bourne, A. A. A New Geometry. 4th edn. Cr. 8vo. Pp. 250. 1919. Bell. 3s. $6 d$.

Elementary Geometry : A Modern Text-book of Practical and Theoretical Geometry. 12th edn. Cr. 8vo. Pp. 474. 1919. 5s. 6d. Complete Key. 4th edn. Cr. 8vo. Pp. 178. 1917. 8s.6d. Bell.

Barnard, S., and Child, J. M. Elements of Geometry. New imp. Cr. 8vo. Pp. 508. 1919. Macmillan. 5s.

A New Geometry for Schools. New imp. Cr. 8vo. Pp. 539. 1916. Macmillan. 5s.

Budden, E. Elementary Pure Geometry with Mensuration. A Complete Course of Geometry. $\mathrm{Cr}$. 8vo. Pp. 292. 1904. Chambers. $3 s$.

Burchett, R. Practical Geometry: A Course of Instruction of Plane Geometrical Figures for the Use of Schools. 18th edn. Cr. 8vo. 1894. Chapman and Hall. 5s.6d.

Davison, C. The Elements of Plane Geometry. Cr. 8vo. Pp. 280. 1920. Cambridge University Press. $10 s$.

and Richards, C. H. Plane Geometry for Secondary Schools. Cr.8vo. Pp.419. 1907. Cambridge University Press. $8 s$.

Dobbs, H. J. A School Course in Geometry, with Answers. Cr. 8vo. Pp. 466. 1913. Longmans. 6s.

Durell, C. V. A Concise Geometry . Cr. 8vo. Pp. 327. 1921. Bell. $5 s$. 
Durell, G. V. Modern Geometry. The Straight Line and Circle. Cr. 8vo. Pp. 156. 1920. Macmillan. $6 s$.

Eagles, T. H. Constructive Geometry of Plane Curves. Cr. 8vo. Pp. 394. 1885. Macmillan. $12 s$.

Edmondson, T. W. Deductions in Geometry. Riders and Practical Problems, with Full Solutions. 5th imp. Cr. 8vo. Pp.223. 1920. University Tutorial Press. $4 s$.

Godfrey, G., and Siddons, A. W. Modern Geometry. Cr. 8vo. Pp. 178. 1908. 6s. Solutions. 5s.6d. Cambridge University Press.

Elementary Geometry, Practical and Theoretical. 3rd edn. Cr. 8vo. Pp. 518. 1918. 2 Parts. 4s. each. Complete in $1 \mathrm{Vol} .7 s$. Solutions by E. A. Price. 3rd edn. 7s, 6d. Cambridge University Press.

-A Shorter Geometry. Cr. 8vo. Pp. 332. 1919.4s.6d. Solutions by E. A. Price. 6s. Cambridge University Press.

- Practical Geometry and Theoretical Geometry. Cr. 8vo. Pp. 396. 1920. Cambridge University Press. $7 s$.

Hall, H. S., and Stevens, F. H. A School Geometry. Parts I-VI. Containing Plane and Solid Geometry, treated both theoretically and graphically. New imp. Gl. 8vo. Pp. 476. 1920.5s 。 Key. 10s. Macmillan.

Lachlan, R. An Elementary Treatise on Modern Pure Geometry. 8vo. Pp. 298. 1893. Macmillan. 9s.

Lawson, G. A New Geometry for Schools. Cr. 8vo. Pp. 260. 1914. Chambers. $2 s, 6 d$.

Low, D. A. Text-book on Practical Solid and Descriptive Geometry. New imp. Cr.8vo. 1920. Part 1. Pp. 120. 3s. Part 2. Pp. 140. 4s. Longmans.

Mackay, J. S. Plane Geometry: Practical and Theoretical. (Corresponding to Euclid's Elements I-VI.) Cr. 8vo. Pp. 388. 1905. Chambers. $3 s .6 d$.
Millar, J. B. Elements of Descriptive Geometry. 3rd edn . Cr. 8vo. Pp. 216. 1913. Macmillan. $7 s$.

Milne, J.J. An Elementary Treatise on Cross-Ratio Geometry. Cr. 8vo. Pp. 312. 1911. Cambridge University Press. $6 s$.

Russell, J.W. Pure Geometry: an Elementary Treatise. New and Revised edn. Cr. 8vo. Pp. 370 . 1905. Oxford: Clarendon Press. $9 s$.

-Sequel to Elementary Geometry. Cr.8vo. Pp. 208. 1907. 6s. Solutions to the Examples (Key). Cr.8vo.Pp.112.1908. 10s.6d. Oxford: Clarendon Press.

Wilson, J. C. On the Traversing of Geometrical Figures. 8vo. $\mathrm{Pp}$. 166. 1905. Oxford: Clarendon Press. 6s. $6 d$.

Workman, W. P., and Cracknell, A. G. The School Geometry? (Euclid I-VI.) 2nd edn. Cr. 8vo. Pp. 439. 1920. University Tutorial Press. $6 s$.

Geometry, Theoretical and Prac. tical. Part 1. (Euclid, 1; iii., 1-34; iv., 1-9.) 4th imp. Cr. 8vo. Pp. 368. 1919. 4s. Part 2. (Euclid, ii ; iii., 35-37; iv ., 10-16 ; vi.) 3rd imp. Cr. 8vo. Pp. 214. 1916, 3s. Part 3. (Euclid, xi.) 2nd imp. Cr.8vo. Pp. 76. 1911. $2 s .3 d$. University Tutorial Press.

\section{b. Conic Sections .}

Bryan, G. H., and Pinkerton, R. H. The Elements of the Geometry of the Conic. Cr.8vo. Pp. 270 . Dent. $4 s, 6 d$.

Cockshott, A., and Walters, F.B. A Treatise on Geometrical Conics. Cr. 8vo. Pp. 216. 1918. 6s. Key to ditto. by $\mathrm{O}$. Emtage. $\mathrm{Cr}$. 8vo. Pp. 128. 1914. 6s, 6d. Macmillan.

Drew, W.H. A Geometrical Treatise on Conic Sections. Cr. 8vo. Pp. 178. 1898. Macmillan. 5s.

Macaulay, F. S. Geometrical Conics. 2nd ed. Cr.8vo. Pp. 310. 1906. Cambridge University Press. 7s. 
Milne, J., and Davis, R. F Geometrical Conics. Cr. 8vo. Pp. 230. 1890. Macmillan. 4s. 6d.

Smith, C. Geometrical Conies. Cr. 8vo. Pp. 268. 1919. 7s. Key to ditto. Cr. 8vo. Pp. 150. 1904. $7 s$. Macmillan.

Smith, J. H. Geometrical Conic Sections. 9th imp. Cr.8vo. Pp. 174. 1918. Longmans. 5s.

\section{c. Solid Geometry .}

Atkinson, E. H. De V. A Textbook of Practical Solid Geometry, etc., for the Use of the Royal Military Academy, Woolwich. New imp. 8vo. Pp. 134. 1914. spon. 7s.6d.

Davison, C. The Elements of Solid Geometry. Cr. 8vo. Pp. 130. 1920. Cambridge University Press. $4 s$.

Godfrey, C., and Siddons, A. W. Solid Geometry. Cr. 8vo. Pp. 120. 1920. 2s. 3d. Solutions by C. L. Beaven. $7 s .6 d$. Cambridge University Press.

Heath, R. S. Solid Geometry. Including the Mensuration of Surfaces and Solids. 4th edn. $\mathrm{Cr}$. 8vo. Pp. 123. 1919. Rivington. $4 s$.

Unwin, P. W. Practical Solid Geometry. Cr. 8vo. Pp. 270. 1909. Bell. 5s.

\section{d. Projective Geometry .}

Cremona, L. Elements of Projective Geometry. Translated by C. Leudesdorf. 3rd edn. 8vo. Pp. 324. 1913. Oxford: Clarendon Press. $12 s, 6 d$.

Filon, L. N. G. An Introduction to Projective Geometry. 2nd edn. Cr.8vo. Pp. 255. 1916. Arnold. 7s. $6 d$.

Hatton, J. L. S. The Principles of Projective Geometry applied to the Straight Line and Conic. Roy. 8vo. Pp. 376. 1913. Cambridge University Press. 12s. 6d.
Mathews, G. B. Projective Geometry. Cr. 8vo. Pp. 364. 1914. Longmans. $6 s$.

Pickford, A. G. Elementary Projective Geometry. Cr. 8vo. Pp. 268. 1909. Cambridge University Press. 5s.

Smart, E. H. A First Course in Projective Geometry. Cr. 8vo. Pp.298. 1913. Macmillan.8s.6d.

Whitehead, A. N. The Axioms of Projective Geometry. Demy 8vo. Pp. 72. 1913. Cambridge University Press. $3 s$.

\section{ANALYTICAL GEOMETRY.}

Askwith, E. H. Analytical Geometry of the Conic Sections. 2nd edn. Demy 8vo. Pp. 443. 1918. Black. 10s. 6d.

Baker, W. M. Algebraic Geometry . A New Treatise on Analytical Conic Sections. 6th 'edn. $\mathrm{Cr}$. 8vo. Pp. 369. 1919. 7s.6d. Key. Pp. 224. 1907. 8s, 6d. Bell.

Bell, R. J. T. An Elementary Treatise on Co-ordinate Geometry of Three Dimensions. 2nd edn. 8vo. Pp. 412. 1918. Macmillan. 12s. 6d.

Briggs, W., and Bryan, G. H. The Right Line and Circle (Coordinate Geometry). 3rd edn. 14th imp. Cr. 8vo. Pp. 296. 1918. 5s. Key. 5s. University Tutorial Press.

Worked Examples in Co-ordinate Geometry. 2nd edn. 4th imp. Cr. 8vo. Pp. 84. 1913. 2s. 3d. University Tutorial Press.

Coleman, P. Co-ordinate Geometry, an Elementary Course. Cr. 8vo. Pp. 240. 1913. Oxford: Clarendon Press. 3s. 6d.

Davison, $C$. The Elements of Analytical Conies. Cr. 8vo. Pp. 246. 1919. Cambridge University Press. 10s. 6d. 


\section{Mathematics}

Gibson, G. A., and Pinkerton, P. Elements of Analytical Geometry. Cr. 8vo. Part 1. The Straight Line and Circle. Part 2. Graphs and Curve Tracing. Part 3. Conic Sections. Each $3 s .6 d$. or in $1 \mathrm{Vol}$. Cr 8vo. Pp. 498. 1919. 8s.6d. Macmillan.

Grace, J. H., and Rosenberg, F. Co-ordinate Geometry: an elementary treatise on the Straight Line, Circle, and Conic. 4th imp. Cr. 8vo. Pp. 412. 1919. University Tutorial Press. 6s. $6 d$.

Hilton, H. Plane Algebraic Curves. 8vo. Pp. 404. 1920. Oxford University Press. 28s.

Jones, A. C. Introduction to Algebraical Geometry, with Answers. 8vo. Pp. 548. 1912. Oxford: Clarendon Press. 10s.

- - Notes on Analytical Geometry, with Answers. Cr. 8vo. Pp. 176. 1903. Oxford: Clarendon Press. $6 s$.

Loney, S. L. Elements of Coordinate Geometry. 3rd edn. Cr. 8vo. Pp. 440. 1919. 7s. Key to ditto. Cr. 8vo. Pp. 268. 1917. 10s. Macmillan.

Milne, J. Analytical Geometry of the Straight Line and Circle. Cr. 8vo. Pp. 243. 1919. Bell. 5s. $6 d$.

Salmon, G. A Treatise on the Analytic Geometry of Three Dimensions. Revised by R.A.P. Rogers. 2 Vols. 8vo. Vol. 1. 6th edn. Pp. 494. 1914. 12s.6d. Vol.2. 5th edn. Pp. 350. 1915. 10s.6d. Longmans .

- A Treatise on Conic Sections. 8vo. Pp. 416. 1917. Longmans. $14 s$.

Scott, G. A. Cartesian Plane Geometry: Analytical Conics. Cr. 8vo. Pp. 428. Dent. 6s. 6d.

Smith, C. An Elementary Treatise on Conic Sections by the Methods of Co-ordinate Geometry. Cr. 8vo. Pp. 460. 1920. 8s.6d. Key to ditto. Cr. 8vo. Pp. 386. 1915. 12s. 6d. Macmillan.
Smith, C. An Elementary Treatise on Solid Geometry. Cr. 8vo. Pp. 258. 1917. Macmillan. 10s.6d.

Tuckey, C. O., and Nayler, W. A. Analytical Geometry: A First Course. Cr. 8vo. Pp. 382. 1918. Cambridge University Press. $6 s$.

\section{XVi. PRAGTICAL GEOMETRY AND GRAPHICS.}

Bates, E. L., and Charlesworth, F. Practical Geometry and Graphics. A Complete Course of Instruction for Technical Students and Practical Men. Cr.8vo. Pp. 630. 1912. Batsford. 5s.

Evans, T. J ., and Pullen, W.W.F. A Treatise on Practical Plane and Solid Geometry. Demy 8vo. 1898. Chapman and Hall. $10 s$.

Harrison, J ., and Baxandall, G.A. Practical Geometry and Graphics for Advanced Students. 2nd edn. G1. 8vo. Pp. 692. 1919. Macmillan. $7 s$.

Low, D. A. Practical Geometry and Graphies. 8vo. Pp. 456. 1912. Longmans. 8s. $6 d$.

Morris, I. H., and Husband, J. Practical Plane and Solid Geometry. Cr.8vo. Pp. 284. 1919. Longmans. 4s.

Paynter, J.E. Practical Geometry for Architects and Builders. Demy 8vo. Pp.421. 1921. Chapman and Hall. 15s.

Smith, R.H. Graphics, or the Art of Calculating by Drawing Lines, applied to Mechanical Engineering. 8vo. Pp. 282. 1889. Longmans. $18 s$.

\section{xVii. MENSURATION.}

Angles, J. W. Mensuration for Marine and Mechanical Engineers Cr. 8vo. Py. 196. 1919. Longmans. $5 s$.

Briggs, W., and Edmondson, T . W. Mensuration and Spherical Geometry. 3rd edn. 9th imp. Cr.8vo. Pp.168. 1918. 5s. Key to Mensuration. $2 s .3 d$. University Tutorial Press. 
Chivers, G. T. Elementary Mensuration: with Answers. 4th imp. Cr. 8vo. Pp. 34t. 1917. Longmans. 6s.

Stevens, F. H. Elementary Mensuration. New imp. Gl. 8vo. Pp. 255. 1919. Macmillan. 4s.

Todhunter, I. Mensuration for Beginners. New imp. Pott. 8vo. Pp. 304. 1918. 3s. Key by F.L. M'Carthy. Cr. 8vo. 8s. 6d. Macmillan.

\section{xviii . EUCLID.}

Archibald, R. C. Euclid's Book on Divisions of Figures. Roy. 8vo. Pp. 196. 1915. Cambridge University Press. $10 s$.

Deakin, R. Euclid. Books I-IV. 2nd edn. 7th imp. Cr. 8vo. Pp. 348. 1919. 4s. Books V., VI., and XI. 4th imp. Cr. 8vo. Pp. 156. 1909. 2s. 3d. University Tutorial Press.

Hall, H. S., and Stevens, F. H. A Text-Book of Euclid's Elements. Books I.-VI. and XI., XII. New edn. Cr.8vo Pp.470. 1918. Macmillan. $5 s$.

Heath, Sir T. L. The First Book of Euclid in Greek. Fcap. 8vo. Pp. 250. 1920. Cambridge University Press. $10 s$.

The Thirteen Books of Euclid's Elements. Translated from the Text of Heiberg . Roy 8vo. 3 Vols. Pp. 434., 436., 554. 1908. Cambridge University Press. 52s.6d.

Hill, M. J. M. The Theory of Proportion. Demy 8vo. Pp. 128. 1914. Constable. 68 .

The Contents of the Fifth and Sixth Books of Euclid. 2nd edn. Fcap. 4to. Pp. 186. 1908. Cambridge University Press. $8 s$.

Nixon, R. C. J. Euclid Revised, containing the Essentials of the Filements of Plane Geometry as given by Euclid in his first Six books. 3rd edn. 7th imp. Cr. 8vo. Pp. 448. 1915. Oxford : Clarendon Press. 6s.
Todhunter, I., and Loney, S. L. The Elements of Euclid for the use of Schools and Colleges. New edn. Cr. 8vo. Pp. 472. 1912. Macmillan. $5 s$.

\section{XiX. NON - EUCLIDEAN GEOMETRY .}

Carslaw, H. S. The Elements of Non-Euclidean Plane Geometry and Trigonometry. Cr. 8vo. Pp. 192. 1916. Longmans. $6 s$.

Coolidge, J. L. Non-Euclidean Geometry, the Elements. 8vo. Pp. 292. 1909. Oxford : Clarendon Press. $15 s$.

Sommerville, D. M. Y. The Elements of Non-Euclidean Geometry. Demy 8vo. Pp. 274. 1914. Bell. 7s, $6 d$.

-Bibliography of Non-Euclidean Geometry, including the Theory of Parallels, the Foundations of Geometry, and space of $\boldsymbol{N}$ dimensions. Demy 8vo. Pp. 416. St. Andrew's University (Frowde). Paper Cover. $10 s$.

XX. TRIGONOMETRY.

\section{a. Elementary.}

Abbott, P. Numerical Trigonometry • Cr. 8vo. Pp. 174. 1918. Longmans. $6 s$.

Adams, H. Practical Trigonometry . For the Use of Engineers, Architects and Surveyors. 3rd edn. Cr. 8vo. Pp. 78. 1919. Pitman. $5 s$.

Borchardt, W. G., and Perrott, A. D. A New Trigonometry for Schools, with or without Answers. 12th edn. Cr. 8vo. Pp. 420. 1919. 5s. 6d. Complete Key. Cr. 8vo. Pp. 423. 1916. 10s. Bell.

Briggs, W., and Bryan, G. H. The Tutorial Trigonometry. 2nd edn. 10th imp. Cr. 8vo. Pp. 334. 1920. University Tutorial Press. 58 .

Buck, R. C. A Manual of Trigonometry, with Diagrams, Examples, and Exercises. 5th edn. Cr. 8vo. Pp. 121. 1919. Griffin. 3s.6d. 


\section{Mathematics}

Davison, C. A Class Book of Trigonometry. Cr. 8vo. Pp. 208. 1916. Cambridge University Press. $4 s .6 d$.

Plane Trigonometry for Secondary Schools. Cr. 8vo. Pp. 342. 1919. Cambridge University Press. 6s. $6 d$.

Dunkley, W. G. Trigonometry for Engineers, with numerous worked practical examples. Cr. 8vo. Pp. 179. 1920. Pitman. 5s.

Goodwin, H. B. Plane and Spherical Trigonometry. 11th imp. 8vo. Pp. 284. 1919. Longmans. 10s.6d.

Hall, H.S., and Knight, S.R. Elementary Trigonometry. 4th edn. G1.8vo. Pp. 430. 1920. 5s. Key. Сr. 8vo. Pp. 315. 1919. 10s. Macmillan.

Hobson, E. W., and Jessop, C. M. An Elementary Treatise on Plane Trigonometry. Fcap. 8vo. Pp. 332. 1913. Cambridge University Press. $7 s .6 d$.

Levett, R., and Davison, G. The Elements of Plane Trigonometry. G1. 8vo. Pp. 552. 1915. Macmillan. $8 s$.

Lock, J. B. Elementary Trigonometry. 6th edn. G1.8vo. Pp.314. 1918. 5s. Key, for Teachers only. Pp. 236. 1910. 10s. 6d. Higher Trigonometry. 4th edn. G1.8vo. Pp. 226. 1919. 5s. Macmillan. and Child, J. M. A New Trigonometry for Schools and Colleges. Cr. 8vo. Pp. 500. 1911. Macmillan. $7 s$.

Loney, S. L. The Elements of Trigonometry. 4th edn. Fcap. 8vo. Pp. 265. 1920. Cambridge University Press. 4s.6d.

- Plane Trigonometry. 11th edn. Cr. 8vo. Pp. 240. 1919. 10s. or in 2 Parts. Part 1. 6s. Solutions. 15s. Part 2. 5s. Solutions. 7s.6d. Cambridge University Press .

Maxwel1, F. W . Trigonometry for the 1918 Examinations. 3rd edn. Demy 8vo. Pp. 100. 1918. James Brown. 2s, 6d.
Mercer, J. W. Numerical Trigonometry. Cr.8vo. Pp.168. 1912. Cambridge University Press . 4s.6d. Trigonometry for Beginners. Cr. 8vo. Pp. 367. 1919. Cambridge University Press. $6 s$.

Palmer, J.H. Practical Logarithms and Trigonometry. G1. 8vo. Pp. 186. 1917. Macmillan. 5s.

Piggot, H. E. Elementary Plane Trigonometry. Cr. 8vo. Pp. 255. 1919. Constable. 7s.6d.

Reed, H. L. Plane Trigonometry. 2nd edn. Cr. 8vo. Pp.320. 1918. Bell. 5s.

Smith, J.H. Elementary Trigonometry. New imp. Cr.8vo. Pp. 232. 1918. 6s. Key. 8s. Longmans.

Swanwick, F. T . Elementary Trigonometry. Cr. 8vo. Pp. 260. 1911. Cambridge University Press . 5s. $6 d$.

Todhunter, I. Plane Trigonometry . Revised by R. W. Hogg. Cr. 8vo. Pp. 414. 1919. 6s. Key to ditto. Cr.8vo. Pp. 486. 1911. 12s.6d. Macmillan.

\section{b. Plane and Spherical.}

Carslaw, H.S. Plane Trigonometry . An Elementary Text-book for Higher Classes of Secondary Schools and for Colleges. 2nd edn. $\mathrm{Cr}$. 8vo. Pp. 322. (1914.) 1920. 5s. Key. Pp. 180. 1915. 8s. Macmillan.

Davison, C. The Elements of Plane Trigonometry. Cr. 8vo. Pp. 280. 1920. Cambridge University Press. $10 s$.

Hobson, E. W. A Treatise on Plane Trigonometry. 4th edn. Demy 8vo. Pp. 398. 1918. Cambridge University Press. 12s.6 6 .

Johnson, W.E. A Treatise on Trigonometry. Cr. 8vo. Pp. 522. 1889. Macmillan. 8s.6d.

M'Glelland, W. J., and Preston, 'T . A Treatise on Spherical Trigonometry. Cr.8vo. Part 1. To the End of Solution of Triangles. Pp. 158. 1912. 5s. Part 2. Pp. 202. 1909. 6s. Macmillan. 


\section{Mathematics}

Todhunter, I. Spherical Trigonometry for the Use of Colleges and Schools. Revised by J.G. Leathem. Cr. 8vo. Pp. 288. 1919. Macmillan. $8 s .6 d$.

\section{xxi. ARITHMETIC.}

Abbott, P. Exercises in Arithmetic and Mensuration. Cr. 8vo. 1918. With Answers. Pp. 620. 8s. 6d. Without Answers. Pp.534.6s.6d. Longmans .

Baker, W. M., and Bourne, A. A. Public School Arithmetic. 5th edn. Cr. 8vo. Pp. 450. 1920. Bell. 5s. $6 d$.

Borchardt, W. G. Practical Arithmetic for Schools. With Answers. 5th edn. Cr.8vo. Pp.529. 1919. 5s. Key to the above. Cr. 8vo. Pp. 649. 1911. 10s.6d. Rivington.

Brooksmith, J. Arithmetic in Theory and Practice. New imp. Cr. 8vo. Pp. 432. 1910. 5s. Key, for Teachers only. Cr. 8vo. $12 s$. 6d. Macmillan.

Castle, F. Workshop Arithmetic. Cr. 8vo. Pp. 182. 1919. Mac. millan. 1s.9d.

Clapham, C. B. Arithmetic for Engineers. 2nd edn. Demy 8vo. Pp. 477. 1920. Chapman \& Hall. $7 s .6 d$.

Comrie, P., and Woodburn, W. New Commercial Arithmetic with Answers. Cr. 8vo. Pp. 224. Chambers. 2s. 6d.

Godfrey, C., and Price, E. A. Arithmetic. Cr. 8vo. Pp. 479. 1919. With answers 6s. Without answers 5s.6d. Cambridge University Press.

Grant, F. I., and Hill, A. M. Commercial Arithmetic, with Answers. Cr. 8vo. Pp. 430. 1920. Longmans. 6s.

Hall, H. S., and Stevens, F. H. A School Arithmetic. New imp. Cr. 8vo. Pp. 552. 1920. With Answers 5s. 6d. Without Answers 4s. 6d. Key. Pp. 347. 1917. 12s. 6d. Macmillan.
Hall, H. S., and Stevens, F. H. Examples in Arithmetic. Taken from "A School Arithmetic," with or without Answers. New imp. Cr. 8vo. Pp. 330. 1919. 3s. 6d. Key. 12s.6d. Macmillan.

Jones, H. S. A Modern Arithmetic with Graphic and Practical Exercises. New imp. Gl. 8vo. Pp. 676. 1918. With or without Answers. Macmillan. 5s.

Lock, J . B. Arithmetic for Schools. 5th edn. Gl. 8vo. Pp. 496. 1918. With or without Answers. 5s. Key. 12s,6d. Macmillan.

Lodge, Sir O. J. Easy Mathematics. Chiefly Arithmetic. 4th imp. Cr. 8vo. Pp. 452. 1917. Macmillan. $5 s$.

Loney, S. L. Arithmetic for Schools. 2nd edn. New imp. GI. 8vo. Pp. 530. 1919. With or without Answers. Macmillan, 5s.

O'Dea, J. J. The New Explicit Arithmetic in Theory and Practice. 4th edn. Cr. 8vo. Pp. 582. 1912. 8s. 6d. Also in two Parts. Part 1. 3s.6d. Part 2. 5s.6d. Longmans.

Pendlebury, C., and Robinson, F. E. New School Arithmetic, with or without Answers. 16th edn. Cr. 8vo. Pp. 512. 1918. Bell. 5s. $6 d$.

Punnett, M. Groundwork of Arithmetic. Cr. 8vo. Pp. 246. 1921 . Longmans. $4 s .6 d$.

Smith, B. Arithmetic for Schools. New edn. Revised by W. H. H. Hudson. Cr.8vo. Pp. 468. 1905. 5s. Key, for Teachers only. 10s. Macmillan.

Smith, J. H. A Treatise on Arithmetic, with Answers. 5s. 6d. W'ithout Answers. 23rd imp. Cr. 8vo. Pp. 376. 1918. 5s. Key. $10 s$. Longmans.

Workman, W. P. The Tutorial Arithmetic, with Answers. 3rd edn. 14th imp. Cr.8vo. Pp. 587. 1920. 6s. 6d. Key. 6s. 6d. University Tutorial Press. 


\section{Mathematics}

Workman, W. P. The School Arithmetic (adapted from the Tutorial Arithmetic), with Answers. 2nd edn. 12th imp. Cr. 8vo. Pp. 555. 1919. 5s.6d. Key.6s.6d. University Tutorial Press.

- and Chope, R. H. Worked Problems in Higher Arithmetic. Cr. 8vo. Pp. 152. 1904. University Tutorial Press. 3s.

\section{xxii. LOGARITHMS \\ AND SLIDE RULE.}

Blaine, R. G. The Slide Rule as an aid in Calculating. 5th edn. Fcap. 8vo. Pp. 152. 1919. Spon. 3s. $6 d$.

Dunlop, H. G., and Jackson, C. S. Slide-Rule Notes. Cr. 8vo. Pp. 136. 1913. Longmans. $3 s .6 d$.

Hoare, C. The Slide Rule and How to Use It. 8th edn. Cr. 8vo. Pp. 110. 1918. Crosby Lockwood. 4s.

Matthews, G. F. Manual of Logarithms. 8vo. Pp. 134. 1890. Macmillan. $5 s$.

O'Dea. J. J. An Elementary Treatise on Logarithms. Cr. 8vo. Pp. 70. 1903. Longmans. 2s.

Pickworth, C. N. Logarithms for Beginners. 7th edn. Cr. 8vo. Pp. 54. 1919. Emmott. 1s.6d. - The Slide Rule. A Practical Manual. 16th edn. Cr. 8vo. Pp. 133. 1919. Emmott. $3 s$. $6 d$.

Wolstenholme, J. Examples for Practice in the Use of Seven-Figure Logarithms. 8vo. Pp. 64. 1888. Macmillan. $5 s$.

\section{xxiii. MATHEMATICAL AND PHYSICAL TABLES.}

Abbott, P. Mathematical Tables and Formulæ. Cr. 8vo. Pp. 62. 1918. Longinans. 2s. $6 d$.

Babbage, G. Tables of Seven-Figure Logarithms of the Natural Numbers from 1 to 108,000 . 8vo. Pp. 224. Spon. 6s.

Barlow's Tables of Squares and Cubes, Square Roots, Cube Roots and Reciprocals of all Integer Numbers up to $10,000 \mathrm{Cr}$. 8vo . Pp. 200. Spon. 6s.
Bottomley, J. T. Four Figure Mathematical Tables, comprising Logarithmic and Trigonometrical Tables, and Tables of Squares, Square Roots, and Reciprocals. 8vo. Pp.60. 1920. Macmillan. 3s.

Buchanan, E. E. Tables of Squares, Containing the Square of every foot, inch, and sixteenth of an inch between one-sixteenth of an inch and fifty feet. 11th edn. 16mo. $\mid \mathrm{Pp}$. 102. Spon. 5s.

Castle, F. Five-Figure Logarithmic and other Tables. Fcap. 4to. Pp. 60. 1920. Macmillan. 1s. $3 d$.

-Logarithmic and other Tables for Schools. 8vo. Pp. 36. 1920. Macmillan. Paper, $6 d$. Cloth, $8 d$.

Chappell. Five Figure Mathematical Tables. Demy 8vo. Pp. 340. Chambers. $7 s, 6 d$.

Clark, J. B. Mathematical and Physical Tables. 3rd edn. Cr. 8vo. Pp. 36. Oliver \& Boyd, 9d.

Cracknell, A. G. (edited by) Mathematical Tables. 5th imp. Demy 8vo. Pp. 56. 1919. University Tutorial Press. 2s. $3 d$.

Dale, J. B. Five Figure Tables of Mathematical Functions. 8th imp. Demy 8vo. Pp. 106. Arnold. $4 s .6 d$.

Doberick, W. Hygrometric Tables for Use with Dry and Wet Thermometers. Cr. 4to. Pp. 17. 1917. Williams \& Norgate. $2 s .6 d$.

Dommett, W. E., and Hird, H. C. Mathematical Tables. Cr.8vo. Pp. 88. 1919. Pitman. 4s.6d.

Freeman, N. H. Beaumé and Specific Gravity Tables for Liquids lighter than water. $\mathrm{Cr} .8 \mathrm{vo}$. Pp. 27. 1914. Spon. 2s.6d.

Godfrey, C., and Siddons, A.W. Four-Figure Tables. Demy 8vo. Pp. 40. Cambridge University Press. 1s. $6 d$.

Hall, W. Tables and Constants to Four Figures. For use in Technical, Physical and Nautical Computation. Demy 8vo. Pp. 68. 1914. Cambridge University Press. $5 s$. 
McAulay, A. Five-Figure Logarithmic and other Tables. $16 \mathrm{mo}$. Macmillan, 3s.

Pryde, J. (edited by). Chambers' Mathematical Tables. Seven-Figure. Cr.8vo. Pp.496. Chambers. $6 s$.

Unwin, W. C. Short Logarithmic and other Tables. 6th edn. Cr. 4to. Pp. 43. 1917. Spon. 2s.

Woodward, C. J. A.B.C. FiveFigure Logarithms, for General Use. 2nd edn. Cr. 8vo. Pp. 116. Spon. $4 s$.

A.B.C. Five-Figure Logarithms with Tables, for Chemists. $\mathrm{Cr}$. 8vo. Spon. 3s. 6d.

Workman, W.P. Memoranda Mathematica : a synposis of facts, formuIxe, and methods in Elementary Mathematies. With Five-Figure Logarithmic Trigonometrical Tables arranged by $\mathbf{W}$. E. Paterson. $\mathrm{Cr}$. 8vo. Pp. 278. 1912., Oxford: Clarendon Press. 6s.

Wrapson, J.P., and Gee, W.W.H. Mathematical Tables for the use of Sturents in Technical Schools and Colleges. Demy 8vo. 1919. Macmillan. 1s. $9 d$. xxiv. STATISTICS.

Bowley, A. L. Elements of Statistics. 4th edn. Demy 8vo. Pp. 471. 1920. King. 24s.

- An Elementary Manual of Statistics. 3rd edn. Demy 8vo. Pp. 226. 1920. Macdonald \& Evans. $7 s, 6 d$.

Elderton, W. P., and E.M. Primer of Statistics. 3rd. edn. Cr. 8vo. Pp. 102. (1912). 1920. Black. 2s.

Higgs, H., and Yule, G. U. (Edited by). Statistics: by the late Sir Robert Giffen, written about the years 1898-1900. Demy 8vo. Pu. 500. 1913. Macmillan. 128.

Jones, D. C. A First Course in Statistics. Demy 8vo. Pp. 296. 1921. Bell. 15s.

Mulhall, M. G. A Dictionary of Statistics. 4th edn. Super Roy. 8vo. Pp. 860. 1899. Routledge. $25 s$.

Webb, A.D. The Nèw Dictionary of Statistics. A Complement to the 4th edn. of Mulhall's Dictionary of Statistics. Super Roy. 8vo. Pp. 700. 1911. Routledge. 25s.

Yule, G. I: An Introduction to the Theory of Statistic's. ith edn. Cr. 8vo. Pp. 413. 1919. Griflin. 12s. Gd. 


\section{MECHANICS.}

\section{i. GENERAL.}

Ball, Sir R.S. Experimental Mechanics. 2nd edn. Cr.8vo. Pp.37G. 1906. Macmillan. $7 s$.

Bowling, G. S. Laboratory Aids in Practical Mechanics for Elementary Students. Cr. 8vo. Pp. 108. 1921. Griffin. $4 s$.

Briggs, W., and Bryan, G. H. Matriculation Mechanics. 3rd edn. 13th imp. Cr. 8vo. Pp. 371 . 1919. 5s. Key. 4s. University Tutorial Press.

Capito, C. A. A. A Text-Book of Mathematics and Mechanies: specially arranged for the Use of Students Qualifying for Science and Technical Examinations. 2 Pts. 2nd edn. Cr. 8vo. Pt. 1. Mathematies. Pp. 181. Pt.2. Mechanies. Pp. 240. Griffin. 7s, 6d. each Vol.

Cox, J. Mechanics. Demy 8vo. Pp. 346. 1919. Cambridge University Press. 12s. $6 d$.

Dobbs, W. J. Examples in Elementary Mechanics, Practical, Graphical and Theoretical. Cr.8vo. Pp. 356. 1908. Methuen. $7 s, 6 d$.

Duncan, J. Mechanics and Heat. Cr. 8vo. Pp. 398. 1920. Macmillan. $5 s$.

Glazebrook, Sir R. T. Mechanics and Hydrostatics. An Elementary Text Book. Cr. 8vo. Pp. 490 . 1918. 9s, also in Parts. 1. Dynamics. 4s. 6d. 2. Statics. $4 s$. 3. Hydrostatics. 3s. Cambridge University Press.

Goodwill, S. G. Elementary Mechanics. Cr. 8vo. Pp. 230. 1913. Oxford : Clarendon Press. 5s .
Gregory, Sir R. A., and Hadley, H. E. A Manual of Mechanies and Heat. Cr. 8vo. Pp. 318. 1918. Macmillan. $4 s$.

Hertz, H. Principles of Mechanics Presented in a New Form. Translated by D. E. Jones and J. T. Walley. 8vo. Pp. 304. 1899. Macmillan. 12s. 6d.

Hopkinson, Bertram. The Scientific Papers of. Collected and Arranged by Sir J. A. Ewing and Sir J. Larmor. Roy. 8vo. Pp. 508. 1921. Cambridge University Press. 63s.

Lamb, H. Higher Mechanics. Demy 8vo. Pp. 282. 1920. Cambridge University Press. 25s.

Lodge, Sir O. J. Elementary Mechanics, including Hydrostatice and Pneumatics. New edn., revised by $A$. Lodge and C.S. Lodge. Cr. 8vo. Pp. 324. N.D. Chambers. 4s. $6 d$.

Loney, S. L. Mechanics and Hydrostatics for Beginners. 16th edn. Fcap. 8vo. Pp. 313. 1920. Cambridge University Press. 5s.

Love, A. E. H. Theoretical Mechanics. 2nd edn. Demy 8vo. Pp. 383. 1906. Cambridge University Press. 12s.

Magnus, Sir P. Lessons in Elementary Mechanics: Introductory to the Study of Physical Science. Cr. 8vo. Pp. 393. 1920. Longmans. 4s. $6 d$.

Morley, A. Mechanics for Engineers: a Text-book of Intermediate Standard. 5th edn. Cr. 8vo. Pp. 302. 1919. Longmans. 6s. 6d.

Parker, G.W. Elements of Mechanics. 2nd edn. 8vo. Pp.280. 1921. Longmans. $6 s .6 \mathrm{~d}$. 
Parkinson, S. An Elementary Treat. ise on Mechanics. 6th edn. Cr. 8vo. Pp. 428. 1881. Macmillan. 9s. 6d.

Porter, A. W. An Intermediate Course of Mechanics. Cr.8vo. Pp. 422. 1905. Murray. 7s. 6d.

Prescott, J. Mechanics of Particles and Rigid Bodies. 8vo. Pp. 544. 1913. Longmans. 14s.

Routh, E.J. A Treatise on the Stability of a Given State of Motion; particularly Steady Motion. 8vo. Pp. 120. 1877. Macmillan. 10s.

Stelfox, S.H. The Laws of Mechanics. A Supplementary Text Book. Cr.8vo. Pp.212. 1920. Methuen. $6 s$.

Taylor, J. E. Theoretical Mechanies, including Hydrostatics and Pneumatics. 11th imp. $\mathrm{Cr}$. 8vo. Pp. 274. 1919. Longmans. 4s.

Thornton, A. Theoretical Mechanics-Solids, Including Kinematics, Statics and Kinetics. 5th imp. Cr. 8vo. Pp. 462. 1909. Long. mans. 6s.

Wells, S. H. Practical Mechanics. An Elementary Manual for the Use of Students in Science and Technical Schools. 7th edn. Cr. 8vo. Pp. 232. 1918. Methuen. 5s.

\section{STATICS AND DYNAMICS.}

Andrews, E.S. Elements of Graphic Dynamics. An Elementary Text Book for Students of Mechanics and Engineering. Demy 8vo. Pp. 200. 1919. Chapman \& Hall. 10s. $6 d$.

Baker, W. M. Elementary Dynamics. 7th edn. Cr. 8vo. Pp. 318. 1017. 6s. Key. Pp. 262. 1907. 10s. 6d. Bell.

Ball, Sir R. S. A Treatise on the Theory of Screws. Roy. 8vo. Pp. 561. 1900. Cambridge University Press. 23s.

Barnard, R. J. A. Elementary Dynamics of the Particle and Rigid Body. Cr. 8vo. Pp. 382. 1916. Macmillan. 6s.
Barton, E. H. Analytical Mechanics; comprising the Kinctics and Statics of Solids and Fluids. 8vo. Pp. 5.56. 1911. Longmans. 12s.6d.

Besant, W. H., and Ramsey, A. S. A Treatise on Dynamics. New edn. 8vo. Pp. 443. 1914. Bell. $12 s$.

Borchardt, W. G. Elementary Statics. with or without Answers. Cr. 8vo. Py. 427. 1915. 5s. Key. Cr. 8vo. Pp. 416. 10s. Gd. Rivington.

_- School Mechanics. Vol. 1. School Statics. Cr. 8vo. Pp. 294. 1919. 6s. Vol. 2. School Dynami('s. Cr. 8vo. Pp. 312. 1920). 6s. Rivington .

Briggs, W'.. and Bryan, G. H. The Tutorial Statios. 3rd edn. 1oth imp. Cr. Svo. P). 376. 1919. University Tutorial Press. 5s.

- The Tutorial Dynamics. 2nd edn. 11th imp. Cr. 8vo. Pp. 424. 1919. University Tutorial Press. 5s.

Grawford, W. J. Elementary Graphic Statics. Cr. 8vo. Pp. 139. 1911. Griffin. 3s.

Cremona, L. Graphical Statics, being two Treatises on the Graphical Calculus and Reciprocal Figures. Translated by T. H. Beare. 8vo. Pp. 178. 1893. Oxford: Clarendon Press. 8s. 6d.

Dobbs, W.J. A Treatise on Elementary Statics. 2nd edn. Cr. 8vo. Pp. 311. 1915. Black. 7s. 6d.

- Elementary Geometrical Statics. G1. 8vo. Pp. 352. 1897. Macmillan. 8s. $6 d$.

Fawdry, R. C. Statics. 3rd edn. Cr.8vo. Pp.330. 1920. Bell. 6s. Dynamics. 2nd edn. Cr. 8vo. Pp. 370. 1919. Bell. 6s.

- Statics and Dynamics-First Parts. Cr. 8vo. Pp. 350. 1919. Bell. 6s.

Gray, A., and J. G. A Treatise on Dynamics. Cr. 8vo. Pp. 646 . 1911. Macmillan. 15s.

Hardy, E. The Elementary Principles of Graphic Statics. 2nd edn. Cr. 8vo. Pp. 206. 1909. Bateford. 48. 


\section{Mechanics}

Heath, R. S. Elementary Statics, and its Applications. Cr.8vo. $\mathrm{Pp}$. 296. 1913. Oxford: Clarendon Press. 5s.

Hicks, W. M. Elementary Dynamics of Particles and Solids. Cr. 8 vo. Pp.432. 1917. Macmillan.7s.6d.

Jackson, G. S., and Milne, R. M. A First Statics. Cr. 8vo. Pp. 372. Dent. 5s. $6 d$.

-and Roberts, W. M. A First Dynamics. 2nd edn. Cr. 8vo. Pp. 412. 1913. Dent. 6s.6d.

Lamb, H. Dynamies. Demy 8vo. Pp. 356. 1914. Cambridge University Press. $15 s$.

Statics, including Hydrostatics and the Elements of the Theory of Elasticity. Demy 8vo. Pp. 356. 1916. Cambridge University Press. $14 s$.

Landon, J. W. Elementary Dynamics. A Text-Book for Engineers. Cr. 8vo. Pp. 254. 1920. Cambridge University Press. 10s.6d.

Lock, J. B. Elementary Dynamics and Statics. G1. 8vo. Pp. 574. 1914. Macmillan. $7 s .6 d$.

Loney, S. L. The Elements of Statics and Dynamics. 15th edn. Fcap. 8vo. Pp. 606. 1919. 10s. Also separately. Statics. 5s.6d. Dynamics. 5s.6d. Solutions. 9s. Cambridge University Press.

Treatise on Elementary Dynamics. 9th edn. Cr. 8vo. Pp. 297. 1917. 8s. Solutions. 8s. $6 d$. Cambridge University Press.

An Elementary Treatise on Statics. 2nd edn. Demy 8vo. Pp. 401. 1920. Cambridge University Press. 14s.

An Elementary Treatise on the Dynamics of a Particle and of Rigid Bodies. 2nd edn. Demy 8vo. Pp. 382. 1919. Cambridge University Press. $14 s$.

Macgregor. J. G. Elementary Treatise on Kinematics and Dynamics. 2nd edn. Cr. 8vo. Pp. 652. 1909. Macmillan. 12s.6d.
Michaelis, D.M.L. The Dynamics of Surfaces. An Introduction to the Study of Biological Surface Phenomena. Translated by W. H. Perkins. Demy 8vo. Pp. 118. 1914. Spon. 4s.6d.

Minchin, G. M. A Treatise on Statics with Applications to Physics. 2 vols. 8vo. Vol. 1. Equilibrium of Coplanar Forces. 7th edn. Pp. 476. 1915. Vol.2. Non-Coplanar Forces. 5th edn, revised by H.T. Gerrans. Pp.378. 1915. Oxford: Clarendon Press. 12s. each.

Norwell, A. Elementary Applied Mechanics (Statics). Cr. 8vo. Pp. 256. 1908. Longmans. 4s.

Pinkerton, R. H. Dynamics and Hydrostatics. 11th edn. Cr. 8vo. Pp.310. N.D. Blackie. 3s $6 d$.

Pirie, G. Lessons on Rigid Dynamics. Cr. 8vo. Pp. 196. 1875. Macmillan. 6s.

Robinson, J. L. Elements of Dynamies (Kinetics and Statics). 7th imp. Cr. 8vo. Pp. 462. 1911. Longmans. $7 s, 6 d$.

Routh, E. J. A Treatise on the Dynamics of a System of Rigid Bodies, with numerous Examples. Vol. 1. The Elementary Part. 7th edn. Svo. Pp. 460. 1913. Mac. millan. $17 \mathrm{~s}$.

A Treatise on Analytical Statics. 2 vols. 2nd edn. Demy 8vo. Vol. 1. Pp. 403. 1909. Vol. 2. Pp. 390. 1909. Cambridge University Press. 15s, each.

Sprague, E. H. The Elements of Graphic Statics. Cr. 8vo. Pp. 200. 1917. Scott, Greenwood. 5s.

Tait, P. G., and Steele, W. J. A Treatise on the Dynamics of a Particle. 7th edn. Cr. 8vo. Pp. 428. 1900. Macmillan. 14s.

Tuckey, C. O., and Nayler, W.A. Statics: A First Course. Cr. 8vo. Pp.300. 1916. Oxford: Clarendon Press. 4s.

Whittaker, E. T. A Treatise on the Analytical Dynamics of Particles and Rigid Bodies. 2nd edn. Roy. 8vo. Pp. 444. 1917. Cambridge University Press. 17s.6d. 
Wight, J. T. Elementary Graphic Statics. Cr.8vo. 1913. Pitman. $5 s$.

Williamson, B., and Tarleton, F. A. An Elementary Treatise on Dynamics: containing Applications to Thermodynamics. 3rd edn. Cr. 8 vo. Pp. 576. 1900. Longmans. $10 s .6 d$.

Worthington, A. M. Dynamics of Rotation; an Elementary Introduction to Rigid Dynamies. Cr. 8vo. Pp. 192. 1920. Longmans. 6s. $6 d$.

\section{iii. HYDROSTATICS AND HYDRODYNAMICS.}

Barton, E. H. An Introduction to the Irechanies of Fluids. 8vo. Pp. 264. 1915. Longmans. $8 s .6 d$.

Besant, W. H., and Ramsey, A. S. A Treatise on Hydromechanics. Demy 8vo. Part 1. Hydrostaties. 8th edn. Pp. 232. 1919. 12s. Part 2. Hydrodynamies. $15 s$. Bell.

Briggs, W., and Bryan, G. H. Matriculation Hydrostatics. 2nd edn. 11th imp. Cr. 8vo. Pp. 216. 1919. 4s. Key. 2s. 3d. University Tutorial Press.

- Intermediate Hydrostatics. 6th edn. Cr. 8vo. Pp. 272. 1919. University Tutorial Press. 5s.

De Villamil, R. A B C of Hydrodynamics. 8vo. Pp. 185. 1912. Spon. 8s. 6d.

Greaves, J. A Treatise on Elementary Hydrostatics. Cr. 8vo. Pp. 218. 1919. 7s. Solutions. 6s. Cambridge University Press.

Greenhill, Sir A. G. Treatise on Ilydrostatics. Cr. 8vo. Pp. 544. 1894. Macmillan. 8s, 6d.

Lamb, H. Hydrodynamies. 4th edn. Roy. 8vo. Pp. 714. 1916. Cambridge University Press . 27s.6d.

Loney, S. L. The Elements of Hydrostatics. 5th edn. Feap. 8vo. Pp. 272. 1918. 5s.6d. Solutions. 6s. Cambridge University Press.
Minchin, G. M. A Treatise on Hydrostatics. 2 Vols. 2nd edn. Cr. 8vo. 1912. Vol. 1. Elemen. tary Part. Pp. 204. 5s. Vol. 2. Advanced Part. Pp. 184. 6s. Oxford: Clarendon Press.

Parker, G. W. Elements of Hydrostatics. Cr.8vo. Pp.158. 1912. Longmans. 4s. 6d.

Pinkerton, R. H. Hydrostatics and Pneumatics. Cr. 8vo. Pp. 344. N.D. Blackie. $4 s, 6 d$.

Sanderson, F. W. Hydrostatics for Beginners. New Imp. Gl. 8vo. Pp. 288. 1912. Macmillan. 3s.

\section{iv. APPLIED MEGHANICS.}

Alexander, T., and Thomson, A. W. Elementary Applied Mechanics. 3rd edn. 8vo. Pp. 532. 1916. Macmillan. 15s.

Andrews, E. S. An Introduction to Applied Mechanies. 2nd imp. Demy 8vo. Pp. 316. 1920. Cambridge University Press. 7s.6d.

Aughtie, H. Applied Mechanics. 2nd imp. Demy 8vo. Book 1. Pp. 184. 1919. Book 2. Pp. 227. 1918. Routledge. 3s. 6d. each.

Bates, E. L., and Charlesworth, F. Mechanics for Builders. 2 Parts. Cr. 8vo. Pp. 210. 1913. Longmans. 4s. each.

Cotterill, J.H. Applied Mechanics: An Elementary General Introduction to the Theory of Structures and Machines. 6th edn. 8vo. Pp. 672. 1906. Macmillan. 21s.

and Slade, J. H. Lessons in Applied Mechanics. Fcap. 8vo. Pp. 534. 1919. Macmillan. 6s. 6d.

Cryer, T., and Jordan, H. G. Text-Book of Applied Mechanies. 9th edn. Pp. 320. 1920. Heywood. 5s.

Duncan, J. Applied Mechanics for Fingineers. 8vo. Pp. 732. 1913. Macmillan. 10s. Bd.

Applied Mechanics for Beginners. New imp. Gl. 8vo. Pp. 345. 1020. Macmillan. 3s.6d. 
Goodman, J. Mechanies Applied to Engineering. 9th edn. Large Cr. 8vo. Pp. 864. 1919. Longmans. $14 s, 6 d$.

Graham, J. Applied Mechanics. Including Hydraulies and the Theory of the Steam Engine. 2nd edn. Cr. 8vo. Pp. 312. 1917. Arnold. 5s. $6 d$.

Jamieson, A. Elementary Manual of Applied Mechanics. 15th edn. Revised by E.S. Andrews. Cr. 8vo. Pp. 413. 1921. Griffin. 6s.

- and Andrews, E. S. A Text-book of Applied Mechanics and Mechanical Engineering. Large Cr. 8vo. Vol. I., Applied Mechanics. 11th edn. Pp. 371. 1919. 6s.; Vol. II.., Strength of Materials . 9th edn. Pp. 332. 1918. 6s.; Vol. III., Theory of Structures. 10th edn. Pp. 278. 1920. 5s. Vol. IV., Hydraulics. 9th edn. Pp. 340. 1921. 5s.; Vol. V.. Theory of Machines. 9th edn. in preparation. Griffin.

Low, D. A. Applied Mechanies: embracing Strength and Elasticity of Materials, Theory and Design of Structures, Theory of Machines and Hydraulies. A Text-book for Engineering Students. 6th imp. 8vo. Pp. 559. 1921. Longmans. 12s. $6 d$.

Mackenzie, T. Practical Mechanics : applied to the Requirements of the Sailor. 5th edn. Cr. 8vo. Pp. 187. 1920. Griffin. 3s. 6d.

Morley, A., and Inchley, W. Elementary Applied Mechanics. Cr. 8vo. Pp. 390. 1919. Longmans. $6 s$.

Pullen, W. W. F. Mechanies: Theoretical, Applied, and Experimental. 4th imp. Cr. 8vo. Pp. 390. 1917. Longmans. 6s. $6 d$.

Rankine, W. J. M. A Manual of Applied Mechanics. Revised by W. J. Millar. 20th edn. Cr. 8vo. Pp. 694. 1919. Griffin. 12s.6d.

Spon's Mechanics' Own Book: a Manual for Handicraftsmen and Amateurs. 7th edn. Demy 8vo. Pp. 714. 1921. Spon. 10s.6d.

\section{v. MECHANISM.}

Cassell's Cyclopædia of Mechanics. Edited by Paul N. Hasluck. 5 vols. Super Roy. 8vo. Pp. 384 each vol. 1914. Cassell. 9s. each vol.

Dunkerley, S. Mechanism, for Use in University and Technical Colleges. 3rd edn. 8vo. Pp. 456. 1919. Longmans. 14s. $6 d$.

Goodeve, T. M. The Elements of Mechanism. Cr. 8vo. Pp. 366. 1912. Longmans. $7 s, 6 d$.

McKay, R. I. The Theory of Machines. 2nd edn. Demy 8vo. Pp. 448. 1920. Arnold. 20s.

\section{vi. STRENGTH AND}

\section{ELASTICITY OF MATERIALS.}

Anderson, Sir J. The Strength of Materials and Structures. Cr. 8vo. Pp. 322. 1914. Longmans. 5s.

Andrews, E. S. The Strength of Materials. A Text-book for Engineers and Architects. Demy 8vo. Pp. 604. 1916. Chapman and Hall. 13s. 6d.

-Elementary Strength of Materials . Demy 8vo. Pp. 216. 1916. Chapman and Hall. $7 s$.

The Stresses in Hooks and other Curved Beams. Demy 8vo. 1920. Pitman. 6s.

and Pearson, K. On a Theory of the Stresses in Crane and Coupling Hooks with Experimental Comparison with Existing Theory. Pp. 28. 1904. Cambridge University Press. $3 s$.

Box, T. A Practical Treatise on the Strength of Materials, their Elasticity, and Resistance to Impact. 4th edn. Cr.8vo. Pp. 536. 1902. Spon. 12s. 6d.

Glapham, C. B. Engineer's Handbook of Strengths. Demy 8vo. In preparation. Chapman and Hall.

Ewing, Sir J.A. The Strength of Materials. 2nd edn. Demy 8vo. Pp. 246. 1914. Cambridge University Press. 12s.6d. 
Humber, W. Handy book for the Calculation of Strains in Girders, and Similar Structures, and their Strength. 6th edn. Cr. 8vo. Pp. 81. 1903. Crosby Lockwood. 7s. $6 d$.

Morley, A. Strength of Materials . 5th edn. 8vo. Pp. 566. 1919. Longmans. $14 s$.

Popplewell, W. C. Strength of Materials. A Manual for Engineering Students. 8vo. Pp. 192. 1907. Gurney and Jackson. $5 s$.

- Testing and Strength of Materials of Construction. New edition in preparation. Scientific Pub. Co.

Searle, G. F. G. Experimental Elasticity. A Manual for the Laboratory. Demy 8vo. Pp. 204. 1920. Cambridge University Press. $8 s$.

Smith, C. A. A Handbook of Testing. Vol.1. Materials. 2nd edn. Demy 8vo. Pp. 298. 1920. Constable. 14s.

Sprague, E. H. The Strength of Structural Elements. Cr. 8vo. Pp. 200. 1917. Scott, Greenwood. $5 \mathrm{~s}$.

Moving Loads by Influence Lines and other Methods. Cr. 8vo. Pp. 172. 1918. Scott, Greenwood. $5 s$.

Unwin, W. G. The Testing of Materials of Construction. A Text-book for the Engineering Laboratory and a Collection of the Results of Experiment. 3rd. edn. 8vo. Pp. 490. 1910. Longmans. 21s.

Woods, R. J. The Strength and Elasticity of Structural Members. and edn. Demy 8vo. Pp. 322 . Arnold. 14s.

\section{vii. MATHEMATICAL THEORY} OF ELASTICITY.

Andrews, E. S. Elastic Stresses in Structures. Translated from Castiglano's "'Theórem de l'Equibre des Systèmes Elastiques et ses Applications." Roy. 8vo. Pp.376. 1919. Scott, Greenwood. 25s .
Love, A. E. H. A Treatise on the Mathematical Theory of Elasticity. 3rd edn. Roy. 8vo. Pp. 642. 1920. Cambridge University Press. $37 s, 6 d$.

Todhunter, I. A History of the Theory of Elasticity. Edited by K. Pearson. Demy 8vo. Vol. 1. Galilei to Saint Venant. Pp.930. 1886. 29s. Vol. 2. Saint-Venant to Lord Kelvin. (2 Parts). Pp. 777., 568. 1893. 37s. 6d. Cambridge University Press.

Young, A. W., Elderton, E. M., and Pearson, $K$. On the Torsion resulting from Flexure in Prisms with Cross-Sections of Uni-Axial Symmetry only. Pp. 75. 1918. Cambridge University Press. 7s. $6 d$.

\section{viii. THEORY AND DESIGN OF}

\section{STRUCTURES.}

Andrews, E. S. The Theory and Design of Structures. 3rd edn. Demy 8vo. Pp.618. 1920. Chapman \& Hall." 13s. $6 d$.

Further Problems in the Theory and Design of Structures. 2nd edn. Demy 8vo. Pp. 236. Chapman \& Hall. $10 s$.

Atherton, W. H. An Introduction to the Design of Beams, Girders, and Columns in Machines and Structures, with Examples in Graphic Statics. Large 8vo. Pp. 250. 1905. Griffin. $7 s .6 d$.

Bamford, H. Moving Loads on Railway Underbridges. Fcap. 4to. Pp. 78. 1907. Pitman. 5s. $6 d$.

Bell, G. J. A Practical Treatise on Segmental and Elliptical Oblique or Skew Arches. 2nd edn. 8vo. Pp. 125. 1906. Spon. 21s.

Chalmers, J. B. Graphical Determination of Forces in Engineering Structures. 8vo. Pp. 442. 1881 . Macmillan. 24s.

Morley, A. Theory of Structures. New imp. 8vo. Pp. 596. 1920. Longmans. $14 s$. 
Pearson, K., Reynolds, W. D., and Stanton, W. F. On a Practical Theory of Elliptic and Pseudoelliptic Arches, with special reference to the Ideal Masonry Arch. Pp. 24. 1909. Cambridge University Press. $4 s$.

Pullen, W. W. F. Application of Graphic Methods to the Design of Structures. 2nd edn. Cr. 8vo. Pp. 340. 1905. Technical Pub. Co. 6s. $9 d$.

Woods, R. J. The Theory of Structures. Demy 8vo. Pp.288. 1914. Arnold. 12s.6d.

\section{ix. GYROSTATICS.}

Chalmers, T. W. The Gyroscopic Compass. A Non-Mathematical Treatment. Demy 8vo. Pp. 177. 1920. Constable. 11s.

Chatley, H. Practical Gyrostatic Balancing. Cr. 8vo. Pp. $7 \dot{2} .1912$. Technical Pub. Co. $2 s .9 d$.

Crabtree, H. An Elementary Treatment of the Theory of Spinning Tops and Gyroscopic Motion. 2nd edn. 8vo. Pp.210. 1914. Longmans. $9 s$.

Gray, A. A Treatise on Gyrostatics and Rotational Motion. Theory and Applications. Super Roy. 8vo. Pp. 550. 1918. Macmillan. 42s.

Johnson, V. E. The Gyroscope: An Experimental Stady from Spinning Top to Mono Rail. Cr. 8vo. Pp. 52. 1911. Spon. 2s.6d.

Perry, J. Spinning Tops and the Use of Gyrostats and the Gyro-Compass . Post 8vo. Pp. 155. 1919. S.P.C.K. $2 s .6 d$.

\section{MEASUREMENTS- WEIGHTS AND GALGULATIONS.}

Adiassewich, A. English Prices with Russian Equivalents. Calculated at Fourteen Rates of Exchange in Roubles per Pood, giving rate per lb., and equivalents per ton. Fcap. 16mo. Pp. 182. Spon. 1s.6d.
Alexander, J. Lead. Weights and Measurements of Sheet Lead. 32mo. Spon. $1 s .6 d$.

Brook, J . French Measure and English Equivalents. For the Use of Engineers, Manufacturers of Iron, Draughtsmen, etc. 2nd edn. Fcap. 16mo. Pp. 80. Spon. 2s.

Clapham, G. B. Metric System for Engineers. Demy 8vo. in preparation. Chapman \& Hall.

Clark, L. A Dictionary of Metric and other Useful Measures. Cr. 8vo. Pp. 113. Spon. 6s.6d.

Delbos, L. The Metric System, A Practical Manual. Cr. 8vo. Pp. 144. 1900. Methuen. 3s.

Dommett, W. E. (edited by). Metric Conversion Tables. Cr. 8vo. Pp. 50. 1918. Pitman. 2s.6d.

Eliott, A.W.M. Rectangular Areas . A Useful Reference Work for Tinplate Manufacturers, Tinplate Merchants, Tin Box Makers, Wood Case Makers, and those engaged in Tinplate Industries. Cr. 8vo. Pp. 104. Scott, Greenwood. $7 s 6 d$.

Golding, H. A. Bonus Tables: For Calculating Wages on the Bonus or Premium Systems. For Engineering, Technical and Allied Trades. Super Roy. 8vo. 1903. Griffin. $9 s$.

Koczorowski, Lt. English Prices with German Equivalents. Calculated at Seven Rates of Exchange in Marks per Kilogramme. Giving rate per lb., and equivalents per ton. Fcap. 16mo. Pp. 95. Spon. $1 s .6 d$.

Lambert, S. English Prices with Spanish Equivalents. Calculated at Seven Rates of Exchange in Pesetas per Kilogramme, giving rate per $\mathrm{lb}$. , and equivalents per ton. Fcap. 16mo. Pp.95. Spon. $1 s .6 d$.

Logan, F. W. A. English Weights, with their Equivalents in Kilogrammes calculated from one pound to one ton by pounds, and from one ton to $\mathbf{1 0 0}$ tons by tons. Fcap. 16mo. Pp.96. Spon. 1s.6d. 


\section{Mechanics}

McCartney, H. P. Metric Weights with English Equivalents. Feap. 16mo. Pp. 84. Spon. 1s.6d.

- English Prices with French Equivalents. Calculated at Seven Rates of Exchange in Francs. Gold per $100 \mathrm{Kilos}$, giving rate per $1 \mathrm{~b}$., and equivalents per ton. Fcap. 16mo. Pp. 97. Spon. 1s.6d.

Molesworth, Sir G. L. Metric Tables. 5th edn. Fcap. $16 \mathrm{mo}$. Pp. 116. 1918. Spon. 2s.6d.

_ - Decimal Tables, for Engineering and Commercial Calculations. Fcap. 16mo. Pp.126. 1919. Spon. 2s. $6 d$.

O'Toole, I. Tables of Seamless Copper Tubes. Oblong 16mo. Pp. 69. 1908. Spon. 3s.6d.

Peddie, A. The Practical Measurer. A Series of Tables for the Use of Wood Merchants, Builders, Carpenters, Joiners, Sawyers, Plasterers, Painters, Masons, Bricklayers, etc. Cr. 8vo. Pp. 448. N.D. Blackie. 7s. $6 d$.

Perkin, F. M. The Metric and British Systems of Weights, Measures, and Coinage. 8vo. Pp. 84. 1907. Pitman. 3s.6d.

Robertson, J. A Dictionary for International Commercial Quotations. To translate units of value from one currency, weight, and measure direct into another, includ- ing exchange. Cr. 4to. Vol. 1. British and European Standards. Pp. 224. 1914. 63s. Vol. 2. British and North and South American Standards. Pp. 228. 1919. 84s. Oxford University Press.

Rossetti, G. A. Metric-English and English-Metric Lengths. Fcap. 16 mo. Pp. 92. Spon. 1s. 6d.

Rownson. Iron Merchants' Tables and Memoranda, Weights and Measures. Oblong 32mo. Pp. 86. Spon. $5 s$.

Slack, J. E., and Dorey, A. "At a Glance.'" Twelve Conversion Tables for International Values of British, Metric and Russian Weights and Measures, Temperatures, and Dates. 8vo. Pp. 76. 1918. Technical Pub. Co. 7s. 6d.

Smith, R. H. Measurement Conversions (English and French): 43 Graphic Tables or Diagrams. 4to. 1895. Griffin. 7s, 6d.

Stobbs, T. Wire and Sheet Gauge Tables. 2nd edn. Cr. 8vo. Pp. 115. 1920. Spon. 5s.

Taylor, T. Gauges at a Glance. Containing all the Principal Gauges of the different Metals, Tinplate Substances, etc., collated and compared. 4th edn. Oblong 8vo. Pp. 82. 1918. Spon. 6s. 


\section{MACHINE DRAWING, DESIGN, DRAUGHTSMANSHIP.}

\section{i. GENERAL.}

Barker, A. H. Graphic Methods of Engine Design. 2nd edn. Cr. 8vo. Pp. 210. 1899. Technical Pub. Co. $4 s .9 d$.

Bowers, R. S. Drawing and Design for Craftsmen. Demy 8vo. Pp. 416. 1919. Cassell. $8 s .6 d$.

Castle, F. Machine Construction and Drawing. Gl.4to. Pp.306. 1920. Macmillan. $5 s$.

- A Manual of Machine Design. Cr. 8vo. Pp. 361. 1919. Macmillan. $7 s .6 d$.

Cryer, T., and Jordan, H. G. Machine Construction and Mechanical Drawing. 13th edn. Cr. 4to. oblong. Pp.137. 1920. Heywood. $5 s$.

Dales, J. H. A Manual of Mechanical Drawing. Cr. 8vo. Pp. 194. 1914. Cambridge University Press. $3 s .6 d$.

A Course in Machine Drawing and Sketching. Demy 8vo. Pp. 192. 1919. Chambers. 3s. 6d.

Dunkley, W. G. The Design of Machine Elements. 2 vols. $\mathrm{Cr}$. 8vo. 1917. Vol. 1. Forces and Stresses; Shaftings and Bearings; Couplings; Springs. Pp. 210. Vol. 2. Screws and Bolts; Clutches; Belts and Pulleys; Gearing. Pp. 220. Scott, Greenwood. 5s. each.

Ellis, G. Modern Technical Drawing . Demy 8vo. Pp. 200. 1913. Batsford. $7 s, 6 d$.

Handy, C. E. Preliminary Machine Drawing Course. Oblong Demy $8 v 0$. Pp. 42. 1920. Longmans. $2 s$.

Hasluck, P.N.(edited by). Practical Draughtsmen's Work. Cr. 8vo. Pp. 168. 1918. Cassell. 3s.
Holt-Butterfill, H. First Principles of Mechanical and Engineering Drawing. Demy 8vo. 1900. Chapman \& Hall. $8 s .6 d$.

Innes, C. H. Problems in Machine Design. 2nd edn. Cr. Svo. Pp. 258. 1908. Technical Pub. Co. 6s.

Jagger, J . E. An Elementary Textbook on Mechanical Drawing. 3rd edn. Cr. 4to. Pp. 261. 1921. Griffin. 15s .

Jones, B. E. (edited by). Mechanical Drawing. Demy 8vo. Pp. 270. 1920. Cassell. 6s.

Jones, T . and T . G. Machine Draw ing. 4 Books. Med. 4to. 1920. Book 1. 69 Plates. 6s. Book 2. Machine Tools. 3rd edn. 48 Plates. 4s, Book 3. Engine and Pump Details. 44 Plates. 5s. Book 4. Machine Drawing for Electrical Engineering Students. 16 Plates. 1s. 4d. Heywood.

Low, D. A. An Introduction to Machine Drawing and Design. Cr. 8vo. Pp. 256. 1919. Longmans. $4 s$.

and Bevis, A. W. A Manual of Machine Drawing and Design. 15th imp. Demy 8vo. Pp. 414. 1919. Longmans. 10s, $6 d$.

Minchin, G. M., and Dale, J. B. Mathematical Drawing. Including the Graphic Solution of Equations. 4th edn. Demy 8vo. Pp. 151. 1920. Arnold. 8s, 6d.

Robson, J. H. Machine Drawing and Sketching for Beginners. 3rd edn. 8vo. Pp. 202. 1918. Technical Pub. Co. 5s.

Rowarth, E. The Engineering Draughtsman. Demy 8vo. Pp. 270. 1919. Methuen. 10s.6d.

- The Elements of Engineering Drawing. 3rd edn. Cr. 8vo. Pp. 146. 1919. Methuen. 4s.6d. 


\section{Machine Drawing, Design, Draughtsmanship.}

Smith, W. H. Guide to Draughtsmanship for Architects, Civil and Mechanical Engineers and Surveyors. Cr. 8vo. Pp. 106. 1917. Spon. $4 s .6 d$.

Spooner, H.J. Engineering Workshop Drawing. Oblong 4to. Pp. 136. 1919. Longmans. $5 s$.

Industrial Drawing and Geometry: an Introduction to Technical Drawing. Oblong 4to. Pp. 184. 1918. Longmans. $7 s .6 d$.

- Machine Drawing and Design for Beginners. Cr. 4to. Pp. 282. 1919. Longmans. $6 s$.

- Machine Design, Construction, and Drawing. 5th imp. 8vo. Pp. 770. 1919. Longmans. $21 s$.

Unwin, W. C., and Mellanby, A.L. The Elements of Machine Design. 2 vols. 8vo. Vol. 1. General Principles, etc. Pp. 546. 1919. Vol. 2. Chiefly Engine Details. Pp. 450. 1918. Longmans. 15s. each vol.

Wells, S. H. A Text-Book of Engineering Drawing and Design. 2 vols. Cr.8vo. Vol.1. Practical Geometry, Plain and Solid. 8th edn. Pp. 203. 1920. 4s. 6d. Vol 2. Machine and Engine Drawing and Design. 6th edn. Pp. 182. 1916. 4s. 6d. Griffin.

\section{ii. GEOMETRICAL DRAWING AND DESIGNING. HAND - LETTERING .}

Adams, H. Theory and Practice of Designing. Demy. 8vo. Pp. 257. 1911. Constable. 7s. 6d.

Dennis, H. J. Advanced Perspective, Third Grade. Angular and Oblique Perspective, Shadows and Reflections. 7th edn. Part 1. Angular and Oblique Perspective, with 31 Plates. 7s, 6d. Part 2. Shadows and Reflections, with $\mathbf{3 9}$ Plates. $7 s .6 d$. or in one volume 15s. Baillière.
Hallett, G. W. T. Hints on Architectural Draughtsmanship. 5th edn. Fcap. 8vo. Pp.86. 1917. Spon. $2 s .6 d$.

Harper, C. G. A Practical Handbook of Drawing, for Modern Methods of Reproduction. 3rd edn. Demy 8vo. 1916. Chapman \& Hall. $8 s, 6 d$.

Jackson, F. G. Decorative Design. An Elementary Text-book of Principles and Practice. 3rd edn. Large Cr. 8vo. 1902. Chapman \& Hall. 9s. $6 d$.

- - The Theory and Practice of Design. An Ädvanced Text-book on Decorative Art. Large Cr. 8vo. 1903. Chapman \& Hall. 11s.

Lindsay, C. T. Geometrical Drawing. Demy 8vo. Pp. 122. 1903. Chapman \& Hall. 7s.

Lineham, W. J. A Treatise on Hand-Lettering for Engineers, Architects, Surveyors, and Students of Mechanical Drawing. Oblong 4to. Pp. 282 and 119 Plates. 1915. Chapman \& Hall. 9s.6d.

Morris, I. H. Geometrical Drawing for Art Students. Cr. 8vo. Pp. 236. 1919. Longmans. 3s.

Spanton, J. H. Geometrical Drawing and Design. G1.8vo. Pp.272. 1919. Macmillan. 3s.

- Science and Art Drawing. 8vo. Part 1. Geometrical. Pp. 596. 1895. 12s. 6d. Part 2. Perspective. Pp. 300. 1900. 6s. Macmillan.

Spooner, H. J. The Elements of Geometrical Drawing. 2nd edn. Cr. 8vo. Pp. 340. 1914. Longmans. 4s. $6 d$.

Watson, J. Oblique and Isometric Projection. Fcap. 4to. Pp. 50. 1905. Arnold. 3s. 6d.

Wright, C. O., and Rudd, W. A. Model Drawing, Geometrical and Perspective, with Architectural Examples. Roy. 8vo. Pp. 263. 1916. Cambridge University Press. 6s. 


\section{CIVIL ENGINEERING.}

\section{i. GENERAL.}

Adams, H. Strains in Ironwork. 4th edn. Cr. 8vo. Pp.65. 1904. Spon. 6s.

Alexander, W. Columns and Struts . Theory and Design, with Practical Examples Worked Out. 8vo. Pp. 277. 1912. Spon. 12s.6d.

Anglin, S. The Design of Structures. A Practical Treatise on the Building of Bridges, Roofs, etc. 6th edn. Large 8vo. Pp.535.1919. Griffin. 16s.

Atcherley, L. W., and Pearson, K. On the Graphics of Metal Arches with special reference to the Relative Strength of Two-pivoted, Three-pivoted and Built-in-Metal Arches. Pp. 64. 1905. Cambridge University Press. $5 s$.

Barber, T. W. Civil Engineering Types and Devices. Demy 8vo. Pp. 250. 1915. Crosby Lockwood. $9 s$.

Bird, H. The Practical Design of Plate Girder Bridges. Demy 8vo. Pp. 188. 1920. Griffin. 15s.

Bligh, W. G. Notes on Instruments best suited for Engineering Field Work in India and the Colonies. 8vo. Pp. 218. 1914. Spon. 5s. $6 d$.

Brightmore, A. W. Structural Engineering. New edn. with additional matter relating to Concrete. Demy 8vo. Pp. 310. 1913. Cassell. 10s. 6d.

Burnside, W. Bridge Foundations. Cr. 8vo. Pp. 148. 1916. Scott, Greenwood. 5s.

Chatley, H. Stresses in Masonry. Cr. 8vo. Pp. 154. 1909. Griffin. $4 s$.

Corbin, T. W. Engineering of ToDay. Cr. 8vo. Pp. 367. 1919. Seeley. $7 s, 6 d$.
Fidler, T. G. Civil Engineering. Cr.8vo. Pp.195. 1905. Methuen. $5 s$.

A Practical Treatise on Bridge Construction: A Text Book on the Construction of Bridges in Iron and Steel; for the use of Students, Draughtsmen, and Engineers. 4th edn. Roy. 8vo. Pp. 486. 1909. Griffin. 30s.

Gibson, A. H., and Ritchie, E. G. A Study of the Circular-Are BowGirder. Imp. 8vo. Pp. 88. 1914. Constable. 10s. $6 d$.

Hunter, A. Bridge and Structural Engineers' Handbook of General Specifications, Formulæ, and Data for the Design of Cranes, Bridges, Foundations, and Workshop Buildings, embodying the practice of Sir William Arrol and Company, Ltd. Large Cr. 8vo. Pp. 316. 1920 . Spon. 21s.

Husband, J., and Harby, W. Structural Engineering. 8vo. Pp. 408. 1919. Longmans. $12 s .6 d$.

Lilly, W. E. The Design of Plate Girders. Demy 8vo. Pp. 132. 1904. Chapman \& Hall. 8s.6d.

Middleton. G. A. T. Stresses and Thrusts. A Text-book on their Determination in Constructional Work, with Examples of the Design of Girders and Roofs. 4th edn. Cr. 8vo. Pp. 217. 1911. Batsford. $5 s .6 d$.

Nielsen, T . Calculation of Columns . A Practical Application of the Theory. 8vo. Pp.36. 1911. Spon. $6 s$.

Rankine, W. J. M. A Manual of Civil Engineering. 24th edn. Revised by W. J. Millar. Large $\mathbf{C r}$. 8vo. Pp. 838. 1920. Griffin. 21s.

Sprague, E. H. The Stability of Arches. Cr. 8vo. Pp. 150. 1916 . Scott, Greenwood. $5 s$. 
Sprague, E.H. Stability of Masonry . Cr. 8vo. Pp. 180. 1915. Scott, Greenwood. 58 .

Taylor, F. N. A Manual of Civil Engineering Practice, Specially arranged for the use of Municipal and County Engineers. 2nd edn. 8vo. Pp. 821. 1920. Griffin. 34s.

- Masonry Applied to Givil Engineering. A Practical Treatise on the Design and Construction of Engineering Works in Stone and Heavy Concrete. Demy 8vo. Pp. 241. 1915. Constable. 7s. 6d.

Thorpe, W. H. The Anatomy of Bridgework. Cr. 8vo. Pp. 190. 1914. Spon. 7s. 6d.

Usborne, P. O. G. The Design of Simple Steel Bridges. Demy $8 v 0$. Pp. 414. 1912. Constable. 12s. 6d.

Vernon-Harcourt, L. F. Civil Engineering as Applied to Construction. Revised by H. Fidler. 2nd edn. Med. 8vo. Pp.642. 1919. Longmans. 25s.

Warren. W. H. Engineering Construction. 3rd edn. Roy. 8vo. 1921. Part 1. In Steel and Timber. Pp. 502. 30s. Part 2. Masonry and Concrete. Pp.510. 36s. Longmans.

Young, E. W. Simple Practical Methods of Calculating Strains on Girders, Arches, and Trusses. 8vo. Pp. 140. 1873. Macmillan. 7s. 6d.

\section{ii. ESTIMATES, FORMULE, etc.}

Ball, W. V. The Law Affecting Engineers, with an Outline of the Law relating to Engineering Contracts, and an Appendix of Forms of Contract. Demy 8vo. Pp. 332. 1909. Constable. 10s.6d.

Coleman, T. E. The Civil Engineers' Cost Book, compiled for the use of Civil and Municipal Engineers, Public Works Contractors, etc. 3rd edn. 16mo. Pp. 441. 1920. Spon. 10s. 6d.
Hoskold, H. D. Engineers' Valuing Assistant : being a Practical Treat: ise on the Valuation of Collieries and Other Mines, etc. 2nd edn. 8vo. Pp. 214. 1905. Longmans. 9s.

Hurst, J. T. Spon's Engineers' Tables for Civil and Mechanical Engineers, Builders, Contractors, Plumbers, etc. 12th edn. 64mo. Pp. 278. 1920. Spon. 2s.

Hutton. W. S. The Works Managers' Handbook of Modern Rules, Tables and Data. 8th edn. Med. 8vo. Pp. 444. 1917. Crosby Lockwood. 18s.

Molesworth, G. L. Pocket Book of Useful Formulæ and Memorands for Civil, Mechanical and Electrical Engineers. 28th edn. Oblong 32mo. Pp.760. 1919. Spon. $10 s$.

Suggate, A. Elements of Engineering Estimating. Cr. 8vo. Pp. 135 . 1912. Technical Pub. Co. 4s. 9d.

\section{iii. SURVEYING : LAND AND MINE.}

Adams, H. Practical Surveying and Elementary Geodesy. Cr. 8vo. Pp. 288. 1913. Macmillan. 5s.

Andrews, E. S. Alignment Charts : Their Principle and Application to Engineering Formulæ. Pp. 32 . Chapman \& Hall. 1s.6d.

Baker, T., and Dixon, F.E. Rudimentary Treatise on Land and Engineering Surveying. 23rd edn. Cr. 8vo. Pp. 250. 1919. Crosby Lockwood. $2 s .6 d$.

Briggs, $\mathbf{H}$. The Effects of Errors in Surveying. Cr. 8vo. Pp. 190. 1912. Griffin. 6s.

Brough, B. H. A Treatise on Mine. Surveying. For the use of Managers of Mines and Collieries, Students, etc. 15th edn. revised by $H$. Dean. Cr. 8vo. 1920. Griffin. 9s.

Bryson, T., and Chambers, G. M. An Introduction to Mine Surveying . 2nd imp. Pp. 296. 1919. E. Arnold. 6s. 
Davies, D. Problems in Land and Mine Surveying. 2nd edn. Cr. 8vo. Pp. 367. 1921. Griffin. 12s. $6 d$.

Eliot, M. E. Y. Tacheometer Surveying, with Special Notes on Plotting, Care and Adjustment of Instruments, Field Work, and Calculations. Cr.8vo. Pp.158. 1916. Spon. 6s.

Ferguson, T. Automatic Surveying Instruments, and their Practical Uses on Land and Water. Cr. 8vo. Pp. 86. 1904. Bale \& Danielsson. $4 s$.

Gribble, T. G. Preliminary Survey and Estimates, including Elementary Astronomy, Route Surveying, Tacheometry, Curve Ranging, Graphic Mensuration, Estimates, Hydrography, and Instruments. Cr. 8vo. Pp. 494. 1913. Longmans, $8 s, 6 d$.

Hearn, G. R. Railway Engineers' Field Book. 12mo. Pp.230.1914. Spon. $21 s$.

Higgins, A. L. The Field Manual. A Practical Treatise of Surveying Methods and Operations. Cr. 8vo. Pp. 948. 1920. Pitman. 21s.

Kennedy, N. A Practical Manual of Surveying with the Tacheometer. 3rd edn. Demy 8vo. Pp. 112. 1912. Crosby Lockwood. 12s.6d.

Leston, G. L. Surveying: Land and Mining. 4th edn. Large Cr. 8 vo. Pp. 386. 1921. Crosby Lockwood. $9 s$.

Middleton, G.A.T. Surveying and Surveying Instruments. 3rd edn. Cr. 8vo. Pp. 174. 1912. Pitman. $6 s$.

Middleton, R. E., and Chadwick, O. A Treatise on Surveying. 4th edn. Revised by M. T. M. Ormsby . 2 vols. Cr. 8vo. Pp. 406., 365. 1920. Spon. 15s, each vol.

O'Donahue, T.A. Field and Colliery Surveying. A Primer designed for the use of Students of Surveying and Colliery Manager Aspirants. Gl. 8vo. Pp. 316. 1918. Macmillan. $5 s$.
Ormsby, M. T. M. Elementary Principles of Surveying. $\mathrm{Cr} .8 \mathrm{vo}$. Pp.244. 1914. Scott, Greenwood. $5 s$.

Park, J. A Text-book of Theodolite Surveying and Levelling: for the Use of Students in Land and Mine Surveying. 5th edn. in Preparation. Griffin.

Pilkington, W. Co-ordinate Geometry applied to Land Surveying. 12mo. Pp. 44. 1909. Spon. 2s.

Popplewell, W. G. The Elements of Surveying and Geodesy. 8vo. Pp. 256. 1915. Longmans. $9 s$.

Salmon, V. G. Practical Surveying and Field Work. Cr.8vo. Pp.212. 1918. Griffin. 7s.6d.

Simms, F. W. Treatise on the Principles and Practice of Levelling. Its application to purposes of Rail. way Engineering and the Construction of Roads. 9th edn. 8vo. Pp. 223. 1907. Crosby Lockwood. $9 s$.

Stewart, B. Handbook on Railway Surveying for Students and Junior Engineers. Cr. 8vo. Pp. 98. 1914. Spon. 3s.6d.

Thomas, W. N. Surveying. Med. 8vo. Pp. ว40. 1920. E. Arnold. $31 s .6 d$.

Threlfall, H. A Text Book on Surveying and Levelling. Large $\mathrm{Cr}$. 8vo. Pp.680. 1920. Griffin. 21s.

Usill, G. W. Practical Surveying. 12th edn. Revised by G.L. Leston. Large Cr. 8vo. Pp. 358. 1916. Crosby Lockwood: $8 s .6 d$.

Wells, G. G., and Clay, A.S. The Field Engineer's Handbook. 2nd edn. 18mo. Pp. 230. 1920. Arnold. 8s. $6 d$.

Whitelaw, J. A Text-Book of Surveying as Practised by Civil Engineers and Surveyors. 6th edn. Demy 8vo. Pp. 516. 1920. Crosby Lockwood. 12s. $6 d$.

Williamson, J . Surveving and Field Work. Demy 8vo. Pp. 385. 1915. Constable. $9 s$.

Xydis, C. Handbook on Tacheometrical Surveying. 8vo. Pp.63. 1909. Spon. $7 s .6 d$. 
Butler, E. Modern Pumping and Hydraulic Machinery. 2nd edn. in preparation. Griffin.

Coleman, T. E. Retaining Walls in Theory and Practice. A Text-book for Students. Cr. 8vo. Pp. 160. 1914. Spon. 4s.

Cunningham, B. The Principles and Practice of Dock Fingineering. 2nd edn. Large 8vo. Pp. 616. 1910. Griffin. 36s.

The Dock and Harbour Engineer's

Reference Book: a compilation of Notes connected with Maritime Engineering and Ports and Harbours. Pocket size. Pp. 326. 1914. Griffin. 10s. 6d.

-The Principles and Practice of Harbour Engineering. 2nd edn. Large 8vo. Pp. 393. 1918. Griffin. 25s.

Dunkerley, S. H. Hydraulies. 2 Vols. 8vo. Vol.I., Hydraulic Machinery, (out of print). Vol. II., The Resistance and Propulsion of Ships. Pp. 260. 1908. Longmans. 12s.

Ekin, T. G. Water Pipe and Sewage Discharge Diagrams. Folio. Pp. 21. 1908. Constable. 6s.

Fergusson, F. F. The Fundamental Principles of Water Power Engineering. Pott 8vo. Pp. 126. 1921. Pitman. 2s. $6 d$.

Fidler, T. C. Calculations in Hydraulic Engineering. 2 Parts. 8vo. Part 1. Fluid Pressure and the Calculation of its Effects in Engineering Structures. 2nd imp. Pp. 168. 1907. 8s. Part 2. Calculations in Hydro-Kinetics. New edn. Pp. 218. 1914. 9s. Longmans.

Garrett, A. ff. Hydraulic Tables and Diagrams for Practical Engineers. Oblong 4to. $P$ ?. 56. 1909. Longmans. 16s. $6 d$.

Gibson, A. H. Hydraulics and its Applications. A Text-book for Engineers and Students. 2nd edn . Demv 8vo. Pp. 828. (1912) 1920 . Constable. 24s.

-Water Hammer in Hydraulic Pipe Lines. 2nd edn. Fcap. 8vo. 1920. Constable. 8s.
Hennell, T. Hydraulic and other Tables for purposes of Sewerage and Water Supply. 3rd edn. Cr. 8vo. Pp. 70. 1920. Spon. 3s.

Lea, F. G. Hydraulies. For Engineers and Engineering Students. 3rd edn. Demy 8vo. Pp. 580 . 1919. Arnold. 18s.

Matthews, E. R. Studies in the Construction of Dams : Earthen and Masonry. Large 8vo. 1919 . Griffin. 4s. $6 d$.

Meares, J. W. Hydro-Electric Development. The Determination of Water-Power Possibilities, Methods of Utilization, Design and Construction of Works. $18 \mathrm{mo}$. Pp. 100. 1920. Pitman. 2s. 6d.

Minikin, R. C. R. Practical River and Canal Engineering. Demy 8 vo. Pp. 130. 1920. Griflin. 12s. 6d.

Moore, E. C. S. New Hydraulic Tables for the Complete Solution of Ganguillet and Kutter's Formula for the Flow of Liquid in Open Channels, Pipes, Sewers, and Conduits. Specially compiled Tables. Med.8vo. Pp. 230. 1901. Batsford. $18 s$.

Park, J. A Text-Book of Practical Hydraulics for the use of Mining Schools, Technical Colleges, Engineers, etc. 2nd edn. Large $\mathbf{C r}$. 8vo. Pp. 320. 1921. Griffin. $21 s$.

Parker, P. A. M. The Control of Water as applied to Irrigation, Power and Town Water Supply Purposes. Large 8vo. Pp. 1,061. 1913. Routledge. 25s.

Pearson, K., Pollard, A. F. G., Wheen, C.W., and Richardson, L. F. An Experimental Study of the Stresses in Masonry Dams. Pp. 44. 1907. Cambridge University Press. $7 s$.

Shield, W. Principles and Practice of Harbour Construction. Med. 8vo. Pp. 314. 1910. Longmans. 17s. $6 d$.

Silk, A. E. Tables for Calculating the Discharge of Water in Pipes for Water and Power Supplies. Cr. 8vo. Pp.63. 1914. Spon. 4s.6d. 


\section{Civil Engineering.}

Sprague, E. H. Hydraulies. Cr. 8vo. Pp. 190. 1914. Scott, Greenwood. $4 s, 6 d$.

Unwin," W. C. A Treatise on Hydraulics. 2nd edn. Demy 8vo. Pp. 339. 1912. Black. 12s.6d.

Vernon-Harcourt, L. F. Rivers and Canals. 2 Vols. 8vo. 1896. Vol. 1. Rivers: their Flow, Control, and Improvement. Pp. 362. Vol. 2. Canals: their Design, Construction, and Development. Pp. 716. Oxford: Clarendon Press . $31 s .6 d$.

Wallace, W. M. Hydraulics in Theory and Practice. Cr. 8vo. Pp. 280. 1914. Technical Pub. Co. 5s.6d.

\section{vii. IRRIGATION.}

Bellasis, E. S. Irrigation Works. The Principles on which their Design and Working should be based, with special Details relating to Indian Canals, and some proposed improvements. 8vo. Pp. 204. 1913. Spon. 10s.6d.

-Punjab Rivers and Works. A description of the Shifting Rivers of the Punjab Plains and of Works on them-Inundation Canals, Flood Embankments, and River Training Works, etc. 2nd edn. Folio. Pp. 64 and 47 Plates. 1912. Spon. 10s. 6d.

Brown, Sir H. Irrigation: Its Principles and Practice as a Branch of Engineering. 2nd edn. Demy 8vo. Pp. 316. 1912. Constable. $16 s$.

Brownlie, T. A. Further Notes on Tube Wells: Boring, Sinking and Working for Irrigation Purposes in India. 2nd edn. Demy 8vo. 1914. Thacker. 7s. 6d.

Buckley, R. B. Irrigation Pocket Book. Facts, Figures, and Formulæ for Irrigation Engineers, being a Series of Notes on Miscellaneous subjects connected with Irrigation. 3rd edn. Cr. 8vo. Pp.630. 1920. Spon. 30s.

The Irrigation Works of India . 2nd edn. 4to. Pp. 336. 1905. Spon. $50 s$.
Buckley, R. B . (compiled by). The Design of Channels for Irrigation for Drainage; being a Statement of the various Formulæ in use and a Guide to the Practical Application of them. Cr. 8vo. Pp. 55. 1911. Spon. $2 s$.

Doyle, K. D. Agriculture and Irrigation in Continental and Tropical Climates. Demy 8vo. Pp. 284. 1921. Constable. 19s.

Mackenzie, N. T . Notes on Irriga tion Works. Demy 8vo. Pp. 119. 1910. Constable. $7 s .6 d$.

Mawson, E. O. Pioneer Irrigation. A Manual of information for Farmers in the Colonies: with Chapters on Light Railways by E. R. Calthrop. Demy 8vo. Pp. 276. 1904. Crosby Lockwood. $12 s .6 d$.

Strange, W. L. Notes on Irrigation, Roads, and Buildings, and on the Water Supply of Towns. Demy 8vo. Pp. 872. 1920. Routledge. $45 s$.

-_- Indian Storage Reservoirs with Earthen Dams. A Practical Treatise on their Design and Location. 2nd edn. 8vo. Pp. 466. 1913. Spon. 25s.

Willcocks, Sir W. Egyptian Irriga tion. 2 Vols. 3rd edn. Supe. Roy. 8vo. Pp. 924. 1913. Sponr $63 s$.

The Irrigation of Mesopotamia. 2 Vols. 2nd edn. Text, super Roy. 8vo., plates, folio. Pp. 136. 46 Plates. 1917. Spon. 30s.

\section{viii. SHORE PROTECTION. LAND RECLAMATION.}

Beazeley, A. Reclamation of Land from Tidal Waters. 8vo. Pp. 326. 1900. Crosby Lockwood. 12s.6d.

Carey, A. E., and Oliver, F. W. Tidal Lands. A Study of Shore Problems. Demy 8vo. Pp. 284. 1918. Blackie. 15s.

Latham, E. The Maintenance o Foreshores. Cr. 8vo. Pp. 90. 1914. Crosby Lockwood. 2s. 6d.

Matthews, E.R. Coast Erosion and ', Protection. 2nd edn. Med. 8vo. Pp. 211. 1918. Griffin. 12s. 6d. 
Butler, E. Modern Pumping and Hydraulic Machinery. 2nd edn. in preparation. Griffin.

Coleman, T.E. Retaining Walls in Theory and Practice. A Text-book for Students. Cr. 8vo. Pp. 160. 1914. Spon. 4s.

Gunningham, B. The Principles and Practice of Dock Engineering. 2nd edn. Large 8vo. Pp. 616. 1910. Griffin. 36s.

-The Dock and Harbour Engineer's Reference Book: a compilation of Notes connected with Maritime Engineering and Ports and Harbours. Pocket size. Pp. 326 . 1914. Griffin. 10s. 6d.

The Principles and Practice of Harbour Engineering. 2nd edn. Large 8vo. Pp. 393. 1918. Griffin. 25s.

Dunkerley, S.H. Hydraulies. 2 Vols . 8vo. Vol.I., Hydraulic Machinery, (out of print). Vol. II., The Resistance and Propulsion of Ships. Pp. 260. 1908. Longmans. 12s.

Ekin, T. C. Water Pipe and Sewage Discharge Diagrams. Folio. Pp. 21. 1908. Constable. $6 s$.

Fergusson, F. F. The Fundamental Principles of Water Power Engineering. Pott 8vo. Pp. 126. 1921. Pitman. 2s. $6 d$.

Fidler, T. C. Calculations in Hydraulic Engineering. 2 Parts. 8vo. Part 1. Fluid Pressure and the Calculation of its Effects in Engineering Structures. 2nd imp. Pp. 168. 1907. 8s. Part 2. Calculations in Hydro-Kinetics. New edn. Pp. 218. 1914. 9s. Longmans.

Garrett, A. ff. Hydraulic Tables and Diagrams for Practical Engineers. Oblong 4to. $P_{Y}$. 56. 1909. Longmans. 16s. $6 d$.

Gibson, A. H. Hydraulics and its Applications. A Text-book for Engineers and Students. 2nd edn. Demy 8vo. Pp. 828. (1912) 1920. Constable. 24s.

Water Hammer in Hydraulic Pipe Lines. 2nd edn. Fcap. 8vo. 1920. Constable. $8 \mathrm{~s}$.
Hennell, T. Hydraulic and other Tables for purposes of Sewerage and Water Supply. 3rd edn. Cr. 8vo. Pp. 70. 1920. Spon. 3s.

Lea, F. G. Hydraulics. For Engineers and Engineering Students. 3rd edn. Demy 8vo. Pp. 580. 1919. Arnold. 18s.

Matthews, E. R. Studies in the Construction of Dams : Earthen and Masonry. Large 8vo. 1919. Griffin. 4s. $6 d$.

Meares, J. W. Hydro-Electric Development. The Determination of Water-Power Possibilities, Methods of Utilization, Design and Construction of Works. $18 \mathrm{mo}$. Pp. 100. 1920. Pitman. 2s.6d.

Minikin, R. C. R. Practical River and Canal Engineering. Demy 8 vo. Pp. 130. 1920. Griflin. 12s. 6d.

Moore, E. C. S. New Hydraulic Tables for the Complete Solution of Ganguillet and Kutter's Formula for the Flow of Liquid in Open Channels, Pipes, Sewers, and Conduits. Specially compiled Tables. Med. 8vo. Pp.230. 1901. Batsford. $18 s$.

Park, J. A Text-Book of Practical Hydraulics for the use of Mining Schools, Technical Colleges, Engineers, etc. 2nd edn. Large $\mathrm{Cr}$. 8vo. P . 320. 1921. Griffin. $21 s$.

Parker, P. A. M. The Control of Water as applied to Irrigation, Power and Town Water Supply Purposes. Large 8vo. Pp. 1,061. 1913. Routledge. 25s.

Pearson, K., Pollard, A. F. G., Wheen, C.W., and Richardson, L. F . An Experimental Study of the Stresses in Masonry Dams. Pp. 44. 1907. Cambridge University Press. 7s.

Shield, W. Principles and Practice of Harbour Construction. Med. 8vo. Pp. 314. 1910. Longmans. 17s. 6d.

Silk, A. E. Tables for Calculating the Discharge of Water in Pipes for Water and Power Supplies. Cr. 8vo. Pp.63. 1914. Spon. 4s.6d. 
Sprague, E. H. Hydraulics . Cr. 8vo. Pp. 190. 1914. Scott, Greenwood. $4 s, 6 d$.

Unwin, W. C. A Treatise on Hydraulies. 2nd edn. Demy 8vo. Pp. 339. 1912. Black. 12s.6d.

Vernon-Harcourt, L. F . Rivers and Canals. 2 Vols. 8vo. 1896. Vol, 1. Rivers: their Flow, Control, and Improvement. Pp. 362. Vol. 2. Canals: their Design, Construction, and Development. Pp. 716. Oxford: Clarendon Press. $31 s, 6 d$.

Wallace, W. M. Hydraulies in Theory and Practice. Cr. 8vo. Pp. 280. 1914. Technical Pub. Co. $5 s .6 d$.

\section{vii. IRRIGATION.}

Bellasis, E. S. Irrigation Works. The Principles on which their Design and Working should be based, with special Details relating to Indian Canals, and some proposed improvements. 8vo. Pp. 204. 1913. Spon. 10s. 6d.

__Punjab Rivers and Works. A description of the Shifting Rivers of the Punjab Plains and of Works on them-Inundation Canals, Flood Embankments, and River Training Works, etc. 2nd edn. Folio. Pp. 64 and 4.7 Plates. 1912. Spon. $10 s .6 d$.

Brown, Sir H. Irrigation: Its Principles and Practice as a Branch of Engineering. 2nd edn. Demy 8vo. Pp. 316. 1912. Constable. $16 s$.

Brownlie, T. A. Further Notes on Tube Wells: Boring, Sinking and Working for Irrigation Purposes in India. 2nd edn. Demy 8vo. 1914. Thacker. 7s. 6d.

Buckley, R. B. Irrigation Pocket Book. Facts, Figures, and Formulæ for Irrigation Engineers, being a Series of Notes on Miscellaneous subjects connected with Irrigation. 3rd edn. Cr.8vo. Pp.630. 1920. Spon. 30s.

The Irrigation Works of India. 2nd edn. 4to. Pp. 336. 1905. Spon. 50s.
Buckley, R. B . (compiled by). The Design of Channels for Irrigation for Drainage; being a Statement of the various Formulæ in use and a Guide to the Practical Application of them. Cr. 8vo. Pp. 55. 1911. Spon. $2 s$.

Doyle, K. D. Agriculture and Irrigation in Continental and Tropical Climates. Demy 8vo. Pp. 284. 1921. Constable. 19s.

Mackenzie, N.T. Notes on Irrigation Works. Demy 8vo. Pp. 119. 1910. Constable. $7 s .6 d$.

Mawson, E. O. Pioneer Irrigation. A Manual of information for Farmers in the Colonies: with Chapters on Light Railways by E. R. Calthrop. Demy 8vo. Pp. 276. 1904. Crosby Lockwood. $12 s, 6 d$.

Strange, W. L. Notes on Irrigation, Roads, and Ruildings, and on the Water Supply of Towns. Demy 8vo. Pp. 872. 1920, Routledge. $45 s$.

-Indian Storage Reservoirs with Earthen Dams. A Practical Treatise on their Design and Location. 2nd edn. 8vo. Pp. 466. 1913. Spon. 25s.

Willcocks, Sir W. Egyptian Irrigation. 2 Vols. 3rd edn. Supe. Roy. 8vo. Pp. 924. 1913. Sponr $63 s$.

The Irrigation of Mesopotamia. 2 Vols. 2nd edn. Text, super Roy. 8vo., plates, folio. Pp. 136. 46 Plates. 1917. Spon. 30s.

\section{viii. SHORE PROTECTION. LAND RECLAMATION.}

Beazeley, A. Reclamation of Land from Tidal Waters. 8vo. Pp. 326. 1900. Crosby Lockwood. 12s. 6d.

Carey, A. E., and Oliver, F. W. Tidal Lands. A Study of Shore Problems. Demy 8vo. Pp. 284. 1918. Blackie. 15s.

Latham, E. The Maintenance o Foreshores. Cr. 8vo. Pp. 90. 1914. Crosby Lockwood. 2s. 6d.

Matthews, E. R. Coast Erosion and Protection. 2nd edn. Med. 8vo. Pp. 211. 1918. Griffin. 12s. 6d. 


\section{Civil Engineering.}

\section{ix. HYDRAULIC MOTORS.}

Ball, Sir R. S. Natural Sources of Power. Ex. Cr. 8vo. Pp. 364. 1908. Constable. 7s.6d.

Björling, P. R. Water or Hydraulic Motors. Cr. 8vo. Pp. 287. 1903. Spon. 9s.

Blaine, R. G. Hydraulic Machinery, with an Introduction to Hydraulics. 3rd edn. 8vo. Pp. 470. 1913. Spon. 15s.

Bodmer, G. R. Hydraulic Motors and Turbines. A Handbook for Engineers, Manufacturers and Students. 3rd edn. Pp. 564. 1902. Pitman. 15s.

Chatley, H. How to Use Water Power. Cr. 8vo. Pp. 92. 1907. Technical Pub. Co. 3s. 6d.

Glarke, J. W. Hydraulic Rams. Their Principles and Construction; with Results of Experiments. 2nd edn. Cr. 8vo. Pp. 132. 1907. Batsford. 3s. 6d.

Gibson, A. H. Natural Sources of Energy. Roy. 16mo. Pp. 140. 1913. Cambridge University Press. $2 s .6 d$.

Marks, Sir G. G. Hydraulic Power Engineering. A Practical Manual on the Concentration and Transmission of Power by Hydraulic Machinery. 2nd edn. Demy 8vo. Pp. 404. 1905. Crosby Lockwood. $12 s .6 d$.

Robinson, H. Hydraulic Power and Hydraulic Machinery. 3rd edn. Demy 8vo. Pp.243. 1920. Griffin. $30 s$.

\section{x. PUMPS.}

Bale, M. P. Pumps and Pumping. A Handbook for Pump Users. 6th edn. Cr. 8vo. Pp. 121. 1912. Crosby Lockwood. 4s.

Björling, P . R : Practical Handbook on Pump Construction. 2nd edn. Cr. 8vo. Pp. 94. 1912. Spon. $6 s$.

Bowden-Smith, E. C. The Efficiency of Pumps and Ejectors. Demy 8vo. Pp. 216. 1920. Constable. $14 s .6 d$.
Bradley, F. A. Pumping and WaterPower. A Guide to the Hydraulic Laws and Conditions influencing Pumping Operations, etc. 8vo. Pp. 125. 1912. Spon. 6s.

Clarke, J. W. Pumps. Their Principles and Construction. 2nd edn. Cr.8vo. Pp.174. 1919. Batsford. $4 s .6 d$.

Colyer, F. Pumps and Pumping Machinery. 2nd edn. 8vo. Part 1. Pp. 212. 1892. Part 2. Pp. 169. 1900. Spon. 12s.6d. each.

Davey, H. The Principles and Construction of Pumping Machinery; Steam and Water Pressure. 2nd edn. Large 8vo. Pp. 350. 1905. Griffin. 25s.

Innes, C. H. Centrifugal Pumps, Turbines and Water Motors. 5th edn. Cr. 8vo. Pp. 342. 1909. Technical Pub. Co. 6s.

Michell, S. Mine Drainage; A Treatise on Direct-Acting Underground Steam Pumping Machinery. 2nd edn. Roy. 8vo. Pp. 396. 1899. Crosby Lockwood. 25s.

Sargeant, E. W. Centrifugal Pumping Machinery and Suction Dredgers. 2nd edn. 8vo. Pp.188. 1918. Griffin. 15s.

Weisbach, J., and Herrmann, G. The Mechanics of Pumping Machinery. 8vo. Pp. 308. 1897. Macmillan. 12s, $6 d$.

\section{Xi. WATER SUPPLY.}

Binnie, Sir A. R. Rainfall, Reservoirs and Water Supply. Demy 8vo. Pp. 168. 1913. Constable. $9 s$.

Burton, W. K., and Greenwell, A. Water Supply of Towns and the Construction of Waterworks. 3rd edn. Super Roy. 8vo. Pp. 334 . 1907. Crosby Lockwood. 28s .

Greenwell, A., and Curry, W. T. Rural Water Supply. A Practical Handbook on the supply of Water and Construction of Waterworks for Country Districts. 3rd edn. Cr. 8vo. Pp. 220. 1913. Crosby Lockwood. 6s. 
Harrison, A. B. Practical Well Sinking. Cr. 8vo. Pp. 66. 1913. Technical Pub. Co. 2s.

Hellins, H. H. The Lay-Out of Small Water Mains. Notes and Tables dealing with various Problems in Simple, Compound, Double and Ring Mains. 8vo. Pp. 45. 1921. Pitman. 7s, 6d.

Houston, Sir A. C. Rural Water Supplies and Their Purification. Demy 8vo. Pp. 152. 1918. Bale \& Danielsson. 7s. 6d.

- Rivers as Sources of Water Supply. Cr. 4to.' Pp. 102. 1917. Bale \& Danielsson. $5 s$.

_- Studies in Water Supply. 8vo. Pp. 216. 1913. Macmillan.6s.6d.

Isler, C. Well Boring for Water, Brine, and Oil : A Manual of Current Practice. 3rd edn. Demy 8vo. Pp. 268. 1920. Spon. 16s.

McPherson, J.A. Waterworks Distribution. A Practical Guide to the Laying ()ut of Systems of Distributing Mains for the Supply of Water to Cities and Towns. 2nd edn. 8vo. Pp. 175. 1907. Batsford. 7s. rid.

Middleton, R. E. Water Supply : A Practical Treatise on the Selection of Sources and the Distribution of Water. 2nd edn. in preparation. Griffin.

Rideal, S., and E. K. Water Supplies: Their Purification, Filtration, and Sterilisation. Demy 8vo. Pp. 250. 1914. Crosby Lockwood. $8 s .6 d$.

Sharp, J. Some Considerations Regarding Cast Iron and Steel Pipes. Roy. 8vo. Pp. 150. 1914. Longmans. $8 s .6 d$.

Taylor, F. N. Small Water Supplies. A Practical Treatise on the Methods of Collecting, Storing, and Conveying Water for Domestic use in Country Mansions, Estates, and Small Villages and Farms. Cr. 8vo. Pp.180. 1912. Batsford. 7s.6d.

Tudsbery, J. H. T., and Bright more, A. W. The Principles of Waterworks Engineering. 3rd edn. 8vo. Pp. 447. 1905. Spon. 24s. xii. WATER PURIFICATION.

Booth, W. H. Water Softening and Treatment: Condensing Plant, Feed Pumps and Heaters for Steam Users and Manufacturers. 2nd edn. Demy 8vo. Pp. 324. 1920. Constable. $9 s .6 d$.

Gollet, H. Water Softening and Purification. 2nd edn. Cr.8vo. Pp. 170. 1908. Spon. 6s.6d.

Don, J., and Chisholm, J. Modern Methods of Water Purification. 2nd edn. Demy 8vo. Pp. 416. 1913. Arnold. 16s.

\section{Xiii. MUNICIPAL ENGINEER - ING. SANITARY SCIENGE AND PLUMBING.}

Adams, H. C. The Sewerage of Sea Coast Towns. Demy 8vo. Pp. 132. 1911. Crosby Lockwood. 6s.

Allan, F. J., and Farrar, R. A. Aids to Sanitary Science. 2nd edn. Fcap. 8vo. Pp. 282. 1903. Baillière. $4 s, 6 d$.

Allsop, R. O. Engineering Work in Public Buildings. Power, Lighting, Heating, Ventilation, Water Supply. 4to. Pp. 168. 1912. Spon. 12s. $6 d$.

Barwise, S. Purification of Sewage. The Scientific Principles of Sewage Purification and their Practical Application. 2nd edn. Demy 8vo. Pp. 234. 1904. Crosby Lockwood. 12s. 6d.

Bennett, S. B. A Manual of Technical Plumbing and Sanitary Science. 3rd edn. Roy.8vo. Pp.300.1919. Batsford. 6s.

Blake, E. H. Drainage and Sanitation. A Practical Exposition of the Conditions vital to Healthy Buildings, their Surroundings and Construction, their Ventilation, Heating, Lighting, Water and Waste Services. For the use of Architects, Surveyors, Engineers, etc. 2nd edn. Demy 8vo. Pp. 531. 1920. Batsford. 15s. 
Boulnois, H. P. Municipal Engineering: surveving the scope of IIunicipal Engineering and the Statutory position, the appointment, training and duties of a Municipal Engineer. Fcap. 8vo. Pp. 110. 1921. Pitman. 2s. 6d.

Clarke, J. W. Modern Plumbing Practice. Vol. 1. Practical Lead Working and Plumbers' Materials, with Chapters on Siphons and their Action, etc. Edited by W. Scott. Large 8vo. Pp. 300. 1914. Batsford. $12 s$.

_-Practical Seience for Plumbers and Engineering Students-Treating of Physies, Iletals, Hydraulies, Heat, Temperature, etc. Svo. Pp. 226. 1903. Batsford. 6s.

Glemesha, w. W. Sewage Disposal in the Tropies. Demy 8vo. Pp. 241. 1910. Thacker. 15s.

Coleman, T. E. Stable Sanitation and Construction. $\mathrm{Cr}$. Svo. Pp. 226. 1897. Spon. 3s.6d.

Crimp, W. S., and Bruges, C. E. Sewers and Water Mains. Tables and Diagrams for use in Designing Sewers and Water Mains. Oblong 4to. Pp. 107. 1897. Batsford. $10 s$.

Davies, P. J. Standard Practical Plumbing, being a complete Encyclopædia for Practical Plumbers, Architects, Builders, Gas-Fitters, Hot-water Fitters, etc. 3 Vols. Vol. 1. 4th edn. Pp. 355. 1905. 7s.6d. Vol.2. 2nd edn. Pp. 805. 1905. 10s. 6d. Vol. 3. Pp. 204. 1905. 5s. Spon. The 3 Vols. $21 s$.

Davis, G. B ., and Dye, F. A Complete and Practical Treatise on Plumbing and Sanitation. 4to. Pp. 818. 1899. Spon. 42s.

Dunbar. A Manual of The Principles of Sewage Treatment. English edition by H. T. Calvert. 2nd edn. in preparation. Griffin.

Easdale, W. C. Sewage Disposal Works, their Design and Construction. 8vo. Pp. 264. 1910. Spon. 10s.6d.
The Empire Municipal Directory of Local Authorities and Officials and Year Book of "Municipal Engineering and the Sanitary Record' 'for 1920-21. 38th vear of publication. 4to. Pp. 268 and Diary. 1921. Sanitary Publishing. Co. $\tau s .6 d$.

Fletcher, Sir B. F., and H. P. Architectural Hygiene: or Sanitary Science as Applied to Buildings. 4th edn. Cr. 8vo. Pp.284. 1911. Pitman. 10s. 6d.

Hart, J.W. Sanitary Plumbing and Drainage. Demy 8vo. Pp. 250. 1904. Scott, Greenwood. 8s. 6d. -External Plumbing Work. A Treatise on Lead Work for Roofs. 2nd edn. Demy 8vo. Pp. 272. 1902. Scott, Greenwood. 8s. 6d. - Hints to Plumbers on Joint Wiping, Pipe Bending and Lead Burning. 3rd edn. Demy 8vo. Pp.313. 1901. Scott, Greenwood. 8s. $6 d$.

Hasluck, P. N. (edited by). Practical Plumbers' Work. Cr. 8vo. Pp. 168. 1919. Cassell. 3s.

Hellyer, S. S. Plumbing. 7th edn. Small post 8vo. Pp. 294. 1905. Bell. 5s.

Herring-Shaw, A. Elementary Science Applied to Sanitation and Plumbers'Work. 2nd edn. Demy 8vo. Pp. 280. 1910. Gurney and Jackson. 6s.

-Domestic Sanitation and Plumbing. 2 Vols. Demy 8vo. Vol. 1: Materials: Soil, Waste and Vent Pipes; Sanitary Fittings; House Drainage; Cesspools; Disposal of House Sewage. Pp. 336. 1909. 6s. 6d. Vol. 2. Water Supply; Domestic Hot Water; Warming and Ventilation. Pp. 374. 1911. $7 s .6 d$. Gurney and Jackson.

and Newsome, H.F.V. Modern Sanitary Engineering and Plumbers' Work; Progressive Scale Drawings of Current Practice. 2 Vols. Large Fcap. Folio. 1913. Vol. 1. Examples of the Jointing and Fixing of Pipes, etc. Pp. 40. 3s. Vol. 2. Examples of the Drainage of Buildings, etc. Pp. 48. 3s. 6d. Longmains. 


\section{Civil Engineering.}

Kershaw, G. B. Sewage Purification and Disposal. Demy 8vo. Pp. 350. 1915. Cambridge University Press. 14s.

Modern Methods of Sewage Purification. A Guide for the Designing and Maintenance of Sewage Purification Works. Med. 8vo. Pp. 369. 1911. Griffin. 25s.

Maguire, W. R. Domestic Sanitary Drainage and Plumbing. 4th edn. 8vo. Pp. 506. 1903. Kegan Paul. 12s.

Maxweil, W. H. (edited by). The Encyclopædia of Municipal and Sanitary Engineering. 4to. Pp. 561. 1910. Constable. 42s.

British Progress in Municipal Engineering. Super Roy. 8vo. Pp. 182. 1904. Constable.6s.

Middleton, G.A.T. The Drainage of Town and Country Houses. A Practical Account of Modern Sanitary Arrangements and Fittings. 8vo. Pp. 176. 1908. Batsford. 5s. $6 d$.

Raikes, H. P. Sewage Disposal Works: Design, Construction, and Maintenance. A Practical Guide to Modern Methods of Sewage Purifica tion. Demy 8vo. Pp. 429. 1913. Constable. $16 s$.

Raynes, F. W. Domestic Sanitary Engineering and Plumbing. Dealing with Domestic Water Supplies, Pump and Hydraulic Ram Work, Hydraulies, Sanitary Work, Heating by Low Pressure, Hot Water, and External Plumbing Work. 2nd edn. Demy 8vo. Pp. 488 . 1920. Longmans. $21 s$.

Reid, G. Practical Sanitation: a Handbook for Sanitary Inspectors and others interested in Sanitation. 19th edn. Cr.8vo. Pp.379. 1919. Griffin. $7 s, 6 d$.

Shone, I. Sewage Drainage Systems : The Shone System and the Gravitation Sewage-Drainage Systems of the Nineteenth Century, etc. 8vo. Pp. 460. 1914. Spon. 25s.

- Drainage and Drainage Ventilation Methods at the Houses of Parliament, etc. 8vo. Pp. 36 and 7 Plates. 1913. Spon. 6s.
Taylor, F. N. The Main Drainage of Towns. Med. 8vo. Pp. 324. 1912. Griffin. 15s.

Thomson, G. Modern Sanitary Engineering. Demy 8vo. Part 1 . House Drainage. 2nd edn. Pp. 280, 1920. 16s. Part 2. Sewerage. Pp. 221. 1921. 18s. Constable.

Vernon-Harcourt, L. F. Sanitary Engineering with respect to Water Supply and Sewage Disposal. Med.8vo. Pp.442. 1907. Longmans. $17 \mathrm{~s} .6 \mathrm{~d}$.

Watson, H.S. Sewerage Systems, Their Design and Construction. Roy.8vo. Pp.329. 1911. Crosby Lockwood. 12s. $6 d$.

Wood, F. Sanitary Fngineering: A Practical Manual of Town Drainage and Sewage and Refuse Disposal. 3rd edn. Cr.8vo. Pp.321. 1914. Griffin. $10 s, 6 d$.

\section{xiv. ILLUMINATION .}

Bloch, L. The Science of Illumination. An Outline of the Principles of Artificial Lighting. Translated by W. C. Clinton. Demy 8 vo. Pp. 180. 1912. Murray. 6s.

Blok, A. Elementary Principles of Illumination and Artificial Lighting. Cr. Svo. Pp. 240. 1914. Scott, Greenwood. $4 s, 6 d$.

Dye, F. Lighting by Acetylene. Cr. 8vo. Pp. 188. 1902. Spon. $6 s$.

Eck, J. Practical Illumination. 8vo. Pp. 85. 1914. Rentell. 1s.

The Application of Arc Lamps to Practical Purposes. 8vo. Pp. 101. 1910. Rentell. 2s.6d.

Gaster, L., and Dow, J. S. Modern Illuminants and Illuminating Engineering. 2nd edn. Demy 8vo. Pp. ว01. 1919. Pitman. 25s.

O'Connor, H. Petrol Air Gas. The Installation and Working of A ir Gas Lighting Systems for Country Houses. 2nd edn. Cr. Svo. Pp. 100. 1912. Crosby Lockwood. 2s. $6 d$. 
Ogley, D. H. Works Lighting. Cr. 8vo. Pp. 134. 1918. Iliffe. $7 s .6 d$.

Trotter, A. P. Illumination: Its Distribution and Measurement. 8 vo. Pp.310. 1911. Macmillan. 10s.6d.

\section{HEATING AND VENTILAT -} ING BUILDINGS.

Birks, F. The Mathematics of Ventilation, Pumping, and Haulage. Cr. 8vo. Pp. 222. 1918. Pitman. 5s.

Dye, F. W. Warming Buildings by Hot Water. 2nd edn. 8vo. Pp. 322. 1917. Spon. 12s.

_- Hot Water Supply. A Practical Treatise upon the Fitting of Hot Water Apparatus for domestic and general purposes. 6th edn. Cr. 8vo. Pp. 237. 1919. Spon. 8s. $6 d$.

- A Practical Treatise upon Steam Heating. 8vo. Pp. 251. 1901. Spon. 12s.

Grierson, R. Some Modern Methods of Ventilation, with Special Reference to Public Buildings : Standards of Ventilation, Design of Ducts, Selection of Fans, Washers and Heaters, etc. Demy 8vo. Pp. 202. 1916. Constable. 8s.6d.
Hart, J. W. The Principles of Hot Water Suppl $y$. Demy 8vo. Pp. 177. 1900. Scott, Greenwood. 8s. $6 d$.

Innes, C. H. Centrifugal and Axial Fans. 2nd edn. Cr. 8vo. Pp. 302. 1916. Technical Pub. Co. 10s.6d.

Raynes, F. W. Heating Systems: Design of Hot Water, and Steam Heating Apparatus. 2nd edn. 8vo. Pp. 344. 1921. Longmans. $21 s$.

White, W. L., and G. M. Heating Engineers' Quantities. Small folio. Pp. 33 and Plates. 1910. Spon. 10s. 6d.

\section{XVi. REFUSE DISPOSAL.}

Goodrich, W. F. Modern Destructor Practice. Med. 8vo. Pp. 294. 1912. Griffin. 18s.

Refuse Disposal and Power Production. Demy 8vo. Pp. 398. 1904. Constable. 16s.

Small Dust Destructors for Institutional and Trade Refuse. Demy 8vo. Pp. 127. 1904. Constable. $4 s$.

Matthews, E. R. Refuse Disposal. 2nd edn. in preparation. Griffin. 


\section{BUILDING CONSTRUCTION.}

\section{i. GENERAL.}

Adams, $\mathbf{H}$. The Mechanics of Building Construction. 8vo. Pp. 252. 1912. Longmans. $7 s .6 d$.

Advanced Building Construction. By the Author of 'Rivington's Notes.' Cr. 8vo. Pp. 254. 1915. Longmans . $6 s$.

Allen, J. P. A Practical Handbook of Building Construction. 5th edn . Med.8vo. Pp.596. 1909. Crosby Lockwood. 5s.6d.

Burns, G. J. Glossary of Technical Terms used in Architecture and the Building Trades. Cr. 8vo, Pp. 136. Spon. $4 s$.

Burrell, E. J. Building Construction. Cr. 8vo. Pp. 260. 1919. Longmans. $4 s$.

Clarke, J. W. Pocket-book of Tables and Memoranda for Plumbers, Builders, Sanitary and Electrical Engineers, etc. 5th edn. Pocket size. Pp. 300. 1909. Batsford. 2s. $6 d$.

Cunningham, B. Building Construction: First Stage. 2nd edn. 5th imp. Cr. 8vo. Pp. 336. 1915. University Tutorial Press. 3s. 6d.

Dean, A. Building Construction. 2 Pts. 8vo. Pp. 128., 189. 1913-14. Routledge. 5s.6d.

Eaton, R. B. Building Construction Drawing. A Class Book for the Elementary Student and Artisan. Imp. 8vo. Pp. 463, +157 Plates. 1921. 16s. Part 1. Pp. 59, +26 Plates. 1914. 2s. Part 2. Pp. 64, +26 Plates. 1914. 2s. Part 3. Pp. 80, +25 Plates. 1917. 3s.6d. Part 4. Pp. 88, +24 Plates. 1919. 5s. Part 5. Pp. 96, +26 Plates. 1919. 5s. Spon.
F owler's Architects' and Builders" Handbook, 1920. Pocket size. Pp. 500. January. Scientific Pub. Co. 2s. $6 d$.

Fullerton, W. Architectural Examples in Brick, Stone, Wood and Iron. 3rd edn. 4to. Pp. 254, 245 Plates. 1914. Spon. 21s.

Harrison, P. T. Bungalow Residences. 2nd edn. Demy 8 vo. Pp. 94 and 24 Plates. 1920. Crosby Lockwood. 7s, $6 d$.

Hurst, J . T. Handbook of Formulæ, Tables, and Memoranda, for Architectural Surveyors, and others engaged in Building. 15th edn. Oblong 32mo. Pp. 512. 1920. Spon. $7 s .6 d$.

Innocent, G. F. The Development of English Building Construction. Roy.8vo. Pp.310. 1916. Cambridge University Press. $12 s$.

Jaggard, W. R. Architectural and Building Construction Plates. Part 1. 30 Drawings (Elementary). 30 Plates in Portfolio. 1913. 10s. 6d. Part 2. 30 Drawings (Advanced). 30 Plates in Portfolio. 1914. 10s. 6d. Cambridge University Press.

-and Drury, F. E. Architectural Building Construction. Demy 8vo. Vol. 1. Pp. 328. 1916. Cambridge University Press. $7 s, 6 d$.

Manson, G. L. Experimental Building Science. Demy 8vo. Vol. 1. Pp.218. 1917. Cambridge University Press. $7 s$.

Mitchell, G. F., and G. A. Build. ing Construction and Drawing. A Text-book on the Principles and Details of Modern Construction. 9th edn. Cr.8vo. Part 1. Pp. 470. 1919. 6s. 6d. Part 2. Advanced Course. Pp. 985. 1919. 10s. 6d. Batsford. 
Molesworth, H. B. Obstruction to Light. A graphic method for the easy determination of questions affecting Ancient Lights. 4to. 1902. Spon. 6s.

Passmore, A. C. Handbook of Technical Terms used in Architecture and Building, and their Allied Trades and Subjects. Demy 8vo. Pp. 380. 1904. Scott, Greenwood. 8s. 6d.

Pearson, J. H. Suburban Houses. A Series of Practical Plans, with Notes on Design and Principles of Construction. 4to. Pp. 12, and 46 Plates. 1905. Spon. 7s.6d.

Pite, B., and others. Building Construction. 2 Vols. Med. 8vo. 1920. Vol. 1. Pp. 460. Vol.2. Pp.370. Longmans. 16s . each vol.

Reid, J. A. Building Construction and Architectural Drawing. 18 Plates with text. 1911. Blackie. $4 s .6 d$.

Riley, J . W . Building Construction for Beginners. New Imp. Gl. svo. Pp. 314. 1920. Mlacmillan. 5s.

Rivington's Notes on Building Construction. A Book of Reference for Architects and Builders and a Text-Book for Students. New edn. of First Two Parts edited by W. N. Twelvetrees. Demy 8 vo. Part 1. Pp. 316. 1915. 9s. Part 2. Pp. 342. 1915. 9s. Part 3. Materials. 7 th edn. Pp. 546. (1910) 1919. 22s. 6d. Part 4. Calculations for Building Structures. 8th edn. Pp. 398. (1912) 1920. 15s. Longmans.

Sage, A. R., and Fretwell, W. E. A Text-book of Elementary Building Construction. $\mathrm{Cr}$. 8vo. $\mathrm{Pp}$. 302. 1914. Methuen. 5s.

Samson, C. G. Every Man His Own Builder. 3rd edn. 8vo. Pp. 362. 1920. Crosby Lockwood. 15s.

Houses, Villas. Cottages and Bungalows. 2nd edn. Demy 8vo. Pp. 150. 1920. Crosby Lockwood. $7 s, 6 d$.

How to Plan a House. For those about to Build. 2nd edn. Cr. 8vo. Pp. 150. 1914. Crosby Lockwood. 5s.
Stock, C. H., and Farrow, F. R. Treatise on Shoring and Underpinning. 3rd edn. 8vo. Pp. 84. 1902. Batsford. 5s. 6d.

ii. ESTIMATES : QUANTITIES : SUPERVISION : REPAIRS.

Bales, 'T. The Builders' Clerk, a Guide to the Management of a Builder's Business. 2nd edn. Fcap. 8vo. 1904. Spon. $2 s$.

Ballard, W. E. Builders' Quantities. Cr. 8vo. Pp. 131. 1913. Longmans. $3 s .6 d$.

Blagrove, G. H. Dangerous Structures and How to Deal With Them. A Handbook for Practical Men. 2nd edn. Cr.8vo. Pp. 168. 1906. Batsford. $5 s, 6 d$.

Blake, E. G. Búilding Repairs. A Practical Guide to their Execution. Demy 8vo. Pp. 216. 1921. Batsford. 8s. $6 d$.

Chatterton, F. (edited by). Specification, with which is incorporated the Municipal Engineer's Specification. No. 23. 1921. Folio. Pp. 552. Feb., 1921. "Technical Journal." 10s.6d.

Coleman, T. E. Approximate Estimates, a Pocket book for Estimating, compiled for the use of Architects, Engineers, Estate Agents, Contractors, etc. 5th edn. 16mo. Pp. 451. 1920. Spon. 10s.6d. New Standard Building Prices. For the use of Architects, Civil Engineers, Builders, Contractors, etc. Cr. 8vo. Pp. 44. 1919. Spon. $4 s$.

Fletcher, Sir B. F., and H. P. Dilapidations, containing all recent Legal Decisions and a chapter on Fixtures. 7th edn. Cr. 8vo. Pp. 200. 1914. Batsford. 7s.6d. Quantities. A Text-book in Tabulated Form for the use of Architects, Surveyors, and Builders. Revised by H. P. Fletcher. 8th edn. Cr.8vo. Pp. 460. 1910. Batsford. $10 s$.

Grey, G. W. Building Supervision. Cr. 8vo. Pp. 158. 1913. Spon. 3s. $6 d$. 
Grubb, H. C. Builders' Quantities. 2nd edn. Cr. 8vo. Pp. 244. 1913. Methuen. 6s.6d.

Hoskins, G. G., and H. P. The Clerk of Works. A Vade Mecum for all engaged in the superintendence of Building Operations. 8th edn. Fcap. 8vo. Pp. 64. 1914. Spon. $2 s .6 d$.

Hurst, J. T. A Handbook of Formulæ, Tables and Memoranda for Architectural Surveyors and Draughtsmen. 16th edn. Oblong 32mo. Pp. 712. 1921. Spon. $10 s$.

Laxton's Builders' Price Book for 1921. Containing about 73,000 Prices, originally compiled by W. Laxton. 104th edn. Cr. 8vo. Pp. 645. Feb., 1921. Kelly. 7s.6d.

Leaning, J. Quantity Surveying, for the use of Surveyors, Architects, Engineers and Builders. 5th edn. 8vo. Pp. 936. 1912. Spon. 25s.

Lewis, H. M. Builders' Quantities. Cr. 8vo. Pp. 54. 1911. Spon. $2 s, 6 d$.

Lockwood's Builders ', Architects', Contractors', and Engineers' Price Book for 1921. Edited by R. S. Ayling. Cr. 8vo. Pp. 860 . Jan., 1921. Crosby Lockwood. $7 s .6 d$.

The Master Builders' Handbook and Diary, 1921. The Official Year Book of the London Master Builders' and Allied Industries Association. Cr. 8vo. Pp. 127 and Diary. 1921 . "'The Builder,' Ltd. $2 s .6 d$.

Metson, G. The Clerk of Works. A Handbook on the Supervision of Building Operations. Cr. 8vo. Pp. 190. 1913. Crosby Lockwood. $3 s .6 d$.

Oultram, J. F. The Builders' Foreman. A Practical Guide to his Training. Cr.8vo. Pp.208. 1916. Batsford. 7s.6d.

Purchase, W. R. Elementary Mand ual of Building Inspection. Cr. 8vo. Pp. 136. 1910. Croslyy Lockwood. $3 s .6 d$.
Rea, J.T. How to Estimate. Being a Complete and thoroughly up-todate Analysis of Builders' Prices. 4th edn. 8vo. Pp. 530. 1919. Batsford. 10s. 6d.

Stephenson, G. Estimating. A Method of Pricing Builders' Quantities for Competitive Work, without the use of a Price Book. 6th edn. Cr.8vo. Pp.178. 1913. Batsford. 5s. 6d.

-The Quantity Students' Assistant. A Handbook of Practical Notes and Memoranda for those learning to take-off Quantities. Cr. 8vo. Pp. 124. 1907. Batsford. 4s.

Pricing of Quantities. Ex. Cr. 8vo. Pp. 217. 1910. Constable. $5 s$.

-Repairs. How to Measure and Value Them. A Handbook for the use of Builders, Decorators, etc. 4th edn. Cr. 8vo. Pp. 108. 1913. Batsford. $4 s$.

Young, C. (edited by). Spon's Practical Builders' Pocket-book. A Reference book of Memoranda, Tables and Official Rules and Regulations for Architects and Builders. 3rd edn. Feap. 8vo. Pp. 532. 1921. Spon. 10s.6d.

Spon's Architects' and Builders' Pocket Price Book, 1921 4 47th edn. Feap.8vo. Pp.298. 1921. Spon. $6 s$.

\section{iii. BUILDING LAW : ARBITRATION.}

Cubitt, H. Building in London. A Treatise on the Law and Practice affecting the Erection and Maintenance of Buildings in the Metropolis . Super. Roy.8vo. Pp.811. 1911. Constable. 31s. 6d.

Fletcher, Sir B . F ., and H.P. Light and Air, with Methods of Estimating Injuries, Reports of recent Cases, etc. 5th edn. Cr. 8vo. Pp. 160 and Plates. 1904. Batsford. $7 s .6 d$.

-Valuations and Compensations. A comprehensive Treatise on Valuing Land and Houses. 4th edn. Cr. 8vo. Pp. 470. 1913. Batsford. $10 s$. 
Fletcher, Sir B. F., and H. P. London Building Acts, 1894-1909. 5th edn. Cr.8vo. Pp. 700. 1914 . Batsford. 10s.

-Arbitrations. A Text Book with the Chief Cases and Forms, Rules, etc. 3rd edn. Cr. 8vo. Pp. 175 . 1904. Batsford. 6s.

Rimmer, E. J. The Arbitration Clause in Engineering and Building Contracts. Cr.8vo. Pp.24. 1912. Constable. $2 s$.

\section{iv. BUILDING MATERIALS.}

Middleton, G. A. T. Building Materials: Their Nature, Properties, and Manufacture. 2nd edn. Large Cr. 8vo. Pp.450. 1916. Batsford. 10s.6d.

Munby, A. E. Introduction to the Chemistry and Physies of Building Materials. Ex. Cr. 8vo. Pp. 365 . 1909. Constable. $7 s .6 d$.

\section{v. CARPENTRY : WOODWORK AND ALLIED TRADES.}

Arkwright, J. P. (edited by). Carpentry and Cabinet Making for Amateurs. 2nd edn. Cr.8vo. Pp. 224. 1919. "Exchange and Mart.", $4 s$.

Ashcroft, H. J. Boat Building Simplified. 3rd edn. Demy 8ve. Pp. 74. 1919. Reiach. 5s.

Barter, S. Manual Instruction: Woodwork. 4th edn. Fcap. 4to. Pp. 364. 1905. Pitman. 7s.6d.

-Manual Instruction: Drawing. Showing the application of Geometrical Drawing to Manual Instruction in Wood and Metal. Fcap. 4to. Pp. 80. 1896. Pitman. 4s.

Binstead, H. E. Furniture. Cr. 8vo. Pp. 142. 1918. Pitman. $3 s$.

Boulton, B. C. The Manufacture and Use of Plywood and Glue. Demy 8vo. Pp. 98. 1920. Pitman. 7s. 6d.

Bowers, R. S., and others. Furniture Making. Demy 8vo. Pp.416. 1919. Cassell. 8s. 6d.
Denning, D. The Art and Craft of Cabinet-making. Cr. 8vo. Pp. 320. 1891. Pitman. 6s.

Ellis, G. Modern Practical Joinery. A Treatise on the Practice of Joiner's Work by Hand and Machine. 4th edn. Cr.4to. Pp.565. 1921. 45s. Also in 3 parts. Part 1. Drawing, Tools, Workshop Practice, Woodworking Machinery. Pp. 231. 15s. Part 2. Constructional .Joinery in House, Shop, and Public Buildings. Pp. 271. 18s. Part 3. Advanced Joinery, SettingOut, Timber, etc. Pp. 187. $12 s, 6 d$. Batsford.

-Modern Practical Carpentry. For the use of Workmen, Builders, Architects, and Engineers. Erecting Roofs, Floors, Partitions, Scaffolding, Shoring, Foundations, Bridges, Gates, Houses, etc. Cr. 4to. Pp. 450. 1915. Batsford. $30 s$.

Fletcher, Sir B. F., and H. P. Carpentry and Joinery. A Text-book for Architects, Engineers, Surveyors, Craftsmen, and Students. 4th edn. Cr. 8vo. Pitman. 10s.6d.

Hasluck, P. N. (edited by). Wood Carving: Comprising Practical Instructions and Examples. Roy. 8vo. Pp. 568. Cassell. 9s .

-Greenhouse and Conservatory Construction and Heating. Cr. 8 vo. Pp. 168. 1907. Cassell. 3s.

Hurst, J . T. Principles of Carpentry. Based upon the original work of Thomas Tredgold. 12th edn. Cr. 8vo. 1919. Spon. 10s.6d.

Jack, G. Woodcarving Design and Workmanship. 2nd edn. Cr. 8vo. Pp.320. 1913. Pitman. 7s.6d.

Jackson, F. G. Wood Carving as an Aid to the Study of Elementary Art. 2nd edn. Demy 8vo. Pp.65. 1913. Chapman and Hall. 4s.6d.

Jones, B. E. (edited by). The Complete Woodworker. Demy 8vo. Pp. 416. 1919. Cassell. 8s.6d.

Leland, C. G. Wood-Carving. 5th edn. Fcap. 4to. Pp. 162. Pitman. $5 s$. 
Philipson, J. The Art and Craft of Coach Building. Small post 8vo. Pp. 191. 1897. Bell. 6s.

Ricks, G. Manual Training: Woodwork. A Handbook for Teachers. Cr. 4to. Pp. 196. 1907. Macmillan. $8 s .6 d$.

Riley, J. W. Manual of Carpentry and Joinery. Cr. 8vo. Pp. 518. 1919. Macmillan. $6 s$.

Rowe, E. Practical Wood-Carving . 2nd edn. 8vo. Pp. 97. 1918. Batsford. 4s.

Rudd, J. H. Practical Cabinet Making and Draughting. Pp. 172. 1912. Benn Bros. 5s. $6 d$.

Scott, W. A. Handrailing for Geometrical Staircases. Cr. 8vo. Pp. 58. 1915. Pitman. 2s.6d.

Sturch, F. Manual Training Drawing (Woodwork). Its Principles and Applications. Feap. Pp.78.1906. Methuen. $7 s, 6 d$.

Terry, C. W . Practical Motor Body Building. A Practical Treatise on the various branches of Motor Body Construction, for Coachbuilders, Draughtsmen, Designers, Students, and others. Demy 8vo. Pp. 348. 1921. Spon. 15s.

Wake, R. The New Education: Woodwark. A Text Book of Manual Instruction, with descriptive lessons on Wood, Tools, and Benchwork. Demy 8vo. 1910.11s. Also in 3 Parts. 4s, each. Chapman and Hall.

Webber, F. C. Carpentry and Joinerv. 7th edn. Cr. 8vo. Pp. 336. 1919. Methuen. 68.

Wells, P. A., and Hooper, J. Modern Cabinet Work, Furniture and Fitments. An Account of the Theory and Production with over 1,000 Workshop Drawings, etc. 2nd edn. in preparation. Cr. 4to. Pp. 400. Batsford. 30s.

\section{vi. COB AND PISE WORK.}

Williams-Ellis, C. Cottage Buildings in Cob, Pisé, Chalk and Clay. Demy 8vo. Pp. 125. 1919. "Country Life"' Office. 6s. vii. BRICKS AND TILES: ARTIFICIAL AND MASONRY STONE.

Ackworth, A. T. The Manufacture of Roofing Tiles. Cr. 8vo. Pp. 136. N.D. Maclaren. 3s.6d.

Bourry, E. A Treatise on Ceramic Industries. A Complete Manual for Pottery, Tile, and Brick Manufacturers. Translated, with some Critical Notes, by A. B. Searle. 3rd edn. Demy 8vo. Pp. 488. 1919. Scott, Greenwood. 14s.6d.

Kloes, J . A. Van Der. A Manual for Masons, Bricklayers, Concrete Workers and Plasterers. Revised and Adapted by A . B. Searle. Demy 8vo. Pp. 247. 1914. Churchill. $8 s .6 d$.

Lefêvre, L. Architectural Pottery. Bricks, Tiles, Pipes, Enamelled Terra-cottas, Ordinary and Incrusted Quarries, Stoneware Mosaics, Faĩences and Architectural Stoneware. Roy, 8vo. Pp. 500. 1900. Scott, Greenwood. 17s.

Mitchell, C. F., and G. A. Brickwork and Masonry. A Practical Text-book for Students and those engaged in the Design and Execution of Structures in Brick and Stone. New edn. in preparation. Batsford

Passmore, A. C. Sand and Clay: Their Analysis and Physical Properties. Cr. 8vo. Pp. 48. 1907. Technical Pub. Co. $2 s .9 d$.

Renwick, W. G. Marble and Marble Working. Med. 8vo. Pp. 250. 1909. Crosby Lockwood. 16s.

Searle, A. B. Modern Brickmaking. 2nd edn. Rov. 8vo. Pp. 510. 1920. Scott, Greenwood. 17s.6d. An Introduction to British Clays, Shales, and Sands. 2nd edn. in preparation. Griffin.

-The Natural History of Clay. Roy. 16mo. Pp. 183. 1912. Cambridge University Press 2s.6d. Clays and Clay Products. 2nd edn. Cr. 8vo. Pp. 172. 1915. Pitman. 3s. 
Searle, A. B. Bricks and Artificial Stones of Non-Plastic Materials : Their Manufacture and Uses. 4to. Pp. 160. 1915. Churchill. 8s.6d.

Watson, J. British and Foreign Building Stones. Cr. 8vo. Pp. 492. 1911. Cambridge University Press. 6s. 6d.

- British and Foreign Marbles and other Ornamental Stones. Cr. 8vo. Pp. 496. 1916. Cambridge University Press. 5s.

\section{viii. CEMENT : CONCRETE.}

Ballard, F. Concrete for House, Farm and Estate. 2nd edn. 8vo. Pp. 65. 1920. Crosby Lockwood. $3 s .6 d$.

Blount, B. Cement : Manufacture; Power; Testing; Methods of Analysis; Chemistry; Uses and ByProducts. Assisted by W. H. Woodcock \& H. J. Gillett. Demy 8vo. Pp. 296. 1920. Longmans. $18 s$.

Butler, D. B. Portland Cement: Its Manufacture, Testing, and Use. 3rd edn. 8vo. Pp. 458. 1913. Spon. $21 s$.

Calcare. The Cement Users' and Buyers' Guide. 32mo. Pp. 115. 1901. Spon. 2s.

Dancaster, E. A. Limes and Cements: their Nature, Manufacture, and Use. 2nd edn. Cr. 8vo. Pp. 232. 1920. Crosby Lockwood. $7 s .6 d$.

Desch, C. H. The Chemistry and Testing of Cement. Demy 8vo. Pp. 276. 1911. E. Arnoid. 12s.

Gatehouse, F. B. A Handbook for Cement Works' Chemists. 2nd edn. Med.8vo. Pp.172. 1917. Griffin. $6 s$.

Lakeman, A. (edited by). Concrete Cottages, Small Garages and Farm Buildings. 8vo. Pp. 182. 1918. Concrete Publications, Ltd. $5 s$.

Potter, T. Concrete: Its Use in Building. 3rd edn. Demy 8vo. Pp. 350. 1908. Batsford. 8s.6d.
Poulsen, A. Cement in Sea-Water. 8vo. Pp. 59. 1909. Spon. 8s.

Redgrave, G. R., and Spackman, C. Calcareous Cements: Their Nature, Preparation and Uses. With some Remarks upon Cement Testing. 2nd edn. Med. 8vo. Pp. 328. 1905. Griffin. 18s.

Searle, A. B. The Chemistry of Cement, Concrete and Bricks. Demy 8vo. Pp. 423. 1913. Constable. 10s. $6 d$.

Setting of Cements and Plasters, The. Faraday Society Report. 1918. Demy 8vo. Pp.71. 1918. Faraday Society. $5 s .6 d$.

Sutcliffe, G. L. Concrete : Its Nature and Uses; for Architects, Builders, etc. 2nd edn. Cr. 8vo. Pp. 396. 1905. Crosby Lockwood. 10s. 6d.

Wheatley, O. Ornamental Cement Work. Demy 8vo. Pp. 128. 1912. Scott, Greenwood. $6 s$.

iX. RE-INFORGED CONCRETE.

Adams, H., and Matthews, E. R. Reinforced Concrete Construction in Theory and Practice. 2nd edn. 8vo. Pp. 330. 1916. Longmans. $15 s$.

Andrews, E. S. Elementary Principles of Re-Inforced Concrete Construction. 2nd edn. Cr. 8vo. Pp. 260. 1918. Scott, Greenwood. 5s. -Regulations of the L.C.C. Relating to Reinforced Concrete. 1916. The official Text, Notes, Explana. tions, etc. Cr. 8vo. Pp. 78 . 1916. Batsford. 3s.

Ball, J. D. W. Reinforced Concrete Railway Structures. Demy 8vo. Pp. 227. 1913. Constable. 9s.

Gantell, M. T. Reinforced Concrete Construction. Part 1. 2nd edn. Cr. 8vo. Pp. 168. 1918. 8s. 6d. Part 2. 8vo. Pp. 256. 1912. 15s. Spon.

Coleman, T. E. Estimating for Reinforced Concrete Work. Cr. 8vo. Pp. 154. 1912. Batsford. 5s.

Davenport, J. A. Graphical Relnforced Concrete Design. A series of Diagrams on Sheets. 1911. Spon. 6s. 
Etchells, E. F. Mnemonic Notations for Engineering Formulæ. Report of the Science Committee of the Concrete Institute with Explanatory Notes by E. F. Etchells . Demy 8vo. J'p. 116. 1919. Spon. 6s.

Faber, O., and Bowie, P.G. Reinforced Conerete Design. Demy 8vo. Vol. I. Theory. Pp. 352. 1919. 14s. Vol. 2. Practice. By O. Faber. Pp. 258. 1920. Arnold. $18 s$.

Gammon, J. C. Reinforced Concrete Design Simplified: Diagrams, Tables, and other Data. 2nd edn. Demy 4to. Pp.124. 1913. Crosby Lockwood. $15 \mathrm{~s}$.

Geen, B. Continuous Beams in Reinforced Concrete. Imp. 4to. 1912. Chapman \& Hall. $10 s$.

Marsh, C. F. A Concise Treatise on Reinforced Concrete. 3rd imp. Demy 8vo. Pp. 233. 1920. Constable. $12 s .6 d$.

-Reinforced Concrete Compression Member Diagram. Roy 8vo. 1914. In cloth covers, mounted on linen. 5s. Unmounted. $3 s, 6 d$. Constable. and Dunn, W. Manual of Reinforced Concrete. 3rd edn. Fcap. 8vo. Pp. 491. 1916. Constable. 14s.

Martin, N. Properties and Design of Reinforced Concrete. Fcap. 4to. Pp. 131. 1912. Constable. 8s.

Rings, F. Reinforced Concrete Bridges. Imp. 8vo. Pp. 193. 1913. Constable. 21s.

Scott, A. A. H. Reinforced Concrete in Practice. Cr. 8vo. Pp. 190. 1915. Scott, Greenwood. 5s.

Twelvetrees, 'W. N. Reinforced Concrete. A Treatise on the Theory and Practice of Reinforced Concrete Construction. Demy 8vo. Pp. 275. 1920. Pitman. 21s.

-Practical Design of Reinforced Concrete Beams and Columns. $\mathrm{Cr}$. 8vo. Pp. 167. 1911. Pitman. 7s. 6d.

Concrete-Steel Buildings. $\mathrm{Cr}$. 8vo. Pp.408. 1907. Pitman.12s.

Williamson, J, Calculating Diagrams for Design of Reinforced Concrete Sections. Imp. Svo. Pp.44. 1920. Constable. 128.

\section{IRON AND STEEL GONSTRUCTION.}

Andrews, E.S., and Cocking, W.C. Tables of Safe Loads on Steel Pillars with Practical Notes on Design and Construction. Vol. 1. Plated Single $\exists$ Beams. Demy 8 vo. 1918. Pitman. 6s.

Beck, E. G. Structural Steelwork: Relating principally to the Construction of Steel Framed Buildings. 8vo. Pp. 462. 1920. Longmans. $21 s$.

Cocking, W. C. The Calculations for Steel-Frame Structures. Cr. 8vo. Pp.312. 1917. Scott, Greenwood. $6 s$.

Farnsworth, A. W. Constructional Steelwork. 2nd edn. in preparation. Griffin.

Fidler, H. Notes on Construction in Mild Steel. Med. 8vo. Pp. 462. 1907. Longmans. 18s. $6 d$.

Hasluck, P. N. (edited bv). Iron, Steel, and Fireproof Construction. Cr. 8vo. Pp. 168. 1906. Cassell. $3 s$.

Schindler, K. Iron and Steel Constructional Work. Translated and Revised from the German, and adapted to British practice. Cr. 8vo. Pp.140. 1912. Scott, Greenwood. $4 s .6 d$.

Sexton, A. H. The Corrosion and Protection of Metals, with special reference to the Preservation of Engineering Structures. Cr. 8vo. Pp.148. 1906. Scientific ub. Co. ss.

Skelton, R. A. and Co. (compiled by). Structural Steel. Consisting of Tables and Notes for Engineers, Architects, Contractors and Iron Merchants. Feap. 4to. Pp. 320. 1915. Pitman. $10 s$.

Spencer, A. S. Practical Design of Steel-Framed Sheds. Roy. 8vo. Pp. 177. 1915. Constable. 12s.

Twelvetrees, W. N. Structural Iron and Steel. Cr. 8vo. Pp. 163. 1900. Pitman. 7s,6d. 


\section{xi. MISGELLANEOUS}

Holt, H. G. Fire Protection in Buildings : a Practical Treatise for Engineers, Architects, etc. Demy 8vo. Pp. 280. 1913. Crosby Lockwood. $9 s$.

Keim, A. W. The Prevention of Dampness in Buildings: with Re marks on the Causes. Nature and Efferts of Saline, Efflorescences and Dry-rot. Translated from the German. Cr. 8vo. Pp. 115. 1902. Scott, Greenwood. 6s.

Montel, A. Building Structures in Earthquake Countries. From the Italian, with additions by the Author. Cr.4to. Pp. 138. 1912. Griffin. 10s. 6d.

\section{xii TOWN PLANNING.}

Aldridge, H. A. The Case for Towr: Planning. A Practical Manual. Roy. 8vo. Pp.679. 1915. Net. Housing and Town Planning Council. $15 s$.

Cadbury, G. Town Planning, with special Reference to the Birmingham Schemes. 2nd imp. 8vo. Pp. 218. 1915. Longmans. 8s.

Julian, J. An Introduction to Town Planning: the Principles of the Subject, and a consideration of the Problems Involved, Powers of Local Authorities, etc. Cr. 8vo. Pp. 156. 1914. Griffin. 6s.

Lanchester, H.V. Town Planning in Madras. 4to. Pp. 123. 1918. Constable. 12s. $6 d$.

Nettlefold, J. S. Practical Town Planning: A Land and Housing Policy. Cr. 8vo. Pp. 493. 1914. St. Catherine Press. 2s. 6d.

Triggs, H. I. Town Planning: Past, Present and Possible. 2nd edn. Roy. 8vo. Pp. 336. Methuen. $16 s$.

Unwin, R. Town Planning in Practice. An introduction to the Art of Designing Cities and Suburbs. 6th imp. Cr. 4to. Pp. 448. 1919. Fisher Unwin. 31s. $6 d$.

Webb, W. Garden First in Land Development. 2nd edn. 8vo. Pp. 142. 1920. Longmans. 5s.

\section{xiii. HOUSE DEGORATION :} PAINTS, ETC.

Bates, A. Motor and Carriage Painting. A Practical Manual. Cr. 8vo. Pp. 164. 1915. Trade Paper Pub. Co. $4 s$.

Brown, w. N. House Decorating and Painting. Cr. 8vo. Pp. 150 . 1900. Scott, Greenwood. 4s. 6d. Workshop Wrinkles for Decora: tors, Painters, Paperhangers, and Others. 2nd edn. Cr. 8vo. Pp. 128. 1907. Scott, Greenwood. 2s. $6 d$.

Coach Painters' Handbook and Guide, The. Cr. 8vo. Pp. 133. Trade Paper Pub. Co. 2s. $6 d$.

Desaint, A. Three Hundred Shades and How to Mix Them. For Architects, Painters and Decorators. Folio. 100 Plates. 1907. Scott, Greenwood. $23 s$.

Duthie, A. L. Stencils and Stencilling; for all Artistic and Decorative purposes. Cr.8vo. Pp.163. 1914. Trade Paper Pub. Co. $4 s$.

Ermen, W. F. A. Materials Used in Sizing. Cr. 8vo. Pp. 126. 1912. Constable. $6 s$.

Fleury, $P$. The Preparation and Uses of White Zinc Paints. Translated from the French. Cr. 8vo. Pp. 280. 1912. Scott, Greenwood. 7s.

Galloway, J.H. Staining, Varnishing and Enamelling. Cr. 8vo. Pp. 122. 1910. Trade Paper Pub. Co. $4 s$.

Hasluck, P. N. (edited by). House Decoration. Roy. 8vo. Pp. 568. 1913. Cassell. 9s.

Practical Graining and Marbling. Cr. 8vo. Pp. 168. 1911. Cassell. 3s.

Hurst, G. H. Colour: A Handbook of the Theory of Colour. 2nd edn. Demy 8vo. Pp. 168. 1916. Scott, Greenwood. 8s.6d.

-Painters' Colours, Oils, and Varnishes. 6th edn. Revised by $\mathbf{N}$. Heaton in preparation. Griffin.

-The Painter's Laboratory Guide. A Student's Handbook of Paints, Colours, and Varnishes. 2nd edn. in preparation. Griffin. 


\section{Building Construction.}

Jennings, A. S. Commercial Paints and Painting. A Handbook for Architects, Engineers, Property Owners, Painters and Decorators. Ex.Cr.8vo. Pp. 236. 1914. Constable. 7s. $6 d$.

Paint and Colour Mixing: A Practical Handbook, 5th edn. Demy 8vo. Pp. 250. 1921. Spon. 12s. 6d.

-Paints and Varnishes, with special reference to their Properties and Uses. Cr. 8vo. Pp. 116. 1920. Pitman. 3s.

and Harrison, C. The Painters' Pocket Book. 4th edn. Pott 8vo. Pp. 258. 1920. Trade Paper Pub. Co. $4 s .6 d$.

Jones, M. W. The Testing and Valuation of Raw Materials used in Paint and Colour Manufacture. For the Laboratories of Colour Works. Cr. 8vo. Pp. 88. 1900. Scott, Greenwood. $6 s$.

Millar, A. Srumbling and Colour Glazing. Cr. 8vo. Pp. 86. 1909. Trade Paper Pub. Co. $4 s$.
Oliver, C. E. The Painters 'Business Book. Cr. 8vo. Pp. 213. 1914. Trade Paper Pub. Co. $4 s$.

Pearce, W. J. Painting and Decorating: A complete Practical Manual for House Painters and Decorators. 4th edn. Cr. 8vo. 1913. Griffin. $12 s .6 d$.

Rothery, G. C. Decorators' Symbols, Emblems, and Devices. Cr. 8vo. Pp. 130. 1907. Trade Paper Pub. Co. 3s. 6d.

Scott-Mitchell, F. Practical Gilding, Bronzing, Lacquering and Glass Embossing. Cr. 8vo. Pp. 184. 1907. Trade Paper Pub. Co. $3 s .6 d$.

Smith, J. C. Paint and Painting Defects, their Detection. Cause and Cure. Cr.8vo. 1912. Trade Paper Pub. Co. $4 s$.

- - and Laurie, A.P. Zine Oxide and its Uses. Cr. 8vo. Pp. 108. 1909. Trade Paper Pub. Co. 2s.6d.

Wright, A. C. Simple Methods for Testing Painters' Materials. Cr. 8vo. Pp. 160. 1903. Scott, Greenwood. $6 s$. 


\section{NAVAL ARCHITECTURE, SHIP- BUILDING.}

\section{i. GENERAL.}

Atherton, W. H., and Mellanby, A. L. Resistance and Power of Steamships. Cr. 8vo. Pp. 208. 1903. Technical Pub. Co. 6s.9d.

Attwood, E. L. War Ships: A Textbook on the Construction, Protection, Stability, etc., of War Vessels. 6th edn. Med.8vo. Pp.346.1917. Longmans. $14 s$.

- Text-book of Theoretical Naval Architecture. 7th edn. 4th imp. Cr.8vo. Pp. 506. (1916). 1919. Longmans. $10 s .6 d$.

- The Modern Warship. Roy. 16mo. Pp. 153. 191. Cambridge University Press. 2s. $6 d$.

- and Cooper, I. G. G. A TextBook on Laying-oft, or the Geometry of Ship-building. 2nd edn. new imp. 8vo. Pp. 132. 1918 (1919). Longmans. $7 s .6 d$.

Ayre, A. L. The Theory and Design of British Shipbuilding. Illustrated by 85 Diagrams. 8vo. Pp. 167. 1920. T. Reed. 6s. 6d.

Baker, G.S. Ship Form, Resistance, and Screw Propulsion. Treated from the practical point of view for the use of Naval Architects, Engineers, and Draughtsmen. 2nd edn. Demy 8vo. Pp. 270. 1921. Constable. $16 s$.

Barnaby, S. W. Marine Propellers. 6th edn. 8vo. Pp. 230. 1920. Spon. 24s.

Biles, Sir J. H. The Design and Construction of Ships. Vol. 1 . Calculations and Strength. 2nd edn. Large. 8vo. Pp. 448. 1919. 34s. Vol. 2. 2nd edn. in preparation. Griffin.
Blocksidge, E. W. Ships' Boats. Their Qualities, Construction, Equipment, and Launching Appliances. 8vo. Pp. 500. 1920. Longmans. 25s.

Brassey's Naval and Shipping Annual. 1920-21. Edited by A. Richardson and A. Hurd. Roy. 8vo. Pp. 383. Jan. 1921. Clowes. 25s.

Cook, C. W. Steel Shipbuilders" Handbook. An Encyclopæedia of the names of parts, tools, operations, etc.. used in the building of steel ships. Cr. 8vo. Pp. 127. 1919. Longmans. 6s. $6 \mathrm{~d}$.

Holms, A. C. Practical Shipbuilding: a Treatise on the Structural Design and Building of Modern Steel Vessels. 2 vols. 3rd edn. 1916. (4th imp. 1918). Vol. 1. Text. Med. 8vo. Pp.652. Vol. 2. Diagrams and Illustrations. Oblong 4to. Pp.172. Longmans. 67s.6d.

Hovgaard, W. General Design of Warships. Super Roy. 8vo. Pp. 315. 1920. Spon. 32s.

Jane's Fighting Ships: 1920. An Encyclopædia of the Navies of the World. Edited by M. Prendergast and 0 . Parkes . 23rd year of Issue. Oblong 4to. Pp. 580. Jan. 1921. Sampson, Low. 42s.

Jordan, G. H. Tabulated Weights of Iron and Steel. Tabulated Weights of Angle, Tee, Bulb, Round, Square and Flat Iron and Steel. For the use of Naval Architects, Shipbuilders, etc. 7th edn. Oblong 32mo. Pp. 742. 1918. Spon. 21s.

Lovett, W. J. A Complete ClassBook of Naval Architecture : Practical, Laying-off, Theoretical. 2nd imp. 8vo. Pp. 294. 1918. Longmans. 10s.6d. 
Lovett, W. J. Applied Naval Architecture. Demy 8vo. Pp. 666. 1920. Longmans. 36s.

McDermaid, N. J. Shipyard Practice as applied to Warship Construction. 2nd edn. new imp. Med.8vo. Pp.336. (1917). 1918. Longmans. $17 s .6 d$.

Mackrow, C., and Woollard, L. Naval Architect's and Shipbuilder's Pocket-Book of Formula, Rules, and Tables. 12th edn. Fcap. 8vo. Pp. 700. 1918. Crosby Lockwood. $16 s$.

Mitchell, J. Naval Architect's Data . Edited by E. L. Attwood. 8vo. Pp. 230. 1919. Longmans. 8s.6d .

Murray, A. J. Strength of Ships. 8vo. Pp. 408. 1916. Longmans. $17 s, 6 d$.

Nicol, G. Ship Construction and Calculations. 8vo. Pp.518. 1920. J. Brown. $23 s$.

Steele, J. E. Naval Architecture: Part 1. Demy 8vo. Pp. 150.1918. Cambridge University Press. 6s. $6 d$.

Thearle, S. J. P. The Modern Practice of Shipbuilding in Iron and Steel. Vol. 1. Text. Demy 8vo. Pp. 268. 1910. 5s. Vol. 2. Plates. 4to. 10s. Collins.

Thomas, J. B. The Strength of Ships. Cr. 8vo. Pp. 295. 1918. Scott, Greenwood. 6s.

Torr, C. Ancient Ships. Demy 8vo. Pp. 152. 1895. Cambridge University Press. 10s. 6d.

Walton, T. Present Day Shipbuilding. For Ship-yard Students, Ships Officers and Engineers. 2nd edn. in preparation. Griffin .

Know Your Own Ship. Revised by J. King. 18th edn. Large $\mathrm{Cr}$. 8vo. Pp. 414. 1920. Griffin. 9s. -Steel Ships: Their Construction and Maintenance. A Manual for Ship Builders, Students, Marine Engineers, etc. 6th edn. Roy.8vo. Pp. 348. 1920. Griffin. 25s.
Watson, T.H. Naval Architecture: A Manual of Laying-off Iron, Steel and Composite Vessels. 3rd edn. Roy. 8vo. Pp. 183. 1917. Longmans. 50s.

\section{ii. MISCELLANEOUS.}

Boycott, G. W. M. Compressed Air Work and Diving. Med. 8vo. Pp. 128. 1909. Crosby Lockwood. $10 s .6 d$.

Davis, R. H. A Diving Manual and Handbook of Submarine Appliances . embodying the Deep Sea Practice adopted by the British Admiralty; and including chapters on the Physics and Physiology of Diving, Salvage Operations, etc. 8vo. Pp. 271. 1919. Pitman. $7 s .6 d$.

Dommett, W. E. Submarine Vessels including Mines, Torpedoes, Guns, Steering, Propelling, and Navigating Apparatus. 5th edn. Cr. 8vo. Pp. 106. 1918. Pitman. 5s.

Domville-Fife, C. W. Submarine Engineering of To-Day. Cr. 8vo. Pp. 324. 1914. Seeley. 7s.6d.

Maginnis, A. G. The Atlantic Ferry : Its Ships, Men, and Working . 3rd. edn. Cr.8vo. Pp.288.1900. Pitman. $3 s$.

Talbot, F. A. Lightships and Lighthouses. Demy 8vo. Pp. 356. 1913. Heinemann. 6s.

- Submarines. Cr. 8vo. Pp. 284. 1918. Heinemann. 5s.

White, H. J. Oil Tank Steamers: Their Working and Pumping Arrangements Thoroughly Explained. 2nd edn. Demy 8vo. Pp. 150. 1919. James Brown. 7s.6d.

Wryde, J. S. British Light-houses : their History and Romance. Demy 8vo. Pp. 383. 1913. Fisher Unwin. 10s, 6d. 


\section{MECHANICAL ENGINEERING.}

\section{i. GENERAL.}

Adams, H. Engineers' Handbook. Comprising Facts and Formulæ, Principles and Practice, in all branches of Engineering. Roy . 8vo. Pp. 582. Cassell. 9s.

- Foundations for Machinery. $\mathrm{Cr}$. 8vo. Pp. 71. 1919. Technical Pub. Co. 3s.6d.

Allen, C. C. Engineering Workshop Practice. 4th edn. Cr. 8vo. Pp. 260. 1917. Methuen. 5s.

Andrews, E.S. A Primer of Engineering Science. An Introductory Text-Book. Cr.8vo. Pp.76.1918. Pitman. 4s.6d.

Barber, T. W. The Engineer's Skatch-Book of Mechanical Movements, Devices, Appliances, Contrivances, and Details employed in the Design and Construction of Ma"hinery for every purpose. 6th edn. 8ro. Pp. 355. 1918. Spon. 1 is.

Bentley, W. Sketches of Engine and Machine Details. 8th edn. Large Cr. 8vo. Pp. 140. 1920. Chapman \& Hall. 3s. 6 d.

Bjorling, P.R. (edited by). Mechanical Engineers' Pocket Book. 2nd edn. Cr. 8vo. Pp. 387. 1919. Pitman. 6s.

Browne, C. L. The Fitting and Erecting of Engines. 2nd edn. Demy 8vo. Pp. 173. 1918. Emmott. כs .

Campin, F. Mechanical Engineering. Comprising Metallurgy, Moulding, Casting, Forging, etc. 3rd edn. Cr. 8vo. 1918. Crosby Lockwood. 3s.

Charnock, G. F. Mechanical Technology: Materials and Preparatory Processes of the Mechanical Industries. Demy 8vo. Pp.645. 1919. Constable. 12s. $6 d$.
Clark, D. K ., and Powles, H. H. P. Mechanical Engineer's PocketBook. 11th edn. Small Cr. 8vo. Pp. 700. 1919. Crosby Lockwood. 7s. $6 d$.

Corbin, T. W. Mechanical Inventions of To-Day. Cr. 8vo. Pp. 324. 1918. Seeley. 7s.6d.

Davies, F. H. Foundations and Machinery Fixing. New imp. Fcap. 8vo. Pp. 152. 1919. Constable. 2s. $6 d$.

Dommett, W. E. (edited by). Mechanics and Draughtsmen's PocketBook. Cr. 8vo. Pp. 135. 1919. Pitman. 2s. 6d.

Greenly, H. Model Engineering. A Guide to Model Workshop Practice. Demy 8vo. Pp.416. 1919. Cassell. 8s. $6 d$.

Haler, P. J., and Stuart, A. H. A First Course in Engineering Science. 2nd imp. Cr.8vo. Pp. 200. 1918. University Tutorial Press. 3s.6d.

Horner, J. G. (edited by). Lockwood's Dictionary of Terms used in the Practice of Mechanical Engineering. 5th edn. with Appendix. Cr. 8vo. Pp. 470. 1918. Crosby Lockwood. 8s, 6d.

Horton, C. M. Opportunities in Engineering. Cr. 8vo. Pp.96.1921. University of London Press. 3s.6d.

Hutton, W. S. Practical Engineer's Handbook. A Treatise on Engines and Boilers, Marine, Locomotive and Stationary. 7th edn. Med. 8vo. Pp. 576. 1911. Crosby Lockwood. $21 s$.

Jervis-Smith, F. J., and Boys, G.V. Dynamometers. Demy 8vo. Pp. 283. 1915. Constable. 14s.

Kennedy, Sir A. B. W. The Mechanics of Machinery. Cr. 8vo. Pp.668. 1907. Macmillan. $8 s .6 d$. 
Lanchester, F.W. Industrial Engineering. Its Present position and Post-war outlook. Cr. 8vo. Pp.61. 1917. Constable. 1s. $6 d$.

Lineham, W, J. A Text-book of Mechanical Engineering. Part 1., Workshop Practice; Part 2., Theory and Examples. 11th edn. 8vo. Pp. 1241. 1920. Chapman \& Hall. $21 s$.

Liversedge, A. J. Commercial Engineering. Demy 8vo. Pp. 369 . 1912. Emmott. 8s. 6d.

Low, D. A. A Pocket-Book for Mechanical Engineers. 8th imp. Feap. 8vo. Pp. 748. 1919. Longmans. 9s.

McLaren, R. S. Mechanical Engineering for Beginners. 4th edn. Cr. 8vo. Pp. 316. 1920. Griffin.6s.

Marks, E. G. R. Mechanical Engineering Materials. 2nd edn. Cr.8vo. Pp. 98. 1906. Technical Pub. Co. 3s. $6 d$.

Pullen, W. W. F. Engineering Tables and Data for the use of Students in Laboratories, \&c. 2nd edn. Demy 8vo. Pp. 96. 1913. Scientific Pub. Co. 1s.6d.

Rankine, W. J. M. A Manual of Machinery and Mill Work. Revised by W.J.Millar. 7th edn. Cr.8vo. Pp. 617. 1893. Griffin. 12s.6d.

Robson, A. G. Engineering Workshop Principles and Practice. 2nd edn. Demy 8vo. Pp. 259. 1919. Emmott. 6s.

Sexton, A. H. Chemistry of Materials of Engineering. 3rd edn. Cr. 8vo. Pp. 337. 1909. Technical Pub. Co. 6s. $9 d$.

Spikes, W.H. Foundations of Engineering. Cr. 8vo. Pp. 272. 1919. Hodder \& Stoughton. 4s.6d.

Stanley, H. Practical Science for Engineeering Students. Cr. 8vo. Pp. 174. 1913. Methuen. 5s.

Taylor, H. G. Laboratory Engineering. Cr. 8vo. Pp. 392. 1913. University of London Press. 7s.6d.

\section{ii. POWER TRANSMISSION :} GEARING .

Bale, M. P. Modern Shafting and Gearing, and the Economical Trans. mission of Power. Cr. 8ro. Pp. 124. 1893. Wm. Rider, $2 s .6 d$.

Butler, E. Transmission Gears: Mechanical, Electric, and Hydraulic, for Land and Marine Purposes. Med.8vo. Pp. 176. 1917. Griffin. 8s. $6 d$.

Dunkley, W. G. Belts for Power Transmission. Pott 8vo. Pp.116. 1921. Pitman. 2s.6d.

Hill, C. W. The Design of Toothed Gears. Med. 8vo. Pp.64. 1918. Griffin. 3s. 6d.

Horner, J. G. Toothed Gearing. A Practical Hand-book for Offices and Workshops. 2nd edn. Cr. 8vo. Pp. 224. 1904. Crosby Lockwood. $7 s .6 d$.

Ingham, A. E. Gearing: A Practical Treatise. Demy 8vo. Pp. 193. 1914. Methuen, 7s.6d.

Puppe, J . Experimental Investigations on the Power Required to Drive Rolling Mills. Translated from the German. 2nd edn. in preparation. Griffin.

Shaw, T.R. The Driving of Machine Tools. Cr.8vo. Pp.225. 1917. Scott, Greenwood. 5s.

Smith, T. A. Power and its Transmission. A Practical Handbook for the Factory and Works Manager. Fcap. 8vo. Pp. 76. 1910. Spon. $2 s .6 d$.

Snell, Sir J. F. C. Power House Design 2nd edn. 8vo. 1921. Longmans. $42 s$,

White, G. T. Toothed Gearing. Cr . 8vo. Pp. 220. 1912. Scott, Greenwood. $4 s, 6 d$.

Wildgoose, A., and Orr, A. J. (compiled by). Wheel Gearing. Tables of Pitch-line Diameters of Wheels, Proportions and Strengths of Teeth, etc. Fcap. 16mo. Pp. 184. 1921. Spon. 3s.

Woollaston, T. R. Power Plant. Demy 8vo. Pp. 117. 1919. Sherratt and Hughes. $5 s$. 


\section{Mechanical Engineering.}

\section{lii. COMPRESSED AIR POWER TRANSMISSION.}

Daw, A.W., and Z. W. Compressed Air Power. A Treat ise on the Development and Transmission of Power by Compressed Air. Demy 8vo. Pp. 399. 1920. Pitman. 21s.

Popplewell, W. C. Compressed Air. A Treatise on the Theory and Practice of Pneumatic Power Transmission. 2nd edn. Demy 8vo. Pp. 295. 1921. Scientific Pub. Co. $10 s$.

\section{iv. LUBRIGATION.}

Archbutt, L., and Deeley, R. M. Lubrication and Lubricants. A Treatise on the Theory and Practice of Lubrication, and on the Nature, Propertiesand Testing of Lubricants . 4th (reprint of 3rd) edn. Large. 8vo. Pp.635. (1920). 1921. Griffin. $30 s$.

Battle, J. R. A Practical Handbook of Industrial Oil Engineering, including the Lubricating Engineer's Handbook. 2 vols. Vol. 1. Lubrication and Industrial Oil. Large Cr. 8vo. Pp. 1,142, 1921. 42s. Vol. 2. Oil Fuels-in preparation. Griffin.

Cree, A. All About Oil for Engineers : a Practical Handbook. 2nd edn. 12mo. Pp. 27\%. 1919. Spon. 9s.

Pamely, C. The Mine Wagon and its Lubrication. Med. 8vo. Pp. 144. 1914. Crosby Lockwood. $7 s, 6 d$.

\section{v. LIFTING AND CONVEYING.}

Broughton, H. H. The Electrical Handling of Materials : a Manual on the Design, Construction, and Application of Cranes, Conveyors, Hoists, and Elevators. 4 Vols. Demy 4to. Vol. 1. Electrical Equipment. 2nd edn. Pp. 216. 1920. 25s. Vols. 2. Structural; 3, Machinery; 4, Methods; in preparation. Benn Bros.

Hill, C. W. Electric Crane Construction. Med. 8vo. Pp. 333. 1911. Griffin. 30s.
Horner, J. G. An Elementary Treatise on Hoisting Machinery. Cranes, their construction and various types. Cr. 8vo. Pp. 264. 1903. Crosby Lockwond. $8 s$. $6 d$.

McCulloch, C., and Futers, T. C. Winding Engines and Winding Appliances : their Design and Economical Working. Demy 8vo. Pp. 460. 1912. Arnold. $21 s$.

Marks, E. C. R. Practical Notes on the Construction of Cranes and Lifting Machinery. 3rd edn. Cr. 8vo. Pp. 260. 1904. Technical Pub. Co. 4s. 9d.

Wallis-Tayler, A. J. Aerial or Wire-Rope Ways. Their Construction and Management. 2nd edn. Demy 8vo. Pp.254. 1920. Crosby Lockwood. 12s. 6d.

Weisbach, J., and Herrmann, G. Mechanics of Hoisting Machinery : including Accumulators, Excavators, and Pile Drivers. 8vo. Pp.312. 1907. Macmillan.12s.6d.

Wilda, H. Cranes and Hoists : Their Construction and Calculation. $\mathrm{Cr}$. 8vo. Pp. 168. 1913. Scott, Greenwood. 4s.6d.

Zimmer, G. F. The Mechanical Handling and Storing of Material. A Treatise on the handling and storing of Material such as Coal, Grain, Timber, etc., by Automatic or Semi-Automatic Machinery. Roy. 8vo. Pp. 766. 1916. Crosby Lockwood. $50 s$.

-Mechanical Handling of Material, and its National Importance During and After the War. Roy. 8vo. Pp.135. 1917. Crosby Lockwood. 10s. 6d.

\section{vi. FOUNDRY WORK.}

Aughtie, H. Practical Pattern Making. A Treatise for Pattern Makers, Foundrymen, Apprentices, etc. 2nd edn. Demy 8vo. Pp. 176. 1901. Scientific Pub. Co. $4 s$.

Horner, J. G. The Principles for Pattern Making for Apprentices and Students in Technical Colleges. 5th edn. Cr. 8vo. Pp. 180. 1892. Pitman. 4s. 
Horner, J. G. Practical Pattern Making. 4th edn. Large Cr.8vo. Pp. 420. 1912. Crosby Lockwood. 8s. $6 d$.

Primrose, H.S., and J.S.G. GunMetal and Brass Founding (under Scientific Control). Cr. 8vo. Pp. 287. 1921. Louis Cassier. 10s.

Shaw, B., and Edgar, J. Patternmaking: aPractical Treatise describing Pattern-making Methods and Appliances. Fcap. 8vo. Pp. 120. 1921. Pitman. 2s. 6d.

Treiber, T. Foundry Machinery. Translated from the German, revised and adapted to British practice. Cr. 8vo. Pp. 148. 1913. Scott, Greenwood. 4s. $6 d$.

\section{vii. MACHINE TOOLS.}

Barrett, E. G. Screw Cutting in the Lathe. Cr. 8vo. Pp. 44. 1912. Technical Pulı. Co. $2 s$.

Bentley, W. Machine Shop Companion : Comprising Practical Notes, Rules and Tables for every-day Workshop Use. 8th edn. Feap. 8vo. Pp. 130. 1920. Chapman \& Hall. 1s. $6 \mathrm{~d}$.

Burley, G. W. Lathes: Their Construction and Operation. $\mathrm{Cr}$. 8vo. Pp. 244. 1915. Scott, Greenwood. 4s. $6 d$.

- Machine and Fitting Shop Practice. Cr.8vo. Vol.1., Measurements and Gauging, Setting-out, Vice-Work, Chipping and Filing. Pp.221. 1918. Vol. 2., Planing, Drilling, Lathe Work and Grinding. 1919. Scott, Greenwood. 5s. each.

- The Testing of Machine Tools. Cr. 8vo. Pp. 240. 1915. Scott, Greenwood. $5 s$.

Camm, F.J., and Others. Screw Cutting. Demy 8vo. Pp. 270. 1920. Cassell. 6s.

Darbyshire, H. Precision Grinding . A Practical Book on the Use of Grinding Machinery for Machine Men. Demy 8vo. Pp. 170. 1907. Constable. 6s. $6 d$.
De Vries, D. Milling Machines and Milling Practice. 8vo. Pp. 464. 1916. Spon. 10s.6d.

The Calculation of ChangeWheels for Screw-Cutting on Lathes . 8vo. Pp. 83. 1914. Spon. 5s.

Fremont, C. Files and Filing. Translated under the supervision of G. Taylor, from the French. Quarto. Pp.160. 1920. Pitman. $21 s$.

Gates, P. Tool and Machine Setting for Milling, Drilling, Tapping, Boring, Grinding and Press Work. Fcap. 8vo. Pp. 103. 1921. Pitman. 2s. 6d.

Griffiths, E.A. Engineering Instru. ments and Meters. Roy. 8vo. Pp. 384. 1920 . Routledge. 31s. $6 d$.

Grimshaw, R." Modern Workshop Hints. Cr. 8vo. Pp. 443. 1902. Sampson Low. $10 s .6 d$.

Guest, J. J. Grinding Machinery . Demy 8vo. Pp. 444. 1915. E. Arnold. $16 s$.

Haddow, A. N. The Design of Drill Jigs. A Practical Manual. Demy 8vo. Pp, 96. 1917. Emmott. $2 s, 6 d$.

Haenig, A. Emery and the Emery Industry. Translated from the German. Cr.8vo. Pp. 104. 1912. Scott, Greenwood. 6s.

Hasluck, P . N. Lathe Work. A Practical Treatise on the Tools, Appliances, and Processes employed in the Art of Turning. 8th edn. Cr. 8vo. Pp. 224. 1918. Crosby Lockwood. $6 s$.

- Screw Threads, and Methods of Producing Them. 9th edn. Pocket size. Pp. 112. 1918. Crosby Lockwood. $2 s$.

Hodgson, R. B . Emery Grinding Machinery: A Text-book of Workshop Practice in General ToolGrinding, and the Design, Construction, and Application of the Machines Employed. Cr. 8vo. Pp. 192. 1903. Griffin. 6s. 
Horner, J. G. Practical Metal Turning: a Handbook for Engineers, Technical Students and Amateurs. Brd edn. Large $\mathrm{Cr} .8 v o$. Pp. 432. 1919. Crosby Lockwood. 12s. fid.

Metal Turning. A Practical Handbook. 3rd edn. Cr. svo. Pp. 168. 1918. Pitman. 4s.

- Modern Milling Machines: their Design, Construction, and Working . Med.svo. Pp.304. 1906. Crosby Lockwood. $14 s$.

- Tools for Engineers and Woodworkers, including Modern Instruments of Measurement. Demy 8vo. Pp. 352. 1905. Crosby Lockwood. $10 s .6 d$.

-_ Turret Lathe Practice. 1)emy 8vo. Pp. 284. 1921. Emmott. 12s. 6d.

The Principles of Fitting. 4th edn. Cr.8vo. Pp.425. 1909 . Pitman. 7s.6d.

How to Lay-Out Turret Lathe Tools. A Handbook for those who Design Tools for Use on Turret and Capstan Lathes and Automatic Turning Machines. 2nd edn. Demy 8vo. Pp. 175. 1919. (Alfred Herbert). Pitman. 6s.

Jackson, A . Home Mechanic's Workshop Companion. Cr. 8vo. Pp. 222. 1920. Frowde \& Hodder . 6s.

Lindsay , Lord. Tables for Engineers and Machinists, giving the values of the different trains of wheels required to produce Screws of any Pitch. Calculated for pinion wheel of 15 teeth. 2nd edn. Oblong 8vo. Pp. 20. 1920. Spon. 1s.6d.

Martin, W. A. Screw Cutting Tables for the use of Mechanical Engineers. 7th edn. Obl. Roy. 8vo. Pp. 16. Spon. 1s.6d.

Parr, A. Machine Tools and Workshop Practice for Engineering Students and Apprentices. 8vo. Pp. 468. 1917. Longmans. 16s.

- Principles of Setting-out : Securing and Tooling Operations. 8vo. Pp. 300. 1913. Longmans. 9s.
Price, W. Turner's Handbook on Screw Cutting, Coning, etc., with Tables, Examples, Gauges, and Formulæ. New imp. Fcap. 8vo. Pp. 56. Spon. 1s.

Pull, E. Modern Milling. A Practical Manual on Milling Machines, Milling Accessories, and Milling Operations. Demy 8vo. Pp. 207. 1917. Pitman. 9s.

_- Serew Cutting for Engineers. 2nd edn. Cr. 8vo. Pp.91. 1918. Croshy Lockwood. 2s. 6d.

-Modern Workshop Practice for Fngineers, Apprentices, and Students. 5th edn. Cr. 8vo. Pp. 389. 1918. Crosby Lockwood. 9s. - Engineer's Measuring Tools : their Construction and Use. Cr. 8vo. Pp. 150. 1918. Crosby Lockwood. $4 s .6 d$.

-The Engineering Workshop Handbook. Roy. 16mo. Pp.162.1919. Crosby Lockwood. $3 s$.

_- Engineering Workshop Exercises. 2nd edn. Cr. 8vo. Pp. 88. 1914. Pitman. 3s.

Robinson, H. C. An Introduction to Eccentric Spiral Turning, or New Uses for Old Chucks. 8vo. Pp. 48. 1906. Spon. 5s.

Robson, A. G. Fngineering Machine Tools and Processes. 8vo. Pp. 317. 1919. Longmans. 12s. $6 d$.

Shaw, T. R. Precision Grinding Machines. Demy 8vo. Pp. 212. 1917. Scott, Greenwood. 12s. 6d. _- Lathes, Screw Machines, Boring and Turning Mills and their Accessories. New edition in preparation. Scientific Pub. Co.

__ Machine Tools for Planing, Shaping, Slotting, Drilling, Boring, Milling, Wheel Cutting, etc. Demy 8vo. Pp. 692. 1903. Scientific Pub. Co. $15 s$.

Shelley, C. P. B. Workshop Appliances. 11th edn. Cr.8vo. Pp.390. 1919. Longmans. 6s. $6 d$.

Thompson, H. Modern Engineering Workshop Practice. A Text-book for the use of Engineering Students, Apprentices, and Practical Engineers. Cr. 8vo. Pp. 328. 1919. Griffin. $9 s$. 


\section{Mechanical Engineering.}

\section{viii. WOOD WORKING MACHINERY .}

Bale, M. P. Saw Mills. Their Arrangement and Management. 5th edn. Cr. 8vo. Pp. 395. 1919. Crosby Lockwood. 10s. $6 d$.

_- Woodworking Machinery. 4th edn. Large Cr. 8vo. Pp. 440. 1919. Crosby Lockwood. 10s. 6d.

Blackmur, W. J. Saw Mill Work and Practice. 2nd edn. Cr. 8vo. Pp. 167. N.D. Wm. Rider. 3s. $6 d$.

Durham, H.W. Saws : their Care and Treatment. Cr. 8vo. Pp. 272. N.D. Wm. Rider. 6s.

Groom, T. R. Joiners' Machines and How to Work Them. Cr. Svo. Pp. 106. N.D. Wm. Rider. 2s.

\section{ix. WELDJNG, ETC}

Amedeo, M. R. Oxy-Acetylene Welding of Copper, Brasses, and Bronzes. Translated with Additions by D. Richardson. 8vo. Pp. 80. 1918. Raggett. 3s.6d.

Granjon, R., and Rosemberg, P. A Practical Manual of Autogenous Welding (Oxy-Acetylene). With a Chapter on the Cutting of Metals with the Blow Pipe. Translated by D. Richardson 9th edn. Demy 8vo. Pp. 274. 1920. Griffin. 6s.

Groth, L. A. Welding and Cutting of Metals by the Aid of Compressed Gases and Electricity. Ex. Cr. 8vo. Pp. 297. 1913. Constable. 8s, 6d.

Thatcher, E. Simple Soldering, both Hard and Soft. Cr. 8vo. Pp. 76. 1914. Spon. 2s. 6d.

Yates, R. F. Home Soldering and Brazing. Cr. 8vo. Pp. 122. 1920. Frowde and Hodder. $4 s, 6 d$.

\section{SHEET METAL WORK.}

Atkins, E. A. Practical Sheet and Plate Metal Work. 2nd edn. Cr. 8vo. Pp. 534. 1912. Pitman. $10 s$.
Barrett, E. G. Principles and Processes of Metal Plate Work. Cr. 8vo. Pp. 132. 1914. Crosby Lockwood. $3 s$.

Georgi, F., and Schubert, A. Sheet-Metal Working. Translated from the German. Demy 8 vo. Pp. 151. 1914. Scott, Greenwood. $8 s, 6 d$.

Hodgson, R. B. Machine and Tools employed in the Working of Sheet Metals. Cr. 8vo. Pp. 311. 1903. Technical Pub. Co. 6s.

Miller, J.S. Metal Work: Teachers' Handbook of Manual Training. 2nd imp. Demy 8vo. Pp. 147. 1903. Pitman. 4s.

Millis, C. T. Metal Plate Work, its Patterns and their Geometry: also Notes on Metals and Rules in Mensuration for the use of Tin, Iron, and Zinc-Plate Workers, Coppersmiths, Boiler Makers, etc. 4th edn. Cr. 8vo. Pp.456. 1919. Spon. 12s. $6 d$.

Newton, T. Pattern Drawing for Sheet-Metal Workers. Demy 8 vo. Pp. 270. 1920. Cassell. 6s.

Pearson, J. C. An Introduction to Metal Working. Fcap. 8vo. Pp. 110. 1904. Murray. 2s.6d.

Warn, R. H., and Horner, J. G. The Sheet-Metal Worker's Instructor. 4th edn. Cr. 8vo. Pp. 272. 1916. Crosby Lockwood. $8 s .6 d$.

\section{xi. METALS. \\ a. Forging .}

Cathcart, W. H. The Value of Science in the Smithy and Forge. Edited by J. E. Stead. 4th edn. Cr. 8vo. Pp. 177. 1920. Griffin. $6 s$.

Horner, J . G. Smithing and Forging. Demy 8vo. Pp. 230. 1921. Emmott. $8 s .6 d$.

Moore, T. The Practical Handbook of Smithing and Forging, Engineers' and General Smiths' Work. New imp. Cr. 8vo. Pp. 248. (1919) 1921. Spon. 7s.6d. 
Saunders, B. Forging, Stamping and General Smithing. 8vo. Pp. 4:37. 1912. Spon. 28s.

Watson, J. Tables for the I'se of Blacksmiths and Forgers. $16 \mathrm{mo}$. Pp. 96. 1919. Longmans. 4s.

\section{b. Coating.}

Brown, W. N. The Principles and Practice of Dipping, Burnishing, Lacquering and Bronzing Brass Ware. Revised edn. Cr. 8vo. Pp. 42. 1912. Scott, Greenwood. $4 s$.

The Art of Enamelling on Metal. 2nd edn. Cr. 8vo. Pp.55. 1914. Scott, Greenwood. 4s.6d.

-A Handbook on Japanning. For Ironware, Tinware, Wood, etc. 2nd edn. Cr. 8vo. Pp. 70. 1913. Scott, Greenwood. 4s.6d.

Grünwald, J. The Theory and Practice of Enamelling on Iron and Steel. With Historical Notes on the Use of Enamel. Translated by H. H. Hodgson. Med. 8vo. Pp. 178. Reprint. 1919. Griffin. $7 s, 6 d$.

-The Raw Materials of the Enamel Industry and their Chemical Technology. Translated by $\mathbf{H}$. $\mathbf{H}$. Hodgson. Med. 8vo. Pp. 236. 1914. Griffin. 1ns. 6d.

-The Technology of Iron Enamelling and Tinning. Translated by H. H. Hodgson. Med. 8vo. Pp. 148. 1912. Griffin. 7s.6d.

Hiorns, A. H. Metal Colouring and Bronzing. Gl. 8vo. Pp. 358 . 1911. Macmillan. 6s.

\section{c. Gold and Silversmiths' Work.}

Davidson, P.W. Educational Metalcraft. A Practical Treatise on Repoussé, Fine Chasing, Silversmithing, Jewellery, and Enamelling. Post 4to. Pp. 248. 1913. Longmans. $6 s$.

Horth, A. G. Repoussé Metalwork, A Scheme of Sheet Metalwork for Schools and Amateurs. Cr. 8vo. Pp. 115. 1905. Methuen. 3s.6d.
Jackson, F. G. Metal Work: Chasing and Repoussé for Home Art Workers. Demy 8vo. Pp. 64. 1903. Chapman and Hall. 4s. 6d.

Leland, C. G. Metal Work. Including Repoussé, Bent Iron, or Stripwork; Flat and Moulded Sheet Metal Work; Nail or Knob, Wire, Easy Silver Ornament and Chasing Work. 2nd edn. Fcap. 4to. Pp. 111. Pitman. 5s.

Maryon, H. Metal Work and Enamelling. A Practical Treatise on Gold and Silversmiths' Work and their Allied Crafts. Demy 8vo. Pp. 344. 1912. Chapman and Hall. 9s. 6d.

Randau, P. Enamels and Enamelling. For Enamel Makers, Workers in Gold and Silver, and Manufacturers of Objects of Art. 2nd edn. Demy 8vo. Pp. 200. 1912 . Scott, Greenwood. 12s.6d.

Wigley, T. B., and Stansbie, J.H. The Art of the Goldsmith and Jeweller. A Manual on the Manipulation of Gold, and the Manufacture of Personal Ornaments. 2nd edn. Demy 8vo. Pp. 276. 1911. Griffin. 9s.

Wilson, H. Silverwork and Jewellery. 2nd edn. Cr. 8vo. Pp.500. 1912. Pitman. 8s. 6d.

\section{xii. HOROLOGY .}

Britten, F. J. The Watch and Clock Makers' Handbook, Dictionary and Guide. 12th edn. Demy 8vo. Pp. 346. 1920. Spon. $12 s .6 d$.

Cunynghame, H. H. Time and Clocks. A description of Ancient and Modern Methods of Measuring Time. Cr. 8vo. Pp. 200. 1906. Constable. 3s. 6d.

Garrard, F. J. Clock Reptiring and Making. The Tools, Materials and Methods used in Cleaning and Repairing all kinds of Timepieces. Cr. 8vo. Pp. 176. 1918. Crosby Lockwood. $6 s$.

- A Practical Handbook on Watch Repairing, Cleaning, and Adjusting. 4th edn. Cr.8vo. Pp. 224. 1919. Crosby Lockwood. $6 s$. 


\section{Mechanical Engineering.}

xiii. MOTOR GAR ENGINEER ING .

Adams, W.P. Motor Car Mechan ism and Management. $\mathrm{Cr}$. 8vo. Part 1. The Petrol Car. 3rd edn. Pp. 266. 1912. Part 2. Electrical and Petrol Flectrical Motor Cars. Pp. 212. 1908. Griffin. 6s. each.

Autocar Handbook, The. A Guide to the Motor Car. 10th edn. Demy 8vo. Pp. 283. 1920. Iliffe. $3 s, 6 d$.

Automobile Engineer Year Book, 1920. Roy. 8vo. Pp. 217. May, 1920. Iliffe. $6 s$.

Berriman, A. E. Motoring. An Introduction to the Car and the Art of Driving It. Demy 8vo. Pp. 332. 1914. Methuen. 12s.6d.

Bickford, J.S. V. Faults and How to Find Them (Motor Car Troubles). 5th edn. Cr.8vo. Pp.176. 1919. Iliffe. $3 s .6 d$.

Bramley-Moore, S. Motors in a Nutshell. Cr.8vo. Pp.160. 1919. Spon. $2 s$.

Brewer, R. W. A. Motor Car Construction. A Practical Manual, with notes on Wind resistance and Body design. Demy 8vo. Pp. 253. 1919. Crosby Lockwood. $9 s$. Carburation in Theory and Practice for Automobile Engineers. 2nd edn. Demy 8vo. Pp. 278. 1918. Crosby Lockwood. 12s. 6d.

Butler, E. The Vaporizing of Paraffin for High-Speed Motors (Electric Ignition Type). $\mathrm{Cr}, 8 \mathrm{vo}$. Pp. 128. 1916. Griffin. 4s.

Butler, H. J. Motor Bodies and Chassis: a Textbook dealing with the complete car, for the use of Owners, Students, and others. Demy 8vo. Pp. 352. 1912. Harper. $7 s, 6 d$.

"Candidus." Small Car Handbook: all About Economic Motoring. 2nd edn. Cr. 8vo. Pp. 225. 1919. Iliffe. $2 s .6 d$.
Clarke, A. G. 'Text-Book of Motor Car Engineering. 2nd edn. 2 Vols. Demy 8vo. 1919. Vol.1. Construction. Pp.456. Vol.2. Design. Pp.405. Constable. 10s.6d, each.

Complete Hints and Tips for Automobilists. 7th edn. $\mathrm{Cr}$. 8vo. Pp. 456. 1919. Iliffe. 5s.

Davies, B. H. Motor Driving Made Easy. Cr. 8vo. Pp. 168. 1919. Iliffe. $3 s$.

Dommett, W. E. Motor Car Mechanism. Cr.8vo. Pp.200. 1913. Scott, Greenwood. 4s, $6 d$.

Gunn, J. The Practical Design of Motor Cars. Demy 8vo. Pp.264. 1910. Arnold, 12s.6d.

Havilland, G. de. The Woman's Motor Manual. Motor Driving and Management of Motor Vehicles for Women drivers. Cr. 8vo. Pp. 181 . 1919. Temple Press. 3s.

Holden-Stone, G. de. The Automobile Industry. Cr. 8vo. Pp. 241. 1904. Methuen. $5 s$.

Jones, L. M. M. Steam Road Vehicles. 2nd. edn. 8vo. Pp. 242. 1921. Iliffe. $5 s$.

Knight, J. H. A Catechism of the Motor Car. 6th edn. Cr.8vo. Pp. 111. 1919. Crosby Lockwood. $3 s .6 d$.

McMillan, D. The Motor Car. New edn. Cr. 8vo. Pp. 166. 1920. Longmans. $4 s .6 d$.

Mantell, L. A Manual of Motor Mechanics and High Efficiency. Tuning, 4th edn. Cr. 8vo. Pp. 233. 1919. Temple Press. 3s.6d.

More, G. G., and Higgs, G. G. The Motorist's Handbook, embracing 250 Practical Points on Motoring, being a Series of Test Questions and Answers on Motoring Matters. 7th edn. Pocket size. Pp. 92. 1920. Larby. $1 s .9 d$.

The Motor Manual, compiled by the Staff of "The Motor." 23rd edn. Demy 8vo. Pp. 238. 1920. Temple Press. 3s.6d. 
Motor Repair Work for the Amateur Mechanic and Owner Driver. 3rd edn. Cr. 8vo. Pp. 130. 1919. Temple Press. 1s.9d.

Nicholson, R. T. The Book of the Ford. How to Get the Best out of a Ford Car. 5th edn. Cr. 8vo. Pp. 255. 1920. Temple Press. 3s.

The Book of the Ford Van. Cr. 8vo. Pp. 119. 1920. Temple Press. 3s.

Northcliffe, Viscount, and others . Motors and Motor Driving. 4th edn. Cr. 8vo. Pp. 548. 1906. Longmans. $10 s .6 d$.

Phillimore, J. Motor Road Transport for Commercial Purposes (Liquid Fuel, Steam, Electricity). Demy 8vo. Pp. 226. 1920. Pitman. 12s. 6d.

Sherrin, G. C. The Montagu Motor Book. Edited by Lord Montagu. Demy 8vo. Pp. 292. 1920. E.J. Burrow. 12s. 6 d.

Spooner, H. J. Motors and Motoring. 13th edn. Cr. 8vo. Pp. 331. 1919. Jack. $3 s .6 d$.

Steam Wagon Manual, The. Maintenance, Overhaul, Garage and Running Repairs. Cr. 8vo. Pp. 104. 1918. Temple Press. 2s.

Strickland, F. A Manual of Petrol Motors and Motor Cars. The Design, Construction and Working . 2nd edn. Large 8vo. Pp. 388 .

- 1914. Griffin. 21s.

Walford, E. W. The Maintenance and Running Repairs of Motor Cars. 3rd edn. Cr. 8vo. Pp. 282. 1920. Iliffe. 5s.

Watson, G. W., and Rogers, F. H. The Motor Mechanic's Handbook: A Manual for Motor Vehicle Owners and Mechanics. New edn. Cr. 8vo. Pp. 278. 1920. Cassell. 3s.6d.

White, T. H. Petrol Motors and Motor Cars. Cr. 8vo. Pp. 212. 1919. Longmans. 6s. 6d.
Whittaker, W. E. de B., and Barron, P. A. (edited by). 'Automobiles of the World, 1921. An Illustrated Encyclopædia of the Motor Industry. Large 4to. Pp. 500. 1921. "Aeroplane"; and General Pub. Co. 42s.

Wimperis, H. E. The Principles of the Application of Power to Road Transport. Cr. 8vo. Pp. 144. 1913. Constable. 5s.

Wyatt, H. The Motor Industry : its Growth, its Methods, its Prospects and its Products. Cr. 8vo. Pp. 140. 1917. Pitman. 3s.

Young, F., and Aston, W. G. The Complete Motorist. 8th edn. Demy 8vo. Pp. 233. 191.5. Methuen. 10s. 6d.

\section{xiv. MOTOR CYCLES.}

Henry, P. Cycle Building and Repairing, including Fnamelling, Repair of Tyres and Wheel Building. Cr. 8vo. Pp. 96. 1913. Spon. 2s. 6d.

Hints and Tips for Motor Cyclists . 7th edn. Pott 8vo. 1920. Iliffe. $2 s$.

Motor Cycles and How to Manage Them. 20th edn. Cr. 8vo. Pp. 104. 1920. Iliffe, 2s. 6d.

Motor Cycling Manual. 5th edn. Cr. 8vo. Pp. 287. 1920. Temple Press. 2s. 6d.

Shepherd, E. G. M. Motor Cycle Overhauling. A Complete Guide to Overhauling, Repairing and Adjusting a Motor Cycle. Cr. 8vo. Pp. 96. 1920. Crosby Lockwood. 2s. 6d.

Tracing Motor Cycle Troubles. 4th edn. Cr. 8vo. 1919. Iliffe. $2 s$.

Two-Stroke Motor Cycles. By the Staff of the "Motor Cycle." Cr. 8vo. Pp. 191. 1921. Iliffe. 3s.

Wyatt, H. (edited by). The Motor Cyclist's A.B.C. Cr. 8vo. Pp. 164. 1920. Newnes. 2s. 


\section{Mechanical Engineering.}

XV. HEAT ENGINES AND STEAM ENGINES: DESIGN, CONSTRUCTION,TESTING, etc.

Anderson, Sir W. On the Conversion of Heat into Work. Cr. 8vo. Pp. 265. 1901. Pitman. 6s.

Boulvin, M. J. The Entropy Diagram and Its Applications. Translated from the French by $B$. Donkin. 8vo. Pp. 82. 1914. Spon. 5s.

Callendar, H. L. The Callendar Steam Tables. Including the Callendar Steam Diagram. Demy 8vo. Pp. 40. 1915. Arnold. 3s, 6d.

Case, J. A Synopsis of the Elementary Theory of Heat and Heat Engines. Demy 8vo. Pp. 66. 1913. Heffer. 3s, 6d.

Grawford, W. J. Calculations on the Entropy-Temperature Chart. Cr. 8vo. Pp. 82. 1912, Griffin. $3 s$.

Dalby, w. E. The Palancing of Engines. Demy 8vo. 3rd edn. Pp.283. 1920. Arnold. 12s.6d.

- Steam Power. 2nd edn. 8vo. Pp. 776. 1920. Arnold. 35̌s.

Duncan, J. Steam and Other Engines. G1. 8vo. Pp.482. 1920. Macmillan. $6 s$.

Ewing, Sir J . A. The Steam Engine and Other Heat-Engines. 3rd edn. Demy 8vo. Pp. 604. 1914. Cambridge University Press. $27 s, 6 d$.

Garratt, H. A. Heat Engines. Cr. 8vo. Pp. 344. 1912. Arnold. 7s. $6 d$.

Haeder, H. A Handbook on the Steam Engine. with Special Reference to Small and Medium-sized Engines, 4th edn. Cr. 8vo. Pp. 552. 1914. Crosby Lockwood. $10 s .6 d$.

Hall, H. R. Governors and Governing Mechanism. 2nd end. $\mathrm{Cr}$. 8vo. Pp. 177. 1907. Technical Pub. Co, 5s. 6d.
Hayward, J. W. Heat Engines: First Stage. 5th imp. Cr, 8vo. Pp.280. 1918. University Tutorial Press. 3s. 6d.

Hobbs, L. M. The Thermo-Dynamic Principles of Engine Design. Large Cr. 8vo. Pp. 151. 190\%. Griffin. $5 s$.

Hurst, G. Hints on Steam Engine Design and Construction. 2nd edn. 8vo. Pp.68. 1915. Griffin. $2 s$.

Inchley, W. The Theory of Heat Engines, 2nd edn. Revised by A. Morley. 8vo. Pp. 504. 1920. Longmans. 12s. $6 d$.

Jamieson, A. Elementary Manual of Heat Engines : Steam, Gas, and Oil. 17th edn. Revised by E. S. Andrews. Cr. 8vo. Pp. 390. 1920. Griffin. 5s.

- A Text-Book of Heat and Heat Engines. (18th edn. of Text-Book on Steam and Steam Fngines). Vol. 1. Revised by E.S. Andrews. Cr. 8vo. Pp. 567. 1919. 8s.6d. Vol. 2. in preparation. Griffin.

King, H. F, Steam Engine Design. Cr.8vo. Pp. 356. 1913. Technical Pub. Co. $8 s$.

Langmaid, J., and Gaisford, $\mathrm{H}$. Elementary Lessons in Steam Machinery and the Marine Steam Engine. 8vo. Pp. 308. 1901. Macmillan. $7 s .6 d$.

Low, D. A. Heat Engines, embracing the Theory, Construction, and Performance of Steam Boilers, Reciprocating Steam Engines, Steam Turbines, and Internal Combustion Engines. A Text-book for Engineering Students. Demy 8vo. Pp. 600. 1920. Iongmans. $17 s .6 d$.

Marks, L. S., and Davis, H. N. Tables and Diagrams of the Thermal Properties of Saturated and Superheated Steam. 9th imp. Roy. 8vo. Pp. 108. 1920. Longmans. $9 s$.

Peel, T. Examples in Heat and Heat Engines. Demy 8vo. Pp. 108. 1919. Cambridge University Press. $5 s$. 
Perry, J. The Steam Engine, and Gas and Oil Engines. 8th imp. 8vo. Pp.680. 1920. Macmillan. 10 s.

Porter, C. T. A Treatise on the Richards Steam Engine Indicator, and the Development and Application of Force in the Steam Engine. 6th edn. 8vo. Pp. 285. 1902. Spon. 9s.

Pratt, H. K. A Manual of the HighSpeed Steam Engine. Demy 8vo. Pp. 270. 1914. Constable. 6s.

Pullen, W. W. F. Steam and Internal Combustion Engineering. 7 th edn. Cr. svo. Pp. 190. Scientific Pub. Co. $4 s$.

-Testing of Engines and Boilers.

A Treatise on the Construction and Use of the Instruments and Methods employed in the Testing of Prime Movers in the Laboratory and Workshop. 2nd edn. Demy 8vo. Pp. 746. 1911. Scientific Pub. Co. $15 s$.

- Indicator Diagrams. A Treatise on the use of the Indicator and its application to the Steam Engine. Demy 8vo. Pp. 242. 1901. Scientific Pub. Co. 6s.

Rankine, W. J . M. A Manual of the Steam Engine and other Prime Movers. Revised by W. J. Millar. With a Section on Gas, Oil, and Air Engines by B. Donkin. 17th edn. Cr. 8vo. 1908. Griffin. $12 s .6 d$.

Richardson, J. The Modern Steam Engine. Theory, Design, Construction, Use. Demy 8vo. Pp. 396. 1908. Constable. 7s.6d.

Ripper, W. Steam Engine Theory and Practice. 7th edn. Demy 8vo. Pp.514. 1914. Longmans.12s.6d. - Heat Engines. Cr. 8vo. Pp. 362. 1919. Longmans. 5s.

Royds, R. The Testing of Motive Power Engines; including Steam Engines and Turbines, Locomotives, Boilers, Condensers, Internal Combustion Engines, Gas Producers, Refrigerators, Air Compressors, Fans, Pumps, etc. 2nd edn. Demy 8vo. Pp. 404. 1920. Longmans. $21 s$.
Sankey, H. R. / The Energy Chart. Practical Applications to Reciprocating Steam Engines. 8vo. Pp. 170. 1907. Spon. 7s. $6 d$.

Smith, G. A. M., and Warren, A. G. The New Steam Tables. Calculated from H. L. Callendar's Researches. Demy 8vo. Pp. 114. 1912. Constable. 4s. 6d.

Smith, R. H. The Economic and Commercial Theory of Heat PowerPlants. Roy.8vo. Pp.315. 1905. Constable. 24s.

Swinburne, J. Entropy : or Thermodynamics from an Engineer's Standpoint, and the Reversibility of Thermodynamics. Cr. 8vo. Pp. 147. 1904. Constable. 5s.

Trinks, W. Governors and the Governing of Prime Movers. 8vo. Pp. 247. 1920. Constable.22s.6d.

\section{XVi. REFRIGERATION.}

Ewing, Sir J.A. The Mechanical Production of Cold. 2nd edn. Demy 8vo. Pp. 214. 1921. Cambridge University Press. 25s.

Springett. B. H. Cold Storage and Ice Making. An Elementary Handbook. Cr. 8vo. Pp. 132. 1921. Pitman. 3s.

Wallis-Tayler, A. J. The Pocket Book of Refrigeration and Icemaking. 7th edn. Cr. 8vo. Pp. 223. 1919. Crosby Lockwood. $5 s$.

-Refrigeration, Cold Storage, and Ice-making. Containing the 3rd edn. of "Refrigerating and Icemaking Machinery." 6th edn. Med. 8vo. Pp. 650. 1920. Crosby Lockwood. 15s.

\section{XVii. STATIONARY AND PORTABLE STEAM ENGINES.}

Fowler, W. H. Stationary Steam Engines. Illustrated with numerous examples from actual practice. Cr.4to. Pp. 306. 1908. Scientific Pub. Co. 12s. 6d. 
Wansbrough, W.D. Portable Steam Engine: its Construction and Management. Demy 8vo. Pp. 179. 1912. Crosby Lockwood. 6s.

\section{xviii. LOCOMOTIVE ENGINEER- ING .}

Ahrons, E. L. The Steam Railway Locomotive: Explaining the Component Parts and Method of Working of Modern Steam Railway Locomotives. Fcap. 8vo. Pp. 124. 1920. Pitman. 2s. 6d.

- Steam Locomotive Construction and Maintenance. Fcap. 8vo. Pp. 144. 1921. Pitman. 2s.6d. The Development of British Locomotive Design. Cr. 4to. Pp. 229. 1915. Locomotive Pub. Co. $6 s$.

Allen, C. E. The Modern Locomotive. Roy. 16mo. Pp.149. 1911. Cambridge University Press . 2s. $6 d$.

A Loco Clerk. Locomotive Office Work. Cr. 8vo. Pp. 60. 1913. Locomotive Pub. Co. $3 s, 6 d$.

Anon. Locomotive Shop Notes. Cr. 8vo. Pp. 92. 1914. Locomotive Pub. Co. 3s.6d.

A. R. B. (edited by). The Locomotive Handbook of Useful Memoranda and Data. Cr. 8vo. Pp. 99. 1913. Locomotive Pub. Co. 1s.6d. Locomotive Engineers' Pocket Book. Pocket size. Pp. 290. 1920. Locomotive Pub. Co. $3 s .6 d$.

- The Locomotive of To-Day. Demy 8vo. Pp. 200. 1920. Locomotive Pub. Co. 3s. 6d.

Booth, W. H. Superheat, Superheating, and Their Control. Demy 8vo. Pp. 166. 1907. Constable. 6s.6d.

Gairns, J. F. Locomotive Compounding and Superheating. Large 8vo. Pp. 210. 190\%. Griffin. 10s. 6d.

- Superheating on Locomotives. 2nd edn. Cr.8vo. Pp.120. 1917. Locomotive Pub. Co. 3s. $6 d$.

Garbe, R. The Application of Highly Superheated Steam to Locomotives. Translated from the German. Med.8vo. Pp.70. 1908. Crosby Lockwood. 8s, $6 d$.
H. D. F . Locomotive Running Shed Notes. Cr. 8vo. Pp. 98. 1916. Locomotive Pub. Co. $2 s, 6 d$.

Hodgson, J. T ., and Williams, J . Locomotive Management from Cleaning to Driving. 4th edn. 8vo. Pp. 454. 1920. Transport, Ltd. $7 s, 6 d$.

Inspector, The. Locomotive Injectors. $\mathrm{Cr}$. 8vo. Pp. 58. 1915. Locomotive Pub. Co. 3s. 6d.

Pendred, V. The Railway Locomotive: What it is, and Why It is What it is. Ex. Cr. 8vo. Pp. 310. 1908. Constable. 7s. $6 d$.

Pettigrew, W. F. A Manual of Locomotive Engineering. 4th edn. in preparation. Griffin.

Sauvage, E. Superheating on Continental Locomotives. Cr. 8vo. Pp. 68. 1911. University of London Press. 5s.

Stretton, C. E. The Locomotive Fngine and its Development. 6th edn. Cr. 8vo. Pp. 270. 1903. Crosby Lockwood. 5s.

S.Y.K. Notes on the Vacuum Brake. Cr. 8vo. Pp. 93. 1914. Locomotive Publishing Co. 1s. 6d.

Taylor, A. T. Modern British Locomotives. 2nd edn. Oblong 8vo. Pp. 130. 1914. Spon. 6s.

Wolff, C. E. Locomotive Practice. A Treatise on the Design of Steam Locomotives. Demy 8vo. Pp. 280. 1903. Scientific Pub. Co. $10 s .6 d$.

\section{Xix. VALVES AND VALVE GEARING.}

Dalby, W. E. Valves and Valve Gear Mechanisms. 2nd imp. Roy. 8vo. Pp. 366. 1919. E. Arnold. $24 s$.

Hurst, C. Valves and Valve-Gearing: A Practical Text-book for the use of Engineers, Draughtsmen. and Students. 8th edn. Large 8vo. Pp. 359. 1919. Griffin. 12s.6d. 
Thorn, W. H. Guide to the Use of the Slide Valve. Cr. 8vo. 1913. T. Reed and Co. $4 s$.

Slide Valve for Engineers. 2nd edn. Demy 8vo. Pp. 150. 1921 . James Brown. 7s. $6 d$.

Wansbrough, W. D. Proportions and Movement of Slide Valves. Cr. 8vo. Pp. 160. 1903. Technical Pub. Co. 6s.

Youngson, P. Slide Valves and Valve Gearing. 3rd ed. Cr. 4to. Pp. 208. 1919. Jas. Munro. 15s.

\section{STEAM BOILERS : CON - STRUGTION AND MANAGE - MENT.}

Bale, M. P. A Handbook for Steam Users. Being Rules for Engine Drivers and Boiler Attendants. New edn. Fcap. 8vo. Pp. 144. 1918. Longmans. $4 s .6 d$.

Batey, J. Steam Boilers and Combustion. Cr. 8vo. Pp. 220. 1915. Scott, Greenwood. 5s.

Bowden-Smith, E. C. Oil Firing for Kitchen Ranges and Steam Boilers. Demy 8vo. Pp. 112. 1920. Constable. $9 s$.

Connor, W. J. The Stoker's Catechism. 16mo. Pp. 63. 1914. Spon. 1s. 6d.

Dahlstrom, K. P. The Fireman's Guide, a Hand-book on the Care of Boilers. 11th edn. Cr.8vo. Pp. 34. 1906. Spon. 2s. 6d.

Foden, J. The Boiler-Makers' and Iron Ship-builders' Companion. 5th edn. Fcap. 8vo. Pp. 222. 1900. Spon. 6s.

Fowler, W. H. Steam Boilers and Supplementary Appliances. A practical Treatise on their Construction, Equipment and Working. New edition in preparation. Scientific Pub. Co.

Gray, J. Practical Design of Marine Single- and Double-Ended Boilers. 2nd edn. Demy 8vo. Pp. 136. 1021. Constable. 12s. 6d.
Hiller, E. G. Steam Boiler Construction. 2nd edn. Demy 8vo. Pp. 203. 1920. Technical Pub. Co. $3 s, 6 d$.

Hodgson, J. T. Modern Boiler Room Practice and Smoke Abatement. Cr. 8vo. Pp. 321. 1920. Transport, Ltd. 3s.6d.

Horner, J. G. Boiler Making and Plating. 2nd edn. Large Cr. 8vo. 1908. Crosby Lockwood. 12s.

Hughes, V. A. B. Steam Injector. Cr. 8vo. Pp. 128. 1912. Technical Pub. Co. $4 s$.

Hutton, W. S. Steam Boiler Construction. 5th edn. Med. 8vo. Pp. 680. 1916. Crosby Lockwood. $21 s$.

Inchley, W. Steam Boilers and Boiler Accessories. Cr. 8vo. Pp. 423. 1912. Arnold. 8s, 6d.

Inspector, The. Specification for a Lancashire Boiler. 2nd edn. Demy \&vo. Pp.123. 1907. Tech. nical Pub. Co. 3s. 6d.

Jackson, P. G. Boiler Feed Water. A Concise Handbook of Water for Boiler Feeding Purposes ; its Effects, Treatment and Analysis. Cr. 8vo. Pp. 111. 1919. Griffin. 4s. 6d.

Moss,H. Heat Drop Tables : Absolute Pressures from the Formule and Steam Tables of H. L. Callendar. Demy 8vo. Pp. 64. 1917. Arnold. 5s .

Heat Drop Tables: H.P. Gauge Pressures : L.P. Absolute Pressures, from H. L. Callendar's Formulæ and Steam Tables. Demy 8vo. Pp. 64. 1917. Arnold. 5s.

Munro, R. D. Steam Boilers : their Defects, Management, and Construction. 5th edn . in preparation. Griffin.

Parsons, H. de B. Steam Boilers: their Theory and Design. 5th edn. 8vo. Py. 395. 1917. Longmans. 12s. $6 d$.

Peattie, J. Steam Boilers, their management and working on land and sea. 5th edn. Cr. 8vo. Pp. 230. 1919. Spon. 6s. 
Powles, H. H. P. Steam Boilers: Their History and Development. Imperial 8vo. Pp. 351. 1905. Constable. 25s.

Pratt, H. K. Boiler Draught. Cr . 8vo. Pp. 145. 1911. Constable. 4s. 6d.

Pull, E. Modern Steam Boilers: Their Construction, Management and Use. Demy 8vo. Pp. 290. 1918. Scott, Greenwood. 12s.6d.

Pullen, W.W.F. Injectors. 3rd edn. Cr. 8vo. Pp. 208. 1906. Technical Pub. Co. 4s.9d.

Rimmer, E. J. Boiler Explosions, Collapses and Mishaps. Demy 8vo. Pp. 150. 1912. Constable. 4s.6d.

Robertson, L. S. Marine Boilers. Their Construction and Working, dealing more especially with Tubulous Boilers. 2nd edn. Demy 8vo. Pp. 658. 1906. Murray. 24s.

-Water-Tube Boilers. 8vo. Pp. 213. 1901. Murray 10s, 6d.

Sexton, M. J. Pocket Book of Boiler Making, Ship Building, and the Steel and Iron Trades in general. 6th edn. Roy. 32mo. Pp. 318. 1918. Spon. 7s. 6d.

Stewart, G. Modern Steam Traps. Cr. 8vo. Pp. 104. 1907. Technical Pub. Co. $4 s$.

Stromeyer, C. E. Marine Boiler Management and Construction: being a Treatise on Boiler Troubles and Repairs, Corrosion. Fuels and Heat, on the Properties of Iron and Steel, on Boiler Mechanies, Workshop Practice and Boiler Design. 5th edn. 8vo. Pp. 458. 1919. Longmans. $21 s$.

Trail1, T. W. Boilers, Marine and Land: their Construction and Strength. 5th edn. 18mo. Pp. 600. 1920. Griffin. 12s, $6 d$.

Wade, C. F. Efficient Boiler Management : with Notes on the Operation of Re-heating Furnaces. 8vo. Pp.580. 1919. Longmans. 12s. 6d. The Fireman's Handbook and Guide to Fuel Economy. A simple Manual for the use of Stokers, Furnacemen, and others operating and controlling Boiler and Furnace Plant. Cr. 8vo. Pp. 90. 1920. Longmans. 2s. 6d.

Walker, S. F. Steam Boilers, Engines and Turbines. Demy 8 vo. Pp. 428. 1908. Harper. 10s.6d.

Wansbrough, W. D. Modern Steam Boilers. (The Lancashire Boiler). Demy 8vo. Pp. 156. 1913. Crosby Lockwood. 5s. $6 d$.

\section{xXi. MARINE ENGINES.}

Anon. Marine Engineers' Construction and Dimensions Reference Book. Cr. 8vo. Pp. 24. Jas. Munro. 2s. $6 d$.

Barnaby, S. W. Marine Propellers. 6th edn. Demy 8vo. Pp. 230. 1920. Spon. 24s.

Bauer, G. Marine Engines and Boilers: their Design and Construction. Translated from the German by E. M. and S. B. Donkin . Med.8vo. Pp.802. 1919. Crosby Lockwood. $25 s$.

Bruce, G. R. Marine Engineering Estimates and Costs. Cr. 8vo. Py. 126. 1919. Jas. Munro. 6s.

Butterworth, F. Engineer Afloat: Training, Work and Pay. Cr. 8vo. Pp. 92. 1914. Technical Pub. Co. $2 s$.

Collings, E. R. Hand-book to the Examination of Engine Room Artificers. 2nd edn. Cr. 8vo. Pp. 356. 1915. T. Reed and Co. 5s.

Constantine, E. Marine Engineers: Their Qualifications and Duties. 2nd edn. Cr.8vo. Pp.332. 1906. Technical Pub. Co. 6s.9d.

Goudie, W.J. The Geometry of the Screw Propeller. Fcap. 4to. Pp. 48. N.D. Blackie. 2s.

Jackson, D. H. Detail Design of Marine Screw Propellers. Demy 8vo. Pp. 104. 1920. Pitman. $6 s$.

Jane, F. T. Warship Engineering. Feap. 8vo. $\mathrm{Pp}$. 32. 1914. Sampson Low. $2 s .6 d$. 


\section{Mechanical Engineering.}

Liversidge, J. G. Engine Room Practice: A Handbook for Engineers and Officers in the Royal Navy and Mercantile Marine. 10th edn. Cr. 8vo. Pp. 412. 1919. Griffin. $7 s .6 d$.

McGibbon, W.C. Marine Engineer's Drawings for Second Class Candidates. 4th edn. Demy 4to Oblong. Pp. 53, ete. 1921. Jas. Munro. 6s. $6 d$.

-Drawing Book for Marine Engineers for First Class certificate. 10th edn. Roy. 4to Oblong. Pp. 34, etc. 1920. Jas. Munro. $8 s .6 d$.

- Board of Trade and Marine Engineering Knowledge. Steam and Oil. 8vo. Pp. 552. 1921. Jas. Munro. $36 s$.

-Indicator Diagrams for Marine Engineers. 5th edn. Cr.4to. Pp. 24n. 1919. Jas. Munro. $15 s$.

- Marine Engineer's Pocket Book. 2nd edn. Frap. 8vo. Pp. 529. 1919. Jas. Munro. 158 .

- and Tod. Questions with Answers. For Marine Engineers' Board of Trade Eaxminations. containing the new questions on Oil Motors and Ash Ejectors, etc. 8th edn. Demy 8vo. Pp. 412. 1918. Jas. Munro. $8 s$.

McMillan, R. A. Guide to the B.O.T. Examination for Extra First Class Fngineers. Demy 8vo. Pp. 460 and Plates. 1920. Griffin. 25s.

Calculations for Marine Engineers . Including all the Arithmetic for 1st and 2nd Class Engineers' Certificate. Demy 8vo. Pp. 356. 1912. Griffin. $10 s$. $6 d$.

Elementaries. Verbals and Draw ings. The Use and Working of Slide Valves, Indicators, Marine Steam Turbine, Ship Electric Lighting, etc. Demy 8vo. Pp. 331 . 1913. Griffin. 10s. 6d.

Martin and Stoddart. Sketch and Record Book for Marine Engineers. Demy 8vo. Pp. 111. 1919. James Brown. 3s. 6d.
Martin, W. D. Hints to Engineers for Board of Trade Exams. 3rd edn. Cr. 8vo. Pp. 148. Jas. Munro. 4s.

- Verbal Questions and Answers as given to Engineers of Trawlers and Drifters for their Certificate. Cr. 8vo. Pp. 132. Jas. Munro. $3 s, 6 d$.

Munro's Marine Engineers' Annual. Pocket Log and Diary. Published Annually in September. Cr. 8vo. Pp. 288. Jas. Munro. $2 s .6 d$.

Reed's Engineer's Handbook. 21st edn. Part 1. Practical Mathematics. Demy 8vo. Pp. 493. 1920. 27s. 6d. Key to ditto. Demy 8vo. Pp. 183. 1920. 8s. 6d. Thos. Reed.

Roberts, C. W. Practical Advice for Marine Engineers. 2nd edn. $\mathrm{Cr}$. 8vo. Pp. 204. 1907. Pitman. $5 s$.

Seaton, A. E. A Manual of Marine Engineering, comprising the Design, Construction, and Working of Marine Machinery. 19th edn. 8vo. Pp. 1,012. 1921. Griffin. 36s. The Screw Propeller: and other Competing Instruments for Marine Propulsion. Large 8vo. Pp. 268. 1909. Griffin. 15s.

and Rounthwaite, H. M. A Pocket Book of Marine Engineering Rules and Tables; for the Use of Marine Engineers, Naval Architects, Designers, Draughtsmen, etc. 14th edn. Pocket size. Pp. 763. 1920. Griffin. 15s.

Sennett, R., and Oram, Sir H.J. The Marine Steam Engine. 8vo. Pp. 512. 1918. Longmans. 26s.

Somerscales, A. N. A.B.C. of Engineering Knowledge. Written specially for Marine Engineers preparing for Board of Trade Examinations. Cr. 8vo. Pp. 314. 1921. Jas. Munro. 12s. $6 d$.

Lessons in Mechanics for Marine Engineers: Treated Arithmetically. Cr. 8vo. Pp. 277. 1921 . Jas. Munro. 7s. 6d. 


\section{Mechanical Engineering.}

Somerscales, A. N. Handbook to Board of Trade Examinations for Extra First-Class Engineers. 4th edn. Demy 8vo. Pp.544. 1907. Jas. Munro. 18s.

Formulæ, Rules and Questions in Steam, including Turbines. $\mathrm{Cr}$. 8vo. Pp. 104. 1919. Jas. Munro. 3s. $6 d$.

Sothern, J. W. M. Marine Engine Indicator Cards. Containing an exhaustive course of Indicator Diagrams specially arranged for Board of Trade Examination candidates, and for the use of Engineer Officers of all Grades. 2nd edn. Rov. 8vo. Pp. 226. 1918. Jas. Munro. $15 s$.

"Verbal Notes" and Sketches for Marine Engineers. A Manual of Marine Engineering Practice. 10th edn. 3rd imp. Roy. 8vo. Pp. 74s. 1920. Jas. Munro. 36s.

Oil Fuel Burning in Marine Practice. A Manual of Instruction. Med.8vo. Pp. 200. 1920. Jas. Munro. $30 s$.

Sothern, R. M. Simple Problems in Marine Engineering Design, including Algebra, for Board of Trade Examinations. 4th edn. $\mathrm{Cr} .8 \mathrm{vo}$. Pp. 228. 1919. Jas. Munro. 7s. 6d.

Thorn, W. T. Arithmetical Guide for Marine Engineers. Demy 3vo. Vol. 1. Second Class. Pp. 240. 1917. 6s. Vol. 2. First Class. Pp. 327, 1919. $7 s .6 d$. James Brown.

Elementary Questions and Answers for Marine Engineers. Demy 8vo. Pp. 322. 1916. James Brown. $7 s .6 d$.

Tod's Verbal Questions and Answers for Marine Engineers. 2 Vols. Cr. 8vo. Pp. 301., 271. James Brown. 5s, each.

Tompkins, A. E. A Text-Book of Marine Engineering. 5th edn. 8vo. Pp. 900. 1921. Macmillan. 36s.
Youngson, P. Board of Trade Examination Calculations for First Class Engineers. 8th edn. Cr. 8vo. Pp. 447. Jas. Munro. 10s.6d.

Board of Trade Examination Calculations for Second Class Engineers. 8th edn. Cr. 8vo. Py.349. Jas. Munro. 10s.6d.

_-Useful Hints to Sea-Going Engineers: and How to Repair and Avoid Breakdowns. 7th edn. Cr. 8vo. Pp. 460. 1921. T. Reed \& Co. 7s. 6d.

Extra Chief Engineers' and Surveyors' Guide to the Examinations of the Board of Trade. Demy 8vo. Pp.610. 1921. Jas. Munro. 45s .

and Shaw, J, H. Practical Mathematics for Second-Class Engineers. 9th edn. Cr. 8vo. Pp.477. 1921 . Jas. Munro. $10 s .6 d$.

xXii. INTERNAL COMBUSTION ENGINES.

Allen, H. Gas and Oil Engines. A Treatise on the Design, Construction, and Working of Internal-combustion Fngines, operated by gas from towns' mains, blast furnaces, pressure and suction producers, as well as by oil and petrol. Demy Svo. Pp. 562. 1907. Scientific Pub.Co. 12s.6d.

- How to Design A Gas Engine, with full working drawings for a 7-B.H.P. Gas Engine. Cr. 4to. Pp. 40. 1907. Scientific Pub. Co. $2 s .6 d$.

Askling, C. W., and Roesler, E. Internal Combustion Engines and Gas Producers. Large 8vo. Pp. 313. 1912. Griffin. 15s.

Bale, M. P. Gas and Oil Engine Management. 4th edn. Cr. 8vo. Pp.176. 1919. Crosby Lockwood. 3s. 6d.

Butler, E. Internal Combustion Engine: Design and Practice. 2nd edn. Demy 8vo. Pp. 289. 1920. Griffin. 21s.

Carburettors, Vaporisers, and Distributing Valves used in Internal Combustion Engines. 2nd edn. Demy 8vo. Pp. 288. 1919. Griffin. $12 s .6 d$. 
Chalkley, A. P. The Diesel Engine for Land and Marine Work. 4th edn. Demy 8vo. Pp. 385. 1919. Constable. 12s. $6 d$.

Clerk, D., and Burls, G. A. The Gas Petrol and Oil Engine. Vol 2. The Gas, Petrol and Oil Engine in Practice. New edn. 8vo. Pp. 848. (1913). 1919. Longmans. $28 s$.

Codd, M. A. Electrical Ignition for Internal Combustion Engines. 2nd edn. Cr. 8vo. Pp. 172. 1918. Spon. $6 s$.

Dommett, W. E. Petrol Engine Construction and Drawing. Demy 4to. Pp. 56. 1912. Arnold. 3s. $6 d$.

Donkin, B. A Text-Book on Gas, Oil, and Air Engines. 5th edn. Revised by 'T. G. Smith; and new matter by Prof. Burstall. Large 8vo. Pp.662. 1911. Griffin.30s.

Garrard, A. Gas, Oil, and Petrol Engines. Including Suction Gas Plant and Humphrey Pumps. Cr. 8vo. Pp. 221. 1916. Pitman.6s.

Haeder, H. A Handbook on the Gas Engine. Translated from the German and edited by W. M. Huskisson. Sm. 4to. Pp. 317. 1911. Crosby Lockwood. $30 s$.

Judge, A. W. Automobile and Aircraft Engines in Theory and Experiment; being a revised and enlarged edition of High Speed Internal Combustion Engines. Med.8vo. Pp. 650. 1921. Pitman. 30s.

Kean, F. J. The Petrol Engine. The Principles of Design and Construction. 2nd edn. Demy 8vo. Pp. 126. 1918. Spon. 6s.

Kershaw, J . W. Elementary Internal Combustion Engines and Gas Producers. New imp. Cr.8vo. Pp. 180. 1920. Longmans. 6s.6d.

Kirschke, A. Gas and Oil Engines. Translated and Revised from the German. and adapted to British Practice. Cr. 8vo. Pp. 160. 1912. Scott, Greenwood. 4s.
Lamb, J. The Running and Maintenance of the Marine Diesel Engine : a reference book for Marine Motor Engineers: giving practical suggestions from Sea experience. 2nd edn. Pocket size. Py, 261. 1921. Griffin. 8s. 6d.

Lieckfeld, G. Oil Motors: Their Development, Construction, and Management. Med.8vo. Pp. 287. 1908. Griffin. 18s.

Marine Oil Engine Handbook. Compiled by the staff of "The Motor Ship and Motor Boat.' 5th edn. Demy 8vo. Pp. 206. 1919. Temple Press. $2 s$ 6d.

Marshall, W. J., and Sankey, H. R. The Gas Engine. Ex. Cr. 8vo. Pp. 294. 1920. Constable.12s.6d.

Martin, W. D. Marine Oil Fngines: Specially for Marine Engineers who are unfamiliar with the working of Oil Engines. 2nd edn. Cr. 8vo. Pp.223. 1919. Jas. Munro.7s.6d.

Okill, J. Gas and Oil Engine Operation. Including Gas Producers and Petrol Engines. Cr. 8vo. Pp. 198. 1919. Pitman. 6s.

Pollock, W. Hot Bulb Oil Engines and Suitable Vessels. Demy $8 v 0$. Pp. 429. 1919. Constable. 42s.

Purday, H. F. P. Diesel Engine Design. Demy 8vo. Pp. 317 . 1919. Constable. $21 s$.

Rose, E. M. Diesel Engine Design. Demy 8vo. Pp. 203. 1919. Emmott. $7 s, 6 d$.

Smith, C. A. Suction Gas Plants. 4th edition in preparation. Griffin.

Spooner, H. J. Notes on, and Drawings of a Four-Cylinder Petrol Engine. 4to. Pp. 26. 1908 . Longmans. 3s. $6 d$.

Supino, G. Land and Marine Diesel Engines. Translated by A. G. Bremner and $J$. Richardson. 4th edn. Large 8vo. Pp. 323. 1920. Griffin. 15s.

Wells, G. J., and Wallis-Tayler, A. J. Diesel or Slow Combustion Oil Engine. A Practical Treatise on their Design and Construction. 4th edn. Demy 8vo. Pp. 320. 1919. Crosby Lockwood. 10s. 6d. 
Wimperis, H. E. A Primer of the Internal Combustion Engine. A Text-book for First and Second Year Students. 3rd imp. Cr. 8vo. Pp. 154. 1919. Constable. $4 s$.

- The Internal Combustion Engine. A Text-Book on Gas, Oil, and Petrol F.ngines, for the use of Students and Engineers. 3rd edn. Demy 8vo. Pp.335. 1919. Constable. 8s.6d.

xxiii. TURBINES : STEAM AND GAS.

Bauer, G., and Lasche, O. Marine Steam Turbines. Translated from the German, and edited by M. G. S. Swallow. Med. 8vo. Pp. 230. 1911. Crosby Lockwood. 12s. 6d.

Davey, N. The Gas Turbine. Demy Svo. Pp. 264. 1914. Constable. $15 s$.

Foster, F. Steam Turbines and Turbo-Compressors. A Treatise on their Design and Construction. Demy 8vo. Pp. 466. 1906. Scientific Pub. Co. 10s,6d.

Goudie, W. J: Steam Turbines: A Text-Book for Engineering Students . New edition in the Press. Longmans.

Holzwarth, H. A Treatise on the Gas Turbine: Theory, Construction, and Records of the Results Obtained from Two Actual Machines. Translated by A. P. Chalkley. Med. 8vo. Pp. 148. 1912. Griffin. 9s.

Jude, A. The Theory of the Steam Turbine. A Treatise on the Principles of Construction of the Steam Turbine, with Historical Notes on its Development. 2nd edn. Large 8vo. Pp.440. 1910. Griffin. 21s .

Morrow, J. Steam Turbine Design, with Especial Reference to the Reaction Type, and including Chapters on Condensers and Propeller Design. New edition in preparation. Arnold.

Neilson, R.M. The Steam Turbine . 4thedn. Med.8vo. Pp.678. 1912. Longmans. $21 s$.
Reed, S. J. Turbines Applied to Marine Propulsion. 2nd edn. Cr. 4to. Pp. 191. 1917. Constable. $16 s$.

Sothern, J. W. M. The Marine Turbine. A Practical Illustrated Description of the Parsons and Curtis Marine Geared-Down Steam Turbines, etc. 6th edn. Roy. 8vo. Pp. 790. 1919. Jas. Munro. 42s.

Suplee, H. H. The Gas Turbine: Progress in the Design and Construction of Turbines operated by Gases of Combustion. Large 8vo. Pp. 262. 1910. Griffin. 15s.

Wilda, H. Steam Turbines: Their Theory and Construction. $\mathrm{Cr} .8 \mathrm{vo}$. Pp. 200. 1912. Scott, Greenwood. 4s. fid.

\section{xxiv. ENGINEERING REFER- ENCE BOOKS, AND MISCELLANEOUS.}

A General Manager. Engineering Estimates, Costs and Accounts. A Guide to Commercial Engineering. 3rd edn. 8vo. $\mathrm{Pp}$. 276. 1911. Crosby Lockwood. $8 s .6 d$.

Brooks, G. (edited by) The Mechanical Engineer's Price Book. 2nd edn. Pocket size. Pp. 182. 1914. Spon. 5s.

Fowler's Mechanical Engineer's Pocket Book, 1921. Edited by W. H. Fowler. $18 \mathrm{mo}$. Pp. 620 . Jan., 1921. Scientific Pub. Co. 3s. Mechanic's and Machinist's Pocket Book, 1921. Edited by W. H. Fowler. $18 \mathrm{mo}$. Pu. 495 . Jan., 1921. Scientific Pub. Co. $2 s .6 d$.

Kempe, H. R., and Smith, W. H. (compiled and edited by). The Engineer's Year-Book of Formulae, Rules, Tables, Data and Memoranda for 1921. A Compendium of the Modern Practice of Civil, Mechanical, Electrical, Marine, Gas, Aero, Mine, and Metallurgical Engineering. With collaboration of Eminent Specialists. 28th year of publication. Large Cr. 8vo. Pp. 2,697. Apl. 1921. Crosby Lockwood. $30 s$. 


\section{Mechanical Engineering.}

Mechanical World Year Book, 1921. 18mo. Pp. 328. Jan., 1921. Emmott. 2s. 6 d.

Practical Engineer Mechanical Pocket Book and Diary, 1921. 23rd year of Issue. Pocket size. Pp. 566. Feb., 1921. Technical Pub. Co. $2 s$.

Rankine, W.J.M. Useful Rules and Tables: for Architects, Builders, Engineers, Mechanics, Shipbuilders, etc., with Appendix for the use of Electrical Engineers by A. Jamieson. 8th edn. 1907. Griffin. $10 s, 6 d$.

Ruff, F. Reference Book for Statical Calculations. Force Diagrams for Frameworks, Tables, Instruc- tions for Statical Calculations, etc., for all Classes of Building and Engineering. Cr. 8vo. Pp. 140. 1906. Spon. 6s.

Sabine, M. H. Miscellaneous Tables for Mechanical Draughtsmen. Folio. Pp. 27. 1921. Technical Pub . Co. $8 s$.

Spon's Workshop Receipts for Manufacturers, Mechanics and Scientific Amateurs. New and thoroughly Revised edition. Cr. 8vo. 1919. Vol. 1. Acetylene to Drying. Pp. 532. Vol. 2. Dyeing to Japanning. Pp. 540. Vol. 3 . Jointing Pipes to Pumps. Pp. 528. Vol. 4. Rainwater to Wire Ropes. Pp. 540. Spon. 7s.6d, each. 


\section{AERONAUTICS.}

\section{i. HISTORICAL AND GENERAL.}

Bacon, G. All About Flying. Feap. 8vo. Pp. 134. 1919. Methuen. $2 s$.

Bailey, G. C. The Complete Airman. Demy 8vo. Pp. 280. 1920. Methuen. 16s.

Bairstow, L. Progress of Aviation in the War Period. Some Items of Scientific and Technical Interest. (Wilbur Wright Lecture, 1919). Pp. 24. 1919. Royal Aeronautical Society. 2s.6d.

Berry, W. H. Aircraft in War and Commerce. 3rd edn. 8vo. Pp. 152. 1919. Burrow. 2s.6d.

Blackburn, C. J ., and Newby, E. J . All About Aircraft. A Simple Text Book. 8vo. Pp. 123. 1919. Burrow. 3s . 6d.

Bright, C. Telegraphy, Aeronautics and War. Demy 8vo. Pp. 401. 1914. Constable. 16s.

Dargon, J . The Future of Aviation. Translated fron the French by $P$. Nutt. Demy 8vo. Pp. 195. 1919. Nutt. 10s. $6 d$.

Gill, N. J. The Aerial Arm. Its Functions and Development. 8vo. Pp. 168. 1919. Aeroplane Publishing Co. 6s. 6d.

Grahame-White, C., and Harper, H. Our First Airways: Their Organization, Equipment, and Finance. Cr. 8vo. Pp. 195. 1919. Lane. 6s. 6d.

Air-Power : Naval, Military and Commercial. Demy 8vo. Pp. 270. 1917. Chapman \& Hall. 7s.6d.

Hamel, G., and Turner, G. C. Flying; some Practical Experiences. 8vo. Pp. 356. 1914. Longmans. 14s.
Holt-Thomas, G. Aerial Transport. Demy 4to. Pp. 278. 1920. Hodder \& Stoughton. $30 s$.

Johnson, V. E. Model Aeroplaning : its Principles and Practice. Demy 8vo. Pp. 265. 1920. Spon. $12 s, 6 d$.

Kennedy, R. Flying Machines. Demy 8vo. Pp. 158. 1909. Technical Pub. Co. 6s. 9d.

Lanchester, F. W. Aircraft in Warfare: the Dawn of the Fourth Arm. Med. 8vo. Pp. 239. 1916. Constable. 12s. $6 d$.

Matthews, R. B., and Others. The British Aircraft Industry: Its Industrial and Commercial Potentialities. A Reprint from The Times, Supplement, for April, 1918. Cr. 8vo. Pp. 305. 1918. Hodder and Stoughton. $6 s$.

Middleton, E. C. Airfare of To. day and of the Future. Cr. 8vo. Pp.192. 1917. Constable. 3s.6d.

Robson, W. A. Aircraft in War and Peace. Cr. 8vo. Pp. 182. 1916. Macmillan. $3 s$.

Spaight, J. M. Aircraft in Peace and the Law. 8vo. Pp.233. 1919. Macmillan. $8 s, 6 d$.

- Aircraft in War. 8vo. Pp. 189. 1914. Macmillan. 7s.6d.

Swinton, A. J. (edited by). The Aeroplane Handbook. Demy 8vo. Pp. 284. 1920. Aeroplane \& General Pub. Co. $21 s$.

Turner, C. C. Aircraft of To-Day . Cr. 8vo. Pp. 315. 1918. Seeley. $7 s, 6 d$

The Struggle in the Air 19141918. A Personal Narrative. Demy 8vo. Pp. 296. 1919. Arnold. $15 s$. 
Winchester, C. Flying Men and their Machines. Demy 8vo. Pp. 242. 1916. Dent. 7s.6d.

\section{ii. THEORY AND PRACTICE OF FLIGHT.}

Aston, W. G. Aeronauties Made Fasy. Cr. 8vo. Pp. 186. 1919. Iliffe. $4 s .6 d$.

Avion. The Way to Fly: A Practical Introduction to Flight for Beginners. Cr. 8vo. Pp. 156. 1919. Pearson. 3s.6d.

Bairstow, L. Applied Aero-dynamies. 8vo. Pp. 578. 1920. Longmans. $32 s$.

Berriman, A. E. Aviation: an Introduction to the Elements of Flight. 2nd edn. Demy 8vo. Pp.388. 1913. Methuen. 12s.6d.

Bryan, G. H. Stability in Aviation. 8vo. Pp. 204. 1911. Macmillan. 6s. $6 d$.

Chatley, H. The Problem of Flight . A Text-book of Aerial Fingineering . 3rd edn. in preparation. Griffin.

Cowley , W. L., and Levy, H. Aeronautics in Theory and Practice. 2nd edn. Demy 8vo. Pp. 343. 1920. Arnold. 25s.

De Villamil, R. Resistance of Air. Demy 8vo. Pp. 192. 1917. Spon. $8 s$. fid.

- The Laws of Avanzini. Laws of Planes moving at an Angle in Air and Water. Super Roy. 8vo. Pp. 23. 1912. Spon. 2s.

Devillers, R. The Dynamics of the Aeroplane. Translated by W. .J. Walker. Demy 8vo. Pp. 310 . 1920. Spon. 21s.

Duchêne, E. A. Flight Without Formulae: Simple Discussions on the Mechanics of the Aeroplane. Translated by J. H. Ledeboer. 3rd imp. 8vo. Pp. 220. 1918. Longmans. $9 s$.

The Mechanics of the Aeroplane. A Study of the Principles of Flight. Translated by $\mathbf{J}$. H. Ledeboer and T. O'B. Hubbard. 8vo. Pp. 240. 1918. Longmans. 9s.
Eiffel, G. The Resistance of the Air and Aviation. Translated by J.C. Hunsaker. 2nd edn. Roy. 4to. Pp. 242. Constable. 42s.

Greenhill, Sir A. G. Dynamies of Mechanical Flight. Demy 8vo. Pp. 121. 1912. Constable. 6s .

- Report on Gyroscopic Theory. 1914. H.M.S.O. 10s.

Report on the Theory of a Stream Line past a Plane Barrier, and of the Discontinuity arising at the Edge, with an Application of the Theory to an Aeroplane. 1911. H.M.S.O. $5 s$.

Appendix to ditto. Theory of a Stream Line past a Curved Wing1916. H.M.S.O. 4s.

Hankin, E. H. Animal Flight: A Record of Observation. Demy 8vo. - Pp. 413. 1914. Iliffe. 12s.6d.

Hobbs, F. D. How to Fly and Instruct on an "Avro." Cr. 8vo. Pp. 75. 1919. Longmans. 3s. 6d.

Hunsaker, J. C. The Triplane and the Stable Biplane. Demy $8 v o$. Pp. 36. 1918. Pitman. 3s.

Lanchester, F. W. Aerial Flight. Demy 8vo. Vol.1. Aerodynamics, 4th edn. Pp. 442. 1918. Vol. 2. Aerodonetics. 2nd edn. Pp. 433 . 1917. Constable. 21s. each.

- The Flying Machine from an Engineering Point of View. Together with a Discussion concerning the Theory of Sustentation and Expenditure of Power in Flight. Demy 8vo. Pp. 143. 1918. Constable. 5s.

Laws, B. C. Stability and Equilibrium of Floating Bodies. Demy 8vo. Pp. 261. 1914. Constable. $10 s, 6 d$.

Le Maitre, W. Natural Stability, and the Parachute Principle in Aeroplanes. Cr. 8vo. Pp. 48 . 1911. Spon. 2s. 6d.

McMinnies, W. G. Practical Flying: Complete Course of Flying Instruction. 2nd edn. $\mathrm{Cr}$. 8vo. Pp. 237. 1918. Temple Press. 5s. 
Roberts, C. Training the Airmen: How they Fly. Cr. 8vo. Pp. 92. 1919. Murray. 3s.6d.

Shaw, H. A Text-book of Aeronautics. Med. 8vo. Pp. 260. 1919. Griffin. 10s. 6d.

Thomson, G. P. Applied Aerodynamics. 4to. Pp. 312. 1920. Hodder \& Stoughton. 42s.

Thurston, A. P. Elementary Aeronautics, or the Science and Practice of Aerial Machines. 2nd edn. Demy 8vo. Pp. 231. 1920. Pitman. 8s. 6d.

Walkden, S. L. Aeroplanes in Gusts, Soaring Flight and the Stability of Aeroplanes. 2nd edn. 8vo. Pp. 280. 1913. Spon. 12s.6d.

\section{iii. DESIGN AND GONSTRUCTION.}

Andrews, S. T. G., and Benson, S. F. The Theory and Practice of Aeroplane Design. Demy 8 vo. Pp. 466. 1920. Chapman \& Hall. $15 s, 6 d$.

Camm, S. Aeroplane Construction. A Handbook on the Various Methods and Details of Construction employed in the Building of Aeroplanes. Demy 8vo. Pp. 146. 1919. Crosby Lockwood. $7 s .6 d$.

Camm, F. J. The Design of Model Aeroplanes. Demy 8vo. Pp. 172. 1919. Benn Bros. 7s.6d.

Fage, A. The Aeroplane: A Concise Scientific Study. 5th edn. Med. 8vo. Pp. 188. 1918. Griffin. 7s. $6 d$.

Hanby, W. Metals in Aircraft Construction. Demy 8vo. Pp. 112. 1920. Standard Air Press. 6s.

Hill, F. T. Practical Aeroplane Construction. A Treatise on Modern Workshop Practice as applied to the Building of Aircraft. Demy 8vo. Pp. 248. 1920. Spon. 12s.6d.

Jones, T. H., and Frier, J. D. Aeroplane Structural Design. A Book for Designers, Draughtsmen and Students. Demy 8vo. Pp. 279. 1920. Pitman. $21 s$.
Judge, A. W. The Design of Aeroplanes. 2nd edn. Med.8vo. Pp. 242. 1917. Pitman. 14s.

- Elementary Principles of Aeroplane Design and Construction. Med. 8vo. Pp. 116. 1919. Pitman. $7 s, 6 d$.

- Fuselage Design. Demy 8vo. Pp. 30. 1919. Pitman. 3s.

- Aircraft and Automobile Materials of Construction. A Treatise for Aireraft, Automobile, and Mechanical F.ngineers, Manufacturers, Constructors, Designers, Draughtsmen, Students, etc. Demy 8vo. Vol.1. Ferrous Materials. Pp. 755. 1920. Vol 2. Non-Ferrous and Organic Materials. Pp. 606. 1921 . Pitman. 25s. each.

Kennedy, R. The Principles of Aero* plane Construction, with Calculations, Formulae. 8vo. Pp. 146. 1911. Churchill. 6s. 6d.

Morgan, A.P. How to Build a $20-\mathrm{ft}$. Bi-plane Glider. Cr. 8vo. Pp. 60 . 1909. Spon. 2s.6d.

Pippard, A. J. S., and Pritchard, J. L. Aeroplane Structures, with an Introduction by L. Bairstow. 8vo. Pp. 374. 1919. Longmans. $21 s$.

\section{iv. AIRSGREWS AND AEROFOILS.}

Fage, A. Airscrews in Theory and Experiment. Cr. 4to. Pp. 208. 1920. Constable. 34s.

Judge, A. W. The Properties of Aerofoils and Resistance of Aerodynamic Bodies. Med. 8vo. Pp. 298. 1917. Pitman. 18s.

Riach, M. A. S. Air-Screws. An Analytical Study in the Application of the Analogy of an Aerofoil having a Rectilinear Motion. Demy 8vo. Pp. 144. 1916. Crosby Lockwood. 10s. 6d.

Park, W. E. A Treatise on Airscrews. Demy 8vo. Pp. 320. 1920. Chapman \& Hall. 21s.

Watts, H. C. The Design of Screw Propellers for Aircraft. 8vo. Pp. 354. 1920. Longmans. 25s . 


\section{'Aeronautics.}

\section{v. AERO ENGINES.}

Burls, G. A. Aero Engines: with a General Introductory Account to the Theory of the Internal Combustion Engine. 11th edn. Demy 8vo. Pp. 206. 1918. Griffin. 8s.6d.

Clark, A. G. Aeronautical Engines. Demy 8 vo. .In preparation. Chapman \& Hall.

Devillers, R. Automobile and Aero Engines. A Handbook for Students, Draughtsmen and Designers. Translated by W.J. Walker. Demy 8vo. Pp. 416. 1919. Spon. 16s.

Kean, F. J. Aeronautical Engines. A critical survey of current practice with special reference to the balancing of inertia forces. 2nd edn. Demy 8vo. Pp. 102. 1918. Spon. 7s. $6 d$.

Klemin, A. A Text-book of Aeronautical Engineering. Demy 8vo. Pp. 317. 1919. Pitman. 15s.

Sylvester, C. Design and Construction of Aero Engines. Demy 8vo. Pp. 147. 1919. Aeroplane Pub. Co. $6 s$.

Wallace, J. Design of Aeroplane Engines. Demy 8vo. Pp. 246. 1920. Benn Bros. 15s.

\section{vi. AERIAL NAVIGATION.}

Card, S. F. Air Navigation Notes and Examples. Demy svo. Pp. 148. 1919. Arnold. 10s. 6d.

Creagh - Osborne, F . The Magnetic Compass in Aircraft. 5th edn. Small Cr. 8vo. Pp. 48. 1918. Arnold. $1 s .6 d$.

Dixie, A. E. Air Navigation for Flight Officers. Demy 8vo. Pp. 234. 1917. John Hogg. 10s. 6d.

Dumbleton, J. E. Principles and Practice of Aerial Navigation. Demy 8vo. Pp. 180. 1920. Crosby Lockwood. 12s. 6d.

Wimperis, H. E. A Primer of Air Navigation. Cr. 8vo. Pp. 142. 1920. Constable. 8s. $6 d$. vii. REFERENGE BOOKS FOR AVIATORS.

Aerial Year Book and Who's Who in the Air, 1920. Cr. 8vo. Pp. 328. 1920. Cross Atlantic Newspaper Service. Paper, 2s.6d. Cloth, $4 s$.

Blake, w. J. The] Aviation Catechism. Roy. 16mo. Pp.64. 1919. Nisbet. 1s.6d.

Dander, M. M. Airman's International Dictionary; including the most important Technical Terms of Aircraft Construction. EnglishFrench-Italian-German, with a "one alphabet" index for these four languages. Pocket size. Pp. 228. 1920. Griffin. 6s.

Dommett, W. E. A Dictionary of Aircraft. Cr. 8vo. Pp. 52. 1918. Pitman. 2s.

_- Aeroplanes and Airships. Cr. 8vo. Pp. 76. 1919. Pitman. Paper, 1s. 9d. Cloth, 3s.

Henslowe, L. Aero Dictionary. English-French : French-English. Feap. 8vo. Pp. 86. 1920. Benn Bros. 5s .

Jane, F. T: All the World's Aircraft, 1920. Edited and compiled by C. G. Grey. Oblong 8vo. Pp. 364. Dec., 1920. Sampson Low. $42 s$.

_- Jane's Pocket Aeronautical Dictionary. Edited by C. G. Grey. Pocket Size. Pp.64. 1919. Sampson Low. 1s. $6 \mathrm{~d}$.

Lycett, J. Aviation Technical Dictionary. Demy 8vo. Pp. 185 . 1919. Nutt. 7s. 6d.

Matthews, R. B. The Aviation Pocket-Book for 1919-20. A Compendium of Modern Practice and a Collection of Useful Notes, Formulæ, Rules, Tables, and Data relating to Aeronautics. 7th edn. Cr. 8vo. Pp. 536. 1920. Crosby Lockwood. 12s. $6 d$.

and Clarkson, G. T. The Aircraft Identification Book. Cr. 8vo. Pp. 118. 1919. Crosby Lockwood. 3s. $6 d$. 


\section{Aeronautics.}

Wade, W.L. (edited by). The Flying Book: The Aviation World Who's Who and Industrial Directory. 8vo. Pp. 290. 1918. Longmans. 5s.

viii. BALLOONS, DIRIGIBLES, etc.

Hoernes, H. A Compendium of Aviation and Aerostaties, Balloons, Dirigibles, and Flying Machines. Pocket size. Pp. 191. 1911. Griffin. 3s .
Pratt, H. B. Commercial Airships. 8vo. Pp. 250. 1920. Nelson. 15s.

Summer, P. H. The Design and Stability of Stream Line Kite Balloons; with useful Tables, Aeronautical and Mechanical Formulæ. 8vo. Pp. 146. 1920. Crosby Lockwood. 10s. $6 d$.

Talbot, F. A. Aeroplanes and Dirigibles of War. Cr.8vo. Pp.296. 1915. Heinemann. 3s. 6d.

Whale, G. British Airships: Past, Present and Future. Cr. 8vo. Pp. 244. 1919. Lane. $7 s .6 d$. 


\section{PHYSICS.}

\section{i. GOLLECTED WORKS AND HISTORICAL.}

Buchanan, J. Y. Scientific Papers. Vol. 1. Demy 8vo. Pp.326. 1913. Cambridge University Press. 5s.

Comptes Rendus of Observation and Reasoning. Demy 8vo. Pp. 492. 1917. Cambridge University Press. 7s. 6d.

Accounts rendered of Work Done and Things Seen. (Scientific Papers). Demy 8vo. Pp. 494. 1919. Cambridge University Press. $21 s$.

Poynting, J. H. Collected Scientific Papers. Edited by G. A. Shakespear and G. Barlow. Roy. 8vo. Pp. 800. 1920. Cambridge University Press. 37s. 6d.

Rayleigh, Lord. Scientific Papers. 6 Vols. Roy. 8vo. Vol. 1. Pp. 577. 1899. 17s, 6d. Vol. 2. Pp. 612. 1900. 17s.6d. Vol. 3. Pp. 608. 1902. 17s. 6d. Vol. 4. Pp. 618. 1903. 18s. 6d. Vol. 5. Pp. 636. 1912. 17s.6d. Vol.6. Pp. 718. 1920. 50s. Cambridge University Press.

Schuster, Sir A. The Progress of Physics during 33 years (18751908). Demy 8vo. Pp. 174. 1911. Cambridge Úniversity Press. 5s.6d.

Stokes, Sir G. G. Mathematical and Physical Papers. 5 vols. Demy 8vo. Vol. 1. Pp. 338. 1880. 21s. Vol. 2. Pp. 374. 1883. 17s.6d. Vol.3. 17s.6d. Vol.4. Pp.386. 1904. 17s. 6d. Vol. 5. Pp. 395. 1905. 21s. Cambridge University Press.

Memoirs presented to the Cambridge Philosophical Society on the occasion of his Jubilee. Demy 4to. Pp. 475. 1900. Cambridge University Press. $21 s$.
Thomson, J. Collected Papers in Physies and Engineering. Selected and arranged by Sir J. Larmor and J. Thomson. Demy 8vo. Pp. 592. 1912. Cambridge Úniversity Press. $18 s$.

Whetham, W. C. D. The Recent Development of Physical Science. Large Cr. 8vo. Pp. 338. 1909. Murray. 7s. 6d.

\section{ii. GENERAL WORKS.}

Aldous, J. C. P. An Elementary Course of Physics. Ex. Cr. 8vo. Pp. 902. 1910. Macmillan. 7s. Gd.

Allen, H. S., and Moore, H. A Text-book of Practical Physies. Ex. Cr. 8vo. Pp. 638. 1920. Macmillan. 10s. 6d.

Bower, W. R., and Satterly, J. Practical Physics. (Being Vol. 6 of The Tutorial Physies. 6th imp. Cr. 8vo. Pp.402. 1918. University Tutorial Press. 6s, 6d.

Brown, S. E. Experimental Science. Cr. 8vo. 1918. 2 Parts. Part 1. Physics. Pp. 280. 6s.6d. Part 2. Chemistry. Pp. 148. 4s.6d. The two parts in one volume. $10 s .6 d$. Cambridge University Press.

Campbell, N.R. Physics: The Elements. Large Roy. 8vo. Pp. 576. 1920. Cambridge University Press. $40 s$.

Candy, H. C. H. A Manual of Physics, Theoretical and Practical, for Medical Students. 2nd edn. Fcap.8vo. Pp.451. 1918. Cassell. 7s. $6 d$.

Catechism Series. Physics. 2nd edn. 2 Parts. Revised by G. C. Knott. I,ivingstone. $18.9 d$. each. 
Christiansen, C. Elements of Theoretical Physics. Translated by $W$. F. Magie. 8vo. Pp. 352. 1897. Macmillan. $16 s$.

Corbin, H. E., and Stewart, A. M . A Handbook of Physies and Chemistry. 5th edn. Cr. 8vo. Pp. 504. 1920. Churchill. 15s.

Crowther, J.A. A Manual of Physics for Medical Students. Cr. 8vo. Pp. 564. 1919. Frowde and Hodder. $16 s$.

Darling, C. R. Liquid Drops and Globules, their Formation and Movements. Cr. 8vo. Pp. 94. 1914. Spon. 3s.6d.

Duncan, J., and Starling, S. G. A Text-book of Physies for the Use of Students of Science and Engineering. 2nd edn. Ex. Cr. 8vo. Pp. 1,118. 1920, 18s. also in Parts ; Dynamies, $6 s$.; Heat, Light and Sound, 7s.6d.; Magnetism and Electricity, 5s.; Heat, 4s. 6d.; Light and Sound, 4s. 6d. Macmillan.

Edser, E. General Physics for Students. A Text-book on the Fundamental Properties of Matter. Gl. 8vo. Pp. 644. 1913. Macmillan. $8 s .6 d$.

Glazebrook, Sir R. T., and Shaw, Sir W. N. Practical Physics. Cr. 8vo. Pp. 660. 1918. Longmans. 11s.

Gray, A. Treatise on Physies. Vol. 1. Dynamies and Propertias of Matter. 8vo. Pp. 712. 1901. Churchill. 18s.

Gregory, Sir R. A., and Hadley, H . E. A Class Book of Physics. New imp. Cr. 8vo. Pp. 516. 1920. Macmillan. 6s.6d.

- and Simmons, A. T. Experimental Science. An Elementary Course of Physies and Chemistry. G1. 8vo. Pp. 346, 1919. Macmillan. 3s.

Exercises in Practical Physics for Schools of Science. 2 Parts. New imp. Gl.8vo. Pp. 208., 182. 1915. Macmillan. 2s. 6d. each part.

Hadley, H. E. Manual of Practical Physics. G1. 8vo. Pp. 274. 1916. Macmillan. 4s.
Houstoun, R. A. The Elements of Physics. 8vo. Pp. 230. 1919. Longmans. $7 s, 6 d$.

An Introduction to Mathematical Physics. 8vo. Pp. 210. 1912. Longmans. $9 s$.

Hurst, H. E., and Lattey, R. T . A Text-book of Physies. Demy 8 vo. Pp. 271. 1916. 12s. 6d. Also in 3 parts. Part 1 . Dynamics and Heat. 4s. Part 2. Light and Sound. 4s. Part 3. Magnetism and Electricity. $5 s$. Constable.

Jackson, C. E. Examples in Physics . 5th edn. Cr.8vo. Pp. 188. 1920. Methuen. $5 s$.

- First Year Physics. 4th edn. Cr. 8vo. Pp.120. 1919. Methuen. $3 s$.

Jones, D. E. Elementary Lessons in Heat, Light and Sound. New imp. Gl. 8vo. Pp. 292. 1920. Macmillan. $3 s$.

Jones, L. M. Practical Physics. Cr. 8vo. Pp. 338. 1909. Longmans. $4 s$.

Jude, R. H., and Gossin, H. Physics: Experimental and Theoretical. Vol. 1., with Examples and exercises. Demy 8vo. Pp.927. 1896. 16s. 6d. Also in 2 Parts. Part 1. Mechanics, Hydrostaties, and Pneumatics. 5s. Part 2. Heat. 9s.6d. Chapman \& Hall.

Kelsey, W. R. Physical Determinations. Laboratory Instructions for the Determination of Physical Quantities connected with General Physics, Heat, Light, etc. 3rd edn. Cr. 8vo. Pp.341. 1907. Arnold. 7s.

Knott, C. G. Physies: an Elementary Text-Book for University Classes. 3rd edn. thoroughly Revised and Amplified, and containing an entirely new Chapter on the Electron Theory and RadioActivity. Cr. 8vo. Pp. 370 . 1913. Chambers. 8s. 6d.

Lommel, Prof. von. Experimental Physics. Translated by G. W. Myers. 8vo. Pp. 685. 1899 . Kegan Paul. 15s.

McDowall, S.A. A Laboratory Note Book of Physics. 2 vols. Pott 4to. Pp. 166., 126. Dent. 4s. each. 


\section{Physics.}

McLean, A. Practical Physics. A Text-book for Technical Schools and Colleges. Demy 8vo. Pp. 402. 1912. Black. 7s.6d.

\section{Poynting, J.H., and Thomson, Sir} J. J. A Text-Book of Physies. Large 8vo. Vol. 1. Properties of Matter. 8th edn. Pp. 235. 1920. 10s.6d. Vol.2. Sound. 7th edn. Pp. 164. 1920. 8s. 6d. Vol. 3. Heat. 6th edn. Pp. 354. 1920. 15s. Vol. 4. Electricity and Magnetism. Parts 1 and 2. 2nd edn. Pp. 359. 1920. 10s. 6d. Part 3 in preparation. Vol. 5. Light, in preparation. Griffin.

Rintoul, D. An Introduction to Practical Physics. New imp. Gl. 8vo. Pp.186. 1917. Macmillan. $3 s$.

Schuster, Sir A., and Lees, G. H. An Intermediate Course of Practical Physies. Cr. 8vo. Pp. 272. 1918. Macmillan. 6s.

- Exercises in Practical Physics. 4th edn. Demy Svo. Pp. 379. 1915. Cambridge University Press. $9 s$.

Siddons, A. W., and Vassall, A. Practical Measurements. Fcap.4to. Pp. 74. 1912. Cambridge University Press. 2s. $6 d$.

Southerns, L. An Outline of Physics. Cr. 8vo. Po. 217. 1920. Methuen. 6s.6d.

Stallo, J. B. Concepts and Theories of Modern Physies. 4th edn. Cr. 8vo. Pp. 368. 1900. Kegan Paul. 7s, $6 d$.

Stanley, H. Practical Applied Physics. Cr. 8vo. Pp. 234. 1914 . Methuen. $5 s$.

Preliminary Practical Science. Some Fundamental Principles of Physical Science, with their practical applications. 2nd edn. Cr. 8vo. Pp. 136. 1920. Methuen. 2s. $6 d$.

Stewart, B . Conservation of Energy . 10th edn. Cr.8vo. Pp.195. 1909 . Kegan Paul. 7s. $6 d$.
Stewart, B., and Gee, W. W. H. Lessons in Elementary Practical Physics. Vol. 1. Cr.8vo. General Physical Processes. Pp.314. 1912. Macmillan. $7 s$.

Stewart, R. W. An Elementary Text-book of Physics. 4 vols. Cr. 8vo. Vol. 1. General Physics. Pp. 421. 1910. 5s. Vol. 2. Sound. Pp. 148. 1909. 3s. Vol. 3. Light. Pp. 226. 1909. 4s. Vol. 4. Heat. Pp. 247. 1910. 4s. Griffin.

- and Don, J. Matriculation Physics: Heat, Light and Sound. 13th imp. Cr. 8vo. Pp.420.1918. University Tutorial Press. 6s. 6d.

Watson, W. A Text-Book of Physics including a collection of Examples and Questions. 7th edn. Revised by $\mathrm{H}$. Moss. Large $\mathrm{Cr} .8 \mathrm{vo}$. Pp. 1,002. 1921. Longmans. 21s.

- Intermediate Physics. 8vo. Pp. 564. 1918. Longmans, 15s. - A Text-Book of Practical Physics. A Book of Reference for the Student working in a Physical Laboratory. Cr. 8vo. Pp. 646 . 1919. Longmans. 10s. $6 d$.

- Elementary Practical Physics : a Laboratory Manual. Cr. 8vo. Pp. 268. 1919. Longmans. $4 s$.

White, W. H. A Handbook of Physies. Cr. 8vo. Pp. 683. 1912. Methuen. 8s. 6d.

Willows, R. S. A Text-book of Physics. 2nd edn. 4th imp. Cr. 8vo. Pp. 520. 1920. Arnold. $9 s$.

Wilson, H. A. Experimental Physics. A Text-book of Mechanics, Heat, Sound and Light. 2nd imp. Demy 8vo. Pp. 413. (1915) 1920. Cambridge University Press. 14s.

Wright, M. R. Sound, Light and Heat. Cr. 8vo. Pp. 288. 1912. Longmans. $5 s$.

Yorke, J. P. Elementary Physies for Engineers. Cr. 8vo. Pp. 174. 1916. Cambridge University Press. 4s. $6 d$. 


\section{a. Heat.}

Eccles, J. R. Advanced Lecture Notes on Heat. Cr. 4to. Pp. 186. 1921. Cambridge University Press. $10 s .6 d$.

Edser, E. Heat for Advanced Students. G1. 8vo. Pp.500. 1920 . Macmillan. 5s, 6d.

Fourier, J. The Analytical Theory of Heat. Translated, with notes, by A. Freeman. Demy 8vo. Pp. 489. 1878. Cambridge University Press. $12 s$.

Glazebrook, Sir R. T. Heat and Light. An Elementary Text-book. Cr. 8vo. Pp. 449. 1919. 10s. Also separately. Heat. 5s. Light. 6s. Cambridge University Press.

Griffiths, E. H. The Thermal Measurement of Energy. Cr. 8vo. Pp. 143. 1901. Cambridge University Press. $3 s . \mathbf{3} d$.

Hart, J. B. A Students' Heat. Cr. 8vo. Pp. 376. Dent. 5s.6d.

Maxwell, J. C. Theory of Heat. 10th edn., revised by Lord Rayleigh. Cr. 8vo. Pp. 362. 1916. Longmans. $6 s .6 d$.

Preston, T. The Theory of Heat. 3rd edn., edited by J. R. Cotter. 8vo. Pp. 860. 1919. Macmillan. $25 s$.

Scarlett, R. H. A School Course of Heat. Cr. 8vo. Pp. 316. 1910. Longmans. $4 s, 6 d$.

Smith, J. H. The Study of Heat. 9th edn. Cr. 8vo. Pp. 144. 1890. Longmans. $3 s .6 d$.

Stewart, R. W. The New Matriculation Heat. 2nd edn. 8th imp. Cr. 8vo. Pp. 245. 1920. University Tutorial Press. $4 s$.

Higher Text-Book of Heat (being Vol. 2. of the Tutorial Physics). 2nd edn. 5th imp. Cr. 8vo. Pp. 407. 1917. University Tutorial Press. 9s. 6d.

- and Satterly, J. Text-Book of Heat: Theoretical and Practical. 3rd imp. Cr. 8vo. Pp.488. 1917. University Tutorial Press. 6s.6d.

Wright, M. R. Advanced Heat. Cr. 8vo. Pp.362. 1919. Longmans. 6s. $6 d$. b. Thermodynamics.

Callendar, H. L. Properties of Steam and Thermodynamic Theory of Turbines. Demy 8vo. Pp. 543. 1920. Arnold. 40s.

Draper, C. H. Heat and the Principles of Thermodynamics. Demy 8vo. Pp. 428. 1917. Blackie. 6s.

Ewing, Sir J.A. Thermodynamies for Engineers. Demy 8vo. Pp. 396. 1920. Cambridge University Press. 30s.

Macaulay, W. H. The Laws of Thermodynamies. Demy 8vo. Pp. 80. 1913. Cambridge University Press. 3s.

Naylor, C. H. Correction Tables for Thermodynamic Efficiency. Demy 8vo. Pp.60. 1917. Arnold. 5s.

Parker, J. A Treatise on Elementary Thermodynamics. Cr. 8vo. Pp. 416. 1891. Cambridge University Press. 9s.

Partington, J. R. A Text-Book of Thermodynamics; with special reference to Chemistry. Demy 8vo. Pp. 562. 1913. Constable. 14s.

Planck, M. Treatise on Thermodynamics. Translated by A. Ogg. 8vo. Pp. 284. 1917. Longmans. $10 s$.

\section{c. High Temperatures .}

Darling, C. R. Pyrometry . A Practical Treatise on the Measurement of High Temperatures. 2nd edn. Cr. 8vo. Pp. 236. 1920. Spon. 10s. 6d.

Griffiths, E. Methods of Measuring Temperature. Large 8vo. Pp. 187. 1918. Griffin. $8 s .6 d$.

Methods and Appliances for the Attainment of High Tempera tures in the Laboratory. Faraday Society Report, 1917. Demy 8vo. Pp. 12. 1917. Faraday Society. 2s. 6d.

Pyrometers and Pyrometry. A General Discussion. Faraday Society Report, 1918. Demy 8vo. Pp. 170. 1918. Faraday Society. 12s. $6 d$. 


\section{d. Gases .}

Burbury, S. H. A Treatise on the Kinetic Theory of Gases. Demy 8vo. Pp. 165. 1899. Cambridge University Press. 9s.

Burstall, F. W. The Energy-Diagram for Gas: with Descriptive Text. Roy. 8vo. Pp. 20. 1912. Constable. $5 s$.

Clowes, F. The Detection and Measurement of Inflammable Gas and Vapour in the Air. Cr. 8vo. Pp. 218. 1896. Crosby Lockwood. 6s.

Eason, A. B. The Flow and Measurement of Air and Gases. Med. 8vo. Pp. 264. 1919. Griffin. 25s.

Haldane, J. S. Methods of Air Analysis. Suitable for work in Physiology, Hygiene, Investigations of Mine Air, Flue Gases, Exhaust Gases from Engines, etc. 3rd edn. Cr.8vo. Pp. 147. 1920. Griffin. 6s.

Jeans, J. H. The Dynamical Theory of Gases. 3rd edn. 4to. Pp. 450 . 1921. Cambridge University Press. $30 s$.

Kimball, A. L. The Physical Properties of Gases. Cr. 8vo. Pp. 246. 1890. Heinemann. 5s.

Occlusion of Gases by Metals, The. A General Discussion. Faraday Society Report, 1919. Demy 8vo. Pp. 93. 1919. Faraday Society. 8s. $6 d$.

Ramsay, Sir W. The Gases of the Atmosphere: the History of their Discovery. 4th edn. Ex. Cr. 8vo. Pp.320. 1915. Macmillan.7s. 6d.

Shaw, Sir W. N. Air Currents and the Laws of Ventilation. Demy 8vo. Pp. 106. 1907. Cambridge University Press. $4 s$.

Watson, H. W. A Treatise on the Kinetic Theory of Gases. 2nd edn. Cr. 8vo. Pp. 102. 1893. Oxford: Clarendon Press. 4s. $6 d$.

\section{e. Light.}

Aldis, W. S. An Elementary Treatise on Geometrical Optics. 8th edn. Pp. 195. 1910. Bell. 4s. $6 d$.
Bateman, H. The Mathematical Analysis of Electrical and Optical Wave Motion. Demy 8vo. Pp. 168. 1915. Cambridge University Press. Ss. 6d.

Boys, C. V. Soap Bubbles, their Colours and the Forces which Mould them. New edn. Post 8vo. Pp. 200. 1920. S.P.C.K. 5s.

Glay, R. S. Treatise on Practical Light. Ex. Cr. 8vo. Pp. 536. 1911. Macmillan. 12s, $6 d$.

-Practical Exercises in Light; a

Laboratory Course for Schools of Science and Colleges. New imp. Gl. 8vo. Pp. 200. 1914. Macmillan. 3s.

Cross, W. E. Elementary Physical Optics. Cr. 8vo. Pp. 312. 1913. Oxford: Clarendon Press. 4s.

Curry, C. E. Electromagnetic Theory of Light. 8vo. Part 1. Pp. 416. 1905. Macmillan. 12s.

Eccles, J . R. Lecture Notes on Light. Cr.4to. Pp.217. 1917. 7s. Key, with 85 pages of diagrams. $12 s .6 d$. Cambridge University Press.

Advanced Lecture Notes on Light. Cr. 4to. Pp. 141. 1919. 7s.6d. Cambridge University Press.

Edser, E. Light for Students. Gl. 8vo. Pp. 588. 1919. Macmillan. $7 s$.

Emtage, W. T. A. Light. Cr. 8vo. Pp.360. 1903. Longmans. 7s.6d.

Glazebrook, Sir R. T. Physical Optics. Cr. 8vo. Pp. 474. 1914. Longmans. $7 s, 6 d$.

Heath, R. S. F.lementary Treatise on Geometrical Optics. 3rd edn. Cr. 8vo. Pp. 247. 1907. Cambridge University Press. $6 s$.

Herman, R. A. A Treatise on Geometrical Optics. Demy 8vo. Pp. 350. 1900. Cambridge University Press. $10 s$.

Hōgner, P. Light, Radiation and Illumination. Translated from the German by J. Eck. Demy 8vo. Pp. 100. N.D. Benn Bros. 7s.6d.

Houstoun, R. A. A Treatise on Light. New imp. Demy 8vo. Pp. 492. 1920. Longmans. 12s.6d. 
Huygens, C. Treatise on Light. Translated by S. P. Thompson. Fcap. 4to. Pp. 142. 1912. Macmillan. $10 s$.

Kelvin, Lord. Baltimore Lectures on Molecular Dynamics and the Wave Theory of Light. Demy 8vo. Pp. 715. 1904. Cambridge University Press. $20 s$.

Lommel, E. Nature of Light: with A General Account of Physical Opties. 7th edn. Cr. 8vo. Pp. 369. 1904. Kegan Paul. 7s.6d.

Maclaurin, R. C. The Theory of Light. Demy 8vo. Pp. 334. 1908. Cambridge University Press. $12 s$. $6 d$.

Mallik, D. N. Optical Theories. Demy 8vo. Pp. 181. 1917. Cambi ilge University Press . 7s, 6d.

Parker, G. W. Elements of Optics . Cr. 8vo. Pp. 130. 1915. Longmans. $4 s .6 d$.

Parkinson, S. A Treatise on Optics. 4th edn. Cr. 8vo. Pp. 378. 1884. Macmillan. 10s.6d.

Percival, A. S. Optics: A Manual for Students. Cr. 8vo. Pp. 416 . 1899. Macmillan. 12s, $6 d$.

- Geometrical Optics. 8vo. Pp. 140. 1913. Longmans, $\gamma s, 6 d$.

Preston, T. The Theory of Light . 4th edn. edited by W. E. Thrift. 8vo. Pp. 642. 1912. Macmillan. $15 s$.

Ramsey, A. S. A Text-Book of Geometrical Optics. Demy 8vo. Pp. 173. 1914. Bell. 8s.6d.

Schuster, Sir A. An Introduction to the Theory of Optics. 2nd edn. Demy 8vo. Pp. 352.1909. Arnold. $16 s$.

Silberstein, L. Elements of the Electromagnetic Theory of Light. Cr.8vo. Pp.56. 1918. Longmans. $4 s .6 d$.

Simplified Method of Tracing Rays through any Optical System of Lenses, Prisms, and Mirrors. 8vo. Pp. 48. 1918. Longmans. 5s.6d.
Stewart, R. W. Text-Book of Eight . (being Vol. 3. of The Tutorial Physics.) 4th edn. 10th imp. Cr. 8vo. Pp. 354. 1919. University Tutorial Press. 6s. $6 d$.

- The New Matriculation Light. 9th imp. Cr. 8vo. Pp. 290. 1920. University Tutorial Press. $4 s$.

Stokes, Sir G. G. On Light. The Burnett Lectures. Cr. 8vo. Pp. 364. 1892. Macmillan. 7s,6d.

Thompson, S. P. Light: Visible and Invisible. 2nd edn. Cr. 8vo. Pp.396. 1919. Macmillan. 8s.6d.

Tolkowsky, M. Diamond Design. A Study of the Reflection and Refraction of Light in a Diamond. Cr. 8vo. Pp. 104. 1920. Spon. $6 s .6 d$.

Walker, J. The Analytical Theory of Light. Roy. 8vo. Pp.432. 1904. Cambridge University Press. $18 s$. $6 d$.

\section{Physiological Optics and Optical Instruments.}

Burch, G. J. Practical Exercises in Physiological Optics. Cr. 8vo. Pp. 164. 1912. Oxford: Clarendon Press. 4s.

Dictionary of British Scientific Instruments. Issued by the British Optical Instrument Manufacturer's Association. Demy 8vo. Pp. 348 . 1921. Constable. $21 s$.

Emsley, H. H., and Swaine, W. The Theory of Modern Optical Instruments; from the German of A. Gleichen: with an Appendix on Rangefinders.8vo. Pp.375. 1918. H. M. Stationery Office. 12s.6d.

Fray, J. The Repairing Optician. A Beginner's Guide to the Optical Workshop. Fcap. 8vo. Pp. 191. 1920. Frowde and Hodder. $8 s, 6 d$.

Hyatt-Woolf, C. The Optical Dictionary. An Optical and Ophthalmological Glossary of English Terms \&c., Relating to Physical, Physiological and Pathological Optics, etc. Demy 8vo. Pp. 87. 1904 . Hatton Press. $4 s$. 
Laurance, L. Simple Calculations for Students of Visual Optics. De y 8vo. Pp. 72. N.D. Hatton Press. 4s. 6d.

-General and Practical Optics. 3rd edn. Demy 8vo: Pp. 370. 1920. Hatton Press. 21s.

- Visual Opties and Sight Testing . 2nd edn. Demy 8vo. Pp. 432 . 1920. Hatton Press. $21 s$.

Orford, H. Modern Optical Instruments. Cr. 8vo. Pp. 100. 1918. Pitman. 4s.

Rohr, M. Von. (edited by). Geometrical Investigation of the Formation of Images in Optical Instruments: embodying the results of scientific researches conducted in German Optical Workshops (Forming Vol. I. of "The Theory of Optical Instruments.") Translated by R. Kanthack. 8vo. Pp. 636. 1920. H.M.S.O. 45s.

Steinheil, A., and Voit, E. Applied Optics : The Computation of Optical Systems. Translated from the German by J. W. French. 2 Vols. Feap. Ato. Vol. 1. Pp. 161. 1918. Vol. 2. Pp. 207. 1919. Blackie. 15s. per vol.

Whittaker, E. T. The Theory of Optical Instruments. 2nd edn. Demy svo. Pp. 80. 1915 . Cambridge University Press . 3s. 6d.

Wright, L. Optical Projection. A Treatise on the use of the Lantern in Exhibition and Scientific: Demontration. 5th edn. Revised by $\mathbf{R}$. S. Wright. 2 parts. Part 1. The Projection of Lantern Slides. Cr. 8vo. Pp. 95. 1920.\$ Longmans. $4 s .6 d$.

\section{g. Colour: Spectra.}

Abney, Sir W.de W. Researches in Colour Vision and the Trichromatic Theory. 8vo. Pp. 432. 1913. Longmans. 25s.

Liveing, G. D., and Dewar, Sir J. Collected Papers on Spectroscopy. Roy. 8vo. Pp. 582. 1915. Cambridge University Press. 30s.
Lockyer, Sir J. N. Studies in Spectrum Analysis. 6th edn. Cr. 8vo. Pp. 270. 1904. Kegan Paul. 8s. 6d.

Lovibond, J. W. Light and Colour Theories, and their Relation to Light and Colour Standardization. 8vo. Pp.90. 1915. Spon. 7s.6d. An Introduction to the Study of Colour Phenomena, explaining a New Theory of Colour based entirely on experimental facts, with applications to scientific and industrial investigations. 8vo. Pp. 48, 10 Plates. 1905. Spon. 7s. 6d.

Lyman, T. The Spectroscopy of the Extreme Ultra-Violet. 8vo. Pp. 142. 1914. Longmans. 6s. $6 d$.

Mees, C. E. K. An Atlas of Absorption Spectra. Cr. 8vo. Pp. 85. 1909. Longmans. 6s. $6 d$.

Parsons, J. H. An Introduction to the Study of Colour Vision. Roy. 8vo. Pp. 316. 1915. Cambridge University Press. 12s. 6d.

Rood, O. N. Colour: a Text-Book of Modern Chromatics, with Applications to Art and Industry. 5th edn. Cr. 8vo. Pp. 338. 1910. Kegan Paul. 7s. 6d.

Roscoe, Sir H. E., and Schuster, Sir A. Spectrum Analysis. 4th edn. 8vo. Pp. 468. 1885. Macmillan. 25s.

Silberstein, L. Report on the Quantum Theory of Spectra. Demy 8vo. Pp.46. 1920. Adam Hilger. $5 s$.

Watts, W. M. An Introduction to the Study of Spectrum Analysis. 8 vo. Pp. 336. 1904. Longmans. $12 s$.

Zeeman, P. Researches in MagnetoOptics. 8vo. Pp. 236. 1913. Macmillan. $7 s, 6 d$.

\section{b. Sound.}

Barton, E. H. A Text Book on Sound. 2nd edn. Ex. Cr. Svo. Pp. 701. 1919. Macmillan. 12s. 6d. 
Bragg, Sir W. H. The World of Sound. Six Lectures delivered before a Juvenile Auditory at the Royal Institution, Christmas, 1919. Cr. 8vo. Pp. 204. 1920. Bell. $6 s$.

Buck, P. C. Acoustics for Musicians . Demy 8vo. Pp. 152. 1918. Oxford: Clarendon Press. $7 s, 6 d$.

Capstick, J. W. Sound. An Elementary Text-book. Cr. 8vo. Pp. 404. 1913. Cambridge University Press. 6s.

Catchpoo1, E. Text-Book of Sound. (Being Vol. 1. of The Tutorial Physies). 5th edn. 10th imp. Cr. 8vo. Pp. 388. 1919. University Tutorial Press. 6s.6d.

Dunk, J. L. Hyperacoustics . Division 1.: Simultaneous Tonality. Large Demy 8vo. Pp. 311. Dent. $9 s .6 d$.

Gurney, E. The Power of Sound. Roy.8vo. Pp.559. 1880. Murray. $28 s$.

Helmholtz, H. L. F. On the Sensations of Tone as a Physiological Basis for the Theory of Music. 4th edn. Roy. 8vo. Pp. 596. 1912. Longmans. 30s.

Lamb, H. The Dynamical Theory of Sound. Demy 8vo. Pp. 303. 1910. Arnold. 15s.

Rayleigh, Lord. The Theory of Sound. Vol. II. 2nd edn. 8vo. Pp. 520. 1896. Macmillan. 15s.

Stewart, R. W. The New Matriculation Sound. 7th imp. Cr. 8vo. $P_{P}$. 220. 1920. University Tutorial Press. $4 s$.

Taylor, S. Sound and Music. 3rd edn. Ex. Cr. 8vo. Pp.236. 1896. Macmillan. $10 s$.

Watt, H. J. The Foundations of Music. Roy.8vo. Pp.256. 1919. Cambridge University Press. $18 s$.

Wood, A. The Physica! Basis of Music. Roy. 16mo. Pp. 163. 1913. Cambridge University Press . $2 s .6 d$.

\section{i. Properties of Matter.}

De Villamil, R. Motions of Liquids. 8vo. Pp. 224. 1914. Spon. $8 s .6 d$.

Fleming, J.A. Waves and Ripples in Water, Air, and Ether. 3rd edn. Cr. 8vo. Pp. 299. 1919. S.P.C.K. $7 s .6 d$.

Maxwell, J.C. Matter and Motion, with Notes and Appendices by Sir J. Larmor, Cr. 8vo. Pp. 178. 1920. S.P.C.K. $5 s$.

Le Bon, G. The Evolution of Matter. Translated by F. Legge. $\mathrm{Cr}$. 8vo. Scott Pub.Co. Gs .

Searle, G. F. C. Experimental Harmonic Motion. A Manual for the Iaboratory, Demy 8vo. Pp. 102. 1915. Cambridge University Press. 6s.

Soddy, F. Matter and Energy. Feap. 8vo. Pp. 256. 1912. Williams and Norgate. $2 s .6 d$.

Wagstaff, C. J. L. Properties of Matter (being Vol. 5 of The Tutorial Physies). 3rd edn. 7th imp. Cr. 8vo. Pp. 287. 1920, University Tutorial Press. 5s.

\section{j. Molecular Physics.}

Cox, J. Beyond the Atom. Roy. 16mo. Pp. 151. 1913. Cambridge University Press. 2s. $6 d$.

Crowther, J.A. Molecular Physics. 2nd edn. Cr.8vo. Pp.198. 1919. Churchill. 6s.

-Ions, Electrons and Ionizing Radiations. Demy 8vo. Pp. 288 . 1919. Arnold. 12s. $6 d$.

Lodge, Sir O. J. Electrons: The Nature and Properties of Negative Electricity. 5th edn. Demy 8vo. Pp. 230. 1919. Bell. 8s.6d.

Mercer, J. E. Some Wonders of Matter. A Popular Introduction to the Study of the Atom, Electrons, Radium, etc. Large Cr.8vo. Pp. 192. 1919. S.P.C.K. 5s.

Perrin, J. Atoms. Translated from the French by D. L. Hammick. 2nd imp. Demy 8vo. Pp. 226. 1920. Constable. $9 s$. 
Richardson, O. W. The Electron Theory of Matter. 2nd edn. Demy 8vo. Pp. 631. 1916. Cambridge University Press. $21 s$.

Thomson, Sir J.J. The Corpuscular Theory of Matter. 2nd imp. Demy 8vo. Pp. 178. 1907. Constable. 7s. 6d.

Electricity and Matter. Cr. 8vo. Pp. 170. 1912. Constable. 9s.

\section{iii. RELATIVITY.}

Carr, H. W. The General Principle of Relativity in its Philosophical and Historial Aspect. $\mathrm{Cr}$. 8vo. Pp. 175. 1920. Macmillan.7s.6d.

Conway, A. W. Relativity. Demy 8vo. Pp. 43. 191. Bell. 2s.

Cunningham, E. Relativity, the Electron Theor; and Gravitation. 2nd edition. Demy 8vo. Pp. 154 . 1921. Longmans. $10 s .6 d$.

- The Principle of Relativity. Demy 8vo. Pp. 235. 1914. Cambridge University Press. $12 s$.

Eddington, A.S. Space, Time, and Gravitation. An Outline of the General Relativity Theory. 2nd imp. Demy 8vo. Pp. 226. (1920) $19-1$. Cambridge University Press. $15 s$.

-Report on the Relativity Theory of Gravitation. 2nd edn. Demy 8vo. 1920. Paper covers, 6s. Cloth, 8s. Physical Society of London (Fleetway Press).

Einstein, A. Relativity: The Special and the General Theory. A Popular Exposition. Translated by $\mathbf{R}$. $\mathbf{W}$. Lawson. Cr. 8vo. Pp. 15i. 1920. Methuen. $5 s$.

Freundlich, E. The Foundations of Einstein's Theory of Gravitation. Authorised English Translation by H. L. Brose. Preface by A. Einstein. Introduction by $\mathbf{H}$. $\mathbf{H}$. Turner. Pp. 77. 1920. Cambridge University Press. $5 s$.

Harrow, B. From Newton to Einstein. Changing Conceptions of the Universe. $18 \mathrm{mo}$. Pp. 95 . sewed. 1920. Constable. 2s. 6d.
Robb, A. A. A Theory of Time and Space. Roy. 8vo. Pp. 380. 1914. Cambridge University Press. 158 . The Absolute Relations of Time and Space. Demy 8vo. Pp. 90. 1921. Cambridge University Press. $5 s$.

Schlick, M. Space and Time in Contemporary Physics. An Introduction to the Theory of Relativity and Gravitation. Rendered into English by H. L. Brose. 8vo. Pp. 99. 1920. Oxford: Clarendon Press. 6s, 6d.

Silberstein, L. The Theory of Relativity. 8vo. Pp. 304. 1914. Macmillan. 12s. 6d.

Slosson, E. E. Easy Lessons in Einstein. A Discussion of the more intelligible features of the Theory of Relativity. Cr. 8vo. Pp, 136. 1920. Routledge. 5s.

\section{iv. GURRENT IN GASES.}

Thomson, Sir J. J. Conduction of Electricity through Gases. Pp. 686. 2nd edn. Demy 8vo. (at present reprinting). Cambridge University Press. $16 s$.

Townsend, J. S. Electricity in Gases. 8vo. Pp. 512. 1914. Oxford : Clarendon Press. 16s.

-The Theory of Ionization of Gases by Collision. Cr. 8vo. Pp. 100. 1910. Constable. 4s. $6 d$.

Wilson, H. A. The Electrical Property of Flames and of Incandescent Solids. $\mathrm{Cr}$. 8vo. Pp. 120. 1912. University of London Press. $6 s$.

\section{v. X-RAYS AND RADIO- ACTIVITY.}

Addyman, F. T. Practical X-Ray Work. Demy 8vo. Pp. 207. 1901. Scott, Greenwood. 12s. 6d.

Arthur, D., and Muir, J. A Manual of Practical X-Ray Work. Demy 8vo. Pp. 351. 1919 . Heinemann. 12s.6d.

Baker, T. T. Radiographic Technique. Demy 8vo. Pp. 208. 1921. Constable. 15s. 


\section{Phiysics.}

Bragg, Sir W.H. Studies in Radioactivity. 8vo. Pp. 208. 1912. Macmillan. 6s. 6d.

Bruce, W. I. A System of Radiography: with an Atlas of the Normal. Folio. Pp. 122. 1907. Lewis. $15 s$.

Bythell, W. J. S., and Barclay, A. E. X-Ray Diagnosis and Treatment. Demy 8vo. Pp. 159. 1912. Frowde and Hodder. 17s.

Colwell, H. A., and Russ, S. Radium, X-Rays, and the Living Cell. With Physical Introduction. New imp. Large 8vo. Pp. 324. 1914. Bell. 15s.

The Examination of Materials by X-Rays. A General Discussion. Faraday Society and Röntgen Society Report, 1919. Demy 8vo. Pp. 152. 1919. Faraday Society. 13s. $6 d$.

The Present Position of the Theory of Ionisation. Faraday Society Report, 1919. Demy 8vo. Pp. 178. 1919. Faraday Society. 12s. $6 d$.

Hyndman, H. H. F. Radiation: An Elementary Treatise on Electromagnetic Radiation and on Röntgen and Cathode Rays. Cr. 8vo. Pp. 307. 1898. Allen and Unwin. 6s.

Joly, J. Radio-Activity and Geology. Cr. 8vo. Pp. 303. 1909. Constable. $10 \mathrm{~s}$.

Kaye, G. W. G. X-Rays: An Introduction to the Study of Röntgen Rays. 3rd edn. 8vo. Pp. 308 . 1918. Longmans. 9s.6d.

Knox, A. V. General Practice and X-Rays. A Handbook for the General Practitioner and Student, with Chapters on the Production of $\mathrm{X}$-Rays and Instrumentation by R. Knox. Cr. 8vo. Pp. 228 . 1921. Black. 15s.

Knox, R. Radiography and RadioTherapeutics. 3rd edn. Super Roy. 8vo. 1919. Vol. I. Radiography. Pp. 384. 35s. Vol. II. Radio-Therapeutics. Pp. 222.18s. Black.
Makower, W. The Radio-active Substances: their Properties and Behaviour. Cr. 8vo. P户́. 313. 1908. Kegan Paul. 7s. 6d.

and Geiger, H. Practical Measurements in Radioactivity . Cr. 8vo. Pp. 161. 1912. Longmans. 6s. $6 d$.

Morton, E. R. Text-Book of Radiology (X-Rays). 2nd edn. Demy 8vo. Pp. 280. 1918. Kimpton. $10 s .6 d$.

Mowat, H. X-Rays. How to Produce and Interpret Them. Demy 8vo. Pp. 216. 1915. Frowde and Hodder. 9s, $6 d$.

Pilon, H. The Coolidge Tube: its Scientific Applications, Medical and Industrial. Authorised Translation. Cr. 8ro. Pp. 98. 1920. Baillière, $7 s, 6 d$.

Raffety, C. W. An Introduction to the Science of Radio-Activity. Cr. 8vo. Pp. 220. 1909. Longmans. 6s.

Rayleigh, Lord. The Becquerel Rays and the Properties of Radium. 2nd edn. Demy 8vo. Pp. 221. 1906. Arnold. 10s.

Richardson, O. W. The Emission of Electricity from Hot Bodies. New Edition in the press. Longmans.

Rutherford, Sir E. Radio-active Substances and their Radiations. Demy 8vo. Pp. 699. 1913. Cambridge University Press. $17 s .6 d$.

Soddy, F. The Interpretation of Radium and the Structure of the Atom. 4th edn. Demy 8vo. Pp. 276. 1920. Murray. 15s.

-Radio Activity. Demy 8vo. Pp. 224. 1904. Benn Bros. 5s.

Turner, D. Radium, its Physics and Therapeutics. 2nd edn. Cr. 8vo. Pp. 184. 1914. Baillière. $5 s$. 


\section{Physics.}

\section{vi. MAGNETISM AND ELECTRI- CITY.}

Allanach, W. Elementary Experimental Magnetism and Electricity. Cr. 8vo. Pp. 284. 1920. Longmans. $5 s$.

Barlow, C. W. C. Mathematical Physics, Magnetism and Electricity. Cr. 8vo. Pp. 320. 1913. University Tutorial Press. 6s, 6d.

Brooks, E. E., and Poyser, A. W. Magnetism and Electricity: A Manual for Students in Advanced Classes, 2nd edn. Cr. 8vo. New imp. Pp. 656. (1914). 1918. Longmans. 12s. $6 \mathrm{~d}$.

Gampbell, N.R. Modern Electrical Theory. 2nd edn. Demy 8vo. Pp. 412. 1913. Cambridge University Press. $16 s$.

Cavendish, H. Electrical Researches : Written 1771-81. Edited by J. Clerk Maxwell. Demy 8vo. Pp. 479. 1879. Cambridge University Press. $18 s$.

Cumming, L. An Introduction to the Theory of Electricity . 4th edn. Cr. 8vo. Pp. 362. 1894. Macmillan. $8 s, 6 d$.

Gurry, C. E. Theory of Electricity and Magnetism. Cr. 8vo. Pp. 458. 1897. Macmillan. 8s.6d.

Emtage, W. T. A. The Mathematical Theory of Electricity and Magnetism. 2nd edn. Cr. 8vo. Pp.236. 1894. Oxford: Clarendon Press. $7 s .6 d$.

Ewing, Sir J.A. Magnetic Induction in Iron and Other Metals. 3rd edn. Demy 8vo. Pp. 411. 1900. Benn Bros. 12s. $6 d$.

Finn, M. Experimental Electriciťy and Magnetism. Cr. 8vo. Pp. 436. 1915. Bell. 5s.

Fitzgerald, G. F. The Scientific Writings of the late George Francis Fitzgerald. Collected and Edited with an Historical Introduction by Sir J. Larmor. 8vo. Pp.640. 1902. Longmans. 15s. $6 d$.

Fleming, J.A. Magnets and Electric Currents. 3rd edn. Cr. 8vo. Pp. 417. 1914. Spon.6s.
Foster, G. C., and Porter, A. W. Elementary Treatise on Electricity and Magnetism. Founded on Joubert's "Traité élémentaire d'Electricité." 3rd edn. 8vo. Pp. 653. 1913. Longmans. 128 .

Fournier d'Albe, E.E. The Electron Theory : a Popular Introduction to the New Theory of Electricity and Magnetism. 3rd edn. Cr.8vo. Pp.346. 1918. Longmans. 7s. 6d.

Glazebrook, Sir R.T. Electricity and Magnetism. An Elementary Text-book. Cr. 8vo. Pp. 448 . 1904. Cambridge University Press. $10 s$.

Gray, A. A Treatise on Magnetism and Electricity. 8vo. Pp. 498. 1898. Macmillan. 14s.

Hadley, H. E. Magnetism and Electricity for Students. Gl. 8vo. Pp. 596. 1920. Macmillan. 7s.

- Magnetism aud Electricity for Beginners. New imp. Gl. 8vo. Pp. 376. 1920. Macmillan. 3s. 6d.

Hansel, C. W. Introductory Electricity and Magnetism. Cr. 8vo. Pp.390. 1919. Heinemann. 4s, 6d.

Heaviside, O. Electromagnetic Theory. 3 Vols. Demy 8vo. 1893. Vol. 1. Pp. 488. 15s. Vol. 2. Pp. 563. 15s. Vol. 3 Pp. 519. 26s. Benn Bros.

Hedges, K. Modern Lightning Conductors. 2nd edn. Med. 8vo. Pp. 125. 1910. Crosby Lockwood. 7s. $6 d$.

Hertz, H. Miscellaneous Papers. Translated by D. E. Jones and G. A. Schott. 8vo. Pp. 366. Macmillan. 12s. $6 d$.

Electric Waves. Translated by D.E. Jones. 8vo. Pp.298. 1900. Macmillan. 12s, 6d.

Hutchinson, R. W. Advanced Texthook of Magnetism and Electricity. 2 Vols. 2nd edn. Cr.8vo. 1920. Vol. 1. Magnetism and Electricity. Pp. 394. Vol. 2. Electrodynamics. Pp. 530. University Tutorial Press. 12s.6d. the 2 vols. 


\section{Physics.}

Hutchinson, F. W. Intermediate Text Book of Magnetism and Electricity. Cr. 8vo. Pp. 628. 1920. University Tutorial Press. 9s. $6 d$.

Jamieson, A. A Practical Elementary Manual of Magnetism and Electricity, specially arranged for the use of Science and Engineering Students. Revised by E. S. Andrews. 11th edn. Cr.8vo. Pp. 386. 1920. Griffin. 5s.

Jeans, J. H. The Mathematical Theory of Electricity and Magnetism. 3rd edn. Roy. 8vo. Pp. 588. 1915. Cambridge University Press. 24s .

Jude, R. H. The School Magnetism and Electricity: based on Potential and Potential Gradient. 4th imp. Cr. 8vo. Pp. 408. 1914. University Tutorial Press. 5s.

and Satterly, J. Matriculation Magnetism and Electricity. 6th imp. Cr. 8vo. Pp. 423. 1920. University Tutorial Press. $6 s, 6 d$.

Lamb, C. G. Notes on Magnetism for the Use of Students of Electrical Engineering. Demy 8vo. Pp.104. 1919. Cambridge University Press. 5s.

Livens, G. H. The Theory of Electricity. Roy. 8vo. Pp. 726. 1918. Cambridge University Press. $31 s, 6 d$.

Lodge, Sir O. J. Lightning Conductors and Lightning Guards. Cr. 8vo. Pp. 543. 1892. Pitman. $15 s$.

Macdonald, H. M. Electric Waves. Demy 8vo. Pp. 209. 1902. Cambridge University Press. $11 s$.

Maxwe11, J. C. Treatise on Electricity and Magnetism, revised by Sir J. J.Thomson. 2 Vols. 3rd edn. 8vo. 1904. Vol.1. Electrostatics: Electrokinematics. Pp. 538. Vol. 2. Magnetism; Electromagnetism. Pp. 524. Oxford: Clarendon Press. 28s.

-Elementary Treatise on Electricity. Edited by W. Garnett. 8vo. Pp. 224. 1881. Oxford: Clarendon Press. 7s. 6d.
Maycock, W. P. First Book of Electricity and Magnetism.4th edn. Cr. 8vo. Pp. 351. 1913. Pitman. 6s.

Palmer, A. R. Magnetic Measurements and Experiments. Cr. 8vo. Pp. 132. 1918. Murby. 2s.

Ogley, D. H. An Elementary Course on Practical Applied Electricity and Magnetism. Cr. 8vo. Pp. 146. 1911. Longmans. 3s.6d.

Penrose, H. E. Magnetism and Electricity for Home Study. Cr. 8vo. Pp. 515. 1918. Wireless Press. 6s.

Pidduck, F. B. A Treatise on Electricity. Demy 8vo. Pp.646. 1916. Cambridge University Press. $16 s$.

Poyser, A. W. Magnetism and Electricity: Stage 1. Cr. 8vo. Pp. 286. 1920. Longmans $4 s$. Advanced Magnetism and Electricity. Cr. 8vo. Pp. 474. 1919. Longmans. $7 s, 6 d$.

Richardson, S. S, Magnetism and Electricity, and the Principles of Electrical Measurement. Cr. 8vo. Pp. 598. 1914. Blackie. 6s.

Sanderson, F.W. Electricity and Magnetism for beginners. New imp. G1.8vo. Pp. 254. 1914. Macmillan. $3 s$.

Schott, G. A. Electromagnetic Radiation and the Mechanical Reactions arising from it. Roy. 8vo. Pp. 352, 1912. Cambridge University Press. 21s.

Slingo, Sir W., and Brooker, A. Problems and Solutions in Elementary Electricity and Magnetism. 5th imp. Cr.8vo. Pp. 170. 1914. Longmans. $2 s .6 d$.

Starling, S. G. Electricity and Magnetism for Advanced Students. 4th edn. Cr.8vo. Pp.598. 1920. Longmans. 12s. $6 d$.

Stewart, R. W. Higher Text-Book of Magnetism and Electricity. (Being Vol. 4 of The Tutorial Physics). 2nd edn. 6th imp. Cr.8vo. Pp.758. 1914. University Tutorial Press. 9s.6d. 


\section{Physics.}

Thompson, S. P. Elementary Lessons in Electricity and Magnetism. Fcap. 8vo. Pp. 760. 1919. Macmillan. 5s. $6 d$.

Thomson, Sir J. J. Elements of the Mathematical Theory of Electricity and Magnetism. 5th edn. Roy. 8vo. Pp. 420. 1921. Cam. bridge University Press. 25s.

Tunzelmann, G. W. de. Electrical Theory and the Problem of the Universe. Large Cr.8vo. Pp.686. 1910. Griffin. 18s.
Whetham, W. C. D. The Theory of Experimental Electricity. 2nd edn. Demy 8vo. Pp. 346. 1912. Cambridge University Press. 10s. $6 d$.

Walker, G. T. Outlines of the Theory of Electromagnetism. Demy 8 vo. Pp. 60. 1910. Cambridge University Press. 58 . Aberration and some other Pro. blems connected with the Electro. magnetic Field. Demy 8vo. Pp. 112. 1900. Cambridge University Press. 7s. 


\section{ELECTRICAL ENGINEERING.}

\section{i. GENERAL TREATISES.}

Alexander, J.H. Elementary Electrical Engineering in Theory and Practice. 4th edn. Cr. 8vo. Pp. 220. 1919. Crosby Lockwood. $5 s$.

Ayrton, W. E., and Mather, T. Practical Electricity. A Laboratory and Lecture Course for First Year Students. 4th edn. Demy 8vo. Pp. 539. 1919. Cassell. $12 s$.

Baillie, T. C. Electrical Engineering. Demy 8vo. Vol. 1. Introductory. Pp. 244. 1915. Cambridge University Press. 5s.6 .

Blythe, E. Machine Drawing for Electrical Engineers. Oblong folio. Pp. 88. 1920. Cambridge University Press. $20 s$.

Brown's Marine Electrician for Sea-going Engineers: With Answers to Board of Trade Questions in Electricity. 3rd edn. Cr. 8vo. Pp. 260. 1920. James Brown. $6 s$.

Cooper, W. R. (edited by). The Electrician Primers. Vol. 1. Theory. 3rd edn. Demy 8vo. Pp. 298. 1917. 7s. 6d. Vol. 2. Electric Traction, Lighting and Power. New edn. in preparation. Vol. 3. Telegraphy, Telephony, Electro-Chemistry, etc. New edn. in preparation. Benn Bros.

Davidge, H. T., and Hutchinson, R. W. Technical Electricity. 3rd edn. 8th imp. Cr. 8vo. Pp. 602. 1919. University Tutorial Press. 8s. $6 d$.

\section{Institution of Electrical Engineers .} Regulations for the Electrical Equipment of Ships. $16 \mathrm{mo}$. Pp. 86. 1919. Spon. 3s.6d.
Fowler's Electrical Engineers' Pocket Book, 1921. Edited by W. H. Fowler. 18mo. Pp. 550. January, 1921. Scientific Pub. Co. $3 s$.

Garcke, E. (edited by). Manual of Electrical Undertakings and Directory of Officials, 1919-20. Vol. 23. 8vo. Pp. 1,551. Apl., 1920. Electrical Press. 27s, 6d.

Gibson, C. R. Electricity of ToDay. Cr. 8vo. Pp. 347. 1915. Seeley. $7 s, 6 d$.

Gill, J.F., and Teago, F. J. Examples in Electrical Engineering. Cr. 8vo. Pp. 173. 1919. Arnold. $7 s .6 d$.

Haslam, A. P. Electricity in Factories and Workshops. Its Cost and Convenience. Large $\mathrm{Cr}$. 8vo. $\mathrm{Pp}$. 328. 1909. Crosby Lockwood. 8s. $6 d$.

Ibbetson, W.S. Practical Electrical Engineering for Elementary Students in Trade and Technical Schools. Cr.8vo. Pp. 155. 1914. Spon. 5s.

Kapp, G. The Principles of Electrical Engineering and their Application. Demy 8vo. Vol. I., Principles. Pp. 368. 1916. Vol. II., Application. Pp. 396. 1919 . Arnold. 18s, each vol.

Electricity. Fcap. 8vo. Pp. 256. 1912. Williams and Norgate. $2 s .6 d$.

Kemp, P. Rudiments of Electrical Engineering. Cr. 8vo. Pp. 263. 1920. Macmillan. 6s. 
Kennelly, A. E. The Application of Hyperbolic Functions to Electrical Engineering Problems. 2nd edn. Cr.8vo. Pp.312. 1917. University of London Press. $7 s .6 d$.

Kinzbrunner, $C$, The Diseases of Electrical Machinery: Their Symptoms, Causes and Remedy. 5th imp. Cr. 8vo. Pp. 76. 1920. Harper. $1 s .9 d$.

- Construction of Electric Machines and Apparatus. Part 1 . (Consisting of 10 plates). 1906. Harper. $2 s, 6 d$.

Larkman, A. E., and A. H . Marine Electrician for Sea-Going Engineers. Cr. 8vo. Pp. 260. 1920. J. Brown. 6s.

Maclean, M. Electricity and Its Practical Applications. Demy 8vo. Pp.492. 1918. Blackie. 12s.6d.

Meares, J. W., and Neale, R. E. Electrical Engineering Practice. A Practical Treatise for Civil, Mechanical, and Electrical Engineers. 3rd edn. 8vo. Pp.663. 1917. Spon. $25 s$.

Mechanical World Electrical Pocket Book, 1921. Cr. 8vo, Pp. 377. Jan., 1921. Emmott. $2 s$.

Molesworth, W. H. Spon's Electrical Pocket Book. A Reference Book of General Electrical Information, Formulæ, and Tables for Practical Engineers. Fcap. 8vo. Pp. 490. 1920. Spon. 8s.6d.

Munro, J., and Jamieson, A. A Pocket-book of Electrical Rules and Tables for the use of Electricians and Engineers. 21st edn. Pocket size. Pp. 840 1920. Griffin. $7 s .6 d$.

Murdoch, W.H.F. The Ventilation of Electrical Machinery. Cr. 8vo. Pp. 80. 1911. Pitman. 3s.6d.

Neale, R. E. Electricity: Its Production and Applications. Cr. 8vo. Pp. 144. 1920. Pitman. 3s.

Palmer, A. R. Electrical Experiments. Cr.8vo. Pp.125. 1918. Murby. 2s.
Parr, G. D. A. Electrical Engineering in Theory and Practice. 8vo. Pp. 456. 1906. Macmillan. $15 s$.

Practical Electrician's Pocket Book, The, 1921. Pocket Size. Pp.594. Mch., 1921. Rentell. 3s.

Practical Engineer Electrical Pocket Book, 1921. 18mo. Pp. 720. 1921. Technical Publishing Co. $2 s$.

Reports of the Committee on Electrical Standards appointed by the British Association for the Advancement of Science. Demy 8vo. Pp.812. 1913. Cambridge University Press. 12s. $6 d$.

Roberts, J. Laboratory Work in Electrical Engineering (Preliminary Grade). Demy 8vo. Pp. 228. 1906. Harper. 6s.

Rosenberg, E. Electrical Engineering: An Elementary Text-Book. Translated by W. W. Haldane Gee, and $C$. Kinzbrunner. 7 th edn. (reprinted). Demy 8vo. Pp. 336 . 1918. Harper. 7s. 6d.

Sewell, T. The Elements of Electrical Engineering. A First Course for Students. 7th edn. Large Cr. 8vo. Pp. 465. 1920. Crosby Lockwood. 8s.6d.

Starling, S. G. An Introduction to Technical Electricity. Cr. 8vo. Pp. 193. 1921. Macmillan. 3s.6d.

Still, A. Polyphase Currents. A Practical Treatise on Polyphase Working for Electrical Engineers. 2nd edn. Cr.8vo. Pp. 300. 1914. Pitman. 7s, 6d.

Thomälen, A. A Text Book of Electrical Engineering. Translated from the German by G. W. O. Howe. 5th edn. Demy 8vo. Pp. 492. 1920. Arnold. 28s.

Thompson, S. P. Electrical Tables and Memoranda. 2nd edn. 64mo. Pp. 144. 1920. Spon. 2s.

Thompson, T. The Engineering Enquiry: Electrical and Mechanical. A Pocket Book for Engineers. Small Cr. 8vo. Pp. 367. 1920. Arrowsmith. 7s. 6d. 
Turner, H. W., and Hobart, H. M. Insulation of Electrical Machines. Med. 8vo. Pp. 297. 1918. Pitman. $21 s$.

Walmsley, R. M. Electricity in the Sarvice of Man. A Popular and Practical Treatise on the Applications of Electricity to Modern Life. Roy. 8vo. Vol. 1. The History and Principles of Electrical Science. Pp. 840. 1911. Vol.2. Part 1. The Technology of Electricity. Pp. 692. 1913. Vol. 2. Part 2. The Technology of Electricity. Pp. 724. 1919. Cassell. 15s. each.

Whittaker's Electrical Engineers' Pocket Book. Edited by R. E. Neale. 4th edn. Pocket size. Pp. 682. 1920. Pitman. 10s.6d.

Young, A. P. The Elements of Electro-Technics. Cr. 8vo. Pp. 356. 1920. Pitman. 7s.6d.

\section{ii. ELECTRIG GENERATION : POWER PLANT.}

Gay, A., and Yeaman, G. H. Central Station Electricity Supply. 2nd edn. Cr. 8vo. Pp.497. 1906. Pitman. 12s. 6d.

Klingenberg, G. Large Electric Power Stations: Their Design and Construction. Translated from the German. Cr.4to. Pp. 276. 1919. Crosby Lockwood. 28s.

Wordingham, C. H. Central Electrical Stations: Their Design, Organisation, and Management. 2nd edn. Large 8vo. Pp.512. Griffin. 30s.

\section{iii. SWITGHBOARDS AND ACGESSORIES.}

Collis, A. G. High and Low Tension Switchgear Design. Demy 8vo. Pp. 232. 1913. Constable. 12s. Switchgear and the Control of Electric Light and Power Circuits. Fcap. 8vo. Pp. 85. 1913. Constable. $1 s .6 d$.

Connan, J. G. Switchboard Measuring Instruments for Continuous and Polyphase Systems. 8vo. Pp. 158. 1914. Spon. 5s.
Garrard, C. Electric Switch and Controlling Gear. 2nd edn. Demy 8vo. Pp.663. 1920. Benn Bros. $25 s$.

Poole, H. E. High Tension Switchgear. Describing the Design, Construction, and Functions of the leading types of Switchgear used in the control of High-Tension Elec. trical Plant. Feap. 8vo. Pp. 126. 1921. Pitman. 2s.6d.

\section{iv. ELEGTRIG GENERATORS} AND MOTORS: GENERAL.

Bottone, A. E. How to Manage the Dynamo. 6th edn. Pocket size. 1912. Pitman. $2 s$.

S. R. The Dynamo: How Made and How Used. 13th edn. Cr. 8vo. Pp. 167. 1904. Allen \& Unwin. $2 s .6 d$.

Electro-Motors: How Made and How Used. 7th edn. revised by C. Sylvester. Cr. 8vo. Pp. 176. 1919. Pitman. 4s, $6 d$.

Bowker, W. R. Dynamo, Motor, and Switchboard Circuits for Electrical Engineers. 2nd edn. Med. 8vo. Pp. 180. 1908. Crosby Lockwood. $8 s .6 d$.

Broadbent, F. Dynamo and Motor Attendants and Their Machines. 10th edn. Cr. 8vo. Pp. 227. 1921. Rentell. 4s. $6 d$.

Broadfoot, S.K. Motors, Secondary Batteries, Measuring Instruments and Switchgear. Fcap. 8vo. Pp. 96. 1919. Constable. $2 s$.

Hawkins, C. C., and Wallis, F. The Dynamo: Its Theory, Design and Manufacture. 5th edn. 2 vols. Med. 8vo. Pp.542.,590. 1909 . Pitman. 12s.6d. each.

Hobart, H. M. Electric-Motors, Continuous, Polyphase, and SinglePhase Motors: Their Theory and Construction. 3rd edn. in preparation. Pitman.

and Ellis, A. G. Armature Construction. A Practical Treatise for Electrical Engineers. Med.8vo. Pp.348. 1918. Pitman. 25s. 


\section{Electrical Engineering.}

Ibbetson, W. S. Motor and Dynamo Control: Theory and Practice. Demy 8vo. Pp. 496. 1920. Spon. $21 s$.

Livingstone, $\mathbf{R}$. The Mechanical Design and Construction of Generators. Demy 8vo. Pp.436. 1914. Benn Bros. $11 s$.

- - The Mechanical Design and Construction of Commutators. Demy 8vo. Pp. 97. 1907. Benn Bros. 7s. $6 d$.

Lummis-Paterson, G. W. The Management of Dynamos . 6th imp. Pp. 300. 1908. Crosby Lockwood. $6 s$.

Maycock, W. P. A Small Book on Electric Motors for Continuous and Alternating Currents. Cr. 8vo. Pp. 192. 1918. Pitman. 6s.

Sewell, T. Alternating and DirectCurrent Dynamos and their Construction. New imp. Large Cr. 8vo. Pp. 328. 1920. Crosby Lockwood. 8s. $6 d$.

Sylvester, C. Armature Winding. A Practical Handbook for Students, Armature Winders, and Engineers in Charge. Cr.8vo. Pp. 183. 1920. Rentell. 7s. 6d.

Wood, L.E. A Practical Treatise on Three-Phase Induction Motors. Cr. 8vo. Pp. 134. 1921. "The Electrical Review' Office. 6s. 6d.

Thompson, S. P. Dynamo-Electric Machinery. A Manual for Students of Electro-technics. 7th edn. 8vo. Vol. 1. Continuous-Current Machines. New edn., by M. Walker, in preparation. Vol.2. AlternatingCurrent Machinery. Pp.900. 1905. 35s. Spon.

- Design of Dynamos (Continuous Current Generators). 8vo. Pp. 243. 1903. Spon. 12s. 6d.

Walker, M. Specification and Design of Dynamo-Electric Machinery. 3rd imp. Roy. 8vo. Pp. 668. 1920. Longmans. $36 s$.

\section{v. GONTINUOUS GURRENT, AND MACHINERY.}

Ashford, C. E., and Kempson, E. W. E. Elementary Theory of
Direct Current Dynamo Electric Machinery. 2nd edn. Cr. 8vo. Pp. 128. 1914. Cambridge University Press. 4s. $3 d$.

Barr, J. R. Principles of DirectCurrent Electrical Engineering . Med.8vo. Pp. 559. 1908. Pitman. 15s.

Bate, A. H. Principles of Electric Power (Continuous Current) for Mechanical Engineers. Cr. 8vo. Pp. 204. 1914. Spon. 6s.

Case, J. The Theory of Direct-Current Dynamos and Motors. Demy 8vo. Pp. 210. 1912. Heffer. 15s.

Cramp, W. Continuous Current Machine Design. Demy 8vo. Pp. 260. 1910. Harper. $7 s$.

Denton, F. M. Elementary Principles of Continuous-Current Armature Winding. Feap. 8vo. Pp. 112. 1921. Pitman. 2s.6d.

Hay, A. An Introductory Course of Continuous Current Engineering. 2nd edn. Demy 8vo. Pp. 372. 1919. Constable. 9s.6d.

Hobart, H. M. Elementary Principles of Continuous-Current Dynnamo Design. Med. 8vo. Pp. 220. 1907. Pitman. 10s. 6d.

Kelsey, W. R. Continuous Current Dynamos and Motors, and their Control. 2nd edn. Cr. 8vo. Pp. 346. 1919. Technical Pub. Co. $10 s$.

MacCall, W . T. Continuous-Current Electrical Engineering. 2nd edn. Demy 8vo. Pp. 474. University Tutorial Press. 13s. 6d.

Maycock, W.P. Continuous-Current Motors and Control Apparatus. Cr. 8vo. Pp. 331. 1917. Pitman. $7 s, 6 d$.

Smith, S. P. Notes on Theory and Design of Continuous-Current Machines. 2nd edn. Demy 8vo. Pp.67. 1920. Benn Bros. 5s.

\section{vi. ALTERNATING CURRENT,} AND MACHINERY.

Barr, J. R., and Archibald, R. D. The Design of Alternating-Current 


\section{Electrical Engineering.}

Machinery. Med. 8vo. Pp. 496. 1913. Pitman. 30s.

Biedermann, E. A. The Estimation of the Dispersion Co-efficient of Three-Phase Induction Motors and its Application to their Design. Demy 8vo. Pp. 58. 1916. Benn Bros. 2s. $6 d$.

Cramp, W., amd Smith, C. F. Vectors and Vector Diagrams, applied to the Alternating Current Circuit. 8vo. Pp. 268. 1909 . Longmans. $9 s$.

Crapper, E. H. Arithmetic of Alternating Currents for Engineers and Students. Cr. 8vo. Pp. 208. 1915. Pitman. 4s. 6d.

Creedy, F. Electric Mechanism. Part 1. Single-Phase Commutator Motors. Demy 8vo. Pp.123.1913. Constable, $7 s .6 d$.

Drysdale, G. V. The Foundations of Alternate Current Theory. Demy 8vo. Pp. 312. 1910. Arnold. 10s. $6 d$.

Ellis, A. G. Elementary Principles of Alternating-Current Dynamo Design. Demy 8vo. Pp. 304. 1910. Blackie. $10 s$.

Frith, J . Alternating Current Machine Design. Demy 8vo. Pp. 131. 1912. Harper. $6 s$.

Hawkins, C. C., Smith, S. P., and Neville, S. Papers on the Design of Alternating-Current Machinery . Demy 8vo. Pp. 407. 1919. Pitman. 21s.

Hay, A. Alternating Currents : Their Theory, Generation and Transformation. 4th edn. (reprinted) Demy 8vo. Pp. 393. 1919. Harper. $7 s, 6 d$.

James, W. H. N. Alternating Currents in Theory and Practice. Demy 8vo. Pp. 354. 1916. Cambridge University Press. $16 s$.

Johnson, V. E. Modern High Speed Influence Machines : their Principles, Construction, and Applications to Radiography, Radiotelegraphy, Spark Photography, Electro-Therapeutics, ete. Demy 8vo. Pp. 290. 1921. Spon. 14s.
Kemp, P. Alternating-Current Electrical Engineering. 8vo. Pp. 505. 1918. Macmillan. 17s.

Kempe, $\mathbf{H}^{:}$. R. Alternating Currents : Their Elements Explained. Cr. 8vo. Pp. 92. 1916. Crosby Lockwood. $3 s .6 d$.

Larner, E. T. The Principles of Alternating Currents. Cr. 8vo. Pp. 144. 1908. Crosby Lockwood. $4 s .6 d$.

Maycock, W.P.Alternating-Current Work. An Introductory Book for Engineers and Students. 2nd edn. Cr.8vo. Pp.428. 1917. Pitman. 10s. $6 d$.

Rhodes, W. G. A Primer on Alternating Currents. Cr.8vo. Pp.154. 1912. Longmans. $3 s .6 d$.

An Elementary Treatise on Alternating Currents. 8vo. Pp. 224. 1902. Longmans. $9 s$.

Russell, A. A Treatise on the Theory of Alternating Currents. 2 Vols. 2nd edn. Demy 8vo. Vol.1. Pp. 548. 1914. Vol.2. Pp.579.1916. Cambridge University Press. $18 \mathrm{~s}$. each.

Smith, C.F. Practical Alternating Currents and Alternating-Current Testing. 8th edn. Demy 8vo. Pp.476. 1919. Scientific Pub. Co. $8 s$.

\section{vii. TRANSFORMERS}

Avery, A. H. Auto-Transformer Design. A Practical Hand-book for manufacturers, contractors, and wiremen. 8vo. Pp. 60. 1909. Spon. 5s.

Bohle, H., and Robertson, D. Transformers: A Treatise on the Theory, Construction, Design, and Uses of Transformers, Auto- Transformers, and Choking Coils. Large 8vo. Pp.370. 1911. Griffin. 25s.

Denton, F.M. Notes on Commerical Transformer Design. Demy 8vo. Pp.57. 1917. Benn Bros. 2s.6d. 
Fleming, J.A. The Alternate-Current Transformer in Theory and Practice. 2 Vols. 3rd edn. Demy 8vo. 1900. Vol. 1. The Induction of Electric Currents. Pp.628. Vol. 2. The Utilisation of Induced Currents. Pp.606. Benn Bros. 15s, each.

Kapp, G. Transformers for Singleand Multi-phase Currents. A Treatise on their Theory, Construction and Use. 2nd edn. Med. 8vo. Pp. 363. 1908. Pitman. 12s.6d.

Painton, E. T. Small Single-Phase Transformers. Pott 8vo. Pp. 105. 1921. Pitman. 2s. 6d.

Sylvester, C. Rotary Converters. Cr. 8vo. Pp.59. 1920. Rentell. $2 s .6 d$.

\section{viii. TRANSMISSION.}

Brew, W. Three-Phase Transmission. 2nd edn. Demy 8vo. Pp. 190. 1914. Crosby Lockwood. $9 s$.

Carter, T. Balancers for Threewire Continuous-current Systems. Demy 8vo. Pp. 98. 1917. Benn Bros. 4s.

Coyle, D., and Howe, F. J . O. Electric Cables: Their Construction and Cost. Cr. 8vo. Pp. 474. 1919. Spon. 18s.

Dick, J.R., and Fernie, F. Electric Mains and Distributing Systems. 2nd edn. Demy 8vo. Pp. 476. 1919. Benn Bros. 18s.

Fleming, A. P. M., and Johnson, R. Insulation and Design of Electrical Windings. Med. 8vo. Pp. 232. 1913. Longmans. 9s.

Kapper, F. Overhead Transmission Lines and Distributing Circuits: Their Design and Construction. Cr. 4to. Pp. 300. 1915. Constable. $16 s$.

La Cour, J.L., and Bragstad, O.S. Theory and Calculation of Electric Currents. Translated by S. P. Smith. Med. 8vo. Pp. 494. 1913. Longmans. 188 .
Maycock, W. P. Electric Circuit Theory and Calculations. 2nd edn. Cr. 8vo. Pp. 355. 1918. Pitman. $10 s .6 d$.

Raymond-Barker, E. Handbook in Cable-break Localisation. Graphic methods. Cr. 8vo. Pp. 68. 1904. "Electrical Review " Office, $2 s .6 d$.

-Cable Fault Localisation Graphs in Practice. Cr. 8v?. Pp. 68. 1909. "'Electrical Review' Office, $2 s .6 d$.

Russell, A. The Theory of Electric Cables and Networks. 2nd edn. Demy 8vo. Pp. 360. 1920. Constable. $24 s$.

\section{ix. TESTING.}

Allen, R. G. Principles and Practice of Electrical Testing : as applied to Apparatus, Circuits, and Machines. 8vo. Pp. 372. 1919. Longmans. $18 s$.

Fisher, H. K. C., and Darby, J. C. H. Students' Guide to Submarine Cable Testing. 5th edn. 3rd imp. Demy 8vo. Pp. 252. 1920. Benn Bros. 9s.6d.

Fleming, J. A. Handbook for the Electrical Laboratory and Testing Room. 2 Vols. Demy 8vo. Vol. 1. Pp. 545. 15s.6d. Vol.2. Pp. 630. 16s. 6d. Benn Bros.

Kempe, H. R. Handbook of Electrical Testing. 7 th edn. 8vo, Pp. 714. 1908. Spon. 25s.

Kinzbrunner, C. The Testing of Alternating Current Machines in Laboratories and Test-Rooms. Vol. 1. Demy 8vo. Pp. 163. 1907. Harper. $5 s$.

- - The Testing of Continuous Current Machines in Laboratories and Test-Rooms. Demy 8vo. Pp. 336. 1904. Harper. $7 s$. 6d.

Oulton, L., and Wilson, N. J . Practical Testing of Electrical Machines. 2nd edn. Fcap. 8vo. Pp. 254. 1921 . Pitman. 6s.

Parr, G. D. A. Practical Electrical Testing in Physics and Electrical Engineering. 2nd edn. 8vo. Pp. 400. 1917. Longmans. 9s. 6d. 


\section{Electrical Engineering.}

Parr, G.D. A. Electrical Engineering Testing. A Practical Work for Second and Third Year Students, Engineers, and others. 3rd edn. 8vo. Pp.550. 1907. Chapman \& Hall. 11s, $6 d$.

Raphael, F. C. Localisation of Faults in Electric Light and Power Mains, with chapters on Insulation Testing. 3rd edn. Demy 8vo. revised (1916). 1920. P . 218. Benn Bros. 12s. 6 d.

Smith, C. F. The Practical Testing of Dynamos and Motors. A Treatise on the Methods and Instruments used in the Testing of Dynamos and Motors. 7th edn. Demy 8vo. Pp. 322. 1919. Scientific Publishing Co. 6s. 6d.

Wright, J. Testing and Localising Faults. Fcap.8vo. Pp.88. 1920. Constable. $2 s$.

Young, J. E. Electrical Testing for Telegraph Engineers. 2nd edn. Demy 8vo. Pp. 322. Benn Bros. 12s. $6 d$.

\section{ELEGTRICAL MEASURE -} MENTS AND INSTRUMENTS.

Bottone, S.R. Electrical Instrument Making for Amateurs. A Practical Handbook. 8th edn. Cr. 8vo. Pp. 280. 1920. Pitman. 6s.

Drysdale, G. V., and Jolley, A. C. Electrical Measuring Instruments: their Design. Construction and Application. In Preparation. Benn Bros.

Edgcumbe, K. Industrial Electrical Measuring Instruments. 2nd edn. Demy 8vo. Pp. 430. 1918. Constable. 16s.

Gerhardi, C. H. W. Electricity Meters: Their Construction and Management. 2nd edn. Demy 8vo. Pp. 514. 1917. Benn Bros. $18 s$.

Hobbs' Arithmetic of Electrical Measurements. 16th edn. revised by $A$. R. Palmer. Cr. 8vo. Pp. 128. 1919. Murby. 2s.
James, W. H. N., and Sands, D. L. Elementary Electrical Calculations. Cr. 8vo. Pp. 224. 1919. Longmans. 5s.

Moreton, H.W. Electrical Measuring Instruments and Supply Meters. Cr.8vo. Pp. 83. 1913. Technical Pub. Co. 2s. 9d.

Murdoch, W.H.F ., and Oschwald, U. A. Electrical Instruments in Theory and Practice. Cr. 8vo. Pp. 366. 1915. Pitman. 12s.6d.

Parr, G. D. A. Electrical Engineering Measuring Instruments for Commercial and Laboratory Purposes. Demy 8vo. Pp. 328. 1903. Blackie. $10 s$.

Price, W. A. The Measurement of Electrical Resistance. 8vo. Pp. 216. 1894. Oxford: Clarendon Press. 6s.

Solomon, H. G. Electricity Meters. Large 8vo. Pp. 343. 1906. Griffin. 18s.

Taylor, W. T. Calculation of Electric Conductors: with Chart. Imp. 8vo. Pp. 34. 1919. Constable. $10 s .6 d$.

Whittaker's Arithmetic of Electrical Engineering. 3rd edn. Cr. 8vo. Pp.212. 1916. Pitman. 3s.6d.

\section{xi. INDUCTION COILS AND} BATTERIES.

Allsop, F. C. Induction Coils and Coil Making. A Treatise on the Construction and Working of Shock, Medical, and Spark Coils. 2nd edn. Cr. 8vo. Pp. 184. 1914. Spon. $3 s .6 d$.

Bonney, G. E. Induction Coils. A Practical Manual for Amateur Coil Makers. 6th edn. Cr. 8vo. Pp. 238. 1919. Pitman. 6s.

Codd, M.A. Induction Coil Design . Demy 8vo. Pp. 243. 1920. Spon. $21 s$.

Cooper, W. R. Primary Batteries: Their Theory, Construction, and Use. 2nd imp. Demy 8vo. Pp. 467. 1920. Benn Bros. 15s. 
Dunton, W. F. The Grouping of Electric Cells. 16mo. Pp. 50. 1914. Spon. $2 s$.

Hare, A. T. The Construction of Large Induction Coils. A Workshop Handbook. Demy 8vo. Pp. 164. 1900. Methuen. 6s.

Mckinnon, E. C. The A.B.C. of Storage Battery Management. Demy 8vo. Pp. 10i. 1920. Electrical Press. 3s. 6d.

Rankin, R. Storage Battery Practice. A Practical Handbook on the Manufacture and Properties of Electric Accumulators, and their Installation and Operation. Demy 8vo. Pp. 170. 1919. Pitman. $7 s .6 d$.

Salomons, Sir D. Management of Accumulators. New edn. Cr.8vo. Pp. 174. 1921. Pitman. 7s. 6d.

\section{xii. ELECTRIG WIRING AND FITTING.}

Bursill, A. The Principles and Practice of Electric Wiring. New imp. Cr. 8vo. Pp. 232. 1919. Longmans. $5 s$.

Clinton, W. C. Electric Wiring. A Primer for the Use of Wiremen and Students. Fcap. 8vo. Pp. 200. 1919. Murray. 3s.6d.

Devey, R. G. Mill and Factory Wiring. New imp. Fcap. 8vo. Pp. 197. 1919. Constable. 2s. 6d.

Dover, A. T. Power Wiring Diagrams. Feap. 8vo. Pp. 208. 1917. Pitman. 7s. 6d.

Havelock, J.H. Electrical Installation Work (including 'Electric Wiremen's Work"'). A Practical Handbook for Students and all engaged in Electrical Installation Work. Demy 8vo. Pp. 374. 1921 . Crosby Lockwood. 15s .

Ibbetson, W. S. Electric Wiring: Theory and Practice. 2nd edn. Cr. 8vo. Pp. 470. 1920. Spon. 18s.

Johnson, T. M. Shipwiring and Fitting. Fcap. 8vo. Pp. 92. 1911. Constable. $2 s$.
Leaf, H. M. Internal Wiring of Buildings. 3rd edn. Cr. 8vo. Pp. 280. 1907. Constable. 3s. 6d.

Maycock, W. P. Electric Wiring Tables. A collection of original and carefully verified Tables for the use of Electrical Engineers. 4th edn. Pocket size. Pp. 185. 1920. Pitman. 5s.

_- Electric Wiring, Fittings, Switches, and Lamps. 5th edn. Cr. 8vo. Pp.629. 1917. Pitman. $10 s .6 d$.

- Electric Wiring Diagrams: A Collection, with brief explanations, of most of the Diagrams given in the seme author's work "Electric Wiring , Fittings, Switches and Lamps.", Cr.8vo. Pp. 146. 1918. Pitman. $5 s$.

Metcalfe, C. C. Practical Electric Wiring for Lighting Installations. 2nd edn. Demy 8vo. Pp. 203. 1919. Harper. 6s.

Paterson, G. W. L. Wiring Calculations for Electric Light and Power Installations. Cr. 8vo. Pp. 96. 1912. Scott, Greenwood. 6s.

Urquhart, J. W. Electric Light Fitting. 4th edn. Cr. 8vo. Pp. 363. 1904. Crosby Lockwood. 6s. _- Electric Ship Lighting. A Handbook on Fitting and Running Ship's Electrical Plant. 4th edn. Cr. 8vo. Pp. 367. 1911. Crosby Lockwood. 8s. $6 d$.

Walker, S. F. Electric Wiring and Fitting. Cr. 8vo. Pp. 160. 1908. Scott, Greenwood. $6 s$.

\section{xiii. ELECTRIC LIGHT AND ILLUMINATION.}

Allsop, F. G. Practical Electric Light Fitting. A Treatise on the Wiring and Fitting up of Buildings from Central Station Mains, and the Laying down of Private Installations. 6th edn. Cr. 8vo. Pp. 290. 1914. Pitman. 6s.

Barham, G. B. The Development of the Incandescent Electric Lamp. Demy 8vo. Pp. 200. 1912. Scott, Greenwood. $6 s$. 


\section{Electrical Engineernng.}

Batstone, S. C. Electric-Light Fitting. Cr. 8,o. Pp. 334. 1914. Pitman. 6s.

Bohle, H. Electrical Photometry and Illumination. Large $8 \mathrm{vo}$. Pp. 233. 1912. Griffin. 12s.6d.

Brooks, E. E., and James, W. H. N. Electric Light and Power. 5th edn. Cr. 8vo. Pp. 431. 1919. Methuen. 6s.6d.

J. F. L. Train Lighting by Electrieity. Cr. 8vo. Pp. 92. 1915. Locomotive Pub. Co. 3s. $6 d$.

Jeh1, F. Manufacture of Carbons for Electric Lighting and other Purposes. Demy 8vo. Pp. 242 . 1899. Benn Bros. 12s. 6d.

Johnson, J. H. Arc Lamps and Accessory Apparatus. Fcap. 8vo. Pp. 132. 1911. Constable. 2s.

Lancaster, M. Electric Cooking, Heating, Cleaning, etc. A Manual of Electricity in the Service of the Home. Demy 8vo. Pp. 348 . 1914. Constable. 4s.

Maycock, W. P. Electric Lighting and Power Distribution. 8th edn. 2 Vols. Cr.8vo. 1918. Vol. 1. Pp. 590. Vol. 2. Pp.680. Pitman. 10s. 6d, each.

Ogley, D. H. Incandescent Electric Lamps and their Application. Cr. 8vo. Pp. 120. 1914. Longmans. $3 s .6 d$.

Percival, G. A. The Electric Lamp Industry. Cr. 8vo. Pp. 133. 1920. Pitman. 3s.

Solomon, M. Electric Lamps. Ex. Cr. 8vo. Pp. 330. 1909. Constable. $7 s .6 d$.

Urquhart, J. W. Electric Light, its Production and Use. 7 th edn. Cr. 8vo. Pp. 444. 1902. Crosby Lockwood. 7s, 6d.

Walker, S. F. Pocket Book of Electric Lighting and Heating. Fcap. 8vo. Pp. 466. 1907. Crosby Lockwood. $5 s$.

Zeidler, J., and Lustgarten, $\mathbf{J}$. Electric Arc Lamps: Their Principles, Construction and Working. Demy 8vo. Pp. 204. 1908. Harper. $6 s$.

\section{xiv. ELEGTRIG BELLS.}

Allsop, F . C. Practical Electric Bell Fitting. 11th edn. Cr.8vo. 1918. Pp. 186. Spon. 5s.

Electric Bell Construction. A Treatise on the Construction of Electric Bells, Indicators, and similar apparatus. New imp. Cr. 8vo. Pp. 143. 1914. Spon. 3s. 6d.

Bottone, S. R. Electric Bells and All About Them. 8th edn. Revised by C. Sylvester. Cr. 8vo. Pp. 187. 1919. Pitman. 3s. 6d.

Redfern, J . B ., and Savin, J . Bells, Indicators, Telephones, Alarms, etc. Fcap. 8vo. Pp. 123. 1913. Constable. $2 s$.

White, H.G. Electric Bells, Alarms, and Signalling Systems. 2nd edn. Cr. 8vo. Pp.112. 1921. Rentell. $3 s .6 d$.

\section{ELEGTRIC TRAGTION .}

Agnew, W. A. The Electric Tram Car Handbook for Motormen, Inspectors, etc. 8th edn. Cr. 8vo. Pp. 140. 1920. "Electrical Review." $3 s .6 d$.

Austin, E. Single-Phase Electric Railways. Demy 4to. Pp. 317. 1915. Constable. $21 s$.

Bowker, W. R. The Practical Construction of Electric Tramways. 8vo. Pp. 119. 1914. Spon. $7 s .6 d$.

Galisch, L. Electric Traction. Cr. 8vo. Pp. 116. 1915. Locomotive Pub. Co. $3 s .6 d$.

Davies, F. H. Electric Power and Traction. Ex. Cr. 8vo. Pp. 299. 1907. Constable. 7s.6d.

Dawson, P. Electric Traction on Railways. Roy. 8vo. Pp. 892 . 1909. Benn Bros. 32s.

Dover, A. T. Electric Traction. A Treatise on the Application of Electric Power to Electric Traction on Railways and Tramways. 2nd edn. Med. 8vo. Pp. 685. 1919. Pitman. 25s. 


\section{Electrical Engineering.}

Dover, A. T. Electric Motors and Control Systems. A Treatise on Electric Traction Motors and their Control. Med.8vo. Pp.388. 1918. Pitman. 18s.

Gant, L. W. Elements of Electric Traction for Motormen and others. Demy 8vo. Pp. 227. 1907. Harper. $6 s$.

Hobart, H. M. Electric Trains. Demy 8vo. Pp. 219. 1910. Harper. $7 s .6 d$.

Electric Propulsion of Ships. Demy 8vo. Pp. 179. 1911. Harper. $6 s$.

Ibbetson, W. S. Tramway Motorman's Handbook. Cr. 8vo. Pp. 216. 1920. Spon. 6s.6d.

Kapp, G. The Electrification of Railways. 4to. Pp. 45. 1908. Rentell. $1 s$.

Rider, J. H. Electric Traction. A Practical Handbook on the Application of Electricity as a Locomotive Power. Cr. 8vo. Pp. 450. 1903. Pitman. 12s. 6d.

Savers, H. M. Brakes for Electric Tramway Cars. Demy 8vo. Pp. 82. 1907. Benn Bros. 4s.

Trewman, H. F. Electrification of Railways. Pott 8vo. Pp. 88 . 1920. Pitman. 2s. 6d.

Wilson, E., and Lydall, F. Electrical Traction. 2 vols. Demy 8 vo. 1907. Vol. 1., Direct Current. Pp. 475. Vol. II., Alternating Current. Pp.328. Arnold. 15s. each.

xvi. ELEGTRICAL APPLICA TION TO THE MOTOR GAR.

Beaumont, W. W. Industrial Electric Vehicles and Trucks. Demy 8vo. Pp. 195. 1920. Griffin. $15 s$.

Bottone, S. R. Magnetos for Automobilists. How Made and How Used. 3rd edn. Cr. 8vo. Pp. 118. 1918. Crosby Lockwood. $2 s .6 d$.
Cross, H. H. U. Automobile Batteries. A Practical Handbook on the Construction, Charging, Repair, and Maintenance of Ignition, Starting, Lighting, and Electric Vehicle Batteries; Dry, Lead, and Alkaline Types. Cr. 8vo. Pp. 101. 1919. Spon. 4s.

Electric Lighting for Cycles and Motor Cycles, Cr. 8vo. Pp. 132. 1920. Spon. 3s. 6d.

Electric Lighting and Starting for Motor Cars. 2nd edn. Cr. 8vo. Pp. 281. 1916. Crosby Lockwood. $5 s$.

Hibbert, W. Magneto and Electric Ignition. 3rd edn. Pp.186. 1919. Pitman. 3s. 6d.

Hutton, F. H. Electricity and the Motor Car : Lighting, Engine Starting and Ignition. 4th edn. Cr. 8vo. Pp. 256. 1920. Iliffe. $5 s .6 d$.

Morgan, J.D. Principles of Electric Spark Ignition in Internal Combustion Engines. Med. 8vo. Pp. 88. 1919. Crosby Lockwood. 8s. $6 d$.

Sylvester, C. Coil Ignition for Motor Cars. A Manual for the Motor Mechanic, Owner-Driver, and all interested in Coil Ignition Svstems. Cr. 8vo. Pp. 239. 1921. Pitman. 10s. 6d.

Young, A. P. Magnetos. The Theory and Practice of Magnetos, Ignition for all Forms of Internal Combustion Engines. 2nd edn. Cr. 8vo. Pp. 240. 1920. Iliffe. $4 s .6 d$.

\section{xvii. ELEGTRO PLATING.}

Barclay, W. R., and Hainsworth, C. H. Electroplating: A Treatise on the Electro-deposition of Metals. With a Chapter on Metal-Colouring and Bronzing. New edition in preparation. E. Arnold.

Bonney, G. E. The Electro-Platers' Handbook. A Practical Manual in Electro-Metallurgy. 5th edn. Cr. 8vo. Pp. 221. 1909. Pitman. 5s. 
Denny, C. W. The Electro-Deposition of Copper and its Industrial Applications. Fcap. 8vo. Pp. 120. 1921. Pitman. 2s.6d.

Field, S. The Principles of ElectroDeposition : A Laboratory Guide to Electro-Plating. Cr. 8vo. Pp. 400. 1911. Longmans. 7s.6d.

Sprague, J . T . Elements of ElectroPlating. Cr. 8vo. Pp. 72. 1914. Spon. 2s,6d.

Watt, A. The Electro-plating and Electro-refining of Metals. Being a new edition of "Electro-Deposition," revised, \&c., by A. Philip. 2nd edn. Large Cr. 8vo. Pp. 704 . 1911. Crosby Lockwood. 14s .

-Electro Plating, based on "Electro Metallurgy Practically Treated." Cr. 8vo. Pp. 192. 1920. Crosby Lockwood. $5 s$.

\section{Xviii ELECTRICWELDING .}

Carpmael, H. Electric Welding and Welding Appliances. Imp. 8vo. Pp. 140. 1920. Constable. 18s.

Marquand, H.S. Electric Welding. Its Theory, Practice, Application and Economics. Demy 8vo. Pp. 204. 1920. Benn Bros. 12s. 6d.

Swift, H. B. Practical Electric Welding. Demy 8vo. Pp. 104. 1920. Spon. 7s. 6d.

\section{Xix. TELEPHONY AND TELE - GRAPHY .}

Allsop, F. C. Telephones, their Construction and Fitting. 8th edn. Cr. 8vo. Pp. 222. 1914. Spon. $5 s$.

Atkins, W. Principles of Automatic Telephony. 2nd edn. Cr. 8vo. Pp. 124. 1915. Benn Bros. $3 s$.

Common Battery Telephony Simplified. 2nd edn. Cr. 8vo. Pp. 190. 1913. Benn Bros. 3s. 6d.

Baker, T. T. The Telegraphic Transmission of Photographs. Cr. 8vo. Pp. 158. 1910. Constable. 2s. $6 d$.
Bell, J., and Wilson, S. The Telegraphist's Guide to the Departmental and City and Guilds Examinations in Telegraphy. 8th edn. Cr. 8vo. Pp. 273. 1920. Rentell. $5 s$.

Crotch, A. The Elements of Telephony. 2nd edn. Cr. 8vo. Pp. 114. 1918. Spon. 2s,6d.

The Hughes and Baudôt Telegraphs. Cr. 8vo. Pp. 83. 1908 . Rentell. 2s.

Telegraphy : an Elementary Textbook on the Principles of Electricity as applied to Telegraph Systems. Cr. 8vo. Pp.165. 1919. Spon. 4s. 6d.

Telegraphic Systems, and other Notes. A Handbook of the Principles on which Telegraphic Practice is Based. Large Cr. 8vo. $\mathrm{Pp} .284$. 1908. Griffin. 6s.

Elementary Telegraphy and Telephony. New imp. 8vo. Pp. 223. 1912. Spon. 6s.

Fleming, J.A. The Propagation of Electric Currents in Telephone and Telegraph Conductors. 3rd edn. Demy 8vo. Pp. 384. 1919. Constable. $21 s$.

Herbert, T. E. Telegraphy: A detailed Exposition of the Telegraph System of the British Post Office. 4th edn. Cr.8vo. Pp.1,039.1920. Pitman. 18s.

and Wardt, R. G. de. The Arithmetic of Telegraphy and Telephony. Cr. 8vo. Pp. 196. 1921. Pitman. $5 s$.

Hill, J. G. Telephonic Transmismission: Theoretical and Applied. 8vo. Pp. 398. 1920. Longmans. $21 s$.

Jones, W. H. Telegraphy for Beginners. The Standard Method. 2nd edn. Cr. 8vo. Pp. 58. 1913. Spon. 2s. $6 d$.

Kingsbury, J . E. The Telephone and Telephone Exchanges : Their Invention and Development. 8vo. Pp. 568. 1915. Longmans. 15s.

Lee, J. Telegraph Practice: A Study of Comparative Method. Cr. 8vo. Pp. 112. 1917. Longmans. $3 s$. 
Malcolm, H. W. The Theory of the Submarine Telegraph and Telephone Cable. Demy 8vo. Pp. 576. 1917. Benn Bros. 22s.

Mordin, R. The Strowger Automatic Telephone Exchange. Demy 8vo. Pp. 186. 1919. Spon. $21 s$.

Pendry, H. W. Elementary Telegraphy. A Manual for Students. 2nd edn. Cr. 8vo. Pp. 247. 1921. Pitman. $7 s, 6 d$.

- The Baudôt Printing Telegraph System. 2nd edn. Cr. 8vo. Pp. 191. 1920. Pitman. 6s.

Poole, J. The Practical Telephone Handbook and Guide to the Telephonic Exchange. 6th edn. Cr. 8vo. Pp. 725. 1919. Pitman. $15 \mathrm{~s}$.

Telegraphy, Telephony and Wireless. Cr. 8vo. Pp. 128. 1921. Pitman. 3s.

Preece, Sir W. H., and Sivewright, Sir J. Telegraphy. Revised and Partly rewritten by $W$. L. Preece. 8vo. Pp. 432. 1919. Longmans. 12s. $6 d$.

Stevens, E.J. Field Telephones and Telegraphs for Army Use. 7th edn. Cr. 8vo. Pp. 160. 1918. Crosby Lockwood, $3 s$.

White, H. G. Telephone Erection and Maintenance. 2nd edn. 8vo. Pp. 129. 1917. Rentell. 2s.6d.

\section{WIRELESS TELEGRAPHY AND TELEPHONY.}

Bangay, R. D. The Elementary Principles of Wireless Telegraphy. Cr. 8vo. 1918. Part I. Pp.212. 4s. Part II. Pp. 241. 4s. Or in 1 vol. 7s. 6d. Wireless Press.

The Oscillation Valve: The Elementary Principles of its Application to Wireless Telegraphy. $\mathbf{C r}$. 8vo. Pp. 215. 1919. Wireless Press. 6s.

Blake, E. Selected Studies in Elementary Physics: A Handbook for the Wireless Student and Amateur. Cr. 8vo. Pp. 176. 1920. Wireless Press. 5s.
Bottone, S. R. Wircless Telegraphy and Hertzian Waves. Revised by C. Sylvester. 5̃th edn. Cr. 8vo. Pp.136. 1919. Pitman. 3s.6d.

Brown, S. W. Simple Fault Tracing: for Wireless Students and Operators. Fcap. 8vo. Pp. 80. 1919. Jas. Munro. 1s.6d.

Coursey, P.R. Telephony Without Wires. Demy 8vo. Pp. 414. 1919. Wireless Press. 15s.

Cross, F. Wireless Explained. Cr. 8vo. Pp. 72. 1918. James Brown. 3s. 6d.

Dowsett, H. M. Wireless Telegraphy and Telephony: First Principles, Present Practice, and Testing. Demy 8vo. Pp. 362. 1920. Wireless Press. 9s.

Eccles, W. H. Continuous Wave Wireless Telegraphy. Part 1 . Demy 8vo. Pp. 415. 1921. Wireless Press. 25s.

Eichhorn, G* Wireless Telegraphy. Large 8vo. Pp. 126. 1906. Griffin. $10 s .6 d$.

Erskine-Murray, J. Handbook of Wireless Telegraphy: Its Theory and Practice. 6th edn. Demy $8 v 0$. Pp. 458. 1918. Crosby Lockwood. $12 s .6 d$.

Fleming, J.A. Principles of Electric Wave Telegraphy and Telephony. 4th edn. 8vo. Pp. 724. 1919. Longmans. $42 s$.

An Elementary Manual of RadioTelegraphy and Radio-Telephony for Students and Operators 3rd edn. 8vo. Pp. 374. (1916) 1919. Longmans. $10 s, 6 d$.

The Wonders of Wireless Telegraphy. 2nd edn. Cr. 8vo. Pp. 280. 1919. S.P.C.K. 7s. 6d.

The Wireless Telegraphist's Pocket Book of Notes, Formulæ, and Calculations. Pocket size. Pp. 352. 1915. Wireless Press. 9s.

The Thermionic Valve and its Development in Radio-Telegraphy and Telephony. Demy 8vo. Pp. 279. 1919. Wireless Press. $15 s$.

Fortescue, C. L. Wireless Telegraphy. Roy. 16mo. Pp. 149. 1913. Cambridge University Press. 2s. $6 d$. 


\section{Electrical Engineering,}

Harris, P. W, The Maintenance of Wireless Telegraph Apparatus. Cr. 8vo. Pp. 127. 11918. Wireless Press. 2s. 6d.

Hawkhead, J. C . , and Dowsett, H . M. The Handbook of Technical Instruction for Wireless Telegraphists. 2nd edn. Demy 8vo. Pp. 310. 1919. Wireless Press. 7s. 6d.

Henstock, J. Final Digest for Wireless Students. 3rd edn. Cr. 8vo. Pp.90. 1918. Jas. Munro. 4s.6d.

Hoyle, B. Standard Tables and Fquations in Radio-Telegraphy. Demy 8vo. Pp. 159. 1919. Wireless Press. 9s.

Leggett, B. Wireless Telegraphy: with Special reference to the Quenched-Spark System. Demy 8vo. Pp. 502. 1921. Chapman and Hall. $30 s$.

Marchant, W. H. Wireless Telegraphy. A Practical Handbook for the Use of Operators and Students. 2nd edn. Cr.8vo. Pp.240. 1919. Pitman. 7s.6d.

_- The Radio-Telegraphist's Guide and Log-Book. Fcap. 8vo. Pp. 142. 1912. Pitman. 5s.6d.

Martin, M.J. The Wireless Transmission of Photographs. 2nd edn. 8vo. Pp. 143. 1919. Wireless Press. 5s.

Monckton, C. C. F. Radio-Telegraphy. Ex. Cr. 8vo. Pp. 289. 1908. Constable. 7s. 6d.

Nottage, W. H. Calculation and Measurement of Inductance and Capacity. Demy 8vo. Pp. 144. 1916. Wireless Press. 3s.6 $d$.

Owen, W. D. Guide to the Study of the Ionic Valve. Its Development and Application to Wireless Telegraphy and Telephony. Fcap. 8vo. Pp.60. 1919. Pitman. 2s.6d.

Penrose, H. E. The Wireless Telegraphy Student's Library . 5 Parts. Cr. 8vo. Paper covers. 1919. Book 1. Direct Current. Pp. 64. Book 2. Alternating Current. Pp. 48. Book 3. High-Frequency Current and Wave Production. Pp. 64 . Book 4. The 1/2-k.w. Ship Set.
Pp. 74. Book 5. The Oscillation Valve. Pp. 50. Wireless Press. 1s. 4d. each.

Rolfe-Martin, A. B . Wireless Telegraphy. A Handbook on the Fundamental Principles and Modern Practice of Radio-Telegraphy for the use of Students of Electrical Engineering. Cr. 8vo. Pp. 256. 1914. Black. 3s.6d.

Ruhmer, E. Wireless Telephony in Theory and Practice. Translated by J. Erskine-Murray. Demy 8vo. Pp. 237. 1908. Crosby Lockwood. $10 s .6 d$.

Shaw, W.J. Practical and Experimental Wireless Telegraphy. A Handbook for Operators. Students and Amateurs. Cr. 8vo. Pp. 102. 1914. Spon. $5 s$.

Shore, A. Alternating Current Work for Wireless Operators. Cr. 8vo. Pp. 163. 1919. Wireless Press. $3 s .6 d$.

Sleeper, M. B. Wireless Design and Practice. Part. 1. Transmitters and Receivers. Part. 2. Practical Circuits. Pp. 246. 1920. Frowde and Hodder. $7 s .6 d$.

Stanley, R. Text-Book on Wireless Telegraphy. New edn. 2 vols. 8vo. 1919. Vol.1. General Theory and Practice. Pp. 486. Vol. 2. Valves, Continuous Waves and Radio-Telephony. Pp. 368. Longmans. $15 \mathrm{~s}$. each.

Turner, L. B. Wireless Telegraphy and Telephony. An Outline for Electrical Engineers and others. Demy 8vo. Py. 207. 1921. Cambridge University Press. $20 s$.

Ward, H. Dictionary of Technical Terms used in Wireless Telegraphy. 2nd edn. Pocket size. Pp. 253. 1919. Wireless Press. 2s.6d.

Willis, S. J. A Short Course in Elementary Mathematics and their Application to Wireless Telegraphy. Demy 8vo. Pp.182. 1917. Wireless Press. $3 s .6 d$.

Year Book of Wireless Telegraphy and Telephony. 1921. Demy 8vo. Pp. 1,855. March, 1921. Wireless Press. 21s. 


\section{CHEMISTRY.}

\section{i. HISTORY .}

Armitage, F. P. A History of Chemistry. 2nd imp. Cr. 8vo. Pp. 286. 1912. Longmans. 7s.6d.

Bauer, H. A History of Chemistry. Translated by R. V. Stanford. Cr. 8vo. 1907. Arnold. 4s.6d.

Brown, J. C. A History of Chemistry from the Earliest Times to the Present Day. 2nd edn. Demy 8vo. Pp. 571. 1920. Churchill. 21s.

Hilditch, T. P. A Concise History of Chemistry. Cr. 8vo. Pp. 274. 1911. Methuen. 5s.

Lowry, T. M. Historical Introduction to Chemistry. Cr. 8vo. Pp. 599. 1915. Macmillan. 10s. fid.

Martin, G. Modern Chemistry and its Wonders. A Popular Account of some of the more remarkable Recent advances in Chemical Science for General Readers. Large Cr.8vo. Pp. 367. 1917. Sampson Low. 10s. $6 d$.

Triumphs and Wonders of Modern Chemistry. Cr. 8vo. Pp. 375. N.D. Sampson, Low. 10s.6d.

Slosson, E. E. Creative Chemistry : Descriptive of Recent Achievements in the Chemical Industries. Demy 8vo. Pp. 311. 1921. University of London Press. 12s. $6 \mathrm{~d}$.

Thorpe, Sir T. E. Essays in Historical Chemistry. 3rd edn. 8vo. Pp. 614. 1911. Macmillan. $15 s$.

History of Chemistry. Cr. 8vo. Pp. 320. Watts. 5s.

Tilden, Sir W. A. The Progress of Scientific Chemistry in Our Own Times: with Biographical Notices. 2nd edn. Cr.8vo. Pp.378. 1913. Longmans. $8 s$.
Tilden, Sir W. A. Chemical Discovery and Invention in the Twentieth Century. 3rd edn. 8vo. Pp. 503. 1919. Routledge. 12s. 6d.

Famous Chemists : the Men and their Work. Demy 8vo. Pp. 312. 1921. Routledge. 12s. $6 d$.

\section{ii. GENERAL.}

Abegg, R., and Herz, W. Practical Chemistry. Translated by $\mathbf{H}$. T. Calvert. Cr. Svo. Pu. 132. 1901. Macmillan. 6s.

Bailey, G. H. Elementary Chemistry. Edited by W. Briggs. 4th edn. 8th imp. Cr. 8vo. Pp. 536. 1914. University Tutorial Press. 6s. $6 d$.

and Bausor, H. W. Chemistry for Matriculation. 7th imp. Cr. 8vo. Pp. 556. 1919. University Tutorial Press. 8s. $6 d$.

Senior Chemistry. 2nd edn. 5th imp. Cr.8vo. Pp. 526. 1919. University Tutorial Press. 6s. $6 d$.

and Briggs, $W$. The Tutorial Chemistry. Part 1. Non-Metals. 4th edn. 9th imp. Cr. 8vo. Pp. 492. 1918. 5s. Part 2. Metals and Physical Chemistry. 3rd edn. 10th imp. Cr. 8vo. Pp. 468. 1918. 6s. 6d. University Tutorial Press.

Bassett, H. L1. The Elements of Chemistry. Cr. 8vo. Pp. 360. 1914. Crosby Lockwood. 7s. 6d.

Bausor, H. W. Senior Practical Chemistry. Cr. 8vo. Pp. 225. 1919. University Tutorial Press. $4 s$.

Bloxam, A. G., and Lewis, S. J. Chemistry, Inorganic and Organic. 10th edn. 8vo. Pp. 878. 1913. Churchill. 24s. 
Bruce, J., and Harper, $H$. Practical Chemistry. 2nd edn. New Imp. Gl. 8vo. Pp. 284. 1919. Macmillan. 2s.

Bryant, V. S. Laboratory Textbook of Chemistry. Part 1. Roy. 4to. Pp. 252. 1913. Churchill. $4 s$.

Cain, J. C. (edited by). Annual Reports of the Progress of Chemistry for 1919. Issued by the Chemical Society. Vol. 16. Demy 8vo. Pp. 243. 1920. Gurney and Jackson. $4 s .6 d$.

Catechism Series. Chemistry. 2nd and 3rd Edns. 2 Parts. Revised by L. Dobbin. Part 1. Inorganic. Part 2. Inorganic and Organic. Livingstone. 1s."9d. each.

Church, A. H., and Kinch, E. Laboratory Guide. A Manual of Practical Chemistry for Colleges and Schools, arranged for Agricultural Students. 9th edn. Post 8vo. 1912. Gurney and Jackson. 6s. $6 d$.

Clowes, F., and Coleman, J. B. Elementary Practical Chemistry and Qualitative Analysis. Part 1. General Chemistry. 7th edn. Post 8vo. Pp. 241. 1919. 7s. 6d. Part 2. Analytical Chemistry. 9th edn. Post 8vo. Pp. 272. 1921. 7s. $6 d$. Churchill.

Donington, G. C. A Class Book of Chemistry. Gl. 8vo. Pp. 546. 1916. Macmillan. 6s.6d.

Dreaper, W. P. Notes on Chemical Research: An Account of Certain Conditions which Apply to Original Investigation. 2nd edn. Cr. 8vo. Pp. 210. 1920. Churchill. 7s.6d.

Dunnicliff, H.B. Practical Chemistry for Intermediate Classes. Cr. 8vo. Pp. 290. 1918. Macmillan. 5s.

Dunstan, A. E. Elementary Experimental Chemistry. 7th edn. Cr. 8vo. Pp. 208. 1918. Methuen. 3s.

and Thole, F. B. A Text Book of Practical Chemistry for Technical Institutes. Cr. 8vo. Pp. 358. 1919. Methuen. $7 s .6 d$.
Dunstan, A. E. and Thole, F. B . A Senior Experimental Chemistry. Cr.8vo. Pp.536. 1919. Methuen. is. $6 d$.

Fenton, H. J. H. Outlines of Chemistry. Part 1. 2nd edn. Demy 8vo. Pp. 424. 1918. Cambridge University Press. $12 s$.

Fournier d'Albe, E. E. Contemporary Chemistry. Cr. 8vo. Pp. 196. 1911. Constable. 4s.

Freund, I. The Experimental Basis of Chemistry. Suggestions for a Series of Experiments Illustrative of the Fundamental Principles. of Chemistry. Edited by A. Hutchinson and M. B. Thomas. Demy 8vo. Pp. 424. 1920. Cambridge University Press. 30s.

Gemmell, G. H. Chemical Notes and Equations, Inorganic and Organic. 2nd edn. P P. 280. 1909. Baillière. $5 s$.

Hale, A. J. Practical Chemistry for Engineering Students. new edn. Cr. 8vo. Pp. 212. 1920. Longmans. 6s. $6 d$.

Hendrick, E. Everyman's Chemistry: The Chemist's Point of View and his Recent Work told for the Layman. 2nd imp. Demy 8vo. Pp. 329. 1919. University of London Press. 8s. $6 d$.

Hood, G. F., and Carpenter, J. A. A Text-Book of Practical Chemistry. 8vo. Pp. 539. 1921. Churchill. 21s.

Hughes, A. M. A Method of Teaching Chemistry in Schools. Cr. 8vo. Pp. 132. 1906. Cambridge University Press. $4 s .3 d$.

Kingzett, C. T. Popular Chemical Dictionary. Demy 8vo. Pp. 374. 1920. Baillière. 15s .

Lewes, V. B., and Brame, J.S. S. Service Chemistry: being A Short Manual of Chemistry and Metallurgy and their Application in the Naval and Military Services. 5th edn. Demy 8vo. Pp. 576. 1920. Arnold. 21s. 
Ludlam, E. B., and Preston, H. Outlines of Experimental Chemistry. 2nd edn. Demy 8vo. Pp. 100. 1917. E. Arnold. 2s. 6d.

Martin, G. Chemical Lecture Charts. A Series of 36 Sheets, 40 by 30 inches, 60s.; backed with linen, $80 s$.; backed with linen, varnished and mounted on rollers, $126 s$. Sampson, Low.

Meldola, R. Chemistry. Fcap. 8vo. Pp. 255. 1913. Williams and Norgate. 2s.6d.

Muir, M.M. P. The Elements of Chemistry. 8vo. Pp.568. 1904. Churchill. 10s.6d.

-and Carnegie, D. Practical Chemistry. A Course of Laboratory Work. Cr. 8vo. Pp. 230. 1887. Cambridge University Press. 4s.6d.

Newth, G. S. Chemical Lecture Experiments. Cr. 8vo. Pp. 356. 1918. Longmans. 9s.

Elementary Practical Chemistry. Cr. 8vo. Pp̣. 300. 1919. Longmans. 4s.

Normandy, F. Sea Water Distillation. Large Cr. 8vo. Pp. 272. 1909. Griffin. 7s, 6d.

Oldham, F. M. The Complete School Chemistry. 14th edn. Cr. 8vo. Pp. 470. 1919. Methuen. is. $6 d$.

O'Shea, L. T. Elementary Chemistry for Coal-Mining Students. New imp. Cr. 8vo. Pp. 332. 1920. Longmans. $9 s$.

Partridge, W. Aids to Chemistry. Frap. 8vo. Pp. 288. 1921 . Baillière. $6 s$.

Perkin, F. M., and Jaggers, E. M. Text-Book of Elementary Chemistry. Cr. 8vo. Pp. 390. 1916. Constable. $4 s$.

Perkin, W. H, and Lean, B. An Introduction to Chemistry and Physics. New Imp. Gl. 8vo. Pp. 238. 1917. Macmillan. 5s .

Pilcher, R. B. The Profession of Chemistry. Cr. 8vo. Pp. 213. 1919. Constable. 6s. $6 d$.
Remsen, I. College Text Book of Chemistry. 2nd edn. 8vo. Pp. 726. 1912. Macmillan. 12s. 6d.

Robinson, W. Everyday Chemistry. Cr.8vo. Pp.144. 1920. Methuen. $3 s .6 d$.

Roscoe, Sir H. E. Lessons in Elementary Chemistry, Inorganic and Organic. Fcap. 8vo. Pp.536. 1918. Macmillan. 6s.

- - and Schorlemmer, C. A Complete Treatise on Inorganic and Organic Chemistry. 8vo. Vol. 1. The Non-Metallic Elements. 5th edn. Revised by J. C. Cain. Pp. 984. 1920. 30s. Vol. 2. The Metals: 5th edn. Pp. 1,470 . 1913. 40s. Vol.3. The Chemistry of the Hydro-Carbons and their Derivatives, or Organic Chemistry. Part 2. 2nd edn. Pp. 755. 1890. 21s. Part 3. 2nd edn. Pp. 483. 1891. 18s. Part 6. Pp. 582. 1892. 21s. Macmillan.

Stewart, A. W. Chemistry and its Borderland. Cr. 8vo. Pp. 326. 1914. Longmans. 6s. 6d.

Tilden, Sir W. A. A Primer of Chemistry. Fcap. 8vo. Pp. 108. Dent. 2s.

Tyler, E. A. A Junior Chemistry. 11th edn. Cr.8vo. Pp.245. 1919. Methuen. 4s.

Valentin, W. G. Practical Chemistry. Revised by W. R. Hodgkinson. loth edn. 8vo. Pp. 496 . 1908. Churchill. 12s. $6 d$.

\section{iii. ORGANIG AND INORGANIG FOR MEDICAL STUDENTS.}

Cohen, J. B. A Class Book of Organic Chemistry. Gl. 8vo. Vol. 1. For First Year Medical Students. Pp. 352. 1919. Vol. 2. For Second Year Medical Students. Pp. 156. 1919. Macmillan. 4s, 6d. each Vol.

Cumming, A. C. Practical Chemistry for Medical Students. 3rd edn. Demy 8vo. Pp. 173.1920. Gurney and Jackson. $8 s$. 
Haas, P. Laboratory Notes on Organic Chemistry for Medical Students. Cr. 8vo. Pp. 136. 1910. Macmillan. $3 s$.

Kellas, A. M. An Introduction to Practical Chemistry for Medical Students. 8vo. Pp. 270. 1909. Frowde and Hodder. 5s.

-A Manual of Practical Inorganic Chemistry for Medical Students. 8vo. Pp. 355. 1910. Frowde and Hodder. $6 s$.

-An Introduction to Practical Organic Chemistry for Medical Students. 8vo. Pp. 212. 1920. Frowde and Hodder. $5 s$.

Luff, A. P., and Candy, H. C. H. A Manual of Chemistry, Theoretical and Practical, Inorganic and Organic, adapted to the requirements of Students of Medicine. 6th edn. Fcap. 8vo. Pp. 744. 1918. Cassell. 12s. 6d.

Macbeth, A. K. Organic Chemistry for Medical, Intermediate Science and Pharmaceutical Students. Cr. 8vo. Pp. 246. 1920. Longmans. 6s. $6 d$.

Myers, J. E., and Firth, J. B. Elementary Practical Chemistry for Medical and other Students. 2nd edn. Cr. 8vo. Pp. 194. 1920. Griffin. $4 s, 6 d$.

Sargeant, F.P. Flementary Organic Chemistry, adapted for the use of Pharmaceutical and Medical Students. 2nd edn. Cr. 8vo. Pp. 107. 1919. Lewis, 4s.

Walker, J. Organic Chemistry for Students of Medicine. 2nd edn. Med.8vo. Pp.344. 1919. Gurney and Jackson. 10s.6d.

Witthaus, R. A. Text-Book of Chemistry, Inorganic and Organic, with Toxicology. For Students of Medicine, Pharmacy, Dentistry and Biology. Revised by R. J. E. Scott. 7th edn. Roy. 8vo. Pp. 400. 1919. Bale and Danielsson. $20 s$.

\section{iv. CALGULATIONS AND REFERENCE BOOKS.}

Annual Tables of Constants and Numerical Data, Chemical, Phy sical and Technological. Compiled and published under the patronage of the International Association of Academies. With a comlete Table of Contents in the English, French, German and Italian Languages. Vol. 1. 4to. Pp. 766. (1910) 1912. 28s.6d. Vol.2. 4to. Pp. 780. (1911) 1913. 28s.6d. Vol. 3. 4to. Pp. 648. (1912) 1914. 28s.6d. Churchill.

Atack, F. W., and Whinyates, L. (edited by). The Chemists' Year Book, 1921. 2 Vols. $18 \mathrm{mo}$. Pp. 1,150. Sherratt and Hughes. 21s.

Bausor, H. W. Chemical Calculations. 2nd edn. 3rd imp. Cr. 8vo. Pp. 144. 1920. 3s. Advanced Course. Pp. 56. 1914. 1s. 9d. University Tutorial Press.

Bayley, T. Pocket Book for Chemists, Chemical Manufacturers, Metallurgists, Dyers, Distillers, Brewers, etc. Edited by R. Ensoll. 8th edn. Fcap. 8vo. Pp.441. 1919. Spon. 10s. 6d.

Castell-Evans, J. Physico-Chemical Tables for the Use of Analysts, Physicists, Chemical Manufacturers, and Scientific Chemists. 2 Vols. Large 8vo. 1920. Vol. 1. Chemical Engineering, Physical Chem. istry. Pp. 580. 36s. Vol. 2. Chemical Physics, Pure and Analytical Chemistry. Pp. 700. 45s. Griffin.

Coward, H.F., and Perkins, W.H. Exercises in Chemical Calculation. Cr. 8vo. Pp. 160. 1919. E. Arnold. 3s. $6 d$.

Ensol1, R. Technical Chemists' Pocket Book. Fcap.8vo. Pp. 204. 1920. Spon. 8s.6d.

Everett, J. D. The C. G. S. System of Units, with Tables of Physical Constants. 5th edn. Globe 8vo. Pp. 308. 1902. Macmillan. 6s. 


\section{Chemistry}

Kaye, G. W. G., and Laby, T. H. Tables of Physical and Chemical Constants, and Some Mathematical Functions. 4th edn. Roy. 8vo. Pp. 170. 1921. Longmans. 14s.

Knox, J . Elementary Chemical Theory and Calculations. 2nd edn. Cr. 8vo. Pp. 109. 1920. Gurney and Jackson. $4 s$.

Physico-Chemical Calculations. 3rd edn. Cr.8vo. Pp. 196. 1919. Methuen. 4s. 6d.

Lupton, S. Elementary Chemical Arithmetic, with 1,200 Problems. Fcap.8vo. Pp. 184. 1920. Macmillan. $5 s$.

Thorpe, Sir T.E. Alcoholometric Tables. Cr. 8vo. Pp. 106. 1915. Longmans. $4 s$. $6 \mathrm{~d}$.

Watts, H. Dictionary of Chemistry. Revised by M. M. Pattison Muir and H. Forster Morley. 4 Vols. 8vo. 1888-1894. Pp. 752., 760., 853., 922. Longmans. £6 $16 s$. $6 d$.

Whiteley, R. L. Chemical Calculations: with Explanatory Notes, Problems, and Answers. $\mathrm{Cr} .8 \mathrm{vo}$. Pp. 132. 1919. Longmans. 3s.

Wilson, F. J., and Heilbron, I. M. Chemical Theory and Calculations. 2nd edn. Cr. 8vo. Pp. 144. 1920. Constable. $4 s, 6 d$.

\section{v. THEORETICAL AND PHYSICAL.}

\section{a. Theoretical .}

Caven, R. M. The Foundations of Chemical Theory. An Introductory Text-book. Demy 8vo Pp. 274. 1920. Blackie. 12s.6d.

Cooke, J. B. The New Chemistry. 11th edn. Cr.8vo. Pp.417. 1903. Kegan Paul. $7 s .6 d$.

Garrett, A. E. The Periodic Law. Cr. 8vo. Pp. 300. 1909. Kegan Paul. 7s. 6d.

Letts, E. A. Some Fundamental Problems of Chemistry, Old and New. Demy 8vo. Pp. 236. 1914. Constable. $8 s$.
Martin, G. Researches on the Affinities of the Elements and on the Causes of the Chemical Similarity or Dissimilarity of Elements and Compounds. 8vo. Pp. 300 . 1905. Churchill. 16s.

Muir, M. M. P. A Treatise on the Principles of Chemistry. 2nd edn. Demy 8vo. Pp. 517. 1889. Cambridge University Press. 18s. 6d.

Nernst, W. Theoretical Chemistry. Revised in accordance with the latest German edition by L. Codd. In the Press. Macmillan.

Ostwald, W. The Fundamental Principles of Chemistry. An Introduction to all Text-Books of Chemistry. Translated by H.W. Morse. 8vo. Pp. 362. 1917. Longmans. $10 s .6 d$.

- Outlines of General Chemistry. Translated by W. W. Taylor. 3rd edn. 8vo. Pp.596. 1912. Macmillan. $21 s$.

Ramsay, Sir W. Modern Chemistry. Systematic. 5th edn. Pott 8vo. Pp. 211. 1912. Dent. 1s. 9d.

- Modern Chemistry. Theoretical. 6th edn. Pott 8vo. Pp. 133. 1917. Dent. 1s. 9d.

Experimental Proofs of Chemical Theory for Beginners. Pott. 8vo. Pp. 158. 1908. Macmillan. 3s.

Roscoe, Sir H. E., and Harden, A. A New View of the Origin of Dalton's Atomic Theory. 8vo. Pp. 202. 1896. Macmillan. 7s.6d.

Scott, A. An Introduction to Chemical Theory. 2nd edn. Demy 8vo. Pp. 272. 1911. Black. 5s.

Tilden, Sir W.A. Introduction to the Study of Chemical Philosophy. The Principles of Theoretical and Systematic Chemistry. 11th edn. Cr. 8vo. Pp. 374. 1912. Longmans. $7 s .6 d$.

Van 'tHoff, J. H. Lectures on Theoretical and Physical Chemistry . Translated by R.A. Lehfeldt . 3 vols. Demy 8vo. 1900. Vol. 1. Chemical Dynamics. Pp. 254. $12 s$. Vol. 2. Chemical Statics. Pp. 156. 8s. 6d. Vol. 3. Relations between Properties and Composition. Pp. 143. 8s. 6d. Arnold. 
Van 'tHoff, J.H. Chemistry in Space. Translated by J. E. Marsh. Cr.8vo. Pp.136. 1891. Oxford: Clarendon Press. $4 s .6 d$.

Wadmore, J.M. Elementary Chemical Theory. Cr. 8vo. Pp. 287. 1911. Methuen. 5s.

Watson, E. R. Colour in Relation to Chemical Constitution. 8vo. Pp. 210. 1918. Longmans. $12 s$. 6d.

\section{b. Physical Chemistry .}

Baly, E. C. C. Spectroscopy . Cr. 8vo. Pp. 702. 1918. Longmans. $14 s$.

Clibbens, D. A. The Principles of the Phase Theory. Heterogeneous Equilibria between Salts and their Aqueous Solutions. 8vo. Pp. 403. 1920. Macmillan. 25s:

Dunstan, A.E., and Thole, F. B. The Viscosity of Liquids. 8vo. Pp. 100. 1914. Longmans. 5s.

Fenton, H.J.H. Physical Chemistry for Schools. Cr. 8vo. Pp. 224 . 1916. Cambridge University Press. 5s. $6 d$.

Findlay, A. Practical Physical Chemistry. 3rd edn. Cr.8vo. Pp.343. 1920. Longmans. $6 s .6 d$.

The Phase Rule and its Applications. 4th edn. Cr. 8vo. Pp. 382. 1918. Longmans. $9 s$.

- Osmotic Pressure. 2nd edn. 8vo. Pp. 128. 1919. Longmans. $7 s$.

Firth, J. B. Practical Physical Chemistry. Cr. 8vo, Pp. 190. 1915. Methuen. 4s.6d.

Friend, J.N. The Theory of Valency. 2nd edn. Cr.8vo. Pp. 206. 1915. Longmans. 6s, $6 d$.

Gray, F. W. A Manual of Practical Physical Chemistry. Cr. 8vo. Pp. 228. 1914. Macmillan. 4s, $6 d$.

Hilditch, T. P. A First Year Physical Chemistry. Cr. 8vo. Pp. 196. 1912. Methuen. 3s.6d.

Jaques, A. Complex Ions in Aqueous Solutions. 8vo. Pp. 158. 3914. Longmans. $6 s$.
Le Bas, G. The Molecular Volumes of Liquid Chemical Compounds, from the Point of View of Kopp. 8vo. Pp. 288. 1915. Longmans. $9 s .6 d$.

Lehfeldt, R. A. A Text-book of Physical Chemistry. 2nd imp. Cr.3vo. Pp.320. Arnold. 8s.6d.

Lewis, W. C.McC. A System of Physical Chemistry. 3rd edn. 3 vols. 8vo. Vol.1. Kinetic Theory. Pp. 494. 1920. 15s. Vol. 2. Thermo-dynamics. Pp. 462. 1920. 15s. Vol. 3. Quantum Theory. Pp. 218. 1919. 7s.6d. Longmans.

Loring, F. H. Studies in Valency. Demy 8vo. Pp. 56. 1913. Simpkin, Marshall. $3 s$.

Optical Rotatory Power. A General Discussion. Faraday Society Report, 1914. Demy 8vo. Pp. 96. 1914. Faraday Society. $7 s .6 d$.

Philip, J. C. Physical Chemistry: its Bearing on Biology and Medicine. 2nd edn. Cr. 8vo. Pp. 334. 1913. Arnold. 8s.6d.

Prideaux, E. B. R. Problems in Physical Chemistry with Practical Applications. 2nd edn. Demy 8 vo. Pp.306. 1920. Constable. 18s.

Redgrove, H.S. On the Calculation of Thermo-Chemical Constants. Demy 8vo. Pp. 106. 1909. Arnold. $6 s$.

Sackur, O . A Text-book of ThermoChemistry and Thermodynamics. Translated and revised by G. E. Gibson. 8vo. Pp. 456. 1917. Macmillan. $12 s$.

Senter, G. Outlines of Physical Chemistry. 8th edn. Cr. 8vo. Pp. 432. 1920. Methuen. 7s.6d.

Sheppard, S. E. Photo-Chemistry. New edition in preparation. Longmans.

Spencer, J. F. An Experimental Course of Physical Chemistry. 2 Vols. Cr. 8vo. 1911. Vol. 1. Statical Experiments. Pp. 228. Vol. 2. Dynamical Experiments. Pp. 256. Bell. 4s. 6d. each. 
Stewart, A. W. Recent Advances in Physical and Inorganic Chemistry. 4th edn. Demy 8vo. Pp. 362. 1920. Longmans. $18 s$.

- Stereochemistry. Cr. 8vo. Pp. 294. 1919. Longmans. 12s. 6d.

Thomsen, J. Thermochemistry. Translated by K. A. Burke. Cr. 8vo. Pp. 512. 1908. Longmans. $12 s .6 d$.

Thomson, Sir J. J. Application of Dynamics to Physies and Chemistry. Cr. 8vo. Pp. 320. 1888. Macmillan. 8s, 6d.

Turner, W. E. S. Molecular Association. 8vo. Pp. 178. 1915. Longmans. $7 s$.

Walker, J. Introduction to Physical Chemistry. 8th edn. 8vo. Pp. 433. Macmillan. 16s.

Whetham, W. C. D. A Treatise on the Theory of Solution, including the Phenomena of Electrolysis. Demy 8vo. new edition in preparation. Cambridge University Press.

Willows, R. S., and Hatschek, E. Surface Tension and Surface Energy, and their Influence on Chemical Phenomena. 2nd edn. Cr. 8vo. Pp. 123. 1919. Churchill. 5s.

Wurtz, Prof. The Atomic Theory. Translated by E. Cleminshaw. sth edn. Cr.8vo. Pp.354. 1910. Kegan Paul. $7 s, 6 d$.

Young, S. Stoichiometry . 2nd edn. 8vo. Pp. 376. 1918. Longmans. 12s. $6 d$.

\section{c. Colloids .}

Burton, E. F. The Physical Properties of Colloidal Solutions. New edition in preparation. Longmans.

Hatschek, E. An Introduction to the Physics and Chemistry of Colloids. 3rd edn. Cr. 8vo. Pp. 126. 1919. Churchill. $5 s$.

Laboratory Manual of Elementary Colloid Chemistry. Cr. 8vo. Pp.135. 1920. Churchill. 6s.6d.

Poschl, V. The Chemistry of the Colloids. Translated by H. H. Hodgson. 2nd edn. Cr.8vo. Pp. 120. 1917. Griffin. 4s.
Rohland, P. The Colloidal and Crystalloidal State of Matter. Translated from the German by H. E. Potts and W. J. Breitland. Cr.8vo. Pp.54. 1911. Constable. $4 s .6 d$.

Searle, A.B. The Use of Colloids in Health and Disease. Demy $8 v o$. $P_{1}$. 127. 1920. Constable. 8s.

Svedberg, $T$. The Formation of Colloids. Cr. 8vo. Pp. 127. 1921. Churchill. 7s, 6d.

Taylor, W. W. The Chemistry of Colloids and Some Technical Applications. 2nd imp. Cr. 8vo. Pp. 328. 1918. Arnold. 8s. 6d.

\section{d. Catalysis.}

Henderson, G. G. Catalysis in Industrial Chemistry. 8vo. Pp. 212. 1919. Longmans. 10s.

Jobling, E. Catalysis and Its Industrial Applications. 2nd edn. Cr. 8vo. Pp.152. 1920. Churchill. $7 s, 6 d$.

Maxted, E. B. Catalytic Hydrogenation and Reduction. Cr. 8vo. Pp. 104. 1919. Churchill. 5s.

Rideal, E. K., and Taylor, H. S. Catalysis in Theory and Practice. 8vo. Pp. 502. 1919. Macmillan. $17 s$.

\section{e. Ferments .}

Oppenheimer, C. Ferments and their Actions. A Text-book on the Chemistry and Physies of Fermentative Changes. Translated by $C$. A. Mitchell. 2nd edn. in preparation. Griffin.

Schutzenberger, Prof. Fermentation. 5th edn. Cr. 8vo. Pp. 339. 1903. Kegan Paul. 7s. 6d.

\section{f. Electrolysis.}

Allmand, A. J. The Principles of Applied Electro-Chemistry. 2nd imp. Demy 8vo. Pp. 547. 1920. Arnold. 2.5s. 


\section{Chemistry}

Elbs, K. Electrolytic Preparations. Exercises for Use in the Laboratory by Chemists and Electro-Chemists. Translated by R.S. Hutton. Demy 8vo. Pp. 110. 1903. Arnold. 6s.

Hale, A. J. The Applications of Electrolysis in Chemical Industry. 8vo. Pp. 158. 1918. Longmans. $8 s$.

The Manufacture of Chemicals by Electrolysis. Demy 8vo. Pp.92. 1919. Constable. $6 s$.

Lehfeldt, R. A., and Moore, T. S. Electro-Chemistry Part 1. General Theory. New imp. Cr. 8vo. Pp. 278. 1920. Longmans. 7s.6d.

Rideal, E, K. Ozone, (ElectroChemistry). Demy 8vo. Pp. 207. 1920. Constable. 12s.

\section{vi. INORGANIC CHEMISTRY.}

Caven, R. M., and Lander, G. D. Systematic Inorganic Chemistry from the Standpoint of the Periodic Law. Cr. 8vo. Pp. 383. 1919. Blackie. $7 \mathrm{~s}, 6 \mathrm{~d}$.

Claude, G. Liquid Air, Oxygen. Nitrogen. Translated by $\mathbf{H}$. E. P. Cottrell. New edition in preparation. Churchill.

Dupré, A., and Hake, W. A Short Manual of Inorganic Chemistry. 3rd edn. Large Cr. 8vo. 1903. Griffin. $7 s, 6 d$.

Friend, J. N. (edited by) A Textbook of Inorganic Chemistry. 10 vols. Med. 8vo. Vol. 1. Introduction to Modern Inorganic Chemistry, by J. N. Friend, H. F. V. Little, W. E. S. Turner The Inert Gases, by H. V. A. Briscoe. 3rd edn. Pp. 400. 1919. 12s. 6d. Vol.2. The Alkali Metals, in preparation. Vol. 3. The Alkaline Earth Metals, in preparation. Vol. 4. Aluminium and its Congeners, including the Rare Earth Metals, by H. F. V. Little. Pp. 495. 1917. 16s. Vol. 5. Carbon and its Allies, by R. M. Caven. Pp. 489. 1917. 15s. Vol. 6. Nitrogen and its Congeners, in preparation. Vol. 7. Sulphur and its
Congeners, in preparation. Vol. 8. The Halogens and their Allies, by G. Martin, and E. A. Dancaster. 2nd edn. Pp. 355. 1919. 12s, fd. Vol. 9. Part 1. Cobalt, Nickel and the Elements of the Platinum Group, by .J. N. Friend. Pp. 385. 1920. 18s. Vol.9. Part 2. Iron and Its Compounds, by J. N. Friend. Pp. 290. 1921. 18s. Vol. 10. The Metal Ammines, in preparation. Griffin.

Hart-Smith, J. Recent Discoveries in Inorganic Chemistry. Demy 8vo. Pp. 102. 1919. Cambridge University Press. $4 s, 6 d$.

Hooton, W. M. Inorganic Chemistry . 7th imp. Cr. 8vo. Pp. 416. E. Arnold. 5s.

Jago, W. Inorganic Chemistry, Theoretical and Practical. Fcap. 8vo. Pp. 466. 1918. Iongmans. 4s. $6 d$.

Inorganic Chemistry, Theoretical and Practical. A Manual for Students in Advanced Classes. 12th imp. Cr. 8vo. Pp. 490. 1911. Longmans. $6 \mathrm{~s}$.

Jeffery, F. H. Notes on Elementary Inorganic Chemistry. Demy 8vo. Pp. 55. 1914. Cambridge University Press. 3s.

Jones, C. Practical Inorganic Chemistry. Gl. 8vo. Pp. 250. 1911. Macmillan. $3 s$.

Kipping, F.S., and Perkin, W. H . Inorganic Chemistry. Cr. 8vo. Pp. 751. Chambers. 8s. 6d.

Levy, S. I. The Rare Earths: Their Occurrence, Chemistry and Technology. New edn. in preparation. Arnold.

Lewis, E. I. Inorganic Chemistry . 3rd edn. Demy 8vo. Pp. 458. 1921. Cambridge University Press . $9 s$.

Lowson, W. Preparations and Exercises in Inorganic Chemistry . Cr. 8vo. Pp. 136. 1914. Methuen. 3s. $6 \mathrm{~d}$.

Ludlam, E. B . Outlines of Inorganic Chemistry, with special reference to its Historical Development . 2nd imp. Cr. 8vo. Pp. 384. 1917. E. Arnold. $5 s$. 
Mellor, J. W. An Introduction to Modern Inorganic Chemistry. Cr. Svo. Pp. 700. 1919. Longmans. $7 s, 6 d$.

- Modern Inorganic Chemistry. New edn. 8vo. Pp. 930. 1921. Longmans. 12s. $6 d$.

Newth, G. S. A Text-book of Inorganic Chemistry. Cr. Svo. Pp. 738. 1920. Longmans. 98.

Oscroft, P. W. Inorganic Chemistry for Upper Forms. 2nd edn. Cr. 8vo. Pp. 504. 1919. Bell. 6s.

Ostwald, W. The Principles of Inorganic Chemistry. Translated by A. Findlay, 4th edn. 8vo. Pp. 836. 1914. Macmillan. 21s.

Partington, J.R. A Text-book of Inorganic Chemistry for University Students. Demy 8vo. Pp. 1,076. 1921. Macmillan. 25s.

Perkin, F. M. Practical Methods of Inorganic Chemistry. Cr.8vo. Pp. 163. 1906. Constable. 3s. 6d.

Price, T. S. Per-acids and their Salts. 8vo. Pp. 130. 1912. Longmans. 5s.

Remsen, I. An Introduction to the Study of Chemistry: Inorganic Chemistry. Cr. 8vo. Pp. 604. 1910. Macmillan. 8s. 6d.

- A Text-book of Inorganic Chemistry. 8vo. Pp. 876. 1907. Macmillan. $18 s$.

Roscoe, Sir H. E., and Harden, A. Inorganic Chemistry for Advanced Students. 2nd edn. Gl. 8vo. Pp. 486. 1915. Macmillan. 5s.

—_and Lunt, $J$. Inorganic Chemistry for Beginners. New imp. Gl. 8vo. Pp. 266. 1920. Macmillan. 3s. $6 d$.

Senter, G. A Text-book of Inorganic Chemistry. 6th edn. Cr. 8vo. Pp.631. 1919. Methuen. 8s.6d.

Shenstone, W. A. Elements of Inorganic Chemistry. Revised by R. G. Durrant. 6th edn. Cr. 8vo. Pp.538. 1919. E. Arnold. 6s.6d.

Spencer, J. F. The Metals of the Rare Earths. 8vo. Pp.289. 1919. Longmans. $13 s$.
Teed, P. L. The Chemistry and Manufacture of Hydrogen. Demy 8vo. Pp. 159. 1919. Arnold. 10 s. $6 d$.

Walker, J. Inorganic Chemistry. 12th edn. Cr.8vo. Pp.327. 1919 . Bell. 5s.

Whiteley, R. L. An Elementary Text-book of Inorganic Chemistry. 2nd edn. Cr. 8vo. Pp. 254. 1911. Methuen. 5s.

vii. LABORATORY WORK AND ARTS.

Dunnicliff, H. B . Laboratory Glassware Economy : a Practical Manual on the Renovation of Broken Glass Apparatus. Gl. 8vo. Pp. 104 . 1919. Macmillan. 4s.

Munby, A. E. Laboratories: their Planning and Fittings. Roy. 8vo. Pp. 239. 1921. Bell. 25s.

Shenstone, W. A. The Methods of Glass-Blowing and of Working Silica in the Oxy-gas Flame for the use of Chemical and Physical Students. 10th imp. Cr. 8vo. Pp. 104. 1918. Longmans. 3s, 6d.

Woollatt, G. H. Laboratory Arts: A Teacher's Handbook dealing with Materials and Tools used in the Construction, Adjustment, and Repair of Scientific Instruments. 2nd imp. Cr. 8vo. Pp. 204. 1918. Longmans. 4s. $6 d$.

Yates, R. F. The Home Chemical Laboratory. Cr. 8vo. Pp. 127. 1920. Frowde \& Hodder. 4s. $6 d$.

viii. ORGANIG GHEMISTRY.

Adie, R. H. Introduction to the Carbon Compounds. 4th imp. Cr. 8vo. Pp. 98. 1912. University Tutorial Press. $4 s$.

Armstrong, E. F. The Simple Carbo-hydrates and the Glucosides. 3rd edn. 8vo. Pp. 250. 1918. Longmans. $18 s$.

Barnett, E. de B. The Preparation of Organic Compounds. 2nd edn. Demy 8vo. Pp. 290. 1920. Churchill. 10s. 6d. 


\section{Chemistry}

Barnett, E. de B. A Text-book of Organic Chemistry. Demy 8vo. Pp.392. 1920. Churchill. 15s.

Bernthsen, A. A Text-book of Organic Chemistry. Translated from the German. Edited by J. J. Sudborough. New edn. Cr. 8vo. Pp. 735. 1920. Blackie. 10s.6d.

Cohen, J. B. Organic Chemistry for Advanced Students. 3rd edn. 3 vols. Demy 8vo. 1920. Vol. 1. Reactions. Pp. 374. Vol. 2. Structure. Pp. 442. Vol. 3. Synthesis. Pp. 385. Arnold. $18 s$. each.

- Practical Organic Chemistry. Gl. 8vo. Pp. 372. 1920. Macmillan. $4 s$.

Theoretical Organic Chemistry. G1. 8vo. Pp. 620. 1920. Macmillan. $7 s$.

Clarke, H. T. An Introduction to the Study of Organic Chemistry. Cr. 8vo. Pp. 492. 1914. Longmans. 12s. 6d.

Dunstan, A. E. A First Year Course of Organic Chemistry: The Aliphatic Compounds. Cr. 8vo. Pp. 168. 1919. Methuen. 4s.

Fischer, E. Introduction to the Preparation of Organic Compounds. Translated by R. V. Stanford. Cr. 8vo. Pp. 175. 1909. Williams \& Norgate. $5 s$.

Hale, A. J. The Synthetic Use of Metals in Organic Chemistry. Cr. 8vo. Pp. 169. 1914. Churchill. $6 s$.

Hilditch, T. P. A Third Year Course of Organic Chemistry. The Heterocyclic Compounds, Carbohydrates, and Terpenes. Cr. 8vo. Pp. 424. 1914, Methuen. 7s.6d.

Keane, C. A. Modern Organic Chemistry. Cr. 8vo. Scott Pub. Co. 7s. $6 d$.

Lewis, E. I. The Elements of Organic Chemistry. 4th imp. Cr. 8vo. Pp. 232. 1919. University Tutorial Press. $4 s$.

Maclean, H. Lecithin and Allied Substances. The Lipins. Roy. 8vo. Pp. 214. 1918. Longmans. 8s. 6d.
Meldola, R. The Chemical Synthesis of Vital Products and the Inter-relations between Organic Compounds. Super Roy. 8vo. Pp. 338. 1904. Arnold. 21s.

Morgan, G. T . Organic Compounds of Arsenic and Antimony. 8vo. Pp. 396. 1918. Longmans. 17s .6d.

Neave, G. B ., and Heilbron, I. M. The Identification of Organic Compounds. 2nd edn. Cr. 8vo. Pp. 96. 1920. Constable. 4s.6d.

Perkin, W. H., and Kipping, F. S. Organic Chemistry. Cr. 8vo. Pp. 684. 1914. Chambers. 8s.6d.

Pope, F. G. Modern Research in Organic Chemistry. 2nd edn. $\mathbf{C r}$. 8vo. Pp. 336. 1919. Methuen. 7s. 6d.

Price, T. S., and Twiss, D. F. A Course of Practical Organic Chemistry. 8vo. Pp. 254. 1919. Longmans. 6s. 6d.

Richter, V. Organic Chemistry, or Chemistry of the Carbon Compounds . Vol. 1. Chemistry of the Aliphatic Series. Newly translated by $\mathbf{P}$. E. Spielmann. 2nd edn. Large 8vo. Pp. 735. 1919. Kegan Paul. 25s.

Stewart, A. W. Recent Advances in Organic Chemistry. 4th edn. Demy 8vo. Pp. 375. 1920. Longmans. $21 s$.

Sudborough, J. J., and James, T. C. Practical Organie Chemistry. Cr.8vo. Pp.380. 1920. Blackie. $7 s .6 d$.

Thole, F. B. A Second Year Course of Organic Chemistry. The CarboCyclic Compounds. Cr. 8vo. Pp. 194. 1912. Methuen. 4s.6d.

Titherley, A. W. A Laboratory Course of Organic Chemistry: including Qualitative Organic Analysis. 2nd edn. 8vo. Pp. 244. 1920. Geo. Philip. 6s.6d.

Wade, J. Introduction to the Study of Organic Chemistry. A Theoretical and Practical Text-book for Students in the Universities and Technical Schools. New edn. Cr. 8vo. Pp.646. 1920. Allen \& Unwin. 8s.6d. 


\section{Chemistry}

Williams, H. E. The Chemistry of Cyanogen Compounds and their Manufacture and Estimation. 8vo. Pp.432. 1915. Churchill. 12s.6d.

Wren, H. The Organometallic Compounds of Zinc and Magnesium. Cr. 8vo. Pp. 100. 1913. Gurney \& Jackson. 2s. $6 d$.

ix. ANALYTICAL CHEMISTRY .

\section{a. General .}

Allen's Commercial Organic Anal ysis. A Treatise on the Properties, Proximate Analytical Examinations, and Modes of Assaying the various Organic Chemicals and Products employed in the Arts, Manufactures, Medicines. etc. With Concise Methods for the Detection and Determination of their Impurities, Adulteration, and Products of Decomposition. By various Specialists. Edited by W. A. Davis, H . Leffmann, and S. S. Sadtler. 4th edn, 9 Vols. 8vo. Vol. 1. Pp. 586. 1909. 28s. Vol. 2. Pp. 530. 1910. 28s. Vol.3. Pp.645. 1910. 28s. Vol.4. Pp.474. 1910. 28s. Vol. 5. Pp. 713. 1911. 28s. Vol. 6. Pp. 736. 1912, 28s. Vol.7. Pp. 574. 1913. 28s. Vol. 8. Pp. 696. 1914. 28s. Vol. 9. Bringing up-to-date the articles in the 8 volumes, and with index for the complete 9 volumes. Pp. 854 . 1917. 33s. Churchill.

Arup, P. S. Industrial Organic Analysis for the use of Technical and Analytical Chemists and Students. 2nd edn. Cr.8vo. Pp. 484 . 1920. Churchill. 12s. 6d.

Baker, T. T. The Spectroscope: Its Uses in General Analytical Chemistry. Cr. 8vo. Pp. 138. 1907 . Baillière. 5s.

Barger, G. The Simpler Natural Bases. New edition in preparation. Longmans.

Candy, H. C. H. Introduction to Chemical Analysis. Cr. 8vo. Pp. 126. 1905. Churchill. 3s.6d.

Clarke, H. T. A Handbook of Organic Analysis: Qualitative and Quantitative. 3rd edn. Cr. 8vo. Pp. 272. 1920. Arnold. 6s. 6d.
Forster, E. L. B. Analytical Chemistry as a Profession for Women. Pocket size. Pp. 135. 1920. Griffin. 3s. 6d.

Gardiner, G. G. Chemical Analysis, Qualitative and Quantitative. A Text-book for Technical Schools and Colleges. Post 8vo. Pp. 491 . 1914. Black. $7 s, 6 d$.

Henderson, G. G., and Parker, M. A. An Introduction to Analytical Chemistry. Cr. 8vo. Pp. 228. 1919. Blackie. 5s.

Johnson, A. E. The Analyst's Laboratory Companion: A Collection of Tables and Data for Chemists and Students. 5th edn. Cr. 8vo. Pp. 18.5. 1921. Churchill. 10s. 6d.

Krauch, C. Testing of Chemical Reagents for Purity. Their Uses, Methods of Testing for Purity and Commercial Varieties. Translated from the German. 2nd edn. Demy 8vo. Pp. 368. 1919. Scott, Greenwood. 17s. 6d.

Landauer, J. Blowpipe Analysis. English Edition by J. Taylor. 3rd edn. Gl. 8vo. Pp. 190. 1901. Macmillan. 4s. 6d.

Lunge, G. (edited by). Technical Methods of Chemical Analysis. English translation edited by c. Keane. 6 vols. Roy. Svo. New edition in preparation. Gurney \& Jackson.

Muter, J. Short Manual of Analytical Chemistry. Qualitative and Quantitative, Inorganic and Organic. Fdited by $J$. Thomas. 10th edn. Roy. 8vo. Pp. 237. 1915. Baillière. 8s. 6d.

Newth, G. S. A Manual of Chemical Analysis. Qualitative and Quantitative. 12th imp. Cr. 8vo. Pp. 488. 1919. Longmans. 9s. $6 d$.

_- Smaller Chemical Analysis. Cr. 8vo. Pp. 15f. 1919. I.ongmans. 3s. $6 d$.

Ostwald, W. Scientific Foundations: of Analytical Chemistry. Translated by G. McGowan. 3rd edn. Cr. 8vo. Pp. 272. 1908. Macmillan. 7s. $6 d$. 


\section{Chemistry}

Prost, E. Manual of Chemical Analysis, as applied to the Assay of Fuels, Ores, Metals, Alloys, Salts and other Mineral Products. Translated from the German. Roy. 8vo. Pp. 300. 1904. Scott, Greenwood. 14s. $6 d$.

Tognoli, E. Reagents and Reactions . Translated from the Italian by C. A. Mitchell. Feap. 8vo. Pp. 236 . 1918. Churchill. 6s.

\section{b. Qualitative Analysis.}

Briggs, W., and Stewa rt, R. W. Qualitative Analysis. 3rd imp. Cr. 8vo. Pp. 172, 1920. University Tutorial Press. 4s.6d.

Brown, J. G., and Bengough, G. D. Practical Chemistry, Qualitative Exercises and Analytical Tables for Students. 6th edn. 8vo. Pp. 80. 1913. Churchill. 2s. 6d.

Caven, R. M. Systematic Qualitative Analysis for Students of Inorganic Chemistry. Large $\mathrm{Cr}$. 8vo. Pp. 252. 1919. Blackie. 5s.

Clowes, F. Qualitative Analysis and Practica! Chemistry. 9th edn. Demy 8vo. Pp. 400. 1920 . Churchill. 12s. 6d.

Fenton, H. J. H. Notes on Qualitative Analysis. new edn. Cr. 4tu . Pp. 161. 1920. Cambridge University Press. $8 s$.

Fresenius. T. W. Introduction to Qualitative Chemical Analysis. 17th edn. of the original work, translated hy C. A. Mitchell. Demy 8vo. Pp. 974, 1921. Churchill. 36s.

Highton, H. P. An Introduction to Qualitative Analysis. 3rd imp. Cr. 8vo. Pp. 182. 1908. Rivington. $4 s$.

Hooton, W. M. Qualitative and Volumetric Analysis. Demy 8vo. Pp.90. 1915. E. Arnold. 3s. 6d.

Perkin, F. M. Qualitative Chemical Analysis: Organic and Inorganic. wh edn. Demy 8vo. Pp. 350 . 1920. Longmans. 9s.
Robertson, P. W., and Burleigh, D. H. Qualitative Analysis in Theory and Practice. 8vo. Pp. 63. 1920. Arnold. 4s. 6d.

Sexton, A. H. Outlines of Qualitative Analysis : for the Use of Students. 4th edn. Cr.8vo. Pp. 191 . 1903. Griffin. $3 s, 6 d$.

Shepherd, J.W. Qualitative Determination of Organic Compounds. Cr. 8vo. Pp. 364. 1913. University 'Tutorial Press. 9s.6 $d$.

Stieglitz, J. Elements of Qualitative Chemical Analysis. 2 vols. Demy 8vo. 1919. Vol. 1. Funda. mental Principles and their Applica tion. Pp. 312. Vol. 2. Laboratory Manual. Pp. 15:. Bell. 8s. 6d. each.

Thole, F. B. Qualitative Organic Analysis. Cr.8vo. Pp.78. 1912. Methuen. 2s. 6d.

Thorpe, Sir T . E., and Muir, M.M. P. Qualitative Chemical Analysis and Laboratory Practice. 12th imp. Cr. 8vo. Pp. 262. 1909. Longmans. $5 s, 6 d$.

Weston, F. E. A Scheme for the Detection of the More Common Classes of Carbon Compounds. 8vo. Pp. 116. 1919. Longmans. 4s. 6d.

\section{c. Quantitative Analysis.}

Auld, S. J. M. An Introdurtion to Quantitative Analysis. Cr. 8vo. Pp. 215. 1912. Methuen. 6s.

Bailey, G. H. Elements of Quanti tative Analysis. Gl. 8vo. Pp. 256. 1905. Macmillan. 5s.

Briggs, W., and Bausor, H. W. Elementary Quantitative Analysis. 2nd imp. Cr.8vo. Pp. 130. 1919. University Tutorial Press. $3 s$.

Clowes, F., and Coleman, J.B. Quantitative Chemical Analysis. Adapted for Use in the Laboratories of Colleges and 'Technical Institutes. 11th edn. 8vo. Pp. 604. 1918. Churchill. 18s.

Crookes, Sir W. Select Methods in Chemical Analysis (chiefly Inorganic). 4th edn. 8vo. Pp. 762 . 1905. Longmans, 22s. 6d. 


\section{Chemistry}

Cumming, A. C., and Kay, S. A. A Text-hook of Quantitative Chemical Analysis. 3rd edn. Med. 8vo. Pp. 1,432. 1919. Gurney \& Jackson. $15 s$.

Highton, H. P. An Introduction to Practical Quantitative Analysis. 2nd edn. Cr.8vo. Py.223. 1906. Rivington. $4 s$.

Kingscott, P. G. R., and Knight, R.S. G. Methods of Quantitative Organic Analysis. 8vo. Pp. 300. 1914. Longmans. $7 s .6 d$.

Mellor, J.W. A Treatise on Quantitative Inorganic Analysis: with special Reference to the Analysis of Clays, Silicates, etc. 2nd edn. in preparation. Griffin .

Schoeller, W.R., and Powell A.R. The Analysis of Minerals and Ores of the Rarer Elements, for Analytical Chemists, Metallurgists and Advanced Students. Med. 8vo. Pp. 249. 1919. Griffin. 16s.

Sexton, A.H. Outlines of Quantitative Analysis: for the Use of Students. 5th edn. Cr. Svo. Pp. 148. 1907. Griffin. 3s.

\section{d. Volumetric Analysis.}

Berry, A. J. Volumetric Analysis. Demy 8vo. Pp. 146. 1915. Cambridge University Press. $8 s .6 d$.

Briggs, W., and Bausor. H.W. Senior Volumetric Analysis. Cr. 8vo. Pp. 68. 1913. University Tutorial Press. 2s. 3d.

Coppock, J. B. Volumetric Analysis, adapted to the Requirements of Students entering for the Internal and External Examinations of Schools, Institutes, Colleges, and Universities. 2nd edn. Cr. 8vo. Pp. 100. 1920. Pitman. 3s.6d.

Hampshire, C.H. Volumetric Analysis for Students of Pharmaceutical and General Chemistry. 3rd edn . Cr. 8vo. Pp. 124. 1921. Churchill. 7s.6d.

Knecht, E., and Hibbert, E. New Reduction Methods in Volumetric Analysis. 2nd edn. Cr. 8vo. Pp. 144. 1918. Longmans. $5 s$.
Prideaux, E. B. R. The Theory and Use of Indicators. An Account of the Chemical Equilibria of Acids, Alkaloids, and Indicators in Aqueous Solution, with Applications. Demy svo. Pp. 390. 1917. Constable. $12 s .6 d$.

Richards, P.A. E. Practical Chemistry, including Simple Volumetric Analysis and Toxicology . Brd edn. Cr.8vo. Pp.157. 1920. Baillière. $5 s$.

Sutton, F. A Systematic Handbook of Volumetric Analysis. 11th edition in preparation. Churchill.

Thornton, A., and Pearson, M. Notes on Volumetric Analysis. Med. 8vo. Pp. 88. 1918. Longmans. 3s. $6 d$.

\section{x. BIOLOGICAL AND PHYSIO - LOGICAL CHEMISTRY.}

Arrhenius, S. Quantitative Laws in Biological Chemistry. Demy 8vo. Pp.164. 1915. Bell. 7s.6d.

Bertrand, G., and Thomas, P. Practical Biological Chemistry. Translated from the 3rd French edition by H. A. Colwell. Demy 8vo. Pp. 379. 1920. Bell. 1ns. 6d.

Cathcart, E. P, The Physiology of Protein Metabolism. 2nd edn. Demy 8vo. Pip. 184. 1921. Longmans. 12s. 6d.

Cole, S. W. Practical Physiological Chemistry. Introduction by $\mathbf{F}$. G. Hopkins. 6th edn. Demy 8vo. Pp. 426. 1920. Heffer. 16s.

Cramer, W. Directions for a Practical Course in Chemical Physiology. 4th edn. Cr.8vo. Pp. 145. 1920. Longmans. $4 s, 6 d$.

Griffiths, A. B. Respiration Proteids. Researches in Biological Chemistry. 8vo. Pp. 126. 1897. Lovell, Reeve. $6 s$.

Jones, W. Nucleic Acids. Their Chemical Properties and Physiological Conduct. 2nd edn. Demy 8vo. Pp. 158. 1920. Longmans. 9s. 
Moore, B. Biochemistry. A Study of the Origin, Reactions and Equilibria of Living Matter. Demy 8vo. Pp. 348. 1921. Arnold. 21s.

Milroy, J.A. and T.H. Practical Physiological Chemistry. 3rd edn. in preparation. W. Green.

Plimmer, R. H. A. The Chemical Changes and Products Resulting from Fermentation. 8vo. Pp.190. 1903. Longmans. 7s. $6 d$.

- Practical Organic and BioChemistry. Roy. 8vo. Pp. 648. 1918. Longmans. $21 s$.

-The Chemical Constitution of the Proteins. Two Parts. Part 1. Analysis. 3rd edn. Roy. 8vo. Pp. 186. 1917. 7s. Part 2. New edn. in preparation. Longmans.

Schryver, S. B. An Introduction to the Study of Biological Chemistry. Cr. 8vo. Pp. 340. 1919. Jack.6s.

\section{xi. PLAN'T CONSTITUENTS.}

Cross, C. F., and Bevan, E. J. Cellulose : An Outline of the Chemistry of the Structural Elements of Plants. With reference to their natural history and industrial uses . Cr. 8vo. Pp. 368. 1918. Longmans. 14s. $6 d$.
Cross, C. F., and Bevan, E. J. Researches on Cellulose, 19001905. 2nd edn. Cr.8vo. Pp. 196. 1913. Longmans. $9 s$.

-Researches on Cellulose, 19051910. Cr. 8vo. Pp. 184. 1912. Longmans. $9 s$.

Haas, P., and Hill, T. G. An Introduction to the Chemistry of Plant Products. Vol. 1. On the Nature and Significance of the Commoner Organic Compounds of Plants. 3rd edn. Demy 8vo. Pp. 428. 1921. Longmans. 16s .

Henry, T. A. The Plant Alkaloids. 8vo. Pp. 474. 1913. Churchill. $21 s$.

Onslow, M. W. Practical Plant Biochemistry. Roy.8vo. Pp.182. 1920. Cambridge University Press . $15 s$.

Osborne, T. B. The Vegetable Proteins. Roy. Svo. Pp. 140. 1919. Longmans. 6s. $6 d$.

Sohn, C. E. Dictionary of the Active Principles of Plants, Alkaloids, Bitter Principles, Glucosides ; their Sources, Nature and Chemical Characteristics, etc. Oblong 4to. Pp. 201. 1894. Baillière. 5s. 


\section{APPLIED AND INDUSTRIAL CHEMISTRY.}

\section{i. GENERAL-INCLUDING CHEMICAL ENGINEERING.}

Allen, A. F. An Introduction to Chemical Engineering. An Elementary Text-book for the use of Students and users of Chemical Machinery. Demy 8vo. Pp. 288. 1920. Pitman. 10s.6d.

Blount, B., and Bloxam, A. G. Chemistry for Engineers and Manufacturers. 2 vols. 2nd edn. Large 8vo. Vol. 1. Chemistry of Engineering, Building, and Metallurgy . Pp. 405. 1918. 14s. Vol. 2. Chemistry of Manufacturing Processes. Pp. 528. 1913. 16s. Griffin .

Buhler, F. A. Filters and Filter Presses for the Separation of Liquids and Solids. With additional matter relating to the Theory of Filtration in Sugar Factories and Refineries. By J.J. Eastick. Super Roy. 8vo. Pp. 194. 1914. Norman Rodger. $15 s$.

Chemical Manufacturers' Directory of England, Wales and Scot land for 1921. 8vo. Pp. 250. (April) 1921. Simpkin. 4s. 6d .

Chemical Trade Year Book and Buyers' Guide, 1920. Incorporating the Chemical Trade Directory. Demy 8vo. Pp. 220. 1920. Bandon \& Morris. $10 s$.

Dyson, S. S., and Clarkson, S. S. Chemical Works: Their Design, Erection, and Equipment. Roy. 8vo. Pp.207. 1912. Scott, Greenwood. $23 s$.

Findlay, A. Chemistry in the Service of Man. 2nd edn. 8vo. Pp. 288. 1919. Longmans, 10s, 6d.
Grossmann, J. The Elements of Chemical Engineering. 2nd edn. Cr. Svo. Pp. 162. 1913. Griffin. 48 .

Hausbrand, E. Drying by Means of Air and Steam. Translated by $\mathbf{A}$. C. Wright. 2nd edn. Cr. 8vo. Pp. 76. 1912, Scott, Greenwood. $6 s$.

Evaporating, Condensing, and Cooling Apparatus: Explanations, Formulæ and Tables for Use in Practice. Translated by A. C. Wright. 2nd edn. Demy 8vo. Pp. 428. 1919. Scott, Greenwood. $14 s, 6 d$.

Hinchley, J.W. Chemical Engineering. Notes on Grinding, sifting, separating and Transporting Solids. Cr.8vo. Pp.112. 1914. Churchill. 2s. $6 d$.

Lunge, G. The Technical Chemists' Handbook. Tables and Methods of Analysis for Manufacturers of Inorganic Chemical Products. 2nd edn. Cr. 8vo. Pp. 280. 1916. Gurney \& Jackson. 10s. 6d.

Marlow, T. G. Drying Machinery and Practice. The Theory and Practice of Drying and Desiccating with description of Machinery and Apparatus. 2nd edn. in preparation. Crosby Lockwood.

Martin, G., assisted by various Specialists. Industrial and Manufacturing Chemistry. Roy. 8vo. Vol.1. Organic.5th edn. Pp.750. 1920. 36s. Vols.2 \& 3. 3rd imp. Inorganic. $P_{1}$. 515., 498. 1920. 28s. each Vol. Crosby Lockwood. 


\section{Applied and Industrial Chemistry}

Molinari, E. Treatise on General and Industrial Inorganic Chemistry. Translated from the Italian by $\mathbf{T}$. H. Pope. 2nd edn. Roy. 8vo. Pp. 896. 1920. Churchill. 42s.

Treatise on General and Industrial Organic Chemistry. Translated from the 3rd Italian edition by 'T. H. Pope. Part 1. Roy. 8vo. Pp.471. 1921. Churchill. 30s.

Pilcher, R. B., and Butler-Jones, F. What Industry Owes to Chem. ical Science. Cr. Svo. Pp. 166 . 1918. Constable. Is.

Thorne, P.C.L. Chemistry from the Industrial Standpoint. Cr. 8vo. Pp. 260. 1919. Hodder and Stoughton. 4s.6d.

Thorpe, Sir T.E., assisted by em inent Contributors. A Dictionary of Applied Chemistry . Revised and enlarged edn. in 6 or 7 vols. 8vo. Vol. 1. A to Calcium. Pp.762. 1921. Vol.2. Calculi to Explosion. Pp. 725. 1921. Longmans. 60s. each vol.

Tinkler, C. K., and Master, H. Applied Chemistry: A Practical Handbook for Students of Household Science and Public Health. Vol. 1. Water, Detergents, Textiles, Fuels, etc. Med. 8vo. Pp. 292. 1920. Crosby Lockwood. 12s. $6 \mathrm{~d}$.

Training and Work of the Chemical Engineer, The. Faraday Society Report, 1917. Demy 8vo. Pp. 60. 1917. Faraday Society. 2s. $6 \mathrm{~d}$.

Villavecchia, V. (edited by). assist ed by Nine Specialists. Treatise on Applied Analytical Chemistry. Translated by T. H. Pope. 8vo. 1918. Vol. 1. Pp. 492. 21s. Vol. 2. Pp. 552. 25s. Churchill.

Wagner, R. Manual of Chemical Technology. Translated and Edited by Sir $W$. Crookes from the J3th German edition as remodelled by F. Fischer. 2nd edn. Roy. 8vo. Pp.992. Reprinted 1904. Churchill. $36 s$.

\section{ii. WATER .}

Coux, H. de la. The Industrial Uses of Water, Composition, Effects, Troubles, Remedies, Residuary Waters, Purification, Analysis. Translated. Roy. 8vo. Pp. 304. 1903. Scott, Greenwood. 12s. $6 d$.

Mitchell, C.A. Mineral and Aerated Waters, and the Machinery for their Manufacture. Demy 8vo. Pp.241. 1913. Constable. 9s.

Paul, J. H. Boiler Chemistry and Feed Water Supplies, 8vo. Pp. 252. 1919. Longmans. $14 s$.

Wilson, H. M., and Calvert, H. T. A Text-Book on Trade Waste Waters. Their Nature and Disposal. Med. 8vo. Pp. 352. 1913. Griffin. 21s.

FERMENTATION : BREW ING : ALCOHOL.

Baker, J . L. The Brewing Industry . Cr.8vo. P’. 191. 1905. Methuen. 5s.

Bater, C. H. Brewing Calculations, Gauging and Tabulation, Formulæ, Tables, and General Information for Brewers, etc. 64mo. Pp. 340. 1914. Spon. 2s.

Brown, A. J. Laboratory Studies for Brewing Students, a Systematic Course of Practical Work in the Scientific Principles underlying the Processes of Malting and Brewing. 8vo. Pp. 212. 1904. Longmans. 9s.

Chapman, A.C. Brewing. Roy . 16mo. Pp. 139. 1912. Cambridge University Press. 2s. 6d.

Harden, A. Alcoholic Fermenta. tion. New Edition in preparation. Longmans .

Jörgensen, A . Micro-Organisms and Fermentation. Translated by S.H. Davies. 5th edn. Demy 8vo. Pp. 500. 1911. Griffin. 18s. 
Lafar, F. Technical Mycology: The Utilisation of Micro-organisms in the Arts and Manufactures. Translated by C. T. C. Salter. 2 vols. Large 8vo. Vol. 1., Schizomycetic Fermentation. Pp. 328 . 1910. 18s. Vol. 2., Eumycetic Fermentation. Pp. 568. 1911. 30s. Griffin.

McIntosh, J.G. Industrial Alcohol. A Practical Manual on the Production and Use of Alcohol for Industrial Purposes and for Use as a Heating Agent, as an Illuminant and as a Source of Motive Power. Demy svo. Pp. 250. 1907. Scott. Greenwood. $8 s .6 d$.

Matthews, G. G. Manual of Alcoholic Fermentation and the Allied Industries. Cr. 8vo. Pp. 311. 1901. Arnold. 8s, 6d.

- and Lott, F. E. The Microscope in the Brewery and Malthouse. 2nd edn. Roy. 8vo. Pp. 252. 1899. Allen and Unwin. 21s.

Mitchell, C. A. Vinegar: Its Manufacture and Examination. Large Cr.8vo. Pp.21\%. 1916. Griffin. $10 s .6 d$.

Rideal, S., and others. The Carbohydrates and Alcohol. Demy 8vo. Pp.234. 1920. Baillière. 12s.6d.

Simmonds, G. Alcohol. Its Production, Properties, Chemistry, and Industrial Applications, with Chapters on Methyl Alcohol, Fusel Oil, and Spirituous Beverages. 8vo. Pp. 594. 1919. Macmillan. 21s.

Sykes, W. J. Principles and Practice of Brewing. For the Use of Students and Practical Men. Revised by A.R. Ling. 3rd edn. Pp. 606. 1907. Griffin. 25s.

Wright, H. E. A Handy Book for Brewers. A Practical Guide to the Art of Brewing and Malting. 3rd edn. Large Cr. 8vo. Pp. 578. 1907. Crosby Lockwood. 14s.

\section{iv. SUGAR AND ITS MANU - FACTURE.}

Geerligs, H. C. P. Methods of Chemical Control in Cane Sugar Factories. new edn. Roy. 8vo. 1917. Norman Rodger. 10s.
Geerligs, H. C. P. Practical White Sugar Manufacture directly from the Cane. Roy. 8vo. Pp. 177. 1915. Norman Rodger. 12s.

Cane Sugar and Its Manufacture. Super Roy. 8vo. Pp. 352. 1909. Norman Rodger. 12s.

The World's Cane Sugar Industry. Past and Present. Super Roy. 8vo. Pp. 400. 1912. Norman Rodger. $12 s$.

Harloff, W.H.'T. and Schmidt, $H$. Plantation White Sugar Manufacture. Translated from the Dutch by.J.P. Ogilvie. Cr.8vo. Pp. 140. 1913. Norman Rodger. 7s. $6 d$.

Heriot, T. H. P. The Manufacture of Sugar from the Cane and Beet. Demy 8vo. Pp. 436. 1920. Longmans. $24 s$.

- Science in Sugar Production : An Introduction to the Methods of Chemical Control. Roy. 8vo. Pp. 104. 1917. Norman Rodger. 6s.

Koppeschaar, E. Evaporation in the Cane and the Beet Sugar Factory . A Theoretical and Practical Treatise. Roy. 8vo. Pp. 116. 1914. Norman Rodger. 7s, $6 d$.

McIntosh, J. G. The Technology of Sugar: Practical Treatise on the Modern Methods of Manufacture of Sugar from the Sugar Cane and Sugar Beet. 3rd edn. Demy 8 vo. Pp. 540. 1916. Scott, Greenwood. $14 s .6 d$.

Mackenzie, J. E. The Sugars and their Simple Derivatives. Med. 8vo. Pp. 250. 1913. Gurney and Jackson. 7s. $6 d$.

Martineau, G. Sugar: Cane and Beet. Cr. 8vo. Pp. 164. 1909. Pitman. 3s.

Maxwell, F. Sulphitation in White Sugar Manufacture. Demy 8 vo. 1916. Norman Rodger. 7s. 6d.

Newlands, J. A. R., and B. E. R. Sugar: A Handbook for Planters and Refiners, being a comprehensive Treatise on the Culture of Sugar-yielding Plants, and on the Manufacture, Refining, and Analysis of Cane, Palm, Maple, Melon, Beet, etc. 8vo. Pp. 876. 1909. Spon. 30s. 


\section{Applied and Industrial Chemistry.}

\section{v. COCOA AND GHOGOLATE.}

Knapp, A. W. Cocoa and Chocolate. Their History from Plantation to Consumer. Demy 8vó. Pp. 213. 1920. Chapman and Hall. 12s. 6d.

Whymper, R. Cocoa and Chocolate: Their Chemistry and Manufacture. 2nd edn. 8vo. Pp. 590. 1921. Churchill. 42s.

\section{vi. FOODS ; FLOUR AND BREAD MAKING, etc.}

Amos, P. A. Processes of Flour Manufacture. Cr. 8vo. Pp. 292. 1919. Longmans. 6s, $6 d$.

Bolton, E. R. , and Revis, C. Fatty Foods: Their Practical Examination. 8vo. Pp. 384. 1912. Churchill. 10s.6d.

Grant, J. The Chemistry of Bread Making. 2nd edn. Cr. 8vo. Pp. 232. 1917. Arnold. 6s.

Hausner, A. The Manufacture of Preserved Foods and Sweetmeats. Translated from the German. 2nd edn. Cr. 8vo. Pp. 225. 1912. Scott, Greenwood. 8s.6d.

Kozmin, P. A. Flour Milling. Translated from the Russian. 2nd edn. Roy. 8vo. Pp. 594. Routledge. $25 s$.

Rew, Sir R. H. Food Supplies in Peace and War. Cr. 8vo. Pp. 192. 1920. Longmans. 6s, $6 d$.

Tibbles, W. Foods: their Origin, Composition, and Manufacture. Demy 8vo. Pp. 958. 1912 . Baillière. 20s .

Wood, T. B. The Story of A Loaf of Bread. Roy. 16mo. Pp. 147. 1913. Cambridge University Press . 2s. $6 d$.

\section{vii. GLUES, AGGLUTINANTS, CASEIN, etc.}

Brunner, R. The Manufacture of Lubricants, Shoe Polishes, and Leather Dressings. Translated from the German. 2nd edn. Cr. 8vo. Pp. 188. 1916. Scott, Greenwood. 8s. 6d.
Lambert, T. Glue, Gelatine, and their Allied Products. 2nd edn. Cr. 8vo. Pp. 165. 1920. Griffin. $6 s$.

- Bone Products and Manures. 2nd edn. Demy 8vo. Pp.172. 1913. Scott, Greenwood. 8s.6d.

Rideal, S. Glue and Glue Testing. 2nd edn. Demy 8vo. Pp. 196. 1914. Scott, Greenwood. 12s.6d.

Scherer, R. Casein: Its Preparation and Technical Utilisation. 2nd edn. Demy 8vo. Pp.182. 1911. Scott, Greenwood. $8 s, 6 d$.

Standage, H. C. Agglutinants and Adhesives of all kinds for all Pur. poses. Demy 8vo. Pp.273. 1907. Constable. $7 s .6 d$.

-Sealing-Waxes, Wafers and Other Adhesives for the Household, Office, Workshop and Factory. Cr. 8vo. Pp. 96. 1902. Scott, Greenwood. $6 s$.

\section{viii. DRUGS AND DISINFEC- TANTS.}

Christian, M. Disinfection and Disinfectants. Translated from the German. Cr.8vo. Pp.112. 1913. Scott, Greenwood. $6 s$.

May, P. The Chemistry of Synthetic Drugs. 3rd edn. 8vo. Pp. 264. 1921. Longmans. 12s. $6 d$.

ix. OILS, FATS, WAXES, SOAP MANUFAGTURE, MARGARINE, etc.

Andés, L. E. Animal Fats and Oils. 3rd edn. Revised by H. B. Stocks. 8vo. Pp. 323. 1920. Scott, Greenwood. 15s .

-Drying Oils, Boiled Oil, and Solid and Liquid Dryers. 2nd edn. Demy 8vo. Pp. 352. 1917. Scott, Greenwood. 14s.6d. Oil Colours and Printers' Inks. Translated from the German. 2nd end. Demy 8vo. Pp. 230. 1918. Scott, Greenwood. 10s. 6d.

Vegetable Fats and Oils. Their Practical Preparation, Purification and Employment for Various Purposes, their Properties, Adulteration and Examination. Translated 


\section{A pplied and Industrial Chemistry.}

by Charles Salter. 3rd edn. Demy 8vo. Pp. 340. 1917. Scott, Greenwood. $14 s .6 d$.

Anon. Manual of Toilet Soap Making : comprising Toilet Soaps, Medicated Soaps, and other Specialities. 2nd edn. Roy. 8vo. Pp. 356. Scott, Greenwood. $21 s$.

Carpenter, W.L. A Treatise on the Manufacture of Soap and Candles, Lubricants and Glycerine. New edn. in preparation. Spon.

Chalmers, T. W. The Production and Treatment of Vegetable Oils, including the Refining and Hydrogenation of Oils, Generation of Hydrogen, Soap Making, Recovery and Refining of Glycerine. and the Splitting of Oils. 2nd edn. Cr. tto. Pp. 164. 1919. Constable. $21 s$.

Clayton, W. Margarine: Manufacture, Analysis, etc. Demy 8vo. Pp. 198. 1920. Longmans. 14s.

Cowell, W. B. Pure Air, Ozone and Water. A Practical Treat ise of their Utilisation and Value in Oil, Grease, Soap, Paint, Glue and other Industries. Cr. 8vo. Pp. 85. 1900. Scott, Greenwood. 6s.

"Expert Oil Refiner." The Practical Compounding of Oils, Tallow and Grease for Lubrication, etc. ?nd edn. Demy 8vo. Pp. 100. 1907. Scott, Greenwood. 8s. 6d.

Friend, J. N. The Chemistry of Linseed Oil. Cr. 8vo. Pp. 104. 1917. Gurney and Jackson. 2s.6d.

Fryer, P. J., and Weston, F. E. Technical Handbook of Oils, Fats and Waxes. Demy 8vo. Vol. 1. Chemical and General. 3rd edn. Pp. 290. 1920. 15s. Vol. 2., Practical and Analytical. Pp. 314. 1918. 15s. Cambridge University Press.

Hurst, G. H. Soaps: A Practical Manual of the Manufacture of Domestic, Toilet, and other Soaps. 2nd edn. Demy 8vo. Pp. 390. 1907. Scott, Greenwood. 14s.6d.

- Textile Soaps and Oils. 3rd edn. Revised by W.H. Simmons. 8vo. Pp. 208. 1921. Scott, Greenwood. 10s. 6d.
Koppe, S. W. Glycerine: Its Production, Uses, and Examination. For chemists, perfumers, soapmakers, pharmacists, and explosives technologists. Translated by W. H. Simmons. Cr. 8vo. Pp. 260. 1915. Scott, Greenwood. 8s. $6 d$.

Lewkowitsch, J. Chemical Technology and Analysis of Oils, Fats, and Waxes. Edited by G. H. Warburton. 6th edn. 3 vols. Med. 8vo. Vol. 1. Pp. 700.1921. 36s. Vols, 2 and 3 in the Press. Macmillan.

-Laboratory Companion to Fats and Oils Industries. 8vo. Pp. 160. 1901. Macmillan. $78.6 d$.

Martin, G. Animal and Vegetable Oils, Fats, and Waxes. Their Manufacture, Refining, and Analvsis, including the Manufacture of Candles, Margarine and Butter. Roy. 8vo. Pp. 228. 1920. Crosby Lockwood. 12s. 6d.

Mitchell, C. A. Edible Oils and Fats. 8vo. Pp. 172. 1918. Longmans. $78.6 d$.

__Oils: Animal, Vegetable, Essential, and Mineral. Cr. 8vo. Pp. 146. 1909. Pitman. 3s.

Parry, E. J. The Chemistry of Essential Oils and Artificial Perfumes. 2 Vols. 3rd edn. Roy. 8vo. Vol. 1. Monographs on Essential Oils. Pp. 525. 1918. 25s. Vol. 2. Constituents of Essential Oils. Synthetic Perfumes and Isolated Aromatics. The Analysis of Essential Oils. Pp. 351. 1919. 17s. 6d. Scott, Greenwood.

-The Raw Materials of Perfumery; their Nature, Occurrence and Fmployment. Cr. 8vo. Pp. 122. 1921. Pitman. 3s.

Pickering, G. F. Aids in the Commercial Analysis of Oils, Fats, and their Manufactured Products . A Laboratory Handbook. Med . 8vo. Pp. 141. 1917. Griffin. 7s.6d.

Sherriff, F. F. The Oil Merchants' Manual and Oil Trade Ready Reckoner. 2nd edn. Demy 8vo. Pp. 214. 1904. Scott, Greenwood. $8 s .6 d$. 
Simmons, W. H. Soap. Its Composition, Manufacture, and Properties. Cr. 8vo. Pp. 133. 1917. Pitman. 3s.

and Appleton, H. A. The Handbook of Soap Manufacture. Demy 8vo. Pp.160. 1908. Scott, Greenwood. $9 s, 6 d$. and Mitchell, C. A. Edible Fats and Oils : Their Composition, Manufacture, and Analysis. Demy 8vo. Pp. 150. 1911. Scott, Greenwood. 8s. 6d.

Southcombe, J. E. Chemistry of the Oil Industries. Demy 8vo. Pp. 213. 1913. Constable. 9s.

Watt, A. Soap Making. The Manufacture of Hard and Soft Soaps,

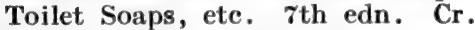
8vo. 1920. Crosby Lockwood. $8 s, 6 d$.

Wright, C. R. A. Animal and Vegetable Fixed Oils, Fats, Butters, and Waxes : their Preparation and Properties, and the Manufacture therefrom of Candles, Soaps, and other Products. 3rd edn. Revised and Enlarged $1 \mathrm{y}$ C. A. Mitchell. Large 8vo. Pp.953. 1921. Griffin. 56s.

x. PIGMENTS, PAINTS, VAR NISHES, RESINS, etc.

"An Analytical Chemist" (compiled by). Recipes for the Colour, Paint, Varnish, Oil, Soap and Drysaltery Trades. 2nd edn. Demy 8vo. Pp. 330. 1912. Scott, Greenwood. 12s, $6 d$.

Andés, L. E. Iron-Corrosion, AntiFouling and Anti-Corrosive Paints. Translated. 2nd edn. Demy 8vo. $\mathrm{P}_{1}, 300$. 1918. Scott. Greenwood. $15 s$.

Bersch, J. Manufacture of Mineral and Lake Pigments. Translated by A. C. Wright. Demy \$vo. Pp. 476. 1901. Scott: Greenwood. $14 s .6 d$.

Church, A. H. The Chemistry of Paints and Painting. 3rd edn. Cr. 8vo. Pp. 388. Seeley. 7s.6d.
Dieterich, K. The Analysis of Resins, Balsams and Gum Resins. Translated from the German. 2nd edn. revised by $H$. B. Stocks. 8vo. Pp. 447. 1920. Scott, Greenwood. 17s. 6d.

Friend, J.N. An Introduction to the Chemistry of Paints. Cr. 8vo. Pp. 214. 1910. Longmans. 5s.

Hurst, G. H. Dictionary of Chemicals and Raw Products used in the Manufacture of Paints, Colours, Varnishes and Allied Preparations. 2nd edn. Demy 8vo. Pp. 378. 1917. Scott, Greenwood. 12s. 6d.

Ingle, H., and Sutcliffe, J. A. L. A Manual of Oils, Resins, and Paints: for Students and Practical Men. Analysis and Valuation. Cr. 8vo. Pp. 138. 1915. Griffin. $4 s$.

Jennison, H. The Manufacture of Lake Pigments from Artificial Colours. 2nd edn. Demy 8vo. Pp. 180, 1920, Scott, Green. wood. 15s.

Laurie, A. P, Facts about Processes, Pigments, and Vehicles. A Manual for Art Students. Cr. 8vo. Pp. 142. 1895. Macmillan. 4.5 .

McIntosh, J. G. The Manufacture of Varnishes and Kindred Industries. Based on and including the "Drying Oils and Varnishes," by A. Livache. 3 Vols. Demy 8vo. Vol.1. The Crushing, Refining and Boiling of Iinseed Oil and other Varnish Oils. 3rd edn. Pp. 500. 1919. 17s. 6d. Vol. 2. Varnish Materials and Oil Varnish Making. 2nd edn. Pp. 220. 1908. 12s.6d. Vol. 3. Spirit Varnishes and Spirit Varnish Materials. 2nd edn. Pp. 482. 1911. 14s. 6d. Scott, Greenwood.

Morrell, R. S., and Waele, A. de. Rubber, Resins, Paints and Varnishes. Demy 8vo. Pp. 248. 1921. Baillière. 12s. 6d.

Parry, E. J. Gums and Resins. Their Occurrence, Properties, and Uses. Cr, 8vo. Pp. 112. 1918. Pitman. 3s. 


\section{Applied and Industrial Chemistry.}

Parry, E.J., and Coste, J.H. The Chemistry of Pigments. Demy 8vo. Pp.280. 1902. Scott, Greenwood. 12s. 6d.

Petit, G. The Manufacture and Comparative Merits of White Lead and Zinc Paints. Translated from the French. Cr. 8vo. Pp. 100 . 1907. Scott, Greenwood. 5s.

Schweizer, V. The Distillation of Resins. The Preparation of Resin Products, Lamp Black, Printing Inks, etc. Translated from the German. 2nd edn. Demy 8vo. Pp. 220. 1917. Scott, Greenwood. 12s. 6d.

Smith, J. C. The Manufacture of Paint. A Practical Handbook for Paint Manufacturers, Merchants and Painters. 2nd edn. Demy 8vo. Pp. 300. 1915. Scott, Greenwood. $12 s .6 d$.

Zerr, G., and Rubencamp, R. A Treatise on Colour Manufacture. A Guide to the Preparation, Examination, and Application of all the Pigment Colours in Practical Use. Translated by $\mathrm{C}$. Mayer. Large 8vo. Pp. 621. 1908. Griffin. 36s.

\section{xi. RUBber, gutta PERCHA, etc.}

Akers, C. E. The Rubber Industry in Brazil and the Orient. Cr. 8vo. Pp. 335. 1914. Methuen. 7s.6d.

Beadle, C., and Stevens, $H$. P. Rubber. Production and Utilisation of the Raw Product. 2nd edn. Cr.8vo. Pp. 150. 1915. Pitman. 3s.

Caspari, W. A. India Rubber Laboratory Practice. Cr. 8vo. Pp. 204. 1914. Macmillan.6s.6d.

Christy, C. The African Rubber Industry. Demy 8vo. Pp. 268. 1911. Bale \& Danielsson. 12s.6d.

Clouth, F. Rubber, Gutta Percha, and Balata. Roy. 8vo. Pp. 252. 1903. Maclaren. 12s. $6 d$.

Dubosc, A., and Luttringer, A. Rubber: Its Production, Chemistry, and Synthesis in the Light of Recent
Research. A Practical Handbook for the use of Rubber Cultivators, Chemists, and others. English edition by E. W. Lewis. Med.8vo. Pp.393. 1918. Griffin. 21s.

Heil, A., and Esch, W. The Manufacture of Rubber Goods. Translated by E. W. Lewis. 2nd edn. 8vo. Pp. 236 1919. Griffin. $12 s, 6 d$.

McIntosh, J. G. India Rubber and Gutta Percha. Based on the French Work of T. Seeligmann, G. L. Torrilhon and H. Falconnet. 2nd edn. Roy. 8vo. Pp. 400. 1910. Scott, Greenwood. 14s. 6d.

Porritt, B. D. The Chemistry of Rubber. Cr. 8vo. New edition in preparation. Gurney and Jackson.

Potts, H. E. The Chemistry of the Rubber Industry. Demy 8vo. Pp. 163. 1915. Constable. 7s. 6d.

Schidrowitz, P. Rubber. 2nd edn. Demy 8vo. Pp. 319. 1916. Methuen. $15 s$.

Terry, H. L. India Rubber and Its Manufacture: with Chapters on Gutta Percha and Balata. 3rd imp. Ex. Cr. 8vo. Pp. 302. 1919. Constable. $8 s, 6 d$.

Torrey, J., and Manders, A. S. (edited by). The Rubber Industry . Demy 8vo. Pp. 470. 1911. Pitman. 15s. 6d.

Weber, C. O. The Chemistry of India-rubber. Including the Outlines of A Theory on Vulcanisation. 5th edn. Large 8vo. $\mathbf{P}_{\mathrm{p}} .324$. 1919. Griffin. 18s.

Whitby, G. S. Plantation Rubber and the Testing of Rubber. Demy 8vo. Pp. 575. 1920. Longmans. $28 s$.

Xii. FUELS, SMOKE PREVENTION, etc.

Barker, A. H. Domestic Fuel Consumption. Demy 8vo. Pp. 169. 1920. Constable. 14s.

Booth, W. H., and Kershaw, J. B. C. Smoke Prevention and Fuel Economy. Demy 8vo. Pp. 194. 1904. Constable. 10s. $6 d$. 


\section{Applied and Industrial Chemistry.}

Brame, J. S. S. Fuel: Solid, Liquid, and Gaseous. 2nd edn. Demy 8vo. Pp. 372. 1917. Arnold. 15s.

Brislee, F.J. An Introduction to the Study of Fuel. A Text-book for those entering the Engineering, Chemical and Technical Industries. 2nd imp. Demy 8vo. Pp. 291. 1920. Constable. 9s. 6d.

Cohen, J. B., and Ruston, A. G. Smoke: A Study of Town Air. Demy 8vo. Pp. 96. 1912. E. Arnold. 5s.

Coste, J. H., and Andrews, E. R. The Examination and Thermal Value of Fuel: Gaseous, Liquid, and Solid. Cr. 8vo. Pp. 224. 1914. Griffin. 7s. 6d.

Kershaw, J. B. C. Fuel, Water, and Gas Analysis for Steam Users. 2nd edn. Demy 8vo. Pp. 212. 1919. Constable. 12s. $6 d$.

The Use of Low-Grade and Waste Fuels for Power Generation. Demy 8vo. Pp. 212. 1920. Constable. $17 s$.

Lewes, V. B. Liquid and Gaseous Fuels and the Part they Play in Modern Power Production. Edited by J. B. C. Kershaw. 2nd edn. Ex. Cr. 8vo. Pp. 348. 1920 . Constable. 12s. 6d.

Nicholson, W. Smoke Abatement. A Manual for the use of Manu. facturers, Inspectors, Medical Officers of Health, Engineers, etc. Cr. 8vo. Pp. 169. 1905. Griffin. $7 s, 6 d$.

Popplewell, W. G. The Prevention of Smoke, Combined with the Economical Combustion of Fuel. Demy 8vo. Pp. 190. 1901 . Scott, Greenwood. 8s.6d.

Taylor, H. S. Fuel Production and Útilization. Med. 8vo. Pp. 313 . 1920. Baillière. 10s. $6 d$.

\section{xil. LIQUID FUELS AND THEIR PRAGTICAL USE.}

Booth, W. H. Liquid Fuel and its Apparatus. Theory, Principles, and Practice: Tables and Data. 2nd edn. Demy 8vo. Pp. 308. 1914. Constable. 9s.

-Liquid Fuel and its Combustion.

Imperial 8vo. Pp. 431. 1903 .

Constable. 24s.

Butler, E. Oil Fuel: Its Supply, Composition, and Application. 4th edn. Cr. 8vo. Pp. 326. 1921. Griffin. 12s. $6 d$.

Hodgett, E. A. B. (compiled by). Liquid Fuel for Mechanical and Industrial Purposes. 8vo. Pp. 142. 1890. Spon. 5s.

Moore, H. Liquid Fuels for Internal Combustion Engines, A Practical Treatise for Engineers and Chemists. 2nd edn. Demy 8vo. Pp. 221. 1920. Crosby Lockwood. 15s.

Sothern, J.W.M. Oil Fuel Burning in Marine Practice. A Manual of Practical Instruction in Oil Fuel Burning. Roy. 8vo. Pp. 198. 1920. Jas. Munro. $30 s$.

\section{xiv. PRODUGER GAS : ACETY -} LENE.

Dowson, J. E., and Larter, A. T . Producer Gas. 4th edn. Demy 8ro. Pp. 379. 1920. Longmans. $21 s$.

Leeds, F. H., and Butterfield, W. J. A. Acetylene: The Principles of its Generation and Use. 3rd edn, in preparation. Griffin.

Sexton, A. H. Producer Gas. A Sketch of the Properties, Manufacture, and Uses of Gaseous Fuel. Demy 8vo. New edn. in preparation. Scientific Pub. Co. 10 s.

\section{PETROLEUM AND MINERAL OILS.}

Campbell, A. Petroleum Refining . 2nd edition in preparation. Griffin.

Evans, E. A. Lubricating and Allied Oils. A Handbook for Chemists, Engineers and Students. Demy 8vo. Pp. 144. 1921. Chapman \& Hall. $9 s .6 d$.

Greene, J. A. (edited by). A Treatise on British Mineral Oil. Geological, by E. H. C. Craig; 


\section{Applied and Industrial Chemistry.}

Retorting, by W. R. Ormandy and F. M. Perkin. Refining, by $A$. Campbell. Chemical, by A. E. Dunstan. Power, by A. H. Seabrook. Large 8vo. Pp. 244. 1919. Griffin. 21s.

Gregorius, R. Mineral Waxes: Their Preparation and Uses. Translated from the German. Cr. 8vo. Pp. 250. 1908. Scott, Greenwood. $7 s$.

Gooday, W. E. Petrol and Petroleum Spirits. A Description of their Sources, Preparation. Examination and Uses. Demy 8vo. Pp. 147. 1918. Arnold. 10s.6d.

Hicks, J. A. The Laboratory Book of Mineral Oil Testing. 3rd edn. Revised by A. G. V. Berry. Cr. 8vo. Pp. 93. 1918. Griffin. 3.. 6 d.

Hurst, G. H. Lubricating Oils, Fats, and Greases: Their Origin, Preparation, Properties. Uses, and Analyses. 3rd edn. Demy 8vo. Pp.381. 1911. Scott. Greenwood. 12s. $6 d$.

Key, A. C. A Primer on the Storage of Petroleum Spirit and Carbide of Calcium, for the use of Local Inspectors and Motorists. 2nd edn. Cr. 8vo. Pp. 143. 1921. Griffin. $5 s$.

Lidgett, A. Petroleum. Cr. 8vo. Pp. 175. 1919. Pitman. 3s.

Redwood, Sir B., and Others. A Treatise on Petroleum. 4 vols. Fourth edition in preparation. Griffin.

and Eastlake, A. The Petroleum Technologist's Pocket Book. Pocket size. Pp. 475. 1915. Griffin. $10 s .6 d$.

Redwood, I. I. A Practical Treatise on Mineral Oils and their By-Products, including the Scotch Shale Oil Industry, ete. Svo. Pp. 336. 1914. Spon. 15s.

Lubricants, Oils, and Greases: Treated theoretically, and giving practical information regarding their Composition, Uses, and Manufacture. 8vo. 1918. Spon. 7s.6d.
Scheithauer, W. Shale Oils and Tars and their Products. Translated from the German. Demy 8vo. Pp. 183. 1913. Scott. Greenwood. 9s.6d.

Talbot, F. A. The Oil Conquest of the World. Demy Svo. Pp. 320. 1914. Heinemann. 6s.

Thomson, J.H., and Redwood, Sir B. The Petroleum Lamp. Cr. 8vo. Pp. 111 . 1902. Griffin. 1s. 6 d.

A Handbook on Petroleum, for Inspectors under the Petroleum Acts. \&e. 3rd edn. Iarge 8vo. Pp. 359. 1913. Griffin. 10s.6d.

Tinkler, C. K., and Challenger, F. The Chemistry of Petroleum and its Substitutes. A Practical Handbook. Med. Rvo. Pp. 368. 1919. Crosby Iockwood. $15 s$.

\section{xvi. COAL : BRIQUETTING, ETC.}

Bone, W. A. Coal and its Scientific Uses. 2nd imp. 8vo. Pp. 506. 1919. Longmans. 22s. 6d.

Franke, G. Handbook of Briquetting. 'Translated by F. C. A. H. Lantsberry. 2 vols. Med. 8vo. Vol. 1. Briquetting of Coals, Brown Coals, and other Fuels. Pr. 659. 1917. 36s. Vol. 2. Rriquetting and Agglomeration of Ores, Metallurgical Products, Metal Swarf and Similar Materials. Pp. 225. 1918. 15s. Griffin.

Putsch, A. Gas and Coal-Dust Firing: A Critical Review of the Various Appliances Patented in Germany for this purpose from 1885 to 1895. Translated from the German by C. Salter. Demy 8vo. Pp.130. 1901. Scott, Greenwood. $6 s$.

Robertson, J.B. The Chemistry of Coal. Cr. 8vo. Pp. 104. 1919. Gurney \& Jarkson. 3s.6d.

Stopes, M. C., and Wheeler, R.V. Monograph on the Constitution of Coal. Roy. 4to. Pp. 58. 1918. H. M. Stationery Office. 2s. 
Summers, A.L. All About Anthracite: The World's Premier Coal. Demy 8vo. Pp.124. 1919. Technical Pub. Co. 7s. $6 d$.

Tonge, J. Coal. Ex. Cr.8vo. Py. 281. Constable. $7 s, 6 d$.

\section{XVii. GAS MANUFACTURE: COAL TAR AND ITS PRODUCTS.}

Barnett, E. de B. Anthracene and Anthraquinone, Demy 8vo. Pp. 448. 1921. Baillière. 25s.

Biddulph-Smith, T. Coke-Oven and By-Product Works Chemistry. Demv 8vo. Pp. 190. 1921. Griffin. $21 s$.

Brooke, T. Modern Retort Settings . Their Construction and Working. Demy 8vo. Pp. 212. 1912. Benn Bros. 9s.

Christopher, J. E., and Byrom, T. H. Modern Coking Practice: including the Analysis of the Materials and Products. 3rd edn. 2 vols. Demy 8vo. 1921. Vol. 1. Raw Materials and Coke. Pp. 142. Vol 2. By-Products. Pp. 148. Crosby Lockwood. 10s. 6d. each vol.

Cooper, E. S. By-Product Coking . New edn. in preparation. Benn Bros .

Findlay, A. The Treasures of Coal Tar. 2nd edn. Cr.8vo. Pp. 137. 1918. Allen \& Unwin. 4s.6d.

Gardner, W. M. The British Coal Tar Industry: its Origin, Development, and Decline. Med. 8vo. Pp. 436. 1915. Williams \& Norgate. 12s.6d.

Hornby, J. Gas Manufacture. 8th edn. Demy 8vo. Pp. 434. 1920. Bell. 12s.

Humphrys, N.H. Construction and Management of Small Gas Works, with a Section on Costs and Capac. ity of Works, by J.H. Brearley. Cr. 8vo. Pp. 265. 1911. Benn Bros. 9s.

Lange, K. R. By-Products of CoalGas Manufacture. Translated from the German. Cr. 8vo. Pp. 164. 1915. Scott, Greenwood. 68 .
Lewes, V. B. The Carbonisation of Coal. A Scientific Review of the Formation, Composition and Destructive Distillation of Coal for Gas, Coke and By-Products, with an addition on Recent Developments by A. B. Searle. 2nd edn. Demy 8vo. Pp.310. 1918. Benn Bros. 12s.6d.

Lunge, G. Coal Tar and Ammonia. 5th edn. 8vo. In 3 Parts. Pp. 1,718. 1916. Gurney \& Jackson. $75 s$.

Malatesta, G. Coal-Tar and their Derivatives. The Production of Tars from Gas Coals, Coke Ovens, Water Gas, Oil Gas, Lignite, Wood and Peat. The Manufacture of Pitch. Asphalt, and Bitumen; and the Chemical Examination and Analysis of the Raw Materials and By-Products of the Industry . Translated from the Italian. Demy 8vo. Pp. 541. 1920. Spon. 21s.

Meade, A. Modern Gasworks Practice. 2nd edn. in preparation. Benn Bros.

"Mentor." Self-Instruction for Students in Gas Engineering. Part 1. Elementary (Ordinary Grade). 5 th edn. Demy 8vo. Pp. 178. 1918. 6s. Part 2. Advanced (Honours Grade). 4th edn. Demy 8vo. Pp. 234. 1921. 10s.6d. Benn Bros.

O'Connor, H. Gas Engineers 'Pocket Book. Manufacture, Distribution and Use of Coal Gas. 3rd edn. Cr. svo. 1007. Crosby Lockwood. $12 s .6 d$.

Scott, J. F. Estimates and Valuations. A Handbook of Data and Prices for Gas Engineers, Building Works and Gasworks Plant, etc. Demy 8vo. Pp. 113. 1913. Benn Bros. 10s. 6d.

Warnes, A. R. Coal Tar and Some of its Products. Cr. 8vo. Pp. 127. 1919. Pitman. 3s.

Coal Tar Distillation and Working-up of Tar Products. 2nd edn. Demy 8vo. Pp.310. 1917. Benn Bros. 12s. $6 d$. 


\section{Applied and Industrial Chemistry.}

Webber, W. H. Y. Gas and Gas Making. Growth, Methods, and Prospects of the Industry. Cr. 8vo. Pp. 141. 1919. Pitman. 3s.

Whitehead, S.E. Benzol : its Recovery, Rectification and Uses. Demy 8vo. Pp. 223. 1920. Benn Bros. $12 s .6 d$.

\section{xviii. CHEMISTRY AND ANALYSIS OF GAS.}

Abady, J. The Gas Analyst's Manunl. 8vo. Pp. 576. 1902. Spon. $21 s$.

Ghandley, C. Gas T'esting and Air Measurement. 2nd edn. Cr. 8vo. Pp. 86. 1913. Methuen. 2s. 3d.

Coste, J. H. The Calorific Power of Gas. Cr. Svo. Pr. 326. 1911. Griffin. $7 s, 6 d$.

Franzen, H. Exercises in Gas Analysis. Translated from the German by T. Callan. Cr. 8vo. Pp. 119. 1913. Blackie. 2s.6d.

Greenwood, H.C. Industrial Gases . Demy 8vo. Pp. 371. 1920. Baillière. 12s. 6d .

Hornby, J. The Gas Engineers' Laboratory Handbook. 3rd edn. Cr. 8vo. Pp. 328, 1911. Spon. $7 s, 6 d$.

Lunge, G. Technical Gas Analysis. Med.8vo. Pp.424. 1916. Gurney \& Jackson. 15s.

Martin, G., Dickson, J. M., Jobling, F., and others. Indus: trial Gases. Including the Lique. faction of Gases, etc. 2nd imp. Roy. 8vo. Pp.158. 191s. Crosby Lockwood. 9s.

Royle, H. M. The Chemistry of Gas Manufacture. Demy 8vo. Pp. 340 . 1907. Crosby I.ockwood. 15s.

\section{xix. DISTRIBUTION OF GAS.}

Briggs, F. W . , and Henwood, J.H. A Manual on Gas-fitting and Appliances. Cr. 8vo. Pp. 191. 1920. Crosby Lo:kwood. 6s.

Hole, W. Distribution of Gas. 4th edition in preparation. Benn Bros.
"Mentor." Self-Instruction for Students in Gas Supply. Part 1. Elementary (Ordinary Grade). 3rd edn. Demy 8vo. Pp. 226. 1920. 6s. Part 2. Advanced (Honours Grade). 2nd edn. Demy 8vo. Pp. 252. 1914. 6s. Benn Bros.

Webber, W. H. Y. Gas Supply in Principle and Practice. Cr. 8vo. Pp. 20s. 1914. Pitman. $4 s$.

- Town Gas and its Uses for the Production of Light, Heat, and Motive Power. Ex. Cr. Svo. Pp. 275. 1907. Constable. 7s, 6d.

- On the Flow of Gas through Orifices and Small Pipes. New edn. Demy 8vo. Pp.35. Paper covers. Benn Bros. 1s. $6 d$.

Woodall, H., and Parkinson, B. R. Distribution by Steel (Gas and Water). Ind edn. Demy 8vo. Pp. 250. 1920. Benn Bros. 15s.

\section{xx. PEAT}

Bjorling, P. R., and Gissing, F . T . Peat: Its Uses and Manufacture. Cr. 8vo. Pp. 185. 1907. Griffin. 7s. $6 d$.

Gissing, F . T . Peat Industry Reference Book. Pocket size. Pp. 316. 1920. Griffin. 7s, $6 d$.

_- Commercial Peat: Its Uses and its Possibilities. Cr. 8vo. Pp. 210. 1919. Griffin. 7s. 6d.

\section{xxi. DYESTUFFS AND DYEING.}

Barnett, E. de B. Coal Tar Dyes and Intermediates. Demy svo. Pp.230. 1919. Baillière. 10s.6d.

Bersch, J. The Manufacture of Earth Colours. Translated from the ard German edn. by C. Salter. Cr. Svo. Pp. 216. 1921. Scott, Greenwood. 7s. 6d.

Gain, J.C. The Chemistry and Technology of the Diazo Compounds. 2nd edn. Demy 8vo. Pp. 109. 1920. Arnold. 12s. $6 a^{3}$.

- The Manufacture of Intermediate Products for Dyes. 2nd edn. 8vo. Pp. 284. 1919. Macmillan. 10s. 


\section{Applied and Industrial Chemistry.}

Cain, J. G, and Thorpe, J. F The Synthetic Dyestuffs, and the Intermediate Products from which they are derived. Theoretical, Practical and Analytical. 5th edn. Large 8vo. Pp.440. 1920. Griffin. $21 s$.

Dreaper, W.P. The Chemistry and Physius of Dyeing. 8vo. Pp. 328 . 1906. Churchill. 10s.6d.

Farrell, F. J. Dyeing and Cleaning . 4th edn. Cr.8vo. Pp. 263. 1917. Griffin. 6s.

Fierz-David, H. E. The Fundamental Processes of Dye Chemistry. Translated by F. A. Mason. 8vo. Pp. 254. 1921. Churchill. 21s.

Fort, M., and Lloyd, L. L. The Chemistry of Dyestuffs. Cr. 8vo. Pp. 311. 1919. Cambridge University Press. 10s. 6d.

Georgievics, G., and Grandmongin, E. A Text-Book of Dye Chemistry (The Chemistry of Dye-Stuffs). Translated by F. A. Mason. 8vo. Pp. 576. 1920. Scott Greenwood. $30 s$.

Green, A. G. A Systematic Survey of the Organic Colouring Matters. Founded on the German of $G$. Schultz and P. Julius. 3rd imp. Imp. 8vo. Pp. 292. 1908. Macmillan. 25s.

The Analysis of Dyestuffs and their Identilication in Dyed and Coloured Materials, Lake Pigments, Foodstuffs, etc. 3rd edn. Large svo. Pp.154. 1920. Griffin. $10 s .6 d$.

Hasluck, P. N. (edited by). Mordants. Methods and Machinery Used in Dyeing. Cr. 8vo. Pp. 168. 1906. Cassell. 3s.

Heerman, P. Dyers' Materials : An Introduction to the Examination, Valuation and Application of the most important Substances used in Dyeing, Printing, Rleaching and Finishing. Translated by A. C. Wright. 2nd edn. Cr. 8vo. Pp. 160. 1919. Scott, Greenwood. 7s.6d.
Higgins, S. H. The Dyeing Industtry : being a Third Edition of "Dyeing in Germany and America." 8vo. Pp. 198. 1919. Longmans. $8 s .6 d$.

Hübner, J. The Chemistry of Dyeing and Bleaching of V'egetable Fibrous Materials. 2nd edn. Demy 8vo. Pp. 457. 1919. Constable. 20s.

Knecht, E., Rawson, C., and Loewenthal, R. A Manual of Dyeing. 2 vols. 6th edn. Pp. 383., 531. 1920. Griltin. 42s.

Martin, G., Beacall, T ., Challen Ler, F., and Sand, H. J. S. Dyestuffs and Coal-Tar Products. 'Their Chemistry, Manufacture, and Application. Roy. 8vo. Pp.162. 1916. Crosby Lockwood. 9s.

Nietzki, R. Chemistry of Organic Dye-Stufls. 'Translated with additions by A. Collin and W. Richatdson. 8vo. Pp.329. 1892. Gurney \& Jackson. $15 s$.

Perkin, A. G., and Everest, A. E. The Natural Organic Colouring Matters. 8vo. Pp. 678. 1918. Longmans. $30 s$.

Ramsay, A. R. J., and Weston, H. C. Artificial Dyestuffs: their Na. ture, Manufacture, and Use. 8voPp.218. 1917. Routledge. 3s.6d.

Rawson, C., Gardner, W. M., and Laycock, W. F. A Dictionary of Dyes, Mordants and other Compounds used in Dyeing and Calico Printing. Reprint of First edn. Large 8vo. Pp. 372. 1918. Griffin. $18 s$.

Soxhlet, D. H. The Art of Dyeing and Staining Marble, Artificial Stone, Bone, Horn, Ivory and Wood, and of Imitating all Sorts of Wood. A Practical Hand-book for the Use of Joiners, Turners, Manufacturers of Fancy Goods, Sticks, Umbrellas, Combs, etc. Translated from the German. Cr. 8vo. Pp. 168. 1902. Scott, Greenwood. 6s.

Wahl, A. The Manufacture of Organic Dyestuffs. Translated with additions from the French by $F$. W. Atack. 3rd imp. Cr. 8vo. Pp. 352. 1919. Bell. 6s. 


\section{Applied and Industrial Chemistry.}

Whittaker, C. M. The Application of the Coal Tar Dye Stuff's, Principles Involved and Methods Employed. Demy 8vo. Pp.226.1918. Baillière. 10s. 6d.

Wood, J.K. The Chemistry of Dyeing. Cr.8vo. Pp. 88. Gurney \& Jackson. 2s.6d.

Zerr, G. Tests for Coal-Tar Colours in Aniline Lakes. Translated by C. Mayer. Med. 8vo. Pp. 242 . 1910. Griffin. 12s. $6 d$.

\section{xxii. INK MANUFAGTURE.}

Lehner, S. Ink Manufacture: Including Writing, Copying, Lithographic, Marking, Stamping, and Laundry Inks. Translated from the German. 2nd edn. Cr. 8vo. Pp.180. 1914. Scott, Greenwood. $6 s$.

Mitchell, C. A., and Hepworth, T. C. The Manufacture of Ink. A Handbook of the Production and Properties of Printing, Writing, and Copying Inks. 2nd edn. Large 8vo. Pp. 272. 1916. Griffin. 9s .

Seymour, A. Modern Printing Inks. A Practical Handbook for Printing Manufacturers and Printers. Demy 8vo. Pp.90. 1910. Scott, Greenwood. $6 s$.

xxiii. PAPER MAKING .

Andès, L. E. The Treatment of Paper for Special Purposes. Translated. Cr. 8vo. Pp. 250. 1907. Scott, Greenwood. $7 s$.

Beadle, C. Chapters on Paper Making. 5 Vols. Vol. 1. Pp. 151. 1908. Vol. 2. Pp. 182. 1919. Vol. 3. Pp. 142. 1907. Vol. 4. Pp. 164. 1907. Vol.5. Pp. 190. 191)8. Crosby Lockwood. 6s, each rol.

Bromley, H. A. Paper and Its Constituents. A Manual of Technical Methods, Chemistry and Analysis of Raw materials; Paper-Making Fibres; Bleaching, Sizing, and Loading Agents and Dyestuffs; Microscopy; and Physical and Chemical Properties of Paper. Demy 8vo. Pp. 239. 1920. Spon. 15s.
Chalmers, T. W. Paper Making and Its Machinery. Including Chapters on the Tub Sizing of Paper, the Coating and Finishing of Art Paper and the Coating of Photographic Paper. Imp. 8vo. Pp. 190. 1920. Constable. 26s.

Clapperton, G. Paper Making. A Practical Manual for Paper Makers and Owners of Paper Mills; with Tables and Calculations. 2nd edn. Cr. 8vo. 1917. Crosby Lockwood. $7 s .6 d$.

Cross, C. F., and Bevan, E. J. A Text-book of Paper Making. 5th edn. Demy 8vo. Pp. 450. 1920. Spon. 30s.

_- Beadle, G., and Sindall, R. W. C. B. S. Standard Units and Standard Paper Tests. 4to. Pp. 25. 1903. Spon. 2s.6d.

and Sindall, R.W. Wood Pulp. 2nd edn. Ex. Cr. 8vo. Pp. 275. 1918. Constable. 8s. 6d.

Maddox, H. A. Paper. Its History, Sources, and Production. Cr. 8vo. Pp. 167. 1917. Pitman. 3s.

Sindall, R. W. The Manufacture of Paper. 2nd imp. Ex. Cr. 8vo. Pp.285. 1919. Constable. 8s.6d.

- Paper Technology: An Elementary Manual on the Manufacture, Physical Qualities, and Chemical Constituents of Paper and of Papermaking Fibres. 3rd edn. Demy 8vo. Pp. 353 and 14 Plates. 1920. Griffin. $21 s$.

Stevens, H. P. The Paper Mill Chemist. 2nd edn. Roy. 12mo. Pp. 325. 1919. Scott, Greenwood, 10s. $6 d$.

Watt, A. Paper Making. The Manufacture of Paper from Rags, Esparto, Straw, Wood Fibre, etc. New imp. Cr. 8vo. 1918. Crosby Lockwood. $8 s, 6 d$.

\section{XXiv . LEATHER MANUFACTURE} AND TANNING.

Adcock, K. J. Leather: From the Raw Material to the Finished Product. Cr. 8vo. Pp. 167. 1915. Pitman. 3s. 


\section{Applied and Industrial Chemistry.}

Bennett, H. G. The Manufacture of Leather. 3rd imp. Demy 8vo. Pp. 442. 1919. Constable. 18s.

Harvey, A. Practical Leather Chemistry. A Handbook of Laboratory Notes and Methods for the Use of Students and Works' Chemists. Med. Svo. Pp. 207. 1919. Crosby Lockwood. 15s.

Procter, H. R. The Principles of Leather Manufacture. New edition in preparation. Spon.

- The Making of Leather. Roy. 16mo. Pp. 161. 1914. Cambridge University Press. $2 s .6 d$.

- Leather Industries Lahoratory Book of Analytical and Experimental Methods. 2nd edn. Svo. Pp. 450. 1919. Spon. 25s.

-... (edited by). Leather Chemists ${ }^{\text {. }}$ Pocket Book. A short compendium of Analytical Methods. $16 \mathrm{mo}$. Pp. 237. 1919. Spon. 7s.6d.

Standage, H. C. The I.eather Workers' Manual. 3rd edn. Svo. Pp. 173. 1920. Scott, Greenwood. 10 s. $6 d$.

Trotman, S. R. Leather Trades' Chemistry . A Practical Manual on the Analysis of Materials and Finished Products. Large 8vo. Pp. 300. 1908. Griffin. $18 s$.

Watt, A. Leather Manufacture. $\Lambda$ Practical Handbook of Tanning, Currying, and Chrome Leather Dressing. 5th edn. Svo. 1919. Crosby Lockwood. 15s.

Wood, .J. T. The Puering, Bating, and Drenching of Skins. Svo. Pp. 315. 1912. Spon. 14s.

xxv. GLASS, POTTERY AND CERAMICS.

Asch, W., and D. The Sili. cates in Chemistry and Commerce. Translated with critical notes and some additions by A. B. Searle. Roy. 8vo. Pp. 120, 1915. Constable. 21s.

Audley, I. A. Silica and the Silicates. Demy 8vo. Pp. 388. 1921. Baillière. 158 .
Bellow, H. R. (edited by): Factory Glazes for Ceramic Engineers, arranged on an exhaustive method for the heat of the Soft Porcelain Kiln, and including the Glazes employed in actual manufacture. Series A. Folio. 1908. Spon. 42s.

Binns, C. F. (edited by). The Manual of Practical Potting. 4th edn. Demy 8vo. Pp. 204. 1907. Scott, Greenwood. 19s. 6d.

Duthie, A . L. Decorative Glass Processes. 2nd imp. Ex. Cr. 8vo. Pp.279. 1908. Constable. 8s.6d.

Hainbach, R. Pottery Decorating. A Description of all the Processes for Decorating Pottery and Porcelain. Translated from the German. Cr. 8vo. Pp. 250. 1907. Scott, Greenwood. 8s. fid.

Hovestadt, H. Jena Glass and its Scientific and Industrial Applications. Translated by .J. D. and Alice Everett. 8vo. P̈p. 436.1902. Marmillan. 18s.

Howorth, J. The Art of Riveting Glass, China. and Earthenware. 2nd edn. 1908. Scott, Greenwood. $1 s$.

Marson, P. Glass and Glass Manufacture. Cr. 8vo. Pp. 138. 1918. Pitman. 3s.

Mellor. J.W.(edited by). Clay and Pottery Industries : Being Vol 1. of the Collected Papers from the County Pottery Laboratory, Staffordshire. By Several Äuthors. Demy 8vo. Pp. 428. 1914. Griffin. $18 \mathrm{~s}$.

Recipes for Flint Glass Making. By a British Glass Master and Mixer, 60 Recipes. Being Leaves from the Mixing Book of Several experts in the Flint Glass Trade. containing up-to-date recipes and valuable information as to Crystal, Demi-Crystal. and Coloured Glass in its many varieties. 2nd edn. Cr. 8vo. 1907. Scott, Greenwood. $12 s .6 d$.

Rosenhain, W. Glass Manufacture. 2nd edn. Ex. Cr. 8vo. Pp. 258. 1919. Constable. 12s.6d. 


\section{Applied and Industrial Chemistry.}

Sandeman, E. A. The Manufacture of Earthenware. A Practical Treatise. 3rd imp. Cr. 8vo. Pp. 384. 1921. Crosby Lockwood. $12 s$.

Searle, A. B. The Clay Workers' Handbook. A Manual for all engaged in the Manufacture of Articles from Clay. 3rd edn. Demy 8vo. Pp. 400. 1921. Griffin. 21s.

- The Ceramic Industries Pocket Book. Pocket Size. Pp. 274. 1920. Pitman. Ss. 6d.

- Refractory Materials : Their Manufacture and Uses. 2nd edition in preparation. Griffin.

Shaw, S. The History of the Stafiordshire Potteries; and the Rise and Progress of the Manufacture of Pottery and Porcelain. With References to Genuine Specimens and Notices of Eminent Potters. A Re-Issue, originally putilished in 1829. Demy 8vo. Pp. 256. 1900. Scott, Greenwood. 6s.

Suffling, E. R. A Treatise on the Art of Glass Painting. Prefaced with a Review of Ancient Glass. Demy 8vo. Pp. 140. 1902. Srott, Greenwood. 8s. 6d.

Whall, G.W. Stained Glass Work. New Imp. Cr. 8vo. Pp. 381. 1920. Pitman. 10s.6d.

\section{XXvi. EXPLOSIVES AND THEIR MANUFACTURE.}

Barnett, E. de B. Explosives. Demy Svo. Pp. 256. 1919. Baillière. $12 s, 6 d$.

Berthelot, M. Explosives and their Powers. Translated and condensed from the French by C. Napier Hake and W. MacNab. 8vo. Pp. 563. 1892. Murray. 28s.

Bichel, C. E. New Methods of Testing Explosives. Translated and edited by A. Iarsen. Med. 8vo. Pp. 67. 1905. Griffin. 7s.6d.

Colver, E. de W. S. High Explosives: A Practical Treatise on their History, Manufacture, Properties. and Use. Roy. 8vo. Pp.830.1918. Crosby Lockwood. 63s.
Guttmann, O. Twenty Years' Progress in the Manufacture of Explosives. Med. 8vo. Pp. 84. 1909. Pitman. 3s. 6d.

The Manufacture of Explosives. A Theoretical and Practical Treatise on the History and Manufacture of Explosives. 2 vols. Med. 8vo. Pp. 348., 448. 1895. Pitman. 50s.

Levy, S. I. Modern Explosives. Cr. 8vo. Pp. 119. 1920. Pitman. 3s.

MacDonald, G. W. Historical Papers on Modern Explosives. Med. 8vo. Pp. 192. 1912. Pitman. 9s.

Marshall, A. Explosives. History and Manufacture: Properties and Tests. 2 vols. Cr. 4to. Pp. 822. 1917. Churchill. 63s.

A Short Account of Explosives. Cr.4to. Pp. 104. 1917. Churchill. $7 s .6 d$.

- Dictionary of Explosives. 8vo. Pp. 159. 1920. Churchill. 15s.

Martin, G., and Barbour, W. Industrial Nitrogen Compounds and Explosives: their Manufacture, Properties and Industrial I'ses" 2nd edn. Roy.8vo. Pp.133.1917. Croshy Lockwood. 9s.

Rise and Progress of the British Explosives Industry, The. By the Explosives Section of the Seventh International Congress of Applied Chemistry. Cr. 4to. Pp. 420. 1909. Pitman. 18s.

Sanford, P. G. Nitro-Explosives. Their Properties, Manufacture and Analysis. 2nd edn. Demy 8vo. Pp. 312. 1906. Crosby Lockwood. $12 s$.

xxvii. ACIDS, ALKALIES, SALTS, etc.

Adlam, G. H. J. A cids, Alkalies and Salts. Cr. 8vo. Pp.121.1920. Pitman. 3s.

Bottler, M. Modern Bleaching Agents and Detergents. Translated from the German. Cr. 8vo. Pp. 160. 1910. Scott, Greenwood. 6s . 


\section{Applied and Industrial Chemistry.}

Calvert, A. F. Salt and the Salt Industry. Cr. 8vo. Pp. 158. 1919. Pitman. 3s.

- Salt in Cheshire. Demy svo. Pp. 1206. 1915. Spon. 30s.

Calvert, G. T. Manufacture of Sulphate of Ammonia and Crude Ammonia. 2nd edn. Demy \&vo. Pp. 161. 1917. Benn Bros. 9s.

Dobbin, L., and Marshall, $H$. Salts and their Reactions. A Class Book of Practical Chemistry. 4th edn. 8vo. Pp. 203. 1920. J. Thin. 6s. 6d.

Grossman, J. Ammonia and its Compounds. Pott. 8vo. Pp. 161 . 1906. Harper. 3s.

Lunge, G. The Manufacture of Sulphuric Acid and Alkali. New edn. in preparation. Gurney \& Jackson.

Martin, G., and Foucar, J. L. Sulphuric Acid and Sulphur Products. 2nd edn. Roy. 8vo. Pp. 85. 1920. Crosby Lockwood. 9s.

Maxted, E. B. Ammonia and the Nitrides, with special reference to their Synthesis. Cr. 8vo. Pp. 124. 1921. Churchill. 7s.6d.

Martin, G., and Clough, G. W . Chlorine and Chlorine Products. Including the Manufacture of Bleaching Powder, Hypochlorites, Chlorates, Bromine, Iodine, etc. 2nd imp. Roy. 8vo. Pp. 108. 1918. Crosby Lockwood. 9s .

Smith, S., and Milsom, F. The Salt and Alkali Industry. The Manufacture of Hydrochloric Acid, Sodium Sulphate, \&c. 2nd edn. Roy. 8vo. Pp. 108. 1920. Crosby Lockwood. 9s.

Partington, J.R. The Alkali Industry. Demy 8vo. Pp. 304. 1918. Baillière. $10 s .6 d$.

Vincent, C. Ammonia and Its Compounds: Their Manufacture and Uses. Translated. Roy. 8vo. Pp. 114. 1901. Scott, Greenwood. $6 s$.

\section{xxviii. UTILISATION OF WASTE PRODUCTS ; WOOD PRODUCTS.}

Dumesny, P., and Noyer, $J$. Wood Products: Distillates and Extracts. Translated from the French by D. Grant. Roy. 8vo. Pp. 320. 1908. Scott, Greenwood. 12s. fid.

Hubbard, E. The Utilisation of Wood Waste. Translated from the German. 3rd edn. Revised by H. B. Stocks, Cr, 8vo. P(), 248. 1920. Scott, Greenwood. 10s. 6d.

Koller, T. The Utilisation of W'aste Products. Translated from the German. 3rd edn. Demy 8vo. Pp.338.'1918: Scott, Greenwood. $12 s .6 d$.

Naylor, W. Trades' Waste: its Treatment and Utilisation. Med. 8vo. Pp. 283. 1902. Griffin. 25s.

Spooner, H.J. Wealth from Waste. Flimination of Waste a World Prohlem. 8vo. Pp. 332. 1918. Routledge. 7 s. 6id.

\section{XXix. MISCELLANEOUS}

\section{CHEMICAL MANUFACTURES.}

Allen, A. W. The Recovery of Nitrate from Chilean Caliche: containing a vocabulary of Terms, an account of the Shanks system, with a criticism of its fundamental features, and a description of a new process. Cr. 8vo. Pp. 66. 1921. Griffin. 6s.

Barrowcliff, M., and Carr, F. H. Organic Medicinal Chemicals (Synthetic and Natural). Demy 8vo. Pp. 345. 1921. Baillière. 15s.

Berkeley, H.R., and Walker, W. M. Practical Receipts for the Manufacturer, the Mechanic, and for Home Use. New imp. 8vo. Pp. 250. 1912. Spon. 7s. 6d.

Böckmann, F. Celluloid: Its Raw Material, Manufacture, Properties, and Uses. Translated from the German. Cr.8vo. Pp.120. 1907. Scott, Greenwood. 6s. 


\section{Applied and Industrial Chemistry.}

Bourcart, E. Insecticides, Fungicides, and Weed Killers. Translated from the Frenth. Demy sro. Pp. 450. 1913. Scott, Greenwond. $14 s .6 d$.

Hodgson, H. H. Celluloid: its Manufacture, Applications, and Substitutes. Translated from the French of Masselon, Roberts, and Cillard. 2nd edn. in preparation. Griffin.
Johnstone, S. J., and Russell. A. The Rare Earth Industry. Their Industrial Application and Exploitation. Roy. 8vo. Pp. 140. 1918. Croshy Lockwond. 9s.

Knox, J. The Fixation of Atmospheric Nitrogen. New edition in preparation. Gurney and Jackson. 


\section{METALLURGY.}

\section{i. GENERAL AND MISCELLANEOUS.}

Gower, A. R. An Elementary Textbook of Practical Metallurgy. 2nd edn. Cr. Svo. Pp. 164. 1913. Chapman and Hall. $4 s$.

Hiorns, A. H. Principles of Metallurgy. 2nd edn. Gl. 8vo. Pp. 404. 1914. Macmillan. $7 s$.

A Text-Book of Filementary Metallurgy. 2nd edn. Globe 8vo. Pp.242. 1913. Macmillan. 3s.6d. - Practical Metallurgy and Assaving. 2nd edn. Gl. Sro. Pp. s14. 1914. Macmillan. $7 s$.

Huntington, A. K., and McMillan, W. G. Metals: Their Properties and Treatment. 3rd edn. Cr, 8vo. Pp. 5\%0. 1914. Longmans. 8s.6d.

MacFarlane, W. Laboratory Notes on Practical Metallurgy. Cr, 8vo. Pp. 152. 1905. Longmans. $3 s$.

Passivity of Metals, The. Faraday Society Report, 1914. Demy 8vo. Pp. 88. 1914. Faraday Society. 7s. 6d.

Rhead, E. L. Metallurgy. Fcap. 8vo. Pp. 296. 1919. Longmans. $5 s$.

Roberts-Austen, Sir W. C. Introduction to Metallurgy, 7th edition in preparation. Griffin.

Addresses and Scientific Papers, together with a Record of the Work of Sir W. C. Roberts-Austen. Compiled and Edited by S. W. Smith. Med.8vo. Pp.393. 1914. Griffin. 25s.

Schnabel, C. Handbook of Metallurgy. Translated and revised by H. Louis. 2 vols. 8vo. Vol. 1 . Copper, Lead, Silver. Gold. 3rd edn. Pp.1,195. 1921. Hos. Vol. 2. Zine, Mercury, Bismuth, Tin, Antimony, Arsenic, Nickel, Cobalt, Platinum, Aluminium. 2nd edn. Pf. 884. 1907. 25s. Macmillan.
Sexton, A. H. A Text-Book of Elementary Metallurgy: including the Author's Practical Laboratory Course. 6th edn. in preparation. Griffin.

Stansbie, J.H. Elementary Practical Metallurgy. Cr. 8vo. Pp. 160. 1915. Churchill. 3s. 6d.

Stobbs, T. Weights of Steel Bars, Sections and Plate Tables. Cr. 8vo. Pp.92. 1920. Spon.6s.6d.

Turner, T Practical Metallurgy. An Introductory Course for General Students. 2nd edn. Cr. 8vo. Pp. 116. 1919. Griffin. 3s.6d.

\section{ii. IRON AND STEEL.}

Allen, H. Metallurgical Manual of Iron and Steel. Cr. 8vo. Pp. 400. 1911. Technical Pub. Co. 8s.

Carnegie, D., and Gladwyn, S. C. Liquid Stcel: Its Manufacture and Cost. 2nd edn. 8vo. Pp. 552. 1918. I.ongmans. 32s.

Davies, J. Galvanized Iron. Its Manufacture and Uses. 8vo. Pp. 139. 1914. Spon. 6s.

Ede, G. The Management of Steel. 7therln. Cr.8ro. Pp.216. 1909. Spon. $6 s$.

Fdwards, C. A. The PhysicoChemical Properties of Steel. 2nd edn. 8vo. Pp. 293. 1920. Griffin. $21 s$.

Transformations iof Pure Iron, The. Faraday Society Report, 1916. Demy 8vo. Pp.34. 1916. Faraday Society. 2s,6d.

Friend, J. N. The Corrosion of Iron and Steel. Cr. 8vo. Pp. 314. 1911. Longmans. 7s, $6 d$.

Greenwood, W. H., and Sexton, A. H. Iron: Its Sources, Properties, and Manufacture. Cr. 8vo. Pp. 256. 1918. Cassell. 4s. 6d. 
Greenwood, W. H., and Sexton, A. H. Steel : Its Varieties, Properties, and Manufacture. Cr.8vo. Pp. 264. 1920. Cassell. 4s. 6d.

Harbord, F. W., and Hall, J. W. The Metallurgy of Steel. 2 vols. Large 8vo. Vol. 1. Metallurgy . Vol. 2. Mechanical Treatment. 7th edn. in preparation. Griffin.

Hatfield, W. H. Cast Iron in the Light of Recent Research. 2nd edn. Med. 8vo. Pp. 310. 1918. Griffin. 12s.6d.

Hearson, $\mathbf{H} . \mathbf{R}$. The Manufacture of Iron and Steel. A Handhook for Engineering Students, Merchants, and Users of Iron and Steel. 8vo. Pp. 103. 1912. Spon. 5s.

Hiorns, A. H. Steel and Iron for Advanced Students. Gl.8vo. Pp. 550. 1911. Macmillan. 12s.6d.

Hood, C. Iron and Steel. Their Production and Manufacture. $\mathrm{Cr}$. 8vo. Pp. 160. 1911. Pitman. $3 s$.

Hudson, O. F., and Bengough, G. D. Iron and Steel: An Introductory Text-Book for Engineers and Metallurgists. With a section on Corrosion. 2nd imp. Demy 8vo. Pp. 183. 1921. Constable.12s. 6d.

Jeans, J. S. The Iron Trade of Great Britain. Cr. 8vo. Pp. 243. 1906. Methuen. 5s.

Jones, J. H. The Tin Plate Industry. A Study in Fconomic Organ ization, with special reference to its relations with the Iron and Steel Industries. Demy 8vo. Pp. 302. 1914. King. 7s,6d.

Jüptner, H. F. v. Siderology : The Science of Iron. (The Constitution of Iron Alloys and Slags). Translated from the German. Demy 8vo. Pp. 350. 1902. Scott, Greenwood. 12s. $6 d$.

Macfarlane, W. The Principles and Practice of Iron and Steel Manufacture. 5th edn. Cr. 8vo. Py. 290. 1917. Longmans. $6 s$.

Parsons, S. J. Malleable Cast Iron . 2nd edn. Demy 8vo. Pp. 187. 1919. Constable. 14s.
Richards, W. A. The Forging of Iron and Steel. 2nd edn. Demy 8vo. Pp. 227. 1918. Constable. $7 s, 6 d$.

Sexton, A. H., and Primrose, J. S. G. The Metallurgy of Iron and Steel. 2nd edn. Demy svo. Pp. 600. 1919. Scientific Pub. Co. 15s.

Turner, T. The Metallurgy of Iron. 6th edn. Demy 8vo. Pp. 502. 1920. Griffin. $18 s$.

\section{iii. NON-FERROUS METALS AND ALLOYS.}

Allen, A. W. Mill and Cyanide Handbook, comprising Tables, Formula, Flow Sheets and Report Forms, compiled and arranged for the Use of Metallurgists, Mill Men and Cyanide Operators. Fcap. 8vo. Pp. 137. 1918. Griffin. 6s.

Buchanan, J. F. B̀rass Founder's Alloys. Cr. Svo. Pp. 129. 1909. Spon. 6s.

Collins, H. F. The Metallurgy of Silver. 2nd edn. in preparation. Griffin ,

-The Metallurgy of Lead. 2nd edn. 8vo. Pp.558. 1910. Griflin. $25 s$.

Downie, J.R. Chemists' Manual of Non-Ferrous Alloys. Demy 8vo. Pp. 168. 1920. Spon. 10s.

Eissler: M. The Metallurgy of Argentiferous Lead. Cr. 8vo. Pp. 396. 1891. Crosby Lockwood. $15 s$.

The Hydro-Metallurgy of Copper. 8vo. Pp. 228. 1902. Crosby Lockwood. 12s. $6 d$.

The Metallurgy of Gold. 5th edn. 8vo. Pp. 639. 1900. Crosby Lockwood. $25 s$.

The Metallurgy of Silver. 5th edn. Cr. 8vo. Pp. 381. 1901. Crosby Lockwood. 12s. $6 \mathrm{~d}$.

Gee, G. E, Recovering Precious Metals from Waste Liquid Residues. A Complete Workshop Treatise, containing Practical Directions for the Recovery of Gold, Silver, and Platinum from every Description of Waste Liquids in the 
Jewellery, Photographic, Electroplating Trades. Demy 8vo. Pp. 388. 1920. Spon. 16s.

Gowland, W. Metallurgy of the Non-Ferrous Metals. 2nd edn. 8vo. Pp. 619. 1918. Griffin. $25 s$.

Gulliver, G. H. A Handbook of Metallic Alloys: Their Structure and Constitution. 4th edn. Cr. svo. Pp. 46\%. 1921. Griflin. $15 s$.

Hiorns, A. H. Mixed Metals or Metallic Alloys. 3rd edn. Gl. 8vo. Pp. 490. 1912. Macmillan. 78 .

Lambert, T. Lead and Its Compounds. Demy 8vo. Pp. 226. 1902. Scott, Greenwood. $S s .6 d$.

Law, E. F. Alloys and their Indus. trial Applications. 4th edn. Demy 8vo. Pp. 352. 1919. Griffin. 15s.

Lones, T. E. Zinc and Its Alloys. Cr.8vo. Pp. 136. 1919. Pitman. $3 s$.

Mortimer, G. Aluminium. Its Manufacture, Manipulation and Marketing. Cr. Svo. Pp. 160. 1920. Pitman. 3s.

Park, J. The Cyanide Process of Gold Extraction. A Text-Book for the use of Metallurgists and Students. 5th edn. Large $\mathrm{Cr}$. Svo. Pp. 347. 1913. Griffin. 10s.6d.

Pattison, J. T. The Manufacture of Aluminium. Cr. 8vo. Pp. 112. 1919. Spon. 7s.6d.

Picard, H. K. Copper. From the Ore to the Metal. Cr. Svo. Py. 139. 1916. Pitman. 3s.

Rose, Sir T. K. The Metallurgy of Gold. 6th edn. Iarge 8vo. Pp. 620. 1915. Griffin. 25s.

The Precious Metals : comprising Gold, Silver, and Platinum. Cr. 8vo. Pp. 311. 1909. Constable. 7s. $6 d$.

Sexton, A.H. Alloys: Non-Ferrous. Demy 8vo. Pp. 298. 1908. Scientific Pub. Co. $7 s .6 d$.

and Primrose, J. S. G. The Common Metals: Non-ferrous. The Metallurgy of Copper, Tin, Zine,
Iead, Antimony, Aluminium and Nickel. Demy 8vo. Py. 500. 1909. Scientific Pub. Co. 10s.

Smith, E. A. The Zine Industry. 8vo. Pp. 232. 1918. Longmans. 10s. $6 d$.

Smythe, J A A . Lead, Including Lead Pigments and the Desilverisation of Lead. Cr. 8vo. Pp. 128. 1920. Pitman. $3 s$.

Stokes, R., White, H. A., Calde cott, W. A., and other contri butors. Rand Metallurgical Practice. Svo. Vol. 1. Pp. 468. 1913. 25s. Vol.2. 2ndedn. Pp. 462. 1919. 25s. Griffin.

Wang, C. Y. Antimony: Its History, Chemistry, Mineralogy, Geology, Metallurgy, Uses, Preparation, Analysis, Production and Valuation, with romplete Bibliography. 2nd edn. Large 8vo. Pp. 227. 1919. Griffin. 15s.

White, B. Silver: its Intimate Association with the Daily Life of Man. Cr. Svo. Pp. 155. 1920. Pitman. 3s.

Gold, its Place in the Economy of Mankind. Cr. 8vo. Pp. $142^{\circ}$. 1920. Pitman. 3s.

\section{iv. ELECTRO -METALLURGY .}

Electric Furnaces. Faraday Society Report, 1918. Demy 8vo. Pp. 37 and Plates. 1918. Faraday Society. $3 s .6 d$.

Kershaw, J. B. C. Electro-Metallurgy. Ex. Cr. 8vo. Pp. 318. 1908. Constable. 7s. $6 d$.

Electro-Thermal Methods of Iron. and Steel Production. Demy 8vo. Pp. 252. 1913. Constable. 9s.

McMillan, W. G., and Cooper, W. R. A Treatise on Electro-Metallurgy. 4th edn. in preparation. Griffin .

Rideal, E. K. Industrial Electrometallurgy, including Electrolytic and Electrothermal Processes. Demy 8vo. Pp. 260. 1918. Baillière. 10s. 6d. 


\section{v. ANALYSIS AND ASSAYING.}

Arnold, J. O., and Ibbotson, F. Steel Works Analysis. A Practical Handbook for Fingineers'and Metallurgists. 4th edn. Cr. 8vo. Pp. 468. 1910. Pitman. 12s. 6d.

Beringer, J. J., and C. A TextBook of Assaying: for the use of Students, Mine Managers, Assnyers, ete. 15th edn. Cr.8vo. Pp.487. 1921. Griffin. 12s. 6 d.

Brown, W. L. Manual of Assaying Gold, Silver, Copper, and Lead Ores. New edition. Revised and enlarged with a Chapter on the Assaving of Fuels $t y$ A. B. Griffiths . Cr. 8vo Pp. 352. 19is. Heinemann. is. $6 d$.

Ibbotson, F. The Chemical Analysis of Steel-Works' Materials. Demy 8vo. Pp. 304. 1920. Longmans. $21 s$.

and Aitchison, L. The Analysis of Non-Ferrous Alloys. New edition in preparation. Longmans.

Macfarlane, W. A Practical Guide to Iron and Steel Works Analyses, with Supplement, being selertions from "Laboratory Notes on Iron and Steel Analyses." 2nd edn. Cr. 8vo. Pp. 350. 1920. Longmans. $9 s$.

MacLeod, W. A., and Walker, C. Metallurgical Analysis and Assaying: A 'Three Y'ears' Course for Students of Schools of Mines. Large 8vo. Pp. 330. 1903. Griffin. $15 s$.

Morgan, J.J. Aids to the Analysis and Assay of Ores, Metals, Fuels, etc. 2nd edn. Feap. Svo. Pp. 146. 1915. Baillière. 3s.

Quantitative Metallurgical Analysis. Tables for Laboratory Use; on the Principle of "Group" Separations. 2nd edn. in preparation. Griffin.

Park, J. Practical Assaving. For the Use of Mining Schools, Miners, and Metallurgists. 5th edn. Large Cr. 8vo. Pp. 354. 1918. Griffin. $9 s$.
Phillips, H. J. Gold Assaying. A Practical Handbook for the accurate Assay of Auriferous Ores and Bullion, and the Chemical Tests required in the Processes of Extraction. Cr. 8 vo. Pp.150. 1904. Crosby Lockwood. 8s. $6 d$.

Pickard, J, A. Modern Steel Analysis. A Selection of Practical Mathods for the Chemical Analysis of Steel. Cr.svo. Pp.136. 1914. Charchill. ðs.

Smith, E. A. The Sampling and Assay of the Precious Metals : Comprising Gold, Silver and Platinum, in Ores. Bullion and Products. Med. 8vo. Pp. 475. 1913. Griffin. 18s.

Wraight, E. A. Assaying in Theory and Practice. Demy 8vo. Pp.324. 1914. Arnold. 10s.6d.

\section{vi. METALLOGRAPHY.}

Desch, C. H. Metallography. New impression in the Press. Longmans.

Intermetallic Compounds. 8vo. Pp. 122. 1914. Longmans. 5s.

Giua, M., and Giua-Lollini, C. Chemical Combination among Metals. Translated by G. W. Robinson. 8vo. Pp. 356. 1918. Churchill. $21 s$.

Goerens, P. Introduction to Metallography. Translated by F. Ibbotson. 8vo. Pp. 224. 1908. Longmans. $9 s$.

Hiorns, A. H. Metallography. Gl. 8vo. Pp. 172. 1902. Macmillan. 7 s.

Mellor, J. W. The Crystallisation of Iron and Steel : an Introduction to the Study of Metallography. New imp. Cr. 8vo. Pp. 124. 1918. Longmans. 8s. 6d.

Osmond, F., and Stead, J. E. The Microscopic Analysis of Metals. 2nd edn. Revised and Corrected by by L. P. Sidney. Large Cr. 8vo. Pp. 330. 1913. Griffin. 10s.6d.

Rosenhain, W. An Introduction to the Study of Physical Metallurgy. 2nd edn. Demy 8vo. Pp. 390 . 1919. Constable. 12s. 6d. 
Savoia, H. Metallography Applied to Siderurgic Products. Translated by R. C. Corbet. Cr. 8vo. Pp. 180 . 1910. Spon. 6s.

\section{vii. HEAT TREATMENT OF METALS.}

Brearley, H. The Heat Treatment of Tool Steel. A Description of the Physical Changes and Properties induced in Tool Steel by Heating and Cooling Operations. New imp.8vo. Pp. 240. 1918. Longmans.12s.6d. The Case-Hardening of Steel. An Illustrated Exposition of the Changes in Structure and Properties induced in Steels by Cementation and Allied Processes. 2nd edn. Demy 8vo. Pp. 218. 1921 . Longmans . $16 s$.

Reiser, F. The Hardening and Tempering of Steel in Theory and Practice. Translated from the German. 2nd edn. Cr.8vo. Pp.120. 1918. Scott, Greenwood. 6s.

\section{viii. FOUNDRY WORK .}

Bower, C. O. Practical Shell Forging and the Plastic Deformation of Steel and its Heat Treatment. Roy. 8vo. Pp. 301. 1919. Library Press. 30s.

Brearley, A . W ., and $H$. Ingots and Ingot Moulds. 8vo. Pp. 234. 1918. Longmans. $16 s$.

Buchanan, J.F. The Moulder's Dictionary (Foundry Nomenclature). Cr.8vo. Pp.233. 1912. Spon.6s.

Dichmann, C. The Basic OpenHearth Steel Process. Translated by A. Reynolds. 2nd imp. Demy 8vo. Pp. 346. 1920. Constable. $12 s .6 d$.
Horner, J. Brassfounding. Demy 8vo. Pp.182. 1918. Emmott. 5s. Practical Ironfounding. 4th edn. Cr. 8vo. Pp. 409. 1914. Pitman. 10 s.

McWilliam, A., and Longmuir, P. General Foundry Practice: A Practical Handbook for Iron, Steel and Brass Founders, Metallurgists, and Students of Metallurgy. 3rd edn. 8vo. Pp. 391. 1920. Griffin. 18s.

Morgan, J. J. Notes on Foundry Practice. 2nd edn. Cr. 8vo. Pp. 138. 1920. Griffin. 4s, $6 d$.

Blast Furnace Practice. 2nd edn. Cr. 8vo. Pp. 54. 1916. Griffin. $2 s .6 d$.

Purves, A. The Brass Moulder Illustrated. A Practical Guide. Cr. Svo. Pp. 165. 1915. Spon. 5s.

Rhead. E. L. The Principles and Practice of Ironfounding. Demy 8vo. Pp. 512. 1910. Scientific Pub. Co, 7s, 6d.

Roxburgh, W. General Foundry Practice. A Treatise on General Iron Founding, Job Loam Practice, Moulding and Casting of Finer Metals, ete. 2nd edn. Ex. Cr. 8vo. Pp. 307. 1919. Constable. $8 s .6 d$.

Sexton, A. H. Principles of Iron Founding and Foundry Metallography. Cr.8vo. Pp.330. 1911. Technical Pub. Co. 8s.

Sharp, J. Modern Foundry Practice. Dealing with the Green-Sand, DrySand and Loam Moulding Processes, the materials used, also detailed descriptions of the machinery and other appliances employed. 2nd edn. New imp. 8vo. Pp. 760 . 1918. Spon. 24s.

Turner, T. Lectures on Iron Founding. 2nd edn. Extra Cr. 8vo. Pp. 146. 1911. Griffin. 4s. 


\section{MILITARY SCIENCE AND ENGINEERING.}

Hicks, J. W. The Theory of the Rifle and Rifle Shooting. An Elementary Treatise on the Scientific Principles of the Small-Arm and its Functions. Cr. 8vo. Pp. 148. 1919. Griffin. $5 s$.

Noble, Sir A. Artillery and Explosives. Essays and Lectures written and Delivered at various times. Med.8vo. Pp. 548. 1906. Murray. $25 s$.

Pollard, H. Automatic Pistols. Demy 8vo. Pp.110. 1920. Pitman. $6 s$.
Rausenberger, F. The Theory of the Recoil of Guns with Recoil Cylinders. Translated by A. Slater. Demy 8vo. Pp. 154. 1909. Crosby Lockwood. 12s. $6 d$.

Sydenham, Lord. Fortification : its past Achievements, Recent Developments, and Future Progress. 2nd edn. Med. 8vo. Pp. 312. 1907. Murray. 24s.

Thomsen, C.F The Field Artillery Officers' Handbook. Oblong Feap. 8vo. Pp. 48. 1918. Spon. 5s. 


\section{ASTRONOMY.}

\section{i. HISTORIGAL AND BIOGRAPHICAL.}

Ball, Sir R. S. Great Astronomers. Demy 8vo. Pp. 371. Pitman. $7 s, 6 d$.

Berry, A. A Short History of Astronomy. Cr. 8vo. Pp. 440. 1898. Murray. $7 s .6 d$.

Dreyer, J. L. E. History of the Planetary Systems from Thales to Kepler. Demy 8vo. Pp. 432. 1906. Cambridge University Press . $12 s .6 d$.

Forbes, G. History of Astronomy. New edn. Cr.8vo. Pp.163. 1921. Watts. 3s. 6d.

Heath, Sir T . Aristarchus of Samos, the Ancient Copernicus. A History of Greek Astronomy to Aristarchus. together with his Treatise on the sizes and distances of the Sun and Moon ; a new Greek Text with Trans. lation and Notes. Med. 8vo. Pp. 434. 1913. Oxford: Clarendon Press. 18s.

Schiaparelli, G. Astronomy in the Old Testament. Authorized Translation, with many corrections and additions. Cr. 8vo. Pp. 186 . 1905. Oxford: Clarendon Press. $4 s$.

\section{ii GENERAL AND GOMPRE - HENSIVE TREATISES.}

Ball, Sir R. S. Elements of Astronomy. Cr. 8vo. Pp. 484. 1917. Longmans. 8s.

A Treatise on Spherical Astronomy. Demy 8vo. Pp. 518. 1908. Cambridge University Press. 14s. A Primer of Astronomy. Reissue. Fcap. 8vo. Pp. 236. 1918. Cambridge University Press. 3s.

The Story of the Heavens. Med. 8vo. Pp. 568. Cassell. 15s.
Ball, Sir R. S. A Popular Guide to the Heavens. 3rd edn. Small 4to. Pp. 96 and 82 Plates. 1910. Geo. Philip. 15s.

- In the High Heavens. A popular account of recent interesting Astronomical events and phenomena. Demy 8vo. Pp. 381. Pitman. $7 s .6 d$.

Barlow, G. W. G., and Bryan, G. H. Elementary Mathematical As. tronomy. 2nd edn. 4th imp. Cr. 8vo. Pp. 456. 1919. University Tutorial Press. 9s.6d.

Chambers, G.F. Astronomy . Fcap. 8vo. Pp. 960. N.D. Hutchinson. $7 s .6 d$.

- Astronomy: for general readers. Cr. 8vo. Pp.268. 1918. Pitman. $4 s$.

and Smyth, W. H. A Cycle of Celestial Objects. Observed, reduced and discussed. 8vo. Pp. 720. 1881. Oxford: Clarendon Press. 6s.

Chapman, R. W. The Elements of Astronomy for Surveyors. Cr. 8vo. Pp. 257. 1919. Griffin. 5s .

Dolmage, G. G. Astronomy of ToDay. Cr. 8vo. Pp. 363. 1919. Seeley. $7 s, 6 d$.

Dyson, Sir F. W . Astronomy . Large Feap. 8vo. Pp. 247. Dent. 3s.6d. - A Primer of Astronomy. Fcap. 8vo. Pp. 118. Dent.2s.

Godfray, H. A Treatise on Astronomy. 4th edn. 8vo. Pp. 336. 1906. Macmillan. 12s. 6d.

Hinks, A. R. Astronomy. Fcap. 8vo. Pp. 256. 1919. Williams \& Norgate. 2s, $6 d$.

Lockyer, Sir N. Elementary Lessons in Astronomy. Feap. 8vo. $\mathrm{Pp}$. 416. 1919. Macmillan. 6s.6d.

Inorganic Evolution as studied by Spectrum Analysis, 8vo. Pp. 208. 1900. Macmillan. 5s. 
Lockyer, Sir N. Stonehenge and other British Stone Monuments Astronomically considered. 2nd edn. Med. 8vo. Pp. 516. 1909. Macmillan. $14 s$.

- The Meteoritic Hypothesis of the Origin of Cosmical Systems. 8vo. Pp. 576. 1890. Macmillan. 17s .

Maunder, E.W. Astronomy without a Telescope. 3rd imp. Demy 8vo. Pp. 288. 1904. Thacker. $\tau s$.

Newcomb, S. Astronomy for Everybody. Demy 8vo. Pp. 341. Pitman. 7s, $6 d$.

Parker, G. W. Elements of Astronomy. 5th edn. 8vo. Pp. 264. 1916. Longmans. $8 s$.

Plummer, H. C. An Introductory Treatise on Dynamical Astronomy. Roy. 8vo. Pp. 364. 1918. Cambridge University Press. $18 \mathrm{~s}$.

Proctor, R. A. Light Science for Leisure Hours : Familiar Essays on Scientific Subjects, Natural Phenomena, etc. Cr. 8vo. Pp. 324. 1919. Longmans. $6 s .6 d$.

__ Our Place Among Infinities. Essays contrasting our Little Abode in Space and Time with the Infinities around us. Cr. 8vo. Pp. 296. 1908. Longmans. $6 s$.

Stirling, W. New Theories in Astronomy. Demy 8vo. Pp. 336. 1906. Spon. 8s.6d.

Tancock, E. O. The Elements of Descriptive Astronomy. 2nd edn. Cr.8vo. Pp. 158. 1920. Oxford: Clarendon Press. $3 s$.

Turner, H. H. Astronomical Discovery. Demy 8vo. Pp.237. 1904. Arnold. 10s.6d.

Webb, T. W. Celestial Objects for Common Telescopes. 6th edn. revised by T. E. Espin. 2 vols. $\mathbf{C r}$. 8vo. 1917. Vol. 1. Pp.273. Vol. 2. Pp. 328. Longmans. Ss. each Vol.

\section{iii. THE MOON.}

Brown, E. W. An Introductory Treatise on the Lunar Theory. Roy. 8vo. Pp. 300. 1896. Cambridge University Press. 15s.
Brown, E. W. The Inequalities in the Motion of the Moon due to the direct Action of the Planets. Roy. $8 v o$. Pp. 106. 1908. Cambridge University Press. 6s.

Godfray, H. An Elementary Treatise on the Lunar Theory. Cr.8vo. Pp. 136. 1885. Macmillan. 5s.6d.

Pickering, W. H. The Moon. A Summary of the Existing Know ledge of our Satellite, with a complete Photographic Atlas. Large Roy. 4to. Pp. 103 and 88 Plates. 1904. Murray. 52s. 6d.

Proctor, R. A. The Moon: Her Motions, Aspect, Scenery and Physical Condition. 8th imp. Cr. 8vo. Pp. 326. 1916. Longmans. 6s.

\section{iv. SOLAR AND STELLAR.}

Ball, Sir R. S. In Starry Realms: The Wonders of the Heavens. Demy 8vo. Pp.a71. Pitmian. 10s.6d.

Chambers, G. F. The Story of the Comets. 2vd edn. 8vo. Pp. 288. 1910. Oxford : Clarendon Press . 6s.

Clark, L., and Sadler, H. The Star Guide. Royal 8vo. Pp. 64. 1886. Macmillan. $5 s$.

Darwin, Sir G. H. The Tides and Kindred Phenomena of the Solar System. 3rd edn. Cr. 8vo. Pp. 437. 1911. Murray. 9s.

Eddington, A. S. Stellar Movements and the Structure of the Universe. 8vo. Pp. 278. 1914. Macmillan. 7s. 6d.

Grew, E. S. The Growth of a Planet. Cr.8vo. Pp.364. 1911. Methuen. $7 s, 6 d$.

Jeans, J . H. Problems of Cosmogony and Stellar Dynamies. Roy. 8vo. Pp. 302. 1919. Cambridge University Press. 21s.

Lockyer, Sir N. Recent and Coming Eclipses. 8vo. Pp. 252. 1900 . Macmillan. $6 s$.

- The Sun's Place in Nature. 8vo. Pp. 376. 1897. Macmillan. 12s.

Sampson, R. A. The Sun. Roy. 16mo. Pp. 141. 1914. Cambridge University Press. 2s. 6 d. 
Young, C. A. The Sun. 4th edn. Cr. 8ro. Pp. 387. 1910. Kegan Paul. 7s. 6d.

\section{v . ASTRONOMICAL ATLASES.}

Cottam, A. Charts of the Constellations. Imp. 4to. Pp. 327. Stanford. $7 s$.

Heath, Sir T . The Twentieth Century Atlas of Popular Astronomy. 2nd edn. Imperial 8vo. Pp.130. and 21 coloured Plates. 1908. Johnston. 10s.

Miremont, Comte de. Popular Star Maps. A Rapid and Easy Method of Finding the Principal Stars. Portfolio. Large 4to. Geo. Philip. 20s.

Orr, M. A. Stars of the Southern Skies. Cr. \&vo. Pp. 104. 1915. Longmans. $3 s, 6 d$.
Proctor, R. A. Large Star Atlas for Observers and Students. In 12 Circular Maps. 7th edn. Folio. Pp.60. 1914. Longmans. 17s.6d.

New Star Atlas for the Library, the School and the Observatory, In Twelve Circular Maps. 23rd imp. Cr. 8vo. Pp. 104. 1915. Longmans. 6s. $6 d$.

-Half Hours with the Stars: a Plain and Easy Guide to the Know ledge of the Constellations. Showing in 12 Maps the position of the principal Star Groups in the Northern Hemisphere night after night throughout each year. 4to. Longmans. $5 s$.

Turner, H. H. The Great Star Map. Being a Brief General Account of the International Project known as the Astrographic Chart. Cr.8vo. Pp. 159. 1911. Murray. 3s. 6d.

Weatherhead, R. The Star Pocketbook, or How to Find Your Way at Night by the Stars. $16 \mathrm{mo}$. Pp. 92. 1917. Longmans. $2 s .6 d$. 


\section{METEOROLOGY.}

Abercromby, R. Weather: a Popular Exposition of the Nature of Weather Changes from Day to Day. 6th edn. Cr.8vo. Pp. 491. 1907. Kegan Paul. 7s.6d.

Allingham, W. Marine Meteorology. for officers of the Merchant Navy. 2nd edn. Cr.8vo. Pp. 198.1917. Griffin. $9 s$.

Beattie, J. C. Report of a Magnetic Survey of South Africa. Med. 4to. Pp. 245. 1909. Cambridge University Press. 20s.

Berry, A. J. The Atmosphere. Roy . 16mo. Pp. 147. 1913. Cambridge University Press. $2 s .6 d$.

Blanford, H. F. A Practical Guide to the Climates and Weather of India, Ceylon, and Burmah, and the Storms of Indian Seas. 8vo. Pp. 384. 1889. Macmillan. 15s.

Bonacina, L. C. W. Climatic Control. 2nd edn. Sm. Cr. 8vo. Pp. 167. 1915. Black. 3s.6d.

Brown, C. Meteorology for Masters and Mates. 5th edn. Demy 8vo. Pp. 96, 1920. James Brown. 3s. 6d.

Cave, C. J. P. The Structure of the Atmosphere in Clear Weather. A Study of Soundings with Pilot Balloons. Demy 4to. Pp. 156. 1913. Cambridge University Press. 12s. $6 d$.

Chapman, E. H. The Study of the Weather. Cr.8vo. Pp. 144.1919. Cambridge University Press. 4s.

Chatley, H. The Force of the Wind. 2nd edn. Cr.8vo. Pp. 91. 1919. Griffin. 3s.6d.

Chree, C. Studies in Terrestrial Magnetism. 8vo. Pp. 214. 1912. Macmillan. 6s, 6d.
Clarke, G. A. Clouds. A Descriptive Illustrated Guide-Book to the Observation and Classification of Clouds. Demy 8vo. Pp. 152 and 40 Plates. 1920. Constable. $21 s$.

Dickson, H. N. Climate and Weather. Feap. 8vo, Pp. 256. 1911. Williams \& Norgate. 2s. 6d.

Elgie, J. H. Elgie's Weather Book for the General Reader. Cr. 8vo. Pp. 263. 1920. Wireless Press. 5s.

Geddes, A. E. M. Meteorology . An Introductory Treatise. Demy 8vo. Pp. 410. 1921. Blackie. $21 s$.

Hepworth, M.W. C. Notes on Maritime Meteorology. Demy 8vo. Pp. 90. 1907. Geo. Philip. 2s.6d.

Horner, D. W. Meteorology for All : being some Weather Problems explained. Cr.8vo. Pp. 200. 1919. Witherby. $6 s$.

Knox, A. The Climate of the Continent of Africa. Roy. 8vo. Pp. 563. 1911. Cambridge University Press. $26 s$.

Lempfert, R. G. K. Meteorology . Cr.8vo. Pp. 196. 1920. Methuen. $7 s, 6 d$.

Moore, Sir J. W. Meteorology: Practical and Applied. 2nd edn. Demy 8vo. Pp. 450. 1910. Heinemann. 10s. 6d.

Rambaut, A.A. Results of Meteorological Observations made at the Radcliffe Observatory, Oxford, in the years 1911 to 1915 . Roy. 8vo. Pp. 232. 1916. Oxford University Press. 15s.

Scott, R. H. Elementary Meteorology. 9th edn. Cr. 8vo. Pp. 424. 1918. Kegan Paul. 7s.6d. 


\section{Meteorology.}

Shaw, Sir W. N. Manual of Meteorology. Part IV. The Relation of the Wind to the Distribution of Barometric Pressure. Roy. 8vo. Pp. 176. 1919. Cambridge University Press. 12s. $6 d$.

Forecasting Weather. Demy 8vo. 2nd edn. in preparation. Constable.

Stacey, W. F. Practical Exercises on the Weather and Climate of the British Isles and North-West Europe. Large Cr.8vo. Pp.64. 1919. Cambridge University Press. $2 s .9 d$.
Taylor, G. Australian Meteorology: A Text-book, including sections on Aviation and Climatology. 8vo. Pp. 324. 1920. Oxford: Clarendon Press. 12s, 6d.

Waldo, F. Modern Meteorology. Cr. 8vo. Scott Pub. Co. 5s. 


\section{MINERALOGY.}

i. GENERAL.

Cole, G. A. J. Outlines of Mineralogy for Geological Students. Cr. 8vo. Pp. 348. 1913. Longmans. 6s.

Evans, J. W. The Determination of Minerals under the Microscope by Means of their Optical Characters. Demy 8vo. Pp. $\mathbf{3 4}$ and Plates. 1915. Murby . 2s, 6d.

Hatch, F. H. Mineralogy. 5th edn. Cr.8vo. Pp. 250. 1916. Pitman. $6 s$.

McGrigor, G.D. Field Analysis of Minerals : for the Prospector, Mining Engineer, etc. Cr. 8vo. Pp. 86. 1915. Technical Bookshop. 3s.6d.

Miers, Sir H. A. Mineralogy : An Introduction to the Scientific Study of Minerals. New edn. in the Press. Macmillan.

Rutley, F. Elements of Mineralogy . Revised by H. H. Read. New edn. Cr.8vo. Pp. 416. 1918. Murby. $6 s$.

Smith, H. G. Minerals and the Microscope. An Introduction to the Study of Petrology. 2nd edn. Cr.8vo. Pp. 128. 1919. Murby. $5 s$.

Spencer, L. J. The World's Minerals. A description of the more common minerals, and a few other important species; with 163 coloured figures. Demy 8vo. Pp. 340 . 1920. Chambers. 20s.

\section{ii . CRYSTALLOGRAPHY .}

Beale, Sir W. P. An Amateur's Introduction to Crystallography from Morphological Observations. 8vo. Pp. 228. 1915. Longmans. 4s. $6 d$.
Bragg, Sir W. H., and W.L. XRays and Crystal Structure. 5th edn. Demy 8vo. Pp. 229. 1918 Bell. 10s. 6d.

Fock, A. Introduction to Chemical Crystallography. Translated and edited by Sir W. J. Pope. Cr. 8vo. Pp. 206. 1895. Oxford: Clarendon Press. $5 s$.

Groth, P. An Introduction to Chemical Crystallography. Translated by H. Marshall. Cr.8vo. Pp. 136. 1906. Gurney \& Jackson. 4s.

Hilton, H. Mathematical Crystallography, and the Theory of Groups and Movements; with an Account of the Geometrical Theory of Crystal Structure. 8vo. Pp. 274. 1903. Oxford: Clarendon Press. 14s.

Lewis, W.J. A Treatise on Crystallography. Demy 8vo. Pp. 624. 1899. Cambridge University Press. $16 s$.

Story-Maskelyne, N. Crystallography. A Treatise. Cr.8vo. Pp. 534. 1893. Oxford: Clarendon Press. 12s. 6d.

Tutton, A. E. H. Crystallography and Practical Crystal Measurement. 8vo. Pp. 946. 1911. Macmillan. $40 s$.

Crystals. Cr. 8vo. Pp. 311. 1911. Kegan Paul. 7s. 6d.

\section{iii. EGONOMIC MINERALOGY.}

Anderson, J.W. Prospector's Handbook. A Guide for the Prospector in search of metal-bearing or other valuable minerals. 13th edn. $\mathrm{Cr}$. 8vo. Pp. 207. 1919. Crosby Lockwood. 5s. 
Beyschlag, F., Vogt, J.H. L., and Krusch, P. The Deposits of the Useful Minerals and Rocks: their Origin, Form and Content. Translated by $\mathrm{S}$. J. Truscott. In 3 Vols. 8vo. Vol. 1. Pp. 542. 1914.21s. Vol. 2. Pp. 760. 1916. 25s. Vol. 3. in preparation. Macmillan.

Cahen, E., and Wootton, W. O. The Mineralogy of the Rarer Metals. A Handbook for Prospectors. 2nd edn. Pocket Size. Pp. 246. 1920. Griffin. 10s. 6d.

Calvert, A. F. Mineral Resources of Minas Geraes (Brazil). 8vo. Pp. 100 and 127 Plates. 1915. Spon. $9 s$.

Collins, J. H. Observations on the West of England Mining Region. An Account of the Mineral Deposits and Economic Geology of Cornwall. Fcap. 4to. Pp. 683. 1912. Technical Bookshop. $21 s$.

Corder, G. A. The Miner's Geology and Prospector's Guide, for Students, Miners, Prospectors, and Explorers. Cr.8vo. Pp. 224. 1914. Spon. 6s.

Cox, S.H. Prospecting for Minerals. A Practical Handbook for Prospectors, Explorers, Settlers, and all interested in the Opening up and Development of New Lands. 7th edn. Cr. 8vo. Pp. 271. 1918. Griffin. 5s .

Crook, T. Eeonomic Mineralogy. A Practica! Guide to the Study of Useful Minerals. Demy 8vo. Pp. 504. 1921. Longmans. 25s.

Curtis, A. H. Manganese Ores. (Imperial Institute Monographs on Mineral Resources). Demy 8vo. Pp. 128. 1919. Murray. 3s.6d.

Davies, G. M. Tin Ores. (Imperial Institute Monographs on Mineral Resources). Demy 8vo. Pp. 121. 1919. Murray."3s.6d.

Duly, S. J. The Natural Wealth of Britain: Its Origin and Exploitation. Cr. 8vo. Pp. 320. 1919. Hodder \& Stoughton. $6 s$.

Fairie, J. Notes on Lead Ores: Their Distribution and Properties. Cr. 8vo. Pp. 64. 1901. Scott, Greenwood. 1s.
Ghambashidze, D. Mineral Resources of Georgia and Caucasia. Manganese Industry of Georgia. 8vo. Pp. 182. 1919. Allen \& Unwin. $8 s .6 d$.

Goodchild, W. Precious Stones. With a Chapter on Artificial Stones. Ex. Cr. 8vo. Pp. 319. 1908. Constable. $7 s$. $6 d$.

Hall, T. C. F. Lead Ores. (Imperial Institute Monographs on Mineral Resources). Demy 8vo. Pp. 137. 1921. Murray. 6s.

Lumb, A. D. The Platinum Metals : (Monographs on Mineral Resources with Special reference to the British Empire). Demy 8vo. Pp. 73. 1920. Murray. 3s.6d.

Mastin, J. The Chemistry, Properties, and Tests of Precious Stones. Fcap. 16mo. Pp. 114. 1911. Spon. 5s.

Merritt, W. H. A Practical Manual of Field Testing for Gold and Silver. 2nd edn. Fcap. 8vo. Pp. 154. 1911. Crosby Lockwood. 6s.

Rankin, D. J. Prospecting for Gold. Fcap. 8vo. Pp. 192. 1901. Crosby Lockwood. $7 s .6 d$.

Rastall, R.H., and Wilcockson, W. H. Tungsten Ores. (Monographs on Mineral Resources with special Reference to the British Empire). Demy 8vo. Pp. 90. 1920. Murray. $3 s .6 d$.

Ronaldson, J . H. Coal. (Monographs on Mineral Resources with special reference to the British Empire). 8vo. Pp. 175. 1920. Murray. $6 s$.

Smith, G. F. H. Gem-Stones, and their distinctive characters. 2nd edn. Cr. 8vo. Pp. 326. 1919 . Methuen. $7 s .6 d$.

Stokes, R.S.G. Mines and Minerals of the British Empire. Demy 8vo. Pp. 423. 1908. Arnold. 1.5s.

Summers, A. I. Asbestos and the Asbestos Industry. The World's Most Wonderful Mineral ; and other Fire-proof Materials. Cr. 8vo.Pp. 116. 1919. Pitman. $3 s$. 


\section{GEOLOGY.}

\section{i. GENERAL.}

Bird, C. Elementary Geology . Cr. 8vo. Pp. 260. 1913. Longmans. $5 s$.

Advanced Geology. A Manual for Students in Advanced Classes and for General Readers. $\mathrm{Cr}$. 8vo. Pp. 438. 1911. Longmans. $7 s .6 d$.

Chamberlin, T. G., and Salisbury, R. D. Geology. 3 Vols. Demy 8vo. Vol. 1. Processes and their Results. Vol. 2. Earth HistoryGenesis-Palæozoic. Pp.692.1919. Vol . 3. Earth History-MesozoicCenozoic. Pp.624. 1909. Murray. 25s . each.

Geology. Shorter Course. Demy 8vo. Murray. 25s.

Cole, G. A.J. Aids in Practical Geology. With a Section on Palæontology. 7th edn. Cr. 8vo. Pp. 447. 1919. Griffin. 10s.6d.

Open-Air Studies in Geology : An Introduction to Geology Out-ofdoors. 2nd edn. Cr. 8vo. Pp. 334. 1902. Griffin. 8s,6d.

Common Stones; Unconventional Essays in Geology. Cr. 8vo. Pp. 259. 1921. Melrose. 6s.

Gardiner, G. J. An Introduction to Geology. Cr. 8vo. Pp. 186. 1914. Bell. 3s. 6d.

Geikie, Sir A. Text-Book of Geology, 4th edn. 2 Vols. Med. 8vo. Pp. 724., 778. 1903. Macmillan. 30s.

Class Book of Geology. 5th edn. Cr. 8vo. Pp. 480. 1919. Macmillan. 7s. $6 d$.

-Outlines of Field Geology. 5th edn. G1. 8vo. Pp. 276. 1912. Macmillan. 3s. 6d.

Geikie, J. Structural and Field Geology. For Students of Pure and Applied Science. 4th edn. 8vo. Pp. 478. 1920. Oliver \& Boyd. 24s.
Geikie, J. Outlines of Geology : for Junior Students and General Readers. 4th edn. Large Post 8vo. Pp. 424. Stanford. 12s.

Green, A. H. First Lessons in Modern Geology. Edited by J. F. Blake. Cr. 8vo. Pp. 220. 1898. Oxford: Clarendon Press. $4 s$.

Gregory, J. W. Geology of To-Day. Cr. 8vo. Pp. 328, 1919. Seeley. $7 s .6 d$.

A Primer of Geology. Fcap. 8vo. Pp. 140. Dent. 2s.

Judd, J. W. (edited by). The Student's Lyell. The Principles and Methods of Geology, as applied to the Investigation of the Past History of the Earth and its Inhabitants. 2nd edn. Large Cr. 8vo. Pp.645. 1911. Murray. 12s.

Lake, P., and Rastall, R. H. A Text Book of Geology. 3rd edn. Demy 8vo. Pp. 522. 1920. Arnold. 21s.

Lapworth, C. Intermediate Textbook of Geology. 12th edn. Cr. 8vo. Pp. 431. Blackwood.7s.6d.

Marr, J . E. An Introduction to Geology. Cr. 8vo. Pp. 238. 1905. Cambridge University Press . 4s. 6d.

Park, J. A Text-book of Geology. and edn. in preparation. Griffin.

Reed, F. R. C. The Geology of the British Empire. 8vo. Pp. 488. 1921. Arnold. 40s.

Roberts, R. D. An Introduction to Modern Geology. Cr. 8vo. Pp. 270. 1906. Murray. $6 s$.

Sorsbie, R. F. Geology for Engineers. Cr. 8vo. Pp. 450.1911. Griflin. 12s. 6d. 
Wallace, A. R. Island Life, or the Phenomena and Causes of Insluar Faunas and Floras. Including a revision and attempted solution of the problem of geological climates. Extra Cr. 8vo. Pp. 584. 1911. Marmillan. 8s. 6d.

Watts, W. W. Geology for Beginners. 3rd edn. Cr. 8vo. Pp. 370. 1920. Macmillan: 3s.6d.

\section{ii . HISTORY.}

Geikie, Sir A. Charles Darwin as Geologist. Cr. 8vo. Pp.91. 1909. Cambridge University Press. $2 s$.

- - The Founders of Geology. 2nd edn. 8vo. Pp. 486. 1905. Macmillan. $10 s$.

Woodward, H. B. History of Geo. logy. $\mathrm{Cr}$. 8vo. Pp. 160. 1911. Watts. 3s. fid.

Zittel K. A von. History of Geology and Palæontology. Cr. 8vo. Pp. 562. 1901. Scott Pub. Co. 7s.6d.

\section{iii. SEISMOLOGY AND \\ ENDOGENETIC STRUGTURES.}

Anderson, T. Volcanic Studies in Many Lands. 1st Series (out of print). 2nd Series. The Text by Prof. T. G. Ronney. Cr. 4to. Murrav. $15 \mathrm{~s}$.

Bonney, T, G. Volcanoes: their Structure and Significance. I.arge Cr.8vo. Pṇ. 379. 1912. Murray. $9 s$.

Davison, C. The Origin of Earthquakes. Roy. 16mo. Pp. 144. 1912. Cambridge University Press. $2 s .6 d$.

A Manual of Seismology . Demy 8vo. Pp. 268. 1921. Cambridge University Press. $21 s$.

_ A Study of Recent Earthquakes . Cr. 8vo. Scott Pub. Co. 7s.6d.

Fisher, O. Physics of the Earth's Crust. 2nd edn. 8vo. Pp. 472. 1889. Macmillan. 12s.

Geikie,Sir A. The Ancient Volcanoes of Great Britain. 2 vols. Super Roy. 8vo. Pp. 502., 508. 1897. Macmillan. 36s.
Gregory, J. W. The Nature and Origin of Fiords. Demy 8vo. Pp. 542. 1913. Murray. 21s.

- The Making of the Earth. F cap. 8vo. Pp. 256. 1912. Williams \& Norgate. 2s. 6d.

Hull, E. Volcanoes, Past and Present . Cr. 8vo. Scott Pub.Co. 5s.

Judd, J. W. Volcanoes: what they are and what they teach. 7 th edn. Cr. 8vo. Pp. 389. 1907. Kegan Paul. 7s.6d.

Knott, C. G. Physies of Earthquake Phenomena. 8vo. Pp.296. 1908. Oxford: Clarendon Press. $14 s$.

Love, A. E. H. Some Problems of Geodynamics. Roy. 8vo. Pp. 189. 1911. Cambridge University Press. 16s.

Milne, J. Earthquakes and other Farth Movements. 6th edn. Cr. 8vo. Pp. 404. 1913. Kegan Paul. $7 s .6 d$.

- Seismology. 2nd edn. Cr. 8vo. Pp. 34. 1908. Kegan Paul. $7 s .6 d$.

Schwarz, E. H. L. Causal Geology. Demy 8ro. Pp. 248. 1910. Blaclie. $7 s .6 d$.

Suess, F. The Face of the Earth. Translated by H. Sollas. 4 vols. Roy.8vo. Vol.1. Pp.616. 1904. 25s. Vol. 2. Pp. 562. 1906. 25s. Vol.3. Pp. 406. 1908. 18s. Vol. 4. Pp. 682. 1909. 25s. Oxford: Clarendon Press.

Swaine, A. T. The Earth, Its Genesis and Evolution. Cr. 8vo. Pp. 296. 1913. Griffin. 9s .

Walker, G.W. Modern Seismology . 8vo. Pp. 100. 1913. Longmans. 6s. $6 d$.

\section{iv. LAND FORMS AND EXO- GENETIC STRUCTURES.}

Avebury, Lord. The Scenery of Switzerland, and the Causes to which it is Due. 5th edn. Cr.8vo. Pp. 538. 1913. Macmillan. 7s.

Ball, Sir R. S. The Cause of an Ice Age. 3rd edn. Cr. 8vo. Pp. 186. 1906. Kegan Paul. 3s.6d. 
Bonney, S. G. Ice Work, Present and Past. 2nd edn. Cr. 8vo. Pp. 309. 1903. Kegan Paul. 7s. 6d.

Bonney, T. G. The Work of Rain and Rivers. Roy. 16mo. Pp. 144. 1912. Cambridge University Press. $2 s .6 d$.

Cole, G. A. J. The Growth of Europe. Feap. 8vo. Pp. 256. 1914. Williams \& Norgate. 2s.6 $d$.

Geikie, Sir A. Earth Sculpture; or the Origin of Land Forms. 2nd edn. Large Cr. 8vo. Pp. 324. 1909. Murray. 7s, 6d.

Marr, J. E. The Scientific Study of Scenery. 5th edn. Cr. 8vo. Pp. 378. 1918. Methuen. 7s, 6d.

Reid, C. Submerged Forests. Roy. 16mo. Pp. 129. 1913. Cambridge University Press. $2 s .6 d$.

Tyndall, J. Forms of Water: in Clouds and Rivers, Ice and Glaciers. 13th edn. Cr. 8vo. Pp. 224. 1909. Kegan Paul. 7s, 6d.

Wright, G. F. Man and the Glacial Period. Cr.8vo. Pp. 400. 1893. Kegan Paul. Ts. 6d.

Wright, W. B. The Quaternary Ice Age. 8vo. Pp. 488. 1914. Macmillan. $21 s$.

\section{v. Petrology.}

Harker, A. Petrology for Students. An Introduction to the Study of Rocks under the Microscope. 5th edn. Cr. 8vo. Pp. 308. 1919. Cambridge University Press. 8s.6d.

The Natural History of Igneous Rocks. Demy 8vo. Pp. 400 . 1909. Methuen. 15s.

Hatch, F. H. Petrographical Tables: an Aid to the Microscopical Determination of Rock Forming Minerals. From the German of Prof. Rosenbusch. Cr. 4to. Pp. 36 . Allen \& Unwin. 3s. 6d.

and Rastall, R. H. Text Book of Petrology. Cr. 8vo. Vol. 1 . Igneous Rocks. 6th. edn. Pp. 484. 1914. Vol.2. The Sedimentary Rocks. Pp. 440. 1913. Allen \& Unwin. $7 s, 6 d$. each.
Holmes, A. The Nomenclature of Petrology : with References to selected Iiterature. Cr. 8vo. Pp. 284. 1920. Murby. 12s.6d.

Petrographic Methods and Calculations, with some Examples of Results Achieved. 8vo. Pp. 536. 1921. Murby. 31s.6d.

Mennell, F. P. A Manual of Petrology. Demy 8vo. Pp. 260. 1910. Chapman \& Hall. 8s. $6 d$.

Milner, H. B., and Part, G. M. Methods in Practical Petrology. Cr. 8vo. Pp. 73. 1916. Heffer. 3s. $6 d$.

Rhodes, J. E. W. Micropetrology for Beginners: an Introduction to the Use of the Microscope in the Examination of Thin Sections of Igneous Rocks. Cr. 8vo. Pp. 131 . 1912. Longmans. 3s. $6 d$.

Rutley, F. The Study of Rocks: an Elementary Text-book of Petrology. 10th imp. Cr.8vo. Pp.336. 1909. Longmans. 6s. 6d.

\section{vi. STRATIGRAPHY.}

Jukes-Browne, A. J. The Student's Handbook of Stratigraphical Geology. 2nd edn. Large Cr. 8vo. Pp. 6f8. 1912. Stanford. 12s.

Kayser, E. Text-Book of Comparative Geology. Translated by $P$. Lake. 2nd edn. Demy 8 vo. Pp. 426. 1895. Allen \& Unwin. 10s.6d.

Marr, J.E. The Principles of Stratigraphical Geology. Cr. 8vo. Pp. 312. 1905. Cambridge University Press. 8s. fid.

\section{vii. GEOLOGICAL MAPS.}

Dwerryhouse, A.R. Geological and Topographical Maps: their Interpretation and Use. A Handbook for the Geologist and Civil Engineer. 2nd edn. Demy 8vo. Pp. 141 . 1919. Arnold. 6s.

Harker, A. Notes on Geological Map Reading. 8vo. Pp. 64. 1920. Heffer. 3s. 6d.

Woodward, H. B. (edited by). Stanford's Geological Atlas of Great Britain and Ireland : with Plates of Characteristic Fossils. 3rd edn. Cr. 8vo. Pp. 200 and 36 Maps. Stanford. 15s. 


\section{Geology.}

\section{viii. TOPOGRAPHICAL GEOLOGY.}

Ashton, W. The Evolution of a Coast Line. Barrow to Aberystwyth and the Isle of Man. With Notes on Lost Towns, Submarine Discoveries, etc. Demy 8vo. Pp. 316. 1920. Stanford. 10s.

Davies, G. MacD. Geological Excursions Round London. Cr. 8vo. Pp. 164. 1914. Murby. 4s.

Dron, R. W. The Coal Fields of Scotland. A Topographical and Geological description of the mining areas of Scotland, with details of the various seams, and many maps of the coal-fields. Demy 8vo. Pp.368. N.D. Blackie. $15 s$.

Falconer, J. D. Geology and Geography of Northern Nigeria. svo. Pp. 312, 1911. Macmillan. 10s.

Hatch, F. H., and Corstorphine, G. S. Geology of South Ifrica. 2nd edn. 8vo. Pp. 410. 1909. Macmillan. 25s.

Jukes-Browne, A. J . The Build. ing of the British Isles. A History of the Construction and Geographical Evolution of the British Region. 3rd edn. Large Post 8vo. Pp.461. 1911. Stanford. $12 s$.

Marr, J . E. The Geology of the Isake District. Demy 8vo. Pp. 232. 1916. Cambridge University Press. $14 s$.

Ramsay, Sir A. C. Physical GeoJogy and Geography of Great Britain. 6th edn. E.tited by H. B. Woodward. Post 8vo. Pp. 421. Stanford. 10s. 6d.

Reed, F. R. C. A Handbook to the Geology of Cambridgeshire. $\mathrm{Cr}$. svo. Pp. 286. 1879. Cambridge University Press. $10 s$.

Ritchie, A . E. The Kent Coal Field: its Evolution and Development. Cr. 8vo. 1920. "Iron and Coal Trades Review.', 7s.6d.

Schwarz, E. H. L. South African Geology. Cr.8vo. Pp. 200. 1912. Blackie. 4s. 6d.

Wadia, D. N. Geology of India. 8vo. Pp. 418. 1919. Macmillan. 18s.
Wang, C. Y. A Bibliography of the Mineral Wealth and Geology of China. Cr. 8vo. Pp. 70. 1921. Griffin. 3s. 6d.

\section{ix. ECONOMIC GEOLOGY .}

Boswell, P. G. H. A Memoir on British Resources of Refractory Sands for Furnace and Foundry Purposes. With Chemical Analyses by H, F. Harwood and A. A. Eldridge. Demy 8vo. Pp. 246. 1918. Taylor and Francis. $8 s .6 d$.

Calvert, A. F. Nigeria and its Tinfields. 2nd edn. Cr. 8vo. Pp. 488. 1912. Stanford. 5s.

Graig, E. H. G. Oil Finding. An Introduction to the Geological Study of Petroleum. 2nd edn. Demy 8vo. Pp. 336, 1920. Arnold. 1 ins.

Danby, A. Natural Rock Asphalts and Bitumens. Their Geology, History. Properties and Industrial Application. Cr. 8vo. Pp. 253. 1913. Constable. $8 s .6 d$.

Gibson, W. The Geology of Coal and Coal Mining. 2nd edn. in Preparation. Arnold.

Howe, J. A. The Geology of Building Stones. Cr. 8vo. Pp. 463. 1910. Arnold, 8s.6d.

Park, J Mining Geology. A TextBook for Mining Students and Miners. 4th edn. Cr. 8vo. Pp. 321 . 1918. Griffin. 9s.

Phillips, J. A. A Treatise on Ore Deposits. 2nd edn. revised hy H. Louis. 8ro. Pp. 968. 1896 . Macmillan. $36 s$.

Thomas, H. H., and MacAlister, D.A. The Geology of Ore Deposits. 2nd imp. Cr.8vo. Pp.427. 1920. E. Arnold. 8s. 6d.

Thompson, A. B. Oil-Field Development and Petroleum Mining. New edn. in preparation. Crostiy I,ockwood.

Oil Fields of Russia and the Russian Petroleum Industry. 2nd edn. Med. 8vo. Pp. 523. Crosby Lockwood. $21 s$.

Woodward, H. B. The Geology of Soils and Substrata. Cr. 8vo. Pp. 382. 1912. Arnold. 8s. 6d. 


\section{PALAONTOLOGY.}

\section{i. GENERAL.}

Davies, A. M. An Introduction to Palæontology. Cr. 8vo. Pp. 426. 1920. Murby. 12s.6d.

Etheridge, R. Fossils of the British Islands, Stratigraphically and Zoologically arranged. Vol. 1. Palæozoic. Roy. 4to. Pp. 476. 1888. Oxford: Clarendon Press. 30s.

Hawkins, H. L. Invertebrate Palæontologv: An Introduction to the Study of Fossils. Cr. 8vo. Pp. 245. 1921). Methuen. fis. fid.

Hutchinson, H. N. Extinct Monsters and Creatures of Other Days. A Popular Account of some of the larger forms of Ancient Animal Life. New edn. Demy 8vo. Pp. 362. 1910. Chapman and Hall. $10 s .6 d$.

Lankester, Sir E. R. Extinct Animals. New edn. Ex. Cr. 8vo. Pp. 346. 1920. Constable. 5s.

Nicholson, H. A., and Lydekker, R. A Manual of Palæontology for the use of Students. With a General Introduction on the Principles of Palæontology. 2 Vols. 3rd edn. 8vo. Pp. 1,653. 1889. Blackwood. 63s.

Pelly, S. A. Glossary and Notes on Vertebrate Palæontology. Fcap. 8vo. Pp. 119. 1918. Methuen. $5 s$.

Woods, H. Palæontology-Invertebrat . 5th edn. Cr.8vo. Pp. 420. 1919. Cambridge University Press. $12 s .6 d$.
Zittel, K. A. von., and Eastman, C. R. Text Book of Palæontology. Med. 8vo. Vol. 1. and edn. Pp. 852. 1913. 31s.6d. Vol. 2. Pp. 292. 1902. 12s. 6d. Macmillan.

\section{ii. PALAEOBOTANY .}

Arber, E. A. N. The Natural History of Coal. Roy. 16mo. Pp. 173. 1912. Cambridge University Press. 2s.6d.

Scott, D. H . Studies in Fossil Botany . Part 1. Pteridophyta. Brd edr. Demy 8vo. Pp. 458. 1920. Black. 25s.

Seward, A. C. Links with the Past in the Plant World. Roy. $16 \mathrm{mo}$. Pp. 150. 1911. Cambridge University Press. $2 s, 6 d$.

- Fossil Plants. A Text Book for Students of Botany and Geology. 4 Vols. Demy 8vo. Vol. 1. Pp. 470. 1898. 12s. Vol.2. Pp.646. 1910. 17s. 6d. Vol. 3. Pp. 674. 1917. 20s. Vol. 4. Pp. 560. 1919. 22s. 6d. Cambridge University Press.

Solms-Laubach, G. Fossil Botany: being an Introduction to Palæophytology from the standpoint of a Botanist. Translated by H.E.F. Garnsey. Revised by I. B. Balfour. Rov.8vo. Pp. 414. 1891. Oxford: Clarendon Press. 15s.

Stopes, M. C. Ancient Plants. Being a simple account of the Past Vegetation of the Earth and of the recent important discoveries made in this realm of Nature Study. Demy 8vo. Pp. 187. 1910. Blackie. $7 s .6 d$. 


\section{MINING.}

\section{i. GENERAL.}

Alford, C. J. Mining Law of the British Empire. Cr. 8vo. Pp. 312. 1906. Griffin. 10s.6d.

Burnham, M. H. Modern Mine Valuation. Med. 8vo. Pp. 171. 1912. Griffin. 12s.6d.

Byrom, T.H. An Elementary ClassBook of Physics and Chemistry of Mining. 3rd edn. Cr. 8vo. Pp. 208. 1918. Crosby Lockwood. $4 s .6 d$.

Coppock, J . B ., and Lodge, G. A. An Introduction to Mining Science: A Theoretical and Practical Textbook for Mining Students. Cr.8vo. Pp. 240. 1919. Longmans. 4s.

Field, E. R. The Mining Engineers' Report Book and Directors' and Shareholders' Guide to Mining Reports ; with Tables and Calculations . 3rd edn. Pocket size. 1909 . Griffin. 3s, 6d.

Forrest, S. N. Mining Mathematics -Junior Course. 6th imp. Cr. 8vo. Pp. 312. 1920. Arnold. 4s. $6 d$.

- Mining Mathematics-Senior Course. 2nd edn. Cr. 8vo. Pp. 336. 1920. Arnold. 5s.

Forster, G. Safety-Lamps in Mines . Demy 8vo. Pp. 83. 1914. Routledge. $2 s, 6 d$.

Foster, Sir C. Le N. The Elements of Mining and Quarrying. An Introductory Text-book for Mining Students. 4th edn. Cr.8vo. Pp. 341. 1919. Griffin. $9 s$.

Ore and Stone Mining. 7th edn. Revised by S. H. Cox. Roy. 8vo. Pp. 829. 1910. Griffin. 34s.

Greenwell, A., and Elsden, J.V. Practical Stone Quarrying. Med. 8vo. Pp. 564. 1913. Crosby Lockwood. $15 s$.
Hatch, F. H., and Valentine. E. J. Mining Tables. Being a Comparison of the Unit of Weight, Measure, Currency, Mining Area, etc., of different countries; together with Tables, Constants, and other data useful to Mining Engineers and Surveyors. 8vo. P1. 208. 1907. Macmillan. $6 s$.

Howe, J. A. Stones and Quarries. Cr.8vo. Pp. 147. 1920. Pitman. $3 s$.

Lamprecht, R. Recovery Work after Pit Fires. Translated from the German. Demy svo. Pp. 175. 1901. Scott, Greenwood. 12s.6d.

Lawn, J. G. Mine Accounts and Mining Book-keeping, for Students, Managers, Secretaries, and others. Edited by Sir C. I e N. Foster. 7th edn. Large 8vo. Pp. 158, 1911. Griffin. 10s. 6d.

Mawson, F. Mining Hand-Sketching and Drawing. Tmp. 8vo. Pp. 47 and 20 Plates. 1915. Spon.2s.6d.

O'Donahue. T. A. The Valuation of Mineral Property: Rules, and Tables. Demy 8vo. Pp. 166. 1910. Crosby Lockwood. 8s, 6d.

Power, F. D. Pocket Book for Miners and Metallurgists: Rules, Formulæ, Tables. and Notes for Use in Field and Office Work. 4th edn. Fcap. 8vo. Pp. 385. 1920. Crosby Lockwood. $7 s .6 d$.

Redmayne, Sir R.A.S., and Stone, G. The Ownership and Valuation of Mineral Property in the United Kingdom. 8vo. Pp. 262. 1920. Longmans. $12 s$. $6 d$.

Schwartz, Dr. von. Fire and Explosion Risks: A Handbook of the Dete tion, Investigation and Prevention of Fires and Explosions. Large 8vo. Pp. 378. (Reprint) 1918. Griffin. 18s. 
Skinner, W. R. (edited by). The Mining Manual and Mining Year Book, 1921. Demy 8vo. Pp. 919. March, 1921. Simpkin, Marshall. $20 s$.

\section{ii. GOAL MINING.}

Bulman, H.F. Coal Mining and the Coal Miner. 8vo. Pp. 350. 1920. Methuen. 15s.

__ and Redmayne, Sir R. A. S. Colliery Working and Management. 2nd edn. in preparation. Crosby Lockwood.

Burns, D. The Elements of Coal Mining. Cr.8vo. Pp. 244. 1917. Arnold. 3s. $6 d$.

- Safety in Coal Mines, A Treatise in Fundamental Principles for Firemen, Colliery Managers, and other Workers in Mines, Sm. Cr. 8vo. Pp. 158. N.D. Blackie. 2s.6d. - and Kerr G. L. The Modern Practice of Coal Mining. Med. 8vo. Part 1. Geology and Boring. Pp. 102. 1919. 5s. Part 2. Drills and Drilling-Coal Cutting Machinery. Pp. 173. 1919. 6s. Part 3. Sinking and Fitting Shafts. Pp. 281. 1919. 6s. Part 4. Explosives and Blasting-Transmission of Power. Pp. 170. 1920, 6s. Pitman.

Cantrill, T. G. Coal Mining. Roy. 16mo. Pp. 159. 1914. Cambridge University Press. 2s. 6d.

Cockin, T. H. Practical Coal Mining. 7th imp. Cr. 8vo. Pp. 440. 1920. Crosby Lockwood. 6s. 6d.

Hughes, H. W. A Text-Book of Coal Mining : :.jr the Use of Colliery Managers and others engaged in Coal-Mining. 6th edn. Demy 8vo. Pp. 563. 1917. Griffin. 30s.

Jones, L. A., and Bellot, H. H. L. The Miner's Guide to the Law Relating to Coal Mines. 3rd e dn. $\mathrm{Cr}$. 8vo. Pp. 398. 1914. Methuen. 3s. $6 d$.

Kerr, G. L. Elementary Coal Mining : for the Use of Students, Miners, and others preparing for Examinations. 6th edn. Cr.8vo. Pp. 261. 1921. Griffin. 6s.
Kerr, G. L. Practical Coal Mining : A Manual for Managers, UnderManagers, Colliery Engineers, and others. 7th edn. Large Cr. 8vo. Pp. 789. 1921. Grittin. 16s.

Parker, J. A Text-book of Coal Mining Science. 8vo. Pp. 432. 1916. Gurney \& Jackson. 4s. 6d.

Peel, R. An Elementary Text-Book of Coal Mining. 19th edn. Cr.8vo. Pp. 3s2. N.D. Blackie. 3s.6d.

Redmayne, Sir R. A. S. Modern Practice in Mining. 4 Vols. 8vo. Vol. 1. Coal : Its Occurrence, Value and Methods of Boring. 2nd edn. Pp. 216. 1919. 10s. 6d. Vol.2. The Sinking of Shafts. 2nd edn. Pp. 290. 1920. 10s.6d. Vol.3. Methods of Working Coal. Pp. 222. 1914. 8s.6d. Vol. 4. The Ventilation of Mines. 2nd edn. Pp. 252. 1918. 10s.6d. Longmans.

Riemer, J. Shaft-Sinking in Difficult Cases. Translated by J. W. Brough. Med. 8vo. Pp. 134. 1907. Griffin. 12s. $6 d$.

- Sim, J., and Wylie, A. M. Laboratory Work for Coal-Mining Students. Cr. 8vo. Pp. 144. 1915. Arnold. 3s.

Tonge, J. The Principles and Practice of Coal Mining. Cr. 8ro. Pp. 372. 1996. Maemillan. 4s.

Wilson, F. H. Coal: Its Origin, Method of Working, and Preparation for the Market. Cr. 8vo. Pp. 138. 1913. Pitman. $3 s$.

iii. BLASTING, VENTILATION, AND COMPRESSED AIR.

Daw, A. W., and Z. W. The Blast. ing of Rock in Mines, Quarries, Tunnels, etc. 2nd edn. 8vo. Pp. 316. 1909. Spon. 15s.

Guttmann, $O$. Blasting and the Use of Fixplosives. 2nd edn. Large 8vo. Pp. 197. 1906. Griffin. 10 s. 6d.

Maurice, W. The Shot-Firer's Guide. A Practical Manual on Blasting. Demy 8vo. Pp. 215. N.D. Benn Bros. 5s. 6d. 


\section{Mining.}

Penman, D. Compressed Air Practice in Mining. 2nd edn. in preparation. Griffin.

Wabner, $\mathbf{R}$. Ventilation in Mines . Translated from the German. Roy. 8vo. Pp. 240. 1903. Scott, Greenwood. 12s. 6d.

\section{iv. ELECTRICITY APPLIED TO} MINING.

Burns, D. Electrical Practice in Collieries. A Manual for Colliery Managers, Engineers and Mining Students, 5th edn. Cr. 8vo. Pp. 417. 1920. Griffin. 10s.6d.

Duncan, W. G., and Penman, D. The Electrical Equipment of Collieries. Demy 8vo. Pp. 310. 1908. Scott, Greenwood. 12s.6d.'

Freudemacher, P. W. Electric Mining Installations. Fcap. 8vo. Pp. 191. 1919. Constable. 2s.6d.

Lunton, A., Parr, G. D. A., and Perkin, H. Electricity as Applied to Mining. 2nd edn. Med. 8vo. Pp. 300. 1906. Crosby Lockwood. 12s. 6d.

Maurice, W. Electric Blasting Apparatus and Explosives. Demy 8vo. Pp. 176. N.D. Benn Bros. $10 s .6 d$.

Patche11, W. H. Application of Electric Power to Mines and Heavy Industries. Demy 8vo. Pp. 848 . 1913. Constable. 12s.6d.

Paterson, G. W. L. Electric Mine Signalling Installations. Cr. 8vo. Pp. 204. 1914. Constable. 5s .

Walker, S. F. Electric Mining Machinery. Demy 8vo. Pp. 387. 1919. Pitman. 15s.

- Electricity in Mining. Demy 8vo. Pp. 405. 1907. Harper. 10s. $6 d$.

\section{v. MINING FOR GOLD, DIAMONDS, ETC.}

Charleton, A. G. Gold Mining and Milling in Western Australia, with Notes on Telluride Treatment, Costs, and Mining Practice in other Fields. 8vo. Pp. 650. 1903. Spon. 12s. 6d.
Cleland, E. D. West Australian Mining Practice. Post 4to. Pp. 267. 1911. Technical Bookshop. $10 s .6 d$.

Denny, G. A. Drilling for Gold and Other Micerals. Med. 8vo. Pp. 168. 1900. Croshy Lockwood. $12 s, 6 d$.

The Deep-I evel Mines of the Rand. and their Future Development. Roy.8vo. Pp.170. 1902. Crosby Lockwood. $25 s$.

Dickson, A. A, C. The Mica Miner's and Prospector's Guide. Cr. Svo. Pp. 58. 1919. Spon. $4 s, 6 d$.

Griffiths, H. D. Bucket Dredging for Tin in the F.M.S. Super Roy. 8vo. Pp. 35. 1917. Technical Bookshop. 5s.

Hatch, F, H., and Chalmers, J. A. Gold Mines of the Rand. Super Roval 8vo. Pp. 324. 1895. Macmillan. 17s.

Hodgson, J. E. The Dredging of Gold Placers. Demy 8 vo. Pp. 65 . 1911. Pitman. 5s.

Horwood, C. B. The Gold Deposits of the Rand. Med.8ro. Pp.400. 1917. Griffin. 18s.

Johnson, J, G. F . Getting Gold: A Gold-Mining Handbook for Practical Men. 6th edn. Cr. 8vo. Pr. 211. 1920. Griffin. 6s.

Kassner, T. Gold Seeking in South Africa: A Hand-book of Hints for intending Explorers, Prospectors, and Settlers; with a chapter on the Agricultural Aspects of SouthAfrica. Cr.8vo. Pp. 144. 1902. Griffin. 4s. fid.

Kirkpatrick, T. S. G. The Hydraulic Gold Miner's Manual. 2nd edn. Cr. 8vo. Pp. 46. 1897 . Spon. $4 s$.

Tinney, W. H. Gold Mining Machinery: its Selection, Arrangement, and Installation. Med. 8vo. Pp.320. 1906. Crosby Lockwood. $12 s, 6 d$. 
Truscott, S. J. Witwatersrand Goldfields, Banket, and Mining Practice. 3rd edn. Super royal 8vo. Pp. 546. 1907. Macmillan. $40 s$.

Wagner, P.A. The Diamond Fields of Southern Africa. Cr. 4to. Pp. 347. 1914. Technical Bookshop. $32 s .6 d$.

Young, R. B. The Banket. A Study of the Auriferous Conglomerates of the Witwatersrand and the Associated Rocks. Med. 8vo. Pp. 135. 1917. Gurney and Jackson. 8s.6d.

\section{vi. ORE DRESSING .}

Eissler, M. Cyanide Process for the Extraction of Gold and its Practical Application on the Witwatersrand Goldfields and elsewhere. 3rd edn. 8vo. Pp. 202. 1902. Crosby Lockwood. 8s.6d.
Hoover, T.J. Concentrating Ores by Flotation. 3rd edn. Med. 8vo. Pp. 320. 1916. Technical Bookshop. 12s. fid.

Julian, H. F., Smart, E., and Allen, A. W. Cyaniding Gold and Silver Ores. A Practical Treatise on the Cyanide Process : its Application, Methods of Working, Design and Construction of Plant, and Costs. 2nd edn. Med. 8vo. Pp. 460. 1913. Griffin. 25s.

Levy, D. M. Modern Copper Smelting. Med. 8vo. Pp 271. 1912. Griffin. 12s, $6 d$.

Lock, G.W. Gold Milling. Principles and Practice. 8vo. Pp. 823. 1901. Spon. $21 s$.

Louis, H. A Handbook of GoldMilling. 3rd edn. Cr. 8vo. Pp. 616. 1902. Macmillan. 12s. 6d. The Dressing of Minerals. Super royal 8vo. Pp.554. 1909. Arnold. $30 s$. 


\section{GEOGRAPHY.}

\section{i. TEAGHING OF GEOGRAPHY.}

Archer, R. L., Lewis, W. J., and Chapman, A. E. The Teaching of Geography in Elementary Schools. 3rd edn. Cr.8vo. Pp. 259. 1918. Black. 5s.

Mill, H.R. A Guide to Geographical Books and Appliances. Revised by A. J. Herbertson, J. F. Unstead, and N. E. MacMunn. 2nd edn. Demy 8vo. Pp. 208. 1910. Geo. Philip. 6s.

Wallis, B. C. The Teaching of Geography. Cr. 8vo. Pp. 232. 1910. Cambridge University Press. $5 s$.

\section{ii. HISTORICAL GEOGRAPHY.}

Beazley, C. R. The Dawn of Modern Geography. A History of Exploration and Geographical Science from the Conversion of the Roman Empire to the early years of the Fifteenth century. 3 Vols. 8vo. Vol. 1. To A.D.900. (Out of print). Vol. 2. A.D. $900-1260$. Pp. 652. 1904. 20s. Vol. 3. A.D. 1260-1420. Pp.638. 1906 . 25s. Vols. 2 and 3. $40 s$. Oxford: Clarendon Press.

Crockett, T., and Wallis, B. C. North America during the Eighteenth Century. A Geographical History. Cr.8vo. Pp.124. 1915. Cambridge University Press. 4s.6d.

Fairgrieve, J . Geography and World Power. 2nd edn. Cr. 8vo. Pp. 381. 1920. University of London Press. 5s.

Fordham, Sir H. G. Studies in Carto-Bibliography. 8vo. Pp. 190. 1914. Oxford: Clarendon Press. 6s.
Freeman, E. A. The Historical Geography of Europe. 8vo. Pp. 664. 13s. 6d. Atlas to the same. 3rd edn. 8vo. 1920. 7s. 6d. Longmans .

George, H. B. The Relations of Geography and History. 4th edn. Cr. 8vo. Pp. 310. 1910. Oxford: Clarendon Press. 4s. 6d.

Heawood, F. A History of Geographical Discovery in the Seventeenth and Eighteenth Centuries. Cr. 8vo. Pp. 487. 1912. Camhridge University Press. $15 s$.

Keltie, Sir J . S., and Howarth, $O$. J.R. History and Geography. Cr . 8vo. Pp. 163. 1913. Watts. 3s. 6d.

Newbigin, M.I. Modern Geography . Fcap. 8vo. Pp. 256. 1911. Williams and Norgate. $2 s .6 d$.

Parkinson, T. W. F. Lessons in Modern Geography. Cr. 8vo. Pp. 148. 1919. Oxford University Press. 3s.

Tozer, H. F. A History of Ancient Geography. Cr. 8vo. Pp. 387. 1897. Cambridge University Press. 10s. 6d.

\section{iii. Physiography .}

Huxley, T. H. Physiography: an Introduction to the Study of Nature. A new edition Revised and partly re-written by Sir R. A. Gregory. Gl. 8vo. Pp. 436. 1919. Maemillan. $7 s$.

Mill, H. R. The Realm of Nature. An Outline of Physiography. 2nd edn. Cr. 8vo. Pp. 416. 1918. Murray . 6s. 
Salisbury, R. D. Physiography . Demy 8vo. Pp. 7\%0. Murray. 25s.

Physiography. Shorter Course. Large Cr. 8vo. Pp. 529. 1909. Murray. $12 s$.

Simmons, A. T. Physiography for Advanced Students. G1.8vo. Pp. 498. 1901. Macmillan. 5s.

- Physiography for Beginners. New imp. G1. 8vo. Pp. 364. 1905. Macmillan. $3 s$.

Thornton, J. Elementary Practical Physiography. New edn. 2 Parts. Cr. 8vo. Part 1. Pp. 370. 1906. Part 2. Pp.220. 1904. Longmans. $4 s$. each part.

- Elementary Physiography : an Introduction to the Study of Nature. Cr. 8vo. Pp. 442. 1917. Long. mans. 4s.

- Advanced Physiography . Cr. 8vo. Pp. 412. 1911. Longmans. 6s.

\section{iv. PHYSICAL GFOGRAPHY.}

Barnard, H. G. Outlines of Physical Geography. 2nd edn. Cr. 8vo. Pp. 156. 1917. Black. 2s.6d.

Geikie, Sir A. Elementary Lessons in Physical Geography. Fcap. 8vo. Pp. 410. 1919. Macmillan. 5s.

Gregory, J. W. Geography: Structural, Physical, Comparative. Large Cr. 8vo. Pp.305. N.D. Blackie. $7 s .6 d$.

Hughes, W., and Gregory, Sir R. A. Class Book of Physical and Astronomical Geography. Cr. 8vo. Pp. 336. Geo. Philip. 3s.6d.

Hunter, W. I. Rivers and Estuaries, or Streams and Tides. 8vo. Pp.76. 1912. Longmans. 2s.6d.

Lake, P. Physical Geography. New edn. Demy 8vo. Pp. 344. 1919. Cambridge University Press. 13s.

Longmans' Geographical Series. Book 5. A Primary Physical Geography. New imp. Cr. 8vo. Pp. 229. 1917. Longmans. 3s.6d.

Newbigin, M. I. An Introduction to Physical Geography. Cr. 8vo. Pp. 336. Dent. 4s, $6 d$.
Poynting, J. H. The Earth: its Shape, Size, Weight, and Spin. Roy. 16mo. Pp. 141. 1813. Cambridge University Press. 2s. 6d.

Russell, I. C. River Development. As Illustrated by the Rivers of North America. Large Cr. 8vo. Pp. 327. Murray. 7s.6d.

Simmons, A. T., and Stenhouse, E. A Class Book of Physical Geography. Cr. 8vo. Pp. 444. 1919. Macmillan. 5s, 6d.

Smith, B. Physical Geography. 2nd edn. Demy 8vo. Pp. 198. 1917. Black. 4s. 6d.

Wood, G. A. A Physical and Ticonomic Geography of the World. 3rd edn. Cr. 8vo. Pp.750. N.D. Normal Press. 6s. 6d.

\section{v. MAP WORK.}

Bryant, V. S., and Hughes, T. H. Map Work. Med. 8vo. Pp. 174. 1918. Oxford: Clarendon Press. $5 s$.

Hinks, A. R. Maps and Survey. Demy 8vo. Pp. 222. 1913. Cambridge University Press. $8 s .6 d$.

Map Projections. Demy 8vo. Pp.138. 1912. Cambridge Üniversity Press. $7 s$.

Newbigin, M. I. Ordnance Survey Maps : their Meaning and Use with Descriptions of Typical 1.inch Sheets. 2nd edn. Fcap. 8vo. Pp. 128. 1920. Johnston. 2s.

\section{vi. COMMERCIAI, AND ECONOMIG.}

Bridge, R. S. Geography of Commerce and Industry. Cr.8vo. Pp. 272. 1920. Hodder and Stoughton. $4 s .6 d$.

Brown, R. N. R. The Principles of Economic Geography. 8vo. Pp. 223. 1920. Pitman. 10s. 6d.

Chisholm, G. G. Handbook of Commercial Geography. 8th edn. 8vo. Pp. 732. 1920. Longmans. $25 s$. 


\section{Geography.}

Chisholm, G.G. A Smaller Commercial Geography. New imp. Cr. 8vo. Pp. 295. 1920. Longmans. $5 s$.

Curr, A. L. Commercial Geography . An Intermediate Text-book. $\mathbf{C r}$. 8vo. Pp. 440. 1915. Black. 5s.

Fairgrieve, J., and Young, E. The Gateways of Commerce: An Introduction to Economic Geography. Cr. 8vo. Pp. 280. 1921. Philip. 3s, 6d.

Herbertson, A. J. Commercial Geography of the World. Cr. 8vo. Pp. 383. N.D. Chambers. 3s.6d.

Howarth, O. J. R. A Commercial Geography of the World. 2nd edn. Cr. 8vo. Pp. 236. 1920. Oxford: Clarendon Press. 4s.

Lyde, L. W. A Commercial Geo graphy of the World. 5th edn. Small Cr. 8vo. Pp. 287. 1919. Black, $4 s, 6 d$.

McFarlane, J. Economic Geography. Demy 8vo. Pp. 568. N.D. Pitman. 10s,6d.

Sargent, A. J. Seaways of the Empire. Large Cr. 8vo. Pp. 171. 1918. Black. 7s, 6d.

Thurston, C. B. An Economic Geography of the British Fmpire. Cr. 8vo. Pp. 388. 1919. University of London Press. 5s.

vii. GENERAL: THE WORLD.

Fry, G.C. Text-Book of Geography . 3rd edn. 11th imp. Cr. 8vo. Pp. 490. 1921. University Tutorial Press. 6s. 6d.

Golding, A. A. An Introduction to General Geography. Cr. 8vo. Pp. 232. 1915. Cambridge University Press. 5s.6d.

Heaton, E. W. The Senior Scientific Geography. Cr. 8vo. Pp. 861. Herbert Russell. $7 s, 6 d$.

Herbertson, A. . ., and F. D. The Senior Geography. 5th edn. Cr. 8vo. Pp. 372. 1918. 5s. With Questions by F. M. Kirk and Statistical Appendix by E. G. R. Taylor. Pp. 436. 4s. With Physiographical Introduction, Questions, and Statistical Appendix. Pp. 564. 5s. Oxford: Clarendon Press.
Herbertson, A. J., and F. D. The Clarendon Geography. 2 Vols. Cr. 8vo. 1912-13. Vol. 1. Principles, British Isles and Furope. Pp. 380. 4s. Vol.2. Asia, Africa, Australia and America. Pp. 376 4s. Oxford: Clarendon Press.

Hughes, W. Class Book of Modern Geography. Physical, Political, and Commercial. Cr. 8vo. Pp. 488. 1912. Geo. Philip. 3s.6d.

-Advanced Class Book of Modern Geography. Cr. 8vo. Pp. 884 . 1908. Géo. Philip. 4s,6d.

Johnston, K. Physical, Historical, Political, and Descriptive Geography. 6th edn. Revised by $\mathbf{A}$. H. Keane. Large Post 8vo. Pp. 491. 1908. Stanford. 12s.

Longmans' Geographical Series . Book 1. First Book of Geography. New imp. Cr.8ro. Pp.182. 1918. Longmans. $3 s$.

-Book 2. The World for Iunior Students. New imp. Cr. 8vo. Pp. 510. 1918. Longmans. 6s.

-Book 3. The World for Senior Students. New imp. Cr. 8vo. Pp. 623. 1918. Longmans. 7s.6d.

Lyde, L. W. Short Text-book of Geography. 2nd edn. Small Cr. 8vo. Pp. 416. 1917. Black. 6s.

Piggott, H., and Finch, R. J. World Studies: An Introduction to General Geography. Demy 8vo. Pp. 390. Dent. 4s.6d.

Simmons, A. T ., and Richardson, H. Introduction to Practical Geography. Gl. 8vo. Pp.392. 1916. Macmillan. $4 s$.

Unstead, J. F., and Taylor, E. G. R. General and Regional Geography for Students. 6th edn. Large 8vo. Pp. 520. 1920. Geo. Philip. $7 s .6 d$.

Wallis, B. C. Essentials of Practical Geography. G1. 8vo. Pp. 232. 1918. Macmitlan. 4s. $6 d$.

-A Geography of the World. GI. 8vo. Pp. 388. 1919. Macmillan. $4 s .6 d$.

_-Practical Exercises in Gergraphy. A Two Years' Course. New imp. Cr. 8vo. Pp. 208. 1920. 8s. Key. 4s.6d. Macmillan. 
Wilmore, A. The Groundwork of Modern Geography. An Introduction to the Science of Modern Geography. Cr. 8vo. Pp. 412. 1920. Bell. 6s.

\section{viii. GENERAL : BRITISH EMPIRE.}

Bunting, W. L., and Collen, H. L. A Geography of the British Empire. 2nd edn. Cr. 4to. Pp. 168. 1916. Cambridge University Press. 6s.

Herbertson, A. J., and Howarth, O. J.R. (edited by). The Oxford Survey of the British Empire. Being a description of the Fmpire and its constitutent territories in their geographical, economic, administrative and social aspects at the present time. 6 Vols. 8vo. 1914. Vol. 1. British Isles, \&c. Pp. 608. Vol. 2. Asia. Pp. 515. Vol. 3. Africa. Pp. 564. Vol. 4. America. Pp. 521. Vol. 5. Australasia. Pp. 596. Vol.6. General Survey. Pp. 394. Oxford: Clarendon Press. 15s. each; the 6 Vols. $70 s$.

-and Thompson, R. L. Geography of the British Empire. 3rd edn. Cr. 8vo. Pp. 256. 1918. Oxford: Clarendon Press. $3 s$.

Longmans' Geographical Series. Book 4. The British Empire. New imp. Cr. 8vo. Pp. 349. 1918. Longmans. 5s.

Newbigin, M. I. The British Em pire Beyond the Seas. 3rd edn. Cr. 8vo. Pp. 250. 1917. Bell. $4 s .6 d$.

\section{ix. DESGRIPTIVE REGIONAL.}

Brooks, L. New Regional Geographies. Cr. 8vo. Book 1. The Americas. Pp. 256. 1919. 4s. Book 2. Asia and Australasia. Pp. 300. 1919. 4s, Book 3 . Africa and Furope. Pp.480. 1919 . 6s. 6d. Part 1. Africa. Pp. 140. 1920. 2s. 6d. Part 2. The British Isles. Pp. 140. 1920. 2s. 6d. Part 3. Europe, including the British Isles. Pp. 340. 1920. 5s. Book 4. The World. In preparation. University of London Press.
Hogarth, D. G. Nearer East (Balkans, Asia Minor, N.E.Africa, Egypt, Arabia, Persia, etc.). (Regions of the World). 8vo. Pp. 312. 1905. Oxford: Clarendon Press, 10s. 6d.

Holdich, Sir T. India. (Regions of the World). 8vo. Pp. 388. 1904. Oxford: Clarendon Press. 10s. 6d.

Little, A. The Far East (China, Japan, Turkestan, Eastern Asia, etc.). (Regions of the World). 8vo. Pp. 342. 1905. Oxford: Clarendon Press. 10s. 6d.

Lyde, L. W. The Continent of Europe. 8vo. Pp.462. 1917. Macmillan. 8s. 6d.

Mackinder, H. J. Britain and the British Seas. (Regions of the World). 2nd edn. 8vo. Pp.388. 1907. Oxford: Clarendon Press. $10 s, 6 d$.

Martin, J. A Geography of Asia. Cr. 8vo, Pp. 306. 1919. Macmillan. 58 .

Partsch, J. Central Europe (Alpine Countries, Germany, Austria, Netherlands, etc.). Translated from the German. (Regions of the World). 8vo. Pp. 372. 1904. Oxford : Clarendon Press. 10s. 6d.

Russell, I. North America (Canada, United States, Mexico, etc.). (Re: gions of the World). 8vo. Pp. 444. 1904. Oxford: Clarendon Press. $10 s .6 d$.

Stanford's Compendium of Geography and Travel. 13 Vols. Large Cr. 8vo. Europe. Vol. 1. The Countries of the Mainland (excluding the North-West). By B. C. Wallis. New edn . in preparation. Europe. Vol. 2. British Isles, Scandinavia, Denmark, and the Low Countries. By B. C. Wallis. New edn. in preparation. North America. Vol. 1. Canada and Newfoundland. By $H$. M. Ami. Pp. 1,069. 1915. North America. Vol. 2. The United States. New edn. in preparation. Australasia. Vol. 1. Australia and New Zealand. By J.W. Gregory. 2nd edn. Pp.657. 1907. 


\section{Geographiy.}

Australasia. Vol. 2. Malaysia and the Pacific Archipelagoes. By F. H.H.Guillemard. 2nd edn. revised by A. H. Keane. Pp. 590. 1908. Africa. Vol. 1. North Africa. By A. H. Keane. 2nd edn. Pp. 640 . 1907. Africa. Vol. 2. South Africa. By A. H. Keane. 2nd edn. 1908. Asia. Vol. 1. Northern and Eastern Asia, Caucasia, Russian Turkestan, Siberia, Chinese Empire, Korea and Japan. By A. H. Keane. 2nd edn. Pp. 554. 1906. Asia. Vol. 2. Sonthern and Western Asia, Afghanistan, India, Indo-China, Malay Peninsula, Turkey in Asia, Arabia and Persia. By A. H. Keane. 2nd edn. Pp. 527. 1909. Central and South America. Vol. 1. South America. By A. H. Keane. 2nd edn. Pp. 638. 1911. Central and South America. Vol. 2. Central America and West Indies. By A. H. Keane. Pp. 500. 1901. Glossary of Geographical and Topographical Terms, and of words of frequent occurrence in the composition of such terms and of place names. By A. Knox. Pp. 432. Stanford. 17s.6d. each Vol.

Taylor, G. Australia, in its Physiographic and Economic Aspects. 3rd edn. Cr. 8vo. Pp. 266. 1920. Oxford: Clarendon Press. 4s.

\section{x. MISCELLANEOUS .}

Fawcett, C. B. Frontiers, a Study in Political Geography. Cr. 8vo. Pp. 108. 1918. Oxford: Clarendon Press. 3s. 6d.

-Provinces of England. A Study of some Geographical Aspects of Devolution. Cr. 8vo. Pp. 296. 1919. Williams and Norgate. 6s. $6 d$.

Fleure, H. J. Human Geography in Western Europe. Cr. 8vo. Pp. 263. 1919. Williams and Norgate. $6 s$.

Keltie, Sir J. S. Applied Geography. 2nd edn. Cr.8vo. Pp. 175. 1908. Geo. Philip. 3s. 6d.

Maguire, T. M. Outlines of Military Geography. Cr. 8vo. Pp. 367. 1900. Cambridge University Press. 12s. $6 d$.

Mill, H. R. New Lands: their Resources and Prospective Advantages. Cr. 8vo. Pp. 292. 1900. Griffin. $5 s$.

Vinall, J. W. T., and Snaith, G. L. Open-Air Geography and Topographical Modelling. 8vo. Pp. 224. 1920. Blackie. 5s. 


\section{NAVIGATION AND SEAMANSHIP.}

\section{NAVIGATION AND NAUTICAL ASTRONOMY .}

Anon. Ru-Ro, the Rule of the Road at Sea. Fully illustrated by Diagrams in colour. Demy 8vo. Pp. 32. Jas. Munro. $2 s .6 d$.

Arnold, H. T. Steamship Naviga tion. Cr. 8vo. Pp. 104. N.D. Blackie, 2s. $6 d$.

Card, S. F. Navigation Notes and Examples. 3rd edn. Demy 8vo. Pp. 262. 1920. Arnold. 12s. 6d.

Cross, F. New Navigation. 3rd edn. Demy 8vo. Pp. 39. 1919. James Brown. 2s. 6d.

Dunraven, Earl of, Self Instruction in the Practice and Theory of Navigation. New edn. 3 Vols. 8vo. 1908. Vols. 1 and 2. Pp. 300.,348. 17s. Vol.3. Pp. 350. 8s.6d. Macmillan.

Gill, J. Text-Book on Navigation and Nautical Astronomy. Revised and Enlarged by W. V. Merrifield. New edı. Med. 8vo. Pp. 446. 1918. Longmans. $21 s$.

Grant, H. C. J. Pocket Book of Practical Navigation. Revised by E.R. G. R. Evans and B. C. Porter. $18 \mathrm{mo}$. Pp. 207. 1920. Gieves. 10s. $6 d$.

Groves-Showell, P. Definitions in Navigation and Nautical Astronomy. Cr.8vo. Pp.115. 1908. Griffin. 3s.

Hall, W. Modern Navigation (Navigation and Nautical Astronomy). 2nd edn. 6th imp. Cr. 8vo. Pp. 337. 1919. University Tutorial Press. 9s.6d.

Hughes, A. J. The Book of the Sextant. Demy 8vo. Pp. 63. 1915. James Brown. 3s. 6d.
Jutsum, J. N. Brown's Rule of the Road Manual. New edn. Cr. 8vo. Pp. 97. 1921. J. Brown. 2s.6d.

Lecky, S. T. S. The Danger Angle and Off-Shore Distance. 12th edn. Sq. 8vo. Pp. 138. 1919. Geo. Philip. $6 s$.

Wrinkles in Practica! Navigation. 12th edn. Roy. 8vo. Pp. 814. 1920. Geo. Philip. 30s.

MacHattie, A. The Navigator's Practical Star Book. For Learners and Experienced Navigators. Containing 40 charts. Roy. 1 to Oblong . Jas. Munro. $7 s, 6 d$.

Millar, W. J.- Latitude and Longitude: How to Find them. 3rd edn. Cr. 8vo. Pp. 60. 1914. Griffin. $2 s$.

Miremont, Comte de. Practical Methods in Modern Navigation. Demy 8vo. Pp. 107. 1905. Geo. Philip. 5s.

Owens, E. W. How to Learn on Shore the Rule of the Road at Sea. Demv svo. Pp. 40. 1906. Geo. Philip. 5s.

Rugg, W. G. Stellar Indicator. Showing meridian passage, hour angle, and meridian altitude of the principal stars in both hemispheres at a glance. Jas. Munro. $2 s .6 d$.

A Treatise on the Projection of the Sphere, showing how to construct and compute all the Astronomical problems, etc. Cr. Ato. Jas. Munro: 3s. 6d.

Rule of the Road, Collison Indicator. Post 4to. Jas. Munro. $2 s .6 d$.

Smith, D. W. The Law Relating to the Rule of the Road at Sea. 2nd edn. Demy 8vo. Pp. 333. 1910. James Brown. 10s. 6d. 


\section{Navigation and Seamanship.}

Stebbing, F. C. Navigation and Nautical Astronomy. 2nd edn. 8vo. Pp. 352. 1903. Macmillan. 8s. $6 d$.

Swainston, C. M. New Guide Book. 16th edn. Demy 8vo. Pp. 594. 1920. T. Reed \& Co. 12s. Gul.

Whall, W. B. Handy Book of the Stars used in Navigation. 8th edn. Oblong 4to. 1920. Geo. Philip. 8s. 6d.

Williamson, A. P. W. Text-Book of Navigation and Nautical Astronomy. New edn. 8vo. Pp. 413. 1920. John Hogg. 10s. 6d.

Wilson -Barker, Sir D ., and Alling ham, W. Navigation: Practical and Theoretical. 3rd edn. Cr.8vo. Pp. 168. 1913. Griffin. 3s. 6d.

ii. EXAMINATION GUIDES ON NAVIGATION AND SEAMAN SHIP.

Cogle and Tait's Extra Master's Guide. Explanations of all questions in Navigation, Nautical Astronomy, and Compass Syllabus. 3rd edn. Cr.4to. Pp. 238. 1904. James Brown. 10s. 6d.

Don, J., and Caird, W. J. Chambers's Navigation: A Guide to the Examinations of Second Hands, Skippers, and Extra Skippers of Fishing Vessels and Trawlers. $\mathrm{Cr}$. 8vo. Pp.312. Chambers. 3s.6d.

Hansen, L. F. Trigonometry and Navigation. A Complete Guide to the B.O.T. Examination for Extra Masters only. Roy. 8vo. 1920. J. Brown. $15 s$.

Morris, C. Extra Master's, Master's, and Mate's Handbook. A Guide to the Board of Trade Examinations. 3rd edn. Demy 8vo. Pp. 564. 1913. James Brown. 10s.6d.

Nicholls, A. E., Concise Guide for Board of Trade Examinations. Revised by Capt. Maxwell. 18th edn. Demy 8vo. Pp. 732. 1920. James Brown. $15 s$. $6 d$.
Tait, Capt. Memory Work, required for the Board of Trade Examinations of Second Mates, Mates, and Masters. 3rd edn. Cr. 8vo. Pp. 94. Jas. Munro. $2 s$.

Tait, J. Tait's Trawler's and Fisherman's Guide. 7th edn. Cr. 8vo. Pp. 216. 1919. James Brown. 3s. $6 d$.

Tait's Guide to the Board of Trade Examinations for Second Mates, Mates, and Masters. Jas. Munro. $8 s$.

Williamson, A. P. W. Home Trade. New Guide to home trade Masters' and Mates' Examinations. 2nd edn. Cr. 8vo. Pp. 146. Jas. Munro. 2s. 6d.

\section{iii. GOMPASS WORK.}

Brown; C. H. Deviation and the Deviascope, including the Practice and Theory of Compass Adjustment. Demy 8vo. Pp. 133. 1918. James Brown. 5s. 6d.

Martin, W. R. Lectures on Compass Adjustment. Demy 8vo. Pp.98. 1906. Geo. Philip. 5s.

Merrifield, J. Magnetism and Deviation of the Compass. $18 \mathrm{mo}$. Pp. 168. 1919. Longmans. 3s. 6d.

Rugg, W. G. Pocket Deviaseope. For Illustrating Compass adjustment. 16mo. Jas. Munro. 1s.6d.

Tait, Capt. New Compass Syllabus, with over 100 Questions and Answers, with diagrams. 2nd edn. Cr. 8vo. Pp. 44. Jas. Munro. 2s.

Tait, J. Home Trade Guide. Full explanations of True and Magnetic Chart, Compass Deviations, Latjtude by Meridian Altitude, Signals, Rule of the Road, etc. 10th edn. Cr.8vo. Pp. 321. 1919. James Brown. 5s.

\section{iv. NAUTICAL TABLES AND TERMS.}

Ansted, A . Dictionary of Sea Terms. Cr. 8vo. Pp. 320. 1919. James Brown. 5s. 


\section{Navigation and Seamanship.}

Brent, G., Walter, A. F., and Williams, G. Ex-Meridian Altitude Tables. 9th edn. Roy. 8vo. Pp. 91. 1920. Geo. Philip. $7 s, 6 d$.

Brown, J. R. (edited by). Brown's Nautical Almanac; Harbour and Dock Guide and Daily Tide Tables for 1921. 8vo. Pp. 681. Dec. 1920. J. Brown. 3s. Gd.

Delbos, L. Nautical Terms in English and French and French and Fnglish. New edn. Cr. 8vo. Pp. 461. 1914. Williams and Norgate. $5 s$.

Jefferson's Nautical Almanac and Tide Tables, Harbour and Lighthouse Guide. Published annually in September. Cr. 8vo. Jas. Munro. $2 s .6 d$.

Norie, J. W. A Complete Set of Nautical Talsles, with Explanations of their Use. Cr. 4to. Pp. 738. 1920. Imray, Laurie. $21 s$.

Pearson's Nautical Almanac and Tide Tables for 1921. 8vo. Pp. 440. Nov., 1920. Imray, Laurie. 3s. $6 d$.

\section{v. SEAMANSHIP.}

Ginsburg, B. W. The Legal Duties of Shipmasters. 3rd edn. Cr. 8vo. Pp. 283. 1911. Griffin. 5s.

MacNab, J . Catechism of the I_aws of Storms, for the Use of Sea Officers. 6th edn. Cr. 8vo. Pp. 73. 1913. Geo. Philip. 4s. $6 \mathrm{~d}$.

Nicholls, Capt. Seamanship. 10th edn. Demy 8vo. Pp.472. 1919. James Brown. 8s. $6 d$.

Owen, H. Ship Economics, or Practical Aids for Shipmasters. 2nd edn. Demy 8vo. Pp. 137. 1918. Geo. Philip. 5s. fd.

Swainston, C. M. Seamanship, Meteorology, and Shipbuilding. 22nd edn. Cr. 8vo. 1918. T. Reed \& Co. 6s.

Tait, J. Seamanship. 12th edn. Cr. 8vo. Pp. 164. 1920. James Brown. 2s.

-New Seamanship. 10th edn. Cr. 8vo. Pp. 443. 1920. James Brown. 7s.6d.
Toda, J., and Whall, W.B. Practical Seamanship. For use in the Merchant Service. 7th edn. Roy. 8vo. Pp.442, 1919. Geo. Philip. $30 s$.

Wilkes, W. H. Notes on the Practical Duties of Shipmusters. Cr. 8vo. Pp. 127. 1911. Griffin. 3s.

Williamson, A. P. W. Ship's Business and Practival Items in Modern Seamanship. 2nd edn. Cr. 8vo. Pp. 45. Jas. Munro. $1 s .6 d$.

Wilson-Barker, Sir D. A Manual of Elementary Seamanship. 8th edn. Cr. 8vo. Pp. 287. 1919. Griffin. 7s. fid.

Things A Sailor Needs to Know. Med.svo. Pp.351. 1919. Griffin. $21 s$.

\section{vi. MARINE SIGNALLING .}

Bernard, D. H. Signalling Made Easy. New edn. Cr. 8vo. Pp. 8.5. 1918. James Prown. 2s. $6 d$.

Brown's Signalling. 22nd edn. Cr. 8vo. Pp. 134. 1020. James Brown. $4 s$, fid.

Rugg, W. G. Signal Manual : for the Use of the Mercantile Marine. 2nd edn. Demy 8vo. Jas. Munro. Is .

\section{vii. CHARTS, TIDES, OGEANOGRAPHY.}

Abbott, T. K. Flementary Theory of the Tides: the Fundamental Theorems Demonstrated without Mathematics and the Influence of the Length of the Day Discussed. 2nd edn. Cr. 8vo. Pp. 40. 1901. Longmans. 2s.

Carpenter, A., and Wilson-Barker, Sir D. Nature Notes for Ocean Voyagers: Observations of Fishes, Birds, and Beasts; with Popular Chapters on Weather, Waves, and Legendary Lore. Med. 8vo. Pp. 197. 1915. Griffin. 6s.

Fowler, G. H. (edited by). Science of the Sea. An Elementary Handbook of Practical Oceanography for Travellers, Sailors and Yachtsmen. Large Cr. 8vo. Pp. 452. 1912. Murray. 10s.6d. 
Jenkins, J. T. A Textbook of Oceanography. Demy 8vo. Pp. 216. 1921. Constable. 15s.

Maxwell, F, W . Book on Chartwork and Plans. 4th edn. Demy $8 v o$. Pp. 67. 1918. James Brown. 2s. 6d.

Messum, S. Hydrographic Surveying. For the use of Beginners and Port and Harbour Masters. $\mathrm{Cr}$. 8vo. Pp. 519. 1910. Griffin. $15 s$.

Murray, Sir J. The Ocean. Fcap. 8vo. Pp. 256. 1919. Williams and Norgate. $2 s, 6 d$.

and Hjort, J. The Depths of the Ocean. A General Account of the Modern Science of Oceanography. Sup Roy. 8vo. Pp.842. 1912. Macmillan. 28s.
Robinson, J.L. Elements of Marine Surveying, with Numerous Exercises. 3rd edn. Cr. 8vo. Pp. 2\%4. 1904. Maemillan. 7s. $6 d$.

Struben, A. M. A. Tidal Power: Tides and their Measurement; the Estimation of Potential Tidal Power; Comparisons between Systems of Development; the Financial aspect of the Problem, etc. Fcap. 8vo. Pp. 127. 1921, Pitman. $2 s, 6 d$.

Whall, W. B. Handy Book of the Tides. 10th edn. Demy 4to. Pp. 37. Geo. Philip. 5s.

Wharton, Sir W. J. L. Hydrographical Surveying. A description of the means and methods employed in constructing Marine Charts. 3rd edn. revised and brought up to date by Sir M. Field. Demy 8vo. Pp. 582. 1920. Murray. $30 s$. 


\section{BIOLOGY.}

\section{i. GENERAL.}

Bidgood, J. A Course of Practical Elementary Biology. Cr. 8vo. Pp. 362. 1914. Longmans. 5s.6d.

Gampbell, H. J. Text Book of Elementary Biology. 3rd edn. Cr. 8vo. Pp. 306. 1905. Allen and Unwin. $6 s$.

Gibson, H. A Primer of Biology . Fcap. 8vo. Pp. 120. 1908. Dent. $2 s$.

Henderson, J. F., and W. D. A Dictionary of Scientific Terms : Pronunciation, Derivation, and Definition of Terms in Biology, Botany, Zoology, Anatomy, Cytology, Embryology, Physiology. Demy 8vo. Pp. 362. 1920. Oliver and Boyd. 18s.

Huxley, T. H. Discourses, Biological and Geological. New imp. Gl. 8vo. Pp. 388. 1908. Macmillan. $6 s$.

and Martin, H. N. A Course of Practical Instruction in Elementary Biology. 3rd edn. Revised and extended by G. B. Howes and D. H. Scott. Cr. 8vo. Pp. 528. 1907. Macmillan. $12 s .6 d$.

Kirkaldy, J. W., and Drummond, I. M. An Introduction to the Study of Biology. Unicellular Organisms; Simple Multicellular Organisms: Higher Plants and Animals. Cr.8vo. Pp.266. 1909 . Oxford: Clarendon Press. 6s. 6d.

Lloyd, F. E., and Bigelow, M.A. The Teaching of Biology in the Secondary School. New edn. Cr. 8vo. Pp. 500. 1919. Longmans. 8 s.

Lloyd, R. E. An Introduction to Biology: for Students in India. 8vo. Pp. 316. 1910. Longmans. $9 s$.
MacFadyen, $A$. The Cell as the Unit of Life: An Introduction to Biology. Edited by R. T. Hewlett. 8vo. Pp. 400. 1908. Churchill. 7s. 6d.

Miall, L. C. History of Biology. Cr. 8vo. Pp. 150. 1911. Watts. 3s. 6 d.

Mitchell, P. G., and Mudge, G. P. Outlines of Biologv. 4th edn. Cr. 8vo. Pp. 364. 1911. Methuen. 7s. $6 d$.

Parker, T.J. Lessons in Elementary Biology. 2nd edn. Cr.8vo. Pp. 528. 1920. Macmillan. 12s. 6d.

Thesing, C. Lectures on Biology. Translated by W. R. Boelter. Med. 8vo. Pp. 342. 1911. Bale and Danielsson, 10s.6d.

Thomson, J. A. The Science of Life. An Outline of the History of Biology and its Recent Advances. Cr. 8vo. Pp. 246. N.D. Blackie. $3 s$.

The Biology of the Seasons. 4th edn. Med. 8vo. Pp. 393. 1915. Melrose. 15s.

Thornton, J. Elementary Biology; Descriptive and Experimental. Revised edn. Cr. 8vo. Pp. 288. 1907. Longmans. 4s. $6 d$.

\section{ii. NATURE STUDY.}

Glaxton, W. J. Methodical Nature Study. Demy 8vo. Pp. 190. 1911. Blackie. 7s. 6 d.

Furneaux, W. S. The Outdoor World; or the Young Collector's Handbook. Cr. 8vo. Pp. 439. 1912. Longmans. 6s. 6d.

A Nature Study Guide. Cr. 8vo. Pp. 308. 1918. Longmans. 6s. 6d. Life in Ponds and Streams. $\mathrm{Cr}$. 8vo. Pp. 426. 1919. Longmans. 6s. Gd. 


\section{Biology.}

Rennie, J. The Aims and Methods of Nature Study. A Guide for Teachers. 3rd imp. Cr. 8vo. Pp. 369. 1917. University Tutorial Press, 5s.

Thomson, J.A. The Wonder of Life. 4th imp. Demy 8vo. Pp. 680. 1920. Melrose. $15 s$.

\section{iii. NATURAL HISTORY.}

Abbey, G. The Balance of Nature and Modern Conditions of Cultivation: A Practical Manual of Animal Foes and Friends. Large 8vo. Pp.300. 1909. Routledge.10s.6d.

Darwin, C. Journal of a Naturalist during a Voyage Round the World in H.M.S. "Beagle." 5th imp. Cr. 8vo. Pp. 521. 1912. Murray. 7s. $6 d$.

Depéret, G. Transformations of the Animal World. Cr. 8vo. Pp.376. 1909. Kegan Paul. 7s. 6d.

Gamble, F. W. The Animal World. Fcap. 8vo. Pp. 265. 1911. Williams and Norgate. $2 s, 6 d$.

Harmer, Sir S. F., and Shipley, Sir A. E. (edited by). The Cambridge Natural History. By Various Writers. 10 Vols. Med. 8vo. Vol. 1. Pp. 694. 1909. Vol. 2. Pp. 572. 1910. Vol. 3. Pp. 550. 1913. Vol. 4. Pp. 566. 1920, Vol. 5. Pp. 596. 1910. Vol. 6. Pp.638. 1918. Vol. 7. Pp. 788. 1910. Vol. 8. Pp. 668. 1920. Vol. 9. Pp. 652. 1909. Vol. 10. New imp. in the Press. Macmillan. 21s. each Vol.

Huxley, J.S. The Individual in the Animal Kingdom. Roy. $16 \mathrm{mo}$. Pp. 167. 1912. Cambridge University Press. $2 s .6 d$.

Lankester, Sir E. R. Science from an Easy Chair. First Series. 8th edn. Cr. 8vo. Pp. 439. Methuen. 7s.6d.

Science from an Easy Chair. Second Series. 2nd edn. Cr. 8vo. Pp. 426. Methuen. 7s.6d.

Diversions of a Naturalist. 2nd edn. Cr.8vo. Pp.440. Methuen. $7 s, 6 d$.
Lankester, Sir E.R. Secrets of Earth and Sea. Cr. 8vo. Pp.262. 1920. Methuen. 8s, 6d.

Latter, O. H. The Natural History of Some Common Animals. Cr. 8vo. Pp. 349. 1913. Cambridge University Press. $6 s$.

Lloyd, R. E. The Growth of Groups in the Animal Kingdom. 8vo. Pp. 194. 1912. Longmans. 6s.

Lydekker, R. The Royal Natural History. 6 Vols. New imp. in preparation. Warne.

Wild Life of the World. A Descriptive Survey of the Creographical Distribution of Animals . 3 Vols. Small Demy 4to. Pp. 486., 452., 460. Warne. 84s.

Animal Portraiture. Imp. Ato. Pp. 105 and 50 Plates. Warne. 758 .

Protheroe, E, Natural History of the World. 8vo. Pp. 584. Routledge. 10s. $6 d$.

Scharff, R. F. The History of the Furopean Fauna. Cr. 8vo. Scott Pub. Co. $7 s, 6 d$.

Sherborn, C. D. (compiled by). Index Animalium. Part 1 (1758. 1800). Roy. 8vo. Pp. 1,264 . 1902. Cambridge University Press. $25 s$.

Smith, G. W. A Naturalist in Tasmania. 8vo. Pp. 152. 1909. Oxford: Clarendon Press. 7s. 6d.

Smith, G. Primitive Animals. Roy. 16mo. Pp. 166. 1911. Cambridge University Press. $2 s .6 d$.

Ward, F. Animal Life under Water. Large Cr. 8vo. Pp. 188. 1919. Cassell. 9s.

Westell, W. P. The Young Naturalist. A Guide to British Animal Life. Cr. 8vo. Pp. 492. 1919. Methuen. $7 s, 6 d$.

\section{iv. ZOOLOGY AND MORPHOLOGY.}

Beddard, F. E. Elementary Practical Zoology. Cr. 8vo. Pp. 362. 1915. Longmans. 4s.6d. 


\section{Biology.}

Borradaile, L. A. Manual of Elementary Zoology. 3rd edn. Cr. 8vo. Pp. 630. 1020. Frowde and Hodder. $18 s$.

Catechism Series. Zoology. By R. A. Staig. 2nd edn. 3 Parts. Cr. 8vo. 1s. 9d. each, also in one volume. Pp. 291. 1921. Livingstone. $5 s, 6 d$.

Dakin, W. J. The Elements of Animal Biology. Cr. 8vo. Pp. 320. 1918. Macmillan. $6 s$.

Gardiner, J. S., and Borradaile, J. A. The Cambridge Notebook for Practical Biology (Zoology). 6th edn. 8vo. Pp. 84. 1919. Frowde and Hodder. $5 s$.

Howes, G. B. An Atlas of Practical Elementary Zootomy. Preface by T. H. Huxley. Med. 4to. Pp. 36 and 24 Plates. 1902. Macmillan. $12 s .6 d$.

Imms, A. D. A Laboratory SketchBook of Zoology, for Indian Students. 4to. Pp.228. 1911. Longmans. $10 s, 6 d$.

Kerr, G. A Primer of Zoology: Fcap. 8vo. Pp.99. Dent. 2s.

Lankester, Sir E. R. (edited by). A Treatisc on Zoology. Demy 8vo. Part 1. Introduction and Protozoa (First Fascicle). Pp. 296. 1909. Part 1. Introduction and Protozoa (Second Fascicle). Pp.451. 1903. Part 2. The Porifera and Cœlentera. Pp. 368. 1900. Part 3. The Echinoderma. Pp. 344. 1900. Part 4. The Platyhelmia, The Mesozoa, and the Nemertini. Pp. 204. 1901. Part 5. Mollusea. Pp. 355. 1906. Part 7. Crustacea (Third Fascicle). Pp. 346. 1909. Part 9. Vertebrata Craniata (First Fascicle). Pp. 518. 1909. Paper covers, 15s. each. Cloth covers, 20s. each. Black.

Lulham, R. An Introduction to Zoology. (Invertebrates). Cr. 8vo. Pp.474. 1913. Macmillan. 8s.6d.

MacLeod, J. The Quantitative Method in Biology. 8vo. Pp. 240. 1919. Longmans. 16s.
Marshall, A. M., and Hurst, C. H. A Junior Course of Practical Zoology. 9th edn. Revised by F. W. Gamble. Cr. 8vo. Pp. 543 . 1920. Murray. 12s.

Masterman, A. T. Elementary Text-Book of Zoology. 2nd edn. Cr. 8vo. Pp. 652. Livingstone. $6 s$.

Morgan, C. L. Animal Biology : an Elementary Text-Book. 4th edn. Cr. 8vo. Pp. 426. 1911. Longmans. 9s. $6 d$.

O'Donoghue, C. H. An Introduction to Zoology for Medical Students. Demy 8vo. Pp. 511. 1920. Bell. $16 s$.

Parker, T. J., and W. N. Elementary Course of Practical Zoology. 5th edn. Cr. 8vo. Pp. 650. 1920. Macmillan. 15s.

_-and Haswell, W. A. A TextBook of Zoology. 2 Vols. 2nd edn. Med. 8vo. Pp. 880., 748. 1910. Macmillan. 36s.

and Haswell, W. A. A Manual of Zoology. Cr. 8vo. Pp. 566. 1915. Macmillan. 10s, 6d.

Russel1, E. S. Form and Function. A Contribution to the History of Animal Morphology. Demy 8vo. Pp. 383. 1916. Murray. 15s.

Sedgwick, A. Student's Text Book of Zoology. 3 Vols. Demy 8vo. Vol. 1. Protozoa to Chactognatha. Pp. 619. 1898. Vol. 2. Chordata to Mammalia. Pp. 705. 1905. Vol. 3. The Introduction to Arthropoda, the Crustacea, and Xiphosura, by $J$. J. Lister; the Insecta and Arachnida, by Sir A.E. Shipley. Pp. 918. 1909. Allen \& Unwin. 15s. each.

- (edited by). Proceedings of the Fourth International Congress of Zoology . (Cambridge, 1898). Demy 8 vo. 1898. Cambridge University Press. 15s.

Shipley, Sir A. E. : and MacBride, E. W. Zoology. An Elementary Text-Book. 4th edn. Demy 8vo. Pp.772. 1920. Cambridge University Press. 20s. 
Thompson, D'A. W. On Growth and Form. Demy 8vo. Pp. 810 . 1917. Cambridge University Press. $24 s$.

Thomson, J. A. The Study of Animal Life. 4th edn. Cr. 8vo. Pp. 477. 1917. Murray. 6s.

- Secrets of Animal Life. Demy 8vo. Pp. 322. 1919. Melrose. 7s. 6d.

--Outlines of Zoology. 7th edn. Cr. 8vo. Pp. 890. 1921. Frowde and Hodder. $18 s$.

Wells, II. G., and Davies, A. M. Text-Book of Zoology. Revised by J.T. Cunningham. 6th edn. 10th imp. Cr. 8vo. Pp. 495. 1917. University Tutorial Press. 9s.6d.

\section{v. INSEGTS : SPIDERS, TICKS.}

Adler, H. Alternating Generations. A Biological Study of Oak Galls and Gall Flies. Translated and edited by C. R. Straton. Cr. 8vo. Pp. 24.2. 1894. Oxford: Clarendon Press. 10s. 6d.

Avebury, Lord. On the Senses, Instincts, and Intelligence of Animals, with special Reference to Insects. 6th edn. Cr. 8vo. Pp. 164. Kegan Paul. 7s. 6d.

Ants, Bees, and Wasps : a Record of Observations on the Habits of the Social Hymenoptera. 17th edn. 3rd imp. Cr.8vo. Pp. 453. 1915. Kegan Paul. 7s, 6d.

Balfour-Browne, F. Keys to the Orders of Insects. Demy 8vo. Pp. 66. 1920. Cambridge University Press. $7 s, 6 d$.

Barrett, G. G. The Lepidoptern of the British Islands. A Descriptive account of their Families, Genera, Species, Preparatory States and Localities. 11 Vols. Demy 8vo. 1893-1907. Vol. 1. Rhopalocera. Vols. 2-11, Heterocera. 12s. each. Large Paper Edition with 504 Coloured Plates. Roy. 8vo. 1893-1907. (Vol. 1. Separately, 639. £33 15s. Labelling List of Species. 1s, 6d. Lovell Reeve.
Bastin, H. British Insects and How to know them. Fcap. 8vo. Pv. 142. 1917. Methuen. 2s.

Bath, W. H. Handbook of Ants, Bees, Dragon Flies, Earwigs, Crickets, and Flies. 5th edn. Cr. 8vo. Pp. 108. 1912. Allen and Unwin. $1 s .6 d$.

Buckton, G. B. Monograph of the British Cicadæ or Tettigidæ. With 82 Coloured Plates, illustrating about 250 Species. 2 Vols. Med. 8vo. Pp. 211., 206. 1891. Lovell Reeve. 63s.

-Monograph of the Membracidæ. With 2 structural and 60 Plates, illustrating about 400 species. Imp. 8vo. Pp. 296. 1903. Lovell Reeve. Coloured, £5 5s. Uncoloured, £2 $15 s$.

Butler, E. A. Pond Life: Insects. 6th edn. Cr.8vo. Pp.127, 1909. Allen and Unwin. 1s. fid.

Carpenter, G. H. Insects: their Structure and Life. A Primer of Entomology. Cr. 8vo. Pp.104. Dent. 6s.

-The Life Story of Insects. Roy. 16mo. Pp.134. 1913. Cambridge University Press. $2 s .6 d$.

Coleman, W. S. British Butterflies. New edn. Cr.8vo. Pp.160. 1910. Routledge. $5 s$.

Crabtree, J. H. Wonders of Insect Life: Details of the Habits and Structure of Insects. Illustrated by the Camera and the Microscope. Cr. 8vo. Pp. 219. 1920. Routledge. $6 s$.

Ealand, C. A. Insect Life. With 50 Coloured Plates and 24 Photographs. Demy 8vo. Pp. 352. 1921.Black. $30 s$.

Edwards, J. The Hemiptera Homoptera of the British Islands. With 2 structural Plates. Demy 8vo. Pp. 271. 1896. 21s. Large Paper Edition, with 28 Plates, illustrating about 300 Species. Super Roy. 8vo. Pp. 283. 1896. Coloured, 50s; uncoloured, 25s. Lovell Reeve. 


\section{Biology.}

Eltringham, H. African Mimetic Butterflies, being descriptions and illustrations of the principal known instances of Mimetic Resemblance in the Rhopalocera of the Fthiopian Region, together with an explanation of the Mullerian and Batesian Theories of Mimicry, and some of the account of the evidences on which these theories are based. Roy. 4to. Pp. 136 and Plates. 1910. Oxford : Clarendon Press. 50s.

Fabre, J. H. The Mason Wasps. Translated by $A$. T. de Mattos. Large Cr. 8vo. Pp. 324. N.D. Hodder and Stoughton. 8s. $6 d$.

-The Mason Bees. Translated by A. T. de Mattos. Large Cr. 8vo. Pp. 324. N.D. Hodder and Stoughton. $8 s .6 d$.

-The Life of the Caterpillar. Translated by A. T. de Mattos. Large Cr. 8vo. Pp. 390. 1917. Hodder and Stoughton. $8 s .6 d$.

- Bramble Bees and Others. Translated by $\mathbf{A}$. T. de Mattos. Large Cr. 8vo. Pp. 484. 1917. Hodder and Stoughton. 8s.6d.

The Hunting Wasps. Translated by A. T. de Mattos. Large $\mathrm{Cr} .8$ vo. Pp. 435. 1919., Hodder and Stoughton. $8 s, 6 d$.

-The Life of the Fly, with which are interspersed some Chapters of Autobiography. Translated by A. T. de Mattos. Large Cr. 8vo. Pp. 477. 1919. Hodder and Stoughton. $8 s .6 d$.

-_.The Glow Worm, and other Beetles. Translated by A. T. de Mattos. Large Cr. 8vo. Pp. 496. 1919. Hodder and Stoughton. $8 s .6 d$.

The Life of the Grasshopper. Translated by A. T. de Mattos. Large Cr. 8vo. Pp. 318. 1917. Hodder and Stoughton. 8s.6d.

The Sacred Beetle and Others. Translated by A. T. de Mattos. Large Cr. 8vo. Pp. 317. 1918. Hodder and Stoughton. 8s. $6 d$.

The Life of the Spider. Translated by $A$. T. de Mattos. Large Cr. 8vo. Pp. 418. 1918. Hodder and Stoughton. $8 s .6 d$.
Fabre, J. H. The Life and Lore of the Insect. Translated by A.T. de Mattos. Cr. 8vo. Pp. 262. 1918. Black. $7 s, 6 d$.

-The Wonders of Instinct: Chapters in the Psychology of Insects. Translated by A. T. de Mattos and B. Miall. 5th imp. Demy 8vo. Pp. 320. 1919. Fisher Unwin. $10 s .6 d$.

-Social Life in the Insect World. Translated by B. Miall. 13th imp. Demy 8vo. Pp. 327. 1920. Fisher Unwin. 10s. 6d.

Forel, A. The Senses of Insects. Translated by M. Yearsley. Demy 8vo. Pp. 331. 1908. Methuen. 12s. 6d.

Fowler, W. W. The Coleoptera of the British Islands. A Descriptive Account of the Families, Genera, and Species, with Notes as to Localities, Habitats, etc. 6 Vols. Demy 8vo. 1887-1913. Lovell Reeve. £6.6s.

Furneaux, W. S. British Butterflies and Moths. Cr. 8vo. Pp. 372. 1916. Longmans. 6s. 6d.

Gillanders, A. T. Forest Entomology. 2nd edn. Cr. 8vo. Pp. 452. 1912. Blackwood. 15s.

Hardy, G. H. The Book of the Fly. Cr. 8vo. Py. 124. 1915. Heinemann. $2 s .6 d$.

Hewitt G. G. The House-Fly. Demy 8vo. Pp. 397. 1914. Cambridge University Press. $18 s$.

House Flies and How they Spread Disease. Roy. 16mo. Pp. 131. 1914. Cambridge University Press. 2s. 6d.

Hofmann, E. The Young BeetleCollector's Handbook. 3rd edn. Cr. 8vo. Pp. 178. 1908. Allen and Unwin. $5 s$.

Kirby, W. E. British Butterflies and Moths. 70 Coloured Plates, containing figures of all the larger Lepidoptera, many Caterpillars and Chrysalides, and 4 Plates of Microlepidoptera. 2nd edn. 8vo. Pp. 510. Routledge. 12s. $6 d$. 


\section{Biology .}

Kirby, W. E. Elementary Text-book of Entomology. 2nd edn. Large Cr.8vo. Pp. 281. 1892. Allen and Unwin. 10s. $6 d$.

Land, H. C. The Butterflies of Europe. In 2 Vols. With 82 Coloured Plates, containing upwards of 900 Figures. Super Roy. 8vo. 1884. Lovell Reeve. $\mathfrak{s} 18 \mathrm{~s}$.

Latter, O. H. Bees and Wasps. Roy. 16mo. Pp. 138. 1913. Cambridge University Press. 2s.6d.

Miall, L. C. Natural History of Aquatic Insects. Cr. 8vo. Pp.408. 190\%. Macmillan. $4 s$.

and Denny, A. The Structure and Life History of the Cockroach (Periplaneta Orientalis). An Introduction to the Study of Inserts. 8vo. Pp. 224. 1886. Lovell Reeve. $7 s, 6 \mathrm{~d}$.

and Hammond, A. R. The Harlequin Fly: its Structure and Life History . 8vo. Pp. 204. 1900. Oxford: Clarendon Press. $7 s, 6 d$.

Mogǵridge, J, T. Harvesting Ants, and Trap-Door Spiders. Notes and Observations on their Habits and Dwellings at Mentone. With Supplement. 8vo. Pp. 304, and 20 Plates. 1873. Lovell Reeve. $12 \mathrm{~s}$.

Moore, F. The Lepidoptera of Ceylon. Rhopalocera and Heterocera. 3 Vols. 215 Coloured Plates. Demy 4to. 1880-1887. Lovell Reeve. \&21 12s.

-and Swinhoe, C. Lepidoptera Indica. Phopalocera. Complete in 10 vols. with 835 Coloured Plates. Demy 4to. 1890-1913. Per Vol. \&9 5s. Complete set (which may be taken in monthly or bi-monthly volumes) £85. Lovell Reeve.

Morris, F. O. Natural History of British Moths. 1933 hand-painted figures. 4. Vols. 6th edn. Super Roy. 8vo. Pp. 285., 180, 227. 327. 1903. Routledge. $70 s$.

British Butterflies. 79 handpainted Plates. Super Roy. 8vo. Pr. 242. 1904. Routledge. 25s.
Nuttall, G.H.F., and others. Ticks. A Monograph of the Ixodoidea. Roy . 8vo. Part 1. Pp. 114. 1908. 7s. 6d. Part 2. Pp. 368. 1911. 14s. Part 3. Pp. 564. 1915. 14s. Bibliography. Part 1. Pp. 74. 1911. 7s.6d. Part 2. Pp.36. 1915. 6s. 6d. Cambridge University Press.

Pearce, E. K. Typical F'lies. A Photographic Atlas. Roy. 8vo. Pp. 60. 1915. Cambridge University Press. $6 s$.

Poulton, E. B. Colours of Animals : their Meaning and Use, especially considered in the Case of Insects. and edn. Cr. 8vo. $\mathrm{P}_{3}, 37$. 1890. Kegan Paul. 7s. fid.

Punnett, R. C. Mimirry in Butterflies. Roy. 8vo. P). 196. 1915. Cambridge University Press. 15s.

Ross, F. H. The Reduction of Domestic Flies. Ilemy 8vo. Pp. 103. 1913. Murray. $5 s$.

Rye, E. C., and Fowler, W. W. British Beetles. 16 Coloured Plates and Wooduts. 2nd edn. Cr. 8vo. Pp. 288. 1889. Lovell Reeve. 10s.6d.

Russell, H. The Flea. Roy. 16mo. Pp. 132. 1913. Cambridge University Press. 2s.6 .

Saunders, E. The Hemiptera Heteroptera of the British Islands: A Descriptive account of the Families, Genera, and Species indigenous to Great Britain and Ireland; with a Structural Plate. Demy 8vo. Pp. 350. 1892. 21s. Large paper edn. With 31 Plates, illustrating about 300 Species. Super Roy . 8vo. Coloured, 63s. Uncoloured, 42s. Lovell Reeve.

The Hymenoptera Aculeata of the British Isles. A Descriptive account of the Families, Genera, and Species indigenous to Great Britain and Ireland. With 3 Structural Plates. Demy 8vo. Pp.391. 1896. Lovell Reeve. $21 s$.

Wild Bees, Wasps, Ants and other Stinging Insects. Cr. 8vo. Pp. 150. Routledge. 4s.6d. 
Scorer, A. G. The Entomologist's Log Book. A Dictionary in Latin and English of the Life-Histories and Food Plants of British Butterflies and larger Moths. 8vo. Pp. 380. 1913. Routledge. 10s.6d.

Sharp, D., and Fowler, W. W. A Catalogue of the British Coleoptera. Pp. 46. 1893. Lovell Reeve. 1s. $6 d$.

Sharpe, E. M. Bowdler. Monograph of the Genus Teracolus. 44 Coloured Plates. Demy 4to. Pp. 156. 1914. Lovell Reeve. 63s.

Shipley, Sir A.E. The Minor Horrors of War. 3rd edn. Large Post 8vo. Pp. 186. 1916. Murray. $2 s$.

More Minor Horrors. Large Post 8vo. Pp. 163. 1916. Murray. $2 s$.

Shuckard, W. E. British Bees. Cr. 8vo. Pp. 371. 1866. Lovell Reeve. 10s. $6 d$.

South, R. The Butterflies of the British Isles. A complete Poeket Guide. Pocket size. Pp. 216. Warne. 8s. $6 d$.

- The Moths of the British Isles. A Complete Pocket Guide: 2 Vols. Pocket Size. Pp. 350., 382 . Warne. 12s.6d. each vol.

Stainton, H. T. British Butterflies and Moths. 2nd edition. 16 Coloured Plates. Cr. 8vo. Pp. 292. Lovell Reeve. 10s. $6 d$.

Staveley, E. F. British Insects. A Familiar Description of the Form, Structure, Habits, and 'Transformations of Insects. Cr. 8vo. Pp. 392. Lovell Reeve. $10 s .6 d$.

Swanton, E. W. British PlantGalls. A Classified Text-Book of Cecidology. Cr. 8vo. Pp. 303. 1912. Methuen. 10s,6d.

Swinhoe, C. Catalogue of Eastern and Australian Lepidoptera Heterocera in the Oxford University Museum. 8vo. Part 1. Sphinges and Bombyces. Pp. 332. 1892. 21s. Part 2. Noctuina, Geometrina, and Pyralidina, by C. Swinhoe; Pterophoridae and Tineina, by Lord Walsingham and $J$. $H$. Durrant. Pp. 638. 1900. 42s. Oxford: Clarendon Press.
Theobald, F. V. Insect Life: A Short Account of the Classification and Habits of Insects. 2nd edn. Cr.8vo. Py.248. 1905. Methuen. $3 s .6 d$.

Tillyard, R. J. The Biology of Dragon-Flies. Demy 8vo. Pp. 409. 1917. Cambridge University Press. 17s.

Tutt, J . W. The British Noctuæ and their Varieties. 4 Vols. Cr. 8vo. Pp. 575. 1891. Allen \& Unwin. $7 s$. each.

Melanism and Melanochroism in British Lepidoptera. Demy 8vo. Pp. 66. 1891. Allen \& Unwin. 5s.

Warburton, C. Spiders. Roy. $16 \mathrm{mo}$. Pp. 146. 1912 . Cambridge University Press. 3s. 6d.

Wilson, O. S. The Larvæ of the British Lepidoptera, and their Food Plants. With 40 Colourer Plates containing over 400 Figures. Super Roy. 8vo. Pp. 396. 1880. Lovell Reeve. 63s.

\section{vi. OTHER INVERTEBRATES.}

Beddard, F. E. The Order Oligochaeta: a Monograph. Structural and Systematic. Demy 4to. Pp. 770. 1895. Oxford: Clarendon Press. 42s.

Earthworms and their Allies. Roy. 16mo. Pp. 155. 1912. Cambridge University Press. 2s.6d.

Beneden, P. J. Animal Parasites and Messmates. 5th edn. $\mathrm{Cr}$. 8vo. Pp. 302. 1904. Kegan Paul. 7s. $6 d$.

Dakin, W. J . Pearls. Roy. 16mo. Pp. 149. 1913. Cambridge University Press. 2s. 6d.

Darwin, C. Vegetable Mould: The Formation of Vegetable Mould through the Action of Earth - Worms . Cr. 8vo. Pp. 298. 1904. Murray. 7s, $6 d$.

Dobell, C. The Amœbre living in Man. Roy. 8vo. Pp. 164. 1919. Bale \& Danielsson. 7s. $6 d$. 
Fantham, H. B., and Porter, A. Some Minute Animal Parasites; or Unseer. Foes in the Animal World. Cr.8vo. Pp.332. 1914. Methuen. 7s. $6 d$.

Griffiths: A. B. The Physiology of the Invertebrata. Demy 8vo. Pp. 486. 1892. Lovell Reeve. 15s.

Huxley, T. H. The Crayfish: an Introduction to the Study of Zoology. 7th edn. Cr. 8vo. Pp. 385. 1906. Kegan Paul. 7s.6d.

Kew, H. W. The Dispersal of Shells. Cr. 8vo. Pp. 305. 1893. Kegan Paul. 7s, $6 d$.

Lovell, M. S. The Edible Mollusca of Great Britain and Ireland, with the Modes of Cooking them. 2nd edn. Cr. 8vo. Pp. 310. Lovell Reeve. $10 s, 6 d$.

Pennington, A. S. British Zoophytes: Hydroida, Actinozoa, and Polyzoa. 24 Plates. Cr.8vo. Pp. 363. 1885. Lovell Reeve. 10s.6d.

Shipley, Sir A. E. Pearls and Parasites. Demy 8vo. Pp. 232. 1908. Murray. 7s,6d.

Stebbing, T. R. R. A History of Crustacea : Recent Malacostraca. Cr. 8vo. Pp.484. 1893. Kegan Paul. $7 s .6 d$.

Step, E. Shell Life. An Introduction to the British Mollusea. Cr. 8vo. Pp. 414. Warne. 7s.6d.

Webb, W. M., and Sillem, C. The British Woodlice. Large Cr. 8vo. Pp. 60. 1906. Duckworth. 6s.

Wollaston, T. V. Testacea Atlantica. The Land and Freshwater Shells of the Azores. Madeiras, Salvages, Canaries, Cape Verde and St. Helena. 8vo. Pp. 588. 1878. Lovell Reeve. $21 s$.

Wood-Jones, F. Coral and Atolls. A History and Description of the Keeling-Cocos Islands, their Fauna and Flora, and a discussion of the Method of Development and Trans. formation of Coral Structures in General. Fully Illustrated. Reissue. Med. 8vo. Pp. 415. 1912. Lovell Reeve. 15s.
Woodward, B. B. The Life of the Mollusea. Cr.8vo. Pp.170.1913. Methuen. $7 s .6 d$.

vii. VERTEBRATES.

\section{a. General .}

Cunningham, J.T., Lydekker, R., Boulenger, G.A., and Thomson, J. A. Reptiles, Amphibia, Fishes, and Lower Chordata. Demy 8vo. Pp.522. 1912. Methuen.12s.6d.

Fitzsimons, F. W. The Natural History of South Africa. Mammals. 4 Vols. Cr. 8vo. Vol. 1. Pp. 197. 1919. 9s. Vol 2. Pp. 207. 1919. 9s. Vol. 3. Pp. 292. 1920. 12s.6d. Vol.4. Pp. 291. 1920. 12s. 6d. Longmans.

Johnston, J. B. The Nervous System of Vertebrates. Med. 8vo. Pp. 370. 1908. Murray. $18 s$.

Kingsley, .J . S. Comparative Anatomy of Vertebrates. 2nd edn. Demy 8vo. Pp. 449. 1919 . Murray. $21 s$.

Reynolds, S. H. The Vertebrate Skeleton. 2nd edn. Demy 8vo. Pp. 552. 1913. Cambridge University Press. 20s.

\section{b. Fishes.}

Beavan, R. Handbook of the Fresh water Fishes of India. 12 Plates. 8vo. Pp. 255. 1877. Lovell Reeve. $10 s .6 d$.

Furneaux, W. S. The Sea Shore. Cr. 8vo. Pp. 454. 1903. Longmans. 6s. $6 d$.

Hickson, S. J. The Fauna of the Deep Sea. Cr. 8vo. Pr. 185. 1893. Kegan Paul. 3s.6d.

Jenkins, J. T. The Sea Fisheries. Roy. 8vo. Pp. 330. 1920. Constable. 24s.

Johnstone, J. British Fisheries: their Administration and their Problems. Demy 8vo. Pp. 350. 1905. Williams \& Norgate. $10 s, 6 d$. Conditions of Life in the Sea. Demy 8vo. Pp. 346. 1903. Cambridge University Press. $12 s$.

Life in the Sea. Roy.16mo. Pp. 152. 1911. Cambridge University Press. 2s. $6 d$. 
McIntosh, W. C. The Resources of the Sea: as shown in the seientific experiments to test the effects of Trawling and of the Closure of certain areas off the Scottish shores. 2nd edn. Demy 8vo. Pp. 360 . 1921. Cambridge University Press. $35 s$.

__ and Masterman, A. T. The Life-Histories of the British Marine Food-Fishes. Demy 8vo. Pp.516. 1897. Cambridge University Press. $28 s$.

Meek. A. The Migrations of Fish. Demy 8vo. Pp. 448. 1916. Arnold. 18s.

Regan, C. T. The Freshwater Fishes of the British Isles. Cr. 8vo. Pp. 311. 1911. Methuen. 7s.6d.

Samuel, A. M. The Herring: its Effect on the History of Britain. Demy 8vo. Pp. 199. 1918. Murray. 12s.

\section{c. Batrachians and Reptiles.}

Boulenger, G. A. The Snakes of Europe. 2nd edn. Cr. 8vo. Pp. 282. 1913. Methuen. 7s.6d.

Ecker. A. Anatomy of the Frog. Translated with annotations and additions by G. Haslam. Med. 8vo. Pp.466. 1899. Oxford: Clarendon Press. 18s.

Leighton, G. R. The Iife-History of British Serpents, and their Local Distribution in the British Isles. Cr. 8vo. Pp. 399. 1901. Blackwood. $5 s$.

Marshall, A. M. The Frog. Edited by F. W. Gamble. 11th edn. Cr. 8vo. Pp. 190. 1919. Macmillan. $6 s$.

\section{d. Birds.}

Atkinson, J, C. British Birds' Eggs and Nests. New edn. Cr. Svo. Pp. 247. N.D. Routledge. 5s.

Bonhote, J. L. Birds of Britain, containing 100 full-page Coloured Plates. 5th imp. Sq. Demy 8vo. Pp. 405. 1917. Black. 16s.

Boraston, J. M British Birds and their Eggs. With a New Method of Identification. With 136 Coloured Plates. Cr.8vo. Pp.311. N.D. Chambers. 10s. 6d.
Bradley, O. C. The Structure of the Fowl. Cr. 8vo. Pp. 153, 1915. Black. 6s.

Coward, T. A. The Migration of Birds. 2nd edn. Roy. 16mo. Pp. 137. 1912. Cambridge University Press. 2s. 6d.

The Birds of the British Isles and Their Eggs. First Series: with 242 coloured illustrations. Pocket size. Vol. 1. The Land Birds (Families Corvidæ to Sulidæ). Pp. 384. 1920. Vol. 2. Families Anatidæ to Tetraonidæ. Pp. 384. 1920. Warne. 12s. 6d. each vol.

Dixon, C. Open-Air Studies in BirdLife: Sketches of British Birds in their Haunts. Cr. 8vo. Pp. 282. 1903. Griffin. 7s, 6d.

Evans, A.H. The Birds of Britain : their Distribution and Habits. Cr. 8vo. Pp. 288. 1916. Cambridge University Press. 5s.

Hudson, W. H. British Birds. With a Chapter on Structure and Classification by F. E. Beddard, Cr. 8vo. Pp. 385. 191s. Longmans. 6s.6d.

Johns, C. A. British Birds in Their Haunts. 15th edn. Post 8vo. Pp. 626. 1920. S.P.C.K. $10 s$.

Millais, J. G. The Natural History of the British Surface-Feeding Ducks. With Coloured Plates by $\mathbf{A}$. Thorburn. and the Author. Roy. 4to. Longmans. $126 s$.

Pycraft, W. P, A History of Birds. Demy 8vo. Pp. 472. 1910. Methuen. 12s. 6d.

Thomson, A.L. Britain's Birds' and their Nests. With 132 Coloured Drawings by G. Rankin. Roy. 8vo. Pp. 368. N.D. Chambers. 25s.

Thorburn, A. British Birds. With 82 Coloured Plates by the Author. 4. Vols. 4to. 1918. Longmans. $£ 1010$ s.

Westell, W. P. The Young Ornithologist. A Guide to the Haunts, Homes and Habits of British Birds. Cr.8vo. Pp.328. 1911. Methuen. $6 s$. 


\section{e. Mammals.}

Beddard, F. E. A Book of Whales. Large Cr. 8vo. Pp. 320. 1900. Murray. $7 s, 6 d$.

Bresslau, E. The Mammary Apparatus of the Mammalia in the Light of Protogenesis and Phylogenesis. Cr.8vo. Pp.178. 1920. Methuen. 5s.

Hartmann, R. Anthropoid Apes. 2nd edn. Cr. 8vo. Pp. 334. 1904. Kegan Paul. 7s.6d.

Lydekker, R. A Geographical History of Mammals. Cr. 8vo. Pp. 412. 1896. Cambridge University Press. 12s.

The Horse and its Relatives. Demy 8vo. Pp. 286. 1912. Allen \& Unwin. 12s.6d.

The Sheep and Its Cousins. Demy 8vo. Pp. 315. 1912. Allen \& Unwin. 12s, $6 d$.

Meysey-Thompson, R. F. The Horse. Its Origin and Development. Demy 8vo. Pp.44s. 1911. Arnold. 15s.

Millais, J. G. The Mammals of Great Britain and Ireland. With coloured Plates by A. Thorburn, G. E. Lodge, H. Grönvold, W. B. Davis, Sir E. Landseer, and the Author. 3 Vols. 4to. Longmans. $£ 1818$ s.

Ridgeway, Sir W. The Origin and Influence of the Thoroughbred Horse. Demy 8vo. Pp.564, 1905. Cambridge University Press. 15s.

Schmidt, O. Mammalia in their Relation to Primeval Times. 2nd edn. Cr. 8vo. Pp. 320. 1894. Kegan Paul. 7s.6d.

Thorburn, A. British Mammals. With 50 Coloured Plates by the Author. 2 Vols. 4to. 1920-21. Longmans. $£ 1010 s$.

-A Naturalist's Sketch Book. With 60 Plates by the Author. 4to. 1919. Longmans. $\& 66 s$.

Westell, W. P. The Book of the Animal Kingdom: Mammals. Feap. 4to. Pp. 379. Dent. 12s.6d.

\section{viii. GEOGRAPHICAL DISTRIBUTION.}

Gadow, H. The Wanderings of Animals. Roy. 16mo. Pp. 156. 1913. Cambridge University Press. 2s.6d.

Newbigin, M. I. Animal Geography. Cr. 8vo. Pp.328. 1913. Oxford: Clarendon Press . 4s.6d.

Scharff, R. F. European Animals: The Geological History and their Geographical Distribution. Demy 8vo. Pp. 272. 1907. Constable. $7 s, 6 d$.

Wallace, A. R. The Geographical Distribution of Animals. With a Study of the relations of living and extinct Faunas as elucidating the past changes of the earth's surface. 2 Vols. 8vo. Pp.528.,620. 1876. Macmillan. $48 s$.

ix. EVOLUTION, VARIATION, HEREDITY, GENETICS, SEX, ORIGIN OF LIFE.

Adami, J.G. Medical Contribution to the Study of Evolution. Demy 8vo. Pp. 390. 1918. Duckworth. $18 s$.

Alexander, F. M. Man's Supreme Inheritance. New edn. Cr. 8vo. Pp.270. 1918. Methuen. 7s.6d.

Ball, W. P. Are the Effects of Use and Disuse Inherited? An Exam. ination of the view held by Spencer and Darwin. Cr. 8vo. Pp. 168. 1890. Macmillan. 3s. 6d.

Bateson, W. The Methods and Scope of Genetics. Cr. 8vo. Pp. 48. 1912. Cambridge University Press. 2s.

Mendel's Principles of Heredity . 3rd imp. Roy. 8vo. Pp. 429. 1913. Cambridge University Press. 15s.

Bennett, W. The Ethical Aspects of Evolution, the Parallel Growth of Opposite Tendencies. 8vo. Pp. 220. 1908. Oxford: Clarendon Press. Gis.

Chamberlain, A. The Child: a Study in the Evolution of Man. Cr. 8vo. Scott Pub. Co. 7s, 6d. 
Clodd, E. The Story of Creation : a Plain Account of Evolution. Cr. 8vo. Pp.258. 1916. Longmans. 68.

Darwin, C. Variation of Animals and Plants under Domestication. 2 Vols. 2nd edn. Cr. 8vo. Pp. 566., 605. 1905. Murray . 15s. - The Foundations of the Origin of Species. Two Essays written in 1842 and 1844. Edited by Sir F. Darwin. Demy svo. Pp. 294. 1909. Cambridge University Press. $7 s .6 d$.

- - The Descent of Man and Selection in Relation to Sex. 2nd edn. Cr. 8vo. Pp. 1031. 1913. Murray. $9 s$.

- The Origin of Species by Means of Natural Selection, or the Preserv. ation of Favoured Races in the Struggle for Life. 6th edn. $\mathbf{C r}$. 8vo. Pp. 432. 1920. Murray. $7 s .6 d$.

Dendy, A. Outlines of Evolutionary Biology, with Glossary of Technical Terms. 2nd edn. Demy 8vo. Pp. 493. 1919. Constable. 15s.

De Vries, $H$. The Mutation Theory: Experiments and Observations on the Origin of Species in the Vegetable Kingdom. 2 Vols. Large 8vo. Pp. 597., 691. 1910-11. Kegan Paul. 36s.

Doncaster, L. Heredity in the Light of Recent Research. Roy. $16 \mathrm{mo}$. Pp. 167. 1912. Cambridge University Press. $2 s .6 d$.

The Determination of Sex. Demy 8vo. Pp. 184. 1914. Cambridge University Press. $12 s$.

Drinkwater, H. A Lecture on Mendelism. Demy 8vo. Pp.31. Dent. 3s. $6 d$.

Galton, F. Hereditary Genius. An Inquiry into its Laws and Consequences. 3rd imp. Cr. 8vo. Pp. 412. 1914. Macmillan. 6s.6d.

and Schuster, E. Noteworthy Families-(Modern Science). An Index to Kinships in near Degrees between Persons whose Achievements are Honourable and have been Publicly Recorded. Cr. 8vo. Pp. 96. 1906. Murray. 6s.
Gates, R.R. The Mutation Factor in Evolution, with particular reference to Wnothera. 8vo. Pp. 370 . 1915. Macmillan. 12s. $6 d$.

Geddes, P., and Thomson, J.A. Sex. Fuap. 8vo. Pp. 255. 1919. Williams \& Norgate. $2 s, 6 d$.

Haldane, J. S. Mechanism, Life and Personality. An Examination of the Mechanistic Theory of Life and Mind. 2nd edn. Cr.8vo. Pp.160. 1921. Murray. 6s.

Hartog, M. Problems of Life and Reproduction. Large Cr.8vo. Pp. 362. 1913. Murray. 7s.6d.

Herbert, S. First Principles of Evolution. 2nd edn. Cr. 8vo. Pp. 348. 1919. Black. 12s.6d.

First Principles of Heredity. 2nd edn. Cr. 8vo. Pp. 199. 1920. Black. 7s, $6 d$.

Hird. D. A Picture Book of Evolution. New edn. Cr.8vo. Pp. 380. 1920. Watts. 12s. 6d.

Huxley, T. H. Darwiniana. New imp. Gl. 8vo. Pp. 475. 1907. Macmillan. 6s.

- Evolution and Ethics and other Essays. New imp. Gl. 8vo. Pp. 334. 1911. Macmillan. 6s.

- Man's Place in Nature and Other Essays. New imp. Gl. 8vo. Pp. 328. 1910. Macmillan. 6s.

Jevons, F. B. Evolution. Cr. 8vo. Pp. 301. 1900. Methuen. 6s.

Johnstone, J. The Philosophy of Biology. Demy 8vo. Pp. 408. 1914. Cambridge University Press. $12 s$.

Judd, J. W. The Coming of Evolution. Roy. 16mo. Pp.171. 1912. Cambridge University Press. $2 s, 6 d$.

Kidd, W. Initiative in Evolution. 8vo. Pp. 272. 1920. Witherby. $15 s$.

Lamarck, J. B. Zoological Philosophy. An Exposition with regard to the Natural History of Animals. Translated, with an Introduction by H. S. Elliot. 8vo. Pp. 502 . 1914. Macmillan. 18s. 


\section{Biology.}

Lluria, E. Super-Organic Evolution : Nature and the Social Problem. Cr.8vo. Pp.233. 1910. Williams \& Norgate. $7 s, 6 d$.

Lock, R.H. Recent Advances in the Study of Variation, Heredity and Evolution. Revised by L. Doncaster. Large Cr. 8vo. Pp. 336. 1916. Murray. 9s.

Macfie, R. G. Heredity, Evolution, and Vitalism: The Results of Modern Research into these Questionstheir Trend and Significance. Demy 8vo. Pp. 302. 1912. John Wright. $6 s$.

MacNamara, N. G. The Evolution and Function of Living Purposive Matter. Cr. 8vo. Pp. 309. 1910. Kegan Paul. 7s. 6d.

Mitchell, P. C. Evolution and the War. Cr. 8vo. Pp. 114. 1915. Murray. $4 s, 6 d$.

Moore, B. The Origin and Nature of Life. Fcap. 8vo. Pp. 256. 1913. Williams \& Norgate. 2s.6d.

Morgan, C. L. Eugenies and Environment. Cr.8vo. Pp.88.1919. Bale and Danielsson. 2s.

Nash, J. T. G. Evolution and Disease. Demy 8vo. Pp. 320. 1912. John Wright. 3s. 6d.

Oliver, F. W., Bayliss, W. M., and others. Life and Its Maintenance: A Symposium on Biological Problems of the Day. Lectures delivered at University College, London, 1918. Cr. 8vo. Pp. 305. 1919. Blackie. $5 s$.

Pearson, K. The Chances of Death, and other Studies in Evolution. 2 Vols. Demy 8vo. Pp. 388, 460. 1897. Cambridge University Press. $27 s$.

The Grammar of Science. 3rd edn. Demy 8vo. Part 1. Physical. Pp. 394. 1911. 10s. Part 2. Biological. In preparation. Black. - Tables for Statisticians and Biometricians. Demy 4to. Pp. 226. 1914. Cambridge University Press. $15 s$.

Poulton, E. B. Essays on Evolution, 1889-1907. 8vo. Pp. 528. 1908. Oxford: Clarendon Press. 128.
Punnett, R. C. Mendelism. 5th edn. Cr. 8vo. Pp. 236. 1919. Macmillan. $7 s, 6 d$.

Reid, Sir G. A. The Laws of Heredity. With a Diagrammatic Representation by $\mathrm{H}$. H. Turner. 2nd edn. Demy 8vo. Pp. 560. 1910. Methuen. $21 s$.

Ritchie, J. The Influence of Man on Animal Life in Scotland. A Study in Faunal Evolution. Roy. 8vo. Pp. 556. 1920. Cambridge University Press. 28s.

Romanes, G.J. An Examination of Weismannism. Cr. 8vo. Pp. 234. 1893. Longmans. $6 s$.

- Darwin and After Darwin: an Exposition of the Darwinian Theory, and a Discussion on Post-Darwinian Questions. Cr. 8vo Part 1. The Darwinian Theory. Brd imp. Pp. 476. 1905. Part 2. Post-Darwinian Questions : Heredity and Utility. New edn. Pp. 356. 1900. Longmans. 10s. 6d. each.

Roper, A. G. Ancient Eugenies. Cr. 8vo. Pp. 80. 1913. Oxford University Press. 3s.

Schmidt, O. Doctrine of Descent and Darwinism. 8th edn. Cr. 8vo. Pp. 338. 1905. Kegan Paul. $7 s, 6 d$.

Seward, A. G. (edited by). Darwin and Modern Science. Essays in Commemoration of the Centenary of the Birth of Charles Darwin and of the Fiftieth Anniversary of the publication of The Origin of Speries . Roy. 8vo. Pp. 595. 1910. Cambridge University Press. 24s.

Thomson, J. A. Darwinism and Human Life. 5th edn. Demy 8 vo. Pp. 263. 1919. Melrose. 7s.6d.

- Heredity. 4th edn. Large $\mathrm{Cr}$. 8vo. Pp. 643. 1920. Murray. $21 s$.

and Geddes, P. Evolution. Fcap. 8vo. Pp. 256. 1918. Williams \& Norgate. 2s.6d.

Vernon, H. M. Variation in Animals and Plants. Cr. 8vo. Pp. 432. 1903. Kegan Paul. 7s.6d. 
Wallace, A. R. Contributions to the Theory of Natural Selection, and Tropical Nature, and other Essays on Descriptive and Theoretical Biology. Cr. 8vo. Pp. 504. 1895. Macmillan. 8s, $6 d$.

Darwinism : An Exposition of the Theory of Natural Selection. 3rd. edn. Cr. 8vo. Pp. 514. 1912. Macmillan. 8s. 6d.

The World of Life: A Manifestation of Creative Power, Directive Mind, and Ultimate Purpose. 5th edn. Cr. 8vo. Pp. 424. 1914. Chapman \& Hall. 6s.

Ward, J.酋 Heredity and Memory. Henry Sidgwick Lecture, 1912. Cr.8vo. Pp.56. 1915. Cambridge University Press. Paper, 1s. Cloth $1 s .6 d$.

Wasmann, E. The Problem of Evolution. 2nd edn. 8vo. Pp. 280. 1912. Kegan Paul. 6s.

Weismann, A. Essays upon Heredity. Authorised Translation. 2 Vols. Cr. 8vo. Vol. 1. Edited by E. B. Poulton, S. Schönland, and Sir A. E. Shipley. 2nd edn. Pp. 488. 1891. 8s. 6d. Vol. 2. Pp. 234. 1892. 6s. Oxford: Clarendon Press.

The Germ Plasm: A Theory of Heredity. Cr.8vo. Scott Pub.Co. $7 s, 6 d$.

- The Evolution Theory. Translated by $\mathbf{J}$. A. and M. Thomson. 2 Vols. Roy. 8vo. Pp. 432., 404. 1904. Arnold. 32s.

Wilson, J. A Manual on Mendelism. Large Cr. 8vo. Pp. 150. 1916. Black. 3s. $6 d$.

\section{x. GYTOLOGY .}

Agar, W. E. Cytology : with special reference to the Metazoan Nucleus. Demy 8vo. Pp. 236. 1920. Macmillan. 12s.

Doncaster, L. An Introduction to the Study of Cytology. Demy 8vo. Pp. 294. 1920. Cambridge University Press. $21 s$.

\section{xi . MICROSGOPY .}

Barnard, J. E. Practical Photomicrography. Demy 8vo. Pp. 344. 1910. Arnold. 16s.
Carpenter, W. B. The Microscope and its Revelations. Edited by $\mathbf{W}$. H. Dallinger. 8th edn. 8vo. Pp. 1202. 1901. Churchill. 32s.

Coles, A. C. Critical Microscopy. How to Get the best out of the Microscope. 8vo. Pp. 112. 1921. Churchill. 7s, $6 d$.

Cross, M.I., and Cole, M.J. Modern Microscopy. A Handbook for Beginners and Students, with chapters on special subjects by various writers. 4th edn. Demy 8vo. Pp. 444. 1912. Baillière. 8s. $6 d$.

Ealand, C. A. The Romance of the Microscope. An Interesting Descriptionof its uses in all branches of Science, Industry, Agriculture, and in the Detection of Crime, with a short account of its origin, history and development. Cr. 8vo. Pp. 314. 1921. Seeley. 6s.

Gosse, P. H., and Bell, J. Evenings at the Microscope: or Researches among the Minuter Organs and Forms of Animal Life. $\mathrm{Cr}$. 8vo. Pp. 434. 1895. S.P.C.K. $5 s$.

Hall, C. A. How to Use the Microscope. A Guide for the Novice. Cr. 8vo. Pp. 8s. 1912. Black. 2s.6d.

Naegeli, $\mathbf{C}$. , and Schwendener, $\mathbf{S}$. The Microscope in Theory and Practice. Translated by F. Crisp and J. Mayall. 2nd edn. Demy 8vo. Pp. 382. 1899. Allen \& Unwin. $9 s$.

Scales, F. S. Practical Microscopy : An Introduction to Microscopical Methods. 2nd edn. Cr. 8vo. Pp. 334. 1909. Baillière. 78.6d.

Spiers, F.S. (edited by). The Microscope: its Design, Construction and Applications. A Symposium and General Discussion by many Authorities. 8vo. Pp. 265. 1920. Griffin. 21s.

Spitta, E. J. Microscopy: The Construction, Theory, and Use of the Microscope. 3rd edn. Med. 8vo. Pp. 500. 1920. Murray. $25 s$.

Wood, J. G. Common Objects of the Microscope. 2nd edn. Revised by E.C. Bousfield. Cr. 8vo. Pp. 198. N.D. Routledge. 4s.6d. 
Wright, Sir A. E. Principles of Microscopy. An Introduction to Work with the Microscope. Super Roy. 8vo. Pp. 272. 1906. Constable. $21 s$.

Wright, L. A Popular Handbook to the Microscope. 3rd imp. Cr. 8vo. Pp. 256. N.D. Religious Tract Society. 5s.

\section{xii. ANTHROPOLOGY.}

Alexander, F. M. Conscious Control in Relation to Human Evolution in Civilization. Cr. 8vo. Pp. 64. 1912. Methuen. 2s.6d.

Avebury, Lord. The Origin of Civilisation, and the Primitive Condition of Man: Mental and Social Condition of Savages. 7th edn. 8vo. Pp. 482. 1912. Longmans. $9 s$.

- Prehistoric Times, as illustrated by Ancient Remains and the Manners and Customs of Modern Savages . 7th edn. Demy 8vo. Pp. 623. 1913. Williams \& Norgate. 12s.6d.

Buttel-Reepen, H. Man and $H$ is Forerunners. Translated by A. G. Thacker. 8vo. Pp. 106. 1913. Longmans. $2 s .6 d$.

Churchward, A. The Origin and Evolution of Primitive Man. Cr. 8vo. Pp. 86. 1912. Allen and Unwin. $5 s$.

Darwin, G. Expression of the Emotions in Man and Animals. Cr. 8vo. Pp. 394. 1901. Murray. $12 s$.

Deniker, J. The Races of Man : an Outline of Anthropology and Ethnography. Cr. 8vo. Scott Pub. Co. 7s. $6 \dot{d}$.

Elliot, G. F. S. Prehistoric Man and His Story. 3rd edn. Temy 8vo. Pp. 320. Seeley. 10s. 6d.

Galton, Sir F, Life History Album. Tables and Charts for recording the development of body and mind from childhood upwards. 2nd edn. Roy. 8vo. Pp. 269. 1914. Cambridge University Press. $7 s .6 d$.
Haddon, A. C., and Quiggin, A.H. History of Anthropology. Cr. 8vo. Pp. 168. 1910. Watts. 3s.6d.

Jackson, J.W. Shells as Evidence of the Migrations of Early Culture. 8vo. Pp. 244. 1917. Longmans. $8 s, 6 d$.

Jones, F. W . Arboreal Man. Demy 8vo. Pp. 230. 1918. Arnold. 8s. 6d.

Keane, A.H. Man, Past and Present. Revised, and largely Re-written, by A. H. Quiggin and A. C. Haddon. Roy. 8vo. Pp. 594. 1920. Cambridge University Press. $36 s$.

Keith, Sir A. The Antiquity of Man. 4th imp. Med.8vo. Pp.539.1920. Williams \& Norgate. 12s. $6 d$.

Marett, R.R. Anthropology. Fcap. 8vo. Pp. 256. 1919. Williams \& Norgate. $2 s, 6 d$.

Quatrefages, A. de. The Human Species. 6th edn. Cr. 8vo. Pp. 508. 1903. Kegan Paul. 7s.6d.

Read, C. The Origin of Man and of his Superstitions. Demy 8vo. Pp. 362. 1920. Cambridge University Press. 18s.

Ripley, W.Z. The Races of Furope. A Sociological Study. 2nd imp. 8vo. Pp. 656. N.D. Kegan Paul. $25 s$.

Smith, G. E. The Migrations of Early Culture. A Study of the Significance of the Geographical Distribution of the Practice of Mummification as Evidence of the Migrations of Peoples and the Spread of certain Customs and Beliefs. 8vo. Pp. 152. 1915. Longmans. $7 s, 6 d$.

Smith, W. G. Man, the Primeval Savage: his Haunts and Relics. Demy 8vo. Pp. 349. Stanford. 10s. $6 d$.

Wright, G. F. The Origin and Antiquity of Man. Cr. 8vo. Pp.545. 1013. Murray. 10s. 6d. 


\section{BOTANY.}

\section{i. GENERAL.}

Alcock, R. A. Botanical names for English Readers, containing a History of Botany, and explaining the derivation and meanings of names of British plants. 8vo. Pp. 246. 1876. Lovell Reeve. 6s.

Arber, A. Water Plants. A Study of Aquatic Angiosperms. Roy . 8vo. Pp. 452. 1920. Cambridge University Press. $31 s, 6 d$.

Herbals : Their Origin and Evolution. A Chapter in the History of Botany, 1470-1760. Roy. 8vo. Pp. 271. 1912. Cambridge University Press. $14 s$.

Atkinson, G.F. Botany for Schools and Colleges. Cr. 8vo. Pp. 493. 1910. Bell. 5s.

Avebury, Lord. On British Wild Flowers considered in Relation to Insects. Cr. 8vo. Pp.210. 1909. Macmillan. 4s. 6d.

Bentham, G., and Hooker, Sir J. D. Outlines of Elementary Botany, as Introductory to Local Floras. 4th edn. Cr. 8vo. Pp.61. Lovell Reeve. $1 s$.

Bevis, J. F., and Jeffery, H. J. British Plants: their Biology and Ecology. 2nd edn. Demy 8vo. Pp. 358. 1920. Methuen. 7s.6d.

Bonnier, G. Name This Flower. Translated from the French and edited by G.S. Boulger. Small Cr. 8vo. Pp. 331. 1917. Dent. $7 s .6 d$.

Bower, F. O. Botany of the Living Plant. 8vo. Pp. 590. 1919. Macmillan. 25s.

The Origin of a Land Flora. A Theory based upon the Facts of Alternation. 8vo. Pp.740. 1908. Macmillan. 21s.
Bower, F. O. Plant Life on Land. Roy. 16mo. Pp.172. 1912. Cambridge University Press. 2s. 6d.

- and Gwynne-Vaughan, D. T. Practical Botany for Beginners. Gl. 8vo. Pp. 320. 1918. Macmillan. $4 s$.

Catechism Series. Botany. 2nd edn. 2 Parts. Revised hy C. R. Whittaker. Livingstone. 1s. $9 d$. each.

Cavers, F. Botany for Matriculation. 6th imp. Cr. 8vo. Pp. 576. 1919. University Tutorial Press. 8s. 6d.

- Practical Botany. 2nd edn. 3rd imp. Cr. 8vo. Pp. 436. 1920. University Tutorial Press. 6s. 6d.

_ Plant Biology. 8th imp. Cr. 8vo. Pp. 476. 1919. University Tutorial Press. 6s.

Church, A. H. Floral Mechanism: Diagrams and Deseriptions of Common Flowers, arranged as an introduction to the Systematic study of Angiosperms. Part 1. Types i-xii. (Jan. to April). Roy. 4to. Pp. 220. 1908. Oxford: Clarendon Press. $21 s$.

Cooke, M. C. Freaks and Marvels of Plant Life: or Curiosities of Vegetation. Post 8vo. Pp. 463. 1904. S.P.C.K. 3s.6d.

Darwin, C. Different Forms of Flowers on Plants of the same Species. Cr. 8vo. Pp. 352. 1892. Murray. 7s, 6d.

Insectivorous Plants. 2nd edn. Cr. 8vo. Pp. 377. 1908. Murray. $7 s, 6 d$.

Climbing Plants : Movements and Habits of Climbing Plants. Cr. 8vo. Pp. 208. 1906. Murray. 7s. $6 d$. 
Darwin, Sir F. The Elements of Botany. 2nd edn. Cr. 8vo. Pp. 252. 1910. Cambridge University Press. 6s. 6d.

Davis, J.R. A. The Flowering Plant, with a Supplementary Chapter on Ferns and Mosses. 3rd edn. Cr. 8vo. Pp.212. 1900. Griffin. 3s.6d.

De Bary, A. Lectures on Bacteria. Translated by H. E. F. Garnsey. Revised by I.B. Balfour. 2nd edn. Cr. 8vo. Pp. 108. 1898. Oxford: Clarendon Press. 5s.

Druce, G. G. The Dillenian Herb. aria, An account of the Dillenian Collections in the Herbarium of the University of Oxford. Edited with an Introduction by S. H. Vines. Cr. 8vo. Pp. 370. 1907. Oxford: Clarendon Press. 12s. $6 d$.

Dykes, W.R. The Genus Iris. Demy Folio. Pp. 254 and Plates. 1913. Cambridge University Press. \&8 $12 s, 6 d$.

Dymes, T. A. The Nature-Study of Plants in Theory and Practice for the Hobby-Botanist. Large $\mathrm{Cr}$. 8vo. Pp. 184. 1920. S.P.C.K. $6 s$.

Edmonds, H. Flementary Botany . Cr. 8vo. Pp. 288. 1919. Longmans. $4 s$.

Elliot, G. F. S. Botany of To-Day. Cr. 8vo. Pp. 852. 1909. Seeley. 7s. $6 d$.

Ellis, D. Medicinal Herbs and Poisonous Plants. Cr. 8vo. Pp. 199. 1918. Blackie. 2s, 6d.

Ellis, E. 'T. (edited by). Black's Gardening Dictionary. Demy 8vo. Pp. 1100. 1920. Black. 15s.

Ellis, G. S. M. Applied Botany. Cr. 8vo. Pp. 256. 1919. Hodder \& Stoughton. $4 s, 6 d$.

Evans, E. Botany for Beginners. G1. 8vo. Pp. 340. 1919. Macmillan. 3s.

- An Intermediate Text-Book of Botany. Cr. 8vo. Pp. 402. 1911. Longmans. $6 s .6 d$.

Ewart, A. J. Elementary Botany . 2nd edn. 9th imp. Cr.8vo. Pp. 356. 1920. University Tutorial Press. 5s.
Farmer, J. B. Plant Life. Fcap. 8vo. Pp. 255. 1919. Williams \& Norgate. 2s. $6 d$.

A Practical Introduction to the Study of Botany : Flowering Plants . Cr. 8vo. Pp. 285. 1915. Longmans. $4 s .6 d$.

Fischer, E. Bacteria. Translated by A.C. Jones. Roy. 8vo. Pp. 206. 1900. Oxford: Clarendon Press. 7s. 6d.

Fritch, F. E., and Salisbury, E.J. An Introduction to the Study of Plants. 4th edn. Demy 8vo. Pp. 405. 1919. Bell. 7s.6d.

An Introduction to the Structure and Reproduction of Plants. Demy 8vo. Pp.466. 1920. Bell. 15s.

Elementary Studies in Plant Life. 3rd edn. Cr. 8vo. Pp. 194. 1919. Bell. 3s. 6d.

Furneaux, W. S. Field and Woodland Plants. Cr. 8vo. Pp. 400. 1911. Longmans. 6s. 6d.

Geddes, P. Chapters in Modern Botany. Cr. 8vo. Pp. 201. 1893. Murray. 4s. 6d.

The Life and Work of Sir Jagadis C. Bose: An Indian Pioneer of Science. Demy 8vo. Pp. 271. 1920. Longmans. $16 s$.

Green, J. R. A History of Botany, 1860-1901. A Continuation of Sachs's History. Cr. 8vo. Pp. 544. 1909. Oxford: Clarendon Press. 9s. $6 d$.

A History of Botany in the United Kingdom. Med. 8vo. Pp. 648 . 1914. Dent, 12s, $6 d$.

A Primer of Botany. Fcap. 8vo. Pp. 128. 1909. Dent. 2s.

Groom, P. Elementary Botany . 16th edn. Cr. 8vo. Pp. 272. 1019. Bell. 5s.

Guppy, H. B. Plants, Secds, and Currents in the West Indies and Azores. Med.8vo. Pp.531. 1917. Williams \& Norgate. $25 s$.

Studies in Seeds and Fruits. An Investigation with the Balance. Demy 8vo. Pp. 258. 1912. Williams and Norgate. $15 s$. 
Hall, C. A. Plant Life. Containing 50 Coloured and 24 Plain Plates. Square Demy 8vo. Pp. 380. 1915. Black. 10s.

Harvey -Gibson, R. J. Outlines of the History of Botany. Demy 8vo. Pp. 274. 1919. Black. 12s.6d.

Heath, F. G. All About Leaves. Cr. 8vo. Pp. 228. 1914. Williams \& Norgate. $2 s .6 d$.

Henslow, G. Botany for Beginners . 5th edn. Cr. 8vo. Pp. 108 and 30 Plates. 2s.6d. Also with the plates coloured by hand. $14 s$. Stanford.

- Floral Rambles in Highways and Byways. Large Cr. 8vo. Pp. 296. 1915. S.P.C.K. 7s.6d.

- The Uses of British Plants. Traced from Antiquity to the present day, together with the derivations of their names. With 288 Illustrations. Cr. 8vo. Pp. 184 . 1905. Lovell Reeve. $6 s$.

Horwood, A. R. The Story of Plant Life in the British Isles. Cr. 8vo. 1914-15. Vol.1. Pp.254. Vol.2. Pp. 372. Vol. 3. Pp. 530 . Churchill. 6s.6d. each.

The Outdoor Botanist. A Simple Manual for the Study of British Plants in the Field. Demy 8vo. Pp. 284. 1920. Fisher Unwin. 188 .

Practical Field Botany. A Guide to the Scope, Methods, Aims, and Limits of Modern Botanical Fieldwork. Cr. Svo. Pp. 210. 1913. Griffin. 6s .

Jackson, B. D. A Glossary of Botanic Terms. 3rd edn. Cr. 8vo. Pp. 440. 1916. Duckworth. 7s,6d.

Johnson, A. F. M. A Text-Book of Botany for Students, with Directions for Practical Work. Cr. 8vo. Pp. 560. N.D. Allman. 8s.6d.

Jones, H. F. Plant Life: Studies in Garden and School. Cr. 8vo. Pp. 272. 1906. Methuen. 5s.

Jones, W. N., and Rayner, M. C. $A$ Text-Book of Plant Biology. Cr. 8vo. Pp. 270. 1920. Methuen. $7 s$.
Laurie, C. L. Field Botany. 3rd edn. Cr. 8vo. Pp. 96. Allman. 1s. $6 d$.

- Flowering Plants. Their Structure and Habitat. 2nd edn. Cr. 8vo. Pp. 167. Allman. 3s.6d.

A Text-Book of Elementary Botany, 13th edn. Cr. 8vo. Pp. 195. Allman. 3s. 6d.

Lowson, . J . M. Text-Book of Botany. 5th edn. 10th imp. Cr. Svo. Pp. 615. 1919. University Tutorial Press. 9s, 6d.

Text- Book of Botany (Indian Edition). Revised and adapted by B. Sahni and M. Willis. 2nd imp. Cr. 8vo. Pp.622. 1919. University Tutorial Press. 9s. 6d.

Massee, G. The Plant World. Its Past, Present, and Future. An Introduction to the Study of Botany. 2nd edn. Cr. 8vo. Pp.212. 1898. Pitman. 3s.

Mudge, G. P., and Maslen, A.J. A Class Book of Botany. 2nd imp. Cr. 8vo. Pp. 528. 1910. E. Arnold. 8s.6d.

Oliver, D. Lessons in Elementary Botany. Fcap. 8vo. Pp. 312 . 1910. Macmillan. 5s.

Oliver, F. W. (edited by). The Exploitation of Plants; by Various Experts. Cr. 8vo. Pp. 170. 1918. Dent. 3s. 6d.

Makers of British Botany. Biographies by living Botanists. Demy 8vo. Pp. 340. 1913. Cambridge University Press. $10 s$.

Praeger, R. L. Open-Air Studies in Botany: Sketches of British Wild Flowers in their Homes. 2nd edn. Cr. 8vo. Pp. 280. 1910. Griffin. $7 s .6 d$.

Rennie, J. School Lessons in Plant and Animal Life. 3rd imp. Cr. 8vo. Pp. 496. 1920. University Tutorial Press. 6s. 6d.

Rendle, A. B. The Classification of Flowering Plants. Vol. 1. Gymnosperms and Monocotyledons. Demy 8vo. Pp. 346. 1904. Cambridge University Press. 12s. $6 d$. 


\section{Botany.}

Sachs, J. von. History of Botany (1530-1860). Translated by H. E. F. Garnsey. Revised by I. B. Balfour. 2nd imp. Cr. 8vo. Pp. 568. 1906. Oxford: Clarendon Press. 10s. (see also Green, J. R.)

Scott, D. G. Elementary Lessons on Plant Life. Cr. 8vo. Pp. 236. 1911. Methuen. 4s.

Stoneman, B. Plants and Their Ways in South Africa. New edn. Cr. 8vo. Pp. 400. 1915. Long. mans. 6s. $6 d$.

Stopes, M. C. The Study of Plant Life. 3rd edn. Demy 8vo. Pp. 202. N.D. Blackie. 6s.

Storey, F. W., and Wright, K. M. South African Botany. Cr. 8vo. Pp. 228. 1916. Longmans. 6s.

Strasburger, E. Handbook of Practical Botany, for the Botanical Laboratory and Private Student. Translated by W. Hillhouse. 6th edn. Demy 8vo, Pp. 527. 1911. Allen \& Unwin. 10s.6d.

Schenck, H., and others. $\Lambda$ Text-Book of Botany. 5th English edn. Revised with the 14th Cerman edn. By W. H. Lang. 8vo. In the Press. Macmillan.

Thoday, D. Botany : a Text-book for Senior Students. 2nd edn. Cr. 8vo. Pp. 541. 1920. Cambridge University Press. $7 s, 6 d$.

Vines, S. H. An Elementary 'Textbook of Botany. 4th edn. Demy 8vo. Pp. 611. 1910. Allen \& Unwin. $10 s$. $6 d$.

A Student's Text-book of Botany . 4th edn. Demy 8vo. Pp. 821. 1910. Allen \& Unwin. 15s.

and Druce, G. C. The Morisonian Herbarium in the possession of the University of Oxford. Cr. 8vo. Pp. 418. 1914. Oxford: Clarendon Press. 15s.

Was ming, E. A Handbook of Sys. tematic Botany, with a revision of the Fungi, by $E$. Knoblauch. Translated by M. C. Potter. Demy 8vo. Pp. 620, 1895, Allen \& Unwin. $15 s$.
Warming, E. Plant Life: A Text Book of Botany for Srhools and Colleges. Translated by M. M. Rehling and E. M. Thomas. Cr. 8vo. Pि. 244. 1911. Allen \& Unwin. $5 s$.

Westell, W.P., and Cooper, C.S. The Young Botanist. Cr.8vo. Pp. 238. 1908. Methuen.6s.

Woodhead, T. W. The Study of Plants. An Introduction to Botany and Plant Ecology. Cr. 8vo. Pp. 440. 1915. Oxford: Clarendon Press. $7 s, 6 d$.

\section{ii. MORPHOLOGY, PHYSIOLOGY, etc.}

Atkins, W. R. G. Recent Researches in Plant Physiology. Cr. 8vo. Pp. 328. 1916. Pitman. 9s.

Avebury, Lord. Flowers, Fruits, and Leaves. $\mathrm{Cr}$.8vo. Pp. 154. 1908. Macmillan. $4 s .6 d$.

A Contribution to our Knowledge of Seedlings. Cr. 8vo. Pp. 295. 1896. Kegan Paul. 7s, 6d.

On Buds and Stipules. Cr. 8vo. Pp. 268. 1899. Kegan Paul. $7 s, 6 d$.

Notes on the Life History of British Flowering Plants. Svo. Pp. 474. 1905. Macmillan. 15s.

Baines, A. E. Germination in its Electrical Aspect. A Consecutive Account of the Electro-Physiological Processes concerned in Evolution, from the formation of the Pollen. grain to the completed Structure of the Seedling. Together with some Further Studies in ElectroPhysiology. Demy 8vo. Pp. 207. 1921. Routledge. 12s, $6 d$.

Bose, Sir J . C. Plant Response as a Means of Physiological Investigation. 8vo. Pp. 822. 1906 . Longmans. $21 s$.

- Researches on Irritability of Plants. 8vo. Pp. 410. 1913. Longmans. $7 s, 6 d$.

Response in the Living and NonLiving. 2nd imp. 8vo. Pp. 220. 1910. Longmans. 10s. $6 d$. 


\section{Botany.}

Brenchley, W. E. Inorganic Plant Poisons and Stimulants. Roy. 8vo. Pp. 120. 1914. Cambridge University Press. 6s.

Candolle, A. de. Origin of Cultivated Plants. 3rd imp. Cr. 8vo. Pp. 476. 1909. Kegan Paul. $7 s, 6 d$.

Cavers, F. Life Histories of Common Plants. 5th imp. Cr. 8vo. Pp.580. 1919. University Tutorial Press. 4s, 6d.

Cox, L. E. Experimental Plant Physiology for Beginners. Cr. 8 vo. Pp. 120. 1915. Longmans. 3s. $6 d$.

Darwin, C. The Effects of Crossand Self-Fertilisation in the Vegetable Kingdom. 2nd edn. Cr.8vo. Pp. 487. 1916. Murray. 9s.

Darwin, Sir F., and Acton, E. H. Practical Physiology of Plants. 3rd edn. Cr. 8vo. Pp. 359. 1915. Cambridge University Press. $6 s$.

De Bary, A. Comparative Anatomy of the Vegetative Organs of the Phanerogams and Ferns. Translated by F. O. Bower and D. H. Scott. Roy. 8vo. Pp.676. 1884. Oxford: Clarendon Press. 36s.

Detmer, W. Practical Plant Physiology : An Introduction to Original Research for Students and Teachers of Natural Science, Medicine, Agriculture and Forestry. Translated by S. A. Moor. 2nd edn. Demy 8vo. Pp. 55.. 1909. Allen and Unwin. $12 s$.

Dixon, H.H Transpiration and the Ascent of Sap in Plants. Svo. Pp. 224. 191. Macmillan. 6s. 6id.

Ewart, A. J. On the Physies and Physiology of Protoplasmic Streaming in Plants. Roy. 8vo. Pp. 132. 1903. Oxford: Clarendion Press. 8s. 6d.

Goebel, K. E. Organography of Plants, especially of the Archegoniatæ and Spermophyta. Translated by I. B. Balfour. 2 Vols. Roy. 8vo. Part 1. General. Pp. 286. 1900. 10s. Part 2. Special. Pp. 94. 1905. 21s. Oxford: Clarendon Press.
Green, J. R. An Introduction to Vegetable Physiology. 3rd edn. 8vo. Pp. 492. 1911. Churchill. $12 s .6 d$.

A Manual of Botany. Vol. 1. Morphology and Anatomy. 3rd edn. Cr. 8vo. Pp. 407. 1904 . Churchill. 8s, 6d.

Haberlandt, G. Physiological Plant Anatomy. Translated by M. Drummond. 8vo. Pp. 794. 1914. Macmillan. 31s. $6 d$.

Haig, H. A. The Plant Cell: Its Vital Processes and Modifications. Large Cr. 8vo. Pp. 217. 1910. Griffin. $7 s, 6 d$.

Heath, F. G. Nervation of Plants. Cr. 8vo. Pp. 187. 1912. Williams and Norgate. 3s.6d.

Henslow, G. Origin of Floral Structures through Insect and other Agencies. 2nd edn. Cr. 8vo. Pp. 360. 1893. Kegan Paul. 7s. 6d. Origin of Plant Structures by Self-Adaptation to the Environment. Cr. 8vo. Pp. 272. 1895. Kegan Paul. 78, 6d.

Jost, L. Lectures on Plant Physiology. Translated by R. J. Harvey-Gilsson. Roy. Svo. Pp. 578. 1907. Supplement incorporating the alterations of the second edition of the German original. Roy. 8vo. Pp. 168. 1913. Oxford: Clarendon Press. 30s.

Keeble, F. IV. Practical Plant Physiology. 2nd edn. Cr. 8vo. Pp. 250. 1919. Bell. 4s. 6d.

- Plant Animals. Roy. 16mo. Pp. 171. 1912. Cambridge University Press. 2s. 6d.

Knuth, P. Handbook of Floral Pollination, based upon $\mathbf{H}$. Muller's Fertilization of Flowers by Insects. Translated by J. R. Ainsworth Davis. 3 Vols. Roy. 8vo. Vol. 1. Historical Development and present stand-point of Flower Pollination. Pp.402. 1906. $18 s$. Vol. 2. Observations made in Europe and the Arctic Regions on Species belonging to the natural orders. Ranunculacex to Styli- 


\section{Botany.}

dieæ, Pp. 712. 1908. 31s. 6d. Vol. 3. Ditto. Goodenovieæ to Cycadeæ; Systematic list of insect visitors, with names of plants visited. Pp. 648. 1909. 28s. Oxford: Clarendon Press.

Onslow, M. Wheldale. The Anthocyanin Pigments of Plants. Roy. 8vo. Pp. 330. 1916. Cambridge University Press. 17s. 6d.

Pfeffer, W. Physiology of Plants. A Treatise upon the Metabolism and Sources of Energy in Plants. Translated and edited with Notes by A. J . Ewart. 2nd edn. 3 vols. Roy. 8vo. Vol. 1. Introduction, Physiological Morphology, Mechanism of Absorption and Translocations, Movements of Water, Food of Plants, etc. Pp.644. 1900. Vol. 2. Growth, Reproduction, and Maintenance. Pp.304. 1903. Vol. 3. Movements, Production of Light, Heat and Electricity, Sources and Transformation of Energy. Pp. 460. 1906. Oxford: Clarendon Press. The 3 Vols. $45 s$.

Scott, D. H. Evolution of Plants. Fcap. 8vo. Pp. 256. 1919. Williams and Norgate. $2 s .6 d$.

An Introduction to Structural Botany. 2 Vols. Cr. 8vo. Part 1. Flowering Plants. 9th edn. Pp. 298. 1917. Part 2. Flowerless Plants. 8th edn. Pp. 298. 1920. Black, 6s. each.

Solereder, H. Systematic Anatomy of the Dicotyledons. A handbook for. Laboratories of Pure and Applied Botany. Translated by L. A. Boodle and F. E. Fritsch. Revised by D. H. Scott. 2 Vols. Roy. 8vo. Pp. 1202. 1908. Vol.'1. Introduction, Polypetalae, Gamopetalae . Vol.2. Monochlamydeae, Addenda, etc. Oxford: Clarendon Press. 24s. each.

Timiriazeff, C. A. The Life of the Plant. Translated from the Russian by $\mathrm{A}$. Cheremeteff. 8vo. Pp.371. 1912. Longmans. 88 . iii. GEOGRAPHIC DISTRIBU TION.

Boulger, P. S. Plant Geography. Pott. 8vo. Pp. 136. Dent. 1s. $9 d$.

Hardy, M. E. The Geography of Plants. Cr. 8vo. Pp. 339. 1920. Oxford: Clarendon Press. $7 s, 6 d$. - An Introduction to Plant Geography. Cr. 8vo. Pp. 192. 1913. Oxford: Clarendon Press. 4s.

Moss, G. E. The Vegetation of the Peak District. Demy 8vo. Pp. 246. 1913. Cambridge University Press. 14s.

Schimper, A.F.W. Geography of Plants. Translated by W.R. Fisher, revised by $P$. Groom and $I$. B. Balfour. Part 1. The Factors. Part 2. Formations and Guilds. Part 3. Zones and Regions-Tropical Climate and Vegetation, Temperate Zones, Arctic Zone. Roy. 8vo. Pp. 870. 1903. Oxford: Clarendon Press. $63 s$.

Warming, E. Oecology of Plants. An Introduction to the Study of Plant Communities. English edn. by $\mathbf{P}$. Groom and I. B. Balfour. Roy. 8vo. Pp. 434. 1909. Oxford: Clarendon Press. 15s.

$$
\text { iv. ALGA. }
$$

Cooke, M. C. Introduction to FreshWater Algæ: with an Enumeration of all the British Species. Cr. 8vo. Pp. 345. 1902. Kegan Paul. 7s. 6d.

Fryer, A., Evans, A. H., and Bennett, A. The Potamogetons (Pondweeds) of the British Isles. Descriptions of all the Species, Varieties, and Hybrids. With 60 Plates. Med. 4to. Pp. 94. 1915. Coloured, \&5 5s. Uncoloured, £3 15s. Lovell Reeve.

Gray, S. O. British Seaweeds. An introduction to the study of the Marine Algæ of Great Britain, Ireland and the Channel Islands. Cr. 8vo. Pp. 335. 1867. Lovell Reeve. 10s.6d. 
Harvey, W. H. Phycologia Australica. A History of Australian Seaweeds. 5 Vols. Roy. 8vo. 300 Plates. 1863. Coloured, £6 10s. Uncoloured, $£ 33 s$. Sets of the uncoloured Plates and letterpress, unbound £2 5s. Lovell Reeve.

-Phycologia Britannica. A History of British Seaweeds. 4 Vols. Roy. 8vo. 360 Plates. 1871.

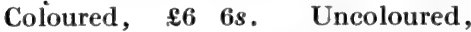
$£ 33 s$. Sets of the uncoloured Plates and letterpress, unbound. \&2 5s. Lovell Reeve.

Nave, J. Collector's Handy-book of Algæ, Desmids, Fungi, Lichens, Mosses, etc. Cr. svo. Pp. 210. 1904. Routledge. 4s.6d.

West, G. S. Algæ. Vol. 1. Myxophyceæ, Peridinieæ, Chlorophycex, together with a brief summary of the Occurrence and Distribution of Freshwater Algæe. Roy. 8vo. Pp. 486. 1919. Cambridge University Press. 30s.

\section{v. FUNGI.}

Badham, M. D. The Esculent Funguses of England. An Account of their Classical History, Uses, Characters, Development, Structure, Nutritions, Properties, Modes of Cooking and Preserving, etc. 2nd edn. 8vo. Pp. 160. 1863. Lovell Reeve. $12 s$.

Berkeley, M. J. Outlines of British Fungology . Containing a description of the larger British Fungi, together with a list of the more minute species. With 24, Plates, illustrating over 170 species. 8vo. Pp. 459. 1860. Coloured, 18s. Uncoloured, 12s. Supplement by W. G. Smith. 6s. Lovell Reeve.

Buller, A. H. R. Researches on Fungi : An Account of the Production, Liberation and Dispersion of the Spores of Hymenomycetes treated Botanically and Physically. Roy. 8vo. Pp. 300. 1909. Longmans. 12s. $6 d$.
Cooke, M. C. Edible and Poisonous Mushrooms: What to Eat and What to Avoid. Cr. 8vo. Pp. 126. 1902. S.P.C.K. $4 s$.

Fungi: their Nature, Influences, Uses, etc. 6th edn. Cr. 8vo. Pp. 311. 1906. Kegan Paul. 7s.6d.

- Comparative Morphology and Biology of Fungi, Mycetozoa and Bacteria. Translated by H. E. F. Garnsey. Revised by I. B. Balfour. Roy. 8vo. Pp. 546. 1887 . Oxford: Clarendon Press. $30 s$.

Grove, W. B. British Rust Fungi (Uredinales). Demy 8vo. Pp.424. 1913. Cambridge University Press. $17 s$.

Massee, G. British Fungi, Phy comycetes and Ustilaginex. With 8 Plates. Cr. 8vo. Pp. 247. 1891. Lovell Reeve. $7 s .6 d$.

- British Fungi. With 40 Coloured Plates. 8vo. Pp. 351. Routledge. 10s. $6 d$.

European Fungus, Flora Agaricaceæ. Cr. 8vo. Pp. 280. 1902. Duckworth. 6s.

Phillips, W. Manual of British Discomycetes : with Descriptions of all the Species of Fungi hitherto found in Britain included in the Family. and Illustrations of the Genera. 2nd edn. Cr.8vo. Pp.474, 1893. Kegan Paul. 7s, 6d.

Swanton, E. W. Fungi and How to Know Them. An Introduction to Mycology. Cr.8vo. Pp.222.1909. Methuen. 10s. 6d.

\section{vi. FERNS AND MOSSES.}

Bagnall, 'J . E. Hand-book of Mosses, with an Account of their Structure, Classification, Geographical Distribution and Habits. 6th edn. Cr. 8vo. Pp. 98. 1910. Allen \& Unwin. 1s. $6 d$.

Bastin, H. British Ferns and How to Know Them. Fcap. 8vo. Pp. 144. 1917. Methuen. $2 s$. 
Berkeley, M. J. Handbook of British Mosses. Containing a description of genera and species, with their geographical distribution; collection and systematic arrangement. With 24 plates, illustrating over 150 species. 2nd edn. 8vo. Pp. 324. 1895. Coloured, $18 s$. Uncoloured, 12s. Lovell Reeve.

Druery, G. T. British Ferns and their Varieties. 40 coloured Plates. 8vo. Pp. 467. N.D. Routledge. $10 s, 6 d$.

Hobkirk, C. P. Synopsis of British Mosses. Containing Descriptions of the Genera and Species, with localities of the rarer ones. 2nd edn. Cr. 8vo. Pp. 240. 1884. Lovell Reeve. 7s.6d.

Hooker, Sir W. J. The British Ferns. Figures and Descriptions, with Analysis of the Fructification and Venation. 66 plates. Roy. 8vo. 1861. Coloured, \&1 $16 s$. Uncoloured, 15s. Lovell Reeve. -Garden Ferns. Figures and Descriptions of Exotic Ferns adapted for Cultivation. Roy. 3vo. 64 Plates. 1862. Coloured, \&1 16s. Uncoloured, 15s. Lovell Reeve.

Plues, M. British Ferns, including Lycopods, and Equiseta. With 16 coloured Plates and Woodcuts. Cr. 8vo. Pp. 281. Lovell Reeve. 10s. fid.

Russell, T. H. Mosses and Liverworts. An Introduction to their study, with hints as to their collection and preservation. Cr. 8vo. Pp. 213. 1908. Sampson Low. $4 s, 6 d$.

Sim, T. R. The Ferns of South Africa. 2nd edn. Demy 8vo. Pp. 394. 1916. Cambridge University Press. 25s.

Step, E. Wayside and Woodland Ferns. A Pocket Guide to the British Ferns, Horsetails, and Club Mosses. Pocket size. Pp. 143. 1908. Warne. 8s. 6d.

vii. FL'SA.

Arber, E. A. N. Devonian Floras: A Study of the Origin of Cormophyta. Demy 8vo. Pp. 114. 1921. Cambridge University Press . 17s. $6 d$.
Baker, J.G. Flora of Mauritius and the Seychelles. 8vo. Pp. 605 . 1877. Lovell Reeve. 42s.

Baker, R. T., and Smith, H. G. A Research on the Pines of Australia. Roy. 4to. Pp. 472. 1910. Routledge. $30 s$.

Bentham, G., and Hooker, Sir J. D. Handbook of the British Flora. A Description of the Flowering Plants and Ferns indigenous to or naturalised in the British Isles. 6th edn. Cr. 8vo. Pp.664. 1918. Lovell Reeve. $12 s$.

-Illustrations of the British Flora, forming an Illustrated Companion to Bentham's 'Handbook," and other British Floras. 1,315 Wood engravings by $W$. H. Fitch and W.G.Smith. 4th edn. Cr.8vo. Pp.354. 1919. Lovell Reeve. 12s. and Mueller, F. Flora Australiensis. A Description of the Plants of the Australian Territory. 7 vols. 8vo. 1863-1878. Lovell Reeve. 42s. per. vol.

Carter, H. G. Genera of British Plants. Cr. 8vo. Pp. 140. 1913. Cambridge University Press. 6s.

Druce, G.C. The Flora of Berkshire. Cr. 8vo. Pp.754, 1897. Oxford: Clarendon Press. $16 s$.

- List of British Plants, found either as natives or growing in a wild state in the British Isles. Cr. 8vo. Pp. 120. 1908. Oxford: Clarendon Press. 3s.

Gregory, E. S. British Violets. Demy 8vo. Pp.131. 1912. Heffer. fis.

Grove, W. B. A Pocket Synopsis of the Families of British Flowering Plants (based upon the System of Engler). Fcap. 8vo. Pp. 56. 1915. Longmans. $1 s, 3 d$.

Harvey, W. H., Sonder, O. W., and Thiselton-Dyer, Sir W. T. Flora Capensis. A Systematic Description of the Plants of Cape Colony, Caffraria and Port Natal. 9 Vols. Svo. 18941900. 42s., each, except Vol. IV. Section 1. 60s. 3 Additional Parts now ready. 15s., 15s., 11s. 3d. Lovell Reeve. 
Hayward, W. R. The Botanist's Pocket Book: containing the chief characteristics of British Plants; with botanicul name, common name, soil and situation, Colour, Growth, and time of fliwering of every Plant, arranged under its own order. 15th edn. Revised by G. C. Druce. Feap. 8vo. Pp. 335. 1917 . Bell. 5s.

Hooker, Sir J. D. Flora of British India. 7 Vols. 8vo. 1872-1897. Lovell Reeve. 42s. per vol.

-Handbook of the New Zealand Flora. A systematic deseription of the Native Plants of New Zealand and the Chatham, Kermadec, Auckland, Campbell and Macquarie Islands. 8vo. Pp.866. 1864-1367. Lovell Reeve. 42s.

-The Student's Flora of the British Isles. 3rd edn. Globe 8vo. Pp. 588. 1884. Macmillan. 10s. 6d.

Jackson, B. D. Index Kewensis ; an enumeration of the Genera and Species of Flowering Plants from the time of Linnaeus to the year 1885 , together with their authors' names, the works in which they were first published, their nativecountries and their synonyms. 2 Vols. Roy. 4to. 1895. Vol. 1. Pp. 1268. Vol. 2. Pp. 1300. With 4 Supplements 1886-1910. Oxford: Clarendon Press. $£ 1616 s$.

Johns, C. A. Flowers of the Field. Edited by C. Elliott. 8th edn. With Chapters on Grasses, also Glossary and Fnglish and Latin Indexes. 8th imp. 8vo. Pp. 398 and 96 Plates. Routledge. 12s,6d.

-Flowers of the Field. 33rd edn. Revised by G. S. Boulger. Large Cr. 8vo. Pp. 612 and 64 Plates. 1911. S.P.C.K. 7s. $6 d$.

Moss, G. E., and others. The Cambridge British Flora. Illustrated from Drawings by $\mathrm{E}$. W. Hunnybun. To be completed in about 10 Vols. Imp. 4to. Vol. 2. in 2 Parts. Pt. 1. Text. Pp. 228. Pt. 2. 206 Plates. £3, or in 1 Volume, 2 10s. Vol. 3 in 2 Parts.
Pt. 1. Text. Pp. 216. Pt. 2. 191 Plates. \&6 15s., or in 1 Volume (plates interspersed with text), \&7 7s. Cambridge University Press.

Oliver, D., Thiselton -Dyer, Sir W. $T$., and Prain, Sir D. Flora of Tropical Africa (Upper Guinea, North Central including the Sahara, Nile Land, Lower Guinea, South Central, and Mozambique). 10 Vols. ready. 8vo. 1868-1920. 42s. each. Vol. VI. Section I. 60s. 3 Additional Parts now ready. 15s. each. Lovell Reeve.

Plues, M. British Grasses. With 16 Coloured Plates and 100 Woodcuts. Cr. 8vo. Pp. 307. Lovell Reeve. $10 s .6 d$.

Pratt, A. The Flowering Plants, Grasses, Sedges, and Ferns of Great Britain. 4 Vols. Med. 8vo. Pp. 266., 279., 258., 215 and 80 Plates in each Vol. Warne. 10s. 6d. each Vol.

Ridley, H. N. Materials for a Flora of the Malayan Peninsula. 3 Parts. 8vo. 1907. Lovell Reeve. 30s.

Rogers, W. M. A Handbook of British Rubi. Demy 8vo. Pp. 129. 1900. Duckworth. 5s.

Step, E. Favourite Flowers of Garden and Greenhouse. 4 Vols. Med.8vo. 1896. Warne. 60s."

Wayside and Woodland Blossoms. A Pocket Guide to British Wild Flowers. 2 Vols. Pocket size. Pp. 189., 187. Warne. 8s.6d. each Vol.

Wild Flowers-Month by Month -In their Natural Haunts. 2 Vols. Med.8vo. Pp. 206., 206. 1905. Warne. 15s.

Strachey, Sir, R., and Duthie, J.F. Catalogue of the Plants of Kumaon and the adjacent portions of Garhwal and Tibet. 8vo. Pp. 276. 1906. Lovell Reeve. 5s.

Thompson, H.S. Flowering Plants of the Riviera. A Descriptive Account of 1,800 of the more interesting Species. Cr. 8vo. Pp. 280. 1914. Longmans. 12s. 
Townsend, F. Flora of Hampshire, including the Isle of Wight, with localities of the less common species. 2nd edn. 8vo. Pp. 696. 1904. Lovell Reeve. 18s.

Ward, H. M. Grasses : a Handbook for use in the Field and Laboratory. Cr. 8vo. Pp. 198. 1908. Cambridge University Press. $7 s$.

Watts, W. M. A School Flora. For the use of Elementary Botanical Classes. Cr. 8vo. Pp.216. 1919. Longmans. $4 s .6 d$.
White, J.W. The Flora of Bristol. An Account of all the Flowering Plants, Ferns, and their Allies that have at any time been found in the neighbourhood of Bristol. Demy 8vo. Pp. 700. 1912. John Wright. 12s. 6d.

Willis, J. C. A Dictionary of the Flowering Plants and Ferns. 4th edn. Cr. 8vo. Pp. 780. 1919. Cambridge University Press. 22s. 


\section{FORESTRY.}

"Acorn." English Timber and Its Economical Conversion. A Handbook for Home Timber Merchants, Manufacturers and Growers. 2nd edn. Cr. 8vo. Pp. 208. Rider. $3 s, 6 d$.

Baterden, J. R. Timber. Ex. Cr. 8vo. Pp. 356. 1908. Constable. 7s. $6 d$.

Bean, W.J. Trees and Shrubs Hardy in the British Isles. 2 Vols. Med. 8vo. Pp.688., 736. 1919. Murray. $48 s$.

Beddoes, W. F. The Management of English Woodlands. Demy 8vo. Pp. 191. 1919. Simpkin, Marshall. 7s. $6 d$.

Bousfield, G. The Timber Merchant and Builders' Vade Mecum. Cr. 8vo. Pp. 120. N.D. Wm. Rider. 5s.

Boyd, J. Afforestation. Cr. 8vo. Pp. 40. 1918. Chambers. $1 s$.

Brandis, Sir D. Indian Trees: An Account of Trees, Shrubs, Woody Climbers, Bamboos, and Palms, Indigenous or Commonly Cultivated in the British Indian Empire. 2nd edn. Demy 8vo. Pp. 303. 1920. Constable. 40s.

Broun, A. F. Sylviculture in the Tropics. 8vo. Pp. 328. 1912. Macmillan. 10s. 6d.

Bullock, W. Timber. From the Forest to its Use in Commerce. Cr.8vo. Pp. 158. 1915. Pitman. $3 s$.

Charpentier, P. Timber. A Comprehensive Study of Wood in all its Aspects, Commercial and Botanical. Translated from the French. Roy. 8vo. Pp. 437. 1902. Scott, Greenwood. 14s. 6d.
Coltman-Rogers, C. Conifers and their Characteristics. Demy 8vo. Pp. 333. 1920. Murray. 21s.

Curtis, C. E. Practical Forestry: and its Bearing on the Improvement of Estates. 4th edn. Cr. 8vo. Pp. 156. 1908. Crosby Lockwood. $5 s$.

Forbes, A. G. The Development of British Forestry. Demy 8vo. Pp. 286. 1910. Arnold. 10s. 6d.

-English Estate Forestry. 2nd edn. Demy 8vo. Pp. 342. 1906. Arnold. 12s . 6d.

Handhook of Forestry. Pocket size. Pp. 216. 1920. Wm. Rider. 4s, $6 d$.

Hanson, G. O. Forestry for Woodmen. Cr. 8vo. Pp. 222. 1911. Oxford: Clarendon Press. 5s.-

Henry, A. Forests, Woods, and Trees in Relation to Hygiene. Demy 8vo. Pp. 326. 1919. Constable. $18 s$.

Howard, A. L. A Manual of the Timbers of the World. Their Characteristics and Uses. With an Account of the Artificial Seasoning of Timber, by S. Fitzgerald. 8vo. Pp. 462. 1920. Macmillan. $30 s$.

Jackson, H. A Short Manual of Forest Management. Demy 8vo. Pp. 80. 1921. Cambridge University Press. $7 s$.

Johns, G. A. British Trees and Shrubs. Revised, edited and annotated by E. T. Cook. 8vo. Pp. 301. Routledge. 10s. $6 d$.

The Forest Trees of Britain. 10th edn . revised by G. S. Boulger. Post 8vo. Pp. 448. 1920. S.P.C.K. 7s. 6d. 
Keen, G. R. Aeroplane Timbers: Their Structure, Formation, and Mechanical and Commercial Properties. Demy 8vo. Pp.88. 1919. Wm. Rider. $6 s$.

Maw, P. T. Forestry : complete Yield Tables for British Woodlands and the Finance of British Forestry. Roy. Oblong 8vo: Pp. 120. 1912. Crosby Lockwood. $7 s .6 d$.

The Practice of Forestry: concerning also the Financial Aspect of Afforestation. Demy 8vo. Pp. 501. 1912. Fisher Unwin. 21s.

Newsham, J.C. The Propagation and Pruning of Hardy Trees. Shrubs, and Miscellaneous Plants; with notes on Manuring and Planting. Demy 8vo. Pp.238. 1913. Crosby Lockwood. $7 s .6 d$.

Nisbet, J. The Forester. A Practical Treatise on British Forestry and Arboriculture, for Landowners, Land Agents, and Foresters. 2 Vol. Roy. 8vo. Pp.526., 657. 1905. Blackwood. 42s .

-The Elements of British Forestry. A Handbook for Students of Forestry. Cr. 8vo. Pp. 357. 1911. Blackwood. 6s. 6d.

-British Forest Trees and their Sylvicultural Characteristics and Treatment. Cr. 8vo. Pp. 368. 1893. Macmillan. $6 s$.

Shaw, N. Chinese Forest Trees and Timber Supply. Demy 8vo. Py. 349. 1914. Fisher Unwin. 10s.6d.

Shipping Marks on Timber. embracing Sawn and Planed Wood, Joinery and other Hard and Soft Woods, exported from Sweden, Norway, Finland, Russia, Canada, the United States, etc. 4to. Pp. 149. 1920. Wm. Rider. 15s.

Stebbing, E. P. Commercial Forestry in Britain: its Decline and Revival. Cr. 8vo. Pp.186. 1919. Murray. 6s.

-British Forestry. Its Present Position and Outlook after the War. Cr. 8vo. Pp. 257. 1919. Murray. $6 s$.
Step, E. Wayside and Woodland Trees. A Pocket Guide to the British Sylva. Poeket size. Pp. 182. Warne. $8 s, 6 d$.

Stevenson, W. The Trees of Commerce. A Practical Manual. Demy 8vo. Pp. 274. 1920. Wm. Rider. $5 s$.

Stone, H. A Guide to the Identifica tion of our more useful Timbers. A Manual for the use of Students of Forestry. Demy svo. Pp. 60. 1920. Cambridge University Press. $7 s, 6 d$.

The Timbers of Commerce and Their Identification. A Complete Guide to the Identification of $\mathbf{3 4 5}$ distinct varieties of Timber. Demy 8vo. Pp. 349. 1918. Wm. Rider. $8 s .6 d$.

Tiffany, F. The Timber Merchants' Handbook. A Practical Guide to the Measurements and Uses of Wood. Cr. 8vo. Pp. 176. N.D. Wm. Rider. 5s.

Unwin, A. H. West African Forests and Forestry. Super Roy. 8vo. Pp. 528. 1920. Fisher Unwin. $63 s$.

Wallis-Tayler, A. J . The Preservation of Wood. Demy 8vo. Pp.340. N.D. Wm. Rider. 10s, 6d.

Ward, H. M. Trees : a Handbook of Forest Botany for the Woodlands and the Laboratory. 5 Vols. Cr. 8vo. Vol. 1. Buds and Twigs. Pp. 282. 1910. รs. 6d. Vols. 2 to 5. (out of print). Cambridge Univer. sity Press.

- Timber and some of its Diseases. Cr. 8vo. Pp. 304. 1909. Macmillan. $7 \mathrm{~s}$.

Webster, A. D. Practical Forestry . A Handbook on the Rearing and Growth of Trees for Profit and Ornament. Demy 8vo. Pp. 318. 1917. Wm. Rider, 7s. 6d.

Town Planting, and the Trees, Shrubs, etc., best adapted for resisting Smoke. Cr. 8vo. Pp. 211. 1910. Routledge. 4s.6d. 


\section{Forestry.}

Webster, A.D. Coniferous Trees. A Concise Description of each Species and Variety, with the most recently approved Nomen. clature, list of Synonyms, and best Methods of Cultivation. Demy 8vo. Pp. 318. 1918. Constable. 21s.

Tree Wounds and Diseases : their Prevention and Treatment. Demy 8vo. Pp. 215. 1916. Williams and Norgate. $7 s, 6 d$.

National Afforestation. Large Cr. 8vo. Pp. 160. 1919. Fisher Unwin. 8s. $6 d$.

Seaside Planting: For Shelter, Ornament and Profit. Cr. 4to. Pp. 156. 1918. Fisher Unwin. $18 s$.
Webster, A. D. Firewoods. Their Production and Fuel Values. $\mathrm{Cr}$. 4to. Pp. 95. 1919. Fisher Unwin. 12s. $6 d$.

Hardy Ornamental Flowering Trees, and Shrubs. Small Demy 8vo. Pp. 233. 1908. Murray. $5 s$.

Whellens, W. H. Forestry Work. 2nd imp. Demy 8vo. Pp. 236. 1919. Fisher Unwin. 8s. $6 d$.

Winn, W. Timbers and Their Uses. 8vo. Pp. 335. 1919. Routledge. $10 s, 6 d$. 


\section{AGRICULTURE.}

\section{i. GENERAL.}

Andrew, R. C. A Farmer's Handbook. A Manual for Students and Beginners. Cr. 8vo. Pp. 142. 1920. Bell. 6s.

Bosworth, G. F. Agriculture and the Land. Cr. 8vo. Pp. 101 . 1917. Cambridge University Press. 2s.

Dudgeon, G. G. The Agricultural and Forest Products of British West Africa. Demy 8vo. Pp. 170. 1911. Murray. 6s.

Encyclopædia of the Farm, by Eminent Agricultural Authorities. 2 Vols. Roy. 8vo. Pp. 845., 827. N.D. W. Green. 30s.

Farmer and Stockbreeder's Year Book, 1921. Roy. 8vo. Pp. 368 . Macdonald. $3 s .6 d$.

Fream, W. Flements of Agriculture. A Text-book prepared under the authority of the Royal Agricultural Society of England. 12th edn. Edited by J. R. Ainsworth-Davis. Cr. 8vo. Pp. 700. 1920. Murray. 7s. $6 d$.

Grasby, W. C. Principles of Australian Agriculture. Cr. 8vo. Pp. 312. 1912. Macmillan. 5s.

Green, F. E. First Advice to Wouldbe Farmers. Cr. 8vo. Pp. 190. 1919. Country Life. $5 s$.

Haggard, Sir R. A Farmer's Year: being his Commonplace Book for 1898. Cr. 8vo. Pp. 512. 1909. Longmans. 6s. $6 d$.

Rural Denmark and Its Lessons. Cr. 8vo. Pp. 350. 1917. Longmans. 6s.

Hall, Sir A. D. Agriculture After the War. Cr. 8vo. Pp. 137. 1917. Murray. 5s.

A Pilgrimage of British Farming, 1910-1912. Iarge $\mathrm{Cr}$. 8vo. $\mathrm{Pp}$. 452. 1914. Murray. $7 s, 6 d$.
Lloyd, E. W. Hints to Farm Pupils. Cr. 8ro. Pp. 112. 1919. Murray. $2 s .6 d$.

McConnell, P. A Note-Book of Agricultural Facts and Figures for Farmers and Farm Students. 9th edn. Fcap. 8vo. Pp. 550. 1919. Crosby Lockwood. 15s.

Mukerji, N. G. Handbook of Indian Agriculture. Brr edn. Demv 8vo. Pp. 634. 1915. Thacker. $15 s$.

Newsham, J. C. Farming Made Easy. Cr. 8vo. Pp. 190. 1918. Pearson. 3s. $6 d$.

Nicholls, H. A. A. A Text-Book of Tropical Agriculture. Cr. 8vo. Pp. 334. 1919. Macmillan. 7s.

Orr, J. Agriculture in Berkshire. A Survey. Demy 8vo. Pp. 218. 1918. Oxford: Clarendon Press. 8s. $6 d$.

Agriculture in Oxfordshire. A Survey, with a chapter on Soils by C. G. T. Morison. Demy 8vo. Pp. 252. 1916. Oxford: Clarendon Press. 8s. $6 d$.

Pawson, H. C. The Study of Agriculture, or Hints for Agricultural Students. Cr. 8vo. Pp. 124. Pp. 124. 1921. Vinton. 5s.

Somerville, W. Agriculture. Feap. 8vo. Pp. 256. 1911. Williams and Norgate. 2s. $6 d$.

Stephens, H. The Book of the Farm. 5th edn. Revised and largely rewritten by J. Macdonald. 3 Vols. Roy. 8vo. 1908. Vol. I. Land and Its Equipment. Pp. 569. Vol. II. Farm Crops. Pp. 573. Vol. III. Farm Live Stock. Pp. 569. Blackwood. 21s. each. 
Tanner, H. Elementary Lessons in the Science of Agricultural Practice. Fcap. 8vo. Pp. 316. 1893. Macmillan. $3 s .6 d$.

Watts, F., and Freeman, W. G. Nature Teaching. Based upon the General Principles of Agriculture. Large Cr. 8vo. Pp. 190. 1913. Murray. $4 s$.

Webb,H.J. Agriculture. A Manual for Advanced Science Students. Cr. 8vo. Pp. 680. 1914. Longmans. $9 s$.

-Elementary Agriculture. Cr. 8vo. Pp. 204. 1919. Longmans. 4s.

Weigall, A. G., and Wrey, C. A Large State Farm. A Business and Fducational Undertaking. Cr. 8vo. Pp. 82. 1919. Murray. 2s.6d.

Wibberley, T. Farming on Factory Lines : or Continuous Cropping for the Large Farmer. 2nd edn. Cr. 8vo. Pp. 267. 1919. Pearson. 6s.

Williams, M. M. Farm Work throughout the Year. Cr. 8vo. Pp.128. 1921. Routledge. 3s.6d.

Willis, J. C. Agriculture in the Tropics. 2nd edn. Demy 8vo. Py.237. 1914. Cambridge University Press. 11s.

Wolff, H. W. The Future of our Agriculture. Demy 8vo. Pp. 510. 1918. King. 12s. $6 d$.

Wrightson, J., and Newsham, $J$. C. Agriculture: Theoretical and Practical. :rd edn. Med. 8vo. Pr. 66s. 1921. Crosby Iockwood. 12s. 6d.

\section{ii. BOTANY : INCLUDING POISONOUS PLANTS, PLANT DISEASES AND PESTS.}

Armstrong, S. F. British Grasse and their Employment in Agriculture. Demy 8vo. Pp. 208. 1917. Cambridge Úniversity Press. $7 \mathrm{~s}$.

Brenchley, W. E. Weeds of Farm Land. Demy 8vo: Pp: 249: 1920. Longmans. $12 s, 6 d$.
Bruck, W. F. Plant Diseases. Translated from the German, and edited by J. R. Ainsworth-Davi . Fcap. 8vo. Pp. 142. 1912. Blackie. 2s. $6 d$.

Butler, E. J. Fungi and Disease in Plants. An Introduction to the Diseases of Field and Plantation Crops, especially those of India and the East. Roy. 3vo. 1918. Thacker. 25s.

Gook, M. T. The Diseases of Tropical Plants. 8vo. Pp. 332. 1913. Macmillan. 10s. 6d.

Duncan, F. M. Insect Pests and Plant Diseases in the Vegetable and Fruit Garden. Cr. 8vo. Pp. 95. 1919. Constable. 3s. 6d.

Eriksson, J. Fungoid Diseases of Agricultural Plants. Demy 8vo. P . 230. 1912. Bailliêre. 8s. 6d.

Fryer, P. J. Insect Pests and Fungus Diseases of Fruit and Hops. A Complete Manual for Growers. Med.8vo. Pp. 528. 1920. Cam. bridge University Press. 45s.

Gunther, R. T. Report on Agricultural Damage by Vermin and Birds in the Counties of Norfolk and Oxfordshire in 1916. Demy 8vo. Pp. 92. 1917. Oxford University Press. 2s. 6d.

Henslow, G. Poisonous Plants in Field and Garden. Post 8vo. Pp. 189. 1901. S.P.C.K. 2s.6d.

Long, H. C. Plants Poisonous to Live Stock. Roy. 8vo. Pp. 128. 1917. Cambridge University Press. 6s. $6 d$.

- - and Percival, J. Common Weeds of the Farm and Garden. Large Post 8vo. Pp. 451. 1910. Murray . 6s.

Massee, G. Diseases of Cultivated Plants and Trees. 2nd edn. Cr. 8vo. Pp. 614. 1915. Duckworth. 7s. $6 d$.

Milburn, T, Fungoid Diseases of Farm and Garden Crops. Cr. 8vo. Pp. 130. 1915. Longmans. 2s.6d. 
Percival. J. Agricultural Botany: Theoretical and Practical. 6th edn. Large $\mathrm{Cr}$. Svo. Pp. 853. 1921. Duckworth. 18s.

Petherbridge, F. R. Fungoid and Insect Pests of the Farm. Cr. 8vo. Pp.182. 1916. Cambridge University Press. 5s. 6d.

Potter, M. C. An Elementary Textbook of Agricultural Botany. 5th edn. Cr. 8vo. Pp. 312. 1919. Methuen. fis.

Tubeuf, C. von. Diseases of Plants induced by Cryptogamic Parasites. Translated from the German by W. J. Smith. Roy. 8vo. Pp. 614. 1897. Longmans. $21 s$.

Ward, H. M. Disease in Plants. Cr. 8vo. Pp. 326. 1901. Macmillan. 8s. $6 d$.

Watson, J. (edited by). Farm Vermin. Helpful and Hurtful. Cr. 8vo. Pp. 80. N.D. Wm. Rider. 2s. 6d.

Weiss, F. E., Imms, A. D., and Robinson, W. Plants in Health and Disease. Cr. 8vo. Pp. 151. 1916. Longmans. $1 s .6 d$.

\section{iii. CHEMISTRY .}

Addyman,F.T. Agricultural Analysis. A Manual of Quantitative Analysis for Students of Agriculture. Cr. 8vo. Pp. 230. 1916. Longmans. $6 s$.

Adie, R.H., and Wood, J.B. Agricultural Chemistry. 2 Vols. Cr. 8vo. Pp. 289., 237. Kegan Paul. 5s. each Vol.

Auld, S. J. M., and Edwardes Ker, D. R. Practical Agricultural Chemistry. Cr. 8vo. Pp. 243. 1913. Murray. 10s. 6d.

Coleman, J. B., and Addyman, F . T. Practical Agricultural Chemistry. Cr. 8vo. Pp. 100. 1919. Longmans. 3s. $6 d$.

Dodgson, J. W ., and Murray, J . A . A Foundation Course in Chemistry for Students of Agriculture and Technology. 2nd edn. Cr. 8vo. Pp. 253. 1920. Hodder and Stoughton. $6 s, 6 d$.
Dymond, T. S. An Experimental Course of Chemistry for Agricultural Students. 6th imp. Cr. 8vo. Pp. 192. 1916. Arnold. $3 s$.

Hall, Sir A. D., and Russell, E. J . The Book of the Rothamsted Experiments. Issued with the Authority of the Lawes Agricultural Trust Committee. 2nd edn. Med. 8vo. Pp. 332. 1910. Murray. 12s.

Ingle, H. Elementary Agricultural Chemistry. For Junior Agricultural Students and Farmers. 3rd edn. Large Cr. 8vo. Pp. 259. 1920. Griffin. $5 s$.

A Manual of Agricultural Chemistry. 4th edn. Demy 8vo. Pp. 440. 1920. Scott, Greenwood. $15 s$.

Johnston, J.F.W. Elements of Agricultural Chemistry. 21st edn. revised by C. A. Cameron and C.M. Aikman. Cr. 8vo. Pp.512. 1912. Blackwood. 6s. 6d.

Mercier, C. A Manual of the Electro Chemical Treatment of Seeds. Cr. 8vo. Pp. 142. 1919. University of London Press, 3s. $6 d$.

Newman, L. F ., and Neville, H. A. D. A Course of Practical Chemistry for Agricultural Students. 2 Vols. Demy 8vo. Vol. 1. Pp. 235. 1920. 10s. 6d. Vol. 2. Pt. 1. Py. 122. 1919. 5s. Cambridge University Press.

Robertson, F. D. S. Practical Agricultural Chemistry. A Manual of Qualitative and Quantitative Analysis for Agricultural Students and Analysts. Large $\mathrm{Cr}$. 8vo. Pp.220. 1907. Baillière. 8s,6d.

Wood, T. B. The Chemistry of Crop Production. Cr. 8vo. Pp. 193. 1920. University Tutorial Press. $5 s .6 d$.

Woodhead, S. A. Elementary Chemistry of Agriculture. Gl. 8vo. Pp. 196. 1919. Macmillan. 3s. 6d. 


\section{iv. GEOLOGY .}

Marr, J. E. Agricultural Geology. Cr.8vo. Pp. 330. 1903. Methuen. 7s. $6 d$.

Rastall, R. H. Agricultural Geology . Demy 8vo. Pp. 342. 1916. Cambridge University Press. 12s.

\section{v. ZOOLOGY.}

Bos, J. R. Agricultural Zoology . Translated by J. R. AinsworthDavis. 3rd edn. Cr. 8vo. Pp. 332. 1904. Methuen. 5s.

Theobald, F. V. A Text-book of Agricultural Zoology. 3rd edn. Cr. 8vo. Pp. 571. 1919. Blackwcod. 10s.6d.

\section{vi. BAGTERIOLOGY.}

Lohnis, F. Laboratory Methods in Agricultural Bacteriology. Translated by $W$. Stevenson and J. H. Smith. Cr. 8vo. Pp. 147. 1913. Griffin. $5 s$.

Percival, J. Agricultural Bacteri. ology: Theoretical and Practical. 2nd edn. Large Cr. 8vo. Pp. 418 . 1920. Duckworth. 12s. 6d.

\section{vii. ECONOMICS.}

Agriculturist's Calculator, The A series of 46 Tables for Land Measuring, Draining, Manuring, Planting, Weight of Hay and Cattle by Measurement, Building, etc. Cr. 8vo. Pp. 591. N.D. Blackie. 9s.

Ashby, A. W. Allotments and Small Holdings in Oxfordshire. A Survey. Demy 8vo. Pp. 198. 1917. Oxford: Clarendon Press. $5 s$.

Bright, T. Agricultural Valuer's Assistant. A Practical Handbook. 5th edn. Cr. 8vo. Pp. 320. 1910. Crosby Lockwood. 7s. 6d.

- Agricultural Surveyor and Estate Agent's Handbook of Practical Rules, Formulæ, Tables and Data. 2nd edn. Fcap. 8vo. Pp.464. 1911. Crosby Lockwood. 7s. $6 d$.
British Agriculture: The Nation's Opportunity. Being the Minority Report of the Departmental Committee of the Employment of Sailors and Soldiers on the Land, by E. G. Strutt, L. Scott, G. H. Roberts, and others. Cr. 8vo. Pp. 168. 1917. Murray. 3s.6d.

Cullyer, J. Tables for Measuring and Manuring Land, and Thatcher's Woik. 19th imp. 18mo. Pp. 150. Pitman. 3s.

Curtis, C. E., and Gordon, R. A. A Practical Handbook of Agricultural Tenancies. Demy 8vo. Pp. 340. 1910. Crosby Lockwood. $10 s, 6 d$.

Faber, $\mathbf{H}$. Co-operation in Danish Agriculture. 8vo. Pp. 198. 1918. Longmans. 9s.

Gordon, L. S. Co-operation for Farmers. Cr. 8vo. Pp. 247. 1918. Williams and Norgate. $6 s$.

Henderson, R. The Young Estate Manager's Guide. Cr. 8vo. $\mathbf{P}_{\mathbf{p}}$. 292. 1898. Blackwood. 7s. 6d.

The Estate Manager. 8vo. Pp. 563. 1910. W. Green. 15s.

Inwood's Tables for Purchasing Estates and for the Valuation of Properties. 30th edn. Revised by W. Schooling. Demy 8vo. Pp. 366. 1921). Crosby Lockwood. 8s. $6 d$.

Long, J. The Small Farm and Its Management. 2nd edn. Cr. 8vo. Pp. 346. 1920. Murray. $7 s .6 d$.

Newsham, .J.C., and Philpott, T. V. Agricultural Arithmetic: For Estate Agents, Farmers, ete. Cr. 8vo. Pp. 264. 1913. Crosby Lockwood. 4s. $6 d$.

Orwin, C. S. Farm Accounts. New edn. in preparation. Cambridge University Press.

Rogers, A. G.L. The Business Side of Agriculture. Cr. 8vo. Pp. 163. 1904. Methuen. 5s. 
Ruston, A. G. Rural Arithmetic. Including Agricultural Measurements and Calculations and Business Transactions of the Farm. Cr. 8vo. Pp. 451. 1916. University Tutorial Press. $5 s$.

Slater, A. Estate Economics. Demy 8vo. Pp. 278. 1917. Constable. $10 s$.

Tomkinson, C. W. State Help for Agriculture. Cr. 8vo. Pp. 189. 1917. Fisher Unwin. 3s.6d.

Wolff, H. W. Co-operation in Agriculture. 2nd imp. Cr. 8vo. Pp. 378. 1914. King. 7s.6d.

\section{viii. ENGINEERING .}

Brown, E. T. Farm Tractors. A Practical Handbook on the Selection and Management of a Tractor. Cr. 8vo. Pp. 160. 1920. Pearson. 3s. $6 d$.

Clayton, C. H. J. Land Drainage: from Field to Sea. Cr, 8vo. Pp. 201. 1919. Country Lifo. $6 s$.

Cleǵhorne, W. S. H. Farm Build. ings and Building Construction in South Africa. 8vo. Pp. 348. 1916. Longmans. $22 s$.

Farming by Motor. A Guide to all types of Farm Tractors and Motor Ploughing. Cr.8vo. 1918. Temple Press. 1s.6d.

Graham, P. A. Reclaiming the Waste. Britain's Most Urgent Problem-Land Reclamation. Cr. 8vo. Pp. 188. 1916. Country Life. 3s. 6d.

Lawrence, C. P. Economic Farm Buildings: Systematic Planning, Improvement, Construction. Med. 8vo. Pp. 202. 1919. Library Press. 10s. 6d.

Sherwood, G. The Farm Tractor Handbook. Cr. 8vo. Pp. 176. 1918. Iliffe. $5 s$.

Vernon, A. Estate Fences: their Choice, Construction, and Cost, with a Chapter on Boundaries and Fences in their Legal Aspect, by T. W. Marshall. Re-issue. 8vo. Pp. 420. 1909. Spon. 10s.6d. ix. HISTORY.

Curtler, W. H. R. History of English Agriculture. Cr. 8vo. Pp. 380. 1909. Oxford: Clarendon Press. $7 s .6 d$.

Green, F. E. A History of the English Agricultural Labourer. His Social Surroundings and Economic Condition from 1894 to the Present Time. Demy 8vo. Pp.366. 1920. King. $16 s$.

Haggard, Sir R. Rural England: being an account of Agricultural and Social Researches. New edn. 2 Vols. Cr. 8vo. Pp.630,, 632. 1906. Longmans. $15 s$.

Hasbach, W. A History of the English Agricultural Labourer. Translated from the German. 2nd edn. Demy 8vo. Pp.486. 1920. King. 10s. $6 d$.

Macdonald, W. Makers of Modern Agriculture. Cr. 8vo. Pp. 94. 1913. Macmillan. 2s. 6d.

Matthews, A. H. H. Fifty Years of Agricultural Politics; being the History of the Central Chamber of Agriculture, 1865-1915. Demy 8vo. Pp. 446. 1915. 10s. 6d. Editionde-luxe (limited to 250 copies). 31s. 6d. Author: 28, Westminster Palace Gardens, S.W.1.

Prothero, R. E. (Lord Ernle). English Farming, Past and Present. 2nd edn. 8vo. Pp. 520. 1919. Longmans. $10 s .6 d$.

\section{ANIMAL HUSBANDRY.}

\section{a. Dairying .}

Barthe1, C. Methods Used in the Fxamination of Milk and Dairy Products. Translated by W. Goodwin. 8vo. Pp. 272. 1910. Macmillan. 7s. 6id.

Freudenreich, E, von. Dairy Bacteriology. A Short Manual for Students in Dairy Schools, Cheese Makers, and Farmers. Translated by .T. R. Ainsworth Davis. 2nd edn. Cr. 8vo. Pp. 178. 1900. Methuen, 3s.6d. 
Matthews, E. F.conomies in Dairy Farming. Demy 8vo. Pp. 79 . 1903. Country Life. 9s.6d.

Mayall, G. Cows, Cowhouses, and Milk. 2nd edn. Cr.8vo. Pp. 144. 1918. Baillière. 4s. 6 $d$.

Newsham, J. C. Dairy Farming . Cr. 8ro. Pp. 174. 1920. Pearson. 3s. $6 d$.

O'Callaghan, M. A. Dairying in Australasia, Farm and Factory. Roy. 8vo. Pp. 700. 1912. Oxford University Press (Angus and Robertson). $20 s$.

Penlington, W. A. G. Science of Dairying. Cr.8vo. Pp. 268.1919. Macmillan. 3s.

Richmond, H. D. Dairy Chemistry . A Practical Handbook for Dairy Chemists and others having Control of Dairies. 3rd edn. Demy svo. Pp. 502. 1920. Griffin. 25s.

The Lahoratory Book of Dairy Analysis. 2nd edn. Cr. 8vo. Pp. 108. 1912. Griffin. 3s.

Sadler, W. Bacteria as Friends and Foes of the Dairv Farmer. Cr. 8vo. Pp. 12s. 1912. Methuen. 2s.

Saker, D. G. Practical Dairying. Cr. 8vo. Pp. 131. 1921. Methuen. $6 s$.

Thomson, G. S. Milk and Cream Testing and Grading Dairy Products. Cr. 8vo. Pp. 224. 1911. Crosby Lockwood. $5 s$.

- The Dairying Industry. Part 1. The Milk and Cream SupplyCity, Farm and Factory. Demy 8vo. Pp. 260. 1907. Crosby Lockwood. 10s. $6 d$.

Dairying (British and Colonial). The Science and Practice. Demy 8vo. Pp. 476. 1913. Crosby Lockwood. 9s.

Walker-Tisdale, G. W. Milk Testing. A simple practical Handbook for Dairy Farmers, Milk Dis. tributors, etc. Cr. 8vo. Pp. 90. 1920. Swarthmore Press. 3s. 6d. -and Jones, $J$. Butter and Cheese. Cr. 8vo. Pp. 151. 1920. Pitman. 3s.
Walker-Tisdale, C. W., and Robinson, T.R. Practical Butter Making. A Treatise for Butter Makers and Students. 4th edn. Cr. 8vo. Pp. 143. 1919. Sivarthmore Press. 5s. idd.

and Woodnutt, W. F. Praetical Cheese Making. A General Guide to the Manufacture of Cheese. ćr. Svo Pp. 198. 1919. Swarthmore Press. 5s. 6d.

Willoughby, E. F. Milk: Its Production and Uses, with Chapters on Dairy Farming, Diseases of Cattle, and on the Hygiene and Control of Supplies. Demy 8 vo. Pp. 2r1. 101)3. Griffin. is.6d.

\section{b. Live Stork.}

I Barton, F. T. Cattle. Sheep and Pigs. Their Practical Breeding and Keeping 2nd edn. Demy 8vo. Pp. 3.53. 192!). Jarrolds. $21 s$.

- The Cottager's Pig: A Practical Treatise on Pig keeping for the Small Holder and Cottager. Cr. svo. Pp. 6i:. 1920. Iarrolds. ?s. 6 d.

Brigham, A.A. Progressive Poultry Culture. The Keeping of Poultry for Profit and Pleasure. 2nd edn. Cr.8vo. Pp.239. 1912. Methuen. $5 s$.

Cheshire, F. R. Bees and Bee-Keeping: Scientific and Practical. A Complete Treatise on the Anatomy, Physiology. Floral Relations, and Profitable Management of the HiveBee. New edn. 2 Vols. Cr. 8vo. 1921. Vol. 1. scientific. Pp. 344. 12s. 6d. Vol. 2. Practical, with an Appendix bringing the work up to date, by J. B. Lamb. Pp. 750 . 15s. Upcott, Gill.

Gowan, T. W. British Bee Keeper's Guide Book to the Management of Bees in Movable Comb Hives, and the Use of Modern Bee Appliances. 23rd edn. Cr. 8vo. Pp. 234. 1919. Paper. 2s. 6d. Cloth. 3s. 6d. "'British Bee Journal."

British Bee-keeper's Practical Note Book. 3rd edn. Cr. 8vo. Pp. 72. N.D. "British Bee Journal." is. 


\section{Agriculture.}

Cowan, T. W. Wax Craft: All about Beeswax-its History, Production, Adulteration. and Commercial Value. Cr.8vo. Py.172. 1908. "British Bec Journal."' $2 s$.

Digges, J. G. The Practical Bee Guide: A Manual of Modern Beekeeping. 4th edn. Cr. 8vo. Py. 239. 191s. Simpkin, Marshall.3s.

Geary, H. The Bee-keeper's VadeMecum. Pocket size. Pp. 202. 1920. Stanley Paul. 2s.6d.

Hanson, S. G. Commercial Egg Farming. From Practical Experience. Cr. 8vo. Pp. 62. 1919. Constahle. 1s, $9 d$.

Herrod-Hempsall, W. Bee-keeping Simplified for the Cottager and Smallholder. 2nd edn. Cr. 8vo. Pp. 52, 1918. "British Bee Journal.', 1s.

_ Producing, Preparing, Exhibiting, and Judging Bee Produce. Cr.8vo. Pp.168. 1912. "British Bee Journal.', $2 s$.

Hodgins, J. E., and Haskett, T. H . Diseases of Live Stock. A Practical Handbook for Farmers and Stockowners. Demy 8vo. Pp. 664. 1910. Baillière. $12 s .6 d$.

Hurst, J. W. Utility Ducks and Geese. Cr. 8vo. Pp. 93. 1919. Constable. $3 s$.

Live Stock Journal Annual, 1921. Roy. 8vo. Pp.335. Dec., 1920. Vinton. 3s. $6 \mathrm{~d}$.

Long, J. British Pigs: The Art of Making them Pay. Cr. 8vo. Pp. 140. 1918. Chapman \& Hall. 4s.

M.R.C.V.S., An. The Farm Vet. A Practical Veterinary Handbook for Farmers. Demy 8vo. Pp. 219. 1914. Macdonald \& Martin. 3s. $6 d$.

Mackenzie, K.J.J. Cattle and the Future of Beef-production in Eng. land. Demy 8vo. Pp. 180. 1919. Cambridge University Press. $7 s, 6 d$.

Matheson, D. Cattle and Sheep. A Practical Manual about Breeds and Breeding, ete. Cr. 8vo. Pp. 202. 1921. Pearson. 5s.
Mayall, G. Pigs, Pigsties, and Pork . 2nd edn. Cr,8vo. Pp.236. 1921. Baillière. $7 s$. (id.

Sheep and Goats. Cr. 8vo. Pp. 136. 1912. Baillière. $4 s, 6 d$.

Moussu, G., and Dollar, J.A.W. Diseases of Cattle, Sheep, Goats, and Swine. Roy. 8vo. Pp. 804. 1905. Baillière. 25s.

Pearse, A. W. The World's Meat Future. An Account of the Live Stock Position and Meat Prospects of all Leading Stock Countries of the World; with full lists of Freezing Works. 2nd edn. Demy 8vo. Pp. 351. 1920. Constable. 21s.

Porter, J. The Stockfeeder's Companion. Large Cr. 8vo. Pp. 336. 1915. Gurney \& Jackson. 5s.

Sessions, H. Cattle Tuberculosis. A Practical Guide to the Farmer, Butcher, and Meat Inspector. 2nd edn. Pp. 126. 1905. Baillière.3s.

Toovey, T. W. Commercial Poultry Farming: a description of the King's Langley Poultry Farm. Cr. 8vo. Pр. 152. 1919. Crosby Lockwood. $7 s .6 d$.

Wilson, J. The Breeding and Feeding of Farm Stock. Cr. 8vo. Pp. 160. 1921. Methuen. 6s.

Wood, T. B., and Marshall, F. H. A. Physiology of Farm Animals. Part 1. General, by F.H. A. Marshall. Demy 8vo. Pp. 216. 1920. Cambridge University Press. $16 s$.

Youatt, W. The Complete Grazier and Farmer's and Cattle Breeder's Assistant. A Compendium of Husbandry. Enlarged and Re-written by $W$. Fream and W. E'. Bear. 15th edn. Roy. 8vo. Pp. 1100. 1908. Crosby Lockwood. $36 s$.

- The Horse. Revised and Enlarged by W. Watson. 8vo. Pp. 598. 1915. Longmans. 10s.6d.

\section{c. Nutrition.}

Hall, Sir A. D. The Feeding of Crops and Stocks. An Introduction to the Science of the Nutrition of Plants and Animals. Large $\mathrm{Cr}$. 8vo. Pp. 314. 1919. Murray. 7s.6d. 
Imperial Institute Monograph. Oil Seeds and Feeding Cakes. With a Preface by W. R. Dunstan. Cr. 8vo. Pp. 137. 1917. Murray. 2s. $6 d$.

Kellner, O.J. The Scientific Feeding of Animals. Translated from the German. 3rd imp. Cr. 8vo. Pp. 418. 1915. Duckworth. 7s.6d.

Morris, T. N. Microscopic Analysis of Cattle-Foods. Cr. 8vo. Pp.82. 1917. Cambridge University Press. $3 s$.

Murray, J. A. The Chemistry of Cattle Feeding and Dairying. Cr. 8vo. Pp. 356. 1914. Longmans. $7 s .6 d$.

Shanahan, E. W. Animal Food Stuffs: their Production, and Consumption, with special reference to the British Empire. 8vo. Pp. 321. 1920. Routledge. 10s. $6 d$.

Wood, T. B., and Halnan, E. T. Composition and Nutritive Value of Feeding Stuffs. 2nd edn. Demy 8vo. Pp. 24. 1917. Cambridge University Press. $1 s$.

Woodruff, H. A. The Economics of Feeding Horses. Cr. 8vo. Pp. 128. 1912. Baillière. 3s. $6 d$.

\section{xi. FIELD GROPS.}

Bald, C. Indian Tea : its Culture and Manufacture. 3rd edn. 8vo. Thacker. 10s, 6d.

Balls, W. L. The Cotton Plant in Egypt: Studies in Physiology and Genetics. 8vo. Pp. 218. 1919 . Macmillan. 6s. 6d.

The Development and Properties of Raw Cotton. Large Cr. 8vo. Pp. 234. 1915. Black. 7s, 6d.

Barker, A. The British Corn Trade. From the Earliest Times to the Present Day. Cr. 8vo. Pp. 140. 1920. Pitman. 3s.

Bradbury, F. Flax Culture and Preparation: A Concise and Complete Description of the Process of Flax Cultivation from the Selection of Seed to the Preparation of Flax for the Market. Demy 8vo. Pp. 166. 1920. Pitman. 10s. $6 d$.
Braham, F. Rubher Planter's NoteBook. A Handy Book of Reference on Para Rubber Planting. Fcap. 8vo. Pị. 116. 1911. Crosby Lockwood. 5s.

Brown, E., and Hunter, H. H. Planting in Uganda: Coffee, Para Rubber, Cocoa: with a Chapter on Fungoid Diseases by G. Massee. 8vo. Pp. 192. 1913. Longmans. 10s. 6d.

Brown, H. Rubber: Its Sources, Cultivation, and Preparation. Demy 8vo. Pp. 260. 1917. Murray. es.

Coghlan, H. L., and Hinchley, J. W. Coconut Cultivation and Plantation Machinery. Cr. 8vo. Pp. 140. 1917. Crosby Lockwood. $4 s$.

Copeland, E. B. The Coco-Nut: The Physiology, Diseases and Pests, Culture, and Products of the CocoNut. 2nd edn. Demy 8vo. Pp. 241. 1921. Marmillan. 20s.

Cowie, G. A. The Fertilization of Tea. Demv 8vo. Pp. 68. 1908. Bale and Danielsson. 2s. $6 d$.

Crookes, Sir W. The Wheat Problem. 3rd edn. With a chapter on Future Wheat Supplies hy Sir R. H. Rew. Cr. Sro. Pp.116. 1917. Longmans. $3 s$. $6 d$.

Deerr, N. Cane Sugar: A Text-Book on the Agriculture of the Sugar Cane. the Manufacture of the Sugar Cane, and the Analysis of Sugar House Products. Roy. Svo. Pp. 592. 1911. Norman Rodger. $20 s$.

Ellmore, W. P. The Cultivation of Osiers and Willows. Cr. 8vo. Pp. 106. 1919. Dent. 4s.

Faber, H. Forage Crops in Denmark. The Feeding Value of Roots, selected Strains of Roots, Quantities in the Trade in Seed. Demy 8vo. Pp. 113. 1920. Longmans. 6s.

Goulding, E. Cotton and other Vegetable Fibres: Their Production and Utilisation. Demy 8vo. Pp. 212. 1919. Murray. 7s.6d. 


\section{Agriculture.}

Gross, E. Hops in their Botanical, Agricultural and Technical Aspect, and as an Article of Commerce. Translated from the German. Demy 8vo. Pp. 340. 1900. Scott, Greenwood. 12s. 6d.

Hart. J. H. Cacao: A Manual on Cultivation and Curing of Cacao. Demy 8vo. Pr.317. 1911. Duck. worth. 7s.6d.

Ibbetson, A. Tea: from Grower to Consumer. Cr. Svo. Pp. 124. 1909. Pitman. 3s.

Johnson, W . H. Cocoa : Its Cultivation and Preparation. Demy 8 vo. Pp. 186. 1912. Murray. 6s.

Rubber: Its Cultivation and Preparation. 2nd edn. Demy svo. Pp.192. 1909. Crosby Lockwood. 10 s. $6 d$.

Keable, B.B. Coflee: From Grower to Consumer. Cr. 8vo. Pu. 130. 1909. Pitman. $3 s$.

Lock, R. H. Rubber and Rubber Planting. Cr.8vo. Pp.260. 1913. Cambridge University Press. 6s. tid.

Manders, A.S. (edited by). Rubber Cotton, Fibres, and other Tropical Agricultural Products Handbook. Demy 8vo. Pp. 1040. Pitman. $5 s$.

Millar, A. Wheat and its Produets, and the Modern Method of Produe: ing Wheaten Flour. Cr. 8vo. Pp. 144. 1916. Pitman. 3s,

Milligan, F. M. Some Essential Notes on Oil Palm Cultivation. Small Cr. 8vo. Pp. 112. 1914. Crosby Lockwood. $3 s$.

Munro, R. W., and Brown, L. C. A Practical Guide to Coconut Planting. 2nd edn. Cr. 8vo. Pp. 223. 1920. Bale \& Danielsson. 15s.

Newland, H.O. The Planting, Cultivation and Expression of Coconuts, Kernels, Cacao, and Edible Vegetable Oils and Seeds of Commerce. Demy 8vo. Pp.111. 1919. Griffin. $6 s$.

Penzer, N. M. Cotton in British West Africa, including Togoland and the Cameroons. Demy 8vo. Pp. 54. 1920. Murlsy. 5s.
Ridley, H. N. Spices. 8vo. Pp. 460. 1912. Macmillan. 10s. fid.

Rutherford's Planters' Note Book of useful Memoranda for every one connected with the Planting Industries of the Middle East. 7th edn. Demy 8vo. Pp. 500. 1918. "Times of Ceylon." $20 s$.

Rutter, W. P. Wheat Growing in Canada, the United States, and the Argentine. Large Cr. 8vo. Pp. 315. 1911. Black. 3s. rid.

Smith, H. H. Soil and Plant Sanitation on Cacao and Rubber Estates; with Sections on Ceará Rubber Culti vation, Castilloa Rubber Cultivation, Funtumia Rubber Cultivation and Rubber Tapping. Cr. 8vo. Pp. 684. 1911. Bale \& Danielsson. $10 s$.

- Coco-Nuts: the Consols of the East. 2nd edn. Cr.8vo. Pp.612. 1913. Bale and Danielsson. 12s.6d. - The Fermentation of Cacao. Cr. 8vo. Pp. 318. 1913. Bale \& Danielsson. 10s.

Tanner, A. E. Tobacco: From Grower to Smoker. Cr. 8vo. Pp. 128. 1912. Pitman. 3s.

Teetgen, A. B. Profitable Herb Growing and Collecting. 2nd edn. Cr. 8vo. Pp. 206. 1919. Country Life. 5s.

Thomson, W. A Practical Treatise on the Cultivation of the Grape Vine. 10th edn. 8vo. Pp. 113. 190?. Blackwood. 5s.

Todd, J. A. The World's Cotton Crops. New edn. in prefaration. Black.

Ugarte, J. P. Collee: its Cultivation and Preparation for the Market. '2nd edn. Large Cr. 8vo. Pp. 101. 1920. Crosby Lockwood. 7s,6d.

Van Hall, C.J.J. Cocoa. 8vo. Pp. 532. 1914. Macmillan. 17s.

Watt, Sir G. Wild and Cultivated Cotton-Plants of the World : \& Revision of the Genus Cossypium, framed primarily with the object of aiding Planters and Investigators who may contemplate the Systematic Improvement of the Cotton Staple. Rov. 8vo. Pp. 420.1907. Longmans. $35 s$. 


\section{Agriculture.}

Wickham, H. A. Para Indian Rubber: Plantation, Cultivation, and Curing. 8vo. Pp. 178. 1908 . Kegan Paul. 3s.6d.

Woodroffe, J.F., and Smith, H.H. The Rubber Industry of the Amazon, and How Its Supremacy can be Maintained. Demy 8vo. Pp. 483. 191.5. Bale \& Danielsson. 21s.

\section{xii. SOILS AND FERTILISERS.}

Collins, S. H. Plant Products and Chemical Fertilisers. Demy 8vo. Pp. 252. 1919. Baillière. 10s.6d. -Chemical Fertilizers and Parasiticides : Sources, Manufacture, Uses, and their Future. Demy 8vo. $\mathbf{P p}$. 285. 1920. Baillière. 10s, $6 d$.

Fritsch, J. The Manufacture of Chemical Manures. Translated from the French. 2nd edn. Revised by H. B. Stocks. Svo. Pp. 395. 1920. Seott, Greenwood. $15 s$.

Griffiths, A. B. A Treatise on Manures: or the Philosophy of Manuring. 3rd edn. Cr. 8vo. Pp. 450. 1892. Pitman. 7s. 6d.

Hall, Sir A. D. Fertilisers and Manures, Large Cr. 8vo. Pp. 384 1919. Murray. 8s.

The Soil. An Introduction to the Scientific Study of the Growth of Crops. 3rd edn. Large Cr. 8vo. Pp. 352. 1920. Murray. 8s.

Knox, G. D. The Spirit of the Soil. Cr. 8vo. Pp. 255. 1915. Constable. $2 s .6 d$.
Murray, J. A. Soils and Manures. 2nd imp. Ex. Cr. 8vo. Pp. 367. 1919. Constable. 8s. $6 d$.

Russell, E. J. The Fertility of the Soil. Roy. 16mo. Pp. 128. 1913. Cambridge University Press . 2s . 6d.

- Lessons on Soil. Cr. 8vo. Pp. 148. 1912. Cambridge University Press. 3s.

-_ A Student's Book on Soils and Manures. 2nd edn. Cr. 8vo. Pp. 240. 1919. Cambridge University Press. 8s.

- Manuring for Higher Crop Production. 2nd edn. Demy 8vo. Pp. 78. 1916. Cambridge University Press. 4s. 6d.

- Soil Conditions and Plant Growth. New edn. in preparation. Longmans.

Sornay, P. de. Green Manures and Manuring in the Tropics. Translated from the French by $F$. W. Flattely. Roy. 8vo. Pp. 460. 1916. Bale \& Danielsson. $16 s$.

Vendelmans, $H$. The Manual of Manures. Cr. 8vo. Pp. 190. 1916. Country Life. 58.

Ville, G. Artificial Manures: Their Chemical Selection and Scientific Application to Agriculture. Revised by Sir William Crookes and $J$. Percival, 8vo. Pp. 386. 1009 . Longmans. 11s. $6 d$.

Warington, R. The Physical Properties of Soil. 8vo. Pp. 232. 1900. Oxford: Clarendon Press. 7s. 6d.

Warrell, C. The Science of the Soil : for Farmers and Land Workers. Cr. 8vo. Pp. 163. 1920. Pitman. 3s. $6 d$. 


\section{ANATOMY.}

\section{i. GENERAL: PRACTICAL, SURGICAL.}

Beesly, L., and Johnston, T. B. Surgical Anatomy for Students and Practitioners. 2nd edn. Cr. Svo. Pp. 537. 1916. Frowde \& Hodder. $16 s$.

Berry, R. J. A. An Atlas of Sectional and Topographical Anatomy . 4to. Pp. 17 and 60 Plates. 1911. W. Green. $42 s$.

Box, G. R., and Eccles, W. McA. Clinieal Applied Anatomy. Roy. 8vo. Pp. 479. 1906. Churchill. $12 s .6 d$.

Braune, W. An Atlas of Topographical Anatomy, after Plane Sections of Frozen Bodies. Translated by E. Bellamy. Large Imp. 8vo. Pp. 200. 1877. Churchill. $40 s$.

Brodie, G. G. Dissections. A Graphic Handhook for Surgeons and Students of Human Anatomy. 2nd edn. Imp. Svo. Pp. 142 and 73 Plates. 1904, Pitman. $25 s$.

Buchanan, A. M. Manual of Anatomy: Systematic and Practical, including Embryology. 5th edn. edited by a Committee of Anatomists in London. Demy 8vo. Pp. 1,755. 1919. Baillière. 30s.

Catechism Series. Anatomy. 3rd edn. 6 Parts. Revised by J. R. Whitaker and C. R. Whittaker. Part 1. Upper Extremity. Part 2. Lower Extremity. Part 3. Head and Neck. Part 4. The Abdomen. Part 5. The Thorax. Part 6. The Bones. Livingstone. 1s. 9d. each.

Surgical Anatomy. 2nd edn. 3 Parts. Written by C.R. Whittaker. 1s. $9 d$. each. Also in one volume, Pp. 177. 1920. Cloth, 5s, 6d. Livingstone.
Glark, H. E. An Elementary TextBook of Anatomy. Cr. 8vo. Pp. 283. N.D. Blackie. 6s.

Cooke, T. Tablets of Anatomy. Being a Synopsis of Demonstrations given in the Westminster Hospital Medical School. 3 Parts. Post 4to. 1898. Part 1. The Bones. Pp. 188. $7 s .6 d$. Part 2. Limbs, Abdomen, Pelvis. Pp. 378. 10s. 6d. Part 3. Head and Neck, Thorax, Brain. Pp.412. 10s.6d. Longmans .

Cunningham, D. J. Manual of Practiral Anatomy. Revised and Edited by A. Rolinson. 7th edn . 3 vols. Cr. 8vo. Vol.1. Superior Extremity : Inferior Extremity . Pp. 481. 1919. Vol. 2. Thorax and At,domen. Pp. 554. 1920. Vol.3. Head and Neck. Pp. 600. 1920. Frowde \& Hodder. $12 s .6 d$. each.

Text-Book of Anatomy. Edited by A. Robinson. 4th edn. 3rd imp. Roy. 8vo. Pp.1631. 1917. Frowde \& Hodder. $42 s$.

Ellis's Demonstrations of Anatomy : being a Guide to the Knowledge of the Human Body by Dissection. 12th edn. Edited by C. Addison. Small 8vo. Pp. 851 . 1905. Murray. 12s.6d.

Ewart, E. D. A Guide to Anatomy, for Students of Medical Gymnastics, Massage, and Medical Electricity. Demy 8vo. Pp.313. 1921. Lew is . 1 iss.

Fagge, C. H. The Pocket Anatomy . 8th edn. Fcap. 8vo. Pp. 312. 1920. Baillière. 5s.

Gray, H. Anatomy : Descriptive and Applied. 21st edn. Edited by $R$. Howden, with Notes on Applied Anatomy, revised by A. J. JexPlake and .J. Clay. Roy. 8vo. Pp. 1382. 1920. Longmans. $42 s$. 
Heath, C., and Lane, J. E. Practical Anatomy : a Manual of Dissections. 9th edn. Cr. 3vo. Pp. 714. 1902. Churchill. 15s.

Hughes, A. W., and Keith, Sir A. A Manual of Practical Anatomy. 3 Parts. Small Roy. Bvo. 1901-2. Part 1. Upper and Lower Extremities. Pp. 296. 12s. 6d. Part 2. Abdomen and Thorax. Pp. 324. 10s. 6d. Part 2. Head, Neck, and Central Nervous System. Pp. 408. i2s. 6d. Churchill.

Jamieson, E. B. A Companion to Manuals of Practical Anatomy . 3rd imp. Fcap. 8vo. Pp. 543. 1918. Frowde \& Hodder. $9 s .6 d$.

- The Basle Nomenclature (B.N.A.) being an Alphabetizal List of Terms showing the old Terminology, the B.N.A. Terminology, and the suggested English Equivalent. Roy. 8vo. Pp. 99. 1916. W. Green. 6s.

Johnston, T. B. Medical Applied Anatomy. Cr.8vo. Pp.436.1915. Black. 12s, $6 d$.

MacEwen, J. A. C. Surgical Anatomy. 2nd edn. Demy 8vo. Pp. 551. 1916. Baillière. $12 s$.

Morris, Sir H. Treatise on Human Anatomy. 5th edn. edited hy C. M. Jackson. Roy. 8vo. Pp. 1554. 1915. Churchill. 36s.

Morton, W. C. Principles of Anatomy: The Abdomen Proper. Demy 8vo. Pu. 174, and 29 large Coloured Plates. 1911. Heinemann. $21 s$.

Orrin, H. C. An X-Ray Atlas of the Systematic Arteries of the Body. 4to. 192). Baillière. 12s, 6d.

Parsons, F. G., and Wright, W. Practical Anatomy. 2 vols. Large Cr. 8vo. 1912. Vol. 1. Pp. 467. Vol. 2. Pp. 382. Arnold. 17s.

Paterson, A. M. The Anatomist's Note Book. Demy 8vo. Pp. 350. 1914. Frowde \& Hodder. 6s, $6 d$.

Potter, S. O. L. A Compend of Human Anatomy. 8th edn. Cr. 8vo. Pp. 446. 1917. Frowde \& Hodder. 6s. $6 d$.
Quain's Elements of Anatomy. Edited by Sir E.A.S. Schafer, J. Symington, and T. H. Bryce. Roy. 8vo. Vol. 1. Embryology, by T. H. Bryce. 11th edn. Pp. 284. 1908. 12s. Vol. 2. Part 2. Splanchnology, by .J. Symington. Pp. 402. 1914. 14s. Vol. 3 . Neurology, hy Sir F. A.S. Schafer \& J. Symington. 2 Parts. 11th edn. Pp. 431., 392. 1909, 14s, each part. Vol. 4. Part 1. Osteology and Arthrology, by T. H. Bryce. Pp. 338. 1915. 1\%s. Longmans.

T'aylor, E. H. Applied Anatomy: A Treatise for Students, House Surgeons, and for Operating Surgeons. Roy. Svo. Pp.766. 1904. Griffin. $\mathbf{3} \dot{\mathbf{b}}$.

Treves, Sir F., Keith, Sir A., and Mackenzie,W.C. Surgical Applied Anatomy. 7th edn. Fcap. 8vo. Pp. 712. 1918. Cassell. 12s.

Walmsley, 'T. A Manual of Practical Anatomy. A Guide to the Dissection of the Human Body. Part 1. The Upper and Lower Limbs. 8vo. Pp. 184. 1920. Longmans. 9s.

Whittaker, C. R. A Manual of Surgical Anatomy. 3rd edn. Cr. 8vo. Pp.440. 1921. Livingstone. $15 s$.

\section{ii. EMBRYOLOGY.}

Assheton, R. Growth in Iength: Embryological Essays. Demy 8vo. Pp. 116. 1916. Cambridge University Press. $2 s .6 d$.

Balfour, F. M. A Treatise on Comparative Embryology. 2 vols. Med. 8vo. 188.5. Vol. 1. Pp.628. $18 s$. Vol.2. Pp. 828. 21s. Macmillan.

Ballantyne, $\mathbf{J}$. W. Manual of Antenatal Pathology and Hygiene. 2 Vols. Roy. Svo. Vol. 1 . The Fotus. Pp. 544. 1920. Vol. 2. The Fmbryo. Pp. 718. 1904. W. Green. 21s. each vol.

Feldman, W. M. The Principles of Ante-Natal and Post-Natal Child Physiology: Pure and Applied. Svo. Pp. 721. 1920. Longmans. 30s. 
Hertwig, O. Text-Book of the Embryology of Man and Mammals. Translated by E. L. Mark. 5th edn. Demy Svo. Pp. 670. 1912. Allen \& Unwin. 21s.

Jenkinson, J. W. Three Lectures on Experimental Embryology; with a Memoir by R. IR. Marett. 8vo. Pp. 128. 1917. Oxford: Clarendon Press. 7s. 6d.

- Vertebrate Embryology, comprising the Early History of the Embryo and its Fætal Membranes, with chapters on Growth, Germ Cells the Development of the Embryo, and a Discussion of the Embryonic Organs. Demy 8vo. Pp.368. 1913. Oxford: Clarendon Press. 12s. $6 d$.

- - Experimental Embryology, with Chapters on Cell Division and Growth, External and Internal Factors, and Driesch's Theories of Development. Demy 8vo. Pp. 350. 1909. Oxford: Clarendon Press. 12s. $6 d$.

Keith, Sir A. Human Eml,ryology and Morphology. 4th edn. Demy 8v's. Pp. 500. 1921. Arnold. 30s.

MacBride, E. W., Kerr, J. G., and others. Text Book of Embryology . 3 vols. Med. 8vo. Vol. 1. Invertebrata, by E. W. MacBride. Pp. 724. 1914. 31s.6d, Vol. 2. Vertebrata (with the exception of Mammalia), by J. G. Kerr. Pp. 604. 1919. 31s. 6d. Vol. 3. Mammalia, by R. Assheton, F. H. A. Marshall, and .J. T. Saunders. In preparation. Macmillan.

Paterson, A. M. A Manual of Embryology. A Manual for Students. Cr. 8vo. Pp. 107. 1915. Frowde \& Hodder. 12s, 6 d.

Przibram, H. Experimental Zoology. Part 1. Embryogeny. Roy. 8vo. Pp. 16s. 190s. Cambridge University Press. 12s.

\section{iii. HISTOLOGY.}

\section{Catechism Series.} Livingstone. $13,9 d$.

Histology •

Goodall , A. Aids to Histology . 2nd edn. Fcap. 8vo. Pp. 143. 1919. Baillière. 3s.
Langley, J . N. Practical Histology . 3rd edn. Cr.8vo. Pp.328. 1920. Heffer. 10s. $6 d$.

Lee, A. B. 'The Microtomist's Vade Mecum: a Handbook of the Methods of Microscopic Anatomy. 8th edn. Edited by J. B. Gatenby. Demy 8vo. Pp. 604. 1921. Churchill. $28 s$.

Mann, G. Methods and Theory of Physiological Histology. 8vo. Pp. 50i. 1902. Oxford: Clarendon Press. 15s.

Radasch, H. E. Elements of Histology. 3rd edn. Cr. 8vo. Pp. 363. 1913. Frowde \& Hodder. 6s.

Schafer, Sir E.A.S. The Essentials of Histology : Descriptive and Practical. For the Use of Students. 11th edn. Demy 8vo. Pp. 589. 1920. Iongmans. $14 s$.

Squire, Sir P. W. Methods and Formula used in the Preparation of Animal and Vegetable Tissues for Microscopical Examination, including the Staining of Bacteria. Cr. 8vo. Pp. 93. 1892. Churchill. 3s. $6 d$.

\section{iv. OSTEOLOGY ; NEUROLOGY;} GLANDS.

Dixon, A. F. Manual of Human Osteology for Students. Cr. Svo. Pp.316. 1912. Frowde \& Hodder. $12 s .6 d$.

Frazer, J. E. The Anatomy of the Human Skeleton. 2nd edn. Cr. 4to. Pp. 282: 1920. Churchill. $36 s$.

Leaf, C. H. The Surgical Anatomy of the Lymphatic Glands. Demy 8vo. Pp. 72. 1898. Constable. $10 s .6 d$.

Lickley, J. D. The Nervous System. An Elementary Handbook of the Anatomy and Physiology of the Nervous System. Fcap. 4to. Pp. 142. 1919. Longmans. 9s.

Obersteiner, Prof. The Anatomy of the Central Nervous Organs in Health and Disease. 'Translated by $A$. Hill. 2nd edn. Large 8vo. Pp.566. 1900. Griffin. 30s. 
Paterson, A. M. Anatomy of the Peripheral Nerves. Demy svo. Pp.176. 1919. Frowde \& Hodder. $12 s .6 d$.

The Human Sternum. Cr. 4to. Pp.112. 1904. Constable. 10s.6d.

Turner, P. Aids to Osteology . 2nd edn. Frap. 8vo. Pp. 195. 1920. Baillière. $4 s .6 d$.

Whitaker, J.R. Anatomy of the Brain and Spina! Cord. 5th edn. Cr. 8vo. Pp. 278. 1921. Livingstone. $12 s .6 \mathrm{~d}$.

\section{v. SURFACE ANATOMY .}

Björkeǵren, M. E. Handbook of Anatomy for Students of Massage. 2nd edn. Demy 8vo. Pp. 219. 1918. Bailìière: 6s .

Jex-Blake, A.J. Physical Signs in the Chest and Aldomen. Demy 8vo. Pp. 124. 1921. Churchill. 9s. $6 d$.

Moorhead, T. G. Surface Anatomy . Cr.8vo. Pp. 158. 1905. Baillière. $4 s, 6 d$.

Rawling, L. B. Landmarks and Surface Markings of the Human Body. 5th edn. Demy 8vo. Pp. 104. 1920. I.ewis. 7s.6d.

Whittaker, C. R. Essentials of Surface Anatomy. 3rd edn. $\mathrm{Cr}$. 8vo. Pp. 88. 1920. Churchill. 7s. 6 d.

Windle. Sir B. C. A. A Handbook of Surface Anatomy and Landmarks. 3rd edn. Post 8vo. Pp. 154. 1902. Lewis. 4s. vi. ARTISTIC ANATOMY.

Armstead, H. W. The Artistic Anatomy of the Horse. Text and 20 original Plates. Roy . 4to. 1900. Baillière. $12 s, 6 d$.

Cuyer, E. The Artistic Anatomy of Animals. Authorised Translation. Edited by G. Haywood. Demy 8vo. Pp. 33.t. 1905. Baillière. 10s. 6d.

Thomson, A. A Handbook of Anatomy for Art Students. 4th edn. 8vo. Pp.481. 1915. Oxford: Clarendon Press. 25s.

\section{vii. COMPARATIVE ANATOMY.}

Bourne, G. C. An Introduction to the Study of the Comparative Anatomy of Animals. 2 vols. Cr. 8vo. Vol. 1. Animal Organisation. The Protozoa and Colenterata. 6th edn. Pp.315. 1919. Vol. 2. The Cœlomate Metazoa 9th edn. Pp. 336. 1909. Bell. 7s. 6d. per vol.

Lang, A. Text Book of ComparativeAnatomy. Translated hy H. M. and $M$. Bernard. With Preface to the English Translation by $\mathbf{E}$. Haeckel. 2 Vols. 8vo. Pp. 580., 632. 1891, 1996. Macmillan. $17 s$. each.

Rolleston, G. Forms of Animal Iife, a Manual of ComparativeAnatomy, with descriptions of selected 'Types. 2nd edn. Revised and enlarged by W. H. Jackson. Roy. 8vo. Pp. 970. 1888. Oxford: Clarendon Press. 3ns. 


\section{PHYSIOLOGY.}

i. GENERAL AND PRAGTICAL.

Alcock, N.H., and Ellison, F. O'B. A Text book of Experimental Physiology. Sm. Roy. 8vo. Pp. 139. 1909. Churchill. 7s. 6d.

Ashby, H. Notes on Physiology. Revised by H. T. Ashty. 8th edn. Cr. 8vo. Pp. 368. 1917. Longmans. 7s. $6 d$.

Bainbridge, F. A., and Menzies. J. A. Essentials of Physiology. 3rd edn. 8vo. Pp. 492. 1919. Longmans. 14s.

Barclay, H. G. Lectures on Elementary Anatomy and Physiology. Demy 8vo. Pp. 298. 1915. Baillière. $6 s$.

Bayliss, W. M. An Introduction to General Physiology. 8vo. Pp. 254. 1919. Longmans. $7 s, 6 d$.

Principles of General Physiology . 3rd edn. Roy. 8vo. Pp. 888. 1920. Longmans. 28s.

Brown, W. L. Physiological Principles in Treatment. 3rd edn. Cr. 8vo. Pp. 416. 1914. Baillière. 8s, $6 d$.

Brubaker, A. P. A Compend of Human Physiologv. 13th edn. Cr. 8vo. Pp. 256. 1912. Frowde \& Hodder. $6 s$.

Buckmaster, G. A., and Kickman, H. R. B. A Course of Practical Physiology. Introductory to Physiology and Medicine. Cr.svo. Pp. 144. 1920. J. Wright. 5s.

Catechism Series. Physiology. 3rd edn. 4 Parts. Revised by A. Goodall. Part 1. Muscles and Nerves, Circulation, Heart, Blood Vessels, Vaso-Motor Mechanism, Blood, Lymphatics. Respiration. Part 2. Voice and Speech, Nutrition, Digestion, Heat Production, General Metabolism, Internal Secretions, etc. Part 3. Excretion, Kidneys, Skin, Senses. Part 4. Nervous System, Reproduction. Livingstone. 1s.9d. each.
Flack, M., and Hill, L. A Textbook of Physiology. Med. 8vo. Pp.800. 1919. Arnold. 25s.

Foster, Sir M. A Text-book of Physiology. 8vo. Part 1. Book 1. Blood : the Tissues of Movement, the Vascular Mechanism. 6th edn. Po. 408. 1893. 12s. 6d. Part 2. Book 2. The Tissues of Chemical Action, with their respective Mechanisms: Nutrition. 6th edn. Pp. 560. 1899. 12s.6d. Part 4. Book 3. The Senses. 6th edn. Pp. 342. 1900. 12s.6d. Part 5. Appendix by A. S. Lea. Py. 298. 1892 . 8s. 6d. Macmillan.

Lectures on the History of Physiology during the Sixteenth, Seventeenth, and Eighteenth Centuries. Demy 8vo. Pp.310. 1901. Cambridge University Press. 12s. $6 d$. _ and Langley, J. N. A Course of Elementary Practical Physiology and Histology. 7th edn. Cr. 8vo. Pp.414. 1902. Macmillan. 8s.6d. and Shore, L.E. Physiology for Beginners. New imp. G1. 8vo. Pp. 271. 1919. Macmillan. 3s.

Furneaux, W. S. Human Physiology. 21st imp. Cr.8vo. Pp.264. 1920. Longmans. $4 s$.

Haldane, J. S. The New Physiology, and other Addresses. Demy 8vo. Pp. 167. 1919. Griffin. 8s.6d.

Halliburton, W. D. A Primer of Physiology. Brd edn. Fcap. 8vo. Pp. 176. 1920. Dent. 2s.

Handbook of Physiology. 15th edn. Being the 2eth of Kirkes'. Square Demy 8vo. Pp. 036. 1920. Murray. 25s.

- - (edited by). Physiology and the National Needs. By Various Writers. Demy 8vo. Pp. 169 . 1919. Constable. 8s. $6 d$.

Harris, D.F. The Functional Inertia of Living Matter : a Contribution to the Physiological Theory of I ife. 8vo. P1. 148. 1908. Churchill. $5 s$. 
Hertwig, $O$. The Cell: Outlines of General Anatomy and Physiology. Translated by $M$. and $H$. J. Campbell. 2nd edn. Demy 8vo. Pp. 368. 1909. Allen \& Unwin. Ss.6d.

Hill, A. The Pody at Work. Demy 8vo. Pp. 460. 1903. Arnold. $16 s$.

Hill, L. A Manual of Human Physiology. 3rd edn. Cr. 8vo. Pp. 496. 1919. Arnold. $7 s .6 d$.

- Moore, B., Flack, M., and others. Further Advances in Phy siology. Demy 8vo. Pp. 448 . 1909. Arnold. 16s.

Hutchison, R. Applied Physiology . Cr. 8vo. Pp. 310. 19!8. Arnold. $7 s .6 d$.

Huxley, T. H. Lessons in Elementary Physiology. New edn Revised by $J$. Barcroft. Feap. 8vo. Pp.628. 1917. Macmillan.6s.

Keith, Sir A. The Engines of the Human Body. Demv 8vo. Pp. 284. 1919. Williams \& Norgate. $12 s .6 d$.

- The Human Body. Fcap. 8vo. Pp. 256. 1912. Williams \& Norgate. 2s. $6 d$.

Lack, L. A. H. An Introduction to Physiology. 8vo. Pp. 226. 1905. W. Green. Ss.

Landois, L. A Text-book of Human Physiology. Including Histology and Microscopical Anatomy, with $S_{p}$ pecial Reference to the Requirements of Practical Medicine. Translated and Edited by A.P. Brulıaker and A. A. Eshner. 5th edn. Large 8vo. Pp. 1,02\%. 1904. Griffin. $36 s$.

Luciani, L. Human Physiology. Translated by F. A. Welby, with a Preface ky J. N. Langley. In 5 Vols. 8vo. Vol. 1. Circulation and Respiration. Pp. 606. 1911. 21s. Vol. 2. Internal SecretionDigestion-Excretion-The Skin. Pp. 566. 1913. 21s. Vol. 3. Muscular and Nervous Systems. Pp. 678. 1915. 21s. Vol. 4. The Sense Organs. Pp.530. 1917. 21 s. Vol. 5. Metabolism-Temperature-Reproduction etc. Pp. 430 . 1921. 30s. Maemillan.
Lyle. H. W. Manual of Physiology. 2nd edn. in preparation. Frowde and Hodder.

McKendrick, J. G. Principles of Physiology. Feap. 8vo. Pp. 255. 1912. Williams \& Norgate. 2s.6d.

MacLeod, J. J. R. Physiology and Biochemistry in Modern Medicine. 2nd edn. Roy. 8vo. Pp. 935. 1919. Kimpton. 42s.

Paton, D. N. Essentials of Human Physio!ogy. 5th edn. Demy 8vo. Pp. 700. 1920. W. Green. 25s.

Pembrey, M. S.. Beddard, A. P., and others. Practical Physiology. ird edn. Demy 8vo. Pp. 498. 1910. Arnold. 16s.

Roberts, F. Synopsis of Physiology. Cr. 8vo. Pp.389. 1920. Churehill. 15s.

Roget, F. F. Altitude and Health. Three Lectures delivered in London for the Chadwick Trust. Demy 8vo. Pp. 198. 1919. Constable. 12s.6d.

Rutherford; A. H. The Ileo-Caecal Valve. Demy 8vo. Pp.69. 1914. Lewis. $6 s$.

Schäfer, Sir E. A. S. (edited by). A Text-Book of Physiology. By British Physiologists. 2 vols. Roy. 8vo. Vol. 1. Pp. 1056. 1898. 31s. 6d. Vol. 2. Pp. 1389. 1300. 42s. Frowde \& Hodder. Experimental Physiology. New edn. Svo. Pp. 136. 1918. Longmans. 6s.

Sherrington, C. S. Mammalian Physiology. A Course of Practical Exercises. Med. 4to. Py. 168. 1919. Oxford: Clarendon Press. 12s. Gid.

Short, A. R. The New Physiology in Surgical and General Practice. 4th edn. Cr. 8vo. Pp. 302. 1920. John Wright. 9s. 6d.

Starlinı, E.H. Principles of Human Physiology. The Chapter on the Sense Organs Revised and Largely Rewritten by $\mathrm{H}$. Hartridge. 3rd eln. Roy. 8vo. Pp. 1329. 1920. Churchill. 25s.

- Primer of Physiology. Feap. 8vo. Pp. 128, 1904. Murray. 1s. 6d. 


\section{Physiology.}

Stewart, G. N. A Manual of Physiology, with Practical Exercises. 8th edn. Demy 8vo. Pp. 12\%0. 1918. Baillière. $21 s$.

Tait, J., and Krause, R. A. Aids to Physiology. Feap. Svo. Pp. 250. 1919. Baillière. 4s.

Thornton, J. Human Physiology. Cr. 8vo. Pp. 472. 1920. Longmans. $10 s, 6 d$.

-Elementary Practical Physiology. Cr. 8vo. Pp. 332. 1919. Longmans. $6 s$.

Waller, A. D. Physiology: the Servant of Medicine. Chloroform in the Laboratory and in the Hospital. Cr. Svo. Pp. 150. 1910. University of London Press. $5 s$.

\section{i1. CHEMICAL PHYSIOLOGY,}

Bayliss, W. M. The Physiology of Food and Economy in Diet. $\mathrm{Cr}$. 8vo. Pp. 116. 1917. Iongmans. 2s. id.

- The Nature of Enzyme Action. 4th edn. Roy. 8vo. Pp. 198. 1919. Longmans. $8 s$.

Beatty; J. The Method of Enzyme Action. 8vo. Pp. 152. 1917. Churchill. 5s.

Halliburton, W. D. The Essentials of Chemical Physiology for the Use of Students. 10th edn. 8vo. Pp. 335. 1919. Longmans. $8 s$.

- Chemical Side of Nervous Activity. Demy 8vo. Pp. 100. 1901. Bale \& Danielsson. $5 s$.

Mann, G. Chemistry of the Proteids. 8vo. Pp.624. 1906. Macmillan. $18 s$.

Starling, E. H. The Feeding of Nations. A Study in Applied Physiology. Cr. Svo. Pp. 156 . 1919. Longmans. 5s.

iii. NERVES, BRAIN, SPEGIAL SENSES.

Gaskell. W. H. The Involuntary Nervous System. New edn. 8vo. Pp. 188. 1920. Longmans. $12 s$.

Greenwood, M. Physiology of the Special Senses. A Manuad for Students. Demy 8vo. Pp. 218. 1910. Arnold. 10s. 6d.
Leduc, S. The Mechanism of Life. Translated by W. D. Butcher. Demy 8vo. Pp. 172. 1911. Heinemann. 6s.

Lucas, $\mathbf{K}$. The Conduction of the Nervous Impulse. \$vo. Pp. 114. 1917. Longmans. 6s.

Luys, J. The Brain and Its Functions. 5th edn. Cr. Svo. Pp. 345. 1907, Kegan Paul. 7s. 6d.

Whitaker. C. R. Nerves of the Human Rorly. Demy 8vo. Pp. 76. 1918. I.ivingstone. 4s.6d.

iv. SECRETIONS, MUSCLES, ELECTRO -PHYSIOIOGY .

Bainbridge, F. A. The Physiology of Muscular Exercise. Svo. Pp. 226. 1919. Longmans. 10s. 6d.

Baines, A. E. Studies in ElectroPhysiology (Animal and Vegetable). 8vo. Pp. 320. 1918. Routledge. $12 s .6 d$.

Biedermann, W. Electro Physiology. Translated by F. A. Welty. 8vo. Vol.1. Pp.534. 1896. Vol. 2. Pp. 508. 1899. Macmillan. 17s. each.

Bose, Sir J . C. Comparative ElertroPhysiology: a Physico-Physiological Study. 8vo. Pp.804. 1907. Longmans, 1 fis.

Cushny, A.R. The Secretion of the Urine. 8vo. Pp. 254. 1917. L.ongmans. $10 s$.

Krogh, A. The Respiratory Exchange of Animals and Man. Roy. 8vo. Pp. 1s2. 1916. Longmans, $9 s$.

Mackenzie, W. c.. The Action of Muscles: Including Muscle Rest and Muscle Re-Education. Edited by C. Mackay. Demy 8vo. Pp. 283. 1919. Lewis. 12s. $6 d$.

Starling, E. H. Fluids of the Body . Demy svo. Pp. 194. 1909. Constable. $6 s$.

Vincent, S. Internal Secretion and the Ductless Glands. 2nd edn. in preparation. Arnold. 


\section{Physiology.}

v. SEXUAL PHYSIOLOGY ETG.

Bell, W. B. The Sex Complex. A Study of the Relationships of the Internal Secretions to the Female Characteristics and Functions in Health and Disease. 2nd edn. Roy. 8vo. Pp. 268. 1920. Baillière. $21 s$.

Bjoch, I. The Sexual Life of our Time in its Relations to Modern Civilisation. Translated from the German by M. E. Paul. Med. 8vo. Pp. 800. Heinemann. 21s. (Sale limited to Members of the Medical, Legal and Scholastic Professions).

Bower, F. O., Kerr, J. G., and Agar, W, E. Lectures on Sex and Heredity. Cr.8vo. Pp.126.1919. Macmillan. $5 s$.

Dawson; E. R. The Causation of Sex in Man. A New Theory of Sex based on Clinical Materials, together with Chapters on Forecasting or Predicting the Sex of the Unborn Child, and on the Determination or Production of either Sex at Will. 2nd edn. Demy 8vo. Pp. 240. 1917. Lewis. 9s.

The Declining Birth-Rate: Its Causes and F.ffects. Prepared by the Council of Public Morals. 2nd edn. Demy svo. Pp. 464. 1917. Chapman \& Hall. 10s. 6d.

Ellis, H. Man and Woman : A Study of Human Secondary Sexual Characters. 4th edn. Cr. 8vo. Scott Pub. Co. 7s, Gd.
Heape, W. Sex Antagonism. Demy 8vo. Pp. 225. 1913. Constable. 7s. $6 d$.

Herbert, S. An Introduction to the Physiology and Psychology of Sex. 2nd edn. Cr. 8vo. Pp.136. 1919. Black. $7 s, 6 d$.

Sex Lore. A Primer on Courtship, Marriage and Parenthood. Cr. 8vo, Pp. 148. 1918. Black. 7s. $6 d$.

Loewenfeld, L. On Conjugal Happiness. Experiences, Reflections and Advice of a Medical Man. Translated by R. F.. S. Krohn. Demy 8vo. Pp. 303. 1913. Bale \& Danielsson. 7s. 6d.

March, N. H. Towards Racial Health. 4th edn. Cr.8vo. Pp. 338. 1920. Houtledge. $5 s$.

Marshall, F.H.A. The Physiolngy of Reproduction. With Contributions by W. Cramer and J. Lochhead. New edn. in preparation. Longmans .

Menzies, K. Autoerotic Phenomena in Adolescence. An Analytical Study of the Psychology and Psychopathology of Onanism. Cr.8vo. Pp. 96. 1919. Lewis. 5s.

Problems of Population and Parenthood. Being the Second Report of and the Chief Evidence taken by the National Birth-rate Commission, 1918-1920. Demy 8vo. Pp. 590. 1920. Chapman \& Hall. $25 s$.

Young, J. Reproduction in the Human Female. Roy. 8vo. Pp. 234. 1911. W. Green. 218. 


\section{BACTERIOLOGY.}

Abderhalden, E. Defensive Ferments of the Animal Organism against Substances Out of Harmony with the Body, the Blood-plasma and the Cells : their Demonstration, and their Diagnostic Significance for Testing the Functions of Different Organs. Translated by J. $\mathrm{O}$. Gavronsky and W. F. Lanchester. 3rd edn. Cr. 8vo. Pp. 262. 1914. Bale \& Danielsson. $\tau s .6 d$.

Abel, R. Laboratory Hand-book of Bacteriology. Translated by M. H. Gordon. 2nd edn. Fcap. 8vo. Pp. 261. 1913. Frowde \& Hodder. $6 s$.

Andrewes, Sir F. W . Lessons in Dis. infection and Sterilization: an Elementary Course of Bacteriology. 2nd edn. Cr.8vo. Pp. 222. 1907. Churchill. 3s. 6d.

Browning, C. H. (edited by). Applied Bacteriology. Studies and Reviews of some Present-day Problems, for the Laboratory Worker, the Clinician, and the Administrator. Cr. 8vo. Pp. 308. 1918. Frowde \& Hodder. $7 s, 6 d$.

Burnet, E. The Campaign Against Microbes. Translated from the French by E. F. Austen. Demy 8vo. Pp. 260. 1909. Bale \& Danielsson. is .

Gatechism Series. Bacteriology. Revised by .T. T. Grant. 2nd edn. 2 Parts. Livingstone. 1s. 9d. each.

Clemsha, W. W. Bacteriology of Surface Water in the Tropics. Roy. 8vo. Pp. 169. 1912. Thacker. $10 s, \mathrm{Gd}$.

Coles, A. C. Clinical Diagnostic Bacteriology, including Serum Diag nosis and Cytodiagnosis. 8vo. $\mathrm{Pp}$. 245. 1904. Churchill. 8s.

Dudgeon, L. S. The Bacteriology of Peritonitis. Demy 8vo. Pp. 256. 1905. Constable. $7 s .6 d$.
Ellis, D. Iron Bacteria. Demy 8vo. Pp. 200. 1919. Metliuen, 10s.6d.

Emery, W. D:E. Clinical Bacteriology and Hæmatology for Practitioners. 6th edn. Demy 8vo. Pp. 324. 1921. Lewis. 15s.

Fowler, G. J. An Introduction to Bacteriological and Enzyme Chemistry. Cr. 8vo. Pp. 336. Arnold. $8 s .6 d$.

Gurney -Dixon, S. The Transmutation of Bacteria. Demy 8vo. Pp. 198. 1919. Cambridge Liniversity Press. 10s. $6 d$.

Hewlett, R. T. A Manual of Bacteriology. Clinical and Applied. 7th edn. Post 8vo. Pp. 789. 1921. Churchill. 21s.

Minett, E. P. Diagnosis of Bacteria and Blood Parasites. 3rd edn. Cr.8vo. Pp.102. 1920. Baillière. 4s. $6 d$.

Moor, C. G., and Hewlett, R. T. Applied Bacteriology: an Elementary Handbook for the use of Students of Hygiene, Medical Officers of Health, and Analysts. 3rd edn. 8vo. Pp. 502. 1906. Baillière. 1 is.

-- and Partridge W. Aids to Bacteriology. srd edn. Feap. 8vo. Pp. 286. 1919. Baillière. 4s.

Muir, R., and Ritchie, J. A Manual of Bacteriology. 7th edn. Cr. 8vo. Pp. 688. 1919. Frowde \& Hodder. 1is .

Nuttall, G. H. F. Blood Immunity and Blood Relationship. A Demonstration of certain Blood-Relationships amongst animals by means of the Precipitin Test for Blood. Including Original Researches by G. S. Graham-Smith and T. S. P. Strangeways. Med. 8vo. Pp. 456. 1904. Cambridge University Press. $20 s$. 


\section{Bacteriology .}

Pallin, W. A. A Treatise on Epizootic Lymphangitis. 2nd edn. Demy 8vo. Pp. 96. 1904. Constable. 3s. $6 d$.

Pitfield, R. L. A Compend of Bacteriology. 2nd edn. Cr. 8vo. Pp. 280. 1013. Frowde \& Hodder. $6 s$.

Schottelius, M. Bacteria. Translated by H. Geoghegan. Cr.8vo. Pp. 345. 1912. Frowde \& Hodder. 8s. $6 d$.

Thoinot, L. H ., and Masselin, E.J. Outlines of Bacteriology: A Practical Handbook for Students. Translated from the French by W. St . C. Symmers. Pocket Size. Pp. 330. 1899. Griffn. 10s.6d.
Trouessart, E. L. Microbes, Ferments and Moulds. Cr. 8vo. Pp. 328. 1894. Kegan Paul. 78.6d.

Woodhead, Sir G. S. Bacteria and their Products. Cr. 8vo. Scott Pub. Co. 5s.

Wright, Sir A. E. Handbook of the Technique of the Teat and Capillary Glass Tube and its Application to Medicine and Bacteriology. Demy 8vo. Pp. 224. 1912. Constable. $10 s .6 d$.

Studies on Immunisation and their Application to the Diagnosis and Treatment of Bacterial Infections. Demy 8vo. Pp. 506. 1909. Constable. 16s. 


\section{MEDICINE.}

\section{A. HISTORICAL; BIOGRAPHICAL, Etc.}

Allbutt, Sir T. C. The Historical Relations of Medicine and Surgery to the end of the 16th Century. $\mathrm{Cr}$. 8vo. Pp. 142. 1905. Macmillan. $3 \boldsymbol{s}$.

Barrett, Sir J. W. The War Work of the Y.M.C.A. in Egvpt. Demy 8vo. Pp. 232. 1919. Lewis. $10 s, 6 d$.

A Vision of the Possible: What the R.A.M.C. might become. An Account of some of the Medical Work in Egypt; together with a Constructive Criticism of the R.A.M.C. Demy 8vo. Pp. 195. 1919. Lewis. $9 s$.

and Deane, P.E. The Australian Army Medical Corps in Egypt. An Illustrated and detailed account of the early organisation and work of the Australian Medical Units in Egypt, 1914-15. Demy 8vo. Pp. 271. 1918. Lewis. 12s. $6 d$.

Bennett, A. H. Finglish Medical Women. Glimpses of their Work in Peace and War. Cr. Svo. Pp. 159. Pitman. 3s. 6d.

Broadbent, W. (edited by). The Writings of the late Sir William Broadbent. Demy 8vo. Pp. 439. 1908. Frowde \& Hodder. 15s.

Budge, Sir E. A. Wallis. Syrian Anatomy, Pathology and Therapenties, or the Book of Medicines. The Syriac Text, edited with Translation, etc. 2 vols. 8vo. Pp. 882., 830. 1913. Oxford University Press. 42s.

Cholmeley, H.P. John of Gaddesden and the Rosa Medicinæ. 8vo. Pp. 184. 1912. Oxford: Clarendon Press, 8s.6d.
Crawfurd, R. The King's Evil, with an Appendix of Proclamations and Bibliography. Med. 8vo. Pp. 188. 1911. Oxford: Clarendon Press. 8s. 6d.

_- Plague and Pestilence in Literature and Art. Med. 8vo. Pp. 230. 1914. Oxford: Clarendon Press. 14s.

Douglas, C. C. The Laws of Health. Cr.8vo. Pp.272. 1915. Blackie. 5s.

Edwardes, E. J. A Concise History of Small-Pox and Vaccination in Europe. Cr. 8vo. Pp.150. 1902. Lewis. $2 s, 6 d$.

Elliott, J. S. Outlines of Greek and Roman Medicine. Demy 8vo. Pp. 177. 1914. Bale \& Danielsson. $7 s .6 d$.

Forster, E. L. B. How to Become A Woman Doctor. Pocket size. Pp. 146. 1918. Griffin. 3s .

Lister, Lord. Six Papers. (Early Stages of Inflammation; Anæsthetics; a New Method of Treating Compound Fractures; Antiseptic Surgery; Nature of Fermentation; Present Position of Antiseptic Surgery.) With a Short Biography and Explanatory Notes by Sir R.J. Godlee. Cr. Svo. Pp. 202. 1921. Bale \& Danielsson. 10s.

Maccabe, F. F. War with Disease. 5th edn. Cr. 8vo. Pp. 145. 1909. Baillière. 2s, 6d.

McKay, W. J. S, The History of Ancient Gynæcology. 8vo. Pp. 322. 1901. Baillière. 7s.6d.

Mackenzie, Sir J. The Future of Medicine. Demy 8vo. Pp. 238. 1919. Frowde \& Hodder. 8s. 6d. 


\section{Medicine.}

Mackenzie, W. L. Health and Disease. Fcap. 8vo. Pp. 254. 1919. Williams \& Norgate. 2s. $6 d$.

Medical Directory, The. 1921. Roy. 8vo. Pp. 2,036. Dec. 1920. Churchill. 36s.

Medical Register, The. 1921 . Roy 8vo. Pp. 1336. Apl. 1921. Constable. $21 s$.

Miles, A. The Edinburgh School of Surgery before Lister. Cr. 8vo. Pp. 220. 1918. Black. 6s.

Milne, J . S . Surgical Instruments in Greek and Roman Times. 8vo. Pp. 200. 1907. Oxford: Clarendon Press. 14s.

Mitchell, P. (edited by). Memoranda on Army General Hospital Administration. By Various Authors. Demy 8vo. Pp. 115. 1917. Bailiière. $5 s$.

Moore, N. The Study of Medicine in the British Isles. A History. 8vo. Pp. 210. 1908. Oxford: Clarendon Press. 15s.

Neuburger, M. The History of Medicine. Translated by E. Playfair. Vol. 1. Medicine from Remote Antiquity to the Middle Ages. $\mathrm{Cr}$. 4to. Pp. 404. 1910. Frowde \& Hodder. 25s.
Paget, S. Pasteur and after Pasteur. Cr. 8vo. Pp. 152. 1914. Black. $6 s$.

Parker, G. The Early History of Surgery in Great Britain : its Organ. isation and Development. Cr. 8vo. Pp. 214. 1920. Black. 7s.6d.

Payne, J. F. English Medicine in Anglo-Saxon Times. 8vo. Pp. 170. 1904. Oxford: Clarendon Press. 8s, 6d.

Poland, J. A Retrospect of Surgery during the Past Century. 8vo. Pp. 9?. 1901. Murray. 6s.

Sprigge, S. S. Some Considerations of Medical Education. Cr. 8vo. Pp. 112. 1910. Baillière. 2s.6d.

Sutton, J. B. Evolution and Disease. Cr. 8vo. Scott Pub. Co. 5s.

Tibbetts, T. M. The Panel Doctor: His Duties and Perplexities. 2nd edn. Cr.8vo. Pp.68. 1916. Bale \& Danielsson. 2s. 6d.

Walsh, J. J. Medieval Medicine. Cr. 8vo. Pp. 221. 1920. Black. $7 s, 6 d$.

Warden, A. A. An English Handbook to the Paris Medical School. 2nd edn. 16mo. Pp. 56. 1910. Churchill. 2s.

\section{B. HYGIENE, PUBLIC HEALTH, MEDICAL JURISPRUDENCE, AND TOXICOLOGY.}

\section{i. HYGIENE.}

Allan, F. J. Aids to Sanitary Science. 2nd edn. Revised by R. A. Farrar. 18mo. Pp. 280. 1920. Baillière. 4s. 6d.

Avery, M. A Text-book of Hygiene for Training Colleges. Cr. Svo. Pp. 340. 1919. Methuen. 7s. Bd.

Beveridge, W. W. O., and Wanhill, C. F. The Sanitary Officers' Handbook of Practical Hygiene. 2nd edn. Cr. Svo. Pp. 244. 1912. E. Arnold. fs.
Brooke, G. E, Marine Hygiene and Sanitation: a Manual for Ships' Surgeons and Port Health Officers. Demy 8vo. Pp. 418. 1920. Baillière. 15s.

Gavanagh, F. The Care of the Body. 2nd edn. Demy 8vo. Pp. 308. 1908. Methuen. 10s. 6d.

Clouston, Sir T. S. The Hygiene of Mind. A Treatise on Mental Health. 7th edn. Demv 8vo. Pp. 308. 1918. Methuen. 10s. Bd. 
Gurwen, K. M. Simple Experimenta) Hygiene, Physiology and Infant Management, for the Use of School Teachers. Cr.8vo. Py.359. 1918. Gritfin. 6s.

Darling, H. G. R. Flementary Hygiene for Nurses, and others. Svo. Pp. 160. 1917. Churchill. 3 .

Davies, A. M., and Melville, C. H. A IIandbook of Hygiene, 4th edn. Pocket size. Pp. 731. 1913. Griffin. 12s. 6d.

Drummond, W. B. An Introduction to School Hygiene. Cr. Svo. Pp. 217. 1915. Arnold. 3s.6d.

El!is, H. The Task of Social Hygiene. 3rd edn. Demy 8vo. Pp. 431 . 1920. Constable. 8s.6d.

Ferguson, R. B. Aids to Mathematics of Hygiene. 5th edn. Fcap. 8vo. Pp. 198. 1919. Baillière. 3s. $6 d$.

Firth, R. H. The 'Theory and Practice of Hvgiene. 3rd edn. PP. 1010. 19.8. Churchill. 24s.

Glaister, J. Manual of Iygiene. For Students and Nurses. Brd edn. Cr. 8vo. Pp. 435. 1921. Livingstone. $7 s, 6 d$.

Hale, C. W. Domestic Science. Cr. 8vo. Part 1. Pp. 340. 1915. 4s. Part 2. Pp. 310. 1916. 5s. 6d. Cambridge University Press.

Hamer, W. H. Manual of Hygiene. 8vo. Pp. 634. 191)2. Churchill. 12s. $6 d$.

Hope, E. W., Browne, F. A., and Sherrington, C. S. A Manual of School Hygiene. New edn. With six additional chapters on Physiology. Cr. 8vo. Pp. 323. 1913. Cambridge University Press. $6 s$.

Hutt, C. W. Crowley's Iygiene of School Life. 2nd edn. Cr. 8vo. Pp. 444. 1916. Methuen. 6s.

Jameson, W. W., and Marchant, F. T. Synopsis of Hygiene. Cr. 8vo. Pp. 40. 1920. Churchill. $18 s$.
Kerr, J. Newsholme's 'School Hygiene' : The Laws of Health in Relation to School Life. 15th edn. Large Cr. 8vo. Pp. 352. 1918. Allen \& Unwin. $4 s, 6 d$.

Knox, E. B . Military Sanitation and Hrgiene. Fcap. 8vo. Pp. 358. 1911. Baillière. $5 s$.

Lelean, P. S. Sanitation in War. 3rd edn. Fcap. 8vo. Pp. 376. 1919. Churchill. $7 s, 6 d$.

Lyster, R. A. School Hygiene. 2nd edn. 8th imp. Cr. 8vo. Pp. 396. 1920. University Tutorial Press. 5s.

- Text-book of Hygiene for Teachers. 5th imp. Cr.8vo. Pp. 504. 1919. University Tutorial Press. 6s. $6 d$.

Macdonald, R. St. J. Field Sanitation. Cr. 8vo. Pp. 202. 1918. Frowde \& Hodder. $6 s$.

Macleod, H. W. G. Methods and Calculations in Hygiene and Vital Statistics. Cr. 8vo. Pp. 158. 1904. Griffin. 6s.

Melville, G. H. Military Hygiene and Sanitation. Demy 8vo. Pp. 423. 1912. E. Arnold. i6s.

Melville-Davison, W. Some New and Interesting points in Ships' Hygiene. Demy 8vo. Pp. 87. 1911. John Wright. 4s.

Moor, G. G., and Cooper, E. A. Field Sanitation. Demy 8vo. Pp. 228. 1918. Baillière. 2s.6d

Notter, J. L., and Firth, R. H. Hvgiene. 9th edn. Cr. 8vo. Pp. 552. 1921. Longmans. 10s.6d.

Practicaly Domestic Hygiene. 6th edn. Cr.8vo. Pp. 328. 1910. Longmans. $5 s$.

Pakes, W. C. C., and Nankivell, A. T. The Science of Hygiene: A Text-book of Laboratory Practice for Public Health Students. 2nd edn. Cr. 8vo. Pp. 176. 1912. Methuen. $6 s$.

Parkes, L.C., and Kenwood, H. R. Hygiene and Public Health. 6th edn. Demy 8vo. Pp. 797. (1917) 1920. Lewis. 22s. $6 d$. 
Porter, C. School Hygiene and the Laws of Health: A Text-book for Teachers and Students. sth edn. Cr. 8vo. Py. 382. 1920. Longmans. $6 s$.

- Elements of Hygiene and Public Health. Cr. 8vo. Py. 426. 191\%. Frowde \& Hodder. 1917. 12s.6d.

Ravenhill, A. Practical Hygiene. 2nd edn. Cr. 8vo. Pp. 744. i 908. E.J.Arnold. $\check{s}$.

Reynolds, E. S. Hygiene for Beginners. New imp. Gl. 8vo. Py. 249. 1919. Macmillan. 3s.

Smith, F. J. Domestic Hygiene for Nurses, with some Physies and Chemistry. and edn. Cr. svo. Pf. 180. 1915. Churchill. 2s.6d.

Stevenson, Sir T., and Murphy, Sir S. F. A Treatise on Hygiene and Public Health. 3 Vols. Rov. 8ro. Vol. 1. 2nd ein. Pp. 1013. 1896. 28s. Vol.2. Pp.847. 1893. 32s. Vol.3. Pp. 460. 1894. 20 s. Churchill.

Sturrock, W. D. First Principles of Hygiene. Cr. Svo. Pi, 25?. 1913. Oxford: Clarendon Press. $3 s$.

Whitelegge, Sir A., and Newman, Sir G. Hygiene and Put:lic Health. 13th edn. Frap. 8vo. Pp. 796. 1917. Cassell. 10s. Gd.

Willoughby : E. F. Hygiene for Students. Gl. Svo. Pp.584. 1909. Macmillan. 5s.

\section{ii. PUBLIC HEALTH.}

Ayling, R. S. Publi: Abattoirs, their Planning, Design, and Ecpuipment. 4to. $\hat{\mathrm{P}}_{\mathrm{Y}} .100$ and 33 Plites. 1709. Spon. 12s. 6d.

Catechism Series. Public Health. 2nd edn. Revised by W. Robertson. ; Parts. Part 1. Water. Part 2. Air and Ventilation, Warming, Lighting, Climate. Part 3. Sewage and its Treatment. Part 4. Vital Statistics, Dwellings, Meteorology Part 5. Eipidemiology, Food. Disinfectants. Hospitals. Is. 9d. each. Also in one Volume, cloth. 9s. Livingstone.
Frederich, R. C., and Forster, A. Public Health Chemical Analysis. Demy 8vo. Pp. 313. 1920. Constable. $21 s$.

Glaister. J. A Text-Book of Pullic Healtl: . 2nd edn. Demy 8vo. Py. 642. 1910. Livingstone, $15 s$.

Hope, E. W. A Text-Book of Public Health. 8th edn. Demy 8vo. Pr. 267. (1915). 1920. Livingstone. 8s. $6 d$.

Kenwood, H. R. Public Health Lahoratory Work. (Chemistry). 7th edn. Demy 8vo. Pp. 1.20. 1920. Lewis. $15 s$.

McKail, D. Public Health Chemistry and Pacteriology. A Practical Manual. Cr. 8vo. Pu. 409. 1912. John Wright. 6s. 6d.

Parsons, H. F. Isolation Hospitals. Demy 8vo. Pp. 289. 1914. Cumbridge University Press. 15s.

Robertson, W. G. A. Manual of Public Health. 4th edn. Cr. 8vo. Pp. 272. 1921. Black. Ss.6d.

Sommerville, D. Practical Sanitary Science. A Handbook for the Public Health Laboratory and edn. Demy svo. Pp. 324. 1914. Baillière. $12 s .6 d$.

_ Aids to Public Health. Fiap. 8vo. Pp. 152. 1913. Baillière. $3 s$.

Stewart, A. W . A Manual of Practical Chemistry for Publie Health Students. Cr.8vo. Pp.8s. 1913. Bale \& Danielsson. $3 s .6 d$.

Taylor, A. The Sanitary Inspector's Handbook. 5th edn. Cr.8vo. P?. 624. 1914. Lewis. 7s. 6d.

\section{iii. WATER ANALYSIS.}

Purvis, J. E., and Hodg̨son, T. R. The Chemical Examination of Water, Sewage, Foods, and other Sulistances. Demy 8vo. Pp. 236. 1914. Cambridge University Press. 10 s. $6 d$.

Stocks, H. B. Water Analysis, for Sanitary and Technical Purposes. $\downarrow$ 5s.
Cr. 8vo. Pp. 144. 1912. Griflin. 
Thresh, J. C. The Examination of Waters and Water Supplies. 2nd edn. Roy. 8vo. 1913. Churchill. $21 s$.

_- A Simple Method of Water Analy sis : for the use of Medical Otficers of Health. 9th edn. Feap svo. Pp. 72. 1919. Churehill. 3s.

\section{iv. FOOD ANALYSIS AND INSPECTION.}

Blyth, A. W. and M. W. Foods: their Composition and Analysis. 6th edn. Large svo. $\mathrm{Pp}$. 644. 1909. Griffin. 21s.

Burrell, B. A. An Elementary Course on Food-Testing. Cr. Svo. Pp. 100. 1910. Baillière. 2s.6d.

Glayton, E. G. A Compendium of Food Microscopy: with Sections on Drugs, Water, and Tobacco. Demy 8vo. $\mathrm{Pp}$. 472. 1909. Baillière. $12 s$.

Greenish. H. G. The Microscopical Examination of Foods and Drugs. In the Entire, Crushed, and Powdered States. 2nd edn. Ray. Svo. Pp.406. 1910. Churchill. 12s. fid.

- and Collin, E. An Anatomical Atlas of Vegetable Powders: an Indispensable Aid to the Microscouic Analysis of Powdered Foods and Drugs. 4to. Pp. 28s. 1904. Churchill. 12s, 6d.

Howarth, W. J. Meat Inspection Problems. with special reference to the Developments of Recent years. Demy 8vo. Pp. 152. 1918. Baillière. $7 s, 6 d$.

Lane-Claypon. J. E. Milk and Its Hygienic Relations. 8vo. $P_{\bar{p}}$. 3.56. 1918. Longmans. 9s.

Litteljohn, A. R. Meat and Its Insuection. A Practical Guide for Meat Inspectors. Students, and Medical Officers of Health. Demy 8vo. P९. 412. 1911. Baillière. 12s.

Mitchell. C. A. Flesh Foods: with Methods for their Chemical, Microscopical, and Bacteriological Examination: for Medical Men, Analysts, and Inspertors. Cr. 8vo. Pp. 351. 1900. Griffin. 10s. 6d.
Moor, C. G., and Partridge, W. Aids to the Analysis of Food and Drugs. 4th edn. Feap. 8vo. Pp. 280. 1918. Baillière. 4s. 6d.

Ostertag, R. Handbook of Meat Inspection. Translated hy E. V. Wilcox. 4th edn. Roy. 8vo. Pp. 942. 1913. Baillière. 45s.

Parry, F. J. Food and Drugs. 2 Vols. Roy. 8vo. 1911. Vol. I. The Analysis of Food and Drugs Chemical and Microscopical. Pp. 724. 23s. Vol. 2. The Sale of Food and Drugs Acts, $1875-1907$. Pp. 184. 8s. 6d. Scott, Greenwood.

Pearmain, T. H., and Moor, C. G. The Analysis of Food and Drugs. Feap. 8vo. Part 1. Milk and Milk Products. Pp. 140. 1897. Part 2. The Chemicgl ani Biological Examination of Water. Pp. 178. 1899. Baillière. 6s. each.

Robertson, W Meat and Focd Inspection. A Handhook for Medical Officers of Health and Sanitary Inspectors. 2nd edn. 8vo. Pp. 306. 1920. Baillière. $18 s$.

Savage, W. G. Milk and the Public Health. 8vo. Pp. 4is. 1912. Macmillan. 12s, (6d.

- Food Poisoning and Food Infections. Demy 8vo. Pp. 258. 1919. Cambridge Úniversity Press. 15s. - The Bacteriological Examination of Food and Water. 2nd edn. Demy 8vo. Pp. 200. 1916. Cambridue University Press. $10 s$.

Thresh, J. C., and Porter, A. E. Preservatives in Food, and Food Examination. Roy. 8vo. Pp. 499. 1906, Churchill. 16s.

Wagner, E. Recipes for the Preserv ing of Fruit, Vegetables and Meat. Translated from the German. $\mathrm{Cr}$. 8vo. Pp. 125. 1908. Scott, Greenwood. 6s.

Walker, A. H. The Food Inspector's Encyclopædia. Demy 8vo. Pp. 310. 1912. Baillière. 8s. 6d.

- The Inspection of Fish, Poultry, Game, Fruit, Nuts, and Vegetables. Demy 8vo. Pp. 102. 1911. Baillière. 6s . 


\section{Medicine.}

Walley's Meat Inspection. 5th edn. Revised and enlarged by S. Stockman. Cr. 8vo. Pp. 308. 1909. W. Green. 10s. $6 d$.

\section{v. EPIDEMICS, MEDICAL GEO-} GRAPHY AND CLIMATOLOGY.

Anderson, D. E. The Epidemies of Mauritius. Demy 8vo. Pp. 328 . 1918. Lewis. 16s.

Bahr, P.H. I Report on Researches on Sprue in Ceylon, 1912-1914. Roy. 8vo. P(). 163. 1915. Cam. bridge University Press. $0 s$.

Begg, C. Sorue: its Diagnosis and Treatment. Demy 8vo. Pp. 128. 1912. John Wright. Bs.

Clemow, F. G. The Geography of Disease. Cr. 8vo. Pp. 624. 1903. Cambridge University Press. 15s.

Giles, G. M. The Outlines of Trepical Climatology. Med. 8vo. Pp. 113. 1904. Bale and Danielsson. 5s.

Climate and Fealth in Hot Countries, and the Outlines of Tropical Climatology. Med. 8vo. Pp.130. 1904. Bale \& Danielsson. 7s, 6d.

Gordon, W. The Place of Climatology in Medicine. Demy 8vo. Pp. 67. 1913. Lewis. 3s. $6 d$.

The Influence of Strong Prevalent Rain-bearing Winds on the Prevalence of Phthisis. Med. Svo. Pp. 122. 1910. Lewis. 7s. 6d.

Hutchinson, J. On Leprosy and Fish Eating. Demy 8vo. Pp. 444. 1906. Constable. 12s. 6d.

Jefterys, W. H., and Maxwell, J. L. 'The Diseases of China, including Formosa and Korea. Svo. Pp. 736. 1911. Bale and Danielsson. 25s.

Johnston-Lavis, H. .J. On the Effects of Volcanic Action in the Production of Epidemic Diseases in the Animal and the Vegetable Creation, and in the Production of Hurricanes and $\Lambda$ bnormal Atmospherical Vicissitudes. Cr. 8vo. Pp. 31. 1914. Bale \& Danielsson. 3s.

\section{vi. TROPICAL HYGIENE.}

Blackham, R. J. Aids to Tropica! Hygiene. New edition in preparation. Baillière.

Boyce, Sir R. W. Health Progress and Administration of the West Indies. 2nd edn. Med. 8vo. Plp. 350. 1910. Murray. 10s.6d.

Field, A. "Verb. Sap:" on going to West Africa, Northern and Southern Nigeria and the Coasts. 3rd edn. Cr. 8vo. Pp.251. 1961. Bale and Danielsson. 2s. $6 d$.

Garry, T. G. Some Factors Influencing Health in Tropical and SubTropical Countries. Cr. Kvo. Pp. 96. 1911. Bale \& Danielsson. 2s. $6 d$.

Harston, G. M. The Care and Treatment of European Children in the Tropics. Cr.8ve. Pp. 219. 1912. Baillière. 8s. Bd.

Lukis, Sir P., and Blackham, R. J. Tropical Hygiene for Residents in Tropical and Sub-Tropical Clinates. :3rd edn: Cr. Svo. Pp. 295. 1915. Thacker. 5s.

Moore, Sir W. Manual of Family Medicine and Hygiene for India. 9th edn. Rewritten by C. A. Sprawson. Demy 8vo. Pp. 686. 1921. Churchill. 10s. 6d.

Muirhead, W.A. Practical Tropical Sanitation. Demy 8vo. Pp. 285 . 1914. Murray. I5s.

Neligan, A. R. Hints for Residents and Travellers in Persia. Cr. svo. Pp. 202. 1914. Bale and Danielsson. 5s.

Ryan, J. C. Health Preservation in West Africa. Cr. 8vo. Pp. 108. 1914. Bale and Danielsson. $5 s$.

Simpson, w. J. Tropical and Subtropical Climates, and the Prinriples of Personal Hygiene in them, as applied to Furopeans. Demy 8vo. Py. 400. 1908. Bale and Danielsson. 15s.

Maintenance of Health in the Tropics. and edn. Cr. Svo. Pp. 186. 1916. Bale and Danielsson. 3s. id. 


\section{Medicine.}

Strachan, H. Lessons in Elementary Tropical Hygiene. 2nd edn. Small Cr. 8vo. Pp. 128. 1918. Constable. $2 s, 6 l$.

vii. SANITARY LAW.

Critchley, H. Aids to the Study of Sanitary Law. Fcap. 8vo. Pp. 88. 1904. Baillière. $3 s$.

Ham, B. B. A Handbook of Sanitary Law, for the use of Candidates for Public Health Qualifications. 8th edn. Fcap. 8vo. Pp. 240 1920. Lewis. 5s.

Hime, T. W. Practical Guide to the Public Health Acts: for Officers of Health and Inspectors of Nuisances. 2nd edn. Pp. 1,096. 1901. Baillière. 15s.

Porter, C. Sanitary Law in Question and Answer for the use of Students of Public Health. 2nd edn. Cr. 8vo. Pp. 180. 1920. Longmans. 6s. 6d.

Robertson, W., and McKendrick, A. Public Health Laws. A Synopsis of the Acts of Parliament bearing on Public Health in the United Kingdom. Cr. 8vo. Pp. 397. 1912. Livingstone. 5s .

-and Porter, C. Sanitary Law and Practice. A Handbook for Students of Public Health and Others. 4th edn. 8vo. Pp. 774. 1917. Sanitary Publishing Co. $15 s$.

\section{viii. MEDICAL JURISPRU -} DENGE.

Atkinson, S. B. The Law in General Medical Practice, or Clinical Jurisprudence. Cr. 8vo. Pp. 139. 1908. Frowde and Hodder. 5s.

Barnett, H. N. Legal Responsibility of the Drunkard. Cr. 8vo. Pp. 76. 1908. Baillière. 2s. $6 d$.

Brend, W. A. A Handbook of Medical Jurisprudence and Toxicology, for the Use of Students and Practitioners. 3rd edn. Pocket size. Pp. 324. 1919. Griffin. 10s, 6d.

An Enquiry into the Statisties of Deaths from Violence and Unnatural Causes in the United Kingdom. Demy 8vo. Pp. 84. 1915. Griffin. $4 s$.
Brockbank, E.M. Life Insurance in General Practice. Cr. 8vo. Pp. 302. 1908. Frowde and Hodder. $7 s .6 d$.

Brouardel, P., and Benham, F. L. Death and Sudden Death. 2nd edn. 8vo. Pp. 350. 1902 . Baillière. $10 s$. $6 d$.

Buchanan, R. J. M. Text-Book of Forensic Medicine and Toxicology. 8th edn. 8vo. Pp. 428. 1920. Livingstone. $10 s$.

Bucknill, J. C. The Care of the Insane and their Legal Control. Cr. 8vo. Pp. 144. 1880. Macmillan. $3 s .6 d$.

Catechism Series. Forensic Medicine. 2nd edn. Revised by $\mathbf{A}$. Allison. Livingstone. 1s, 9d.

Collie, Sir J. Malingering. 2nd edn. Demy 8vo. Pp. 680. 1917. Arnold. 18s.

Medico-Legal Examinations and the Workmen's Compensation Act., 1906. Demy 8vo. Pp. 132. 1912 Baillière. 5s.

Glaister, J. A Text-Book of Medical Jurisprudence and Toxicology. 4th edn. Demy 8vo. Pp. 917. 1921. Livingstone. $30 s$.

Hawthorne, C. O. Forensic Medicine. 3rd edn. Cr. 8vo. Pp. 352. 1912. Arnold. 7s, 6d.

Jones, A . B., and Llewellyn, J. L. Malingering, or the Simulation of Disease. With a chapter by W. M. Beaumont on Malingering in $\mathrm{Re}$ lation to the Eye. Roy. 8vo. Pp. 708. 1917. Heinemann. 25s.

Knocker, D. (edited by). Accidents in their Medico-Legal Aspect. A Practical Guide, for the expert witness, solicitor, and barrister, consisting of a series of articles by leading medical and surgical authorities as to the effects of injuries to the various parts of the human body, with special reference to the Workmen's Compensation Act, etc. Roy.8vo. Pp. 1,294. 1910. Also. Thin paper edition. 1912. Baillière. 30s, each. 
McKendrick, A. Malingering and its Detection under the Workmen's Compensation and other Acts. Cr. 8vo. Pp. 96. 1912. Livingstone. $1 s .6 d$.

-Back Injuries and their Significance under the Workmen's Compensation and other Acts. Cr. 8vo. Pp. 182. 1916. Livingstone. $2 s .6 d$.

Mann, J. D. Forensic Medicine and Toxicology. Revised and Edited by W. A. Brend. 5th edn. 8vo. Pp. 750. 1914. Griffin. 21s.

Murrell, W., and Robertson, W. G. A. Aids to Forensic Medicine and Toxicology. 8th edn. Fcap. 8vo. Pp. 164. 1914. Baillière. 3s .

Robertson, W. G. A. Manual of Medical Jurisprudence and Toxicology. 4th edn. Cr. 8vo. Pp. 426. 1921. Black. 12s.6d.

Smith, F. J. Lectures on Medical Jurisprudence and Toxicology. 2nd edn. Cr. 8vo. Pp. 480. 1908. Churchill. 8s. 6d.

Law for Medical Men. A book for Practitioners, containing Abstracts from Acts of Parliament interesting to Medical Men. 8vo. Pp. 414. 1913. Churchill. 10s.6d.

Sutherland, W. D. Blood Stains: their Detection and the Determination of their Source. A Manual for the Medical and Legal Professions. 8vo. Pp. 192. 1907. Baillière. 10s. 6d.

Taylor, A. S. The Principles and Practice of Medical Jurisprudence. Edited by F. J. Smith. With a Section on Indian Medical Jurisprudence by $W$. J. Buchanan. 7th edn. 2 Vols. Roy. 8vo. Pp. 1860. 1920. Churchill. 63s.
Wellington, R. H. The King's Coroner. Vol. 1. A Complete Collection of the Statutes relating to the Office, with a short history of the same. Pp. 300. 1905. 8s. 6d. Vol.2. The Procedure and Practice in his Judicial and Ministerial Capacities. Pp.164. 1906. 7s.6d. Baillière.

\section{ix. TOXICOLOGY.}

Blyth, A. W., and M. W. Poisons : their Effects and Detection. 5th edn. Demy 8vo. Pp. 780. 1920. Griffin. 36s.

Catechism Series. Toxicology . 2nd edn. Revised by A. Allison. Livingstone. $1 s .9 d$.

Gadd, $H$. The Poisons and Pharmacy Act, 1908. With Notes. Cr. 8vo. Pp. 56. 1909. Baillière. $1 s$.

Glaister, J. Poisoning by Arseniuretted Hydrogen or Hydrogen Arsenide. Its Properties, Sources, Relations to Scientific and Industrial Operations, Symptoms, Postmortem Appearances, Treatment, and Prevention. Cr. 8vo. Pp. 290. 1908. Livingstone. 5s .

-And Logan, D. D. Gas Poisoning in Mining and other Industries. Demy 8vo. Pp. 550. 1914. Livingstone. 12s.

Legge, T. M., and Goadby, K. W. Lead Poisoning and Lead Absorption. Demy 8vo. Pp. 308. 1912. E. Arnold. 12s. 6d.

Murrell, W. What to Do In Cases of Poisoning. 11th edn. Roy. 32mo. Pp. 283. 1916. Lewis. 3s. 6d.

Oliver, Sir T. Lead Poisoning, from the Industrial, Medical and Social Points of View. Cr. 8vo. Pp. 304. 1914. Lewis. 3s.

Oppenheimer, C. Toxines and Anti-Toxines. Translated by C.A. Mitchell. Cr. 8vo. Pp. 282. 1906. Griffin. 9s.

Rambousek, J. Industrial Poisoning. Translated by T. M. Legge. Demy 8vo. Pp. 376. 1913. E. Arnold. 14s. 


\section{PATHOLOGY.}

i. PATHOLOGIGAL ANATOMY, HISTOLOGY, LABORATORY METHODS.

Cammidge, P. I. The Fæces of Children and Adults: their Examination and Diagnostic Significance, with Indications for Treatment. Demy 8vo. Pp. 516. 1916. John Wright. 17s. 6d.

Campbell, A. W. Histological Studies on the Localisation of Cerebral Function. Med. 4to. Pp.380. 1905. Cambridge University Press. 22s.

Fletcher, G., and McLean, H. The Link between the Practitioner and the Laboratory. A Guide to the Practitioner in his Relations with the Pathological Laboratory. Cr. 8vo. Pp. 91. 1920. Lewis. $4 s .6 d$.

Hall, J. W., and Herxheimer, G. Methods of Morbid Histology and Clinical Pathology. 8vo. Pp. 306. 1905. W. Green. 9s.

Jaksch, V. Clinical Diagnosis. The Chemical, Microscopical, and Bacteriological Evidence of Disease. Translated by Sir A. E. Garrod. 5th edn. Large 8vo. Pp. 628. 1905. Griffin. 30s.

Lazarus-Barlow, W. S. The Elements of Pathological Anatomy and Histology for Students. Roy. 8vo. Pp. 718. 1903. Churchill. 24s.

Leyton, A. S. F. The Essentials of Morbid Histology. For the use of Students. 8vo. Pp. 236. 1912. Longmans. $9 s$.

\section{ii. EXAMINATION OF THE URINE.}

Bedford, C.H. A Clinical Handbook of Urine Analysis. 2nd edn. Cr. 8vo. Pp. 181. 1904. W. Green. $6 s .6 d$.

Carruthers, T. Urine Examination Made Easy. A Plan of Examination, with Common Tests fully described. 4th edn. Cr. 8vo. Pp. 48. 1921. Churchill. 2s.
Hewat, A. F. The Examination of the Urine and other Clinical Sideroom Methods. 6th edn. 1917. Livingstone. $2 s .6 d$.

Mann, J. D. The Physiology and Pathology of the Urine. 2nd edn. 8vo. Pp. 338. 1913. Griffin. $7 s .6 d$.

iii. POST-MORTEM EXAMINA TION.

Beattie, J. M. Post-Mortem Methods. Demy 8vo. Pp. 242. 1915. Cambridge University Press. $12 s$.

Box, C. R. Post-Mortem Manual. A Handbook of Morbid Anatomy and Post-Mortem Technique. 2nd edn. Cr. 8vo. Pp. 370. 1919. Churchill. 10s.6d.

Gibson, A. G. A Handbook for the Post-Mortem Room. 16mo. Pp. 148. 1911. Frowde and Hodder. $4 s .6 d$.

Kelynack, T. W. The Pathologist's Handbook: A Manual for the PostMortem Room. Fcap. 8vo. Pp. 200. 1899. Churchill. 4s. 6d.

Miller, J. Post-Mortem Technique and Practical Pathology. A Textbook for Students and Practitioners. Cr. 8vo. Pp. 444. 1914. Black. $12 s .6 d$.

Rolleston, Sir H. D., and Kanthack, A. A. Manual of Practical Morbid Anatomy. Cr. 8vo. Pp. 259. 1894. Cambridge University Press. $7 s$.

Shennan, T. Post-Mortems and Morbid Anatomy. Roy. 8vo. Pp. 512. 1912. Constable. $18 s$.

Thursfield, M., and Branson, W. P. S. Medical Morbid Anatomy and Pathology. Cr.8vo. Pp. 270. 1909. Lewis. 6s.

\section{iv. GENERAL PATHOLOGY.}

Adami, J. G., and McCrae, J.A. Text-book of Pathology . 2nd edn. 8vo. Pp. 870. 1914. Macmillan. $31 s .6 d$. 
Beattie J. M., and Dickson, W. E. C. A Text-book of General Pathology for the use of Students and Practitioners. 2nd edn. 8vo. Pp. 541. 1921. Heinemann. $31 s .6 d$.

Burnford, J.M. Applied Pathology . A Guide to the Application of Modern Pathological Methods to Diagnosis and Treatment. Demy 8v. Pp. 396. 1913. University. of London Press. $10 s .6 d$.

Campbell, H. Aids to Pathology. 4th edn. Fcap. 8vo. Pp. 256. 1921. Baillière. 4s. $6 \mathrm{~d}$.

Gatechism Series. Pathology. 2nd edn. 5 Parts. Revised by J. Miller. Part 1. Animal Parasites, Degenerations and Infiltrations, Hyperaemia Oedema, Hæmorrhage, Necrosis, Gangrene, Thrombosis. Part 2. Embolism, Tumours. Part 3. Diseases of Vessels, of Ductless Glands, Heart, Blood. Part 4. Inflammation, Phagocytosis, Infection, Fever, Immunity, Diseases of the Lungs. Part 5. Diseases of Pleura, Abdomen, Brain and Nerves. 1s. $9 d$. each, also in one volume, cloth, 9s. Livingstone.

French, H. Medical Laboratory Methods and Tests. 3rd edn. Fcap. 8vo. Pp. 210. 1913. Baillière. 68 .

Green, T. H. A Manual of Pathology and Morbid Anatomy. 12th edn. Revised by W. C. Bosanquet and W. W. Topley. Demy 8vo. Pp. 613. (1918). 1920. Baillière. $22 s .6 d$.

Herschell, G., and Weiss, R. Elementary Clinical Pathology for Nurses. 2nd edn. 1913. Churchill. $1 s$.

Hewlett, R. T. Pathology : General and Special, for Students of Medicine. 4th edn. Post 8vo. Pp. 640. 1917. Churchill. 12s, 6d.

Horder, Sir T. J. Clinical Pathology, with a Full Account of Vaccine Therapy. Demy 8vo. Pp. 224. 1910. Frowde and Hodder. 8s. $6 d$.
Lazarus-Barlow, W. S. A Manual of General or Experimental Pathology for Students and Practitioners. 2nd edn. Roy. 8vo. Pp. 736 . 1904. Churchill. $21 s$.

Panton, P. N. Clinical Pathology. 8vo. Pp. 456. 1913. Churchill. $14 s$.

Pembrey, M. S., and Ritchie, J. (edited by). A Text-book of General Pathology. Demy 8vo. Pp. 785. 1913. Arnold. 21s.

Woodhead, Sir G. S. Practical Pathology. A Manual for Students and Practitioners. 4th edn. 8vo. Pp. 820. 1910. Frowde and Hodder. 17s.

\section{v. SPECIAL PATHOLOGY.}

Adami, J. G. Inflammation. An Introduction to the Study of Pathology. 4th edn. Ex. Cr. 8vo. Pp. 272. 1909. Macmillan.6s. 6d.

Beattie, J. M., and Dickson, W. E. C. Text-Book of Special Pathology. New edition in preparation. Heinemann.

Garrod, Sir A. E. In-born Errors of Metabolism. Cr. 8vo. Pp. 174. 1909. Frowde and Hodder. 3s, 6d.

Haig, A. Uric Acid as a Factor in the Causation of Disease. 7 th edn. 8vo. Pp. 952. 1908. Churchill. $14 s$.

Uric Acid in the Clinic. 8vo. Pp. 312. 1910. Churchill. 5s.

Uric Acid: an Epitome of the Subject. 2nd edn. 8vo. Pp. 170. 1906. Churchill. 2s.6d.

Macgregor, J. M. A Contribution to the Pathology of the Endometrium. 8vo. Pp. 56. 1905. W. Green. 10s, 6d.

Paton, D. N. The Nervous and Chemical Regulations of Metabolism. 8vo. Pp. 228. 1913. Macmillan. $6 s$.

Robertson, A. W. Studies in Electro-Pathology. 8vo. Pp. 312. 1918. Routledge. 12s, 6d.

-The Treatment of Inflammation and Sepsis by Lipoid-Paraffin Dressings. Cr. 8vo. Pp. 83. 1919. Routledge. 3s. $6 d$. 
Walker, E. W. A. The General Pathology of Inflammation, Infection, and Fever. Cr.8vo. Pp. 271. 1904. Lewis. 4s. 6d.

\section{vi. HAMATOLOGY.}

Barcroft, J. The Respiratory Function of the Blood. Roy. 8vo. Pp. 330. 1914. Cambridge University Press. $21 s$.

Buckmaster, G. A. The Morphology of Normal and Pathological Blood. Demy 8vo. Pp. 244. 1906. Murray. 10s.6d.

Burnham, F. W. E. Hæmocytes and Hæmic Infections. A Handbook for Students and Practitioners . Roy. 8vo. Pp.462. 1913. Lewis. $15 s$.

Gruner, O. C. The Biology of the Blood-Cells : with a Glossary of Hæmatological Terms. For the use of Practitioners of Medicine. Large 8vo. Pp. 392. 1913. John Wright. $21 s$.

\section{PRACTICE}

\section{i. GENERAL TREATISES.}

Aitchison, R. S. A Medical HandBook for the use of Practitioners and Students. 5th edn. Pocket size. Pp. 390. 1920. Griffin. 10s. 6d.

Allbutt, Sir T. C., and Rolleston, Sir H. D. (edited by), A System of Medicine. By Many Writers. 2nd edn. 9 Vols. 8vo. Vol. 1. Prolegomena and Infectious Diseases. Pp. 1,228. 1911. 31s, 6d. Vol. 2. Part 1. Infectious Diseases (contd.), Intoxications. Pp. 1,098. 1912. 31s. 6d. Vol. 2. Part 2. Tropical Diseases and Animal Parasites. Pp. 1,074. 1914. 31s.6d. Vol. 3. Certain General Diseases, Diseases of the Stomach. Pp. 1,054. 1913. 31s. 6d. Vol. 4. Part 1. Diseases of the Liver, Pancreas, and Ductless Glands. Pp. 778. 1914. 31s. 6d. Vol. 4. Part 2. Diseases of the Nose, Pharynx, Larynx, Trachea and Ear. Pp. 584. 1909. 81s. 6d. Vol.5. Diseases of the Respiratory System,
Jones, G. P. Blood Pictures: An Introduction to Clinical Hæmatology. 2nd edn. Demy 8vo. Pp. 91. 1921. John Wright. 6s.6d.

Oliver, G. A Contribution to the Study of the Blood and Blood Pressure. Demy 8vo. Pp. 288. 1901. Lewis. 7s. $6 d$.

Studies in Blood Pressure, Physiological and Clinical. 3rd edn. Edited by W. D. Halliburton. Demy 8vo. Pp. 263. 1916. Lewis. 9s.

Pappenheim, A. Clinical Examination of the Blood and its Technique. A Manual for Students and Practitioners. Translated from the German by $\mathrm{R}$. Donaldson. $\mathrm{Cr}$. 8vo. Pp. 87. 1914. John Wright. 3s. 6d.

\section{OF MEDICINE.}

Disorders of the Blood. Pp. 984. 1912. 31s. 6d. Vol. 6. Diseases of the Heart and Blood Vessels. Pp. 878. 1910. 31s, 6d. Vol. 7. Diseases of the Muscles, the Trophoneuroses, Diseases of the Nerves, Vertebral Column, and Spinal Cord. Pp. 916. 1911. 31s. 6d. Vol. 8. Diseases of the Brain and Mental Diseases. Pp. 1,084. 1911.31s.6d. Vol. 9. Diseases of the Skin. General Index. Pp. 887. 1920. 31s. 6d. Macmillan.

Ballantyne, J. W. (edited by). Encyclopædia Medica. 2nd edn. 15 Vols. Roy. 8vo. Vol. 1. Pp. 759. 1915. Vol. 2. Pp. 685. 1915. Vol. 3. Pp. 680. 1916. Vol. 4. Pp. 693. 1916. Vol.5. Pp. 774. 1917. Vol. 6. Pp.666. 1919. Vol. 7. Pp. 618. 1921. Vols. 8 to 15 in preparation. W. Green. 30s. per Vol.

Bristowe, J. S. A Treatise on the Theory and Practice of Medicine. 7th edn. Demy 8vo. Pp. 1,285 . 1890. Murray. 21s. 
Carter, A.H. Elements of Practical Medicine. 11th edn. Revised by A. G. Gibson. Cr. 8vo. Pp. 713. 1920. Lewis. 16s.

Catechism Series. Medicine. 2nd edn. 5 parts. Revised by W. R. Jack and.$J$. Henderson. Part 1. Infectious Diseases. Part 2. Disorders of Nutrition, Kidneys, Blood, Ductless Glands. etc. Part 3 . Diseases of the Alimentary Tract. Part 4. Diseases of the Respiratory and Circulatory Systems. Part 5. Diseases of the Nervous System. $1 s .9 d$. each, also in one volume, cloth, 9s. Livingstone.

Charteris, M. and F. J. The Practice of Medicine. 9th edn. Cr.8vo. Pp. 700. 1909. Churchill. $9 s, 6 d$.

Comrie, J. D. (editcd by). Black's Medical Dictionary. 6th ern. Demy 8vo. Pp. 8.78. 1916. Black. 15s.

Craig, M. Psychological Medicine. 3rd edn. 8vo. Pp. 496. 1917. Churchill. 15s.

Dieulatoy, G. A Text-Book of Medicine. 2nd English Translation from the 16th French edition by V. E. Collins, and .J. Alexander. 2 Vols. Roy. 8vo. Pp. 2.180. 1912. Baillière. $30 s$

Drummond, W, B. (edited ty). Dent's Medical Dictionary. Med. 8vo. Pp. 696. Dent. IOs. 6d.

Dutton, T. Kimpton's Pocket Medical Dictionary, for Practitioners, Students, and Nurses. 2nd edn. Feap. Svo. Pp. 220. 1915. Kimpton. 3s. 6d.

Fvans, W. Medical Science of To-Day. Ex. Cr. 8vo. Pp. 324. 1912. Seeley. 7s.6d.

Fagge, G. H., and Pye-Smith, P. H. A Text-book of Medicine. 2 Vols. 4th edn. Roy. Svo. Pp. 2,200. 1901-2. Churchill. 42x.
Flemins, R. A. A Short Practice of Medicine. 3rd edn. 8vo. Pp. 694. 1919. Churchill. $21 s$.

Gibson, G. A. (edited hy). A Text Book of Medicine. By British Teachers. 2 Vols. Roy. 8ro. 1901. Vol. 1. Pp. 848. Vol. 2. Pp. 220. Frowde and Hodder. 1 ss. each.

Grimshaw, .J. The People's Medical Guide. 8vo. Pp. 860. 1912 . Churchill. 10s.6d.

Hoblyn, R. D. Dictionary of Terms used in Medicine and the Collateral Sciences. Revised t.y J. A. P. Price. 15th edn. Small Post 8vo. Pp. 878. Bell. 10s. 6d.

Horder, Sir T. J. Medical Notes. Pott 8vo. Pp. 124. 1921. Frowde and Hodder. $6 s$.

Hudson, B. Aids to Medicine. 2nd edn. Fcap. 8vo. Pp. 332. (1916). 1921. Baillière. $4 s$.

Hurct, A. F. Medical Diseases of the War. 2nd edn. Demy svo. Pp. 326. 1918. Arnold. 12s. 6d.

Jack, W. R. (Late Wneeler). Handbook of Medicine. 6tl, edn. $\mathrm{Cr}$. 8vo. Pp. 568. 1921). Livingstone. 12 5. $6 d$.

Medical Annual, The, 1921. A Year Book of Treatment and Prac. titioner's Index. Being a Review of the World's P'rogress in Medicine and Surgery. Arranged in Alphahetical order for Easy Consultation. 39tt: year. Associate Fditors : Medicine, C. F. Coombs; Surgery, A. R. Short. Issued Annually. 8vo. Pp.724. May. John Wright. $20 s$.

Monro, T. K. Manual of Medicine. 4th edn. Demy 8vo. Pp. 1,069 . (191i). 1921. Baillière. $21 s$.

Murphy, J. K. (edited by). The Practitioner's Encyclopdæia of Medicine and Surgery. In all their Branches. 2nd edn. Cr. 4to. Pp. 1,463. 1913. Frowde and Hodder. 35s. 
Osler, Sir W. Aequanimitas. With other Addresses to Medical Students, Nurses, and Practitioners of Medicine. 2nd edn. 4th imp. Post 8vo. Pp. 485. 1920. Lewis. $10 s$. -and McCrae, T. (edited by). A System of Medicine. 5 Vols. 2nd edn. Roy. 8vo. 1915. Vol. 1. Bacterial Diseases; Infectious Diseases, Non-Bacterial Fungus Infections; The Mycoses. Pp. 1,093. Vol. 2. Protozoal Infections; Metazoan Infections; Intoxicants; Diseases of Metabolism; Diseases of the Respiratory System, etc. Pp. 1,144. Vol. 3. Diseases of the Digestive System; Diseases of the Urinary System. Pp. 1,090. Vol. 4. Diseases of the Circulatory System; of the Blood; of the Iymphatic System; of the Ductless Glands; etc. Pp. 1,076. Vol. 5. Diseases of the Nervous System; of the Locomotor System. Pv. 1,092. Frowde and Hodder. £7 $15 \mathrm{~s}$. the set, or $35 \mathrm{~s}$. each Vol.

Quain, Sir R. Dictionary of Medicine. By Various Writers. Fdited by H. M. Murray. Assisted by J. Harold and W. C. Bosanquet. 3rd edn. 8vo. Pp. 1,910. 1910. Longmans. $25 \mathrm{~s}$.

Roberts, F. T. The Theory and Practice of Medicine. 10th edn. Large 8vo. $\mathrm{Pp}, 1,449$. 1909. Lewis, $12 s .6 d$.

Scott, T. B. Modern Medicine and Some Modern Remedies. 2nd edn. Cr. 8vo. Pp. 213. 1919. Lewis. 6s. $6 d$.

Squire, J.E. Medical Hints. Fcap. 8vo. Pp. 128. 1915. Frowde and Hodder. 3s. $6 d$.

Stedman, T.I. A Practical Medical Dictionary of words used in Medicine with their derivation and pronunciation, including Dental, Veterinary, Chemical, Botanical, Electrical, Iife Insurance, and other special terms; Anatomical Titles, Pharmaceutical Preparations, Synonyms. ath edn: Med. 8vo. Pp. 1,113. 1917. Frowde and Hodder. 25s.
Taylor, Sir F. The Practice of Medicine. 11th edn. 8vo. Pp. 1,108. 1918. Churchill. 24s.

Thomson, S., and Steele, J. C. A Dictionary of Domestic Medicine and Household Surgery. Revised by A. Westland. 39th edn. Roy. 8vo. Pp. 790. 1911. Griffin. 9s.

Tidy, H.L. A Synopsis of Medicine: for Practitioners and Students. Cr. 8vo. Pp. 967. 1920. John Wright. $21 s$.

Whitla, Sir W. A Manual of the Practice and Theory of Medicine. 2 Vols. Cr.8vo. Pp. 1,900. 1908. Baillière. 25s.

Williams, L. Minor Maladies and their Treatment. 4th edn. Pp. 412. (1918). 1920. Baillière. $8 s .6 d$.

Woodwark, A. S. Manual of Medicine. Cr. 8vo. Pp. 420. 1912. Frowde and Hodder. 12s. $6 d$.

\section{ii. CLINICAL MEDICINE AND DIAGNOSIS.}

Brand, A. T., and Keith, J. R . Clinical Memoranda for General Practitioners. Cr. 8vo. Pp. 218. 1909. Baillière. $3 s .6 d$.

Burnet, J. The Pocket Clinical Guide. 2nd edn. Fcap. 16mo. Pp. 147. 1915. Black. 3s.6 $d$.

Bury, J. Clinical Medicine: A Practical Handbook for Practitioners and Students. 3rd edn, Revised by the Author. Assisted by A. Ramsbottom. Large 8vo. Pp. 552. 1912. Griffin. 21s.

Crookshank, F. G. Essays and Clinical Studies. Demy 8vo. Pp. 252. 1911. Lewis. $7 s, 6 d$.

French, H. (edited by). An Index of Differential Diagnosis of Main Symptoms. By Various Contributors. 3rd edn. Large 8vo. Pp. 931. (1917). 1920. John Wright. $42 s$.

Gee, S. J. Medical Lectures and Clinical Aphorisms. With Recollections by J. W. Legg. 4th edn. Cr. 8vo. Pp. 416. 1915. Frowde and Hodder. $6 s$. $6 \mathrm{~d}$. 
Gibson, G. A., and Russell. Physical Diagnosis. A Guide to Methods of Clinical Investigation. Revised by F. D. Boyd. 3rd edn. Cr. 8vo. Pp. 468. 1902. Frowde and Hodder. $9 s$.

Hutchison, R., and Rainy, $H$. Clinical Methods. A Guide to the Practical Study of Medicine. 7th edn. Fcap. 8vo. Pp. 700. 1920. Cassell. 12s. $6 d$.

Keith, R. D. Clinical Case-Taking: An Introduction to Elementary Clinical Medicine. Cr. 8vo. Pp. 104. 1918. Lewis, $4 s, 6 d$.

Latham, A., and Torrens, $\mathbf{J}$. Medical Diagnosis. 8vo. Pp.654. 1915. Churchill. 15s.

Leftwich, R. W. An Index of Symptoms as a Clue to Diagnosis. 7th edn. Cr. 8vo. Pp. 595. 1920. Murray. 15s.

- Tabular Diagnosis. Cr. 8vo. Pp. 359. 1913. Arnold. 7s. 6d.

McKisack, H. L. A Dictionary of Medical Diagnosis. A Treatise on the Symptoms observed in Diseased Conditions, for the use of Students and Practitioners. 2nd edn. Demy 8vo. Pp. 602. 1912. Baillière. $12 s$.

_-Systematic Case Taking. A Practical Guide to the Examination and Recording of Medical Cases for the use of Medical Students. Cr. 8vo. Pp. 180. 1912. Baillière. $3 s .6 d$.

March, H. Clinical Essays and Lectures. 8vo. Pp. 315. 1902. Churchill. 7s. 6d.

Sargent, P., and Russell, A. E. Emergencies of General Practice, both Surgical and Medical. 2nd edn. Demy 8vo. Pp. 465. 1911. Frowde and Hodder. 17s.

Saundby, R. Urgent Symptoms in Medical Practice. Cr. 8vo. Pp. 437. 1915. Arnold. 8s.6d.

Savill, T, D. A System of Clinical Medicine. 5th edn. 2nd imp. Med. 8vo. Pp. 894. (1918) 1920. Arnold. 28s.
Scott, H. H. Post-Graduate Clinical Studies for the General Practitioner. Demy 8vo. Pp. 175. 1907. Lewis. $8 s$.

Short, A. R. (edited by). An Index of Prognosis, and Results of Treatment. By Various Contributors. 2nd edn. Large 8vo. Pp. 770. 1918. John Wright. 30s.

Smith, F. J. Introduction to the Outlines of the Principles of Differential Diagnosis, with Clinical Memoranda. Ex. Cr. 8vo. Pp. 364. 1899. Macmillan. 7s, 6d.

Smith, W. J. A Medical and Surgical Help for Shipmasters and Officers in the Merchant Navy. Revised by A. Chaplin. 5th edn. Iarge Cr. 8vo. Pp. 373. 1919. Griffin. 6s.

Snowman, J. Lenzmann's Manual of Emergencies: Medical, Surgical and Obstetric: Their Pathology Diagnosis and Treatment. Demy 8 vo. Pp. 353. 1919. Bale and Danielsson, $15 s$.

Stevens, W. M. Medical Diagnosis. Demy 8vo. Pp. 1,610. 1910 . Lewis. $15 s$.

Todd, T. W. The Clinical Anatomy of the Gastro-Intestinal Tract. Cr. 8vo. Pp. 276. 1915. Longmans. $7 s .6 d$.

Watson, D. C. Clinical Lectures in Medicine for Nurses and Junior Medical Practitioners. Cr. 8vo. Pp. 304. 1918. [Livingstone. 4s, $6 d$.

Whiting, A. J. Aids to Medical Diagnosis. 2nd edn. Fcap. 8vo. Pp. 176. 1918. Baillière. 3s.

Zimmern, A., and Perol, P. Electro-Diagnosis of War. Edited by E. P. Cumberbatch. Cr. 8vo. Pp. 230. 1918. University of London Press. $7 s .6 d$.

iii. INFEGTIOUS DISEASES.

\section{a. General Fevers.}

Byam, W., Carroll, J. H., Churchill, J. H., Dimond, L., Sorapure, V. E., Wilson, R. M., and Lloyd, Ll. Trench Fever: A Louse-Borne Disease. Demy 8 vo. Pp. 212. 1919. Frowde and Hodder. 10s. $6 d$. 
Ker, G. B. A Manual of Fevers. Cr. 8vo. Pp. 324. 1911. Frowde and Hodder. 8s. $6 d$.

Rogers, Sir L. Fevers in the Tropics, their Clinical and Microscopical Differentiation. 3rd edn. Cr. 4to. Pp. 361. 1919. Frowde and Hodder. 30s.

\section{b. General Infectious Diseases.}

Armstrong, H. G., and Fortescue Brickdale, J. M. A Manual of Infectious Diseases occurring in Schools. Cr. 8vo. Pp. 150. 1912. John Wright. $3 s$.

Goodall, E. W., and Washburn, J. W. A Manual of Infectious Diseases. 2nd edn. Demy 8 vo. Pp. 438. 1908. Lewis. 15s.

Ker, C. B. Infectious Diseases. A Practical Handbook. 2nd edn. Cr. 4to. Pp. 639. 1920. Frowde and Hodder. 42s.

Ledingham, J. C. G., and Arkwright, J. A. The Carrier Problem in Infectious Disease, with particular reference to Enteric Fever, Diphtheria, Cerebro-Spinal Meningitis, Bacillary Dysentery and Cholera, Demy 8vo. Pp. 320. 1912. Arnold. 12s.6d.

Seaton, E. C. Infectious Diseases and their Preventive Treatment. Cr. 8vo. Pp. 230. 1911. University of London Press. $7 s .6 d$.

\section{c. Beri-beri.}

Wright, H. The Etiology and Pathology of Beri-beri. Roy. 8vo. Pp. 100. 1902. Churchill. 3s.

On the Classification and Pathology of Beri-beri. Roy. 8vo. Pp. 74. 1903. Bale and Danielsson. $3 s .6 d$.

\section{d. Cerebro-Spinal Fever.}

Foster, M., and Gaskell, J. F. Cerebro-Spinal Fever. Roy. 8vo. Pp. 232. 1916. Cambridge University Press. 12s. 6d.

Horder, Sir T. J. Cerebro-Spinal Fever. Fcap. 8vo. Pp. 179. 1915. Frowde and Hodder. $3 s, 6 d$.
Worster-Drought, C., and Kennedy, A. M. Cerebro-Spinal Fever. The Etiology, Symptomatology, Diagnosis, and Treatment of Epidemic Cerebro-Spinal Meningitis. Demy 8vo. Pp. 514. 1919. 35s. Black.

\section{e. Cholera.}

Rogers, Sir L. Cholera and its Treatment. Demy 8vo. Pp. 250. 1911. Frowde and Hodder. 12s. $6 d$.

\section{f. Diphtheria.}

Harding, M. E. The Circulatory Failure of Diphtheria. Demy 8vo. Pp. 192. 1920. University of London Press. 10s. $6 \mathrm{~d}$.

Newsholme, Sir A. Epidemic Diphtheria: A Research on the Origin and Spread of the Disease from an International Standpoint. 2nd edn. Demy 8vo. Pp. 192. 1900. Allen and Unwin. 8s.6d.

Nuttall, G. H. F., and Graham Smith, G. S. The Bacteriology of Diphtheria. Re-issue with Bibliography, recording the more important work published since 1908 . Roy. 8vo. Pp. 746. 1913. Cambridge University Press. $21 s$.

\section{g. Dysentery, Malarial Diseases.}

Alport, A. G. Malaria and Its Treatment: in the Line and at the Base. Demy 8vo. Pp. 300. 1919. Bale and Danielsson. $21 s$.

Armand-Delille, P., Abrami, P., Paisseau, G., and Lemaire, $H$. Malaria in Macedonia: Clinical and Hæmatological Features, Principles of Treatment. Edited by Sir R . Ross. Cr. 8vo. Pp. 140. 1918. University of London Press. $7 s .6 d$.

Brown, W. C. Amœbic or Tropical Dysentery; its Complications and Treatment. Fcap. 4to. Pp. 279. 1910. Bale and Danielsson. $7 s, 6 d$.

Cope, Z. Surgical Aspects of Dysentery, including Liver-Abscess. 8vo. Pp. 168. 1920. Frowde and Hodder. 12s. $6 d$.

Newell, A. G. Blackwater Fever. Demy 8vo. Pp. 127. 1909 . Bale and Danielsson. 5s. 
Phillips, L. P. Amœbiasis and the Dysenteries. Demy 8vo. Pp. 158. 1915. Lewis. 9s.

Rat, J. N. Frambœsia (Yaws). Pp. 60. 1904. Bale and Danielsson. $2 s .6 d$.

Rogers, Sir L. Dysenteries, their Differentiation and Treatment. Demy 8vo. Pp. 333. 1913. Frowde and Hodder. 12s. $6 d$.

Ross, Sir R. The Prevention of Malaria, with Contributions by Leading Experts. Med. 8vo. Pp. 711. 1911. Murray. 24s.

Vincent, H., and Muratet, L. Dysenteries. Cholera, and Exanthematic Typhus. Edited by G. C. Low. Cr. 8vo. Pp. 236. 1917. University of London Press. $7 s .6 d$.

Willoughby, W. G., and Cassidy, L. Anti-Malarial Work in Macedonia among British Troops. Cr. 8vo. Pp. 78. 1918. Lewis. 3s. 6d.

Wright, H. The Malarial Fevers of British Malaya. Roy. 8vo. Pp. 100. 1902. Churchill. 3s.

\section{h. Plague.}

Simpson, W. J. A Treatise on Plague. Roy. 8vo. Pp. 490. 1905. Cambridge University Press . $21 s$.

Tuck, G. L. (Wu Lien-Teh). North Manchurian Plague Prevention Service Reports (1911-1913). Roy. 8vo. Pp. 193. 1914. Cambridge University Press. 10s. $6 d$.

\section{i. Small -Pox.}

Collie, A. Small-Pox and its Diffusion. Demy 8vo. Pp. 58. 1912. John Wright. $2 s$.

Hanna, W. Studies in Small-Pox and Vaccination. Cr. 4to. Pp. 52. 1913. John Wright. 7s. 6d.

McVail, J. G. Half-a-Century of Smallpox and Vaccination. Demy 8vo. Pp. 94. 1919. Livingstone. $5 s .6 d$.

Ricketts, T. F. The Diagnosis of Smallpox. Med. 8vo. Pp. 170. 1908. Cassell. 16s.
Wanklyn, W. How to Diagnose Small-Pox. Demy 8vo. Pp. 104 . 1913. Murray. 5s.

\section{j. Tetanus.}

Courtois-Suffit, and Giroux, $R$. Abnormal Forms of Tetanus. Edited by Sir D. Bruce and F. Golla. Cr. 8vo. Pp. 249. 1918. University of London Press. $7 s .6 d$.

\section{k. Typhoid Fever.}

Vincent, H., and Muratet, L. Typhoid Fevers and Paratyphoid Fevers: Symptomatology, Etiology, Prophylaxis. Translated and Edited by J. D. Rolleston. 2nd edn. Cr. 8vo. Pp. 315. 1917. University of London Press. $7 s, 6 d$.

Webb-Johnson, A. E. Surgical Aspects of Typhoid and ParaTyphoid Fevers. Demy 8vo. Pp. 190. 1919. Frowde and Hodder. $10 s .6 d$.

Wright, Sir A. E. A Short Treatise on Anti-Typhoid. Demy 8vo. Pp. 86. 1904. Constable. 3s. 6d.

\section{Venereal Diseases: Syphilis: Gonorrhea.}

Bayly, H. W. Venereal Disease: Its Prevention, Symptoms, and Treatment. 8vo. Pp. 170. 1919. Churchill. 10s. 6d.

The Clinical Pathology of Syphilis and Para-Syphilis. Fcap. 8vo. Pp. 208. 1912. Baillière. 5s.

Browning, C. H., and McKenzie, J. Recent Methods in the Diagnosis and Treatment of Syphilis. 3rd impression in preparation. Constable.

-and Watson, D, Venereal Diseases. A Practical Handbook for Students. Cr. 8vo. Pp. 352. 1919. Frowde and Hodder. 16s.

Burke, E. T. The Venereal Problem. A Description of the Venereal Diseases, their History, Prevalence, their effect upon the National Life, their Propagation and Spread, and Methods for their Control and Eradication. Cr. 8vo. Pp. 224. 1919. Kimpton. 7s.6d. 


\section{Medicine.}

Carpenter, G. Syphilis of Children in Every-day Practice. Cr. 8vo. Pp.112. 1901. Baillière. 3s.6d.

Findlay, L. Syphilis in Childhood. Cr. 8vo, Pp. 166. 1919. Frowde and Hodder. $8 s .6 d$.

Fox, W. S. Syphilis and its Treatment, with especial reference to Syphilis of the Skin. Roy. 8vo. Pp. 203. 1920. Lewis. 36s.

Harrison, L. W. The Treatment of Syphilis: a Critical Review. Imp. 8vo. Pp. 74. 1917. Oxford: Clarendon Press. 2s. 6d.

Diagnosis and Treatment of Venereal Diseases in General Practice. 2nd edn. Demy 8vo. Pp. 490. 1919. Frowde and Hodder. $25 s$.

-A Manual of Venereal Diseases for Students. Cr.8vo. Pp.375. 1920. Frowde and Hodder. 16s.

Hayes, R. The Intensive Treatment of Syphilis and Locomotor Ataxia by Aachen Methods. 3rd edn. Cr. 8vo. Pp. 100. 1919. Baillière. $4 s .6 d$.

Jones, L. V. Gonorrhœal Arthritis: its Pathology, Symptoms, and Treatment. Cr. 8vo. Pp. 52. 1901. Lewis. 2s. $6 d$.

Lambkin, F.J. Syphilis, its Diagnosis and Treatment. Demy 8 vo. Pp. 204. 1910. Baillière. $5 s$.

Lumb, N. P. L. Gonococcal Infection in the Male: for Students and Practitioners. 8vo. Pp. 339. 1920 Bale and Danielsson. $25 s$.

The Systematic Treatment of Gonorrhœea. 2nd edn. Cr. 8vo. Pp. 131. 1920. Lewis. 5s.

Luys, G. A Text-book on Gonorrhœa and its Complications. Translated and Edited by A. Foerster. 3rd edn. in preparation. Baillière.

McDonagh, J. E. R. Venereal Diseases: Their Clinical Aspect and Treatment. Roy. 8vo. Pp. 419. 1920. Heinemann. 63s.

McIntosh, J., and Fildes, $P$. Syphilis. Demy 8vo. Pp. 227. 1911. Arnold. 10s.6d.
Magian, A. C. A Modern Handbook of Venereal Diseases. Being an Outline of these Affections and of their History and Treatment. 2nd edn. Demy 8vo. Pp. 224. 1919. Heinemann. $10 s .6 d$.

Marshall, G. F., and French, E. G. Syphilis and Veneral Disease. 4th edn. Demy 8vo. Pp. 446. 1921. Baillière. 25s .

May, O. Prevention of Venereal Diseases. Cr. 8vo. Pp. 257. 1918. Frowde and Hodder. $7 s, 6 d$.

Pollock, C. E., and Harrison, L. W. Gonococcal Infections. $\mathrm{Cr}$. 8vo. Pp. 243. 1912. Frowde and Hodder. $6 s$.

Power, Sir D'A., and Murphy, J. K. (edited by). A System of Syphilis. 5 Vols. 2nd edn. Roy. 8vo. 1914. Vol. 1: Pp. 443. 8s. 6d. Vol. 2. Pp. 396. 8s.6d. Vol. 3. Pp. 342. 10s. 6d. Vol. 4 (out of print). Vol. 5. Pp. 364. 10s. 6d. Frowde and Hodder.

Prevention of Venereal Disease, The. Being the Report of and the Evidence taken by the Special Committee on Venereal Disease. Demy 8vo. Pp. 272. 1921. Williams and Norgate. $21 s$.

Reid, Sir G. A. Prevention of Venereal Disease. Cr. 8vo. Pp. 463. 1920. Heinemann. 15s.

Russ, C. A New Treatment of Gonorrhœa. Demy 8vo. Pp. 45. 1914. Lewis. $3 s$.

Thibierge, G. Syphilis and the Army. Edited by C. F. Marshall. Cr.8vo. Pp.232. 1918. University of London Press. $7 s .6 d$.

Watson, D. Gonorrhœa and its Complications in the Male and Female. Roy. 8vo. Pp. 395. 1914. Kimpton. 15s.

Watson, J. K. The Venereal Diseases Problem: A book more especially for Nurses and Midwives. Cr. 8vo. Pp.76. 1917. Baillière. $3 s .6 d$. 
m. Yellow Fever.

Boyce, Sir R. W. Yellow Fever and Its Prevention. A Manual for Medical Students and Practitioners. Med.8vo. Pp.380. 1911. Murray. $10 s .6 d$.

\section{iv. DISEASES DUE TO PARA- SITES.}

Alcock, A. Entomology for Medical Officers. 2nd edn. 8vo. Pp. 396. 1920. Gurney and Jackson. $18 s$.

Boyce, Sir R.W. Mosquito or Man? The Conquest of the Tropical World. 3rd edn. Med. 8vo. Pp. 280.1910. Murray. 10s. 6d.

Braun, M., and Luhe, M. A Handbook of Practical Parasitology. Translated by L. Forster. Rov. 8vo. Pp. 216. 1910. Bale and Danielsson. 10s. $6 d$.

Glarke, J. J. Protozoa and Disease. Part 1. Unicellular Organisms and the Cell; the Four Classes of Protozoa : the Parasites of Malaria : the Foundations of Parasitic Protozoology. Pp. 198. 1903. Part 2. Causation of Smallpox and Syphilis. Pp. 150. 1908. Part 3. The Cause of Cancer. Pp. 124. 1912. Part 4. Rhizopod Protozoa, the Cause of Cancer and other Diseases. Pp. 202. 1915. Baillière. 7s. 6d. each.

Da Costa, B. F. B. Sleeping Sickness. A Record of Four Years' War against it in Principe, Portuguese West Africa. Translated by J. A. Wyllie. Large Roy. 8vo. Pp. 274. 1916. Baillière. 7s.6d.

Fantham, H. B., Stephens, J. W. W., and Theobald, F. V. The Animal Parasites of Man. Roy. 8vo. Pp. 964. 1916. Bale and Danielsson. 45s.

Graham, J. Hydatid Disease in its Clinical Aspects. Demy 8vo. Pp. 216. 1891. Frowde and Hodder. $16 s$.

Laveran, A., and Mesnil, F. Trypanosomes and Trypanosomiases. Translated and Edited by $D$. Nabarro. Roy. 8vo. Pp. 538 . 1907. Baillière. 21s.
Lloyd, L1. Lice and their Menace to Man. Demy 8vo. Pp. 152. 1919. Frowde and Hodder. $\boldsymbol{T}_{s} .6 \mathrm{~d}$.

\section{v. CONSTITUTIONAL DISEASES.}

\section{a. Cancer.}

Bell, R. Health at Its Best v. Cancer and other Diseases. $\mathbf{C r}$. 8vo. Pp. 320. 1908. Fisher Unwin. $5 s$.

Greighton, C. Some Conclusions on Cancer. Roy. 8vo. Pp.381. 1920. Williams and Norgate. 42s.

Gould, Sir A. P. The Bradshaw Lecture on Cancer. Demy 8vo. Pp. 77. 1910. Bale and Danielsson. 3s.6d.

Green, C. E. The Cancer Problem: A Statistical Study. 4th edn. Roy. 8vo. Pp. 149. 1917. W. Green. $21 s$.

Gruner, O.C. The exact Diagnosis of Latent Cancer. Roy. 8vo. Pp. 86. 1919. Lewis. 7s.6d.

Morris, Sir H. On tine Treatment of Inoperable Cancer. Demy 8vo. Pp. 38. 1902. Bale and Danielsson. 3s. 6d.

Moullin, C. W. M. Treatment of Sarcoma and Carcinoma by Injections of Mixed Toxins. Demy 8vo. Pp. 60. 1898. Bale and Danielsson. 3s. 6d.

Robson, Sir A. W. M. Cancer and Its Treatment. Cr. 8vo. Pp. 70 . 1905. Baillière. $3 s, 6 d$.

Ross, F. W. F. Cancer: The Problem of Its Genesis and Treatment. Demy 8vo. Pp. 270. 1912. Methuen. 7s. 6d.

Russell, R. Notes on the Causation of Cancer. Cr. 8vo. Pp. 126. 1916. Longmans. 3s.6d.

Saleeby, C. W. The Conquest of Cancer: A Plan of Campaign. Being an account of the Principles and Practice hitherto of the Treatment of Malignant Growths by Specific on Cancrotoxic Ferment. Demy 8vo. Pp. 420. 1907 . Chapman and Hall. 7s.6d. 


\section{Medicine.}

Shaw-MacKenzie, J. A. The Nature and Treatment of Cancer. 4th edn. Pp. 118. 1906. Baillière. $2 s .6 d$.

\section{b. Rheumatism, Gout .}

Bannatyne, G. A. Rheumatoid Arthritis. 4th edn. 8vo. Pp.191. 1906. John Wright. 7s. 6 $\ell$.

Danie1, P. L. Arthritis: A Study of the Inflammatory Diseases of the Joints. Large Cr. 8vo. Pp. 523. 1911. Bale and Danielsson. 12s.6 d.

Lindsay; J. Gout. Cr. 8vo. Pp. 224. 1913. Frowde and Hodder. $6 s$.

Llewellyn, L.J. Gout, with a section on Ocular Disease in the Gouty, by W. M. Beaumont. Svo. 1020 . Heinemann. 30s.

- and Basset, A. Fibrositis (Gouty. Infective, Traumatic), socalled Chronic Rheumatism. Roy. 8vo. Pp.694, 1915. Heinemann. $30 s$.

Poynton, F. J., and Paine, A. Researches on Rheumatism. Roy. 8vo. Pp. 480. 1913. Churchill. $15 \%$.

Stockman, R. Rheumatism and Arthritis. Roy. 8vo. Pp. 138. 1920. W. Green. 15s.

\section{vi . TUBERCULOSIS.}

Bandelier, B., and Roepke, Dr. A Clinical System of Tuberculosis. Describing all forms of the Disease. Translated by G. B. Hunt. Roy. 8vo. Pp. 538. 1913. Bale and Danielsson. $21 s$.

Bardswell, N. D. Advice to Consumptives: Home Treatment, After Care, and Prevention. 2nd edn. Cr. Svo. Py. 169. 1920. Black. $3 s .6 d$.

The Expectation of Isife of the Consumptive after Sanatorium Treatment. Demy 8vo. Pp. 130. 1910. Frowde and Hodder. 4s.

-and Chapman, J. E. Diets in Tuberculosis. Cr. 8vo. Pp. 191. 1908. Frowde and Hodder. 6s, 6d.
Bruce, O. Lectures on Tuberculosis to Nurses. Cr. 8vo. Pp. 142. 1913. Lewis. $3 s$.

Burton-Fanning, F. W . The OpenAir Treatment of Pulmonary Tuberculosis. 2nd edn. Cr. Svo. Pp. 181. 1916. Cassell. 5s.

Cheyne, Sir W. W. Tuberculous Disease of the Bones and Joints. Their Pathology, Symptoms and Treatment. 2nd edn. Demy 8vo. Pp. 415. 1911. Frowde and Hodder. 18s.

Clarke, H. Studies in Tuberculosis. Cr.4to. Pp.78. 1909. Constable. 5s.

Cobbett, L. The Causes of Tuberculosis. Demy 8vo. Pp. 724. 1917. Cambridge University Press. $23 s$.

Cornet, G. Tuberculosis in Children (Scrofulosis). Translated by J. E. Bullock. Roy. 8vo. Pp 539. 1914. Bale and Danielsson $15 s$.

-Acute General Military Tuber. culosis. Translated by F. S. Tinker. Demy 8vo. Pp: 121. 1914. Bale and Danielsson. $6 s$.

Greighton, G. Contributions to the Physiological Theory of Tuberculosis. Roy. 8vo. Pp. 242 . 1908. Williams and Norgate. 12s. $6 d$.

Crofton, W. M. Pulmonary Tuberculosis: its Diagnosis, Prevention and Treatment. Cr.8vo. Pp. 128. 1917. Churchill. 6s.

Day, J. R. Sea-water Treatment. Demy svo. Pp.97. 1914. Bale and Danielsson. $4 s$.

Diver, E. W. Consumption: its Prevention and Treatment. 2nd edn. Cr. 8vo. Pp. 149. 1911. Bale and Danielsson. 2s. $6 d$.

Flv, L. W. Joint Tuberculosis . Large \$vo Pp. 243. 1911. John Wright. 12s.6d.

Fraser, I. Tuberculosis of the Bones and Joints in Children. Roy. 8vo. Pp.352. 1914. Black. 20s. 
Ghon. A. The Primary Lung Focus of Tuberculos is in Children. Trans. lated by D. B. King. Roy. 8vo. Pp.200. 1915. Churchill. 10s. 6d.

Griffiths, F. G. Studies in Pulmonary Tuberculosis: its Dissemination, Specific Diagnosis and Treatment, and. some Points in its Pathology. Cr. 4to. Pp. 122. 1911. Baillière. $5 s$.

Héricourt, J. The Social Diseases : Tuberculosis, Syphilis, Alcoholism, Sterility. Translated, with a final chapter, by B. Miall. Cr. 8vo. Pp. 256. 1920. Routledge. 6s.

Hort, E. G. Rational Immunisation in the Treatment of Pulmonary Tuberculosis. Imp. 8vo. Pp. 91. 1909. Bale and Danielsson. 3s. $6 d$.

Kelynack, T. N. (edited by). Tuberculosis in Infancy and Childhood: Its Pathology, Prevention, and Treatment. By Various Authors. Roy. 8vo. Pp. 390. 1908. Baillière. 12s. $6 d$.

King, D. B . Scheme for Dealing with Tuberculous Persons in the County of London: its application to other Cities. with some observations on the National Organisation of the Campaign against Tuberculosis. $\mathrm{Cr}$. 4to. Pp. 54 and 8 diagrams. 1915. Bale and Danielsson. $5 s$.

Laird, J. Notes on the Treatment of Tuberculosis. Cr. 8vo. Pp. 84. 1912. John Wright. 2s. 6d.

Lees, D. B. The Diagnosis and Treatment of Incipient Pulmonary Tuberculosis. Demy 8vo. Pr.116. 1913. Lewis. 5s .

Maylard, A. E. Abdominal Tuberculosis. 8vo. Pp. 376. 1909. Churchill. 12s. 6d.

Minchin, W. C. The Treatment, Prevention, and Cure of Tuberculosis and I.upus with Oleum Allii. 2nd edn. Cr. Svo. Pp. 126. 1915. Baillière. $5 s$.

Newsholme, Sir A. The Prevention of Tuberculosis. 2nd edn. Demy 8vo. Pp. 441. 1910. Methuen. 12s. 6d.
Otabe, S. The Science and Art of deep Breathing as a Prophylactic and Therapeutic Agent in Consumption. Cr. 8vo. Pp. 124. 1919. Bale and Danielsson. 5s.

Overend, W. The Radiography of the Chest. Vol. 1. Pulmonary Tuberculosis. Demy 8vo., Pp. 130. 1920. Heinemann. 17s. 6d.

Pearson, S. V. The State Provision of Sanatoriums. Demy 8vo. Pp. 88. 1913. Cambridge University Press. 3s.

Rivers, W. C. Three Clinical Studies in Tuberculous Predisposition. Demy 8vo. Pp. 272. 1917. Allen and Unwin. 12s.6d.

Riviere, C. The Early Diagnosis of Tubercle. 3rd edn. Cr. 8vo. Pp. 318. 1921. Frowde and Hodder. $15 s$.

The Pneumothorax Treatment of Pulmonary Tuberculosis. Cr. 8vo. Pp. 202. 1917. Frowde and Hodder. $6 s$.

Sutherland, H. G. Pulmonary Tuberculosis in General Practice. Demy 8vo. Pp. 290. 1916 . Cassell. 10s. 6d.

(edited by). The Control and Eradication of Tuberculosis: A Series of International Studies by many Authors. Roy. 8vó. Pp. 46.7. 1911. W. Green. 15s.

Thomson, H. H. Consumption: Its Prevention and Home Treatment. 2nd edn. Cr. 8vo. Pp.108. 1921. Frowde and Hodder. $4 s$.

Consumption in General Practice. Demy 8vo. Pp. 350. 1912. Frowde and Hodder. 14s.

Tuberculosis and Public Health. Cr. 8vo. Pp. 116. 1920. Longmans. 5s.

Walsham, H. The Channels of Infection in Tuberculosis. Roy. 8vo. Pp. 150. 1904. Bale and Danielsson. 12s. $6 d$.

Walters, F. R. The Open-Air or Sanatorium Treatment of Pulmonary Tuberculosis. Svo. Pp. 339. 1909. Baillière. $6 s$. 
Walters, F. R. Sanatoria for the Tuberculous, including a Description of many existing Institutions and of Sanatorium Treatment in Pulmonary Tuberculosis. 4th edn. Demy 8vo. Pp.445. 1913. Allen and Unwin. 12s. $6 d$.

Wolf-Eisner, A. The Ophthalmicand Cutaneous Diagnosis of Tuberculosis. Translated by B. I. Robert. Roy. 8vo. Pp. 200. 1908. Bale and Danielsson.7s.6 $d$.

\section{viii. DISEASES OF THE NER-} VOUS SYSTEM.

a. General (including Alcoholism).

Ash, E. The Problem of Nervous Breakdown. Demy 8vo. Pp. 311. 1919. Mills and Boon. 10s.6d.

Ballance, Sir C. A., and Stewart, Sir J. P. The Healing of Nerves. 4to. Pp. 124. 1901. Macmillan. 12s. 6id.

Bristowe, J.S. Lectures and Essays on Diseases of the Nervous System . 8vo. Pp. 403. 1888. Murray. $12 s, 6 d$.

Brown, W. L. The Sympathetic Nervous System in Disease. 8vo. Pp. 178. 1920. Frowde and Hodder. 10s. $6 d$.

Dana, C. L. 'Text-hook of Nervous Diseases. 9th edn. Roy. 8vo. Pp. 665. 1921. J. Wright. 35s.

Harris, D. F. Nerves. Fcap. svo. Pp. 254. 1913. Williams and Norgate. $2 s, 6 d$.

Harris, W. Nerve Injuries and Shock. Feap. 8vo. Pp. 12 . 1915. Frowde and Hodder. $3 s .6 d$.

Hollander, B. Nervous Disorders of Men. 2nd edn. Cr. 8vo. Pp. 260. 1916. Kegan Paul. 4s.

-Nervous Disorders of Women. and edn. Cr. 8vo. Pp. 238. 1936. Kegan Paul. 4s.

Jones, E. Treatment of the Neuroses . Demy 8vo. Pp. 24.1. 1920. Baillière. 10s. 6d.

Loosmore, C. Nerves and the Man: A Popular Psychological and Constructive Study of Nervous Breakdown. Cr. 8vo. Pp. 235. 1920. Murray. 6s.
Mark, L. P. Acromegaly: A Personal Experience. Demy 8vo. Pp. 168. 1912. Baillière. $7 s .6 d$.

Schofield, A. T. Functional Nerve Diseases. Demy 8ro. Pp. 324. 1908. Methuen. 10s.6d.

Souttar, H.S., and Twining, E.W . Injuries of the Peripheral Nerves. Folio. Pp. 163. 1920. J. Wright. $18 s .6 d$.

Stewart, Sir J.P. The Diagnosis of Nervous Diseases. 5th edn. Demy 8vo. Pp. 584. 1920. Arnold. $30 s$.

-and Evans, A. Nerve Injuries and their Treatment. 2nd edn. Demy 8vo. Pp. 262. 1919. Frowde and Hodder. 12s. $6 d$.

Thomson, H. C. Diseases of the Nervous System. 2nd edn. Cr.8vo. Pp. 568. 1915. Cassell. 12s.

Tinel, J. Nerve Wounds : Symptomology of Peripheral Nerve Lesions caused by War Wounds. Authorised Translation by F. Rothwell. Revised and Edited by C. A. Joll. Roy. 8vo. Pp. 329. 1918. Baillière. 17s. 6d.

Cooper, J. W. A. Pathological Inebriety: its Causation and Treatment. Cr. 8vo. Pp. 168. 1913. Baillière. $3 s, 6 d$.

Hare, F. On Alcoholism: its Clinical Aspects and Treatment. Cr. 8vo. Pp. 282. 1912. Churchill. $5 s$.

Horsley, Sir V., and Sturge, M.D. Alcohol and the Human Body. An Introduction to the Study of the Subject, and a Contribution to National Health. fith edn. Gl. 8vo. Pp. 378. 1920. Macmillan. $3 s$.

Kelynack, T. N. (edited by). The Drink Problem of To-Day in its Medico-Sociological Aspects. 2nd edn. Demy 8vo. Pp. 330. 1916. Methuen. 10s.6d.

Rivers, W. H. R. The Influence of Alcohol and other Drugs on Fatigue. Roy.8vo. Pp.144. 1908. Arnold. 7s. $6 d$. 
Wingfield, H. The Forms of Alcoholism and their Treatment. Cr. 8vo. Pp. 84. 1919. Frowde and Hodder. 5s.

\section{b. Diseases of the Brain and Spinal Cord.}

Bolton, J. S. The Brain in Health and Disease. Demy 8vo. Pp. 481. 1914. Arnold. 18s.

Williamson, R. T. Diseases of the Spinal Cord. Roy. 8vo. Pp. 443. 1908. Frowde and Hodder. 15s.

Wyllie, J. Meningitis, Sinus Thrombosis and Abscess of the Brain. With Appendices on Lumbar Puncture and its Uses; and Diseases of the Nasal Accessory Sinuses. Post 8vo. Pp. 267. 1911. Lewis. $6 s, 6 d$.

\section{c. Neurasthenia and other}

special Disorders of the Nervous System.

Appelt, A. The Real Cause of Stammering and its Permanent Cure. A Treatise on PsychoAnalytical Lines. 2nd edn. Cr. 8vo. Pp. 246. 1920. Methuen. $7 s$.

Auerbach, S. Headache. Its Varieties, their Nature, Recognition and Treatment. Translated by E. Playfair. Cr. 8vo. Pp. 208. 1913. Frowde and Hodder. $6 s$.

Babinski, $J_{\text {., }}$ and Froment, $\mathbf{J}$. Hysteria or Pithiatism, and Reflex Nervous Disorders. Edited by $\mathbf{E}$. F. Buzzard. Cr. 8vo. Pp. 332. 1918. University of London Press. $7 s .6 d$.

Ballet, G. Neurasthenia. Translated from the French by $P$. C. Smith. 3rd edn. Demy 8vo. Pp. 438. 1911. Kimpton. $7 s, 6 d$.

Barnett, H. N. Sea Sickness, its True Cause and Cure. Cr. 8vo. Pp. 40. 1907. Baillière. 1s.6d.

Bruce, W. Sciatica. A Fresh Study, with notes of nearly 700 cases. Cr.8vo. Pp.188. 1913. Baillière. 5s.
Cobb, I. G. A Manual of Neurasthenia. Nervous Exhaustion. Demy 8vo. Pp. 382. 1920. Baillière. $15 s$.

Gowers, Sir W. R. The Borderland of Epilepsy : Faints, Vagal Attacks, Vertigo, Migraine, Sleep Symptoms, and their Treatment. 8vo. Pp. 127. 1907. Churchill. 4s. 6d. Epilepsy and other Chronic Convulsive Diseases: their Causes, Symptoms, and Treatment. 2nd edn. 8vo. Pp. 330. 1901. Churchill. 10s.6d.

Hartenburg, P. Treatment of Neurasthenia. Translated by $\mathbf{E}$. Playfair. Cr.8vo. Pp. 291. 1914. Frowde and Hodder. $6 s$.

Hurst, A. F. Croonian Lectures on the Psychology of the Special Senses, and their Functional Disorders. 8vo. Pp.134. 1920. Frowde and Hodder. 12s, 6d.

Hurry, J. B. The Vicious Circles of Neurasthenia and their Treatment. 8vo. Pp. 106. 1915. Churchill. 3s. $6 d$.

Hutchinson, J. On Facial Neuralgia and its Treatment-with especial reference to the Surgery of the Fifth nerve and the Gasserian Ganglion. 2nd edn. Demy 8vo. Pp. 230. 1919. Bale and Danielsson. 15s.

Rixon, C. H. L., and Matthew, D. Anxiety Hysteria. Modern Views on Sane Neurosis. Cr. 8vo. Pp. 124. 1920. Lewis. 4s. 6d.

Vittoz, R. Treatment of Neurasthenia by Means of Brain Control. Translated from the French by $H$. B. Brooke. 2nd edn. Cr. 8vo. Pp. 132. 1913. Longmans. 4s.

d. Nervous Disorders Caused by War, including Shell Shock.

Crile, G. W. A Physical Interpretation of Shock, Exhaustion, and Restoration. An Extension of the Kinetic Theory. Edited by $\mathbf{A}$. F. Rowland. 4to. Pp. 248. 1921. Frowde and Hodder. 25s. 
Culpin, M. Psychoneuroses of War and Peace. Demy 8vo. Pp. 130. 1920. Cambridge University Press. 10 s.

Eder, M. D. War Shock. The Psychoneuroses in War; Psychology and Treatment. Cr. 8vo. Pp. 154. 1917. Heinemann. 5s.

Lepine, J. Mental Disorders of War. Edited by C. A. Mercier. Cr. 8vo. Pp. 244. 1919. University of London Press. 7s, 6d.

MacCurdy, J. T. War Neuroses. Preface by W. H. R. Rivers. Demy 8vo. Pp. 144. 1918. Cambridge University Press. $7 s .6 d$.

Marr, H. C. Psychoses of the War. Including Neurasthenia and Shell Shock. Demy 8vo. Pp. 336. 1919. Frowde and Hcdder. 16s.

Miller, H. C. (edited by). Functional Nerve Disease. An Epitome of War Experience for the Practitioner. Demy 8vo. Pp. 219. 1920. Frowde and Hedder. 8s. $6 d$.

Mott, Sir F. W. War Neuroses and Shell Shock. Demy 8vo. Pp. 368. 1919. Frowde and Hodder. 16s.

Read. C. S. Military Psychiatry in Peace and War. Roy. 8vo. Pp. 176. 1920. Lewis. 10s. $6 d$.

Smith, G. E., and Pear, T. H. Shell Shock and its Lessons. 2nd edn. Cr. 8vo. Pp. 152. 1919. Longmans. $2 s .6 d$.

Yealland, L. R. Hysterical Disorders of Warfare. 8vo. Pp. 264. 1918. Macmillan. 7s.6d.

\section{e. Mental Disorders; Insanity ; Psychiatry .}

Ballard, E. F. An Epitome of Mental Disorders. Post 8vo. Pp. 244. 1917. Churchill. 7s. fid.

Bianchi, L. Text-book of Psychiatry for Physicians and Students. Translated by J. H. MacDonald. Roy. 8vo. Pp. 920. 1906. Baillière. $21 s$.

Clouston, Sir T.S. Unsoundness of Mind. Demy 8vo. Pp. 392. 1911. Methuen. 10s.6d.
Clouston, Sir T. S. Clinical Lectures on Mental Diseases. 6th edn. Cr.8vo. Pp. 750. 1904. Churchill. $16 s$.

Cole, R. H. Mental Diseases: A Text-book of Psychiatry for Medical Students and Practitioners. 2nd edn. Demy 8vo. Pp. 358. 1918. University of London Press. $15 \mathrm{~s}$.

Handbook for Attendants on the Insane. Published by the Authority of the Medico-Psycholcgical Association. 6th edn. Pp.406. 1920. Baillière. is .

Hart, B. The Psychology of Insanity. 3rd imp. Rcy. 16mo. Pp. 116. 1919. Cambridge University Press. $3 s$.

Kraepelin, E. Manic-Depressive Insanity and Paranoia. Translated from the German by R. M. Barclay. Edited by G. M. Robertson. 8vo. Pp.280. 1921. Livingstone. 21s.

Lectures on Clinical Psychiatry. Authorised Translation, revised and edited by T. Johnstone. 3rd edn. Pp. 386. 1916. Baillière. $12 s$.

Maudsley, H. Responsibility in Mental Disease. 6th edn. Cr.8vo. Pp. 340. 1906. Kegan Paul. $7 s .6 d$.

Mercier, C. A. Sanity and Insanity . Cr. 8vo. Scott Pub. Co. 5s.

- A Text-book of Insanity and Other Mental Diseases. 2nd edn. Cr. 8vo. Pp. 348. 1914. Allen \& Unwin. $7 s .6 d$.

- Crime and Insanity. Fcap. 8vo. Pp. 255. 1911. Williams \& Norgate. $2 s .6 d$.

Overbeck-Wright, A. W. Lunacy in India. 8vo. Pp. 416. 1921. Baillière. 21s .

Savage, Sir G. The Increase of Insanity. Demy 8vo. Pp. 80 . 1907. Cassell. 2s. 6d.

Schofield, A. T* The Management of a Nerve Patient. Cr. 8vo. Pp. 280. 1905. Churchill. 5s.

Sherlock, E.B. The Feeble-Minded. A Guide to Study and Practice. 8vo. Pp.348. 1911. Macmillan.10s.6d. 
Stoddart, W. H. B. Mind and Its Disorders. A Text-book for Students and Practitioners: 3rd edn. Demy 8vo. Pp. 600. 1919. Lewis. $20 s$.

Tanzi, E. A Text-book of Mental Diseases. Translated from the Italian by W. F. Robertson and T.C. Mackenzie. Roy. 8vo. Pp. 820. 1909. Heinemann. 24s.

Tredgold, A. F. Mental Deficiency (Amentia). 3rd edn. Demy 8vo. Pp.551. 1920. Baillière. 25s.

Younger, E. G. Insanity in Every day Practice. 4th edn. Cr. 8vo. $\mathrm{Pp}$ : 144. 1917. Baillière. 6s.

\section{viii. DISEASES OF THE BLOOD, LYMPHATIGS AND GLANDS.}

Coles, A. C. The Blood: How to Examine and Diagnose its Diseases. 3rd edn. 8vo. Pp. 350. 1905. Chrrchill. 10s. 6d.

Ednunds, A. Glandular Enlargements and other Diseases of the Lymphatic System. Cr. 8vo. Pp. 230. 1908. Frowde \& Hodder. 6s.

Gulland, G. L., and Goodall, A. The Blood: A Guide to its Examination and to the Diagnosis and Treatment of its Diseases. 2nd edn. Roy. 8vo. Pp. 400. 1914 . W. Green. $21 s$.

Hunter, W. Pernicious Anæmia: its Pathology, Infective Nature, Symptoms, Diagnosis and Treatment, including Investigations on the Physiology of Hæmolysis. Large 8vo. Pp. 480) 1901. Griffin. 30s.

McGarrison, $R$. The Thyroid Gland in Health and Disease. Roy, 8vo. Pp. 304. 1918. Baillière. $16 s$.

The Etiology of Endemic Goitre. Demy 8vo. Pp. 222. 1913. Bale \& Danielsson. $10 s .6 d$.

Murray, G.R. Diseases of the Thyroid Gland. Part 1. Myxœdema and Cretinism. Demy 8vo. Pp. 120. 1900. Lewis. $7 s, 6 d$. ix. DISEASES OF THE HEART AND GIRCULATORY SYSTEM.

Allbutt, Sir T. C. Diseases of the Arteries, including Angina Pectoris. 2 Vols. 8vo. Pp. 550., 566. 1915. Macmillan. 30s.

Bishop, L. F. Arteriosclerosis. A Consideration of the Prolongation of Life and Efficiency after Forty. 2nd edn. Demy 8vo. Pp. 389. 1915. Frowde \& Hodder. 12s.6d.

Blackhall-Morison, A. The Sensory and Motor Disorders of the Heart: Their Nature and Treatment. Demy 8vo. Pp. ¿68. 1914. Baillière. 7s. $6 d$.

Broadbent, Sir W. H., and Sir J. F. H. Heart Disease and Aneurysm of the Aorta, with special Reference to Prognosis and Treatment. 4th edn. Pp.496. 1906. Baillière. $12 s .6 d$.

Brockbank, E. M. The Diagnosis and Treatment of Heart Disease. Practical Points for Students and Practitioners. 4th edn. Cr. 8vo. Pp. 166. 1919. Lewis. 5s.

Brunton, Sir T. L. Collected Papers on Circulation and Respiration. First Series. 8vo. Pp.710. 1906. Macmillan. $7 s, 6 d$. - Therapeutics of the Circulation. Fcap. 8vo. Pp. 536. 1916. Murray . 6s.

Caton, R. The Prevention of Valvular Disease of the Heart. Demy 8vo. Pp. 102. 1904. Cambridge University Press. 5s.

Cowan, J. Diseases of the Heart, with Chapters by W. T. Ritchie and A. J. Ballantyne. Demy 8vo. Pp. 447. 1914. Arnold. 15s.

Dampier-Bennett, A. G. Physical Methods in the Treatment of Heart Disease. Cr. 8vo. Pp.111. 1907. John Wright. 3s.6d.

Goulston, A. Cane Sugar and Heart Disease. Demy 8vo. Pp. 116. 1914. Baillière. 5s .

Haward, W. Phlebitis and Thrombosis: Hunterian Lectures. Cr.8vo. Pp.96. 1906. Baillière. $7 s .6 d$. 
Hay, J. Graphic Methods in Heart Disease. 2nd edn. Demy 8vo. Pp. 202. 1921. Frowde \& Hodder. $12 s, 6 d$.

Lea. E. Heart: Past and Present. Cr. 8vo. Pp.308. 1919. Baillière. $7 s .6 d$.

Mackenzie, Sir J. Diseases of the Heart. 3rd edn. Cr. 4to. Pp. 525. 1918. Frowde \& Hodder. 31s. 6 d.

-Principles of Diagnosis and Treatment in Heart Affection. Demy 8vo. Pp. 272. 1916. Frowde \& Hodder. 8s. 6d.

Poynton, F. J. Heart Disease. Including Thoracic Aneurysm. $\mathrm{Cr}$. 8vo. Pp. 320. 1907. Frowde \& Hodder. $6 s$.

Price, F. W. Diseases of the Heart. Their Diagnosis, Prognosis, and Treatment by Modern Methods, with a Chapter on the ElectroCardiograph. Demy 8vo. Pp.468. 1918. Frowde \& Hodder. 21s.

Ritchie, W. T. Auricular Flutter. 8vo. Pp. 156. 1914. W. Green. $10 s .6 d$.

Russell, W. The Sphygmometer : its Value in Practical Medicine. Demy 8vo. Pp. 157. 1921. Baillière. $7 s .6 d$.

Sutherland, G. A. The Heart in Early Life. Cr. 8vo. Pp. 227. 1914. Frowde \& Hodder. 6s.6d.

Thorne, L.T. The 'Nauheim' Treatment, in England, of Di eases of the Heart and Circulation. 5th edn. Cr.8vo. Pp.168. 1918. Baillière. 5s.

Thorne, W.B. The Schott Methods of the Treatment of Chronic Diseases of the Heart : with an Account of the Nauheim Baths, and of the Therapeutic Exercises. 5th edn. 8vo. Pp. 140. 1906. Churchill. $5 s$.

Trotter, L. B. C. Embolism and Thrombosis of theMesentericVessels. Demy 8vo. Pp. 156. 1913. Cambridge University Press. 8s.
Verdon, W. Angina Pectoris. Demy 8vo. Pp. 430. 1920. Baillière. $18 s .6 d$.

Wilson, R. McN. The Hearts of Man. Cr. 8vo. Pp. 202. 1918. Frowde \& Hodder. $6 s$.

- and Carroll, J.A. The Nervous Heart : its Nature, Causation, Prognosis, and Treatment. Cr. 8vo. Pp. 144. 1919. Frowde \& Hodder. $6 s$.

Wilson, T.S. The Early Diagnosis of Heart Failure, and other Essays on the Heart and Circulation. 8vo. Pp. 617. 1915. Murray. 15s.

\section{DISEASES OF THE RESPIRA - TORY SYSTEM.}

Adam, J. Asthma and its Radical Treatment. Cr. 8vo. Pp. 192 . 1913. Kimpton. 6s.

Allen, R.W. The Bacterial Diseases of Respiration, and Vaccines in their Treatment. Roy. 8vo. Pp. 246. 1913. Lewis. $9 s$.

Anderson, H. G. The Medical and Surgical Aspects of Aviation, with Chapters on Applied Physiology of Aviation, by M. Flack, and the Aero-Neuroses of War Pilots, by $O$. H. Gotch. Demy 8vo. Pp.271. 1919. Frowde \& Hodder. 12s, $6 d$.

Berkart, J . B . "Nervous Asthma.' The Pathology and Treatment. 8vo. Pp. 54. 1916. Oxford University Press. 3s. 6d.

Brockbank, E. M., and Rams bottom, A. The Clinical Examination of Diseases of the Lungs. Cr. 8vo. Pp. 96. 1921. Lewis. $4 s, 6 d$.

Gruchet, R., and Moulinier, T . Air Sickness : its Nature and Treatment. Translated by J. R. Earp. Fcap. 8vo. Pp. 110. 1920. Bale \& Danielsson. $5 s$.

Hamilton, D. J . On the Pathology of Bronchit is, Catarrhal Pneumonia, Tubercle, and Allied Lesions of the Human Lung. 8vo. Pp. 260 . 1883. Macmillan. 8s.6d. 
Hood, D. W . C. Some of the Clinical Aspects of Pneumonia. Demy 8vo. Pp.125. 1907. Bale \& Danielsson. 5s.

Knuthsen, L. F. B. Obstinate Hiccough: the Physiology, Pathology, and Treatment. Roy. 8vo. Pp. 180. 1902. Churchill. 6s.

Lindsay, J . A. Lectures on Diseases of the Lungs. 2nd edn. 8vo. Pp. 520. 1906. Baillière. $10 s, 6 d$.

Mann, Dr. Atlas of Killian's Tracheo-Bronchoscopy. 15 coloured Plates representing Pathological Preparations from cases examined during life by means of Tracheo-Bronchoscopy. Translated by T. Guthrie. Demy Folio. 1911. Bale \& Danielsson. $22 s$.

West, S. Diseases of the Organs of Respiration. An Epitome of the Etiology, Patbology. Symptoms, Diagnosis and Treatment of Diseases of the Lungs and Air Passages. 2nd edn. 2 Vols. Large 8vo. P 934. 1909. Griffin. 42s.

White, R. P. Catarrhal Fevers, commonly called Colds: their Causes, Consequences, Control and Cure. Demy 8vo. Pp. 119. 1902. Lewis. $4 s$.

Xi. DISEASES OF THE DIGES TIVE SYSTEM AND OF THE STOMACH.

Abrahams, A. Indigestion. The 4th edn. of Herschell's Text-book. Demy 8vo. Pp. 228. 1920. Arnold. $10 s .6 d$.

Bolton, C. Ulcer of the Stomach. Demy 8vo. Pp. 412. 1913. Arnold. 15s.

Bosanquet, W. C. The Stomach, Pancreas, and Intestines. Large Cr. 8vo. Pp. 674. 1910. Bale \& Danielsson. 12s. 6d.

Brunton, Sir T. L. Disorders of Digestion: Their Consequences and Treatment. 8vo. Pp. 406. 1910. Macmillan. 10s. $6 d$.

On Disorders of Assimilation, Digestion, etc. 8vo. Pp. 516. 1904. Macmillan. 10s. $6 d$.
Cobb, I. G. The Organs of Internal Secretion, their Diseases and Therapeutic Application. A Book for General Practitioners. 2nd edn. Cr.8vo. Pp. 288. 1918. Baillière. $8 s .6 d$.

Dutton, T. Indigestion clearly Explained, Treated, and Dieted. 7th edn. Cr. 8vo. Pp, 220. 1911. Kimpton. 3s. 6d.

Fenwick, W.S. Ulcer of the Stomach and Duodenum, and its Consequences. Roy. 8vo. Pp. 400. 1900. Churchill. 10s.6d.

Hunter, G. Oral Sepsis as a Cause of Septic Gastritis, Toxic Neurit is, and other Septic Conditions; with Illustrative Cases. Demy 8vo. Pp. 30. 1901. Cassell. 3s.6d.

Langenhagen, M. de. Muco-Membranous Entero-Colitis: Symptoms, Complications. Etiology and Treatment. Fcap. 8vo. Pp.121.1903. Churchill. 3s. $6 d$.

Peters, O. H. Observations upon the Natural Histology of Epidemic Diarrhcea. Roy. 8vo. Pp. 178. 1911. Cambridge University Press. $7 s$.

Pickerill, H. D. Stomatology in General Practice; a Text-book of Diseases of the Teeth and Mouth for Practitioners. Demy 8vo. Pp. 280. 1912. Frowde \& Hodder. $17 s$.

Saundby, R. The Treatment of Diseases of the Digestive System. 2nd edn. Cr. 8vo. Pp. 191. 1914. Griffin. $4 s, 6 d$.

Smith, J.S.K. The Cure of Obesity and Obese Heart. Cr. 8vo. Pp. 102. 1916. Churchill. 3s. 6d.

\section{xii. DISEASES OF THE LIVER AND GALL BLADDER.}

Robson, Sir A. W. M. Diseases of the Gall-Bladder and Bile-Ducts. 3rd edn. Demy 8vo. Pp. 501. 1904. Baillière. $15 \mathrm{~s}$.

Rolleston, Sir H. D. Diseases of the Liver, Gall Bladder, and BileDucts. 2nd edn. 8vo. Pp. 828. 1912. Macmillan. 31s. 6d. 


\section{xiii. DISEASES OF THE} INTESTINES.

Bigg, G. S. Indigestion, Constipation, and Liver Disorder. Cr. 8vo. Pp. 176. 1913. Baillière. 3s. 6d.

Bryce, A. Intestinal Toxœmia, or Auto-Intoxication in the causation of Disease. Cr. 8vo. Pp. 192. 1921. Melrose. 6s.

Harley, V., and Goodbody, F. The Chemical Investigation of Gastric and Intestinal Diseases by the Aid of Test Meals. Demy 8vo. Pp. 269. 1906. Arnold. 8s.6d.

Hurst, A. F. The Sensibility of the Alimentary Canal. Demy 8vo. Pp. 83. 1911. Frowde \& Hodder. $6 s$.

Constipation and Allied Intestinal Disorders. 2nd edn. Demy 8vo. Pp. 460. 1919. Frowde \& Hodder . $16 s$.

White, W. H., Andrewes, Sir F.W., Harley, V., Saundby, R., Lane, Sir W. A., and Colyer, J. F. Alimentary Toxœmia: its Sources, Consequences, and Treatment. Roy . 8vo. Pp. 384. 1913. Longmans. 4s. $6 d$.

\section{xiv. DISEASES OF THE}

\section{RECTUM AND PERITONEUM.}

Ball, Sir C. B. The Rectum: Its Diseases and Developmental Defects. Cr. 4to. Pp. 332. 1910. Frowde \& Hodder. 20s.

Cripps, H. On Diseases of the Rectum and Anus. 4th edn. 8vo. Pp.602. 1913. Churchill.10s.6d.

Edwards, F. S. Diseases of the Rectum, Anus and Sigmoid Colon. Being the 3rd edn. of Cooper and Edwards' Diseases of the Rectum and Anus. 8vo. Pp. 456. 1908. Churchill. 10s. 6d.

Hawkins, H. P. Diseases of the Vermiform Appendix: with a Consideration of the Symptoms and Treatment of the Resulting Forms of Peritonitis. 8vo. Pp. 148. 1895. Macmillan. $7 s$.
Mummery, J.P.L. The Sigmoidoscope. A Clinical Handbook on the Examination of the Rectum and Pelvic Colon. Cr.8vo. Pp. 90. 1906. Baillière. $3 s .6 d$.

-Diseases of the Rectum and Anus .

Demy 8vo. Pp. 358. 1914.

Baillière. $10 s$.

\section{Xv. DISEASES OF THE GENITO -} URINARY SYSTEM.

Cammidge, P. I. Glycosuria and Allied Conditions. Demy 8vo. Pp. 475. 1913. Arnold. 18s.

Cooper, A. The Sexual Disabilities of Man and their Treatment and Prevention. 4th edn. Cr. 8vo. Pp. 274. 1920. Lewis. 7s.6d.

Corbett-Smith, A. The Problem of Sex Diseases. A Study in the Causes, Svmptoms, and Erlects of Sexual Disease, and the Education of the Individual therein. 2nd edn. Roy. 8vo. Pp. 123. 1920. Bale \& Danielsson. $2 s, 6 d$.

Corner, E. M. Male Diseases in General Practice. An Introduction to Andrology. Demy 8vo. Pp. 478. 1910. Frowde \& Hodder. $17 s$.

Dalton, G. A Practical Manual of Venereal and Generative Diseases: Spermatorrhoea, Sterility and Impotence in both sexes. Cr.8vo. Pp. 164. 1913. Kimpton. 5s.

Eccles, W. McA. The Imperfectly Descended Testis: its Anatomy, Physiology, and Pathology. Cr. 8vo. Pp. 152. 1903. Baillière. 7s. $6 d$.

Fenwick, E.H. Obscure Diseases of the Urethra. 8vo. Pp. 160. 1902. Churchill. 6s.6d.

Kidd, F. Common Diseases of the Male Urethra. 2nd edn. 8vo. Pp. 144. 1919. Longmans. $6 s$.

\section{xvi. DISEASES OF THE KIDNEYS .}

Billington, W. Movable Kidney : its Etiology, Pathology, Diagnosis, Symptoms, and Treatment. Demy 8vo. Pp. 168. 1910. Cassell. 7s. $6 d$. 


\section{Medicine.}

Blum, V. Renal Diagnosis in Medicine and Surgery. Translated by W. B. Christopherson. Demy 8vo. Pp. 152. 1914. Bale \& Danielsson. $7 s, 6 d$.

Herringham, Sir W. P., and Williamson, H. Kidney Diseases. Demy 8vo. Pp. 394. 1912. Frowde \& Hodder. $17 s$.

Kidd, F. Common Infections of the Kidneys: Demy 8vo. Pp. 331. 1920. Frowde \& Hodder. 18s.

Macleod, J. J. R. Diabetes: Its Pathological Physiology. Demy 8vo. Pp. 224. 1913. Arnold. 10s. $6 d$.

Pavy, F. W. On Carbohydrate Metabolism, with an Appendix on the Assimilation of Carbohydrate into Proteid and Fat, followed by the Fundamental Principles and the Treatment of Diabetes Dialectically Discussed. Demy 8vo. Pp. 150. 1906. Churchill. 6s.

Wilson, H. W., and Howell, C. M. H. Movable Kidney: Its Pathology, Symptoms and Treatment. Demy 8vo. Pp. 112. 1908. Arnold. 4s. $6 d$.

\section{xvii. DISEASES OF THE BLADDER.}

Fenwick, E. H. Operative and Inoperative Tumours of the Urinary Bladder: A Clinical and Operative Study based on 500 Cases. 8vo. Pp. 120. 1901. Churchill. 5s.

Ulceration of the Bladder: Simple, Tuberculous and Malignant: a Clinical Study. 8vo. Pp. 85. 1900. Churchill. 5s.

\section{xviii. DISEASES OF THE ABDOMEN.}

Adams, J.E., and Cassidy, M. A. Acute Abdominal Diseases, including Abdominal Injuries and the Complications of External Hernia. Demy 8vo. Pp. 582. 1913. Baillière. 12s. $6 \mathrm{~d}$.

Battle, W. H. The Acute Abdomen. 2nd edn. Demy 8vo. Pp. 306 . 1914. Constable. 10s. $6 d$.
Bishop, E. S. Essentials of Pelvic Diagnosis : with Illustrative Cases. And an Appendix on the Examination of the Blood by C. H. Melland. Demy 8vo. Pp. 207. 1903. John Wright. 9s.6d.

Chubbe, C. P. B. The Diagnosis and Treatment of Intussusception. 2nd edn. Demy 8vo. Pp. 101. 1921. Frowde \& Hodder. 7s.6d.

Corner, E. M. Clinical and Pathological Observations on Acute Abdominal Diseases, Due to Conditions of the Alimentary Tract and the Uniformity of their Origin. Demy 8vo. Pp. 98. 1904. Constable. $3 s .6 d$.

Lennander, K. G. Observations on the Sensibility of the Abdominal Cavity. Translated by A. E. Barker. Demy 8vo. Pp. 76. 1903. Bale and Danielsson. $3 s$.

Sawyer, J.E.H. Physical Signs of Diseases of the Thorax and Abdomen. Cr. 8vo. Pp. 200. 1908. Baillière. $5 s$.

\section{Xix. TROPICAL MEDICINE.}

Balfour, A. War Against Tropical Disease. Cr. 4to. Pp. 219. 1920. (Wellcome Bureau of Scientific Research), Baillière. $12 s, 6 d$.

Brooke, G. E. Aids to Tropical Medicine. 2nd edn. Fcap. 8vo. Pp. 238. 1917. Baillière. 3s. 6d. _ Medico Tropical Practice. 2nd edn. Cr. 8vo. Pp. 522. 1920. Griffin. $18 s$.

Brown, W. G. Sprue and its Treatment. Fcap.4to. Pp. 270. 1908. Bale \& Danielsson. $6 s$.

Gastellani, A., and Chalmers, A.J. Manual of Tropical Medicine. 3rd edn. Demy 8vo. Pp. 2,448 . 1919. Baillière. $45 s$.

Crispin, E. S. The Prevention and Treatment of Diseases in the Tropics. Pocket size. Pp. 96. 1912. Griffin. 1s. 6d. 
Daniels, C. W. Tropical Medicine and Hygiene. 3 Parts. 2nd edn. Demy 8vo. Part 1. Diseases due to Protozoa. 1913. Part 2. Diseases due to Metazoa, and an Article on Venomous Snakes, by A. Alcock. 1914. Part 3. Diseases due to Bacteria and other Vegetable Parasites, etc. 1917. Bale \& Danielsson. $8 s, 6 d$. each. and Newham, H. B. G. Laboratory Studies in Tropical Medicine. 4th edn. Demy 8vo. 1918. Bale \& Danielsson. 21s.

Fothergill, C. F. Blood Examination and its Value in Tropical Disease. Cr. 8vo. Pp. 42. 1907. Kimpton. $2 s, 6 d$.

Giles, G. M. A Handbook of the Gnats or Mosquitoes, including a Revision of the Anophelinæ. For the use of Students of Tropical Medicine, giving the Anatomy and LifeHistory of the Culicidæ. 2nd edn . Roy. 8vo. Pp. 542. 1902. Bale \& Danielsson. 23s.6d.

A Revision of the Anophelinæ. A First Supplement to the above. Roy. 8vo. Pp. 47. 1904. Bale \& Danielsson. 2s.6d.

Graham-Smith, G. S. Flies in Relation to Disease: Non-bloodsucking Flies. 2nd edn. Demy 8vo. Pp. 405. 1914. Cambridge University Press. 15s.

Hindle, E. Flies in Relation to Disease: Bloodsucking Flies. Demy 8vo. Pp. 414. 1914. Cambridge University Press. $15 s$.

Lambart, H. C. A Practical Handbook of the Tropical Diseases of Asia and Africa. Large Cr. 8vo. Pp. 339. 1914. Griffin. 10s, 6d.

Manson, Sir P. Tropical Diseases : A Manual of the Diseases of warm Climates. Edited by P.H. MansonBahr. 7th edn. Demy 8vo. Pp. 976. 1921. Cassell. 31s. 6d.

- Lectures on Tropical Diseases. Demy 8vo. Pp. 238. 1905. Constable. $7 s, 6 d$.
Masters, W. E. Essentials of Tropical Medicine. Large 8vo. Pp. 609. 1920. Bale \& Danielsson. $42 s$.

Wenyon, C. M., and O'Connor, F. W. Human Intestinal Protozoa in the Near East. Cr. 4to. Pp. 220. 1918. Bale \& Danielsson. $10 s .6 d$.

\section{xx. OGGUPATIONAL DISEASES.}

Gollis, E. L., and Greenwood, M. The Health of the Industrial Worker. With a Chapter on Reclamation of the Disabled, by A. J. Collis. Roy. 8vo. Pp. 470. 1921. Churchill. $30 s$.

Hill, L. Caisson Sickness, Demy 8vo. Pp. 266. 1912. Arnold. 10s. $6 d$.

Mosso, A. Fatigue. Translated by M. and W. R.Drummond. 3rd edn. Cr. 8vo. Pp. 334. 1915. Allen \& Unwin. 3s. 6d.

Oliver, Sir T. Diseases of Occupation: from the Legislative, Social, and Medical Points of View. 3rd edn. Demy 8vo. Pp. 496. 1916. Methuen. 15s.

- Occupations from the Social, Hygienic and Medical Points of View. Demy 8vo. Pp. 120. 1916. Cambridge University Press. $8 s .6 d$.

Parry, L. A. The Risks and Dangers to Health of Various Occupations and their Prevention. Demy 8vo. Pp. 196. 1900. Scott, Greenwood. $8 s, 6 d$.

Saundby, R. Old Age: Its Care and Treatment. Demy 8vo. Pp. 312. 1913. Arnold. 8s. 6d.

Weber, Sir H. On Longevity and Means for the Prolongation of Life. 5th edn. 8vo. Pp. 314. 1919. Macmillan. $12 s$. 


\section{SURGERY.}

\section{i. GENERAL TREATISES.}

Back, I., and Edwards, A. T. Synopsis of Surgery . Cr. 8vo. Pp. 480. 1920. Churchill. 15s.

Barnett, H. N. (edited by). The Student's Text-book of Surgery. By various contributors. Roy. 8vo. Pp. 796. 1916. Heinemann. $21 s$.

Bland -Sutton, Sir J. Selected Lectures and Essays, including Ligaments and Morphology. 4th edn. Demy 8vo. Pp. 330. 1920. Heinemann. 15s.

Gaird, F. M., and Gathcart, C. W. A Surgical Handbook, for Practitioners, Students, House-Surgeons, and Dressers. 19th edn. Pocket size. Pp. 379. 1921. Griffin. 8s. $6 d$.

Catechism Series. Surgery. 3rd edn. 5 parts. Written by C. R. Whittaker. 1s. 9d. each, also in one volume, cloth $9 s$. Livingstone.

Cheyne, Sir W. W., and Burghard, F. F. A Manual of Surgical Treatment. Revised and Re-Written with the assistance of T. P. Legg and A. Edmunds. 5 Vols. Roy. 8vo. Vol. 1. Pp. 576. 1914. 27s. 6d. Vol. 2. Pp. 598. 1912. 27s. 6d. Vol. 3. Pp. 604. 1916. 27s. 6d. Vol. 4. Pp.650. 1913. 30s. Vol. 5. Pp. 648. 1917. 30s. Longmans.

Choyce, C. G., and Beattie, J. M. (edited by). A System of Surgery. By various Contributors. 3 Vols. Med. 8vo. Vol.1. Surgical Pathology, Tumours, General Surgery, etc. Pp. 958. 1912. Vol. 2. Surgical Diseases of the Breast, Tongue and Mouth, Gastro-Intesttinal and Genito-Urinary Tracts, etc. Pp. 1106. 1912. Vol. 3. Surgical Diseases of the Caroid-
Vascular, Lymphatic, Respiratory and Nervous Systems, Nose, Throat and Ear, Muscles, Tendons, Joints, Bones, etc. Pp. 902. 1914. Cassell. 30s . per vol.

Cooke, A. Groundwork of Surgery . Cr. 8vo. Pp. 191. 1919. Heffer. 7s. $6 d$.

Gunning, J. Aids to Surgery. 4th edn. Fcap. 8vo. Pp. 428. 1920. Baillière. 4s. $6 d$.

Elder, A. V. The Ship-Surgeon's Handbook. 2nd edn. Cr.8vo. Pp. 400. 1911. Baillière. $6 s$.

Gask, G. E., and Wilson, H. W. (edited by). Surgery. A Text-book by Various Authors. Roy. 8vo. Pp. 1250. 1920. Churchill. 42s.

Groves, E. W. H. Synor sis of Surgery : For Students and Practitioners. 5th edn. Cr. 8vo. Pp. 628. 1920. John Wright. 17s.6d.

Howard, R. The Practice of Surgery. 2nd edn. 2nd imp. Roy. 8vo. Pp. 1251. 1920. Arnold. $35 s$.

Lister, Lord. The Collected Papers. 2 vols. Demy 4to. Pp. 1,015. 1909. Vol. 1. Introductory Essay; Physiology; Pathology and Bacteriology. Vol. 2. Antiseptic Surgery; Surgery; Addresses. Oxford: Clarendon Press. $42 s$.

Morison, R. An Introduction to Surgery. Large 8vo. Pp. 162. 1920. John Wright. 8s. $6 d$.

Surgical Contributions from 1881-1916. 2 Vols. Large 8vo. 1916. Vol. 1. General Surgery. Pp. 427. 15s. Vol. 2. Abdominal Surgery. Pp. 953. 30s. John Wright. The 2 vols, 428. 
Power, Sir D'A. The Practitioner's Surgery. 3 Vols. Roy. 8vo. Pp. 672.,527.,587. 1919. Frowde \& Hodder. ${ }_{4} 14 s .6 \mathrm{~d}$.

Rose, W., and Carless, A. A Manual of Surgery for Students and Practitioners. 10th edn. Demy 8vo. Pp. 1558. 1920. Baillière. $30 s$.

Thomson, A., and Miles, A. A Manual of Surgery. 3 vols. $\mathrm{Cr}$. 8vo. Vol. 1. General Surgery. 5th edn. Pp. 828. 1919. 12s.6d. Vol. 2. Regional Surgery. 5th edn. Pp. 939. 1915. 12s.6 $d$. Vol. 3. Operative Surgery. 3rd edn. Pp. 637. 1920. 16s. Frowde \& Hodder.

Warren, R. A Text-book of Surgery . 2 vols. Roy. 8vo. Pp. 1500. 1915. Churchill. 27s.

\section{ii . OPERATIVE SURGERY .}

Allingham, H.W . Operative Surgery. Cr. 8vo. Pp. 382. 1903. Baillière. $7 s, 6 d$.

Burghard, F. F. (edited by). A System of Operative Surgery. By British Surgeons. 5 vols. 2nd edn. Roy. 8vo. 1914. Vol.1.Pp.736. 21s. Vol. 2. Pp. 717. 21s. Vol. 3. Pp. 755. 21s. Vol. 4. Pp. 521. 24s. Vol. 5. Pp. 275. 18s. Frowde \& Hodder. The set, $84 s$.

Catechism Series. Operative Surgery. 2nd edn. 3 Parts. Written by C. R. Whittaker. Part 1. Arteries, Nerves, Excisions, Thorax, Head and Neck. Part 2. Amputations. Part 3. Abdomen. 1s. 9d. each, also in one volume, eloth, $5 s, 6 d$. Livingstone.

Corner, E. M., and Pinches, H. J . Operations of General Practice. 3rd edn. Demy 8vo. Pp. 354. 1910. Frowde \& Hodder. $17 s$.

Fitzwilliams, D. C. L. A Manual of Operative Surgery, with Surgical Anatomy and Surface Markings. Demy 8vo. Pp. 458, 1913. Baillière. 10s, 6d.
Guthrie, C.C. Blood-Vessel Surgery and its Application. Demy 8vo. Pp. 376. 1912. Arnold. 15s.

Jacobson, W.H.A. The Operations of Surgery. 6th edn. Revised by R. P. Rowlands and $P$. Turner. 2 vols. Roy. 8vo. Pp. 1,040., 940. 1915. Churchill. 50s.

Lockwood C. B. Clinical Surgery. 2ndedn. Cr.8vo. Pp. 397. 1911. Frowde \& Hodder. 6s.

MacLennan, A. Surgical Materials and their Uses. Cr.8vo. Pp. 260. 1915. Arnold. 4s.6d.

Orrin, H. C. Aids to Operative Surgery. Fcap. 8vo. Pp. 244. 1921. Baillière. $6 s$.

Pearson, G. Y. Modern Surgical Technique in its Relation to Operations and Wound-Treatment. 2nd edn. Demy 8vo. Pp. 504. 1911. Bale \& Danielsson. 10s. $6 d$.

Schmieden, V., and Turnbull, A. The Course of Operative Surgery. A Handbook for Practitioners and Students. 2nd edn. Roy. 8vo. Pp. 369. 1920. Baillière. 25s.

Short, A.R. When to Advise Operation in General Practice. Cr.8vo. Pp. 279. 1916. John Wright. $7 s, 6 d$.

Smith, E.A. Suture of Arteries. An Experimental Research. Demy 8vo. Pp. 70. 1909. Frowde \& Hodder. $2 s, 6 d$.

Spencer, W. G. Animal Experiments and Surgery. Cr. 8vo. Pp. 187. 1920. University of London Press. 6s.

Taylor, E. H. Operative Surgery: The Head and Neck, the Thorax, the Abdomen. Cr. 4to. Pp. 536. 1914. Churchill. 32s.

Treves, Sir F ., and Hutchinson, $J$. The Student's Handbook of Surgical Operations. 3rd edn. Cr. 8vo. Pp. 512. 1911. Cassell. 9s.

Tubby, A. H., and Jones, R. Modern Methods in the Surgery of Paralyses. Ex. Cr. 8vo. Pp. 326. 1903. Macmillan. 10s. 
Waring, H. J. Manual of Operative Surgery. 4th edn. Cr. 8vo. Pp. 778. 1912. Frowde \& Hodder. 14s.

Wheeler, Sir W. I . de C. Handbook of Operative Surgery. 3rd edn. Demy 8vo. Pp. 372. 1918. Baillière. 12s.

\section{iii. DIAGNOSIS (INGLUDING X-RAY DIAGNOSIS).}

Carson, H. W. Aids to Surgical Diagnosis. Fcap. 8vo. Pp. 148. 1906. Baillière. $3 s .6 d$.

Davidson, Sir J. M. Localization by X-Rays and Stereoscopy . Roy. 8 vo. Pp. 83. 1916. Lewis $9 s$.

Gage, H. C. X-Ray Observations for Foreign Bodies and their Localisation. Demy 8vo. Pp. 96 . 1920. Heinemann. 6s.

Gould, Sir A. P. and E. P. Elements of Surgical Diagnosis. 5th edn. Fcap. 8vo. Pp. 722. 1919. Cassell. 12s. 6d.

Rea, R. L. Chest Radiography at a Casualty Clearing Station. $\mathrm{Cr}$. 4to. Pp. 24 and Atlas. 1919. Lewis. $15 s$.

\section{iv. SURGICAL THERAPEUTICS} AND PATHOLOGY.

Bowlby, Sir A.A., and Andrewes, Sir F. W. Surgical Pathology and Morbid Anatomy. 7th edn. Med. 8vo. Pp. 660. 1920. Churchill. $30 s$.

Doyen, E., and Spencer-Browne, H. Surgical Therapeutics and Operative Technique. 3 vols. Large Roy. 8vo. Vol. 1. General Technique, Treatment of Cancer, Operations on the Bloodvessels, Nerves, Surgery of the Head. Pp. 756 . 1917. Vol. 2. Surgery of the Head (contd.), of the Thorax, Upper and Lower Extremities. Pp. 688. 1920. Vol. 3. Operations on the Abdomen, Pelvis, and GenitoUrinary Organs. $\mathbf{P}_{\rho}$. 822. 1920. Baillière. 3 vols., £5.
Elmslie, R. C. The After Treatment of Wounds and Injuries. 8vo. Pp. 332. 1919. Churchill. 15s.

Mummery, J. P. L. After-Treatment of Operations. 4th edn. Cr. 8vo. Pp. 286. 1916. Baillière. $6 s$.

Todd, A. H. A Practical Handbook of Surgical After-Treatment. Cr. 8vo. Pp. 268. 1915. Arnold. $5 s$.

Turner, W., and Carling, E. R. Treatment after Operation: with a chapter on the Eye, by $L$. V. Cargill. Demy 8vo. Pp. 248. 1912. University of London Press. $10 s .6 d$.

\section{v. ANAESTHETICS.}

Barton, G. A. H. A Guide to the Administration of Ethyl-Chloride. 2nd edn. Demy 8vo. Pp. 54. 1907. Lewis. $2 s$.

Blomfield, J. Anæsthetics. A Practical Handbook. 4th edn. Cr. 8vo. Pp. 151. 1918. Baillière. $6 s$.

Boyle, H. E. G. Practical Anæsthetics. 2nd edn. Cr. 8vo. Pp. 219. 1911. Frowde \& Hodder. $6 s$.

Buxton, D. W. Anæsthetics: their Uses and Administration. 6th edn. Demy 8vo. Pp. 562. 1920. Lewis. $21 s$.

Collum, R. W., and Gray, Sir H. W. M. The Practice of Anæsthetics and General Surgical Technique. Large Cr. 8vo. Pp. 398. 1909. Bale \& Danielsson. $10 s$.

Gardner, H.B. Surgical Anæsthesia . 2nd edn. Demy 8vo. Pp. 232. 1916. Baillière. 8s. $6 d$.

Hirschel, G. Text-book of Local Anæsthesia, for Students and Practitioners. Translated by R. E. S. Krohn. Roy. 8vo. Pp. 193. 1915. Bale \& Danielsson. 8s. $6 d$.

Hobday, F. T. G. Anæsthesia and Narcosis of Animals and Birds. Demy 8vo. Pp. 98. 1915. Baillière. 5s. 
Lawrie, E. Chloroform: A Manual for Students and Practitioners. $\mathrm{Cr}$. 4to. Pp. 120. 1901. Churchill. $5 s$.

Luke, T. D. Guide to Anæsthetics for the Student and Practitioner. 4th edn. 8vo. Pp. 165. 1908. W. Green. 5s.

Mortimer, J. D. Anæsthesia and Analgesia. Cr. 8vo. Pp. 384. 1911. University of London Press . $6 s$.

Probyn-Williams, R. J. A Practical Guide to the Administration of Anæsthetics. 2nd edn. Cr. 8vo. Pp. 236. 1909. Longmans. 5s.6d.

Ross, J. S. A Handbook of Anæsthetics. With Chapters upon Local and Spinal Anæsthesia, by W. Q. Wood, and upon Intratracheal Anæsthesia, by H. T. Thomson. Cr. 8vo. Pp. 226. 1919. Livingstone. $7 s, 6 d$.

Silk, J. F. W. Modern Anæsthetics. 2nd edn. Cr.8vo. Pp. 206. 1920. Arnold. $7 s .6 d$.

vi. ASEPSIS AND ANTISEPSIS.

Lockwood, C. B. Aseptic Surgery. 3rd edn. Cr. 8vo. Pp.287. 1909. Frowde \& Hodder. $6 s$.

Upcott, H. Antiseptic Methods for Surgical Nurses and Dressers. Cr. 8vo. Pp. 60. 1907. Baillière. 2s. 6d.

Vallack, A. S. Principles and Practice of Asepsis. Cr. 8vo. Pp. 106. 1905. Baillière. 2s.6d.

\section{vii. NURSING.}

Bishop, E. S. Lectures on Surgical Nursing. Fcap. 8vo. Pp. 143. 1909. John Wright. 2s. 6d.

Childe, C. P. Surgical Nursing and Technique: A Book for Nurses, Dressers, House Surgeons, etc. 3rd edn. Cr. 8vo. Pp. 248. 1920. Baillière, $6 s$.

Darling, H. G. R. Surgical Nursing and After-treatment. Cr. 8vo. Pp. 500. 1917. Churchill. 8s.6d.
Howard, R. Surgical Nursing and the Principles of Surgery for Nurses. 4th edn. Cr.8vo. Pp. 336. 1920. Arnold. $7 s .6 d$.

Miles, A. Surgical Ward Work and Nursing. A Handbook for Nurses and others. 4th edn. Demy 8vo. Pp. 426. 1921. Scientific Press. 10s. $6 d$.

\section{viii. FRAGTURES.}

Groves, E. W. H. Modern Methods of Treating Fractures. Demy 8vo. Pp. 286. 1916. John Wright. 7s. $6 d$.

Imbert, L., and Réal, P. Fracture of the Lower Jaw. Edited by Sir J. F. Colyer. Cr.8vo. Pp. 188. 1918. University of London Press . $7 s .6 d$.

Leriche, R. The Treatment of Fractures. Edited by F. F. Burghard. 2 vols. Cr. 8vo. 1918. Vol. 1 . Fractures involving Joints. Pp. 240. Vol 2. Fractures of the Shaft. Pp. 330. University of London Press. 7s.6d. each vol.

Mennel1, J. B. The Treatment of Fractures by Mobilisation and Massage. 8vo. Pp. 474. 1911. Macmillan. 12s.

Pearson, M. G., and Drummond, J. Fractured Femurs. Their Treatment by Calliper Extension. 8vo. Pp. 104. 1919. Frowde \& Hodder. $10 s, 6 d$.

Pringle, J. H. Fractures and Their Treatment. Roy. 8vo. Pp. 396. 1910. Frowde \& Hodder. 17s.

Romer, F. Modern Bonesetting for the Medical Profession. Demy 8vo. Pp. 88. 1915. Heinemann. 5s.

Walton, A. J. Fractures and Separated Epiphyses. Demy 8vo. Pp. 296. 1910. Arnold. 10s. 6d.

\section{MINOR SURGERY ; BANDAG-} ING; EMERGENCIES, ETC.

Bidwell, L. A. Minor Surgery. 2nd edn. Demy 8vo. Pp. 300. 1912. University of London Press . $10 s .6 d$. 
Cope, V.z. Pye's Elementary Bandaging and Surgical Dressing. 14th edn. Pocket size. Pp. 232. 1919. John Wright. $3 s, 6 d$.

Fitzwilliams, D.C.L. A Practical Manual of Bandaging. Demy 8vo. $\mathrm{P}$. 100. 1915. Baillière. 4s.

MacLeod, J.M.H. Burns and their Treatment. Including Dermatitis from High Explosives. Fcap. 8vo. Pp. 179. 1918. Frowde \& Hodder. $6 s$.

Pye's Surgical Handicraft. A Manual of Surgical Manipulations, Minor Surgery, and other Matters connected with the work of House Surgeons, Surgical Dressers, etc. Edited and re-written by $\mathbf{W}$. $\mathbf{H}$. Clayton-Greene. 8th edn. Demy 8vo. Pp. 639. 1919. John Wright. $21 s$.

Rankin, W. Elements of Bandaging and the Treatment of Fractures and Dislocations. Cr. 8vo. Pp. 126. 1913. Frowde \& Hodder. 6s.

Sargent, P. Surgical Emergencies. Cr.8vo. Pp. 256. 1907. Frowde \& Hodder. $6 s$.

Williams, G. Minor Surgery and Bandaging : For the use of HouseSurgeons, Dressers, and Junior Practitioners. 17th edn. Cr. 8vo. Pp. 460. 1919. Churchill.10s.6d.

\section{x. WAR SURGERY AND GUN - SHOT WOUNDS.}

Dupuy, G. M. The Stretcher Bearer. Oblong Feap. 8vo. Pp. 160. 1915. Frowde \& Hodder. $2 s$.

Duval, P. War Wounds of the Lung: Notes on their Surgical Treatment. Authorised English Translation. Large 8vo. Pp. 99. 1918. John Wright. 8s. $6 d$.

Gray, Sir H. W. M. Early Treatment of War Wounds. Demy 8vo. Pp. 315. 1919. Frowde \& Hodder. $10 s$.

Grégoire, R., and Courcoax, Dr. Wounds of the Pleura and Lung. Edited by C. H. Fagge. Cr. 8vo. Pp. 234. 1919. University of London Press. $7 s, 6 d$.
Groves, E. W. H. Gunshot Injuries of Bones. Fcap. 8vo. Pp. 128. 1915. Frowde \& Hodder. 3s.6d.

Hughes, B., and Banks, H. S. War Surgery from Firing Line to Base. With special chapters by $L$. F. Smith and Miss C. Bilton. Roy. 8vo. Pp. 634. 1918. Baillière. $30 s$.

Hull, A.J ., and other contributors. Surgery in War. 2nd edn. 8vo. Pp.640. 1918. Churchill. 25s.

Makins, Sir G. H. Gunshot Injuries of the Arteries. Demy 8vo. Pp. 64. 1914. Frowde \& Hodder. $2 s .6 d$.

- Gunshot Injuries to the BloodVessels. Founded on Experience gained in France during the Great War, 1914-1918. Large 8vo. Pp. 251. 1919. John Wright. 21s.

Morison, J. R. Bipp Treatment of War Wounds. Fcap. 8vo. Pp. 71. 1918. Frowde \& Hodder. 2s. 6d.

Murphy, J.K. Wounds of the Thorax in War. Fcap. 8vo. Pp. 156. 1915. Frowde \& Hodder. 3s.6d.

Ombrédanne, Prof., and Ledoux Lebard, M. Localisation and Extraction of Projectiles. Edited by A. D. Reid. Cr. 8vo. Pp. 411. 1918. University of London Press . $12 s .6 d$.

Page, C. M. The Field Service Pocket-Book. Fcap. 8vo. Pp. 174. 1917. Frowde \& Hodder. 6s.

Penhallow, D. P. Military Surgery • 2nd edn. Demy 8vo. Pp. 575 . 1918. Frowde \& Hodder. 21s.

Sencert, L. Wounds of the BloodVessels. Edited by F. F. Burghard. Cr.8vo. Pp. 288. 1918. University of London Press. 7s. $6 d$.

Smith, F. Modern Bullet Wounds and Modern Treatment, with Special Regard to Long Bones and Joints, Field Appliances and First Aid. Cr. 8vo. Pp. 96. 1903 . Churchill. 3s.

Spencer, G. G. Gunshot Wounds. Cr. 8vo. Pp. 299. 1908. Frowde \& Hodder. 6s. 
Wallace, C. War Surgery of the Abdomen. 8vo. Pp. 152. 1918. Churchill. 10s. 6d.

and Fraser, J. Surgery at a Casualty Clearing Station. Cr. 8vo. Pp. 320. 1918. Black. 10s. 6d.

\section{Xi. REGIONAL SURGERY.}

a. Head and Neck.

Ballance, Sir G.A. Some Points in the Surgery of the Brain and its Membranes. 2nd edn. 8vo. Pp. 468. 1908. Macmillan. 15s.

- Fssays on the Surgery of the Temporal Bone. 2 Vols. Demy 4to. Pp. 278., 372. 1919. Macmillan. 105s.

Bell, W. B . The Pituitary. A Study of the Morphology, Physiology, Pathology, and Surgical Treatment of the Pituitary, together with an Account of the Therapeutic Uses of the Extracts made from this Organ. Roy. 8vo. Pp. 368. 1919. Baillière. $30 s$.

Bourget, J. Mis-shapen Noses and their Surgical Correction without Cicatrix. Roy. 8vo. Pp. 72. 1920. Baillière. 3s.

Chatelin, C., and De Martel, $\mathbf{T}$. Wounds of the Skull and the Brain : Clinical Forms and Medico-Surgical Treatment. Edited by F. F. Burghard. Cr. 8vo. Pp. 336. 1918. University of London Press . 8s.6d.

Martinier, P., and Lemerle, G. Injuries of the Face and Jaw and their Repair and the Treatment of Fractured Jaws. Translated by H. L. Whale. Small Cr. 8vo. Pp. 361. 1917. Baillière. 5s.

Murray, R. W. Hare Lip and Cleft Palate. Demy 8vo. Pp.29. 1902. Churchill. 3s.

Owen, E. Cleft-Palate and Hare Lip : the Earlier Operation on the Palate. Cr. 8vo. Pp. 112 . 1904 . Baillière. 2s.6d.

Rawling, L.B. The Surgery of the Skull and Brain. Cr.4to. Pp. 351 . 1912. Frowde \& Hodder. 25s. Surgery of the Head. Fcap. 8vo. Pp. 150. 1915. Frowde \& Hodder. 3s. $6 d$.
West, C. E., and Scott, S. R. The Operations of Aural Surgery, together with those for the Relief of the Intracranial complications of Suppurative Otitis Media. Demy 8vo. Pp. 213. 1909. Lewis. $7 s, 6 d$.

Whale, H. L. Injuries to the Head and Neck. Demy 8vo. Pp. 342 . 1919. Baillière. 15s .

\section{b. Lungs and Heart.}

Ballance, Sir C. A. The Bradshaw Lecture on the Surgery of the Heart. Delivered before the Royal College of Surgeons, Dec.11, 1919, Demy 8vo. Pp. 154. 1920. Macmillan. $10 s .6 d$.

Garrè, G., and Quincke, H. Surgery of the Lung. Translated from the German by D. M. Barcroft. 2nd edn. Roy. 8vo. Pp. 279. 1913. Bale \& Danielsson. 12s.6d.

\section{c. Abdomen .}

Abadie, G. Wounds of the Abdomen. Erited by Sir W. A. Lane. Cr.8vo. Pp. 316. 1918. University of London Press. 8s.6d.

Barnard, H. L. Contributions to Abdominal Surgery. Demy 8vo. Pp. 411. 1910. Arnold. $16 s$.

Battle, W. H., and Corner, E. M. The Surgery of the Diseases of the Appendix Vermiformis and their Complications. 2nd edn. Demy 8vo. Pp. 308. 1911. Constable. 10s. $6 d$.

Bidwell, A. L. A Handbook of Intestinal Surgery. 2nd edn. Demy 8vo. Pp. 230. 1910. Baillière. 6s.

Cripps, H. Cancer of the Rectum, especially considered with regard to its Surgical Treatment. 6th edn. 8vo. Pp. 266. 1913. Churchill. $5 s$.

Hill, W. On Gastroscopy. Demy 8vo. Pp. 54. 1912. Bale \& Danielsson. 3s. 6d.

Hood, D. W. C. The Early Treatment of Appendicitis. Demy 8vo. Pp. 42. 1900. Bale \& Danielsson. 2s. $6 d$. 
Lane, Sir W. A. Operative Treatment of Chronic Intestinal Stasis. 4th edn. Demy 8vo. Pp. 340. 1918. Frowde \& Hodder. 20s.

Lockwood, C. B . Appendicitis: its Pathology and Surgery. 2nd edn. 8vo. Pp. 356. 1906. Macmillan. $10 s$.

Maylard, A. E. Practice and Problem in Abdominal Surgery. Med. 8vo. Pp. 402. 1913. Churchill. $8 s .6 d$

Morison, J. R., and Richardson, W. G. Abdominal Injuries. Fcap. 8vo. Pp. 116. 1915. Frowde \& Hodder. 3s. $6 d$.

Mummery, J. P.L. Diseases of the Colon and their Surgical Treatment. Demy 8vo. Pp. 328. 1910. Baillière. $10 s$.

Owen, E. Appendicitis: A Plea for Immediate Operation. Cr. 8vo. Pp. 214. 1914. John Wright. 3s. $6 d$.

Robson, Sir A. W. M., and Cam midge, P. J. Gall-Stones: Their Complications and Treatment. $\mathrm{Cr}$. 8vo. Pp. 326. 1909. Frowde \& Hodder. $6 s$.

- and Moynihan, Sir B. G. A. Diseases of the Stomach and their Surgical Treatment. 2nd edn. Demy 8vo. Pp.524. 1904. Baillière. $15 s$.

Wallis, Sir F. C. Surgery of the Rectum for Practitioners. Demy 8vo. Pp. 370. 1912. Frowde \& Hodder. 17s.

- Surgery of the Rectum. 8vo. Pp. 174. 1907. Baillière. 6s.

\section{d. Amputations.}

Broca, A. Ligations and Amputations for Students and Practitioners. Translated by E. Ward. Demy 8vo. Pp. 285. 1917. John Wright. 8s. $6 d$.

Huggins, G . M. Amputation Stumps - Their Care and After Treatment. Fcap. 8vo. Pp. 240. 1918. Frowde \& Hodder. 7s. $6 d$.

\section{e. Genito-Urinary Organs.}

Clarke, W. B. Handbook of the Surgery of the Kidneys. Demy $8 v 0$. Pp. 209, 1911. Frowde \& Hodder. $12 s, 6 d$.

Deanesly, E. Modern Methods of Diagnosis in Urinary Surgery. Cr. 8vo. Pp. 104. 1907. Lewis. 8s.

Freyer, Sir P.J. Clinical Lectures on Enlargement of the Prostate, with a description of the Author's Operation of Total Enucleation of the Organ. 5th edn. Demy 8vo. Pp. 182. 1920. Baillière. $10 s$. $6 d$.

Clinical Lectures on the Surgical Diseases of the Urinary Organs. 2nd edn. in preparation. Baillière.

Herring, H. T. The Sterilisation of Urethral Instruments, and their Use in some Urinary Complaints. Demy 8vo. Pp. 192. 1903. Lewis. $5 s$.

Kidd, F . Urinary Surgery: A Review . 8vo. Pp. 446. 1910. Longmans. $7 s .6 d$.

Lumb, N. P. L. The Urethroscope in the Diagnosis and Treatment of Urethritis. Demy 8vo. Pp. 64, and 13 Plates. 1919. Bale \& Danielsson. $10 s .6 d$.

Walker, J.W. T. Surgical Diseases and Injuries of the Genito-Urinary Organs. 2nd edition in preparation. Cassell.

Estimation of the Renal Function in Urinary Surgery. Demy 8vo. Pp. 274. 1908. Cassell. 78.6d.

Wallace, Sir G. S. Prostatic Enlargement. Demy 8vo. Pp. 222. 1907. Frowde \& Hodder. $14 s$.

\section{xii. SURGICAL DISEASES.}

\section{a. Hernia.}

Eccles, W. McA. Hernia : Its Etiology, Symptoms, and Treatment. 3rd edn. Demy 8vo. Pp. 254, 1908. Baillière. $7 s .6 d$.

Moullin, G. W. M. The Surgical Treatment of Ulcer of the Stomach. Demy 8vo. Pp. 53. 1902. Bale \& Danielsson. 2s. $6 d$. 
Murray, R. W. Hernia: Its Cause and Treatment. 2nd edn. 8vo. Pp. 192. 1910. Churchill. 6s .

Turner, P. Inguinal Hernia: The Imperfectly Descended Testicle and Varicocele. 8vo. Pp. 110. 1919. Churchill. 10s. 6d.

\section{b. Tumours.}

Bland-Sutton, Sir J. Tumours, Innocent and Malignant. 6th edn. Demy 8vo. Pp. 780. 1917 . Cassell. 21s.

Cathcart, C. W. The Essential Similarity of Innocent and Malignant Tumours. A Study of Tumour Growth. Imp. 8vo. Pp.79. 1907. John Wright. $3 s$.

Emery, W. D'E. Tumours: their Nature and Causation. Cr. 8vo. Pp. 166. 1918. Lewis. 6s.

Fenwick, W. S. Cancer and other Tumours of the Stomach. Roy. 8vo. Pp. 380. 1902. Churchill. 10s. $6 d$.

Kettle, E. H. The Pathology of Tumours. Demy 8vo. Pp. 232. 1916. Lewis. 12s. $6 d$.

Lockyer, C. Fibroids and Allied Tumours (Myoma and Adenomyoma): their Pathology, Clinical Features, and Surgical Treatment. Super Roy. 8vo. Pp. 624. 1919. Macmillan. $63 s$.

Moullin, C. M. The Biology of Tumours. Demy 8vo. Pp. 55 . 1916. Lewis. 2s, 6d.

White, C. P. Tumours: Pathology of Growth. Demy 8vo. Pp. 247. 1913. Constable. 10s. 6d.

Wyllie, J. Tumours of the Cerebellum. Post 8vo. Pp. 119. 1908. Lewis. $4 s$.

\section{c. Diseases of the Locomotive System.}

Bristow, W. R. Treatment of the Joint and Muscle Injuries. Demy 8vo. Pp. 160. 1917. Frowde \& Hodder. 6s.
Broca, A. Disabilities of the Locomotor Apparatus: the Result of War Wounds. Translated by J, R. White, edited by Sir R. Jones. Cr. 8vo. Pp. 268. 1918. University of London Press . $7 s, 6 d$.

Jones, Sir R. Injuries to Joints. 2nd edn. Fcap. 8vo. Pp. 196. 1920. Frowde \& Hodder. $6 s$.

Shenton, E. W. H. Disease in Bone and its Detection by the X-Rays. 8vo. Pp. 84. 1911. Macmillan. $4 s .6 d$.

White, J. R. Chronic Traumatic Osteomyelitis: Its Pathology and Treatment. Demy 8vo. Pp. 159. 1919. Lewis. 12s, $6 d$.

Whitelocke, R. H. A. Sprains and Allied Injuries of Joints. 2nd edn. Demy 8vo. Pp.299. 1910. Frowde \& Hodder. 8s. 6d.

\section{xiii. ORTHOPADIC SURGERY}

Broca, A., and Ducroquet, D. Artificial Limbs. Translated and edited by R. C. Elmslie. Cr. 8vo. Pp. 172. 1918. University of London Press. $7 s, 6 d$.

Calot, F. Indispensable Orthopædics . Translated from the French by $A$. H. Robinson. 2nd edn, in preparation. Baillière.

Dampier-Bennett, A. G. Re-education of Co-ordination by Movements: with special Reference to Locomotor Ataxy. 8vo. 1907. John Wright. 10s, 6d.

Daw, S. W. Orthopædic Effects of Gunshot Wounds and their Treatment. Feap. 8vo. Pp.242. 1919. Frowde'\& Hodder. $7 s .6 d$.

Falconer, W. W. Arthrometry, or the Measurement of the Movements of Joints. Notes of a New and Simple System for showing the Mobility of injured limbs by means of an Instrument called an Arthrometer. Demy 8vo. Pp. 27. 1918. Bale \& Danielsson. $2 s .6 d$.

Jansen, M. On Bone Formation, its Relation to Tension and Pressure. 8vo. Pp. 124. 1921. Longmans. $20 s$. 
Jones, Sir R., (edited by). Orthopædic Surgery of Injuries. By Various Authors. 2 Vols. Roy. 8vo. Pp. 540., 692. 1921. Frowde \& Hodder. 70s.

- Notes on Military Orthopædics. Demy 8vo. Pp. 143. 1918. Cassell. 3s. $6 d$.

Lorenz, A., and Saxl, A. Orthopædics in Medical Practice. Translated by L. C. P. Ritchie. Demy 8vo. Pp. 300. 1913. Bale \& Danielsson. $7 s, 6 d$.

Roth. P. B . Notes on Military Orthopædics. Cr. 8vo. Pp. 56. 1916. Kimpton. 1s.6d.

- Orthopædics for Practitioners. An Introduction to the Practical Treatment of the Commoner Deformities. 8vo. Pp. 207. 1920. Arnold. 10s. 6d.

\section{xiv. DEFORMITIES AND THEIR SURGICAL TREATMENT.}

Barwell, R. Lateral Curvature of the Spine and Pelvic Deviations. 6th edn. Cr. 8vo. Pp. 115. 1905. Baillière. 3s.

Bennie, P. B. and A. B. Rational and Effective Treatment of Hip Disease. Demy 8vo. Pp. 120. 1907. Baillière. 5s.
Bigg, R. H. Caries of the Spine, being an advanced chapter of the Spine, its Deformities, Debilities, and Deficiencies. 8vo. Pp. 82 . 1902. Churchill. 2s.6d.

An Essay on the General Priuciples of the Treatment of Spinal Curvatures. 8vo. Pp. 248. 1906. Churchill. 5s.

Chance, E. J. On the Nature, Causes, and Treatment of Bodily Deformities. Edited by J. Poland. Cr. 8vo. Vol. 1. Pp. 315. 1905. 7s. 6d. Vol. 2. Pp. 338. 1919. 18s. Murray.

Glarke, J. J. Congenital Dislocation of the Hip. Demy 8vo. Pp. 100. 1910. Baillière. 3s.6d.

Jansen, M. Achondroplasia : its Nature and its Cause. A Study of the Stunting of Growth in the Different Stages of Development of the Skeleton. Demy 4to. Pp. 106. 1912. Baillière. 6s.

Smith, J. S. K. Lateral Curvature of the Spine and Flat Foot: Their Treatment by Exercises. Demy 8vo. Pp. 137. 1911. John Wright. 6s. 6 d.

Tubby, A. H. Deformities, including Diseases of the Bones and Joints. 2nd edn. 2 Vols. 8vo. Pp. 916., 890. 1912. Macmillan. 45s. 


\section{OPHTHALMOLOGY.}

\section{i. GENERAL TREATISES AND OPERATIVE OPHTHALMOLOGY .}

Adams, P. E. H. Pathology of the Eye. Cr. 8vo. Pp. 204. 1912. Frowde \& Hodder. $6 s$.

Axenfeld, T. Bacteriology of the Eye. Translated by A. MacNab. Roy. 8vo. Pp. 418. 1908. Baillière. 10s, $6 d$.

Ballantyne, A. J . A Pocket Book of Ophthalmology. Cr. 8vo. Pp. 119. 1920. Livingstone. 5s, 6d.

Berry, G. A. Manual of Practical Ophthalmology. Cr. 8vo. Pp. 590. 1904. Frowde \& Hodder. 12s. $6 d$.

Catechism Series. Diseases of the Eye. Written by W. G. Sym. Livingstone. $1 s .9 \mathrm{~d}$.

Elliot, R. H. Tropical Ophthalmology. Demy 8vo. Pp. 550. 1920. Frowde \& Hodder. $31 s, 6 d$.

Forrest, J. Eye, Nose, Throat, and Ear. A Manual for Practitioners and Students. Demy 8vo. Pp. 412. 1914. Kimpton. 10s.6d.

Grimsdale, H. B ., and Brewerton, E. W. Ophthalmic Operations . Demy 8vo. Pp. 436. 1920. Baillière. $21 s$.

Harman, N. B . Aids to Ophthalmology. 6th edn. Fcap. 8vo. Pp. 234. 1919. Baillière. 3s.6d.

Higgens, C. A Manual of Ophthalmic Practice. 2nd edn. Revised by A. W. Ormond. Cr. 8vo. Pp. 383. 1903. Lewis. 7s. 6d.

Hinshelwood, $\mathbf{J}$. Congenital Word. Blindness. Cr. 8vo. Pp. 121. 1917. Lewis. $4 s$.

Letter, Word, and Mind-Blindness. Cr. 8vo. Pp. 88. 1900. Lewis. $3 s$.
Jessop, W. H. H. Manual of Ophthalmic Surgery and Medicine. 2nd edn. Cr. 8vo. Pp. 550. 1908. Churchill. 10s. $6 d$.

Juler, H. E. A Handbook of Ophthalmic Science and Practice. 3rd edn. Demy 8vo. Pp. 733. 1904. Murray. 21s.

Marshall', C. D. Diseases of the Eyes. 8vo. Pp.320. 1912. University of London Press. $10 s .6 d$.

May, C. H. Manual of the Diseases of the Fye : for Students and Practitioners. 4th edn. Demy 8vo. Pp. 452. 1920. Baillière. 18s .

Maynard, F. P. Manual of Ophthalmic Operations. 2nd edn. Roy.8vo. Pp.267. 1921. Livingstone. $21 s$.

Mayou, M. S. Diseases of the Eye. 3rd edn. Cr. 8vo. Pp. 342. 1920. Frowde \& Hodder. 10s, 6d.

Parsons, J. H. The Ocular Circulation. Demy 8vo. Pp. 84. 1903. Bale \& Danielsson. 3s.

Diseases of the Eye. 3rd edn. 8vo. Pp. 676. 1918. Churchill. $18 s$.

The Pathology of the Eye. 4 Vols. Roy. 8vo. Vols. 2 and 3. (Vols. 1 and 4 out of print). Frowde and Hodder. 15s. each.

Ramsay, A.M. Clinical Ophthalmology for the General Practitioner. Cr. 4to. Pp. 520. 1920 . Frowde \& Hodder. 42s.

Diathesis and Ocular Diseases. Cr. 8vo. Pp. 192. 1909. Baillière. $5 s$.

Grant, J. D., Whale, H. L. and West, C. E. Injuries of the Eyes, Throat, Nose and Ears. Fcap. 8vo. Pp. 160. 1915. Frowde \& Hodder. $3 s .6 d$. 
Swanzy, H. R. Handbook of the Diseases of the Eye and their Treatment. Revised and edited by $L$. Werner. 12th edn. Demy 8vo. Pp. 689. 1919. Lewis. 22s.6d.

Sym, W. G. Diseases and Injuries of the Eye. A Text-book for Students and Practitioners. Cr. 8vo. Pp. 493. 1913. Black. 12s. $6 d$.

Yarr, Sir M. Manual of Military Ophthalmology for the Use of Medical Officers of the Home, Indian, and Colonial Services. 2nd edn. Cr. 8vo. Pp. 228. 1909. Cassell. 6s.

\section{ii. EXAMINATION OF THE} EYE; OPHTHALMOSCOPY .

Allbutt, Sir T. G. On the Use of the Ophthalmoscope. 8vo. Pp. 422. 1871. Macmillan. 15s.

Fisher, J. H. Ophthalmological Anatomy, with some Illustrative Cases. Roy. 8vo. Pp.196. 1904. Frowde \& Hodder. 8s. 61 .

Frost, W. A. The Fundus Oculi. An Ophthalmoscopic Atlas, Illustrating its Physiological and Pathological Conditions. 4to. 47 Plates. 1901. Frowde \& Hodder. $63 s$.

Gowers, Sir W . R .. and Gunn, M. A Manual and Atlas of Medical Ophthalmoscopy. 4th edn. 8vo. Pp. 330. 1904. Churchill. 14s.

Gray, K. J. The Human Eye. 24 fully-covered diagrams, describing and illustrating its Structures, Functions, Diseases and Attachments, with special reference to it as an Optical Instrument. Oblong 4to. Sampson, Low. $21 s$.

Hardwicke, W. W. Sight Testing Made Easy. 4th edn. Cr. 8vo. Pp. 88. 1920. Churchill. 5s.

Hartridge G. The Ophthalmoscope. A Manual for Students. 6th edn. Cr.8vo. Pp.160. 1919. Churchill. $6 s .6 d$.

Landolt, E. and $M$. Defective Ocular Movements and their Diagnosis. 8vo. Pp. 97. 1913. Frowde \& Hodder. 6s. $6 d$.
Maddox, E. E. Ophthalmological Prisms and the Decentring of Lenses. A Practical Guide to the Uses and Construction of Prisms and Prismatic Combinations, and the Centring of Spectacle Lenses. 5th edn. Pp. 205. 1907. John Wright. 6s. 6d.

Thompson, S. P. Optical Tables and Data, for the use of Opticians. 2nd edn. Oblong 8vo. Pp. 130. 1907. Spon. 7s. 6d.

Thomson, A. The Anatomy of the Human Eye. 67 Stereoscopic photographs in box, with letterpress and Key plates. Roy. 8vo. Pp. 62. 1912. Oxford: Clarendon Press. 63s.

\section{iii. DISEASES OF THE CONJUNCTIVA.}

Boldt, J. Trachoma. Translated by J. H. Parsons and T. Snowball. Roy. 8vo. Pp. 284. 1904. Frowde \& Hodder. 8s. $6 d$.

MacCallan, A. F. Trachoma and its Complications in Egypt. Demy 8vo. Pp. 80. 1913. Cambridge University Press. 7s.6d.

Mayou, M. S. The Changes Produced by Inflammation in the Conjunctiva. Demy 8vo. Pp. 179. 1905. Bale \& Danielsson. 10s. 6d.

iv. DISEASES OF THE LENS: CATARACT.

Elliot, R. H. The Indian Operation of Couching for Cataract. Roy. 8vo. Pp. 106. 191\%. Lewis. 7s. $6 d$.

Herbert, $\mathbf{H}$. Cataract Extraction. 3rd edn. Pp. 399. 1908. Baillière. 12s. $6 d$.

\section{v. DISEASES OF THE OPTIC NERVE.}

Onodi, A. The Optic Nerve and the Accessory Sinuses of the Nose. A Contribution to the Study of Canalicular Neuritis and Atrophy of the Optic Nerve of Nasal Origin. Translated by L. Luckhoff. Small 4to. Pp. 110. 1910. Baillière. 10s. 6d. 
Parsons, J. H. The Neurology of Vision. Two Lectures : The Afferent Visual Paths; The Innervation of the Pupil. Demy 8vo. Pp. 70. 1904. Frowde \& Hodder. 2s.6d.

\section{vi. PARALYSIS OF THE EYE.}

Hughes, E. L. Squint, and Ocular Paralysis: with a short account of the Disturbances of Muscle Balance. Demy 8vo. Pp.216. 1907. Lewis. $7 s .6 d$.

Worth, C. A. Squint, its Causes, Pathology and Treatment. 5th edn. Demy 8vo. Pp. 260. 1921 . Baillière. 12s, $6 d$.

\section{vii. WOUNDS AND INJURIES.}

Beaumont, W. M. Injuries of the Eyes of the Employed, and the Workmen's Compensation Act: Problems in Prognosis. Cr. 8vo. Pp. 168. 1907. Lewis. 5s.

Lagrange, F. Fractures of the Orbit and Injuries of the Eye in War. Translated by $\mathrm{H}$. Child and edited by J. H. Parsons. Cr. 8vo. Pp. 260. 1918. University of London Press. $7 s, 6 d$.

\section{viii. GLAUCOMA.}

Elliot, R. H. Glaucoma: A Textbook for the Students of Ophthalmology. Demy 8vo. Pp. 562. 1918. Lewis. 25s.

- Glaucoma. A Handbook for the General Practitioner. Demy 8vo. Pp. 71. 1917. Lewis. 4s.

Henderson, T. Glaucoma. An Inquiry into the Physiology and Pathology of the Intra-Ocular Pressure. Demy 8vo. Pp. 238. 1910. Arnold. 10s. 6d.

\section{ix. COLOUR BLINDNESS.}

Edridge-Green, F. W. The Physiology of Vision : with special reference to Colour Blindness. 8vo. Pp. 292. 1920. Bell. 12s.

The Hunterian Lectures on Colour-Vision and Colour-Blindness. 8vo. Pp. 76. 1911. Kegan Paul. $5 s$.

\section{REFRAGTION AND OPTICAL DEFEGTS.}

"An Ophthalmic Surgeon." The Optician's Handbook. An Introduction to the Study of the Refraction of the Eye, its Anomalies, and their Estimation and Correction by means of Glasses. Cr. 8vo. Pp.73. N.D. Hatton Press. $4 s$.

Blair, C. Eurors of Refraction, and their Treatment. A Clinical Pocket book for Practitioners and Students. 2nd edn. Pp. 106. 1910. John Wright. 2s.6d.

Clarke, E. Problems in the Accommodation and Refraction of the Eye : a brief Review of the Work of Donders and the Progress made during the last fifty years. Roy. 8vo. Pp. 120. 1914. Baillière. $2 s .6 d$.

Errors of Accommodation, and Refraction of the Eye: a Handbook for Students. 4th edn. Cr. 8vo. Pp. 252. 1918. Baillière. $7 s .6 d$.

Hartridge, G. The Refraction of the Eye. A Manual for Students. 16th edn. Cr. 8vo. Pp. 294. 1919. Churchill. $7 s, 6 d$.

Lohmann, W. Disturbances of the Visual Functions. Translated by A. MacNab. Roy. 8vo. Pp. 185. 1913. Bale and Danielsson. 15s.

Morton, A. S. Refraction of the Eye: its Diagnosis and the Correction of its Errors. 7th edn. Small 8vo. Pp. 104. 1906. Lewis. 5s.

Muirhead, I. B. Extra-Ocular Pressure and Myopia. $\mathrm{Cr}$. 8vo. Pp. 104. 1916. Bale and Danielsson. $3 s .6 d$.

Parsons, J.H. Elementary Ophthalmic Optics, including Ophthalmoscopy and Retinoscopy. 8vo. Pp. 170. 1901. Churchill. 6s.6d.

\section{THERAPEUTICS ; SPECTACLES, etc.}

Adam, C. Handbook of Treatment. for Diseases of the Eye (Ophthalmic Therapeutics). Translated from the German by W. G. Sym and E. M. Lithgow. Cr. 8vo. Pp. 264. 1911. Heinemann. $10 s$. 


\section{Ophthalmology.}

Burnham, G. H. The Combined Treatment in Diseases of the Eye. Cr. 8vo. Pp. 100. 1906. Lewis. 3s.

Fergus, F. Elementary Ophthalmic Optics. Cr. 8vo. Pp. 106. 1903. Blackie. 3s. $6 d$.
Percival, A. S. The Prescribing of Spectacles. 2nd edn. Cr. 8vo. Pp. 168. 1912. John Wright. 5s. $6 d$.

Raxworthy, H. C. Prescription Pitfalls, and How to Avoid them, for Opticians. Demy 8vo. Pp. 38. 1918. Hatton Press. 1s. 6d. 


\section{OTOLOGY; RHINOLOGY ; LARYNGOLOGY.}

\section{i. GENERAL TREATISES.}

Biggs, G. N. Diseases of the Ear, Nose, and Throat. Demy 8vo. Pp. 486. 1914. University of London Press. 10s. 6d.

Friel, A.R. Obiter Scripta: Throat, Nose, and Ear. For the General Practitioner. Cr. 8vo. Pp. 40. 1914. John Wright. 2s.6d.

Kelson, W. H. Diseases of the Throat, Nose and Ear. Demy 8vo. Pp. 285. 1915. Frowde and Hodder. 10s. 6d.

Lamb, W. Practical Guide to the Diseases of the Throat, Nose and Ear: for Senior Students and Practitioners. 4th edn. Cr. 8vo. Pp.384. 1917. Baillière. 10s.6d.

Laurens, G. Oto-Rhino-Iaryngology; for the Student and Practitioner. Translated from the French by H. C. Fox. Demy 8vo. Pp. 339. 1919. John Wright. 17s.6d.

McBride, P. Diseases of the Throat, Nose and Ear. A Clinical Manual for Students and Practitioners. 3rd edn. Roy. 8vo. Pp.762. 1900. Frowde and Hodder. 25s.

McKenzie, D. Diseases of the Throat, Nose and Ear. Roy. 8vo. Pp.661. 1920. Heinemann. 42s. Diagnosis of Diseases in Throat, Nose, and Ear. 2nd edition in preparation. Heinemann.

Parker, C. A., and Colledge, L. Diseases of the Nose and Throat, and their Treatment. 2nd edn.

- Demy 8vo. Pp. 624. 1921. Arnold. 25s.

Porter, W. G. Diseases of the Throat, Nose, and Ear. For Practitioners and Students. Revised by A. L. Turner. 3rd edn. Demy 8vo. Pp. 300. 1919. John Wright. 12s. 6d.
Stuart-Low, W. The Care of the Nose and Throat. Cr. 8vo. Pp. 79. 1919. Baillière. $3 s .6 d$.

Syme, W. S., and S. G. A Handbook of Diseases of the Ear, Nose, and Throat. Cr. 8vo. Pp. 337. 1920. Livingstone. $9 s$.

Thomson, Sir St. G. Diseases of the Nose and Throat, comprising Affections of the Trachea and GEsophagus. A Text-book for Practitioners and Students. 2nd edn. Med.8vo. Pp. 858. 1916. Cassell. $30 s$.

Tilley, H. Diseases of the Nose and Throat. 4th edn. Demy 8vo. Pp. 864. 1919. Lewis. $28 s$.

Yonge, E. S. Handbook of the Diseases of the Nose and Throat. 8vo. Pp. 416. 1909. W. Green. $9 s$.

\section{ii. DISEASES OF THE EAR.}

Bourgeois, H., and Sourdille, Dr. War Otitis and War Deafness: Diagnosis, Treatment, Medical Reports. Edited by J . Dundas Grant . Cr. 8vo. Pp. 249. 1918. University of London Press. $7 s .6 d$.

Gray, A. A. Otosclerosis (Idiopathic Degenerative Deafness). Demy 8vo . Pp.211. 1917. Lewis. 15s.

Diseases of the Ear, with Stereoscope and Stereoscopic Plates. Demy 8vo. Pp. 400. 1910. Baillière. 15s.

The Labyrinth of Animals, including Mammals, Birds, Reptiles and Amphibians. 1908. 4to. Vol. 1. With 31 Stereoscopic Plates. Pp. 210. 21s. Vol. 2. Pp. 265. 25s. Churchill. 


\section{Otology ; Rhinology ; Laryngology.}

Heath, C. J. Diagnosis and Treatment in Otitis Media (Mastoid Disease). Demy 8vo. Pp. 58 . 1919. Baillière. 2s, $6 d$.

Hovell, T.M. A Treatise on Diseases of the Ear, including the Anatomy and Physiology of the Organ. 2nd edn. 8vo, Pp. 850. 1901. Churchill. $21 s$.

Lake, R. Handbook of Diseases of the Ear for the Use of Students and Practitioners. -4th edn. Demy 8vo. Pp. 302. 1912. Baillière. $7 s .6 d$.

Love, J. K. Diseases of the Ear in School Children. An Fssay on the Prevention of Deafness. Cr. 8vo. Pp. 94. 1919. John Wright. 5s. $6 d$.

The Deaf Child. A Manual for Teachers and School Doctors. $\mathrm{Cr}$. 8vo. Pp. 192. 1911. John Wright. $5 s .6 d$.

Milligan, Sir W., and Wingrave, W. A Practical Handbook of the Diseases of the Ear. 8vo. Pp. 624. 1911. Macmillan. 18s.

Politzer, A. A Text-book of the Diseases of the Ear: for Students and Practitioners. Translated and edited by M. J. Ballin. 5th edn. 8vo. Pp. 906. 1909. Baillière. 25 .

Tod, F. H. Diseases of the Ear. New edition in preparation. Frowde and Hodder.

Wrightson, Sir T. An Enquiry into the Analytical Mechanism of the Internal Ear. With an Appendix on the Anatomy of the Parts concerned, by Sir A. Keith. 8vo. Pp. 268. 1918. Macmillan. 12s.6d.

Yearsley, M. Text-book of Diseases of the Ear. 8vo. Pp. 463. 1908. Kegan Paul. 18s.

\section{iii. DISEASES OF THE NOSE.}

Dighton, C. A. A Manual of Diseases of the Naso-Pharynx, with special reference to the part played by them in Disease of the Ear and the Treatment of these conditions. Roy. 8vo. Pp. 182. 1912. Bailliere. 10s. $6 d$.
Keegan, D. F . Rhinoplastic Operations : with a description of Recent Improvements in the Indian Method. Roy. 8vo. 1000. Baillière. 5s.

Onodi, A. Relations of the Lachrymal Organs to the Nose and Nasal Accessory Sinuses. Translated by D. Mackenzie. Imp. 8vo. Pp. 252. 1913. Bale and Danielsson. $10 s$.

-The Anatomy and Topography of the Accessory Air Sinuses of the Nose in Childhood. Translated by C. Prausnitz. Imp. 8vo. Pp. 429. 1911. Bale and Danielsson. 21s.

Turner, A. L. Accessory Sinuses of the Nose: their Surgical Anatomy and the Diagnosis and Treatment of their Inflammatory Affections. Roy. 8vo. Pp. 225. 1901. W. Green. $12 s$.

-and Porter, W. G. The Skiagraphy of the Accessory Nasal Sinuses. 4to. Pp. 57 and Plates. 1912. W. Green. 16s .

Waggett, E. B. Diseases of the Nose. 3rd imp. Cr. 8vo. Pp. 294. 1912. Frowde and Hodder. $6 s$.

Williams, P. W. Rhinology: A Text Book of Diseases of the Nose and the Nasal Accessory Sinuses. 8vo. Pp. 290. 1910. Longmans. 12s. $6 d$.

Yonge, E. S. Hay Fever and Paroxysmal Sneezing. 8vo. Pp. 158. 1910. W. Green. $6 s$.

\section{iv. DISEASES OF THE THROAT.}

Barwell, H. Diseases of the Larynx. 2nd edn. Cr. 8vo. Pp. 300. 1910. Frowde and Hodder. $6 s$.

Brunings, W. Direct Laryngoscopy, Bronchoscopy, and Fsophagoscopy. Translated and edited by W. G. Howarth. Demy 8vo. Pp. 384. 1912. Baillière. 15s .

Mann, M.S. Text Book of TracheoBronchoscopy, Technical and Practical. Translated by A.R. Moodie. Roy. 8vo. Pp. 292. 1920. Bale and Danielsson. 31s. $6 d$. 


\section{GYNECOLOGY AND OBSTETRICS.}

\section{i. DISEASES OF WOMEN.}

Berkeley, C. (edited by). Diseases of Women. By Ten Teachers. Med.8vo. Pp.662. 1919. Arnold. $30 s$.

Bland-Sutton, Sir J., and Giles, A. E. The Diseases of Women. A Handbook for Students and Practitioners of Medicine. 7 th edn. Demy 8vo. Pp. 571. 1916. Heinemann. 15s.

Fothergill, W. E. Manual of Diseases of Women. $\mathrm{Cr}$. 8vo. Pp. 452. 1910. W. Green. 9s.

Paramore, R.H. The Statics of the Female Pelvic Viscera. Vol. 1. Demy 8vo. Pp. 401. 1918. Lewis. $18 s$.

Phillips, Sir J. Outlines of the Diseases of Women. A Concise Handbook for Students. 4th edn. Cr. 8vo. Pp.296. 1906. Griffin. 7s. $6 d$.

Stevens, T. G. Diseases of Women. New edn. Demy 8vo. Pp. 460 . 1919. University of London Press. $20 s$.

ii. GYNACOLOGY .

$$
\text { a. Pathology. }
$$

Orthmann, E. G. A Handbook of Gynæcological Pathology. Translated from the German by C. $H$. Roberts. Demy 8vo. 1904. Bale and Danielsson. $5 s$.

Roberts, C. H. Outlines of Gynæcological Pathology and Morbid Anatomy. Small Roy. 8vo. Pp. 360. 1901. Churchill. 21s .

\section{b. General .}

Aarons, S. J. Aids to Gynæcology . 5th edn. Fcap. 8vo. Pp. 132. 1916. Baillière. 3s.

Ballantyne, J. W. Essentials of Gynæcology. Cr. 8vo. Pp. 279. 1905. W. Green. 5s.
Bell, W. B. The Principles of Gynæcology. A Manual for Students and Practitioners. 3rd edn. Roy. 8vo. Pp. 688. 1919. Baillière. $38 s$.

Berkeley, C., and Bonney, V. A Guide to Gynæcology in General Practice. 2nd edn. Cr. 4to. Pp. 491. 1919. Frowde and Hodder. $31 s, 6 d$.

Cameron, S. J. A Manual of Gynæcology for Students and Practitioners. 2nd edn. Med. 8vo. Pp. 575. 1919. Arnold. 25s.

Catechism Series. Gynæcology. 4th Reprint. Written by B. P. Watson. Livingstone. 1s. 9d.

Eden, T. W., and Lockyer, C. Gynæcology: General, Regional, and Operative, for Students and Practitioners. 2nd edn. Roy. 8vo. Pp. 944. 1920. Churchill. 42s.

- (edited by). The New System of Gynæcology. By many Writers. 3 Vols. Cr. 4to. Pp. 788., 884., 880. 1917. Macmillan. £6 6s.

Herman, G. E., and Maxwell, R. D. The Student's Handbook of Gynæcology. 2nd edn. Fcap. 8vo. Pp. 588. 1913. Cassell. $10 s$.

Jellett, H. A Practice of Gynæcology, being the 4th edn. of "A Short Practice of Gynæcology .", Roy.8vo.Pp.632.1916. Churchill. $21 s$.

- A Short Practice of Gynæcology, being a shortened edition of the above. Roy.8vo. Pp. 436. 1917 . Churchill. 15s.

Solomons, B. A Handbook of Gynæcology. For the Student and General Practitioner. Demy 8vo. Pp. 248. 1919. Baillière. 12s. 


\section{Gynæcology and Obstetrics.}

\section{c. Diagnosis ; Operations ; Therapeutics.}

Aarons, S. J . Gynæcological Therapeutics. Cr. 8vo. Pp. 192. 1910. Baillière. $6 s$.

Barbour, A. H. F., and Watson, B. P. Gynæcological Diagnosis and Pathology. New imp. in preparation. W. Green .

Berkeley, G., and Bonney, V. A Text-book of Gynæcological Surgery. 2nd edn. Med. 8vo. Pp. 842. 1920. Cassell. 42s.

Giles, A. E. Gynæcological Diagnosis. A Manual for Students and Practitioners. Demy 8vo. Pp. 222. 1906. Baillière. $\tilde{z} s .6 \mathrm{~d}$.

- Gynæcological Nursing. Cr. 8vo. Pp.202. 1912. Baillière. $4 s .6 d$.

McKay, W. J. S. Operations upon the Uterus, Perineum, and Round Ligaments. 2nd edn. Demy 4to. Pp. 472. 1911. Baillì̀re. 10s.6d.

Sloan, S. Electro-Therapy in Gynæcology. Demy 8vo. Pp.298. 1917. Heinemann. 12s. $6 d$.

\section{d. Disorders; Diseases.}

Birnbaum, R. A Clinical Manual of the Malformations and Congenital Disease of the Fœtus. Translated and annotated by G. Blacker. Roy. 8vo. Pp. 394. 1912. Churchill. 15s.

Fenwick, B. Uterine Fibroids and other Pelvic Tumours. 2nd edn. Demy 8vo. Pp. 166. 1913. Bale and Danielsson. 3s. 6d.

Giles, A. E. Sterility in Women. Demy 8vo. Pp. 243. 1919. Frowde and Hodder. $10 s$.

Lewers, A. H. N. Cancer of the Uterus. A Clinical Monograph on its Diagnosis and Treatment. 8vo. Pp. 341. 1902. Lewis. 10s. 6d.

McGann, F. J . Cancer of the Womb. Its Symptoms, Diagnosis, Prognosis and Treatment. Roy. 8vo. Pp. 172. 1907. Frowde and Hodder. 20s.
Wertheim, E., and Micholitsch, $\mathbf{T}$. The Technique of Vagino-Peritoneal Operations. Translated by C. Lockyer. 8vo. Pp. 336. 1907. Macmillan. 25s.

\section{e. Cancer of the Breast.}

Creighton, C. Cancer and other Tumours of the Breast. Roy. 8vo. Pp. 296. 1902. Williams and Norgate. 12s. 6d.

Leaf, C. H. Cancer of the Breast: Clinically Considered. Demy $8 v o$. Pp. 164. 1912. Constable. 10s.6d. The Clinical Causes of Cancer of the Breast. Demy 8vo. Pp. 64. 1904. Constable. $2 s$.

Lockwood, C. B. Cancer of the Breast. Demy 8vo. Pp. 237. 1913. Frowde and Hodder.12s. $6 d$.

\section{iii . OBSTETRICS.}

a. General : Labour.

Ballantyne, J. W. Essentials of Obstetries. Cr. 8vo. Pp. 251. 1904. W. Green. 5s.

Berkeley, C., and Bonney, V. The Difficulties and Emergencies of Obstetric Practice. 3rd edn. 8vo. Pp. 809. 1920. Churchill. 42s.

Edgar, J. C. The Practice of Obstetrics. 4th edn. Super Roy. 8vo. Pp. 1,062. 1913. Frowde and Hodder. $30 s$.

Greenwood, w. O. ScopolamineMorphine: Semi-Narcosis during Labour. Cr. 8vo. Pp. 129. 1918. Frowde and Hodder. $6 s$.

Jardine, R. Clinical Obstetrics. 3rd edn. Roy. 8vo. Pp. 744. 1910. Kimpton. $21 s$.

Lea, A. W. W. Puerperal Infection. Cr. 4to. Pp. 400. 1910. Frowde and Hodder. 25s.

Moses, O. St. J. Manual of Obstetrics. For the use of Students and Junior Practitioners. 8vo. Pp. 536. 1920. Churchill. 21s.

Nall, S. Aids to Obstetrics. 8th edn. Revised by C. J. N. Longridge. Fcap. 8vo. Pp. 224. 1921. Baillière. $3 s$. 


\section{Gynæcology and Obstetrics.}

Oldfield, C. Herman's Difficult Labour: A Guide for Students and Practitioners. 6th edn. Cr. 8vo. Pp. 574. 1920. Cassell. $16 s$.

Robinson, G. D. An Atlas of Normal Labour, with an Appendix showing Sylvester's and Schultze's Methods of Artificial Respiration. $\mathrm{Cr}$, 4 to. Pp. 104 and Plates. 1921. Heinemann. 25s.

Swayne, J.G. and W.G. Obstetric Aphorisms. For the use of Students commencing Midwifery Practice. 11th edn. Feap. 8vo. Pp.232. 1913. Churchill. 3s.6d.

Tweedy, E. H., and Wrench, G. T. Practical Obstetrics. 4th edn. Demy 8vo. Pp. 540. 1919. Frowde and Hodder. $21 s$.

\section{b. Midwifery .}

Andrews, H. R. Midwifery for Nurses. 5th edn. Cr. 8vo. Pp. 310. 1920. Arnold. 6s.

Barbour, A. H. F., and Watson, B.P. Midwifery Primer. Cr. 8vo. Pp.173. 1911. W.Green. 1s.6d.

Berkeley, C. A Handbook of Midwifery: for Midwives, Maternity Nurses, and Obstetric Dressers. 5th edn. Fcap. 8vo. Pp. 550. 1920. Cassell. 7s. 6d.

Andrews, H . R ., and Fairbairn, J. S. (edited by). Midwifery - By Ten Teachers. 2nd edn. 8vo. Pp. 784. 1920. Arnold. 30s.

Bourne, A. W. Synopsis of Midwifery. Cr. 8vo. Pp. 212. 1913. John Wright. $7 s, 6 d$.

Calder, A. B. Lectures on Mid. wifery for Junior Students and Midwives. 2nd edn. Demy 8vo. Pp. 266. 1912. Baillière. $6 s$. Questions and Answers on Midwifery for Midwives, 4th edn. Pp. 184. 1919. Baillière. $2 s$.

Catechism Series. Midwifery. 2nd edn. 2 Parts. Revised by R. M. Barclay. Livingstone. 1s. $9 d$. each.

Cullingworth, G. J. A Short Manual for Monthly Nurses. 6th edn. Feap. 8vo. Pp. 136. 1907. Churchill. 1s.6d.
Donald, A. An Introduction to the Study of Midwifery. For the use of Young Practitioners, Students and Midwives. 8th edn. Cr. 8vo. Pp. 192. 1920. Griffin. 5s.

Eden, T. W. A Manual of Midwifery. 5th edn. 8vo. Pp. 760. 1919. Churchill. 24s.

Fairbairn, J. S. A Text-book for Midwives. 2nd edn. Roy. 8vo. Pp. 328. 1918. Frowde and Hodder. 22s. $6 d$.

Fothergill, W. E. Manual of Midwifery. 4th edn. Cr. 8vo. Pp. 507. 1907. W. Green. 9s.

Handbook to Midwives and Maternity Nurses. 3rd edn. Cr. 8vo. Pp. 288. 1918. W. Green. 15s.

Hart, D. B. A Guide to Midwifery . Demy 8vo. Pp. 765. 1912 . Heinemann. 12s.6d.

Jardine, R. Practical Text-Book of Midwifery for Nurses. 7 th edn. Cr. 8vo. Pp. 312. 1920. Kimpton. $7 s, 6 d$.

Jellett, H. A Short Practice of Midwifery for Nurses. 5th edn. Cr.8vo. Pp.480. 1918. Churchill. $8 s .6 d$.

A Short Practice of Midwifery. 8th eln. Demy 8vo. Pp. 564. 1921. Churchili. 18s.

and Madill, D. G. Manual of Midwifery . For Students and Prac. titioners. 3rd edn. 8vo. Pp. 1,212. 1921. Baillière. 42s.

Johnstone, R. W. Text-book of Midwifery. For Students and Practitioners. 3rd edn. Cr. 8vo. Pp. 495. 1918. Black. 15s.

Kerr, J. M. Operative Midwifery . A Guide to the Difficulties and Complications of Midwifery Practice. 3rd edn. Roy. 8vo. Pp. 742. 1916. Baillière. $30 s$.

Longridge, C.J. . ., and Banister, J.B. A Manual for Midwives. 3rd edn. Cr. 8vo. Pp. 356 . 1920. Churchill. 7s. 6d. 
Marks, G. C. Maternity Nurses' Charts and Case Book. 1908. Baillière. $1 s$.

- Pupil Midwives' Register of Cases. 1911. Baillière. 1s, 6d.

- The Maternity Nurses' Daily Guide, or Pocket book of Reference. 3rd edn. Pocket size. Pp. 148. 1918. Baillière. 2s .

Norton, F. The Midwife's Companion. Cr. 8vo. Pp. 108. 1914. Churchill. $1 s$.

Skinner, M. L. Midwifery Made Easy. Fcap. 8vo. Pp.132. 1913. Baillière. 2s. 6d.

Watson, J. K. A Complete Handbook of Midwifery for Midwives and Nurses. 4th edn. Cr. 8vo. Pp. 384. N.D. Scientific Press. 10s.6d.

Wrench, G. T. Practical Midwifery for Nurses and Midwives. 8vo. Pp. 338. 1908. Frowde and Hodder. 7s. $6 d$.

\section{c. Popular .}

Bull, J. Hints to Mothers on the Management of their health during the period of Pregnancy. Fcap. 8vo. Pp. 354. 1909. Longmans. 1s. $9 d$.

The Maternal Management of Children in Health and Disease. Fcap. 8vo. Pp. 366. 1905. Longmans. 2s. $6 d$.
Campbell, H. Y. Practical Motherhood. Demy 8vo. Pp. 555. 1910. Longmans. $8 s$.

Chavasse, P. H. Advice to a Wife on the Management of her Own Health, and on the Treatment of some of the Complaints incidental to Pregnancy, Labour, and Suckling. 17th. edn. revised by G. T. Wrench. Fcap. 8vo. Pp. 356. 1921. Churchill. 2s.6d.

Advice to a Mother on the Management of her Children. 18th edn. edited by T. D. Lister. Fcap. 8vo. Pp. 352. 1919. Churchill. 2s.6d.

Cunnington, C. W. Nursery Notes for Mothers. Cr. 8vo. Pp. 150. 1913. Baillière. 2s.6d.

Hewer, J.L. Our Baby : for Mothers and Nurses. 16th edn. Cr. 8vo. Pp. 167. 1920. John Wright. 2s. 6d.

King, F. T. Feeding and Care of Baby. New imp. Demy 8vo. Pp. 162. 1921. Macmillan. $2 s$.

Westland, A. The Wife and Mother : A Medical Guide to the Care of Health and the Management of Children. 7th edn. Cr.8vo. 1920. Griffin. 5s.

Wrench, G. T. The Healthy Marriage. A Medical and Psychological Guide for Wives. 2nd edn. Cr. 8vo. Pp. 308. 1916. Churchill. 4s. $6 d$. 


\section{DISEASES AND HYGIENE OF CHILDREN.}

\section{i. GENERAL : NUTRITION, Etc.}

Ashby, H. T. Infant Mortality . Demy 8vo. Pp. 240. 1915. Cambridge University Press. 12s.6d. Brockbank, E. M. Children-Their Care and Management. Cr. 8vo. Pp. 271. 1912. Frowde and Hodder. $3 s .6 d$

Cameron, H.C. Diet and Disease in Infancy. Roy. 8vo. Pp. 216. 1915. Churchill. 10s.6d.

Cunning, Mrs. J., and Campbell, Miss A. The Healthy Girl. Cr. 8vo. Pp. 201. 1916. Frowde and Hodder. $5 s$.

Davis, F. Childhood: its Nature, Nurture, Psychology and Education in Relation to Social Life. Roy. 8vo. Pp. 100. 1912. Bale and Danielsson. $7 s .6 d$.

Feldman, W. M. A Manual of Nursery Hygiene. 2nd edn. Cr. 8vo. Pp. 182. 1912. Baillière. $2 s .6 d$.

Fordyce, A. D. The Hygiene of Infancy and Childhood, and the Underlying Factors of Disease. Demy 8vo. Pp. 300. 1910. Livingstone. $6 s$.

-Diet in Infancy: the essential introduction to the study of disease in childhood. Cr. 8vo. Pp. 184. 1908. W. Green. 3s. 6d.

Forsyth, D. Children in Health and Disease. A Study in Child Life. Demy 8vo. Pp. 362. 1909 . Murray. 12s.

Fowler, J. S. Infant Feeding . Cr. 8vo. Pp. 240. 1909. Frowde and Hodder. $6 s$.

Gorst, Sir J.E. The Children of the Nation: How their Health and Vigour should be promoted by the State. 2nd edn. Demy 8vo. Pp. 307. 1907. Methuen. 10s.6d.
Hellier, J. B. Infancy and InfantRearing: A Guide to the Care of Children in Early Life. 2nd edn. Cr. 8vo. Pp. 178. 1908. Griffin. $3 s .6 d$.

McCaw, J. Aids to the Feeding and Hygiene of Infants and Children. Frap. 8vo. Pp. 120. 1903. Baillière. $3 s$.

Mackenzie, W.L. The Health of the School Child. Cr. 8vo. Pp. 128. 1906. Methuen. 3s.6d.

MacMillan, J. C. Infant Health. A Manual for District Visitors, Nurses, and Mothers. Fcap. 8vo. Pp. 136. 1915. Frowde and Hodder. 2s. $6 d$.

Moll, A. The Sexual Life of the Child. Translated by M. E. Paul. Demy 8vo. Allen and Unwin. 15s. (Sold only to the Medical, Legal and Scholastic Profession).

Newman, Sir G. Infant Mortality : A Social Problem. Demy 8vo. Pp. 364. 1906. Methuen. 10s.6d.

Pritchard, E. The Infant: Nutrition and Management. Cr. 8vo. Pp. 265. 1914. Arnold. 3s.6d. Steven, E. M. Medical Supervision in Schools, being an account of the systems at work in Great Britain, Switzerland, Germany, Canada, and the United States. Small 4to. Pp. 278. 1910. Baillière. $5 s$.

Vincent, $R$. The Nutrition of the Infant. 4th edn Demy 8vo. Pp. 362. 1913. Baillière. 10s,6d.

Wallace, J. S. Child Welfare: and the Teachings of certain Dentists, School Medical Officers, Medical Officers of Health and other Medical Men. Demy 8vo. Pp.122. 1919. Baillière. $5 s$.

Young, H. Medical Fducation and Infant Feeding. Cr. 8vo. Pp. 120. Routledge. 3s. 6d. 


\section{Diseases and Hygiene of C'hildren.}

\section{ii. DIAGNOSIS : DISEASES AND TREATMENT.}

Binet, A., and Simon, T. Mentally Defective Children. Translated by W. B. Drummond. Cr. 8vo. Pp. 192. 1914. Arnold. 3s.

Burnet, J. Manual of Diseases of Children. 2nd edn. Cr. 8vo. Pp. 424. 1919. Livingstone. 8s.6d.

Cameron, H. C. The Nervous Child. Cr. 8vo. Pp. 210. 1919. Frowde and Hodder. 6s.

Elder, G., and Fowler, J. S. The Diseases of Children: A Clinical Handbook. Pocket size. Pp. 404. 1899. Griffin. 10s.6d.

Fenwick, W. S. Disorders of Digestion in Infancy and Childhood. Demy 8vo. Pp. 391. 1897. Lewis. $10 s .6 d$.

Fordyce, A. D. Diseases of Children . New edn. Cr.8vo. Pp.506. 1921. Black. 18s.

Freyberger, L. The Pocket Formulary for the Treatment of Diseases in Childrer, with an Appendix on Poisons, their Symptoms and Treatment. 5th edition in preparation. Heinemann.

Garrod, A. E., Batten, F. E., and Thursfield, J. H. (edited by). Diseases of Children. Super Roy. 8vo. Pp. 1195. 1913. Arnold. $30 s$.

Goodhart, Sir J. F., and Still, G. F. The Diseases of Children. 11th edn. 8vo. Pp.960. 1921 . Churchill. $32 s$.

Guthrie, L. G. Functional Nervous Disorders in Childhood. Demy 8vo. Pp. 310. 1907. Frowde and Hodder. 8s. $6 d$.

Hollander, B. Abnormal Children. 2nd edn. Cr. 8ro. Pp. 232. 1916. Kegan Paul. $4 s$.

Hutchison, R. Lectures on Diseases of Children. 4th edn. Demy 8vo. Pp. 428. 1920. Arnold. 21s.

Ireland, W. W. The Mental Affections of Children, Idiocy, Imbecility and Insanity. 2nd edn. 8vo. Pp. 450. 1900. Churchill. 14s.
Jansen, M. Feebleness of Growth and Congenital Dwarfism, with special reference to Dysostosis Cleido-Craniates. Roy. 8vo. Pp. 94. 1921. Frowde and Hodder. 12s. $6 d$.

Kelynack, T. N. (edited by). Defective Children. Demy 8vo. Pp. 480. 1915. Bale and Danielsson. $7 s .6 d$.

Kirmisson, E. A Handbook of the Surgery of Children. Translated with notes by J. K. Murphy. 8vo. Pp. 834. 1910. Frowde and Hodder. $20 s$.

Lapage, C. P. Feeblemindedness in Children of School Age. With an Appendix on Treatment and Training, by $M$. Dendy. Cr. 8vo. Pp. 324. 1920. Longmans. $10 s .6 d$.

McCaw, J. Aids to the Diagnosis and Treatment of Diseases of Children. 5th edn. Fcap. 8vo. Pp. 416. 1920. Baillière. 6s. Diseases of Children. A Manual for Students and Practitioners. Demy 8vo. Pp. 536. 1014 . Baillière. $12 s$.

Macdonald, D. M. Practical Prescribing and Treatment in the Diseases of Infants and Children. 16mo. Pp. 199. 1915. Frowde and Hodder. $6 s$.

Miller, R. Medical Diseases of Children : for General Practitioners and Senior Students. Demy 8vo. Pp. 541. 1911, John Wright. $12 s .6 d$.

Römer, P. H. Epidemic Infantile Paralysis (Heine-Medin Disease). Translated by $H$. R. Prentice. Roy. 8vo. Pp. 220. 1913. Bale and Danielsson. $7 s .6 d$.

Shuttleworth, G. E., and Potts, W A. Mentally Deficient Children their Treatment and Training 5th edn. In the Press. Lewis.

Smith, E. Diseases of Children. 3rd edn. Roy. 8vo. Pp. 850 . 1909. W. Green. 10s. 6d.

Still, G. F . Common Disorders and Diseases of Childhood. 3rd edn. Demy 8vo. Pp. 861. 1918. Frowde and Hodder. $20 s$. 
Sutherland, G. A. Treatment of Diseases in Children. 2nd edn. Demy 8vo. Pp. 409. 1912. Frowde and Hodder. 12s.6d.

Taylor, J. Paralysis and other Diseases of the Nervous System in Childhood and Early Life. 8vo. Pp. 520. 1905. Churchill.12s.6d.

Thomson, J. The Clinical Study and Treatment of Sick Children. 3rd edn. Med. 8vo. Pp. 912. 1921. Oliver and Boyd. 32s. $6 d$.
Vulpius, $O$. The Treatment of Infantile Paralysis. Translated by A. H. Todd. Roy. 8vo. Pp. 328. 1912. Baillière. $10 s .6 d$.

Wallace, J.S. Occasional Papers on the Prevention of some Common Diseases in Childhood. Demy 8vo. Pp. 112. 1912. Baillière. 4s.6d. Whipham, T. R. G. The Medical Diseases of Children. Demy 8vo. Pp. 428. 1912. University of London Press. 10s. $6 d$.

Young, M. The Mentally Defective Child. Cr. 8vo. Pp. 151. 1916. Lewis. $4 s$. 


\section{DENTISTRY.}

\section{i. GENERAL.}

Dentists' Register, The. 1921. Roy. 8vo. Pp. 163. Apl. 1921. Conswable. $3 s .4 d$.

Pedley, R. D., and Harrison, F . Our Teeth: How Built up, How Destroyed, How Preserved. Demy 8vo. Pp. 97. 1908. Blackie. 5s.

Sturridge, E. Periodontal Disease and its Treatment by Ionic Medication. Demy 8vo. Pp. 139. 1920. Kimpton. $10 s .6 d$.

Underwood, A. B. G. Synopsis of Dentistry. Cr. 8vo. Pp. 216. 1920. Churchill. 9s. 6d.

Underwood A.S. Studies in Comparative Odontology. $\mathrm{Cr}$. 8vo. Pp. 160. 1903. Baillière. 5s.

\section{ii. ANATOMY AND PHYSIOLOGY.}

Gabell, D. Aids to Dental Anatomy and Physiology. 3rd edn. Fcap. 8vo. Pp. 144. 1921. Baillière. $3 s .6 d$.

Hopewell -Smith, A. An Introduction to Dental Anatomy and Physiology, Descriptive and Applied. Roy. 4to. Pp. 392. 1913.

- Churchill. 18s.

-Dental Microscopy. 3rd edn. Roy.8vo. Pp. 240. 1914. Bale and Danielsson. 15s.

Mummery, J. H. The Microscopic Anatomy of the Teeth. Demy 8vo. Pp. 389. 1919. Frowde and Hodder. 25s.

Tomes, C. S. A Manual of Dental Anatomy, Human and Comparative. Edited by $H$. W. M. Tims and A. Hopewell-Smith. 8vo. Pp.624. 1914. Churchill. 18s.
Widdowson, T. W. Notes on Denta Anatomy and Dental Histology, Human and Comparative. 3rd edn. Demy 8vo. Pp. 197. 1915. Bale and Danielsson. 7s, 6d.

\section{iii. MEDICINE AND DISEASES.}

Grow, D. A. Pyorrhcea Alveolaris in its Clincial Aspect. Cr. 8vo. Pp. 128. 1921. Baillière. 6s.

Pickerill, H. P. The Prevention of Dental Caries and Oral Sepsis. 2nd edn. Demy 8vo. Pp. 390 . 1914. Baillière. $14 s$.

Wallace, J.S. The Cause and Prevention of Decay in Teeth. An Investigation into the Causes of the Prevalence of Dental Caries, with suggestions on its Prevention. 2nd edn. 8vo. Pp. 108. 1902 . Churchill. 5s.

Supplementary Essays on the Cause and Prevention of Dental Caries. Cr. 8vo. Pp. 80. 1906. Baillière. 3s. $6 d$.

Wallis, C. E. An Atlas of Dental Extractions, with Notes on the Causes and Relief of Dental Pain. 2nd edn. Roy. 8vo. Pp. 26 and 11 Plates. 1919. Churchill. 6s.

Witkowski. The Tightening of Loose Teeth, some Technical Innovations. Translated from the German by $\mathbf{E}$. Neumann and $W$. M. Gabriel. Cr. 8vo. Pp. 86. 1912. Baillière. 5s.

\section{iv. OPERATIVE DENTISTRY.}

Alderson, W. E. Dental Anæsthetics: A Text-book for Students and Practitioners, with a Contribution on Analgesia by J. Bolam. 2nd edn. Fcap. 8vo. Pp. 106. 1912. John Wright. 3s. 
Bennett, N. G. (edited by). The Science and Practice of Dental Surgery. Cr.4to. Pp. 797. 1914. Frowde and Hodder. $42 s$.

Coleman, F. Extraction of Teeth. 2nd edn. Cr. 8vo. Pp. 185. 1914. Lewis. 5s.

- and Hilliard, H. Anæsthetics in Dental Surgery. Cr. 8vo. Pp. 308. 1912. Lewis. 7s. $6 d$.

Colyer, Sir J.F. Dental Surgery and Pathology. 4th edn. 8vo. Pp. 913. 1919. Longmans. 32s.

- and S. Dental Disease in its Relation to General Medicine. Cr. 8vo. Pp. 198. 1911. Longmans. $6 s$.

Gibbs, J. H. The Extraction of Teeth. Demy 8vo. Pp. 16?. 1912. Livingstone. $8 s .6 d$.

Luke, T. D., and Ross, J. S. Anæsthesia in Dental Surgery. 4th edn. Cr. 8vo. Pp. 264. 1919. Heinemann. 8s. 6d.

Mills, G. P., and Humphreys, $H$. Surgery for Dental Students. 2nd edn. Demy 8vo. Pp. 352. 1919. Arnold. 14s.

Sewill, H. Dental Surgery, including Special Anatomy and Pathology. A Manual for Students and Practitioners. 4th edn. Edited by W. J. England and J. S. Sewill. Large Cr. 8vo. Pp. 634. 1901. Baillière. 12s.

Tomes, Sir J. A System of Dental Surgery. Revised and Enlarged by C. S. Tomes and W. S. Nowell. Post 8vo. Pp.790. 1906. Churchill. $15 s$.

Underwood, A. S., and B. A Handbook on Surgery; intended for Dental and Junior Medical Students. Cr.8vo. Pp.252. 1912. Bale and Danielsson. $3 s, 6 d$.

Underwood, A. S., and Gabell, D. Aids to Dental Surgery. 3rd edn. in the Press. Baillière.

Widdowson, T.W. Notes on Dental Surgery and Pathology. Demy 8vo. Pp. 357. 1915. Bale and Danielsson. 10s. 6d.

\section{v. MEGHANICAL AND METALLURGY.}

Buxton. J. L. D. Handbook of Mechanical Dentistry. Demy 8vo. Pp. 269. 1920. Churchill. 16s.

Fenchel, A. Metallurgy, with Special consideration of Dental Metallurgy. Translated by H. J. Morris. Demy 8vo. Pp. 299. 1911. Bale and Danielsson. $7 s .6 d$.

Griffiths, A. B. Dental Metallurgy: a Manual for Students and Dentists. Demy 8vo. Pp. 200. 1908. Scott, Greenwood. 8s.6d.

Hepburn, W. B. Notes on Dental Metallurgy. For the Use of Dental Students and Practitioners. 2nd edn. Cr. 8vo. Pp. 262. 1915. Baillière. $7 s .6 d$.

Hunter, C. Mechanical Dentistry. A Practical Treatise on the Construction of the various kinds of Artificial Dentures. 7th edn. Cr. 8vo. Pp. 280. 1920. Crosby Lockwood. $5 s$.

Mamlock, H.J. Porcelain Filling of Teeth (Inlays). Translated from the German by W. M. Gabriel. Demy 8vo. Pp. 88. 1913. Baillière. $5 s$.

Smith, E. A. A Manual of Dental Metallurgy. 4th edn. Cr. 8vo. Pp. 301. 1920. Churchill. 12s.6d.

\section{vi. MATERIA MEDICA AND THERAPEUTICS.}

Barritt, W., and A. The Simplex Handbook of Dental Materia Medica and Therapeutics. Oblong 8vo. Pp. 352. 1914. Kimpton. 7s, $6 d$.

Glassington, C. W . Dental Materia Medica, Pharmacology and Therapeutics. 2nd edn. Cr. 8vo. Pp. 300. 1911. Churchill. 7s,6d.

Sturridge, E. Dental ElectroTherapeutics. 2nd edn. Demy 8vo. Pp. 320. 1918. Kimpton. $16 s$. 


\section{DERMATOLOGY}

Adamson, H. G. Modern Views upon the Significance of Skin Eruption. Demy 8vo. Pp. 103. 1912. Bale \& Danielsson. 3s.6d.

Davis, H. Skin Diseases in General Practice. Their Recognition and Treatment. 2nd edn. Demy 8vo. Pp. 352. 1921. Frowde \& Hodder. $25 s$.

Evans, W. The Diseases of the Skin. 8vo. Pp. 392. 1912. University of London Press. 10s. 6d.

Gardiner, F. A Handbook of Skin Diseases. Cr. 8vo. Pp. 180. 1919. Livingstone. $6 s$.

Jamieson, W. A. Diseases of the Skin. 4th edn. Demy 8vo. Pp. 680. 1894. Frowde \& Hodder. $21 s$.

- Care of the Skin in Health. $\mathrm{Cr}$. 8vo. Pp. 190. 1912. Frowde \& Hodder. 2s. $6 d$.

Low, R. C. Carbonic-Acid Snow as a Therapeutic Agent in the Treatment of Diseases of the Skin. Cr. 8vo. Pp. 129. 1911. W. Green. 5s.

MacLeod, J. M. H. Diseases of the Skin. A Text-book for Students and Practitioners. Roy. 8vo. Pp. 1327. 1920. Lewis. 70s.

- Practical Handbook of the Pathology of the Skin. An Introduction to the Histology, Pathology, and Bacteriology of the Skin, with Special Reference to Technique. Demy 8vo. Pp.432. 1903. Lewis. $15 s$.

Morris, Sir M. Diseases of the Skin : An Outline of the Principles and Practice of Dermatology . 6th edn . Cr. 8vo. Pp. 770. 1917. Cassell. 12s. $6 d$.

Paul, C. N. The Influence of Sunlight in the Production of Cancer of the Skin. Cr.4to. Pp.57.1918. Lewis. 10s, $6 d$.
Radcliffe-Crocker, $\mathrm{H}$. Diseases of the Skin : their Description, Pathology, Diagnosis, and Treatment; with Special Reference to the Skin Eruption of Children. 3rd edn. 2 Vols. Med. 8vo. Pp. 1421. 1905. Lewis. 30s.

Schultz, F . The X-Ray Treatment of Skin Diseases. Translated by $\mathbf{J}$. Burnet. Roy. 8vo. Pp. 178 . 1912. Heinemann. 12s.6d.

Sequeira, J. H. Diseases of the Skin. 3rd edn. Roy.8vo. Pp.658. 1919. Churchill. 38s.

Sibley, W. K. The Treatment of Diseases of the Skin. New edition in the Press. Arnold.

Startin, J. (edited by). Pharmacopœia of Diseases of the Skin. 6th edn. Pp. 64. 1907. John Wright. 2s. $6 d$.

Walker, N. An Introduction to Dermatology . 6th edn. 8vo. Pp. 381. 1919. W. Green. 20s.

Walsh, D. Diseases of the Skin. A Handbook for Students and Practitioners. Demy 8vo. Pp. 316 . 1913. Baillière. 7s. $6 d$.

The Hair and its Diseases ; including Ringworm, Greyness, and Baldness. 2nd edn. Pp. 102. 1908. Baillière. 3s. $6 d$.

White, R. P. Occupational Affections of the Skin. A brief account of the Trade Processes and Agents which give rise to them. 2nd edn. Demy 8vo. Pp. 374. 1920. Lewis. 25s.

Whitfield, A. A Handbook of Skin Diseases and their Treatment. 2nd edn. 8vo. Pp. 320. 1921. Arnold. $18 s$. 


\section{THERAPEUTICS.}

\section{i. GENERAL TREATISES.}

Brown, W. L., and Murphy, J. K. (edited by). The Practitioner's Encyclopædia of Medical Treatment, Methods of Treatment and Agents in Treatment. $\mathrm{Cr}$. 4to. $\mathrm{Pp} .897$. 1915. Frowde \& Hodder. 35s .

Bruce, J. M., and Dilling, W. J. Materia Medica and Therapeutics. An Introduction to the Rational Treatment of Disease. 11th edn. Fcap. 8vo. Pp. 676. 1918. Cassell. 9s.

Calwell, W. A Text-book of Medical Treatment. Roy. 8vo. Pp.634. 1910. Arnold. 16s.

Carre1, A., and Dehelly, G. The Treatment of Infected Wounds. Translated by H. Child. 2nd edn. Cr.8vo. Pp.278. 1918. Baillière. $6 s$.

Farquharson, R. A Guide to Therapeutics. 5th edn. Cr. 8vo. Pp. 417. 1891. Murray. 7s.6d.

Fothergill, J. M., and Murrell, W. The Practitioner's Handbook of Treatment: or the Principles of Therapeutics. 4th edn. 8vo. Pp. 708. 1897. Macmillan. 15s.

Goldsbrough, G.F . First Principles in Therapeutics. Med. 8vo. Pp. 144. 1916. Bale \& Danielsson. 7s. $6 d$.

Hewlett, R. T., and Nankivell, A. T. The Principles of Preventive Medicine. Large Cr.8vo. Pp.544. 1921. Churchill. 21s.

Hutchison, R., and Sherren, $J$. (edited by). An Index of Treatment. A Complete Guide to Treatment in a form convenient for Reference. By various contributors. 7th edn. Large 8vo. Pp. 1142. 1919. John Wright. 30s.
Keith, Sir A. Menders of the Maimed . The Anatomical and Physiological Principles underlying the Treatment of Injuries to Muscles, Nerves, Bones, and Joints. Demy 8vo. Pp. 336. 1919. Frowde \& Hodder. $16 s$.

Latham, A., and English, Sir T . C. (edited by). A System of 'Treatment. By Many Writers. 8vo. 1912. Vols. 1 \& 2 General Medicine and Surgery. Vol. 3. Special Subjects. Vol. 4. Obstetrics and Gynæcology . Churchill. 30s, each.

Leftwich, R. W . A Pocket-Book of Treatment. 3rd edn. Small Cr. 8vo. Pp. 343. 1916. Arnold. $7 s .6 d$.

Aids to Rational Therapeutics, with U.S.A. Pharmacopœia equiv alents. Fcap. 8vo. Pp. 244. 1918. Baillière. 4s. fid.

Swietochowski, G. De. MechanoTherapeutics in General Practice. Cr. 8vo. Pp. 155. 1914. Lewis. $4 s .6 d$.

Tirard, N. I. C. Text-book of Medical Treatment (Diseases and Symptoms). 8vo. Pp. 700. 1900. Churchill. 15s.

Whitla, Sir W. A Dictionary of Treatment, including Medical and Surgical Therapeutics. 6th edn. Demy 8vo. Pp. 1093. 1920. Baillière. 30s.

Yeo, I. B., Crawfurd, R., and Buzzard, E. F. A Manual of Medical Treatment, or Clinical Therapeutics. 5th edn. 2 Vols. Cr. 8vo. Pp.1680. 1913. Cassell. $30 s$. 


\section{Therapeutics.}

\section{ii. PRESCRIBING.}

Burnet, J. The Pocket Prescriber. 5th edn. Fcap. $16 \mathrm{mo}$. Pp. 98 . 1919. Black. 2s.

- Hints on Prescription Writing . 4th edn. 18mo. Pp. 32. 1920. Wm. Bryce. $2 s$.

Colbeck, E. H., and Chaplin, A. The Science and Art of Prescribing. 2nd edn. Fcap. 8vo. Pp. 210. 1919. Kimpton. 5s.

Griffiths,W.H. Lessons on Prescriptions and the Art of Prescribing. Pott. 8vo. Pp. 158. 1903. Macmillan. 3s.6d.

Hogarth, C. W., and others (compiled by). The Preseriber's Pharmacopoia for General Use. 2nd edn. Fcap. 8vo. Pp.30. 1913. Frowde \& Hodder. $1 s$.

Lucas, E. W. The Book of Prescriptions, with Notes on the Pharmacology and Therapeutics of the more important Drugs and an Index of Diseases and Remedies. 10th edn. Fcap. 8vo. Pp. 392. 1915. Churchill. 7s, 6d.

MacDonald, D. M. The Student's Pocket Prescriber and Guide to Prescription Writing. 6th edn . 32mo. Pp. 200. 1919. Livingstone. 2s. 6d.

The Practitioner's Practical Prescriber. 16mo. Pp. 198. 1913. Frowde \& Hodder. $6 s$.

Marshall, C. A Manual of Prescribing for Students and Practitioners of Medicine. Fcap. 8vo. Pp. 382. 1908. Churchill. 6s.6d.

Prichard, A. H. Practical Prescribing; with Clinical Notes. Cr. 8vo. Pp. 315. 1913. Frowde \& Hodder. $7 s .6 d$.

\section{iii. DIETETICS.}

Burnet, Sir R. W. Foods and Dietaries: A Manual of Clinical Dietetics. 5th edn. Large Cr. 8vo. Pp. 216. 1917. Griffin. 4s.

Cammidge, P. J. Diabetic Dieting and Cookery. Demy 8vo. Pp. 230. 1920. University of London Press, $10 s, 6 d$.
Curgenven, J. S. The Child's Diet. 2nd edn. Cr. 8vo. Pp. 123. 1914. Lewis. $3 s$.

Fothergill, J. M. Food for the Invalid, the Convalescent, the Dyspeptic, and the Gouty. 2nd edn. Cr. 8vo. Pp. 178. 1894. Macmillan. 3s. 6d.

Gillespie, A.L. The Natural History of Digestion. Cr, 8vo. Scott Pub. Co. $7 s, 6 d$.

Goodfellow, J. The Dietetic Value of Bread. Cr.8vo. Pp.348. 1892. Macmillan. $6 s$.

Hutchison, R. Food and the Principles of Dietetics. 4th edn. Demy 8vo. Pp. 637. 1916. Arnold. $18 s$.

McCay, D. The Protein Element in Nutrition. Demy 8vo. Pp. 216. 1912. Arnold. 10s. 6d.

McKillop, M. Handbook of Food Values. Cr. 8vo. Pp. 142. 1916. Routledge. $1 s, 6 d$.

Pavlov, I. P. The Work of the Digestive Glands. Translated by Sir W. H: Thompson. 2nd edn. 8vo. Pp. 280. 1910. Griffin. 12s.6d.

Poole, W. H., and Mrs.' Cookery for the Diabetic. Cr. 8vo. Pp.72. 1915. Longmans. 2s. $6 d$.

Sohn, C. E. Nutrition. A Guide to Food and Dieting. Cr. 8vo. Pp. 272. 1914. Kimpton. 3s.6d.

Starling, E.H. Recent Advances in the Physiology of Digestion. 2nd edn. Demy 8vo. Pp.166. 1911. Constable. $6 s$.

Stewart, D. The Essentials of Food. Cr. 8vo. Pp. 190. 1911. Bale \& Danielsson. $3 s .6 d$.

Sutherland G. A. (edited by). A System of Diet and Dietetics. 8vo. Pp. 905. 1908. Frowde \& Hodder. $30 s$.

Tibbles, W. Dietetics, or Food in Health and Disease. Demy 8vo. Pp.638. 1914. Baillière. 14s.

Wallace, J. S. The Role of Modern Dietetics in the Causation of Disease. Cr. 8vo. Pp. 94. 1905. Baillière. 4s. $6 d$. 


\section{Therapeutics.}

iv. MINERAL WATERS.

Cotar, C. The Mineral Waters of Vichy. For the Use of General Practitioners. Post 8vo. Pp. 216. 1913. Lewis. 4s.

Yeo, I. B. Therapeutics of Mineral Springs and Climates. Cr. 8vo. Pp. 760. 1904. Cassell. 12s.6d.

\section{v. MASSAGE AND MOVEMENT CURES.}

Camus, J., and others. Physical and Occupational Re-education of the Maimed. Translated by W. F. Castle. Cr. 8vo. Pp. 208. 1918. Baillière. $5 s$.

Copestake, B.M. G. The Theory and Practice of Massage. 3rd edn. Demy 8vo. Pp. 286. 1920. Lewis. $12 s .6 d$.

Deane, H. E. Gymnastic Treatment for Joint and Muscle Disabilities. Cr. 8vo. Pp. 146. 1918. Frowde \& Hodder. $5 s$.

Despard, L.L. Text Book of Massage and Remedial Gymnastics. 2nd edn. 3rd imp. Roy. 8vo. Pp. 436. 1920. Frowde \& Hodder. $22 s$. $6 d$.

- Handbook of Massage for Beginners. 8vo. Pp. 264. 1915. Frowde \& Hodder. $7 s, 6 d$.

Dowse, T. S. Lectures on Massage and Electricity in the Treatment of Disease. 6th edn. Demy 8vo. Pp. 447. 1906. John Wright. 9s. 6d.

_ Massage Primer for Learners. 8th edn. Pp. 151. 1916. John Wright. $2 s$.

Eccles, A. S. The Practice of Massage: its Physiological Effects and Therapeutic Uses. 2nd edn. Cr. 8vo. Pp.374. 1898. Baillière. $7 s, 6 d$.

Ellison, M. A. A Manual for Students of Massage. 3rd edn. Demy 8vo. Pp. 204. 1909. Baillière. $6 s$.

Fox, R. F., McKenzie, R. T., Hernaman-Johnson, F., and Mennell, J. B. Physical Remedies for Disabled Soldiers. Demy 8vo. Pp. 291. 1917. Baillière. $7 s .6 d$.
Frenkel, H.S. Treatment of TabeticAtaxia by the Aid of Gymnastic Exercise. Translated from the German by L. Freyberger. 2nd edn. Demy 8vo. 1917. Heinemann. 12s. $6 d$.

Hood, W. P. The Immediate Treatment of Injuries by Friction and Movement. Cr. 8vo. Pp. 188. 1902. Macmillan. 4s, $6 d$.

Kleen, E.A.G. Massage and Medical Gymnastics : with Contributions by J. Arvedson, P. Haglund, E. Zander. Translated by M. L. Dobbie. 2nd edn. Roy. 8vo. Pp. 632. 1920. Churchill. 32s

Mennell, J. B. Massage: Its Principles and Practice. 2nd edn. Demy 8vo. Pp. 552. 1920. Churchill. 21s.

Palmer, M. D. Lessons on Massage. 5th edn. Demy 8vo. Pp. 350. 1918. Baillière. 12s .

Timberg, R. Home Exercises for Spinal Curvatures. 2nd edn. Cr. 8vo. Pp. 80. 1920. Heinemann. $6 s$.

Waddington, V. What Every Masseuse Should Know: Comfortable Grasps for Joint Movements. Demy 16mo. Pp. 121. 1917. Methuen. $3 s .6 d$.

vi. SERUM THERAPY AND IMMUNISATION.

Bayliss, W. M. Intravenous Injection in Wound Shock. 8vo. Pp. 184. 1918. Longmans. $9 s$.

Bosanquet, W. C., and Eyre, J . W. H. Serums, Vaccines, and Toxins in Treatment and Diagnosis. 3rd edn. Cr. 8vo. Pp. 456. 1916. Cassell. 9s.

Calmette, A. Venoms, Venomous Animals and Antivenomous Serum Therapeutics. Translated by $\mathbf{E}$. E. Austen. Roy. 8vo. Pp. 419. 1908. Bale \& Danielsson. 15s.

Crofton, W. M. Therapeutic Immunisation: Theory and Practice. $\mathrm{Cr}$. 8vo. Pp. 2ะ2. 1918. Churchill. $7 s .6 d$. 
Digby, K. H. Immunity in Health. The Functions of the Tonsils and other Subepithelial Lymphatic Glands in the Borily Economy. Demy 8vo. Pp. 130. 1919. Frowde \& Hodder. 8s. $6 d$.

Emery, W. D'E. Immunity and Specific Therapy. An Account of the Main Phenomena of Infection and Immunity, and their Application in the Prevention, Diagnosis, and Treatment of Disease. 2nd edn. in preparation. Lewis.

Hewlett, R. T. Serum and Vaccine Therapy, Bacterial Therapeutics ahd Prophylaxis, Bacterial Diagnostic Agents. 2nd edn. Cr. 8vo. Pp.416. 1910, Churchill. 8s.6d.

Jones, D. W. C. An Introduction to Therapeutic Inoculation. Cr. 8vo. Pp.188. 1911. Macmillan.3s.6d.

Metchnikoff, F. Immunity in Infective Diseases. Translated by F. G. Binnie. Roy. 8vo. Pp. 608. 1907. Cambridge University Press. $21 s$.

Muir, R. Studies on Immunity. Demy 8vo. Pp. 227. 1909. Frowde \& Hodder. 8s. $6 d$.

Paton, D. M. New Serum Therapy. Cr.8ro. Pp.320. 1906. Baillière. $6 s$.

Shera, A. G. Vaccines and Sera. Their Clinical Value in Military and Civilian Practice. Fcap. 8vo. Pp. 217. 1918. Frowde \& Hodder. 7s. $6 d$.

Sternberg, G. M. Infection and Immunity. Large Cr. 8vo. Pp. 293. 1905. Murray. 7s,6d.

Wright, Sir A. E. On PharmacoTherapy and Preventive Inoculation. Demy 8vo. Pp. 136. 1905. Constable. $4 s$. $6 d$.

Wolff-Eisner, A. Clinical Immunity and Sero-Diagnosis. Translated by $\mathbf{R}$. W. Matson. Demy 8vo. Pp. 198. 1911. Baillière. $7 s .6 d$.

\section{vii. VACCINATION; SALVARSAN.}

Allen, R. W. Vaccine Therapy: Its Theory and Practice, 4th edn. Demy 8vo. Pp.454. 1912. Lewis. $10 s .6 d$.

- Practical Vaccine Treatment. For the General Practitioner. Cr. 8vo. Pp. 320. 1919. Lewis. $9 s$.

Copeman, S.M. Vaccination, with special reference to its Natural History and Pathology. Cr. 8vo. Pp. 268. 1899. Macmillan. 6s.

McDonagh, J. E. R. Salvarsan in Syphilis and Allied Diseases. Demy 8vo. Pp. 170. 1912. Frowde \& Hodder. $8 s .6 d$.

Martindale, W. H., and Westcott, W. W. "Salvarsan" or "606" (Dioxy-Diamino-Arsenobenzol); its Chemistry, Pharmacy, and Therapeutics. Demy 8vo. Pp.92. 1911. Lewis. $5 s$.

Millard, C. K. The Vaccination Question in the Light of Modern Experience. An Appeal for Reconsideration. Demy 8vo. Pp. 261. 1914. Lewis. 7s.6d.

Stopford-Taylor, G., and MacKenna, R. W. Treatment of Syphilis by Salvarsan. Demy 8vo. Pp.96. 1914. Heinemann. 5s.

\section{viii. TUBERGULIN.}

Armstrong, W. E. M. I. K. Therapy, with Special Reference to Tuberculosis. Demy 8vo. Pp. 91. 1914. Lewis. $5 s$.

Bandelier, B., and Roepke, Dr. Tuberculin in Diagnosis and Treatment. Translated by W. B. Christopherson. 2nd edn. Roy. 8vo. Pp. 323. 1913. Bale \& Danielsson. 15s.

Bardswell, N. D. Preliminary Report on the Treatment of Pulmonary Tuberculosis with Tuberculin. Demy 8vo. Pp.163. 1914. Lewis. 6s. 
Barr, W, I. K. Therapy (Immunkörper-Immune Substances) in Pulmonary Tuberculosis. Demy 8vo. Pp.. 92. 1916. John Wright. 3s. $6 d$.

Clark, H. Dispensary Treatment of Pulmonary 'Tuberculosis. Roy. 8vo. Pp. 288. 1915. Baillière. 15s.

Cochrane, A.W.R., and Sprawson, C.A. A Guide to the Use of Tuberculin. 2nd edn. Cr. 8vo. Pp. 189. 1915. Bale \& Danielsson. $7 s .6 d$.

Riviere, C., and Egmont, E. Tuberculin Treatment. 2nd edn. Cr. 8vo. Pp. 263. 1913. Frowde $\&$ Hodder. 6s. $6 d$.

Robertson, N. The Treatment of Tuberculosis by Means of Spengler's Immune Bodies (I. K. Therapy). Cr.8vo. Pp.165. 1917. Baillière. $5 s$.

Robin, A. Treatment of Tuberculosis. Ordinary Therapeutics of Medical Men. Translated by L. Blane, and $\mathbf{H}$. de Méric, 8vo. Pp.624. 1913. Churchill. 21s.

Sahli, H. Tuberculin Treatment, including a Discussion of the Nature and Action of Tuberculin and of Immunity to Tuberculosis. Translated by W. B. Christopherson. Demy 8vo. Pp. 206. 1912. Bale \& Danielsson. $7 s, 6 d$.

ix. CLIMATOTHERAPY, ETC.

Braun, J. The Curative Effects of Baths and Waters. Abridged Translation from the 3rd German edn., with Notes by Sir H. Weber. Demy 8vo. Pp. 658. 1875. Murray. $18 s$.

Fox, R. F. The Principles and Practice of Medical Hydrology. 8vo. Pp. 312. 1913. University of Iondon Press. $6 s$.

Luke, T. D., and Forbes, N. H. Natural Therapy. A Manual of Physiotherapeutics and Climatology. Demy 8vo. Pp. 316. 1913. John Wright. $5 s$.

Macfie, R.C. Air and Health. 2nd edn. Demy 8vo. P P. 353. 1909. Methuen. 10s. 6d.
Waller, H. E. Theory and Practice of Thyroid Therapy. For General Prartitioners. Demy 8vo. Pp. 166. 1911. Bale \& Danielsson.5s.

Weber, Sir H., and Parkes, F. Climatotherapy and Balneotherapy . The Climates and Mineral Water Health Resnrts (Spas) of Furope. Roy. 8vo. Pp. 833. 1907. Murray. 15s.

\section{X . X-RAYS ; RADIUM ; THERMO- THERAPY.}

Dominici, M., and Warden, A. A. The Technique and Results of Radium-Therapy in Malignani Disease. 1912. Churchill. $2 s$.

Finzi, N. S. Radium Therapeutics. Demy 8vo. Pp.120.1913. Frowde \& Hodder. $7 s, 6 d$.

Green, A. A. R. An X-Ray Atlas of the Skull. 4to. Pp. 38 and 11 Plates. 1918. Longmans. 10s.6d.

Lyth, E. R. Studies on the Influence of Thermal Environment on the Circulation and the Body-heat. Demy 8vo. Pp.80. 1913. Bale \& Danielsson. $2 s, 6 d$.

Taylor, G. G. S. Clinical Records of "Light' 'and 'X-Ray"' Therapy. Roy. 8vo. Pp. 33. 1904. Bale \& Danielsson. $5 s$.

Walsh, D. The Röntgen Rays in Medical Work. With Section on Apparatus by L. Jones. 4th edn. Demy 8vo. Pp. 452. 1907. Baillière. $15 s$.

Walsham, H., and Orton, G. H. The Röntgen Rays in the Diagnosis of Diseases of the Chest. Demy 8vo. Pp. 80. 1906. Lewis. 6s.

Wickham, L. Radium Therapy. Translated by S. E. Dore. Roy. 8vo. Pp. 326. 1910. Cassell. $15 s$.

\section{Xi. ELEGTROTHERAPY, ETG.}

Crook, H. E. High Frequency Currents. Their Production, Physical Properties, Physiological Effects and Therapeutical Uses. 2nd edn. Demy 8vo. Pp. 214. 1909. Baillière. $8 s, 6 d$. 


\section{Therapeutics.}

Cumberbatch, E. P. Essentials of Medical Electricity. 5th edn. Cr. 8vo. Pp. 404. 1921. Kimpton. $10 s .6 d$.

- Diathermy, its Production and Uses in Medicine and Surgery . Demy 8vo. Pp. 203. 1921. Heinemann. $21 s$.

Friel, A. R. Electric Ionization: A Practical Introduction to its Use in Medicine and Surgery. Demy 8vo. Pp. 78. 1920. John Wright. $8 s$.

Garton, W. Electro-Therapeutics for Military Hospitals. Cr. 8vo. Pp. 56. 1917. Lewis. $2 s .6 d$.

Harris, J. D. Lectures on Medical Electricity to Nurses. Cr. 8vo. Pp. 96. 1913. Lewis. 3s.

Harris, W. Electrical Treatment. 3rd edn. Cr.8vo. Pp.365. 1919. Cassell. 10s. $6 d$.

Humphris, F. H. Electro-Therapeutics for Practitioners. 2nd edn. Demy 8vo. Pp. 310. 1921. Frowde \& Hodder. $21 s$.

Jones, H. L. Medical Electricity. A Practical Handbook for Students and Practitioners. 8th edn. Revised by L. W. Bathurst. Demy 8vo. Pp. 590. 1920. Lewis. $22 s .6 d$.

Magill, E. M. Notes on Galvanism and Faradism. 2nd edn. Cr. 8vo. Pp. 240. 1919. Lewis. 6s.

Parsons, J. J. The Healing of Rodent Cancer by Electricity. Cr. 8vo. Pp. 90. 1906. Bale \& Danielsson. $5 s$.

Redding, J. M. Aids to ElectroTherapeutics. Pott 8vo. Pp.204. 1920. Baillière. 5s.
Saberton, C. Diathermy in Medical and Surgical Practice. Cr. 8vo. Pp. 150. 1920. Cassell. 7s.6d.

Turner, D. A Manual of Practical Medical Electricity, the Rontgen Rays, Finsen Light, Radium and its Radiations, and High Frequency Currents. 4th edn. Demy 8vo. Pp.458. 1905. Baillière. 10s.6d.

Webb, J. C. Electro-Therapy: Its Rationale and Indications. $\mathrm{Cr}$. 8vo. Pp. 90. 1920. Churchill. 5s.

\section{Xii. PSYGHO-THERAPEUTICS ; HYPNOTISM.}

Brown, H. Advanced Suggestion (Neuroinduction). 2nd edn. Cr. 8vo. Pp. 414. 1021. Baillière. 10s. $6 d$.

Hilger, W. Hypnosis and Suggestion. Their Nature, Mode of Action, Signification and Position amongst Remedial Measures. Translated from the German by R. W. Felkin. Demy 8vo. Pp. 233. 1912. Heinemann. 10s. 6d.

Moll, A. Hypnotism. Cr. 8vo. Scott Pub. Co. $78.6 d$.

Schofield, A. T. Unconscious Therapeutics: or the Personality of the Physician. 2nd edn. Cr.8vo. Pp. 330. 1906. Churchill. 5s.

Tuckey, C. L. Treatment by Hypnotism and Suggestion; or PsychoTherapeutics. 7th edn. With an additional Chapter on Treatment by Suggestion during the War, by A. P. Allan. Demy 8vo. Pp. 427. 1921. Baillière. $12 s$.

Wingfield, H. E. An Introduction to the Study of Hypnotism: Experimental and Therapeutic. 2nd edn. Cr.8vo. Pp.203. 1920. Baillière. $7 s, 6 d$. 


\section{PHARMACY AND MATERIA MEDICA.}

i. GENERAL.

Beddoes, T. P. Prescribers' Formulary and Index of Pharmacy. Based on the 1914 B.P. 2nd edn. Pocket size. Pp. 148. 1915. Baillière. 2s. 6d.

Bennett, R. R. Materia Medica and Pharmacy, for Medical Students; with an Appendix on Incompatibility. 4th edn. Fcap. 8ro. Pp. 288. 1921. Lew is. 7s.6d.

Medical and Pharmaceutical Latin for Students of Pharmacy and Medicine. 2nd edn. Cr. 8vo. Pp. 458. 1914. Churchill, 7s.6d.

Crossley -Holland, W. The Pharmacy Handbook. Cr. 8vo. Pp. 232. 1914. Frowde \& Hodder. 7s, 6d.

Forster, E. L. B. How to Become a Dispenser. Cr. 8vo. Pp.98.1917. Fisher Unwin. 2s, 6d.

Hale-White, Sir W. Materia Medica, Pharmacy, Pharmacology and Therapeutics. 17th edn. Fcap. 8vo. Pp. 728. 1920. Churchill. $10 s .6 d$.

Ince, J. The Latin Grammar of Pharmacy, for the Use of Medical and Pharmaceutical Students. 9th edn. Cr. 8vo. Pp. 376. 1918. Baillière. $7 s, 6 d$.

Lucas, E. W. The Book of Receipts : containing a Veterinary Materia Medica; Pharmaceutical Formularies for the Manufacture of Proprietary Articles, Toilet Preparations, Dietetic Articles, etc., with numerous Chemical and other Tables. Cr. 8vo. Pp.460. 1907. Churchill. 8s.6d.

and Stevens, H. B. Practical Pharmacy. 3rd edn. Roy. 8vo. Pp. 431. 1921. Churchill. 27s.

- First Lines in Dispensing. 2nd edn. Cr. 8vo. Pp. 180. 1919. Churchill. $6 s$.
MacEwan, P. Pharmaceutical Formulas. 'P.F.' being 'The Chemist and Druggists' Book of Useful Recipes for the Drug Trade. 9th edn. Cr. 8vo. Pp. 1,078. 1919. "The Chemist and Druggist", Office. $17 s, 6 d$.

Pharmaceutical Pocket Book for Practitioners and Students, The. 10th edn. 18mo. Pp. 360. 1921 . Pharmaceutical Press. $3 s .6 d$.

Stark, A. C. Aids to Practical Pharmacy. 2nd edn. Fcap. 8vo. Pp. 165. 1911. Baillière. 3s.

Sutherland, W. G., and Warwick, F.J. Dispensing Made Easy: with numerous Formulæ and Practical Hints to secure Accuracy, Simplicity, Rapidity, and Economy . 4th edn. Pp.102. 1910. John Wright. $3 s .6 d$.

Whitla, Sir W. Elements of Pharm. acy, Materia Medica, and Therapeutics. 10th edn. Cr.8vo. Pp.686. 1915. Baillière. $10 s .6 d$.

Wootton, A.C. Chronicles of Pharmacy. 2 Vols. 8vo. Pp.440, 340. 1910. Macmillan. 21s .

Year Book of Pharmacy, 1920. Demy 8vo. Pp. 632. Oct., 1920. Churchill. 12s, $6 d$.

\section{ii. PHARMACOPGIAS.}

The British Pharmacopøia, 1914. Demy 8vo. Pp. 633. 1914. Constable. 10s. $6 d$.

Craig, W. Posological Tables. Being a Tabular Arrangement of all the Medicines contained in the 1914, B.P., with Dose, etc. $32 \mathrm{mo}$. 1915. Livingstone. $1 s .6 d$.

Gadd, H.W. A Synopsis of the British Pharmacopoia, 1914, and of the Poison Laws of Great Britain and Ireland. 10th edn. Pocket size. Pp. 200. 1918. Baillière. 2s. 


\section{Pharmacy and Materia Medica.}

Lucas, E. W., and Stevens, H. B. The Book of Pharmacopœias and Unofficial Formularies. Based upon the 1914 B.P. Cr. 8vo. Pp. 532. 1915. Churchill. 7s, 6d.

Martindale, W. H., and Westcott, W. W. The Extra Pharmacopœia. 17th edn. 2 Vols. Fcap. 8vo. Vol. 1. Pp. 1145. 1920. 27s. Vol. 2. Pp. 720. 1921. 17s.6d. Lewis .

Squire, Sir P. W. Companion to the British Pharmacopoia, comparing the strength of its various Preparations with those of the United States and other Foreign Pharmacopœias, etc. 19th edn. 8vo. Pp. 1708. 1918. Churchill. $25 s$.

Pocket Companion to the British Pharmacopœia. Based upon the 1914 B. P. 2nd edn. Fcap. 8vo. Pp. 1056. 1915. Churchill. 12s. $6 d$.

The Pharmacopœias of Thirty of the London Hospitals, arranged in Groups for Comparison. 8th edn. 12mo. Pp. 494. 1910. Churchill. $5 s$.

- The Pharmacopœia of the Hospital for Diseases of the Throat. 7th edn. Feap. 8vo. Pp. 76. 1914. Churchill. 2s.6d.

Thompson, G.J.S. A Compendium of the Pharmacopœias and Formularies (official and unofficial) with Practical Aids to Prescribing and Dispensing. Revised in accordance with the 1914 B.P. 5th edn. 12mo. Pp. 404. 1915. Bale and Danielsson. 6s.

\section{iii. MATERIA MEDICA.}

Catechism Series. Materia Medica . 2nd edn. Revised according to the 1914 B.P. Revised by J. A. Whitla. In one volume. cloth, 5s. 6d. 3 Parts. 1s. 9d. each. Livingstone.

Collie, A. E. Aids to Materia Medica . Frap. 8vo. Pp. 124. 1919. Baillière. 3s.
Fernie, W. T. Herbal Simples Approved for Modern Uses of Cure. A Handbook of Curative Herbal Simples supplied from the Garden, Field, Hedgerow, and Store-closet. 3rd edn. Cr. 8vo. Pp. 596. 1914. John Wright. 6s. 6d.

Ghosh, R. A Treatise on Materia Medica and Therapeutics. 8th edn. by B. H. Deare and B. N. Ghosh. 8vo. Pp. 710. 1920. Simpkin. Marshall. 9s.6d.

Greenish, H. G. A Text-book of Materia Medica: for Students of Pharmacy and of Medicine. Brd. edn. 8vo. Pp. 580. 1920. Churchill. 27s.

Marshall, C. A Text-book of Materia Medica for Students of Medicine. 8vo. Pp. 648. 1905, Churchill. $10 s .6 d$.

Nunn, A. W. Materia Medica, Step by Step. Fcap. 8vo. Pp. 240. 1911. Churchill. 3s.6d.

Southall, W. Organic Materia Medica: A Handbook treating of the more important of the Animal and Vegetable Drugs. 8th edn. Cr. 8vo. Pp. 410. (1915). 1919. Churchill. 12s.6d.

Waring, E. J ., and Lukis, Sir C.P. Remarks on the Uses of some of the Bazaar Medicines and Common Medical Plants of India. 6th edn. Fcap. 8vo. Pp. 347. 1907. Churchill. 6s.

\section{iv. PHARMACOLOGY .}

Brickdale, J. M. F. A Text-book of Pharmacology and Medical Treatment for Nurses. Roy. 8vo. Pp. 406. 1920. Oxford University Press. 25s.

Cow, D. V. Synopsis of Pharmacology. Cr. 8vo. Pp. 132. 1920. Churchill. 7s. 6d.

Cushny, A. R. A Text-book of Pharmacology and Therapeutics, or the Action of Drugs in Health and Disease. 7th edn. Roy. 8vo. Pp. 712. 1918. Churchill. 24s. 
Dixon, W. E. Practical Pharmacology, for the use of Students of Medicine. Demy 8vo. Pp. 96. 1919. Cambridge University Press. $7 s .6 d$.

A Manual of Pharmacology . 5th edn. in preparation. Arnold.

Francis, F., and Brickdale, J. M. F. The Chemical Basis of Pharmacology. Demy 8vo. Pp. 384. 1908. Arnold. 15s.

Freyberger, L. The Practitioner's Pocket Pharmacology and Formulary. Fcap. 8vo. Pp.545. 1917. Heinemann. 12s, 6d.

Gadd, H. W. Drugs: their Production, Preparation, and Properties. Cr.8vo. Pp. 192. 1904. Baillière. $5 s$.
Martindale, W. H. Digitalis Assay . A Method of Chemical Standardisation to Equal Physiological Assay. Demy 8vo. Pp. 47. 1913. Lew is. $2 s$.

Pembrey, M. S., and Phillips, C. D.F. The Physiological Action of Drugs. An Introduction to Practical Pharmacology. Demy 8vo. Pp. 1,908. 1901. Arnold. 5s.6d.

Sainsbury, H. Drugs and the Drug Habit. Demy 8vo. Pp.321. 1909 . Methuen. 10s. $6 d$.

White, Sir W.H. (edited by). Textbook of Pharmacology and Therapeuties. Roy. 8vo. Pp. 1050. 1901. Frowde \& Hodder. 21s. 


\section{NURSING.}

\section{GENERAL AND MEDICAL.}

Ashdown, A. M. A Complete System of Nursing. Demy 8vo. Pp. 746. 1920. Dent. 12s.6d.

'Bryan, M. T. The Nurses' Complete Medical Dictionarv. Pocket size. Pp. 208. 1912. Baillière. 2s. 6d.

Cook, J . B. Index of Practical Nursing. 2nd edn. Cr. 8vo. Pp. 176. 1920. Baillière. $6 s$.

Cuff, H. E. Lectures on Medicine to Nurses. 7th edn. Cr. 8vo. Pp. 265. 1920. Churchill. 7s. 6d.

Domville, E. J. A Manual for Hos. pital Nurses and others engaged in Attending on the Sick. 9th edn. Cr. 8vo. Pp.160. 1907. Churchill. $1 s$.

Fitzwilliams, D. C. L. A Nursing Manual for Nurses and Nursing Orderlies. Cr. 8vo. Pp. 466 . 1914. Frowde \& Hodder. 6s. 6d.

Forsyth, D. Lectures on Medical Diseases for Nurses. Cr. 8vo. Pp. 230. 1914. Baillière. 3s. 6d.

Groves, E.W.H., and Brickdale, J. M. F. Text Book for Nurses : Anatomy, Physiology, Surgery and Medicine. 2nd edn. 4th imp. Roy. 8vo. Pp. 456. 1921. Frowde \& Hodder. 25s.

Gullan, M. A. Theory and Practice of Nursing. Demy 8vo. Pp. 230. 1920. Lewis. 10s. 6d.

Hassard, E. M., and Mrs A. R. Practical Nursing. For Male Nurses in the R.A.M.C. and other Forces. Cr. 8vo. Pp. 352. 1910. Frowde \& Hodder. 4s. 6 d.
Henderson, $J$. Medicine for Nurses . Cr. 8vo. Pp. 270. 1921. Arnold. $8 s .6 d$.

Humphry, L. A Manual of Nursing : Medical and Surgical. 39th edn. Cr. 8vo. Pp. 267. 1917. Griffin. $3 s .6 d$.

Luckes, E. C. E. General Nursing . loth edn. Cr.8vo. Pp.360. Kegan Paul. 5s.

Morten, H. (edited by). A Complete System of Nursing. By Medical Men and Nurses. 4th edn. Cr. 8vo. Pp. 402. 1915. Dent. 9s. 6d.

- compiled by). The Nurse's Dictionary, with Phonetic Punctuation by M. I. Burdett. 10th edn. Pocket size. Pp. 208. N.D. Scientifec Press. 3s. 6d.

Stewart, I., and Cuff, H. E. Practical Nursing. 5th edn. Cr. 8vo. Pp. 458. 1919. Blackwood. $6 s$.

Watson, J. K. A Handbook for Nurses; with Examination Questions based on the Contents of the Chapters. 6th edn. Cr. 8vo. Pp. 788. 1921. Scientific Press. 10s . 6d.

Weeks -Shaw, C., and Radford, W. A Text-book of Nursing for Home and Hospital Use. 2nd edn. Cr. 8vo. Pp. 358. 1896. Arnold. 4s. $6 d$.

Woodwark, A. S. Medical Nursing . Cr. 8vo. Pp. 324. 1914. Arnold. $5 s$. 


\section{VETERINARY.}

\section{i. PHYSIOLOGY AND ANATOMY .}

Bradley, O. C. Outlines of Veterinary Anatomy. Cr. 8vo. Pp. 244. 1897. Baillière. 10s.6d.

A Guide to the Dissection of the Dog. Demy 8vo. Pp. 249. 1919. W. Green. $15 s$.

The Topographical Anatomy of the Limbs of the Horse. Roy. 8vo. Pp. 183. 1920, W. Green. 21s. and Browne, T.G. Atlas of the Horse: Its Anatomy and Physiology. Feap. folio. Pp. 38 and 13 Plates by G. Dupuy. 1918 . Baillière. $7 s, 6 d$.

Paton, D. N., and Orr, J.B. Essentials of Veterinary Physiology. 3rd edn. Roy. 8vo. Pp. 693. 1920. W. Green. $25 s$.

Share-Jones, J. T. The Surgical Anatomy of the Horse. 4 Vols. Demy 4to. Vol. 1. Head and Neck. Pp. 172. 1906. Vol. 2. The Fore Limb. Pp. 202. 1907. Vol. 3. The Hind Limb. Pp. 230. 1908. Vol. 4. The Foot and Trunk. Pp.270. 1914. Baillière. $16 s .6 d$. each.

Smith, Sir F. Manual of Veterinary Physiology. 5th edn. Demy 8vo. Pp. 908. 1921. Baillière. 35s .

Strangeway, T. Veterinary Anatomy. 10th edn. Demy 8vo. Pp. 617. 1917. W. Green. 25s.

\section{ii. MEDICINE AND SURGERY .}

Cadiot, P. J ., and Dollar, J. A. W . Studies in Clinical Veterinary Medicine, and Surgery. Roy. 8vo. Pp. 620. 1903. Baillière. 15s.

Courtenay, E., and Hobday, F. T . G. Manual of the Practice of Veterinary Medicine. 3rd edn. Demy 8vo. Pp. 472. 1913. Baillière, $12 s$.
Dollar, J. A. W. Regional Veterinary Surgery and Operative Technique. Reissue. svo. Pp. 1164. 1920. Baillière. 25s.

Fleming, G., and Craig, J. Veterinary Obstetrics: including the Diseases and Accidents Incidental to Pregnancy and Parturition. 3rd edn. Demy 8vo. Pp. 536. 1917. Baillière. $18 s$.

Hoare, E. W. (edited by). A System of Veterinary Medicine. By Various Writers. 2 Vols. Roy. 8vo. 1913-14. Vol. 1. Microbial Diseases. Pp. 1344. Vol. 2. General Diseases, including a Section on Parasites. Pp. 1644. Baillière. $55 s$.

Hobday, F. T. G. Surgical Diseases of the Dog and Cat: with Chapters on Anæsthetics and Obstetrics. 3rd edn. in preparation. Baillic̀re.

MacCabe, F. F . Horse-Mastership. A Lecture, with Notes on the Schooling of Jumpers, the Bacteriology of Coughing, and the Diseases carried by Horse-Flies, Ticks, and Tse-tse Flies. Cr. 8vo. Pp.82, 1911. Baillière. $3 s .6 d$.

Reeks, H. C. The Common Colics of the Horse: their Causes, Symptoms, Diagnosis and Treatment. 3rd edn. Pp.386. 1914. Baillière. 6s. $6 d$.

Diseases of the Horse's Foot . 2nd edn. in preparation. Baillière.

Smythe, R.H. Wounds of Animals and their Treatment. Cr.8vo. Pp. 204. 1918. Baillière. 7s, 6d.

Thompson, H. Elementary Lectures on Veterinary Science for Agricultural Students, Farmers, and Stockkeepers. 4th edn. Demy 8vo. Pp. 560. 1919. Baillière. 15s . 
Twort, F. W., and Ingram, G. L . Johne's Disease: a Monograph. (Enteritis chronica pseudotuberculosa bovis). Demy 8vo. Pp. 192. 1913. Baillière. 10s, 6d.

Williams, W. The Principles and Practice of Veterinary Medicine. 9th edn. Revised by W. $O$. IVilliams and F. S. H. Baldrey. 8vo. Pp. 1004. 1909. Baillière. $25 s$.

\section{iii. THERAPEUTICS ; TOXI - GOLOGY, etc.}

Banham, G. A., and Young, W. J. Table of Veterinary Posology and Therapeutics, with Weights, Measures, etc., for the use of Students and Practitioners. Revised in accordance with the 1914 B.P. 4th edn. Fcap. 8vo. Pp. 288. 1918. Baillière. 5s.

Hoare, E. W. A Manual of Veterinary Therapeutics: A Guide to the Treatment of Diseases of Domestic Animals. 3rd edn. Demy 8vo. Pp. 968. 1916. Baillière. $21 s$.

Jowett, W . Notes on Blood-Serum Therapy, Preventive Inoculation, and Toxin and Serum Diagnosis. For Veterinary Practitioners and Students. Cr. 8vo. Pp.212. 1907. Baillière. 6s .

Lander, G. D. Veterinary Toxicology. Demy 8vo. Pp. 324. 1912. Baillière. $8 s, 6 d$.

Nunn, J.A. Veterinary Toxicology . Cr. 8vo. Pp. 204. 1907. Baislière. 5s.

Peacey, E. Common Diseases of Pigs and their Diagnosis, including Swine Fever and its Treatment with Serum. Cr. 8vo. Pp.122. 1918. Baillière. 4s. $6 d$.
Scott, W. Clinical Bacteriology and Vaccine Therapy for Veterinary Surgeons. Demy 8vo. Pp. 236. 1913. Baillière. 8s.6 $d$.

Smythe, R. H. Veterinary Parasitology. Cr. 8vo. Pp. 144. 1911. Baillière. $6 s$.

Steel, J. H. A Treatise on the Diseases of the $\mathrm{Ox}$; being a Manual of Bovine Pathology for Veterinary Students and Practitioners. 8vo. Longmans. $21 s$.

\section{iv. GENERAL.}

Barton, F. T. The Horse: Ailments and Accidents. Cr. 8vo. Pp. 202. 1907. Arnold. 2s.6d.

Horses and Practical HorseKeeping. 2nd edn. Demy 8vo. Pp. 644. Jarrolds. $21 s$.

Cross, H. F. The Camel and Its Diseases, being Notes for Veterinary Surgeons and Commandants of Camel Corps. Cr. 8vo. Pp. 159. 1917. Baillière. 5s.

Fleming, G., and MacOueen, J. Practical Horse-Shoeing. 11th edn. Cr. 8vo. Pp. 140.1916. Baillière. 3s. 6d.

Galvayne, S. The Twentieth Century Book on the Horse. 3rd edn. Demy 4to. Pp. 372. 1912. Baillière. 25s.

Leese, A. S. Tips on Camels, for Veterinary Surgeons on Active Service. Roy. 8vo. Pp. 56. 1917. Baillière. 2s.6d.

Linton, R. G. Veterinary Hygiene. Roy. 8vo. Pp. 443. 1921. W. Green. $26 s$. 


\section{TEXTILES.}

\section{i. HISTORIGAL AND ECONOMIC.}

Chapman, S. J. The Lancashire Cotton Industry. Demy 8vo. Pp. 320. 1904. Sherratt \& Hughes. 7s. $6 d$.

The Cotton Industry and Trade. Cr.8vo. Pp.183. 1905. Methuen. $5 s$.

Glapham, J. H. The Woollen and Worsted Industries. Cr. 8vo. Pp. 316. 1907. Methuen. 7s.6d.

Daniels, G. W. The Early English Cotton Industry; with some unpublished letters of Samuel Crompton. Cr. 8vo. Pp. 245. 1920. Longmans. $8 s, 6 d$.

Horner, J. The Linen Trade of Europe during the Spinning Wheel Period. Demy 8vo. Pp.605.1920. M'Caw, Stevenson \& Orr. $25 s$.

Rawlley, T. C. The Silk Industry and Trade. 8vo. Pp. 188. 1919. King. 10s, $6 d$.

- Economics of the Silk Industry . A Study in Industrial Organisation. 8vo. Pp.365. 1919. King. 10s.6d.

\section{ii. RAW MATERIALS.}

Barker, A. F., and Priestley, E. Wool Carding and Combing. With Notes on Sheep Breeding and Wool Growing. Cr.8vo. Pp.276. 1919. Cassell. 7s. $6 d$.

Bigwood, G. Cotton. (Staple Trades and Industries.) Demy 8vo. Pp. 212. 1918. Constable. 6s. 6d.

Bowman, F. H. The Structure of the Cotton Fibre and its Relation to Technical Applications. Cr. 8vo. Pp. 490. 1908. Macmillan. $10 s .6 d$.

The Structure of the Wool Fibre and its Relation to the Use of Wool for Technical Purposes. Cr. 8vo. Pp.496. 1908. Macmillan.10s.6d.
Carter, H. R. Combers and Combing. Demy 8vo. Pp. 144. 1915. Bale \& Danielsson. 5s. $6 d$. - Ramie (Rhea) China Grass, the new Textile Fibre. Cr. 8vo. Pp. 140. 1911. Technical Pub. Co. $6 s .9 d$.

- Flax and its Products. Demy 8vo. Pp. 317. 1920. Bale \& Danielsson. 10s. 6d.

Cordage Fibres: their Cultivation, Extraction and Preparation for the Market. Demy 8vo. Pp. 124. 1909. Bale \& Danielsson. 2s. $6 d$.

- Jute and its Manufacture. Demy 8vo. Pp. 198. 1921. Bale \& Danielsson. $5 s$.

Georgievics, G. Chemical Technology of Textile Fibres. Translated from the German. New edn. in preparation. Scott, Greenwood.

Mitchell, C. A., and Prideaux, R. M. Fibres used in Textile and Allied Industries. Demy 8vo. Pp. 200. 1910. Scott, Greenwood. 8s. $6 d$.

Ormerod, F. Wool. (Staple Trades and Industries). Demy 8vo. Pp. 229. 1918. Constable, 6s, $6 d$.

Priestman, H. Principles of Wool Combing. 2nd edn. Demy 8vo. Pp. 248. 1921. Bell. 12s.

Woodhouse, T., and Kilgour, P. Cordage and Cordage Hemp and Fibres. Cr. 8vo. Pp. 123. 1919. Pitman. 3s.

iii. SPINNING AND DOUBLING. a. Cotton.

Balls, W. L. Handbook of Spinning Tests for Cotton Growers. Demy 8vo. Pp.59. 1920. Macmillan. $3 s .6 d$.

Dobson, B. Some Difficulties in Cotton Spinning. Cr. 4to. Pp. 131. 1901. Heywood. 2s.6d. 
Dobson, B. Humidity in Cotton Spinning. New edn. revised by $W$. Midgley. Cr. 4to. Pp. 145 . 1901. Heywood. 3s. 6d.

Lomax, J . W. Fine Cotton Spinning . A Practical Manual. Cr. 8vo. Pp. 130. 1913. Emmott. 3s.6d.

Nasmith, J . Student's Cotton Spinning. 4th edn. Cr.8vo. Pp. 636 . 1920. Heywood. 15s.

Taggart, W. S. Cotton Spinning. 3 Vols. Cr. 8vo. Vol.1. Including all Processes up to the end of Carding. 6th edn. Pp. 322.1919. $8 s .6 d$. Vol. 2. Including the Processes up to the end of Fly-frames. 6th edn. Pp. 306. 1921. 8s. 6d. Vol. 3. 5th edn. Pp. 520. 1920. 10s. Macmillan.

Thornley, T. Cotton Spinning. Flementary, or First Year. 4th edn. Cr. 8vo. Pp.320. 12s.6d. Intermediate, or Second Year. 3rd edn. Cr. 8vo. Pp. 320. 1916. 8s.6d. Honours, or Third Year. 2nd edn . Cr. 8vo. Pp. 216. 1907. 6s. Scott, Greenwood.

Cotton Waste; its Production, Manipulation and Uses. 2nd edn. Demy 8vo. Pp. 412. 1921. Scott, Greenwood. 17s. 6 $6^{\circ}$.

Wakefield, S. Cotton Doubling and Twisting. 4 Vols. Demy 8vo. 1916. 40s. Also in sections, paper covers. Sec. 1. Yarn Testing. 4s .; Sec. 2. Doubler Winding, $4 s$.: Sec. 3. Ring and Flyer Twisting, 6s. 6d.; Sec. 4. Twiner Twisting, 6s. 6d.; Sec. 5. Clearing and Gassing, 5s.6d.; Sec.6. Preparing, Reeling, and Bundling, 5s.; Sec. 7 . Threads and their Manufacture, 8s.6d.; Sec. 8. Costs, Waste, and Organisation, 6s.6d. Marsden.

b. Woollen and Worsted.

Priestman, H. Principles of Worsted Spinning. 2nd edn. Demy 8vo. Pp. 365. 1921. Longmans. 15s. - Principles of Woollen Spinning . 8vo. Pp. 332. 1908. Longmans. $10 s .6 d$.

Turner, H. Worsted Spinners' Practical Handbook. Cr. 8vo. Pp. 148. 1915. Scott, Greenwood 7s.
Vickerman, C. Woollen Spinning . A Text Book for Students in Technical Colleges, and for skilled practical men in Woollen Mills. Cr. 8vo. Pp. 364. 1894. Macmillan. 7s.6d.

$$
\text { c. Jute, Flax, Silk . }
$$

Carter, H. R. The Spinning and Twisting of Long Vegetable Fibres (Flax, Hemp, Jute, Tow, and Ramie). 2nd edn. Med. 8vo. Pp. 434. 1919. Griffin. 24s.

- Flax, Hemp and Jute Spinners' Catechism. Demy 8vo. Pp. 276. 1910. Bale \& Danielsson. 7s. 6d. - Rope, Twine, and Thread Making. Demy 8vo. Pp. 151. 1909. Bale \& Danielsson. $5 s$.

_ Modern Flax, Hemp and Jute Spinning and Twisting. A Practical Handbook for the Use of Flax, Hemp, and Jute Spinners, Thread, Twine and Rope Makers. Demy 8vo. Pp. 200. 1907. Scott, Greenwood. 8s. 6d.

Leggatt, W. The Theory and Practice of .Jute Spinning. New edn. Demy 8vo. Pp. 300. 1021. Wm. Kidd. $21 s$.

Rayner, H. Silk Throwing and Waste Silk Spinning. New edn . in preparation. Scott, Greenwood.

Sharp, P. Flax, Tow, and Jute Spinning. Cr. 8vo. N.D. Simpkin, Marshall. $5 s$.

\section{iv. WEAVING AND SIZING.}

Bell, T. F. Jacquard Weaving and Designing. Demy 8vo. Pp. 311. 1895. Longmans. 14s.

Brown, A. A Practical Treatise on the Construction of the Power Loom and the Art of Weaving. 10th edn. Sm. Cr. 8vo. Pp. 162. 1921. Simpkin, Marshall. 5s.

Gruner, A. Power-Loom Weaving and Yarn Numbering, According to Various Systems, with Conversion Tables. Translated from the German. Cr. 8vo. Pp. 150. 1900. Scott, Greenwood. 8s. 6d.

Heylin, H. B. The Cotton Weavers' Handbook. 2nd edn. in preparation. Griffin . 
Hooper, L. Weaving for Beginners, with Plain Directions for Making a Hand Loom, Mounting it, and starting the Work. Demy 4to. Pp. 122. 1920. Pitman. 5s.

-Hand-Loom Weaving, Plain and Ornamental. New imp. Cr. 8vo. Pp. 368. 1920. Pitman. 10s.6d.

Kinzer, H., and Walter, K. Theory and Practice of Damask Weaving. Translated from the German. Roy. 8vo. Pp. 110. 1903. Scott, Greenwood. 9s. 6d.

Kretschmar, C. Yarn and Warp Sizing in all its Branches. Translated from the German. Roy . 8vo. Pp. 181. 1911. Scott, Greenwood. 12s. 6d.

Leggatt, W. Theory and Practice of the Art of Weaving Linen and Jute Manufactures, by Power Loom . Part 1. Letterpress. 4s. Part 2. Diagrams. 6s. Wm. Kidd .

Marsden, R. Cotton Weaving. Sm. Post 8vo. Pp. 533. 1895. Bell. 10s. 6d.

Nisbet, H. Preliminary Operations of Weaving. Vol. 1. Preparation of Grey or Plain Warps. Demy 8vo. Pp.414. 1914. Emmott. 10s.6d. Theory of Sizing for Manufacturers of Textile Fabrics. Cr. 8vo. Pp. 86. 1912. Emmott. 3s. 6d.

Taylor, J.T. Cotton Weaving and Designing. New Imp. Cr. 8vo. Pp. 360. 1919. Longmans. 9s.

Woodhouse, T. Heaids and Reeds for Weaving: Setts and Porters. Cr. 8vo. Pp.97. 1920. Emmott. 4s. $6 d$.

and Milne, T. Jute and Linen Weaving. Cr. 8vo. Pp. 618. 1914. Macmillan. 15s.

\section{v. DYEING AND PRIN'TING.}

Beech, F. The Dyeing of Cotton Fabrics. A Practical Handbook for the Dyer and Student. 2nd edn. Demy 8vo. Pp. 272. 1917. Scott, Greenwood. 12s. $6 d$.

- The Dyeing of Woollen Fabrics. Demy 8vo. Pp. 228. 1902. Scott, Greenwood. $8 s .6 d$.
Blackwood, W. Engraving for Calico Printing. Med. 8vo. Pp. 291. 1913. Griffin. 12s. $6 d$.

Ganswindt, A. Dyeing Silk, Mixed Silk Fabrics and Artificial Silks. Translated from the German by $\mathbf{C}$. Salter. Demy 8vo. Pp. 230. 1921. Scott, Greenwood. 12s. 6d.

Hurst, G. H. Silk Dyeing. Small Post 8vo. Pp. 226. 1892. Bell. $7 s .6 d$.

Knecht, E., and Fothergill, J. B . The Principles and Practice of Textile Printing. Med. 8vo. Pp. 631. 1912. Griffin. 42s.

Paterson. D. The Colour Printing of Carpet Yarns : a Manual for Colour Chemists and Textile Printers. Demy 8vo. Pp. 136. 1900. Scott, Greenwood. $8 s, 6 d$.

- Colour Matching on Textiles. A Manual intended for the use of Students of Colour Chemistry, Dyeing and Textile Printing. Demy 8vo. Pp.132. 1901. Scott, Greenwood. $8 s .6 d$.

- Textile Colour Mixing. 2nd edn. Demy 8vo. Pp. 140. 1915. Scott, Greenwood. 8s,6d.

Rothwell, C.F.S. Textile Printing . A Practical Manual, including the Processes used in the Printing of Cotton, Woollen, Silk, and HalfSilk Fabrics. 2nd ern. in preparation. Griffin.

\section{vi. BLEACHING AND FINISHING .}

Beaumont, R. The Finishing of Textile Fabrics (Woollen, Worsted, Union, and other Cloths). Demy 8vo. Pp. 260. 1909. Scott, Greenwood. 12s, 6d.

Carter, H. R. Bleaching and Dyeing of Flax, Hemp and Jute Yarns and Fabrics. Demy 8vo. Pp. 176. 1911. Bale \& Danielsson. 2s. 6d.

Duerr, G., and Turnbull, W. Bleaching and Calico Printing . Large 8vo. Pp. 15s. 1896. Griffin. $12 s .6 d$.

Polleyn, F. Dressings and Finishings for Textile Fabrics and their Application. Demy 8vo. Pp. 280. 1911. Scott, Greenwood. 8s. $6 d$. 


\section{Textiles.}

"Practical Bleacher." Modern Bleaching and Finishing. Cr. 8vo. Pp.70. N.D. Heywood. 2s.

Tailfer, L. Practical Treatise on the Bleaching of Linen and Cotton Yarn and Fabrics. 2nd edn. Demy 8vo. Pp. 337. 1917. Scott, Greenwood. $17 s$.

Trotman, S. R., and Thorp, E. L. The Principles of Bleaching and Finishing of Cotton. 2nd edn. Large 8vo. Pp. 359. 1918. Griffin. $21 s$.

Woodhouse, T. The Finishing of .Tute and Linen Fabries. Demy 8vo. Pp. 326. 1916. Emmott. 8s.6d.

\section{vii. DESIGNING, TESTING,} RESEARCH.

Ashenhurst, T.R. Design in Textile Fabrics. Cr. 8vo. Pp. 256. 1907. Cassell. $4 s .6 d$.

Barker, A. F. An Introduction to the Study of Textile Design. 2nd edn. Demy 8vo. Pp. 230. 1919. Methuen. $8 s .6 d$.

and Midgley, E. Analysis of Woven Fabries. Demy 8vo. Pp. 316. 1914. Scott, Greenwood. $8 s .6 d$.

Beaumont, R. Colour in Woven Design. A Treatise on the Science and Technology of Textile Colouring in Woollen, Worsted, Cotton. and Silk Materials. 2nd edn. Med. 8vo. Pp. 372. 1912. Pitman. $21 s$.

Dumville, J., and Kershaw, S. Worsted Cone Drawing. Demy 8 vo. Pp. 104. 1921. Heywood. 7s.6d.

Herzfeld, J. The Technical Testing of Yarns and Textile Fabrics. with Reference to Official Specifications. Translated from the German. 3rd edn. revised by D. T. Nisbet. 8vo. Pp. 217. 1920. Scott, Greenwood. 17s. 6d.

Nisbet, $H$. Grammar of Textile Design. 2nd edn. Demy 8vo. Pp. 514. 1919. Scott, Greenwood. $21 s$.
North, B ., and Bland, N. Chemistry for Textile Students. A Manual suitable for Technical Students in the Textile and Dyeing Industries. Demy 8vo. Pp. 379. 1920. Cambridge University Press. $30 s$.

Stephenson, C., and Suddards, F . A Text-book Dealing with Ornamental Design for Woven Fabrics. 3rd edn. Demy 8vo. Pp. 286. 1905. Methuen. 8s.6d.

Watson, W. Textile Design and Colour; Filementary Weaves and Figured Fabrics. New edn. in the Press. Longmans.

_ Advanced Textile Design. 8vo. Pp. 474. 1913. Longmans. 14s. Woodhouse, T., and Milne, $\mathbf{R}$. Textile Design: Pure and Applied. Cr. 8vo. Pp. 528. 1912. Macmillan. 12s. $6 d$.

viii. GENERAL MANUFACTURE.

Beaumont, R. Woollen and Worsted : The Theory and Technology of the Manufacture of Woollen, Worsted, Union Yarns, and Fabries. 2nd edn. Roy. 8vo. Pp. 716. 1919. Bell. 42s.

- Union Textile Fabrication, with numerous original Diagrams, Sectional Drawings, and Photographic Reproductions of Spun and Woven Specimens. Demy 8vo. Pp. 376. 1920. Pitman. 21s.

- Standard Cloths: Structure and Manufacture (General, Military and Naval). Demy 8vo. Pp. 342. 1916. Scott, Greenwood. 14s. 6d.

Carter, H. R. The Manufacture of Linen, Hemp, and Jute Fabrics. Demy 8vo. Pp. 97. 1909. Bale \&. Danielsson. 3s. 6d.

Chamberlain, J., and Quilter, J. H. Knitted Fabrics. Cr. 8vo. Pp. 155. 1919. Pitman. 3s.

Davis, W. Hosiery Manufacture. A Treatise showing the Development and Application of the Principles of Knitted Fabric Manufacture. Demy 8vo. Pp.146. 1920. Pitman. 9s.

Foltzer, J. Artificial Silk and its Manufacture. Translated from the French by T. Woodhouse. Demy 8vo. Pp. 256. 1921. Pitman. $21 s$. 
Hooper, L. Silk. Its Production and Manufacture. Cr. 8vo. Pp. 134. 1911. Pitman. 3s.

Hunter, J. A. Wool. From the Raw Material to the Finished Product. Cr. 8vo. Pp. 128. 1912. Pitman. 3s.

Lord, R. T. Decorative and Fancy Textile Fabrics. For Manufacturers and Designers of Carpets, Damask, Dress and all Textile Fabrics. Demy 8vo. Pp. 200. 1898. Scott, Greenwood. 8s.6d.

Moore, A. S. Linen. From the Field to the Finished Product. Cr. 8vo. Pp. 141. 1914. Pitman. $3 s$.

Peake, R. J. Cotton. From the Raw Material to the Finished Product. Cr. 8vo. Pp. 132. 1909. Pitman. 3s.

Radcliffe, J. W. The Manufacture of Woollen and Worsted Yarns. Cr.8vo. Pp.350. 1915. Emmott. $6 s$.

Reiser, N. Faults in the Manufacture of Woollen Goods and their Prevention. Translated from the German. Cr. 8vo. Pp.170. 1903. Scott, Greenwood. 6s.

\section{ix. TEXTILE MACHINERY.}

Booth, N. The Ring Spinning Frame : a Guide for Overlookers and Students. Cr. 8vo. Pp. 76. 1912. Scott, Greenwood. $4 s$.

Dobson, B. Evolution of the Spinning Machine. Cr.8vo. Pp.164. 191.5. Marsden. 2s.

Lander, C. H. Ventilation and Humidity in Textile Mills and Factories. Cr. 8vo. Pp. 184 . 1914. Longmans. $6 s$.

Nasmith, J. Recent Cotton Mill Construction and Engineering. 3rd edn. Cr. 8vo. Pp. 382. 1909. Heywood. $7 s, 6 d$.

Roberts, T. Tappet and Dobby Looms: Their Mechanism and Management. $\mathrm{Cr}$.8vo. $\mathrm{Pp.228.} 1912$. Emmott. 3s. 6d.
Taggart, W. S. Textile Mechanics. 8 vo. Pp. 123. 1915. Routledge. $2 s .6 d$.

Cotton Machinery Sketches. Sup. Royal 8vo. Pp. 134. 1911. Macmillan. $3 s$.

Thornley, T. Cotton Combing Machines. Demy 8vo. Pp. 343. 1902. Scott, Greenwood. $8 s .6 d$.

\section{x. CALGULATIONS AND}

REFERENCE BOOKS, etc.

Barker, A. F. Wool and the Textile Industries: Raw Material to Fin. ished Fabric, in English, French, Italian and Spanish. With a Technical Glossary (in Pocket). 8vo. Pp. 42. 1919. Jowett and Sowry. $10 s$.

Blanco, A. F. (compiled by). Piece Goods Manual. Fabries described; Textile, Knit Goods, Weaving terms explained; with Notes on the Classification of Samples. Demy 8vo. Pp. 196. 1918. King. 5s.

Bradbury, F. Calculations in Yarns and Fabries. 3rd edn. $\mathrm{Cr}, 8 v o$. Pp. 322. 1920. Halifax: F. King. $6 s .6 d$.

Garter, H. R. Practical Mill and Factory Arithmetic. Demy 8vo. Pp. 186. 1911. Bale and Danielsson. 2s. $6 d$.

Gook. Cotton Spinning Calculations. Cr. 8vo. Pp. 94. 1915. Marsden. 2s.

Cotton Year Book, 1921. 16th edn. Cr.8vo. Pp.708. 1921. Marsden. $7 s, 6 d$.

Hardman, A. H. Productive Costs in Cotton Spinning Mills. $\mathrm{Cr}$. 8vo. Pp. 132. 1912. Emmott. $3 s .6 d$.

Heylin, H. B. Cottons, Linens, Woollens, Silks; How to Buy and Judge Materials. Cr.8vo. Pp.101. 1919. Heywood. 3s.

-A Handbook for Buvers and Sellers in the Cotton Trade. Being a Handbook for Merchants, Shipping Manufacturers, etc. Med.8vo. Pp. 242. 1913. Griffin. 10s. 6d. 
Mackie, J. How to Make a Woollen Mill Pay. Cr. 8vo. Pp. 76. 1904. Scott, Greenwood. 4s.6d.

Palmer, T. F. Dictionary of Technical Textile Terms. (Trilingual). Vol. 1. English-FrenchSpanish. Pocket size. Pp. 68. 1920. Hirschfeld. 5s.

Reiser, N. Spinning and Wenving Calculations, especially relating to Woollens. Translated from the German. Demy 8vo. Pp. 160. 1904. Scott, Greenwood. 12s.6d.

Taggart, W. S. Cotton Spinning Calculations. New edn. Cr. 8vo. Pp. 255. 1920. Macmillan. Ts.6d.

Textile Manufacturer's Year Book. 1921. Cr. 8vo. Pp. 344. March, 1921. Emmott. 3s.6d.

Whitwam, J. H. Textile Calculations. Manufacture and Mechanism. Demy 8vo. Pp. 43s. 1920. Pitman. 25s.

Winterbottom, J. Cotton Spinning Calculations and Yarn Costs: a Practical and Comprehensive Manual of Calculations, Yarn Costs and other Data involved in adapting the Machinery in all Sections, and for all Grades, of Spinning and Doubling. New edn. in the Press. Longmans .

Woodhouse, T., and Brand, A. Textile Mathematics. Parts 1 and 2. Cr. 8vo. Pp. 122 each. 1921. Blackie. 2s. 6d. each.

Wool Year Book, 1921. Cr. 8vo. Pp.612. 1921. Marsden. 7s.6d.

\section{Xi. LACE, EMBROIDERY, etc.}

Brinton, R. S. Carpets. Cr. 8vo. Pp. 130. 1919. Pitman. 3s.

Channer, C. G., and Roberts, M.E. Lace Making in the Midlands, Past and Present. Cr. 8vo. Pp. 90. 1900. Methuen. 3s. 6d.

Christie, Mrs. A. H. Embroidery and Tapestry Weaving. 4th edn. Cr.8vo. Pp. 320. 1920. Pitman. 10s. $6 d$.
Milroy, M. E. W. Home Lace Making. A Handbook for Teachers and Pupils. 2nd edn. Cr. 8vo. Pp. 64. 1917. Scott, Greenwood. 2s. 6d.

Okey, T. An Introduction to the Art of Basket Making. Demy 8vo. Pp. 162. 1915. Pitman. 58.

Poole, B. W. The Clothing Trades Industry. Cr.8vo. Pp.110.1920. Pitman. $3 s$.

Smith, W. The Chemistry of Hat Manufacturing. Lectures delivered before the Hat Manufacturers' Association. Revised and edited by $A$. Shonk. Cr. 8vo. Pp. 132. 1906. Scott, Greenwood. 8s. $6 d$.

Symonds, M. Elementary Embroidery. Feap. 4to. Pp. 164. 1915. Pitman. 7s.6d.

Walker, L. Varied Occupations in Weaving and Cane and Straw Work. G1. 8vo. Pp. 242. 1901. Macmillan. 3s. $6 d$.

- Varied Occupations in String Work. Gl. 8vo. Pp. 270. 1914. Macmillan. 3s.6d.

Wilkinson, M. E. Art Needlework and Design, Point Lace. A Manual of Applied Art. Oblong Quarto. 1907. Scott, Greenwood. 4s. 6d.

\section{xii . BOOT AND SHOE MANUFAGTURE.}

Harding, J. S. The Boot and Shoe Industry. Cr. 8vo. Pp. 136. 1918. Pitman. 3s.

Hasluck, P. N. (edited by). Boot and Shoe Pattern Cutting and Clicking. Cr.8vo. Pp.168. 1906. Cassell. 3s .

Plucknett, F. Introduction to the Theory and Practice of Boot and Shoe Manufacture. 8vo. Pp. 336. 1916. Longmans. $7 s, 6 d$.

\section{Xiii . LEATHER WORK.}

Garter, E. E. Artistic Leather Work. A Handbook on the Art of Decorating Leather. Cr. 8vo. Pp. 63. 1912. Spon. 3s.6d. 


\section{T'extiles.}

Ell is, B. E. Gloves and the Glove Leland, C. G. Leather Work:

Trade. Cr. 8vo. Pp. 156. 1921. Stamped, Moulded, Cut, Cuir-

Pitman. $3 s$. Bonilli, Sewn, etc. 3rd edn. Fcap. 4to. Pp. 96. Pitman. 5s. 


\section{GRAPHIC ARTS.}

\section{i. PRINTING AND ITS ALLIED BRANCHES.}

Cumming, D. Handbook of Irithography. An Exhaustive, Practical treatise on the various methods adopted in working the process. 2nd edn. Cr.8vo. Pp. 243. 1919. Black. $10 s, 6 d$.

Fletcher, F. M. Wood-block Printing. A description of the craft of woodcutting and colour printing based on the Japanese Practice. Cr.8vo. Pp. 132. 1916. Pitman. $8 s .6 d$.

Harrap, C. Transferring. The Practice of Transferring to Stone, Zinc and Aluminium as applied to Planographic Printing. Cr. 8vo. Pp. 162. 1912. Raithby, Lawrence. $3 s .6 d$.

Hart, H. Rules for Compositors and Readers at the University Press, Oxford. Revised by Sir J. Murray and H. Bradley. 24th edn. 24mo. Pp. 120. 1921. Oxford University Press. $2 s$.

Herrick, T. P. Embossing, Blocking, Die-Stamping. A Practical Guide. 4th edn. Cr.8vo. Pp.84. N.D. Raithby, Lawrence. $1 s .6 d$.

Jacobi, C. T. Printing: A Practica l Treatise on the Art of Typography as applied more particularly to the Printing of Books. 6th edn. Small post 8vo. Pp. 446. 1919. Bell. $10 s .6 d$.

Some Notes on Books and Printing : a Guide for Authors, Publishers and others. 4th edn. Demy 8vo. Pp. 180. 1912. Bell. 6s.

Joyner, G. Display Work (Typography). Demy 8vo. Pp. 42. 1919. Raithby, Lawrence. $1 s .9 d$.
Joyner, G. Practical Printing. A Handbook of the Art of Typography. 2 Vols. 6th edn. Large $\mathbf{C r}$. 8vo. 1911. Vol. 1. Arts of Composition, Press and Machine Work. Pp. 840. Vol.2. Colour Printing, Warehouse Work, Stereotyping, Electrotyping, Estimating, etc. Pp. 530. Raithby, Lawrence. 9s. the 2 vols.

Kirkbride, J . Fngraving for Illustration, Historical and Practical Notes. Cr. 8vo. Pp. 72. 1903. Scott, Greenwood. 2s. $6 d$.

Legros, L. A., and Grant, J. C. Typographical Printing Surfaces: the Technology and Mechanism of their Production. 8vo. Pp. 756. 1916. Longmans. 67s. 6d.

Naylor, T. E. Principles and Practice of Newspaper Make-up. The Production of Newspapers from the standpoint of the Practical Journalist and Printer. Cr. 8vo. Pp. 80 . 1918. Raithby, Lawrence. 28.6d.

Paton, H. Etching, Dry-Point and Mezzotint. A Practical Treatise for the Painter-etcher. 2nd edn. Med. 8vo. Pp. 213. 1909. Raithby, Lawrence. $15 s$.

Peddie, R. A. An Outline of the History of Printing: to which is added the History of Printing in Colours. New impression in preparation. Grafton.

Philip, A. J. The Production of the Printed Catalogue: Preparation, Printing and Publication. Cr. 8vo. Pp. 151. 1910. Grafton. 6s.

Possnett, V. Stonework: How and Why. Cr. 8vo. Pp. 112.1912. Raithby, Lawrence. $2 s .6 d$.

Practical Notes on Stereotyping and Electrotyping. 2nd edn. Cr.8vo. Pp.152. 1914. Raithby, Lawrence. $3 s .6 d$.

Rhodes, H. J. The Art of Lithography. Demy 8vo. Pp. 344. 1914. Scott, Greenwood. 12s.6d. 
Southward, J. Modern Printing: A Text-book for the Trade Classes in Typography and the Auxiliary Arts . 3rd edn. Revised, re-arranged, and brought up-to-date by the editor of The British Printer, with the assistance of experts in all departments. 2 Vols. Demy $8 v o$. Pp. 448., 398. 1915. Raithby, Lawrence. 6s, each.

Stewart, J. Compositor's Russian Primer. Cr. 8vo. Pp. 40. 1917. Raithby, Lawrence. $2 s .6 d$.

Thorp, J. Printing for Business : A Manual of Printing Practice in Non-Technieal Idiom. Demy 8vo. Pp. 180. 1919. John Hogg . $10 s$. $6 d$.

Wilkinson, W. T. Photo-Mechanical Processes: Photo-Zincography, Photo-Lithography, Photogravure and Collotype. 3rd edn. Cr. 8vo. Pp. 216. N.D. Raithby, Law rence, $4 s$.

Williams, H. W. Greek in Type. An Essay for Printers, designed to provide practical acquaintance with the Language for purposes of printing. 8vo, Pp.32. N.D. Raithby, Lawrence. $1 s$.

\section{ii. BOOKS AND BOOKBIND. ING.}

Adam, P. Practical Bookbinding. Translated from the German. Cr. 8vo. Pp. 180. 1903. Scott, Greenwood. $6 s$.

Aldis, H. G. The Printed Book. Roy. 16mo. Pp. 140. 1916. Cambridge University Press. $3 s .6 d$.

Cockerell, D. Bookbinding and the Care of Books. 4th edn. Cr. 8vo. Pp.352. 1920. Pitman. 10s.6d.

Coutts, H. T., and Stephen, G. A. Manual of Library Bookbinding. Cr. 8vo. Pp. 264. 1911. Grafton. $10 s .6 d$.

Crane, W. The Decorative Illustration of Books. 5th edn. Cr. 8vo. Pp. 350. 1916. Bell. 8s.6d.

Davenport, $C$. The Book: Its History and Development. Ex. Cr. 8vo. Pp. 264. 1907. Constable. $7 s .6 d$.
Horne, H. P. The Binding of Books . 2nd edn. 8vo. Pp. 245. 1915. Kegan Paul. 5s.

Philip, A.J. The Business of Ecckbinding. Cr.8vo. Fp.223. 1912. Grafton. $7 s, 6 d$.

Plomer, H. R. Short History of English Printing, 1476-1900. 2nd edn. 8vo. Pp 288. 1915. Kegan Paul. 5s.

Pollard, A. W. Early Illustrated Books. 2nd edn. 8vo. Pp. 262. 1917. Kegan Paul. 5s.

Zaehnsdorf, J. W. Bookbinding . 9th edn. Small post 8vo. Pp. 190. 1920. Bell. 7s. 6d.

iii. PAPER AND STATIONERY.

Bromley, H.A. Outlines of Stationery Testing. Cr. Svo. Pp. 74 . 1913. Griffin. $3 s$.

Dawe, E. A. Paper and Its Uses. With 35 Samples of Paper. 2nd edn. Cr. 8vo. Pp. 160. 1919 . Crosby Lockwood. $8 s, 6 d$.

Graham, V. (compiled by). Printers' and Stationers' Ready Reckoner and Compendium. $\mathrm{Cr}$. 8vo. Pp. 112. 1904. Scott, Greenwood. $4 s, 6 d$.

Maddox, H. A. What a Stationer and Printer Ought to know About Paper. 2nd edn. Cr.8vo. 1919. Raithby, Lawrence. $1 s .6 d$.

iv. MISGELLANEOUS.

Brown, J. D. A Manual of Practical Bibliography. Fcap. 8vo. Pp. 175. Routledge. $3 s$.

Cannons, H. G. T. A Bibliography of Industrial Efficiency and Factory Management: Classified and Annotated. (Books, Magazine Articles, etc.) 4to. Pp. 167. 1920 . Routledge. $10 s .6 d$.

Educational Expert, An. Manuscript Writing and Lettering. A Handbook showing the Historical Development and Practical Applica. tion to Modern Handwriting of several Manuscript Styles derived from Ancient Roman Letters. Fcap. 4to. Pp. 178. 1918. Pitman. 5s. 


\section{Graphic Arts.}

Hope, Sir W.H.St.J. Heraldry for Craftsmen and Designers. Cr. 8vo. Pp. 496. 1913. Pitman. 10s.6d.

Johnston, E. Writing and Illuminating and Lettering. 10th edn. Cr. 8vo. Pp. 512. 1918. Pitman. 8s. $6 d$.
Johnston, E. Manuscript and In scription Letters for Schools and Classes and the Use of Craftsmen. 16 Plates with full Notes and Descriptions. 3rd edn. Portfolio. 1920. Pitman. 7s. 6d.

Lascelles, T. W . Engraving . Cr. 8vo. Pp. 128. 1920. Pitman. $3 s$. 


\section{PHOTOGRAPHY, PHOTO-MICRO- GRAPHY, CINEMATOGRAPHY.}

\section{i. PHOTOGRAPHY .}

Abney, Sir W. de W. A Treatise on Photography. 10th edn. Cr. 8vo. Pp. 444. 1918. Longmans. 8s. Instantaneous Photography. $\mathrm{Cr}$. 8vo. Pp. 95. 1896. Sampson, Low. 18 .

-Negative Making. Post 8vo. Pp. 113. 1893. Sampson, Low. 1s.

and Clark, L. Platinotype Printing. Post 8vo. Pp. 175. 1895. Sampson, Low. 2s. 6d.

Bayley, R. C. Photography Made Easy. Cr. 8vo. Pp. 264. 1920. Iliffe. $3 s$.

-Photographic Enlarging. 3rd edn. Cr. 8vo. Pp. 170. 1920. Iliffe. $3 s .6 d$.

The Complete Photographer. 6th edn. Demy 8vo. Pp. 432. 1920. Methuen. 15s.

Bedford, E. J. Nature Photography for Beginners. Sq. Demy 8vo. Pp. 168. N.D. Dent. $98.6 d$.

Beeson, F. T., and Williams, $A$. Amateur Photography. Pott 8vo. Pp. 288. 1920. Nelson. 2s. 6d.

Bennett, H. W. Intensification and Reduction. Cr. 8vo. Pp. 124. 1904. Iliffe. 1s. $6 d$.

Brown, G. E., and Mackie, A. Photographic Copyright. Cr. 8vo. Pp. 90. 1912. Henry Greenwood. $1 s$.

Glark, L. Platinum Toning.. $\mathrm{Cr}$. 8vo. Pp. 96. Iliffe. 1s.6d.

Cole, R. S. A Treatise on Photographic Optics. 2nd edn. Pp. 330. N.D. Sampson, Low. 2s. 6d.

Crabtree, J. H. Camera Work for Pleasure, Utility and Profit. $\mathrm{Cr}$. 8vo. Pp. 142. 1920. Routledge. $1 s, 6 d$.
Davis, C. F. L. Telephotography . 2nd edn. by L. Booth. Cr. 8vo. Pp. 128. 1921. Routledge.3s.6d.

D'Heliecourt, R. Photographic Enamels. Cr. 8vo. Pp.94. 1905. Iliffe. $1 s .6 d$.

Ferguson, W. B. (edited by). The Photographic Researches of Ferdinand Hurter and Vero C. Driffield. Being a Reprint of their Published Papers, together with a History of their Early Work and a Bibliography of Later Work on the same subject. Quarto. Pp. 386. 1920. Royal Photographic Society of Great Britain. 25s .

Gamble, W. Photography and Its Applications. Cr. 8vo. Pp. 144 . 1920. Pitman. 3s.

Garrett, A. E., and Vogel, H. The Advance of Photography, its History and Modern Applications. 8vo. Pp. 395. 1911. Kegan Paul. $12 s .6 d$.

Gower, H. D., Jast, L. S., and Topley, W. W. The Camera as 'Historian. Cr. 8vo. Pp. 259. 1916. Sampson, Low . 6s .

Harris, G. T. Practical Slide Making. Cr.8vo. Pp. 131.1904. Iliffe. $1 s, 6 d$.

Hewitt, C. Practical Professional Photography. 2 Vols. Cr. 3vo. Pp. 126., 114. 1902-4. Iliffe. 1s. 6d. each.

Hibbert, L. J. A Manual of Photographic Technique: describing Apparatus, Materials, and the details of Procedure. Pott 8vo. Pp. 128. 1921. Pitman. 2s,6d.

Hughes, A. L. Photo-Electricity . Demy 8vo. Pp. 152. 1914. Cambridge University Press, $8 s$. 


\section{Photography, Photo-Micrography, Cinematography.}

Johnson, G. L. Photography in Colours. 3rd edn. Cr. 8vo. Pp. 316. 1919. Routledge. 6s.

Johnson, R. The Art of Retouching Negatives and Finishing and Colouring Photographs. 10th edn . Revised by T. S. Brace and $\mathbf{A}$. Braithwaite. Demy 8vo. Pp. 100. 1920. Marion. 5s.

Jones, C. Photography of To-Day . Cr.8vo. Pp.342. 1920. Seeley. $7 s .6 d$.

Lambert, F. C. Lantern Slide Making. Cr.8vo. Pp.141. Iliffe. $1 s .6 d$.

Lummer, O. Contributions to Photographic Optics. Translated by S.P. Thompson. 8vo. Pp. 148 . 1900. Macmillan. 7s.6d.

Marriage, E. Elementary Telephotography . Demy 8vo. Pp.117. 1901. Iliffe. $3 s .6 d$.

Meldola, R. The Chemistry of Photography. Cr. 8vo. Pp. 398. 1913. Macmillan. 7s.

Mortimer, F. J. Magnesium Light Photography. Cr. 8vo. Pp. 96. Iliffe. $1 s .6 d$.

- and Coulthurst, S. L. The Oil and Bromoil Processes. 2nd edn. Cr. 8vo. Pp. 99. 1912. Iliffe. 1s. $6 d$.

Norton, G., and Bonner, J. The Lantern and How to Use it. Cr. 8vo. Pp. 143. Iliffe. 1s.6d.

Orford, H. Lens Work for Amateurs. 4th edn. Cr.8vo. Pp. 231. 1919. Pitman. 3s. 6d.

Penlake, R. How to Colour Photographs and Lantern Siides. $\mathrm{Cr}$. 8vo. Pp. 177. Iliffe. 1s.6d.

Pigg, J. I. The Photographic Instructor. Revised by $\mathbf{P}$. R. Salmon. Cr.8vo. Pp. 260. 1921. Chapman and Hall. 3s. $6 d$.

Piper, C. W. A First Book of the Lens. Cr. 8vo. Pp. 170. 1901. Iliffe. $3 s .6 d$.

Robinson, H. P. The Studio and What to do in it. 3rd edn. Cr.8vo. Pp. 166. 1905. Iliffe. 3s.6d.
Smith, R. E. B . Toning Bromide Prints. Cr. 8vo. Pp. 104. 1904. Iliffe. $1 \mathrm{~s}, 6 \mathrm{~d}$.

Sparrow, F. W. . The Principles of Simple Photography. Cr. 8vo. Pp. 130. 1902. Iliffe. 1s.6d.

Taylor, J. T. The Optics of Photography and Photographic Lenses. 3rd edn. with a new chapter on Anastigmatic Lenses, by P. F. Everitt. Cr.8vo. Pp. 270. 1904. Pitman. $4 s$.

Taylor, W. Photographic Chemicals and How to Make Them. Cr. 8vo. Pp. 107. Iliffe. 1s. 6d.

Townsend, C. F. Chemistry for Photographers. 5th edn. Cr. 8vo. Pp.129. Iliffe. 1s.6d.

Vogel, E. Practical Pocket-book of Photography: A Short Guide to the Practice of all the usual Photographic Processes for Professionals and Amateurs. 2nd edn. $12 \mathrm{mo.}$ Pp. 223. 1903. Allen and Unwin. $2 s .6 d$.

Wall, E. J. The Dictionary of Photography and Reference Book for Amateurs and Professional Photographers. 10th edn. Edited by F.J. Mortimer. Cr. 8vo. Pp. 696. 1920. Iliffe. 12s. $6 d$.

Carbon Printing. Cr. 8vo. Pp. 104. Iliffe. 1s.6d.

Warren, E. J. The Platinotype Process. Cr.8vo. Pp.84. Iliffe. $1 s .6 d$.

Watkins, A. Photography : its Prin. ciples and Applications. 2nd edn. Ex. Cr. 8vo. Pp. 349. 1920. Constable. 12s. 6d.

Wheeler, O. A Primer of Photography. Cr. 8vo. Pp. 210. 1910. Methuen. 3s.6d.

\section{ii PHOTO-MICROGRAPHY.}

Bousfield, E. C. Guide to the Science of Photo-Micrography . 2nd edn. 8vo. Pp. 174. 1892. Churchill. $6 s$.

Duncan, F. M. First Steps in Photo-Micrography. Cr. 8vo. Pp. 104. Iliffe. 1s. $6 d$. 


\section{Photography, Photo-Micrography, Cinematography.}

Hind, H. L., and Randles, W. B . Handbook of Photo-Micrography. 8vo. Pp. 304. Routledge. 8s.6d.

Pringle, A. Practical Photo-Micrography. 3rd edn. Cr. 8vo. Pp. 176. 1902. Iliffe. $3 s .6 d$.

Spitta, E. J. Photomicrography . Demy 4to. Pp. 163. 1899 . Scientific Press. 15s.

West, G. The Practical Principles of Plain Photo-Micrography. Cr. 4to. Pp. 159. 1916. Author: University College, Dundee. 4s.6d.

iii. GINEMATOGRAPHY .

Cinema, The. Its Present Position and Future Possibilities: being the Report and chief evidence taken by the Cinema Commission of Enquiry, instituted by The National Council of Public Morals. Demy 8vo. Pp. 362. 1917. Williams and Norgate. 12s, fid.
Donaldson, L. Cinematography for Amateurs. Cr, 8vo. Pp. 94. Iliffe. $1 s, 6 d$.

Foster, R. B. Hopwood's Living Pictures. Their History, PhotoProduction, and Practical Working. 2nd edn. Demy 8vo. Pp. 387. 1915. Hatton Press. 6s.

Ibbetson, W. S. The Kinema Operators' Handbook; Theory and Practice. Cr. 8vo. Pp. 160. 1921. Spon. 4s. 6d.

Jones, B. E. (edited by). The Cinematograph Book. Large Cr. 8vo. Pp. 224. 1919. Cassell. $4 s$.

Talbot, F. A. Practical Cinematography. Cr. 8vo. Pp. 274. 1913. Heinemann. $3 s .6 d$. 


\section{SCIENTIFIC MANAGEMENT, ESTIMATING AND COSTING, etc.}

\section{i. SGIENTIFIC AND WORKS' MANAGEMENT.}

Amar, J . The Human Motor and the Scientific Foundations of Labour. 8vo. Pp. 470. 1920. Routledge. $30 s$.

Batey, J. The Science of Works' Management. Cr. 8vo. Pp. 232. 1914. Scott, Greenwood. $5 s$.

Burton, F. G. The Commercial Management of Engineering Works. 2nd edn. Demy 8vo. Pp. 448. 1911. Scientific Pub. Co. 15s.

Elbourne, E. T . Factory Administration and Cost Accounts. A Reference Book of the Principles and Practice of Industrial Administration and Costing for Present Day Requirements. 3rd edn. Roy. 8vo. Pp. 832. 1921. Longmans. $45 s$.

The Management Problem. Cr. 8vo. Pp. 153. 1920. Library Press. 4s. 6d.

Gilbreth, F. Motion-Study for the Handicapped : with 73 Photographs, presenting the author's latest inventions in fatigue-saving, fatigueregistering, etc. Cr.8vo. Pp.irs. 1920. Routledge. $8 s .6 d$.

Hutchins, B. L., and Harrison, A. History of Factory Legislation. 2nd edn. Demy 8vo. Pp. 314. 1911. King . $7 s \cdot 6 d$.

Hutton, J . E. Welfare and Housing . A Practical Record of War-Time Management. Cr. 8vo. Pp. 200. 1918. Longmans. $5 s$.

McKillop, M., and A. D. Efficiency Methods : an Introduction to Sciertific Managemen. 2nd imp. Cr. 8vo. Pp. 223. 1920. Routledge. is.
Wilson, R.M. The Care of Iluman Machinery. Cr. 8vo. Pp. 250. 1921. Frowde and Hodder. 10s, $6 d$.

\section{ii. INDUSTRIAL ORGANISA - TION.}

Amar, J. The Physiology of Industrial Organisation and the Re-emplovment of the Disabled. Edited with Notes and Introduction by A. F. S. Kent. Super Roy. 8vo. Pp. 396. 1918. Library Press. $30 s$.

Cowee, G. A. Practical Safety Methods and Devices. Rov. 8vo. Pp.443. 1916. Routledge.12s.6d.

Fisher, B. Industrial Loyalty: its Value, Creation, Preservation. Cr. 8vo. Pp. 79. 1918. Routledge. 2s. 6d.

Fleming, A.P. M., and Pearce, J. G. The Principles of Apprentice Training. with special reference to the Engineering Industry. Cr. 8vo. Pp. 216. 1916. Longmans. 4s.6d.

Freeman, A. Boy Life and Labour: The Manufacture of Inefficiency. Demy 8vo. Pp. 268. 1914. King. $4 s$.

Hamilton, C. Technical School Organisation and Teaching. 8vo. Pp. 190. 1913. Routledge. 3s.

Hazell, W. H. Office Organisation for Printers. Demy 8vo. Pp. 109. 1919. Raithby, Lawrence. 6s.

Herford, R. O., Hildage, H. T ., and Jenkins, H. G. Outlines of Industrial Administration based on a Course of Lectures given at Sheffield University. Demy 8vo. Pp. 132. 1920. Pitman. 6s. 
Ioteyko, J. The Science of Labour and its Organisation. $\mathrm{Cr} .8 \mathrm{vo} . \mathrm{Pp}$. 207. 1919. Routledge. $3 s .6 d$.

Jackman, W. T. The Development of Transportation in Modern England. 2 Vols. Rov.8vo. Pp.476., 368. 1916. Cambridge University Press. 24s

Lawson, F. M: Industrial Control. The Application to Industry of Direction. Control and Light. Demy 8vo. Pp. 144. 1920 . Pitman. 8s. 6d.

Lee, J. Management. A Study of Industrial Organisation. Demy 8vo. Pp. 135. 1921. Pitman.5s.

Proud, E. D. Welfare Work: Employers, Fxperiments for Improving Working Conditions in Factories. 3rd edn. Demy 8vo. Pp. 388. 1918. Bell. 10s.

Souster, E. G. W. The Design of Factory and Industrial Buildings. With Chapters on Welfare Work and Industrial Research Departments. Demy 8vo. Pp. 166. 1919. Scott, Greenwood. 10s.6d.

Spencer, H. The Commercial Organisation of Engineering Factories. 8vo. Pp. 221. 1914. Spon. 12s. 6d.

Williamson, J.G. Counting House and Factory Organisation. A Practical Manual of Modern Methods Applied to the Counting House and Factory. Demy 8vo. Pp. 180. N.D. Pitman.6s.

Wright, H. 'T. Organisation as applied to Industrial Problems. 8vo. Pp. 287. 1920. Griffin.

\section{iii. ESTIMATING AND COSTING .}

Burton, F. G. Engineering Estimating and Cost Accounts. 2nd edn. Cr. 8vo. Pp. 134. 1900. Technical Pub. Co. $4 s$.

Elbourne, E. T. The Costing Problem. Cr. 8vo. Pp. 145. 1919. Library Press. $4 s .6 d$.

The Federation Printers' CostFinding System and Accountancy Systems. Demy 8vo. 1919 . Raithby, Lawrence. $10 s$.

Lunt, H. J. Manual of Cost Accounts . Demy 8vo. Pp. 152. 1920. Pitman. 6s.

Matheson, E. The Depreciation of Factories, Mining, Municipal and Industrial Undertakings, and their Valuation. 4th edn. 8vo. Pp. 230. 1910. Spon. 12s. 6d.

Newman, E. W. Theory and Practice of Costing. Demy 8vo. Pp. 202. 1921. Pitman. 10s,6d.

Pearn, S., and F. Workshop Costs . 2nd edn. Folio. Pp. 34 and 42 Forms. 1905. Technical Pub. Co. $15 s$.

Ridgway, A. C. Cost Accounts in Principle and Practice. Demy 8vo. Pp. 120. N.D. Pitman. 5s .

Smith, D., and Pickworth, P.C.N. Engineers' Costs and Economical Workshop Production. 2nd edn. Demy 8vo. Pp. 248. 1919. Emmott. is. 6d.

Smith, T. S. Concise Costing for Housing. Folio. Pp. 54. 1920. Technical Journals, Ltd. 58 . 


\section{DICTIONARIES OF TECHNICAL TERMS IN ENGLISH AND OTHER LANGUAGES.}

Fletcher, J. J. A Pocket Glossary of English-French, French-Finglish Technical Terms. 4th edn. Pocket size. Pp. 200. 1917. Crosby Lockwood. $2 s$.

Garcia, A. Dictionary of Railway Terms: Spanish-English, EnglishSpanish. Demy 8vo. Pp. 356 . 1912. Constable. 12s. 6d.

Halse, E. A Dictionary of Spanish, Spanish-American, Portuguese, and Portuguese-American Mining, Metallurgical, and Allied Terms, with English-Spanish-Portuguese Supplement. 2nd edn. Cr. 8vo. Pp.454. 1914. Griffin. 12s.6d.

Hewlett, G. English-Spanish and Spanish-English Sea Terms and Phrases. Pocket size. Pp. 368 . 1907. Griffin. 4s.

Hodgson, E. S. Tri-Lingual Artillery Dictionary. 3 Vols. Pocket size. 1918. Vol. 1. EnglishFrench-Italian. Pp. 100. Vol. 2. French-Italian-English. Pp. 115. Vol. 3. Italian-French-English . Griffin. 5s, each.

Horner, J. G ., and Holtzmann, $O$. A Pocket Glossary of EnglishGerman, German-English Technical Terms. Pocket size. Pp. 300. 1913. Crosby Lockwood. 3s. 6d.

Huelin, D. C. Technological Dictionary in the English, Spanish, German and French Languages, containing Technical Terms and Locutions employed in Arts, Trades, and Industry in General, Military, and Naval Terms. 4. Vols. Cr. 8vo. Vol. 1. English-Spanish-GermanFrench. $\quad$ Pp. 609. 1906. Vol. 2. German-English-French-
Spanish. Pp.720. 1908. Vol. 3. French - German - SpanishEnglish. In preparation. Vol. 4. Spanish - French - English - German . Pp. 750. 1910. Spon. 15s. each.

Jackson, W. Dictionary of Fnglish and Spanish Technical and Commercial Terms used principally in the Iron, Steel, Hardware and Engineering Trades. English-Spanish, Spanish-English. 16mo. Pp. 164. 1911. Spon. $3 s$.

Lucas, F. English-French and French-English Dictionary of the Motor Car, Cycle, and Boat. $\mathrm{Cr}$. 8vo. Pp. 171. 1915. Spon. 3s.

Meycliar, L. English-Russian and Russian-English Engineering Dictionary. Embracing Terms relating to Mechanical and Marine Engineering and Naval Architecture. $16 \mathrm{mo}$. Pp. 100. 1909. Spon. 3s.

Monteverde, R. D. A Pocket Glossary of English-Spanish, Spanish-English Technical Terms. 2nd edn. Pocket size. Pp. 309. 1917. Crosby Lockwood. 3s. $6 d$.

Purington, G. W., and Toderovich, G. Russian-English, English-Russian Mining Terms and Relative Technical Words. Pocket Size. Pp. 128. 1920. Griffin. 7s.6d.

Serraillier, L. A Railway Technical Vocabulary. French, English, and American Technical Expressions relating to Railway Management. Cr. 8vo. Pp. 220. 1897. Pitman. $7 s .6 d$. 


\section{Dictionaries of Technical Terms.}

Slater, J. A. Dictionary of the World's Commercial Products : with French, German, and Spanish equivalents for the Names of the Products. 2nd edn. Demy 8ro. Pp. 165. N.D. Pitman. 3s.6d.

Steenbeck, W. H. Engineers' and Erectors' Pocket Dictionary. English-German-Dutch. Pitman . 2s.6d.
Topham, J. French Technical Words and Phrases. An EnglishFrench and French-English Dictionary. 3rd edn. Pocket size. Pp.320. 1919. Marlborough. 5s. Webber, E. International Technical Dictionary in Four Languages. English - Italian - French - German. Feap. 16mo. Pp. 921. 1917. Pitman. 15s. 



\section{LIST OF PUBLISHERS.}

*The Publishers denoted by the asterisk have kindly contriłuted, or undertaken to contribute, towards the cost of this Catalogue on the basis of payment according to the number of Titles of their books included.

Aeroplane and General Publishing Co., 61, Carey Street, W.C.2.

Allen and Unwin, Ltd., 40, Museum Street, W.C.1.

*Allman and Son, 17, Creechurch Lane, E.C.3.

*Arnold (Edward), 41 and 43, Maddox Street, W.1.

*Arrowsmith (J.W.), Ltd., 11, Quay Street, Bristol.

Baillière, Tindall and Cox, 8, Henrietta Street, Covent Garden, W.C.2.

Bale and Danielsson, Ltd., 83-91, Great Titchfield Street, W.1.

*Batsford (B. T.), Ltd., 94, High Holborn, W.C.1.

*Bell (Geo.) and Sons, Ltd., 6, Portugal Street, W.C.2.

Benn Brothers, Ltd., 8, Bouverie Street, E.C.4.

*Black (A. and C.), Ltd., 4-6, Soho Square, W.1.

Blackie and Son, Ltd., 50, Old Bailey, E.C.4.

*Blackwood (Wm.), and Sons, 36, Paternoster Row, E.C.4.

British Bee Journal, 23, Bedford Street, W.C.2.

*Brown (James) and Son, 52-58, Darnley Street, Pollokshields, Glasgow .

*Bryce (W.), 54, Lothian Street, Edinburgh.

Burrow (E. J.), and Co., Ltd., 89, Kingsway, W.C.2.

*Cambridge University Press, St. Dunstan's House, 133-137, Fetter Lane, E.C. .4.

Cassell and Co., Ltd., La Belle Sauvage, Ludgate Hill, E.C.4.
* Cassier (Louis) Co., Ltd., Bedford Street, W.C.2.

*Chambers (W. and R.), Ltd., 38, Soho Square, W.1.

*Chapman and Hall, Ltd., 11, Henrietta Street, Covent Garden, W.C.2.

*Christophers, 22, Berners Street W.1

*Churchill (J. and A.), 7, Great Marlborough Street, W.1.

*Clowes (W.) and Sons, Ltd, 94, Jermyn Street, S.W.1.

*Constable and Co., Ltd., 10-12, Orange Street, Leicester Square, W.C.2.

* "Country Life"' Office, 17-21, Tavistock Street, Covent Garden, W.C.2.

*Crosby Lockwood, 7, Stationer's Hall Court, Ludgate Hill, E.C.4.

Denny (A. and F.), 147, Strand, W.C. 2 .

*Dent (J. M.), and Sons, Ltd., 10-13, Bedford Street, W.C.2.

*Duckworth and Co., 3, Henrietta Street, Covent Garden, W.C.2.

*Emmott and Co., Ltd., 20, Bedford Street, W.C.2.

Faraday Society, 10, Essex Street, Strand. W.C.2.

Fisher, Unwin. Ltd., 1, Adelphi Terrace, W.C.2.

*Frowde and Hodder, The "Lancet" Building, 1 and 2, Bedford Street, W.C.2.

*Gieves Publishing Co., Ltd., 13, Paternoster Row, E.C.4.

Grafton and Co., 8, Coptic Street, Bloomsbury, W.C.1.

Green (W.) and Son., Ltd., 2 and 4, St. Giles Street, Edinburgh.

Griffin (Charles) and Co., Ltd., 12, Exeter Street, Strand, W.C.2. 
*Gurney and Jackson, 33, Paternoster Row, E.C.4.

Harper Brothers, 45, Albemarle Street, W.1.

*Harrap (G.) and Co., Ltd., 2 and 3, Portsmouth Street. Kingsway, W.C.2.

*Hatton Press, 123, Fleet Street, E.C.4.

*Heffer (W.) and Sons., Itd ., 4, Petty Cury, Cambridge.

*Heinemann (W), 20 and 21, Bedford Street, W.C.2.

*Heywood (John), Ltd., 20 and 22, St. Bride Street, E.C.4.

His Majesty's Stationery Office, Imperial House, 19, Kingsway, W.C.2.

Hodder and Stoughton, St. Paul's House, Warwick Square, E.C.A .

Hogg (John), 13, Paternoster Row, E.C.4.

*Iliffe and Sons., Ltd., 20, 'Tudor Street, E.C.4.

Imray, Laurie, Ltd., 15̆6, Minories, E.1.

*Jack (T. C. and F. C.), Ltd., 35, Paternoster Row, E.C.4.

*Jarrolds, Ltd., 10 and 11, Warwick Lane, E.C.4.

*Johnston (W. and A. K.) Ltd., Edina Works, Edinburgh .

*Kegan, Paul and Co., Ltd., 68-74, Carter Lane, E.C.4.

*Kidd (Wm.) and Sons, 7, Whitehall Street, Dundee.

Kimpton (Henry), 263, High Holborn, W.C.1.

*King (F.) and Sons, Halifax.

King (P. S.) and Son, Ltd., 2 and 4, Great Smith Street, Westminster, S.W.1.

*Lane (John), Vigo Street, W.1.

*Lewis (H. K.) and Co., Ltd., 136, Gower Street, W.C.1.

*Library Press, Ltd., 26, Portugal Street, W.C.2.

*Livingstone (E. and S.), 17, Teviot Place, Edinburgh.

*Locomotive Publishing Co., Ltd., 3, Amen Corner, E.C.4.
*Longmans, Green and Co., 38-41, Paternoster Row, E.C.4.

Lovell, Reeve and Co., Ltd., 6, Henrietta Street, Covent Garden, W.C.2.

*Macdonald and Evans, 29, Essex Street, W.C.2.

*Macdonald and Martin, 6, Essex Street, W.C.2.

*Macmillan and Co., Ltd., 10-15, St. Martin's Street, Leicester Square, W.C.2.

*Marlborough (E.) and Co., 51, Old Bailey, E.C.4.

Marsden, 10-11, Fetter Lane, E.C.4.

*M'Caw, Stevenson and Orr, Ltd., Belfast.

* Melrose (A.), Ltd., 3, York Street, Covent Garden, W.C.2.

*Methuen and Co., Ltd., 36, Fssex Street, Strand, W.C.2.

*Munro (Jas.) and Co., Ltd., 60, Brown Street, Glasgow.

* Murby (Thomas) and Co., 1, Fleet Lane, E.C.4.

*Murray (John), 50a, Albemarle Street, W.1.

*Nelson ('T.) and Sons, Ltd., 35, Paternoster Row, E.C.1.

*Newnes (G.), Ltd., 8-11, Southampton Street, Strand, W.C.2.

*Nisbet (J.) and Co., Ltd., 22, Berners Street, W.1

*Oliver and Boyd, Tweeddale Court, High Street, Edinburgh.

*Oxford University Press (including Clarendon Press), Amen Corner, E.C.4.

Pearson (C. A.), Ltd., 16-18, Henrietta Street, Covent Garden, W.C.2.

*Philip (Geo.) and Son., Ltd., 32, Fleet Street, E.C.4.

*Pitman (Sir Isaac) and Sons, Ltd., 39 and 41, Parker Street, W.C.2.

*Raggett and Co., 30, Red Liợ Square, W.C.1.

*Raithby, Lawrence and Co.. Ltd., 231 and 232, Strand, W.C.2.

*Reed (Thomas), and Co., Ltd., 184 , High Street West, Sunderland. 


\section{List of Publishers.}

*Rentell (S) and Co., Ltț., 36-39, Maiden Lane, W.C.2.

*Rider (Wm.) and Son, Ltd., 8-11, Paternoster Row, E.C.4.

Rivingtons, 34, King Street, Covent Garden, W.C.2.

*Rodger (Norman), 2, St. Dunstan's Hill, E.C.3.

*Routledge (G.) and Sons, Ltd ., 68-74, Carter Lane, E.C.4.

*St. Catherine Press, Stamford Street, S.E.1.

*Sampson, Low and Co., Ltd., 100, Southwark Street, S.E.1.

*Sanitary Publishing Co., Ltd., 8, Breams Buildings, Chancery Lane, E.C.4.

*Scientific Press, Ltd., 28 and 29, Southampton Street, W.C.2.

*Scientific Publishing Co., 53, New Bailey Street, Salford, Manchester.

* Scott, Greenwood and Son, 8, Broadway, Ludgatc Hill, E.C.4.

*Scott Publishing Co., Ltd., 1, Paternoster Buildings, Paternoster Square, E.C.4.

Seeley, Service and Co., Ltd., 38 , Great Russell Street, W.C.1 .

Sherratt and Hughes, 27, St. Ann Street, Manchester.

Simpkin, Marshall and Co., I.td., 4, Stationers' Hall Court, E.C.4.

*S.P.C.K., 6, St. Martin's Place, W.C.2.

*Spon (E. and F. N.), Itd., 57, Haymarket, S.W.1.

Stanford (E.), Ltd., 12-14, Long Acre, W.C.2.
Swarthmore Press, 40, Museum Street, W.C.1.

Technical Bookshop, 723, Salisbury House, E.C.2.

Technical Publishing Co., Ltd., 1, Gough Square, E.C.4.

*Temple Press, Itd., 7-15, Rosebery Avenue, E.C.1.

*Thacker (W.) and Co., 2, Creed Lane, Ludgate Hill, E.C.4.

*Thin (James), 54-56, South Bridge, Edinburgh .

*Trade Papers Publishing Co., Ltd. 329, High Holtorn, W.C.1.

*Transport, Ltd., Queen Anne's Chambers, Westminster, S.W.1.

*University Tutorial Press, Ltd., 25, High Street, New Oxford Street, W.C.2.

University of London Press, Ltd., St. Paul's House, Warwick Square, E.C.4.

*Vinton and Co., Ltd., 8, Breams Buildings, Chancery Lane, E.C.4.

Warne (F.) and Co., 1-4, Bedford Court, Bedford Street, W.C.2.

*Watts and Co., 17, Johnson's Court, Fleet Street, E.C.4.

*Williams and Norgate, 14, Henrietta Street, Covent Garden, W.C.2.

*Wireless Press, Itd., 12 and 13, Henrietta Street, Covent Garden, W.C.2.

*Witherby and Co., 326, High Holborn, W.C.1.

*Wright (John) and Sons, Ltd., Stonebridge, Bristol. 



\section{INDEX OF AUTHORS, COLLABORATORS AND TRANSLATORS.}

Aarons, S. J. 275, 276

Abadie, G. 265

Abady, J. 146

Abbey, G. 185

Abbott, E. 8

- P. 34, 36, 37

T. K. 182

Abderhalden, E. 229

Abegg, R. 122

Abel, R. 229

Abercromby, R. 162

Abney, Sir W. de W. 102, 307

Abrahams, A. 256

Abrami, P. 245

Ackworth, A. T. 65

Acorn. 208

Acton, E. H. 202

Adam, C. 271

- J. 6, 255

- Mrs. J. 6

- P. 305

Adami, J. G. 193, 239, 240

Adams, H. 34, $48,49,50,61,66,72$

- H. C. 57 J. E. 258 P. E. H. 269 W. P. 79

Adamson, H. G. 284

- J. W. 4

R. 6, 13

Adcock, K. J. 148

Addis, A. W. C. 52

Addison, C. 221

Addyman, F. T. 104, 213

Adiassewich, A. 45

Adie, R. H. 130, 213

Adlam, G. H. J. 150

Adler, H. 187

Agar, W. E. 196, 228

Agnew, W. A. 117

Ahrons, E. L. 83

Aikman, C. M. 213

Ainslie, D. 9, 11, 12, 18

Ainsworth-Davis, J. R. 211, 212, 214, 215

Aitchison, L. 156

— R. S. 241
Aitken, T. 52

Akers, C. E. 142

Albee, E. 4

Alcmaeon. 6

Alcock, A. 248, 259

N. H. 225

R. A. 198

Alderson, W. E. 282

Aldis, H. G. 305

- W. S. 100

Aldous, J. C. P. 96

Aldridge, H. A. 68

Alexander, F. M. 193, 197

_. . . 45,242

- J. H. 109

- S. 8

- T. 42

- W. 49

Alford, C. J. 171

Aliotta, A. 1

Allan, A. P. 290 F. J. 57, 232

Allanach, W. 106

Allbutt, Sir T. C. 1, 231, 241, 254, 270

Allen, 132

- A. F. 136

- A. W. $151,154,174$

C. C. 72

C. E. 83

C. J. 52

- G. T. 52

- H. 87, 153

- H. S. 96

J. P. 61

- R. G. 114

- R. W. 255, 288

Alleyne, S. F. 8

Allingham, H. W. 261

- W. 162, 181

Allison, A. 237, 238

Allman, G. J. 21

Allmand, A. J. 128

Allsop, F. C. 115, 116, 117, 119

R. O. 57

Alport, A. C. 245

Amar, J. 310 


\section{Name Index.}

Amedeo, M. R. 77

Ami, H. M. 178

Amos, P. A. 139

- S. 1

Anderson, D. E. 236

H. G. 255

- Sir J. 43

- J. W. 164

T. 167

Sir W. 81

Andés, L. F. 139, 141, 148

Andrew, R. C. 211

Andrewes, Sir F. W . 229, 257, 262

Andrews, F. R. 143

- E. E. 27, 40, 42, 43, 44, 50, 66,

$67,72,81,107$

- H. R. 277

S. T. G. 93

T. 21

Angles, J. W. 33

Anglin, S. 49

Ansted, A. 181

Appelt, A. 252

Appleton, H. A. 141

A. R. B. 52, 83

Arber, A. 198

— F. A. N. 170, 205

Archbutt, L. 74

Archer, R. L. 175

Archibald, R. C. 34

- R. D. 112

Arch imedes . 3, 22

Aristotle. 6

Arkwright, J. A. 245

- J. P. 64

Armand-Delille, P. 245

Armitage, F . P 122

Armstead, H. W. 224

Armstrong, E. F. 130

- H. E. 1 .

- H. G. 245

- S. F. 212

W W. E. M. 288

Arnall. 52

Arnold, F. V. 6

H. T. 180

J. O. 156

R. B. 8

Arrhenius, S. 134

Arrol, Sir W. and Co. 49

Arthur, D. 104

Arup, P. S. 132

Arvedson, J. 287

Asch, D. 149

W. 149

Ash, E. 251

Ashby, A. W. 214
Ashby, H. 225

H. T. 279

Ashoroft, H. J. 64

Ashdown, A. M. 294

Ashenhurst, T. R. 300

Ashford, C. E. 112

Ashton, W. 169

Askling, C. W. 87

Askwith, F. H. 30, 32

Assheton, R. 222, 223

Aston, W. G. 80, 92

Atack, F. W. 125, 147

Atcherley, I. W. 49

Atherton, W. H. 44, 70

Atkins, E. A. 77 W. 119 W. R. G. 201

Atkinson, E. H. De V. 23

$$
\text { G. F. } 198
$$

J. C. 192

- S. B. 237

Attwood, E. L. 70, 71

Audley, J. A. 149

Auerbach, S. 252

Aughtie, H. 42, 74

Auld, S. J. M. 133, 213

Austen, E. E. 229, 287

- Sir W. C. R. 158

Austin, E. 117

Avanzini. 92

Avebury, Lord , 4, 167, 187, 197, 198. 201

Aveling, F. 8

Avery, A. H. 113

- M. 232

"Avion." 92

Axenfeld, T. 269

Ayling, R. S. 63, 234

Ayre, A. I. 70

Ayrton, W. E. 109

Babbage, C. 37

Babinski, J. 252

Back, I. 260

Bacon, G. 91 R. 2,3

Badger, F. E. G. 53

Badham, M. D. 204

Bagnall, J. E. 204

Bahr, P. H. 236

Bailey, G. C. 91 G. H. 122,133

Baillie. J. B. 10 T. C. 109

Bain, A. 13, 15

Bainbridge, F. A. 225, 227

Baines, A. E. 17, 201, 227

Bairstow, L. 91, 92 
Baker, G. S. 70

H. F. 21,23

J. G. 205

J. L. 137

R. T. 205

T. 50

T. T. 104, 119, 132

W. M. $25,28,30,32,36,40$

Bald, C. 218

Baldrey, F. S. H. 296

Baldwin, J. M. 9, 15

Bale, M. P. 56, 73, 77, 84, 87

Bales, T. 62

Balfour, A. 258

F. M. 222

204

I. B. 170，199，201，202，203,

Balfour-Browne, F. 187

Ball, Sir C. B. 257

- J.D.W. 66

167 Sir R. S. $39,40,56,159,160$,

W. P. 193

W. V. 50

W. W. R. 21, 22

Ballance, Sir C. A. 251, 265

Ballantyne, A. J. 254, 269 J. W. $222,241,275,276$

Ballard, E. F. 253 F. 66 P. B. 15, 17 W. E. 62

Ballet, G. 252

Ballin, M. J. 274

Balls, W. L. 218, 297

Balsillie, D. 9

Baly, E. C. C. 127

Bamford, H. 44

Bandelier, B. 249, 288

Bangay, R. D. 120

Banham, G. A. 296

Banister, J. B. 277

Banks, H. S. 264

Bannatyne, G. A. 249

Barber, T. W. 49,72

Barbour, A. H. F. 276, 277 W. 150

Barclay, A. E. 105 H. C. 225 R. M. 253, 277

W. R. 118

Barcroft, D. M. 265

- J . 226, 241

Bardswell, N. D. 249, 288

Barger, G. 132

Barham, G. B. 116

Barker, A. 218
Barker, A. E. 258

- A. F. 297, 300, 301

A. H. $28,47,142$

Sir D. W. 181, 182 E. R. 114

Barlow, 37 C. W. C. 106,159 G. 96 W. S. I. 239,240

Barnaby, S. W . 70, 85

Barnard, F. P. 4 H.C. 176

- H. L. 265 J. E. 196 R. J. A. 40 S. 25,30

Barnes, A. A. 53

Barnett, E. de B. 130, 131, 145, 146, 150

H. N. 237, 252, 260

Barr, J. R. 112 W. 289

Barrett, C. G. 187 E. G. 75, 77 Sir J. W. 231

Barritt, A. 283

- W. 283

Barron, P. A. 80

Barrow, I. 21

Barroweliff, M. 151

Barter, S. 64

Barthel, C. 215

Bartlett, F. C. 13

Barton, E. H. 40, 42, 102

- F. T. 216,296 G. A. H. 262

Barwell, H. 274

R. 268

Barwise, S. 57

Basset, A. 249 A. B. 29

Bassett, H. Ll. 122

Bastin, H. 187, 204

Bate, A. H. 112

Bateman, H. 29, 100

Bater, C. H. 137

Baterden, J. R. 208

Bates, A. 68

— E. L. 24, 33, 42

Bateson, W. 193

Batey, J. 84, 310

Bath, W. H. 187

Batstone, S. C. 117

Batten, F. E. 280

Battle, J. R. 74 W. H. 258, 265

Bauer, G. 85, 89 
Bauer, H. 122

Bausor, H. W. 122, 125, 133, 134

Baxandall, G. A. 33

Bayley, R.C. 307

- T. 125

Bayliss, W. M. 195, 225, 227, 287

Bayly, H. W. 246

Beacall, T. 147

Beadle, C. 142, 148

Beale, Sir W.P. 164

Bean, W. J. 208

Bear, W. E. 217

Beare, J. I. 6 T. H. 40

Beardmore, N. 53

Beattie, J.C. 162 J. M . 239, 240, 260

Beatty, J. 227

Beaumont, R. 299, 300 W.M. 271

W. W. 118

Beavan, R. 191

Beazeley, A. 52, 55

Beazley C. R. 175

Beck, E. G. 67

Beddard, A. P. 226 F. E. $185,190,193$

Beddoes, T. P. 291 W. F. 208

Bedford, C. H. 239

- E.J. 307

Beech, F. 299

Beesly, L. 221

Beeson, F. T. 307

Begg, C. 236

Bell, G. J. 44

- J. 119,196

- R. 248

- R. J. T. 30,32 T. F. 298 W. B. 228, 265, 275

Bellamy, E. 221

Bellasis, E. S. 53, 55

Bellot, H. H. L. 172

Bellow, H. R. 149

Beneden, P. J. 190

Benet.t, W. 11

Bengough, G. D. 133, 154

Benham, F. L. 237

Benn, A. W. 4, 6

Bennett, A. 203

A. G. D. 254, 267

- A.H. 231

H. G. 149

H. W. 307

N.G. 283

R. R. 291
Bennett, S. B. 57 W. 193

Bennie, A. B. 268 P. B. 268

Benson, S. F. 93

Bentham, G . 3, 198, 205

Bentley, W. 72, 75

Bergson, H. 9, 10

Beringer, C. 156 J. J. 156

Berkart, J. B. 255

Berkeley. 10 C. 275,276

H. 22

- H. R. 151 M. J. 204, 205

Bernard, D. H. 182 H. M. 224

Bernstein, 15

Bernthsen, A. 131

Berriman, A. E. 79, 92

Berry, A. 159 A. G. V. 144

A. J. 134, 162

G. A. 269

G. G. 7

R. J. A. 221

W. H. 91

Bersch, J. 141, 146

Berthelot, M. 150

Bertrand, G. 134

Besant, W. II. 29, 40, 42

Bevan, E. J. 135, 148 J. O. 6

Beveridge, W. W. O. 232

Bevis, A. W. 47 J. F. 198

Beyer, O. W. 18

Beyschlag, F. 165

Bianchi, L. 253

Bichel, C. E. 150

Bickford, J. S. V. 79

Biddulph-Smith, T. 145

Bidgood, J. 184

Bidweıl, A. I. 265 L. A. 263

Biedermann, F. A. 113 W. 227

Bigelow, M. A. 184

Bigg, G. S. 257 R. H. 268

Biggs, G. N. 273

Bigwood, G. 297

Biles, Sir J. H. 70

Billington, $\mathbf{W} \cdot \mathbf{2 5 7}$

Binet, A. 15, 19, 280

Binnie, Sir A. R. 56 
Binnie, F. G. 288

Binns, C. F. 149

Binstead, H. E. 64

Bird, C. 166

- H. 49

Birks, F. 60

Birnbaum, R. 276

Bishop, E. S. 258, 263

$$
\text { L. F. } 254
$$

Bjorkegren, M. E. 224

Björling, P. R. 56, 72, 146

Black, J. 3

Blackburn, C. J. 91

Blacker, G. 276

Blackluall-Morison, A. 254

Blackham, R. .J. 236

Blackmur, W. J. 77

Blackwood, W. 299

Blagrove, G. H. 62

Blaine, R. G. 28, 37, 56

Blair, C. 271

Blake, A. J. J. 221, 224

- E. 120

E. G. 62

E. H. 57

- W. J. 94

Blane, L. 289

Blanco, A. E. 301

Bland, N. 300

Bland-Sutton, Sir J. 260, 267,"275

Blanford, H. F. 162

Bligh, S. M. 15

- W. G. 19

Bloch, I. 228

$$
\text { L. } 59
$$

Blocksidge, E. W. 70

Blok, A. 59

Blomficld, J. 262

Blount, B. 66, 136

Bloxam, A. G. 122, 136

Blum, V. 258

Blyth, A. W. 235, 238 M. W. 235, 238

Blythe, E. 109

Bôcher, M. 23

Böckmann, F . 151

Bodmer, G. R. 56

Boelter, W . R . 184

Bohle, F. 113, 117

Bolam, J. 282

Boldt, J. 270

Bolton, F. R. 139

- J. S. 252, 256

Bon, G , Le. 20, 103

Bonacina, L. C. W . 162

Bonar, J. 6

Bone, W. A. 144
Bonhote, J. L. 192

Bonner, J. 308

Bonney, G. E. 115, 118

- S. G. 168

T. G. 167,168

- V. 275, 276

Bonnier, G. 198

Boodle, L. A. 203

Booth, N. 301 W. H. 57, 83, 142, 143

Boraston, J. M. 192

Borchardt, W. G. 25, 34, 36, 40

Borradaile, L. A. 186

Bos, J . R . 214

Bosanquet, B. 9, 11, 12, 13

W. C. $240,243,256,287$

Bose, Sir J . C. 199, 201, 227

Boswell, P. G. H. 169

Bosworth, G. F. 211

Bottler, M. 150

Bottomley, J. T. 37

Bottone, A. E. 111

S.R. 111, 115, 117, 118, 120

Boulenger, G. A. 191, 192

Boulger, G. S. 198, 206, 208 P.S. 203

Boulnois, H. P. 52, 58

Boulton, 4 B. C. 64

Boulvin, M. J. 81

Bourcart. E. 152

Bourgeois, H. 273

Bourget, J 265

Bourne, A. A. 25, 30, 36

- A. W. 277 G. C. 224

Bourry, E. 65

Bousfield, E. C. 308

- G. 208

- P. 19

Boutroux, E. 6

Bowden-Smith, F. C. 56,84

Bower, C. O. 157

— F. O. 2, 189, 202, 228 W. R. 96

Bowers, R. S. 47, 64

Bowie, P. G. 67

Bowker, W. R. 111, 117

Bowlby, Sir A. A. 262

Bowley, A. L. 22, 38

Bowling, G. S. 39

Bowman. F. H. 297

Box, C. R. 221, 239 T. 43,53

Boyce, Sir R. W . 236, 248

Bovcott, G. W. M. 71

Boyd, J. 208 


\section{Name Index.}

Boyle, H. F. G . 262

Boys, C. V. 72,100

Brace, T. S. 308

Brackenbury, L. 15

Bradbury, F. 218, 301

Bradby, M. K. 18, 19

Bradley, F. A. 56 F. H. 9 O. C. 192, 295

Bragg, Sir W. H. 103, 105, 164

- W. L. 164

Bragstad, O. S. 114

Braham, F. 218

Braithwaite, A. 308

Brame, J. S. S. 123, 143

Bramley-Moore, S. 79

Brand, A. 302 A. T. 243

Brandis, Sir D. 208

Branford, B. 22

Branson, W. P. S. 239

Brassey, 70

Braun, J. 289

M. 248

Braune, W. 221

Brearley, A. W. 157

- H. 157 J. H. 145

Breitland, W. J. 128

Bremner, A. G. 88

Brenchley, W. E. 202, 212

Brend, W. A. 237, 238

Brent, C. 182

Bresslau, E. 193

Brett, G. S. 15

Brew, W. 114

Brewer, R. W. A. 79

Brewerton, E. W. 269

Brickdale, J. M. F. 245, 292, 293, 294

Bridge, R. S. 176

Bridger, A. E. 15

Bridges, J. H. 2

Briggs, F. W. 146

- H. 50

W. $1,25,26,32,33,34,39,40$, $42,122,133,134$

Brigham, A. A. 216

Bright, C. 91 T. 214

Brightmore, A. W . 49, 57

Brill, A. A. 19

Brindley. 3

Brinton, R. S. 302

Briscoe, H. V. A. 129

Brislee, F. J. 143

Bristow, W. R. 267
Bristowe, J. S. 241, 25]

Britten, F. J. 78

Broad, C. D. 9

Broadbent, F. 111

- Sir J. F. H. 254

W. 231

Sir W. H. 231, 254

Broadfoot, S. K. 111

Broca, A. 266, 267

Brockbank, E. M. 237, 254, 255, 278

Brodetsky, S. 24

Brodie, C. G. 221

Bromley, H. A. 148, 305

Brook, J. 45

Brooke, G. E. 232,258

- H. B. 252

T. 145

Brooker, A. 107

Brooks, F. E. 106, 117

G. 89

L. 178

Brooksmith, J. 36

Brose, H. L. 104

Brouardel, P. 237

Brough, B. H. 50

- J. W. 172

Broughton, H. H. 74

Broun, A. F. 208

Brown, 182

A. 298

A. J. 137

C. 162

C. H. 181

E. 218

E. T. 215

E. W. 1,160

G. E. 307

Sir H. 55

H. 218,290

J. C. 122,133

J. D. 305

J. R. 182

L. C. 219

R. N.R. 176

S. E. 96

S. W. 120

W. 17

W. C. 245, 258

W. L. 156, 225, 251, 285

W. N. 68,78

Browne, A. J. J. 168, 169

C. L. 72

E. A. 233

F. B. 187

H. S. 262

T. G. 295

Browning, C. H. 229, 246 


\section{Name Index.}

Brownlie, T. A. 55

Brubaker, A. P. 225, 226

Bruce, B. J. 123 Sir D. 246

G. R. 85

J. M. 285

O. 249

W. 252

W. I. 105

Bruck, W. F. 212

Bruges, C. F. 58

Brunings, W. 274

Brunner, R. 139

Brunt, D. 15

Brunton, Sir T. L. 254, 256

Bryan, G. H. 25, 26, 31, 32, 34, 39, $40,42,92$ M. T. 294

Bryant, V. S. 123, 176 W. W.

Bryce, A. 257 T. H. 222

Bryson, T. 50

Buchanan, A. M. 221.

E. E. 37

J. F. 154,157

J. Y. 96

R. J. M. 237

Buck, P. C. 103 R. C. 26, 34

Buckley, R. B. 55

Buckmaster, G. A. 225, 241

Bucknill, J. C. 237

Buckton, G. B. 187

Budden, E. 30

Budge, Sir E. A. W. 231

Buhler, F. A. 136

Bull, J. 278

Buller, A. H. R. 204

Bullork, A. B. 11 J. E. 249 W. 208

Bulman, H. F. 172

Bunting, W. L. 178

Burbury, S. H. 100

Burch, G. J. 101

Burchett, R. 30

Burdett, M. I. 291

Burghard, F. F. 260, 261, 263, 264, 265

Burke, E. T. 246

Burleigh, D. H. 133

Burley, G. W. 75

Burls, G. A. 88, 94

Burnet, E. 229

J. $6,243,280,284,286$

Sir R. W. 286
Burnford, J. M. 240

Burnham, F. W. E. 241 G. H. 272 M. H. 171

Burns, C. D. 6

D. 172,173 G. J. 61

Burnside, W . 27, 49

W. S. 26

Burrell, B. A. 235 E. J. 61

Bursill, A. 116

Burstall, F. W. 88, 100

Burton, E. F. 128

— F. G. 310,311 W. K. 56

Burton-Fanning, F. W. 249

Bury, J . 243

- J. B. 9

Busiquet, R. 53

Butcher, W. D. 227

Butler, D. B. 66

— E. $54,73,79,87,143$

- E.A. 187

- E. J. 212 H. .J 79

Butler-Jones, F. 137

Buttel-Reepen, H. 197

Butterfield, W. J. A. 143

Butterworth, F. 85

Buxton, D. W. 262

- J. L. D. 283

Buzzard, E. F . 252, 285

Byam, W. 244

Byles, C. B. 52

Byrom, T. H. 145, 171

Bythell, W.J.S. 105

Cadbury, G. 68

Cadiot, P. J. 295

Cahen, E. 165

Cain, J. C. $123,124,146,147$

Caird, F. M. 260

- W. J. 181

Calcare. 66

Caldecott, $\mathrm{W}^{\top}$. A. 155

Calder, A. B. 277

Caldwell, W. 9

Calisch, L. 117

Callan, T. 146

Callendar, H. L. 81, 84, 99

Calmette, A. 287

Calot, F, 267

Calthrop, E. R. 55

Calvert, A. F. $151,165,169$ G. T. 151

H. 'T. $58,122,137$

Calwell, W. 285 


\section{Name Index.}

"Cambridge Graduates." 2

Cameron, C. A. 213 H. C. 279,280 S. J. 275

Camm, F.J. 75, 93 S. 93

Cammidge, P. J. 239, 257, 266, 286

Campbell, Miss A. 279 A. 143,144

A. W. 239

H. 240

H. J. 184, 226

H. Y . 278

J. E. 27

M. 226

N.R. 96,106

Campin, F. 72

Camus, J. 287

"Candidus." 79

Candolle, A. de. 202

Candy, H. C. H. 96, 125, 132

Cannons, H. G. T. 305

Cantell, M. T. 66

Cantrill, T. C. 172

Capito, C. A. A. 39

Capstick, J. W. 103

Card, S. F. 94, 180

Carey, A. E. 52, 55

- F.S. 28

Cargill, I.. V . 262

Carless, A. 261

Carling, E. R. 262

Carnegie, D. 124, 153

Carpenter, A. 182

G. 247

- G.H. 187

- J.A. 123

- W. B. 196

-.. W. L. 140

Carpmael, H. 119

Carr, F. H. 151 H. W . 9, 104

Carrel, A. 285

Carroll, J. A. 255 J. H. 244

Carruthers, T. 239

Carslaw, H. S. 28, 34, 35

Carson, H. W. 262

Carter, A. H. $\mathbf{2 4 2}$

- E. E. 302

H. G. 205

H. R. 297, 298, 299, 300, 301

T. 114

Case, J. 81, 112

Caspari, W. A. 142

Cassidy, L. 246

M. F. 258
Castell-Evans, J. 125

Castellani, A. 258

Castle, F. 24, 36, 37, 47 W. F. 287

Catchpool, E. 103

Cathcart, C. W. 77, 260, 267 E. P. 134

Caton, R. 254

Caunt, G. W. 28, 52

Cavanagh, F. 232

Cave, C. J. P. 162

Caven, R. M. 126, 129, 133

Cavendish, H. 106

Cavers, F. 198, 202

Cayley, A. 21

Chadwick, O. 51

Chalkley, A. P. 88, 89

Challenger, $F . \quad 144,147$

Chalmers, A. J. 258

- J.A. 173

J. B. 44

T. W. $45,140,148$

Chamberlain, A. 193

- J. 300

Chamberlin, T. C. 166

Chambers, G. F. 159,160

- G. M. 50

Chance, E. J. 268

Chandley, C. 146

Channer, C. C. 302

Chaplin, A. 244, 286

Chapman, A. C. 137

A.E. 175

- E. H. 162

- J.E. 249

R.W. 159

- S. J. 297

Chappell, 37

Charlesworth, F. 24, 33, 42,

Charleton, A. G. 173

Charnock, G. F. 72

Charpentier, P. 208

Charteris, F. J. 242

- M. 242

Chatley, H. 45, 49, 53, 56, 92, 162

Chatterton, F. 62

Chavasse, P. H. 278

Cheremeteff, A. 203

Cheshire, F. R. 216

Cheyne, Sir W. W. 249, 260

Child, H. 271, 285

J. M. 25, 30, 35

Childe, C. P. 263

Chisholm, G.C. 176, 177

- J. 57

Chivers, G. T. 34

Cholmeley, H. P. 231 


\section{Name Index.}

Chope, R. H. 37

Choyce, C. C. 260

Chree, C. 162

Christian, M. 139

Christiansen, C. 97

Christie, A. H. 302

Christopher, J. E. 145

Christopherson, W. B . 258, 288, 289

Christy, C. 142

Chrystal, G. 26

Chubbe, C. P. B. 258

Church, A. H. 123, 141, 198

Churchill, J. H. 244

Churchward, A. 197

Clapham, C. B . 36, 43, 45

- J. H. 297

Claparède, E. 18

Clapperton, G. 148

Clark, A. G. 94

- D. K. 52,72

— H. 289

H. E. 221

- J.B. 37

L. $45,160,307$

Clarke, A. G. $\quad 79$

- F. 271

G. A. 162

H. 249

H. T. 131,132

J.J. 248, 268

J. W. $56,58,61$

R. F. 13

W. B. 266

Clarkson, G. T. 94

C.S. 136

Claude, G. 129

Claxton, W. J. 184

Clay, A. S. 51

- F. ${ }^{-}{ }^{2} 2$

- R.S. 100

Claypon, J. E. L. 235

Clayton, C. H.J. 215

E. G. 235

S. C. 53

W. 140

Clayton-Greene, W. H. 264

Cleghorne, W. S. H. 215

Cleland, E.D. 173

Clemow, F. G. 236

Clemesha, W. W. $\quad 58,229$

Clerk, D. 88

Clibbens, D.A. 127

Clifford, W. K. 21

Clinton, W. C. $\quad 59,116$

Clodd, F. 194

Clough, G. W. 151
Clough, W. T. 1

Clouston, Sir T. S. 232, 253

Clouth, F. 142

Clowes, F. 100, 123, 133

Cobb, I. G. 252, 256

Cobbett, L. 249

Cochrane, A. W. R . 289

Cockerell, D. 305

Cockin, T. H. 172

Cocking, W. C. 67

Cocks, O. II. 24

Cockshott, A. 31

Codd, L. 126

- M. A. 88,115

Cofley, P. 13

Coghlan, H. L. 218

Cogle. 181

Cohen, J. B. 124, 131, 143

Colbeck, E. H. 286

Coie, G.A.J. $164,166,168$ M. J. 196

- R. H. 253

R.S. 307

S. W. 134

W. H. 53

Coleman, F. 283

- J. B. 123, 133, 213

- P. 32

- T.F. $54,58,62,66$

W.S. 187

Coles, A. C. $196,229,254$

Colledge, L. 273

Collen, H. L. 178

Collet, H. 57

Collie, A. 246

- A. E. 292

- Sir J. 19, 237

Collin, A. 147

- E. 235

Collings, E. R . 85

Collingwood, R. G. 8

Collins, H. F. 154

- J. H. 165

- S. H. 220

- V. E. 242

Collis, A. G. 111

- A. J. 259 E. L. 259

Collum, R. W. 262

Coltman-Rogers, C. 208

Colver, E. de W.S. 150

Colwell, H. A. 105, 134

Colyer, F. 56

— Sir J. F. 257, 263, 283

- S. 283

Compayré, G. 4

Comrie, J. D. 242 
Comrie, P. 36

Connan, J. C. 111

Connor, W. J. 84

Constantine, F. 85

Conway, A. W. 104

- Sir M. 20

Cook, 301

C. W. 70

E. T. 208

J. B. 294

M.T. 212

Sir T. A. 12

Cooke, A. 260

B.W. 53
B. B. 126
M.C. $198,203,204$
T. 221

Coolidge, J. L. 29, 34

Coombs, C. F. 242

Cooper, A. 257

C.S. 201

— E.A. 233

- E.S. 145

I. C. G. 70

- J.W.A. 251

W. R. $109,115,155$

Cope, Z. 245, 264

Copeland, E. B. 218

Copeman, S. M. 288

Copestake, B. M. G. 287

Coppock, J. B. 134, 171

Corbett-Smith, A. 257

Corbin, H. E. 97 T. W. 49,72

Corder, G. A. 165

Corner, E. M. 257, 258, 261, 265

Cornet, G. 249

Corstorphine, G. S. 169

Costa, B. F. B. Da. 248

Coste, J. F. 142, 143, 146

Cotar, C. 287

Cottam, A. 161

Cotter, J. R. 99

Cotterill, J. H. 42

Cottrell, H. E. P. 129

Coulthurst, S. L. 308

Coupland, W. C. 10

Cour, J. L. La. 114

Courcoax, Dr. 264

Coursey, P. R. 120

Courtenay, E. 295

Courtois-Suffit. $\mathbf{2 4 6}$

Coutts, H. T. 305

Coux, H. de la. 137

Cow, D. V. 292

Cowan, J. 254 T. W. 216, 217
Coward, H. F . 125

T.A. 192

Cowee, G. A. 310

Cowell, W. B. 140

Cowie, G. A. 218

Cowley, W. L. 92

Cox, J. 39, 103

L. E. 202

S. H. 165, 171

Coyle, D. 114

Crabtree, H. 45 J. H. 187, 307

Cracknell, A. G. 24, 26, 31, 37

Craig, E. H. C. 143,169

- J. 295

- M. 242

W. 291

Cramer, W. 134, 228

Cramp, W. 112, 113

Crane, W. 305

Crapper, F. H. 113

Crawford, W.J. 40,81

Crawfurd, R. 231, 285

Creagh-Osborne, F. 94 .

Cree, A. 74

Creedy, F. 113

Creighton, C. 248, 249, 276

-J. E. 17

Cremona, L. 32, 40

Cressy, E. 4

Crile, G. W. 252

Crimp, W. S. 58

Cripps, H. 257, 265

Crisp, F. 196

Crispin, F. S. 258

Critchell, J. T. 4

Critchley, H. 237

Croce, B. 9, 11, 12, 13

Crocker, H. R. 284

Crockett, T. 175

Crofton, W. M. 249, 287

Crook, H. E. 289 T. 165

Crookes, Sir W. 133, 137, 218, 220

Crookshank, F. G. 243

Cross, C. F. 135,148

- F. 120,180

- H. E. 296

- H. H. U. 118

- M.I. 196

W.E. 100

Crossley-Holland, W. 291

Crotch, A. 119

Crow, D. A. 282

Crowley. 233

Crowther, J. A. 2, 97, 103

Crozier, J. B. 6 
Cruchet, R. 255

Cryer, T. 42,47

Cubitt, H. 63

Cuff, H. E. 294

Cullingworth, C. J. 277

Cullis, C. E. 27

Cullyer, J. 214

Culpin, M. 253

Cumberbatch, E, P . 244, 290

Cumming, A. C. 124, 134

- D. 304 L. 106

Cunning, J. 260, 279

Cunningham, B. 54, 61

- D.J. 22

- F. 104

- J. T. 187,191

Cunnington, C. W. 278

- S. 21

Cunynghame, H. H. 78

Curgenven, J.S. 286

Curr, A. L. 177

Curry, C. E. 100, 106

CW. T. 56

Curtis, A. H. 165 C. E. 208. 214

Curtler, W. H. R. 215

Curwen, K. M. 233

Cushny, A. R . 227, 292

Cutler, H. A. 52

Cuyer, E. 224,

Da Costa, B. F. B. 248

Dahlstrom, K. P. 84

Dakin, W. J. 186,190

Dalby, W. E. 81,83

Dale, J. B. 37,47

Dales, J. H. 47

Dallinger, W. H. 196

Dalton, G. 257

$$
\text { J. } \mathbf{3}
$$

Dampier-Bennet, A. G. 254, 267

Dana, C. L. 251

Danby, A. 169

Dancaster, E. A. $\quad 66,129$

Dander, M. M. 94

Daniel, P. L. 249

Daniels, C. W. 259

- G. W. 297

Darby, J. C. H. 114

Darbyshire, H. 75

D'Arcy, C. F. 11

Dargon, J. 91

Darling, C. R. 97, 99

H. C. R. 233, 263

Darwin, C. 3, 185, 190, 194, 197, 198, 202

Sir F. 1, 3, 194, 199, 202
Darw in, Sir G. H. 1,160

Davenport, C. 305

- J.A. 66

Davey, H. 56

- N. 89

David, H. E. F. 147

Davidge, H. T. 109

Davidson, Sir J. M. 262

- P. W. 78

Davies, A. M. $170,187,233$

- B.H. 79

D. 51

F. H. 72,117

G. M. 165

G. MacD . 169

J. 153

P. J. 58

S. H. 137

Davis, A. 3

C.F.L. 307

- F. 279

G. B. 58

H. 284

H. N. 81

J.R.A. 199，202，211，212,

214,215

R.F. 32

R. H. 71

- W. 300

W. A. 132

W. B. 193

Davison, C. $\quad 26,28,30,32,35,167$, 233

Daw, A. W. 74, 172

- S.W. 267

Z. W. 74, 172

Dawe, E. A. 305

Dawson, E. R. 228

D. 117

Day, J. R . 249

Deakin, $R$. 26, 34

Dean, A. 61

Deane, H. E. 287

- P. E. 231

Deanesly, F: 266

Deare, B. H. 292

Dearle, N.B. 1

De Bary, A. 199, 202

Deeley, R. M. 74

Deerr, N. 218

Dehelly, G. 285

Delbos, L. 45, 182

Delille, P. A. 245

Dell, J. A. 18

De Martel, T. 265

De Montmorency, J. E. G. 4

Dendy, A. 194 
Denby, M. 280

Deniker, J. 197

Denning, D. 64

Dennis, H. J. 48

Denny, A. 189

C. W. 119

G. A. 173

Denton, F. M. 112, 113

Depéret, C. 185

Desaint, A. 68

Descartes. 10

Desch, C. H. 66, 156

Despard, L. L. 287

Detmer, W. 202

Deussen, P. 9

Devey, R. G. 116

De Villamil, R. 42, 93, 103

Devillers, R. 92,94

De Vries, D. 75

- H. 194

Dewar, Sir J . 102

Dewey, J. 6

De Wulf, M. 6

Dexter, S. G. F. 18

D'Heliecourt, R. 307

Dichmann, C. 157

Dick, J. R. 114

Dickson, A. A. C. 173

- H. N. 162

J. M. 146

L. F. 26

W. E. 240

Dieterich, K. 141

Dieulafoy, G. 242

Digby, K. H. 288

Digges, J . G. 217

Dighton, C. A. 274

Dilling, W. .J. 285

Dimond. L. 244

Diophantus. 22

Diver, E. IV. 219

Dixie, A. E. 94

Dixon, A. C. 23

- A. F. 223

C. 192

F. E. 50

- H. H. 202

S. G. 229

- W. E. 293

Dobbic, M. L. 287

Dobbin, L. 123,151

Dobbs, H. J. 30 W. J. 24, 39, 40

Dobell, C. 190

Doberick, W. 37

Dobson, B. 297, 298, 301

Dodd, S. 278
Dodgson, J. W. 213

Dollar, J. A. W. 217, 295

Dolmage, C. G. 159

Dominici, M. 289

Dommett, W. E. $37,45,71,72,79$, 88,94

Domville, E. J. 294

Fife, C. W. 71

Don, J. 57, 98, 181

Donald, A. 277

Donaldson, L. 309 R. 241

Doncaster, L. 194, 195, 196

Donington, G. C. 123

Donkin, B. 88 E. M. 85

S. B. 85

Donnan, F. G. 1

Dore, S. E. 289

Dorev, A. 46

Douglas, A. H. 6 C. 6 C. C. 231

Dover, A. T. $116,117,118$

Dow, J.S. 59

Downie, J. R. 154

Dowse, T. S. 287

Dowsett, H. M. 120,121

Dowson, J. E. 143

Doyen, E. 262

Doyle, K. D. 55

Draper, C. H. 99

- J. W. 4

Dreaper, W. P. 123, 147

Drever, J. 15

Drew, W. H. 31

Dreyer, J. L. E. 159

Driesch, H. 9

Driffield, V. C. 307

Drinkwater, H. 194

Dron, R. W. 169

Drought, C. W. 245

Druce, G. C. 199, $201 \quad 205,206$

Druery, C. T. 205

Drummond, I. M. 184

- J. 263

M. $18,202,259$

W. B. 18, 233, 242, 259, 280

Drury, F. E. 61

Drysdale, C. V. 113, 115

Dubose, A. 142

Duchène, E. A. 92

Ducroquet, D. 267

Duddington, N. A. 10

Dudgeon, G.C. 211

- L. S. 229

Duerr, G. 299 
Duff, C. M. 9

Duly, S. J. 165

Dumbleton, G. F. 94

Dumesny, P. 151

Dumville, B. 18

- J. 300

Dunbar. 58

Duncan, D. 3

- F.M. 212, 308

— J. $39,42,81,97$

W. G. 173

Dundas Grant, .J. 273

Dunk, J. L. 103

Dunkerley, S. 43, 54

Dunkley, W. G. $35,47,73$

Dunlop, H. C. 37

Dunn, J. T. 1 W. 67

Dunnicliff, H. B. 123,130

Dunraven, Earl of. 180

Dunstan, A. F。 . 1, 123, 127, 131 , 144

Dunstan, W. R. 218

Dunton, W. F. 116

Duprat, L. 11

Dupré, A. 129

Dupuy, G. M. 264

Durell, C. V. 30,31

Durham, H. W. 77

Durrant, J. H. 190 R. G. 130

Duthie, A. L. 68,149

- J. F. 206

Dutton, T. 242, 256

Duval, P. 264

Dwerryhouse, A. R. 168

Dye, F. 58, 59

F. W. 60

Dyer, Sir W. T. T. 205, 206

Dykes, W. R. 199

Dymes, T. A. 199

Dymond, T. S. 213

Dyson, Sir F. W. 159 S. S. 136

Eagles, T. H. 31

Ealand, C. A. 187, 196

Earo, J. R. 255

Easdale, W. C. 58

Eason, A. B. 100

Eastlake, A. 144

Eastman, C. R. 170

Eastwood, G. S. 26

Eaton, R. B. 61

Eccles, A. S. 287 J. R. 99,100 W. H. 120 W. McA. 221, 257,266
Eck, J. 59, 100

Ecker, A. 192

Eddington, A. S. 104,160

Ede, G. 153

F.den, T. W. 275, 277

Eder, M. D. 19, 253

Edgar, J. 75

J.C. 276

Edgcumbe, K. 115

Edge, F. J. 52

Edmonds, H. 199

Edmondson, T. W . 31, 33

F.dmunds, A. 254, 260

Edridge-Green, F. W. 271

Edser, E. 97, 99, 100

Edwardes, E. J. 231 Ker, D. R. 213

Edwards, A. T. 260

ㄱ. C.A. 153 F. S. 257 J. 28,187

Egmont, E. 289

Eichborn, G. 120

Eiffel, G, 92

Einstein, A. 104

Eisner, A. W. 251, 288

Eissler, M. 154,174

Ekin, T. C. 54

Elbourne, E. T. $\quad 310,311$

Elbs, K. 129

Elder, A. V. 260

- G. 280

Eldderton, E. M . 38, 44

- W.P. 38

Elgie, J. H. 162

Eliot, M. E.Y. 51

Eliott, A. W. M. 45

Elliot, G. F. S. $\quad 197,199$

- H.S. 194

_ R. H. 269, 270, 271

Elliott, C. 206

- F.B. 27

__ J.S. 231

Ellis. 221

- A. G. 111, 113, B. E. 303

C. W. 65

D. 199,229

E. T. 199

G. 47,64

G. S. M. 199

H. 228,233

Ellison, F. O'B. 225

- M.A. 287

Ellmore, W. P. 218

Elmslie, R. C. 262, 267

Elsden, J. V. 171 


\section{Name Index.}

Eltringham, H. 188

Ely, L. W. 249

Emery, W. D'E. 229, 267, ,288

Emsley, H. H. 101

Emtage, W. T. A. 100,106

England, W. J. 283

English, Sir T. C. 285

Ensoll, R. 125

Erdmann, J. E. 6

Eriksson, J. 212

Ermen, W. F. A. 68

Ernle, Lord. 215

Erskine-Murray, J. 120

Esch, W. 142

Eshner, A. A. 226

Espin, T. E. 160

Etchells E. F. 67

Etheridge, R. 170

Fucken, R . 9, 11

Evans, A. 251

- A. H. 192, 203

- E. 199

- E. A. 143

- E.R.G.R. 180

- J.C. 125

- J.W. 164

- T. J. 33

W. 242, 284

Everest, A. E. 147

Everett, A. 149

$$
\text { J. D. } 125,149
$$

Everitt, P. F. 308

Ewart, A. J. 199, 202, 203

- - E. D. 221

Ewing, Sir J. A. 39, 43, 81, 82, 99, 106

Eyre, J. W. H. 287

Faber, H. 214, 218

- O. 67

Fabre, J. H. 188

Fage, A. 93

Fagge, C. H. 221, 242, 264

Fairbairn, J. S. 277

Fairgrieve, J. 175, 177

Fairie, J. 165

Fairweather, W. C. 1

Falconer, J.D. 169

- W.W. 26 r

Falconnet, $\mathrm{H} . \quad 142$

Fanning, F. W. B. 249

Fantham, H. B. 191,248

Faraday, M. 2, 4

Farmer, J. B. 199

Farnsworth, A. W. 67

Fariquharson, R. 285

Farrar, R. A. 57, 232

Farrell, F.J. 147
Farrow, F. R. 62

Fawcett, C. B. 179

Fawdry, R.C. 22,40

Feldman, W. M. 222, 270

Felkin R. W. 290

Fenchel, A. 283

Fenton, H. J. H. 123, 127, 133

Fenwick, B. 276

- E. H. 257, 258

W. S. $256,267,280$

Feré. C. 19

Fergus, F. 272

Ferguson, R. B. 233 T. 51 W. B. 307

Fergusson, F. F. 54

Fernie, F, 114 W. T. 292

Ferrers, N. M. 30

Fidler, H. 67

T.C. 49,54

Field, A. 286

- E.R. $\quad 171$

- Sir M. 183

S. 119

Fielden, J. R. 26

Fierz-David, H. E. 147

Fife, C.W.D. 71

Figgis, J. N. 6

Fildes, $P$. 247

Filon, L. N. G. 32

Finch, R. J. 177

Findlay, A. $127,130,136,145$

- L. 247

Finn, M. 106

Finzi, N. S. 289

Firth, J. B. 125, 127

- R. H. 233

Fischer, E. 131,199

- F. 137

Fisher, B. 310

- G. M. 7

H. K. C. 114

- J. H. 270

- O. 167

W. R. 203

Fitzgerald, G.F. 106 S. 208

Fitzsimons, F. W. 191

Fitzwilliams, D. C. L. 261, 264, 294

Flack, M. 225, 226, 255

Fl:ttely, F. W. 220

Fleming, A. P. M. 114, 310

- G. 295,296

- J. A. $103,106,114,119,120$

- R.A. 242 
Fletcher, Sir B. F. 4, 58, 62, 63, 64

L C. 239

- F. M. 304

H.P. $58,62,63,64$ J. J. 312

Fleure, H. J. 179

Fleury, P. 68

Flint, R. 6

Flower, Sir W. H. 3

Fock, A. 164

Foden, J. 84

Foerster, A. 247

Foltzer, J. 300

Forbes, A. C. 208

G. 3,159

N. H. 289

Fordham, Sir H. G. 175

Fordyce, A. D. $\quad 279,280$

Forel, A. 188

Forrest, J. 269

— S. N. 24, 171

Forster, A. 234

- F. L. B. 132, 231, 291

G. 171

L. 248

Morley, H. 126

Forsyth, A. R. 23, 29, 30

$$
\text { D. } 279,294
$$

Fort, M. 147

Fortescue, C. L. 120

Fortescue-Brickdale, J. M. 245, 292, 293,294

Foster, Sir C. Le N. 171

- F. 89

- G. C. 106

- Sir M. 225

M. $\mathbf{2 4 5}$

- R. B. 309

Fothergill, C. F. 259

- J.B. 299

- J. M. 285,286

W. E. 275,277

Foucar, L. J. 151

Fourier, J. 99

Fournier D'Albe, E. E. 106, 123

Fowler. 61

G. H. 182

G. J. 229

J.S. 279,280

R. H. 30

W. H. $82,84,89,100$

W. W. $188,189,190$

Fox, H. C. 273

R. F. 287,289

R. H. 3

W.S. 247

Francis, F. 293
Franke, G. 144

Frankland, W. B. 22

Franzen, H. 146

Fraser, A. C. 7

J. 249, 265

Fray, J. 101

Frazer, J. E. 223

Fream, W. 211, 217

Frederick, R. C. 234

Freeman, A. 99, 310 E. A. 175 N. H. 37 W. G. 212

Fremont, C. 75

French, C. H. 26

- E. G. 247 H. 240,243 J. W. 102

Frenkel, H. S. 287

Fresenius, T. W. 133

Fretwell, W. E. 62

Freud, S. 19

Freudemacher, P. W. 173

Freudenreich, E. von. 215

Freund, I. 123

Freundlich, E. 104

Freyberger, L. 280, 287, 293

Frever, Sir P. J. 266

Frier, J. D. 93

Friel, A. R . 273, 290

Friend, J. N. 127, 129, 140, 141, 153

Frith, J. 113

Fritsch, F. E. 199, 203 J. 220

Froment, J. 252

Frost, P. 24, 30 W. A. 270

Fry, G. C. 177

Fryer, A. 203 P. J. 140,212

Fuller, Sir B. 15 B. A. G. 9

Fullerton, W. 61

Furneaux, W. S. 184, 188, 191, 199 , 225

Futers, T. C. 74

Gabell, D. 282, 283

Gabriel, W. M. 282, 283

Gadd, H. 238

- H. W. 291, 293

Gadow, H. 193

Gage, H. C. 262

Gairns, J. F. 83

Gaisford, H. 81

Galileo. 2

Galloway, J. H. 68

Galton, Sir F . 3, 194, 197 
Galvayne, S. 296

Gamble, F. W. 185, 192 W. 307

Gammon, J. C. 67

Ganswindt, A. 298

Gant, L. W. 118

Garbe, R. 83

Garcia, A. 312

Garcke, E. 109

Gardiner, C. J. 166 F. 284 G. G. 132 J.S. 186

Gardner, H. B. 262

- P. 4

- W. M. 145, 147

Garlick, A. 18

Garnett, W. 107

Garnsey, H. E. F. 170, 199, 201, 204

Garrard, A. 88

- C. 111 F. J. 78

Garratt, H. A. 81

Garrè, C. 265 .

Garrett, A. E. 126, 307

- A. ff. 54

Garrod, Sir A. E. 239, 240, 280

Garry, T. G. 236

Garton, W. 290

Gask, G. E. 260

Gaskell, J. F . 245 W. H. 227

Gaster, L. 59

Gatehouse, F. B. 66

Gates, P. 75

R. R. 194

- S. B. 24

Gavronsky, J . O. 229

Gay, A. 111

Geary, H. 217

Geddes, A. E. M. 162

— P. 194, 195, 199

Gee, G. F. 154

- S. J. 243

W. W. H. 38, 98, 110

Geen, B. 67

Geerligs, H. C. P. 138

Geiger, H. 105

Geikie, Sir A. 166, 167, 168, 176 J. 166

Gemmell, G. H. 123

Geoghegan, H. 230

George, H. B. 175

Georgi, F. 77

Georgievics, G. 147, 297

Gerhardi, C. H. W. 115

Gerrans, H. T. 41
Ghambashidze, D. 165

Ghon, A. 250

Ghosh, B. N. 292

- R. 292

Gibb, D. 24

Gibbs, G. H. 283

Gibson, A. G. 239, 242

A. H. $49,54,56$

C. R. 1,109

G. A. $26,28,33,242,244$

- H. 184

- J. 9

— R. J. H. 200, 202

W. 169

W. R. B. 9, 10, 13

Gilbreth, F. 310

Giffen, Sir R . 38

Giles, A. E. 275, 276

G. M. 236,259

Gill, Sir D. 8

- J. 180

- J. F. 109

- N. J. 91

Gillanders, A. T. 188

Gillespie, A. L. 286

Gillett, H. J. 66

Ginsburg, B. W. 182

Giroux, R . 246

Gissing, F. T. 146

Giua, M. 156

Giua-Lollini, C. 156

Gladwyn, S. C. 153

Glaisher, J. W. L. 21

Glaister, J. 233, 234, 237, 238

Glissington, C. W. 283

Glazebrook, Sir R. T. 1, 39, 97, 99, 100,106

Gleichen, A. 101

Glover, F. P. 24 J. 53 W. 15

Goadby, K. W. 238

Godfray, H. 159, 160

Godfrev, C. 26, 31, 32, 36, 37

Godlee, Sir R. J. 3, 231

Goebel, K. E. 202

Goerens, P. 156

Golding, A. A. 177 H. A. 25,45

Goldsbrough, G. F. 285

Golla, F. 246

Gom!,erz, T. 7

Goodall, A. 223, 225, 254 F.W. 245

Gooday, W. E. 144.

Goodbody, F. 257

Goodchild, W. 165 
Goodeve, T. M. 43

Goodfellow, J. 286

Goodhart, Sir J. F . 280

Goodman, J. 43

Goodrich, W. F. 60

Goodwill, S. G. 39

Goodwin, H. B. 35

Gordon, L. S. 214

M. H. 229

R. A. 214

W. 236

Gorst, Sir J. E. 279

Gosse, P. H. 196

Gossin, H. 97

Gotch, O. H. 255

Goudie, W. J. 85, 89

Gould, Sir A. P. 218.262 E. P. 262

Goulding, E. 218

Goulston, A. 254

Gower, A. R. 153

H. D. 307

Gowers, Sir W. R. 17, 252, 270

Gow land, W. 155

Grace. 53 J. H. 27, 33

Graham, J. 28, 43, 248 P. A. 215 V. 305

Graham-Smith, G. S. 229, 24.5, 259

Grahame-W hite C. 91

Grandmongin, E. 147

Granger, F. S. 15

Granjon, R. 77

Grant, D. 151

F. L. 36

H. C. J. 180

J. 139

J. C. 304

J. D. 269, 273

J. T. 229

Grasby, W. C. 211

Gray, A. 3, 23, 40, 45, 97, 106

A. A. 273

F. W. 127

H. 221

Sir H. W. M. 262, 264

J. 84

J. G. 40

K. J. 270

S. O. 203

Greaves, J. 42

Green, A. A. R. 289

A. G. 147

A. H. 166

C. E. 248

F. E. 211.215
Green, F. W. E. 271

- J.A. 15

- J. R. 199, 201, 202

T. H. 240

Greene, J. A. 143

- W. H. C. 264

Greenhill, Sir A. G. 23, 42, 92

Greenish, H. G. 235, 292

Greenly, H. 72

Greenstreet, W. J. 2, 11

Greenwell, A. 56, 171

Greenwood, H. C. 146

- M. 227, 259

W. H. 153, 154

W. O. 276

Grégoire, R. 264

Gregorius, R. 144

Gregory, E. S. 205 J. W. $166,167,176,178$ Sir R. A. 1, 39, 97, 175, 176

Grew, E. S. 160

Grey, C. G. 94 G.W. 62

Gribble, T. G. 51

Grierson, R. 60

Griffiths, A. B. 156, 191, 220, 283 A.P. 134

E. A. 75

E. D. 1

E. H. 99

F. G. 250

H.D. 173

W. H. 286

Grimsdale, H. B. 269

Grimshaw, J. 212 R. 75

Grönvold, H. 193

Groom, P. 199, 203 T. R. 77

Gross, E. 219

Grossmann, J. 136, 151

Groth, L. A. 77

P. 164

Grove, W. B. 204, 205

Groves, E. W. H. 260, 263, 264, 294

Groves-Showell, P. 180

Grubb, H. C. 63

Gruner, A. 298 O.C. 241,248

Grunwald, J . 78

Guest, J. J. 75

Guillemard, F. H. H. 179

Gullan, M. A. 294

Gulland, G. L. 254

Gulliver, G. H. 155

- J. H. 12

Gunn, .J. 79 
Gunn, J. A. 10 M. 270

Gunther, R. T. 212

Guppy, H. B. 199

Gurden, R. L. 52

Gurney, E. 103

Gurney-Dixon, S. 229

Guthrie, C. C. 261

- I. G. 280 T. 256

Guttentag, W. E. 144

Guttmann, O. 150, 172

Gwynne-Vaughan, D. T. 198

H.D.F. 83

Haas, P. 125, 135

Haberlandt, G. 202

Hackwood, R. W. 52

Haddon, A. C. 197

Haddow, A. N. 75

Hadley, H. E. 39, 97, 106

Haeckel, E. 224

Haeder, H. 81, 88

Haenig, A. 75

Haig, H. A. 202

Haggard, Sir R . 211, 215

Haglund, P. 287

Haig, A. 240

Hainbach, R . 149

Hainsworth, C. H. 118

Hake, C. N. 150

- W. 129

Haldane, E. S. 10 J. S. 100, 194, 225

Halden, G. M. 53

Hale, A. J. 123, 129, 131

C. W. 233

Hale-White, Sir W. 291

Haler, P. J. 24, 72

Hall, Sir A. D. 211, 213, 217, 220

- C. A. 196, 200

- C. J. J. Van. 219

H. R. 81

H. S. $26,31,34,35,36$

J. W. 154, 239

T. C. F. 165

W. 37,180

Hallett, G. W. T. 48

Halliburton, W. D. 225, 227,241

Halnan, E. T. 218

Halse, E. 312

Ham, B. B. 237

Hamel, G. 91

Hamer, W. H. 233

Hamilton, C. 310

- D. J. 255

Sir W. R. 23

Hammick, D. L. 103
Hammond, A. R. 189

Hampshire, C. H. 184

Hanby, W. 93

Handy, C. E. 47

Hankin, E. H. 92

Hanna, W. 246

Hannay, A. H. 8

Hansel, C. W. 106

Hansen, L. F. 181

Hanson. C. O. 208 S. G. 217

Harbord, F. W. 154

Harby, W. 49

Harcourt, L. F. V . 50, 55, 59

Harden, A. $126,130,137$

Hardie, R. P. 6

Harding, .J. S. 302 M.F. . 245

Hardman, A. H. 301

Hardwicke, W. W. 270

Hardy, E. 40

- G. H. 23, 28, 188

M. E. 203

Hare, A. T. 116

- F. 251

Harker, A. 168

Harloff, W. H. T. 138

Harley, V . 257

Harman , N. B. 269

Harmer, Sir S. F. 185

Harold, J. 243

Harper, C. G. 48 H. 91, 123

Harrai, C. 304

Harris, D. F . 225, 251

- G. T. 307 J. D. 290

P. W. 121 W. 251,290

Harrison, A. 310

A. B. 57 C. 69 F. 282 J. 33

L. W. 247

P. T. 61

Harrow, B. 104

Harston, G. M. 236

Hart, B. 253

- D. B. 277 H. 304

J. B. 99

J. H. 219

J. W. 58, 60

Hart-Smith, J. 129

Hartenburg, P. 252

Hartmann, E. 10 
Hartmann, R. 193

Harteg, M. 194

Hartridge, G . 270, 271

- H. 226

Harvey, A. 149 F. W. 24 W. H. 204, 205

Harvey-Gibson, R. J. 200

Hasbach, W. 215

Haskett, T. H. 217

Haslam, A. P. 109 G. 192

Hasluck, P. N. 43, 47, 58, 64, 67, 68, $75,147,302$

Hassard, A. R. 294 E. M. 294

Haswell, W. A. 186

Hatch, F. H. 164, 168, 169, 171, 173

Hatfield, W. H. 154

Hatschek, E. 128

Hatton, J . L. S. 30, 32

Hausbrand, E. 136

Hausner, A. 139

Havelock, J. H. 116 T. H. 24

Havilland, G. de . 79

Haward, W. 254

Hawkhead, J. C. 121

Hawkins, C. C. 111, 113

- H. L. 170 H. P. 257

Hawthorne, C. O. 237

Hay, A. 112, 113 J. 255

Hayes, R. 247

Hayward, F. H. 15

- J.W. 81 R. B. 23 W. R. 206

Haywood, G. 224

Hazell, W. H. 310

Heape, W. 228

Hearn, G. R. 51

Hearson, H. R. 154

Heath, C. 222 C. J. 274

F. G. 200,202

R. S. $32,41,100$

Sir T. L. 8, 22, 34, 159, 161

Heaton, E. W. 177

Heaviside, O. 106

Heawood, E. 175

Hedges, K. 106

Heerman, P. 147

Hegel, G. W. F. 10

Heî̀l, A. 142

Heilbron, I. M. 126, 181
Hellier, J. B. 279

Hellins, H. H. 57

Hellyer, S. S. 58

Helmholtz, H. L. F. 103 H. von. 3

Hempsall, W. H. 217

Henderson, A. 30

- - G. G. 128,132

- J. 242, 294

- J. F. 184

- R. 214

T. 271

- W.D. 184

Hendrick, F. 123

Hennell, T. 54

Henrici, O. 23

Henry, A. 208 P. 80 T. A. 135

Henslow, G. 200, 202, 212

Henslowe, L. 94

Henstock, J. 121

Henwood, J. H. 146

Hepburn, W. B. 283

Hepworth, M. W. C. 162 T. C. 148

Herbert, A. 76

- H. 270 S. 194,228 T. E. 119

Herbertson, A. J . 175, 177, 178 F. D. 177

Herford, R . O . 310

Héricourt, J. 250

Heriot, T. H. P. 138

Herman, G. E. 275, 277 R. A. 100

Hernaman-Johnson, F . 287

Herrick, T. P. 304.

Herring, H. T. 266

Herring-Shaw, A. 58

Herringham, Sir W. P. 258

Herrmann, G. 56, 74

Herrod-Hempsall, W. 217

Herschel. 3

Herschell, G . 240

Hertwig, O. 223, 226

Hertz, H. 39, 106

Herxheimer, G 239

Herz, W. 122

Herzfeld, J. 300

Hewat, A. F . 239

Hewitt, C. 188, 307

Hewlett, G. 312

R. 'T. 184, 229, 240, 285, 288

Heylin, H. B. 298, 301

Heywood, H. 27 
Hibbert, E. 134

$\longrightarrow$ L. J. 307 W. 118

Hicks, J. A. 144 J. W. 158 W. M. 41

Hickson, S. J. 191

Higgens, C. 269

Higgins, A. L. 51 S. H. 147

Higgs, G. G. 79 H. 38

Highton, H. P. 133, 134

Hildage, H. T. 310

Hilditch, T. P. 122, 127, 131

Hilger, W. 290

Hill, A. 223, 226

- A. M. 36 C. W. 73,74

F. T, 93 J. G. 119

L. $225,226,259$

M. J. M. 34

T. G. 135

W. 265

Hiller, E. G. 84

Hillhouse, W. 201

Hilliard, H. 283

Hilton, H. 27, 33, 164

Hime, H. W. L. 30 T. W. 237

Hinchley, J. W. 136, 218

Hind, H. L. 309

Hindle, E. 259

Hinks, A. R. 159,176

Hinshelwood, J. 269

Hiorns, A. H. 153, 154, 155, 156

Hird, D. 194

H. C. 37

Hirsch, W. 19

Hirschel, G. 262

Hjort, J. 183

Hoare, C. 37

- E. W. 295, 296

Hobart, H. M. 111, 112, 118

Hobbs. 115

— F. D. 92 I. M. 81

Hobday, F. T. G. 262, 295

Hobhouse, I. . T. 7, 10

Hobkirk, C. P. 205

Hoblyn, R. D. 242

Hobson, E. W. 22, 23, 35

Hodgett, E. A. B. 143

Hodgins, J . E. 217

Hodgkinson, W. R . 124

Hodgson, E. S. 312
Hodgson, H. H. 152

_-J.E. 173

- J. T. 83, 84

R. B. 75,77

T. R. 234

Hodson, F. 1

Hoernes, H. 95

Hoffding, H. 7, 15

Hofmann, E. 188

Hogarth, C. W. 286

D. G. 178

Hogben, L. T. 3

Högner, P. 100

Holden-Stone, G . de 79

Holdich, Sir T. 178

Hole, W. 146

Holland, W. C. 291

Hollander, B . 251, 280

Holman, H. 13, 18

Holmes, A. 168

Holms, A. C. 70

Holt, F. B. 10

H. G. 68

R. B. 53

Holt-Butterfill, H. 47

Holt-Thomas, C. 91

Holtzmann, O. 312

Holzwarth, H. 89

Hood, C. 154

D. W. C. 256,265

G. F. 123

W. P. 287

Hooker, Sir J. D. 2, 3, 198, 205, 206

Sir W. J. 3, 205

Hooper, .J. 65

L. 299,301

Hooton, W. M. 129, 133

Hoover, T. J. 174

Hope, E. W. 233, 234

— Sir W. H. St. J. 305

Hopewell-Smith, 1. 282

Hopkinson, B. 21,39 J. 21

Horder, Sir T. J. 240, 242, 245

Hornby, J. 145, 146

Horne, H. P. 305

Horner, D. W. 163

- J. 157, 297

- J. G. 72, 73, 74, 75, 76, 77, 84, 312

Horsley, Sir V. 251

Hort, E. C. 250

Horth, A. C. 78

Horton, C. M. 72

Horwood, A. R. 200

C. B. 173

Hoskins, G. G. 63 
Hoskins, H. P. 63

Hoskold, H. D. 50

Hough, W. S. 6

Houston, Sir A. C. 57

Houstoun, R. A. 97, 100

Hovell, T. M. 274

Hovenden, F. 25

Hovestadt, H. 149

Hevgaard, W. 70

Howard, A. L. 208 R. 260,263

Howarth, O.J. R. 175, 177, 178 W. G. 274 W. J. 235

Howden, R. 221

Howe, F. J. O. 114 J. A. 169,171

Howell, C. M. H. 258

Howes, G. B. 184, 186

Howorth, J. 149

Hovle, B. 121

Hubbard. F. 151 'T. O'B. 92

Hubner, J . 147

Hudson, B. 242 H. P. 25

O. F. 15 .

R. W. H. T. 30

W. H. 192

W. H. H. 36

Huelin, D. C. 312

Huggins, G. M . 266

Hughes, A. J 180

- A. L. 307

A. M. 123

A. W. 222

B. 264

E. L. 271

H. W. 172

T. H. 176

V. A. R. 84

W. 176,177

Hull, A. J. 264 E. 167

Humber, W. 44

Hume. 10

Humphreys, H. 283

Humphris, F. H. 290

Humphry, L. 294

Humphrys, N. H. 145

Hunnybun, E. W. 206

Hunsaker, J . C. 92

Hunter, A. 49

C. 283

G. 256

Hunt, G. B. 249

Hunter, H. H. 218
Hunter, J. 3

—.J. A. 301

W. 3, 254

W. I. 176

Huntington, A. K. 153

Hurd, A. 70

Hurry, J. B. 252

Hurst, A. F. 242, 252, 257

C. 81,83

C. H. 186

G. H. 68, 140, 141, 144, 299

H. E. 97

J. T. 50, 61, 63, 64

J.W. 217

Hurter, F. 307

Husband, J. 33, 49

Huskisson, W. M. 88

Hutchins, B. L. 310

Hutchinson, H. N. 170

- J. 236, 252, 261

- R. 226, 244, 280, 285, 286

R. W. 106, 107, 109

Hutt, C. W. 233

Hutton, F. H. 118

- J.E. 310

- R.S. 129

W. S. 50, 72, 84

Huxley, J. S. 185

L. 3

T. H. 2, 3, 10, 175, 184, 186,

$191,194,226$

Huygens, C. 101

Hyatt-Woolf, C. 101

Hyndman, H. H. F. 105

Ibbetson. A . 219

W. J. 24

— W. S. 109, 112, 116, 118, 309

Ibbotson, F. 156

Illingworth, S. R . 2

Imbert, L. 263

Imms, A. D . 186, 213

Ince, J. 291

Inchley, W. 43, 81, 84

Ingham, A. E. 73

Ingle, H. 141, 213

Ingram, G. L. 296

Innes, C. 60

C. H. 47,56

Innocent, C. F. 61

Inwood, 214

Ioteyko, J. 311

Ireland, W. W. 280

Irvine, M. C. W. 13

Isler, C. 57

J. F. L. 117

Jack, G. 64

W. R. 242 


\section{Name Index.}

Jackman, W. T. 311

Jackson, A. 76

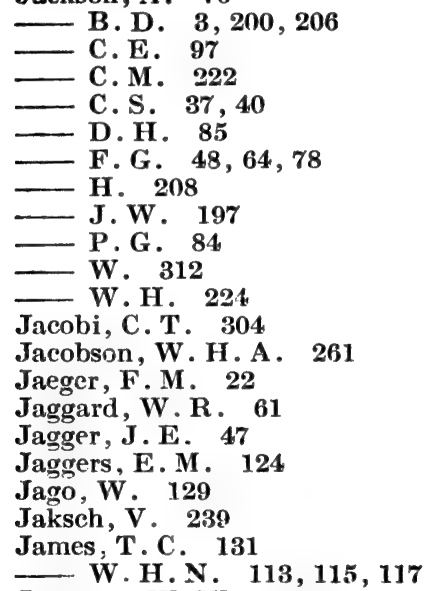

Jameson, W. W. 233

Jamieson, A. $\quad 43,81,90,107,110$ E. B. 222

W. A. 284

Jane, F. T. $70,85,94$

Janet, P. 7

Jansen, M. 267, 268, 280

Jaques, A. 127

Jardine, R. 276, 277

Jarvis, W. H. 53

Jast, I. . S. 307

Jeans, J. H. $100,107,160$

- J.S. 154

Jefferys, W. H. 236

Jefferson, 182

Jeffery, F. H. 129

- H. J. 198

Jehl, F. 117

Jellett, H. 275, 277

Jenkins, H. G. 310 J. T. 183,191

Jenkinson. 53

J.W. 223

Jennings, A. S. 69

Jennison, H. 141

Jessop, C. M . 30, 35

Jervis-Smith, F. J. 72

Jessop, W. H. H. 269

Jevons, F. B. 10, 194

- H. A. 13

$$
\text { W.S. } 13
$$

Jex-Blake, A. J . 221, 224

Jobling, E. 128, 146

Johns, C. A. $192,206,208$
Johnson, A. E. 132

A. E.W. 246

A. F. M. 200

— G. L. 308

- J.C.F. 173

- J.H. 117

- R. 114,308

- T.M. 116

- V. E. 45, 91, 113

W. E. 35

W. H. 219

Johnston, E. 305,306

G. A. 11

- J.B. 191

- J.F.W. 213

- K. 177

T. B. 221,222

-Lavis, H. J. 236

Johnstone, J. 191, 194 S. J. 152

T. 253

Joll, C. A. 251

Jolley, A. C. 115

Joly, C. J. 23

J. 105

N. 2

Jones, A. B. 237

A. C. 33,199

- A. .J. 15

- B. E. $47,64,309$

C. 129,308

C. P. 241

D. C. 38

D. E. $39,97,106$

D. W. C. 288

— E. 19, 251

- E. E. C. 11,13

- F.B. 137

— F. W. 191,197

H. 7

- H. F. 200

H.L. 290

- H. Macnaughten. 17

- H.S. 36

- J. 216

J. H. 154

- J. T.S. 295

- L. 289

— L.A. 172

- L. M. M. 79

L. V. 247

— M. W. 69

- Sir R. 267, 268

- R. 261

- T. 47

- T.G. 47

- T.H. 93 
Jones, T. W. 53

- W. 134

W. H. 119

W. N. 200

Jordan, C. H. 70 H. G. 42,47

Jörgensen, A. 137

Jost, L. 202

Jowett, W. 296

Joyner, G. 304

Judd, J. W. 166, 167, 194

Jude, A. 98 R. H. 97, 107

Judge, A. W . 88,93

Jukes-Browne, A. J. 168,169

Juler, H. E. 269

Julian, H. F. 174

- J. 68

Julius, P. 147

Jung, C. G. 19

Juptner, H. F. v. 154

Jutsum, J . M . 180

Kanthack, A. A. 239

- R. 102

Kapp, G. $109,114,118$

Kapper, F . 114

Kassner, T. 173

Kay, S. A. 134

Kaye, G. W. C. 105, 126

Kayser, E. 168

Keable, B. B. 219

Kean, F. J. 88,94

Keane, A. H. $\quad 177,179,197$ C. 132 C. A. 131

Keary, C. F. 7

Keatinge, M. W. 18

Keeble, F. W. 202

Keegan, D. F. 271

Keen, G. R. 209

Keim, A. W. 68

Keith, Sir A. 197, 222, 228, 226, 274,285

$$
\text { J. R. } 243
$$

R. D. 244

Kelland, P. 23

Kellas, A. M. 125

Kellner, O. J. 218

Kelsey, W. R. 97, 112

Kelson, W. H. 273

Keltie, Sir J. S. 175,179

Kelvin, Lord. 3, 7, 21, 101

Kelynack, T. N. 250, 251, 280

T. W. 239

Kemp, P. 109, 113

Kempe, H. R. $\quad 89,113,114$

Kempson, E. W. E. 112
Kennedy, A. 52

Sir A. B. W. 72

A. M. 245

N. 51

- R. 91, 93

Kennelly, A. E. 110

Kenwood, H. R. 233, 234

Ker, C. B. 245

- D.R. E. 213

Kerr, G. 186

—.G. L. 172

— J. 5, 233

- J. G. 223, 228

J. M. 277

Kershaw, G. B. 59

- J. B. C. $142,143,155$ J. W. 88

- S. 300

Kettle, E. H. 267

Kew, H. W. 191

Key, A. C. 144

Keynes, J. N. 13

Kickman, H. R. B. 225

Kidd, F. 257, 258, 266

W. 194

Kilgour, P. 297

Kimball, A . L. 100

Kimmins, C. W. 18

Kinch, E. 123

King, D. B. 250

— F. T. 278

- H. E. 81

- J. 71

Kingsbury, J. E. 119

Kingscott, P. C. R. 134

Kingsley, J. S. 191

Kinzer, H. 299

Kingzett, C. T. 123

Kinzbrunner, C. 110, 114

Kipping, F. S. 129, 131

Kirby, W. E. 188,189

Kirkaldy, J. W. 184

Kirkbride, J. 304

Kirkpatrick, T.S. G. 173

Kirkup, T. 5

Kirmisson, E. 280

Kirschke, A. 88

Kitchin, D. B. 10

Kleen, E. A. G. 287

Klein, A. 13

- F. 27

Klemin, A. 94

Klingenberg, G. 111

Kloes, J. A. Van Der. 65

Knapp, A. W . 139

Knecht, E. 134, 147, 299

Knight, J.H. 79 
Knight, R. S. G. 134 S. R. 26,35 W. 12

Knoblauch, E. 201

Knocker, D. 237

Knott, C. G. 21, 22, 25, 96, 167

Knox, A. 162,179

— A. V. 105

_ E.B. 233

- G. D. 220

J. 126,152

R. 105

Knuth, P. 202

Knuthsen, L. F. B. 256

Koczorowski, Lt. 45

Koenigsberger, I. 3

Koller, T. 151

Koppeschaar, E. 138

Kozmin, P. A. 139

Kraepelin, E. 253

Krauch, C. 132

Krause, R. A. 227

Kretschmar, C. 299

Krogh, A. 227

Krohn, R. E. S. 228, 262

Krusch, P. 165

Kulpe, 0 . 7, 17

L. H. 53

Laby, T. H. 126

Lachlan, R . 31

Lack, L. A. H. 226

La Cour, J. L. 114

Lafar, F. 138

Lagrange, F . 271

Laird, .J. 250

Lake, $P$. $166,168,176$

L R. 274

Lakeman, A. 66

Lamarck, J. B. 194

Lamb. 53 C. G. 107 H. $28,39,41,42,103$

J. 88

J. B. 216

W. 273

Lambart, H. C. 259

Lambert, F. C. 308

$$
\text { S. } 45
$$
T. 139,155

Lambkin, F. J. 247

Lamprecht, $R$. 171

Lancaster, M. 117

Lanchester, F. W. 73, 91, 92

H. V. 68

- W. F. 229

Land, H.C. 189

Landauer, J. 132
Lander, C. H. 301 G. D. 129,296

Landois, L. 226

Landolt, E. 270 M. 270

Landon, J. W. 41

Landseer, Sir E. 193

Lane, J. E. 222

- Sir W. A. 257, 265, 260

Claypon, J. E. 235

Lang, A. 224

W.H. 201

Lange, K. R. 145

Langenhagen, M.de. 256

Langley, J. N. 223, 225, 226

Langmaid. J. 81

Lankester, Sir E. R. $170,185,186$

Lantsberry, F. C. A. H. 144

Lapage, C. P. 280

Lapworth, C. 166

I.arard, C. E. 25

Larkman, A. E . 28, 110

- A. H. 110

Larmor, Sir J. 89, 96, 108

Larner, E. T. 113

Larsen, A . 150

Larter, A. 'T' 143

Lascelles, T.W. 306

Lasche, 0 . 89

Latham, A. 244, 285

- E. 55

Latter, O. H. 185, 189

Lattey, R. T. 97

Laurance, L. 102

Laurens, G. 273

Laurie, A. P. 69, 141 C. L. 200 S.S. 5

Laveran, A. 248

Lavis, H. J. J. 236

Law, E. F. 155

- H. 52

Lawn, J. G. 171

Lawrence, C. P. 215

Lawrie, E. 263

Laws, B. C. 92

Lawson, A. W. 104 F. M. 311 G. 31

Laxton, 63

Laycock, W. F. 147

Lazarus-Barlow, W. S. 239, 240

Lea, A. S. 225

- A. W. W. 276

- E. 255

Leach, A. F. ${ }^{54}$ 
Leaf, C. H. 223, 276

- H. M. 116

Jean, B. 124

Leaning, J. 63

Leathem, J . G. 24, 28, 35

Le Bas, G. 127

Le Bon, G. 20, 103

Leckv, S. T. S. 180

Ledeboer, J . H. 92

Ledingham, J . C. G. 245

Ledoux-Lebard, M . 264

Leduc, S. 227

Lee, A. B. 223

- J. 119,311

- V. 13

Leeds, F. H. 143

Lees, C. H. 98

D. B. 250

Leese, A. S. 296

Letêvre, L. 65

Leffmann, H. 132

Leftwich, R. W. 244, 285

Legg, J. W. 243

- T. P. 260

Legge, F. 103

T. M. 238

Leggatt, W . 298, 299

Leggett, B . 121

Legros, L. A. 304

Lehfeldt, R.A. $126,127,129$

Lehner, S. 148

Leibniz, 10

Leighton, G. R . 192

Leland, C. G. 64, 78, 803

Lelean, P. S. 283

Lemaire, $H$. 245

Le Maitre, W. 92

Lemerle, G. 265

Lempfert, R. G. K. 162

Lennander, K. G . 258

Lenzmann. 244

Leonard, E. M . 5

Lepine, J. 253

Leri, A. 19

Leriche, R. 263

Leston, G. L. 51

Letts, E. A. 126

Leudesdorf, C. 32

Leupp, F. E. 3

Levett, R. 35

Levy, D. M. 174 H. 92

S. I. 129,150

Lewers, A. H. N. 276

Lewes, G. H. 5 V.B. $123,143,145$

Lewis, E. I. 129, 131
Lewis, E. W. 142

- H. M. 63

L. P. 53

S. J. 122

W. C. McC. 127

W. J. 164, 175

Leyton, A. S. F. 239

Libby, W. 5

Lickley, J. D. 223

Lidgett, A. 144

Lieckfeld, G. 88

Lilly, W. E. 49

Lindsay, C. T. 48

- J. 7, 249

— J. A. 256

Lord. 76

Lineham, W. J. 48, 73

Ling, A. R. 138

Lintern, W. 52

Linton, R. G. 296

Lister, J. J. 186

— Lord. 231, 260 T. D. 278

Lithgow, E. M . 271

I.ittlejohn, A. R. 235

Little, A. 178

- A. G. 3

- H. F. V. 129

Liveing, G. D. 102

Livens, G. H. 107

Liversedge, A. J. 73

Liversidge, J . G. 86

Livingstone, R. 112

Llewellyn, J. L. 237, 249

Lloyd, A. H. 7

E.W. 211

- F. E. 184

Ll. 244, 248

- L.L. 147 R.E. 184,185

Lluria. E. 195

Lochhead, J. 228

Lock, G. W. 174 J. B. $35,36,41$ R. H. 195, 219

Lockwood, 63 C. B. $261,263,266,276$

Lockyer, C. 267, 275 Sir J. N. $102,159,160$

Lodge, A. 28

—-G.A. 171

G. E. 193

Sir O. J. 2, 3, 36, 39, 103

R. C. 11

Logan, D. D. 238

Loewenfeld, L. 228

Loewenthal, R. 147 
Logan, F. W. A. 45

Lohmann, W. 271

Lohnis, F. 214

Lommel, E. 101

- von. 97

Lomax, J. W. 298

Lones, T. E. 155

Loney, S. L. 33, 34, 35, 36, 39, 41, 42

Long, C. E. 19
H. C. 212

J. 214,217

Longmuir, P. 157

Longridge, C. J. N. 276, 277

Loosmore, C. 251

Lord, R. T. 301

Lorenz, A. 268

Loring, F. H. 127

Lossky, N. O. 10

Lott, F. E. 138

Louch M. 18

Louis, H. $\quad 52,153,169,174$

Love, A. E. H. $29,39,44,167$ J. K. 274

Loveday, T. 15,17

Lovell, M. S. 191

Lovett, W. J . 70.71

Lovibond, J. W. 102

Low, B. 19

D.A. $31,33,43,47,73,81$ G. C. 246

R. C. 284

W. S. 273

Lowndes, M. E. 15

Lowry, T. M. 122

Lowson, J . M. 200

W. 129

Lucas, E. W. 286, 291, 292

- F. 312 K. 227

Luciani, L. 226

Luckes, E. C. E. 294

Luckhoff, L. 270

Ludlam, F. B. 124, 129

Luff, A. P. 125

Luhe, M. 248

Luke, T.D. 263, 283, 289

Lukis, Sir C.P. 236, 292

Lulham, R. 186

Lumb, A. D. 165

- N. P. L. 247,266

Lummer, O. 308

Lummis-Paterson, G. W . 112

Lunge, G. $132,136,145,146,151$

Lunt, H. J. 311

- J. 130

Lupton, A. 173
Lupton, S. 126

Lustgarten, J. 117

Luttringer, A. 142

Luys, G. 247

- J. 227

Lyall, M. 7

Lycett, J. 94

Lydall, F. 118

Lyde, L. W. $\quad 177,178$

Lydekker, R . 3, 170, 185, 191, 193

Lyell, Sir C. 166

Lyle, H. W. 226

Lyman, T. 102

Lyster, R. A. 233

Lyth, E. R. 289

M.R.C.V.S. 217

MacAlister, D. A. 169

McAulay, A. 23, 38

Macaulay, F. S. 27, 31 W. H. 99

Macbeth, A. K. 125

MacBride, E. W. 186,223

McBride, P. 273

Maccabe, F. F. 231, 295

MacCall, W. T. 112

MacCallan, A. F. 270

McCann, F. J. 276

McCarrison, R. 254

M'Carthy, F. L. 34

MeCartney, H. P. 46

McCaskill, A. 1

McCaw, J. 279, 280

McCay, D. 286

M'Clelland, W. J. 35

McConnell, P. 211

McCrae, J. A. 239 T. 243

McCulloch, C. 74

MacCurdy, J. T. 253

McDermaid, N. J. 71

McDonagh, J. E. R. 247, 288

Macdonald, D. M., 280, 286

- G. 18

- G. W. 150

- H. M. 107

- J. 211

- J.H. 253

- R. St. J. 233

- W. 215

McDougall, W. 15, 16, 17, 20

McDowall, S. A. 97

MacEwan, P. 291

MacEwen, J.A.C. 222

MacFadyen, A. 184

McFarlane, J . 177

Macfarlane, W. 153, 154, 156

Macfie, R.C. 195,289 
McGibbon, W.C. 86

McGowan, G. 132

Macgregor, J. G. 41

- J.M. 240

MeGrigor, G. D. 164

MacHattie, A. 180

McIntosh, J , 247

- J. G. 138, 141, 142

W.C. 192

MeKail, D. 234

McKay, R. F . 43

Mackay, J. S. 25, 31

McKay, W. J. S. 231, 276

McKendrick, A. 237, 238 J. G. 226

Mackenna, R. W. 288

McKenzie, D. 273, 274

- J. 246

Mackenzie, Sir J. 231, 255

- J. A. S. 249

- J. E. 138

- J.S. 10,11

K. J. J. 217

N.T. 55

R. T. 287

T. 43

T. C. 254

W. C. 222, 227

W. L. 232, 279

Mackie, A. 307

- J. 302

McKillop, A. D. 310 M. 286,310

MacKinder, H.J. 178

McKinnon, E. C. 116

McKisack, H. L. 24.4

Mackrow, C. 71

M'Lachlan, N. W. 25

McLaren, R. S. 73

Maclaurin, R. C. 101

McLean, A. 98

Maclean, H. 131, 239 M. 110

MacLennan, A. 261

Macleod, H. W. G. 233

- J. 186

- J. J.R. 226, 258

J. M. H. 264, 284 W. A. 156

MacMahon, P. A. 27

MeMillan. 86

$$
\text { D. } 79
$$

MacMillan, J.C. 279 W. G. 153,155

McMinnies, W. G. 92

MacMunn, N. E. 175

$\mathrm{NacNab}, \mathrm{A} . \quad 269,271$
MacNab, J. 182

$$
\text { W. } 150
$$

MacNamara, N.C. 16,195

Macnaughten-Jones, H. 17

McNeile, A. M. 28 J. D. 28

Macpherson, H. 3

McPherson, J.A. 57

McQueen, E. N. 16

MacQueen, J . 296

Macrobert, T. M. 23

McTaggart, J. Me'T. E. 10

McVail, J. C. 246

McWilliam, A. 157

Maddox, E. E. 270

H. A. 148, 305

Madill, D. G. 277

Magian, A. C. 247

Magie, W. F. 97

Magill, E. M. 290

Maginnis, A. G. 71

Magnus, L. 7

- Sir P. 39

Maguire, T. M. 179

W. R. 59

Maher, M. 16

Maitland, F. 2

Maitre, W. le. 92

Makins, Sir G. H. 264

Makower, W. 105

Malatesta, G. 145

Malcolm, H. W. 120

Mallik, D. N. 101

Mamlock, H. J. 283

Manacorda, H. 16

Manders, A.S. 142, 219

Mann, Dr . 256

- G. 223, 227

- H. L. 25

- J. D. 238, 239

M. S. 274

Manson, G. L. 61

- Sir P. 259

- Bahr, P. H. 259

March, H. 244

- N. H. 228

Marchant, F. T. 233 W. H. 121

Marett, R.R. 16, 197, 223

Mark, E. L. 223

- H. T. 5 L. P. 251

Marks, E. C. R. 73, 74

— Sir G.C. $\quad 56,278$

L L. S. 81

Marlow, T. G. 136

Marquand, H.S. 119 
Marr, H. C. 253

J. E. 166, 168, 169, 214

Marriage, F. 308

Marsh, C.F. 67 J.E. 127

Marsden, R. 299

Marshall, A. 150 A. M. 186,192

C. 286,292

C. D. 269

F. H. A. 217, 223, 228

H. 151, 164

H. R. 16

T.W. 215

W. J. 88

Marson, P. 149

Martel, T. de. 265

Martin. 86

A. B. R. 121

G. $122,124,126,129,136,146$,

$147,150,151$

- H. N. 184
- J. ${ }^{178}{ }^{121}$
M. J. 121
N. $67{ }^{76}$
W. A. ${ }^{76}$
W. W. 86,88
W. R. ${ }^{181}$

Martindale, W. H. 288, 292, 293

Martineau, G. 138

Martinier, P. 265

Maryon, $\mathrm{H}$. 78

Maskelyne, N. S. 164

Maslen, A. J. 200

Mason, A. C. 7

- F.A. 147

Massee, G. 200, 204, 212

Masselin, E. J. 230

Master, H. 137

Masterman, A. T. 186, 192

Masters, W. E. 259

Mastin, J. 165

Mather, T. 109

Matheson, D. 217 E. 311

Mathews, G. B. 23, 27, 32

Matson, R. W. 288

Matthew, D. 252

Matthews, A. H. H. 215

- C. G. 138

E. 216

- E.R. 54, 55, 60

G. F. 37

R. B. 91,94

Mattos, A. T. de. 188

Maudsley, H. 16, 253

Maunder, E. W. 160
Maurice, W. 172,173

Maw, P. T. 209

Mawson, E. O. 55

F. 171

Maxim, Sir H. S. 3

Maxted, F. B. 128, 151

Maxwell, Capt. 181

- F. 138

F. W. 35,183

- J. C. $99,103,106,107$

- J. L. 236

- R. D. 275

W. H. 59

May, C. H. 269

O. 247

- P. 139

Mayall, G. 216, 217

J. 196

Maycock, W.P. 107, 112, 113, 114, 116,117

Mayer, C. 142,148

Maylard, A. E. 250,266

Maynard, F. P. 269

Mayo, C. H. P. 28

Mayor, J. B. 7

Mayou, M. S. 269,270

Meade, A. 14.5

Meares, J. W. 54, 110

Meek, A. 192

Mees, C. E. K. 102

Meldola, $R$. 124, 131,308

Mellanby, A. L. 48, 70

Melland, C. H. 258

Mellone, S. H. 13, 16

Mellor, J. W. 25, 130, 134, 149.156

Melville, C. H. 233

Davison, W. 233

Mennell, F. P. 168

J. B. 263, 287

"Mentor." 145, 146

Menzies, J. A. 225

K. 228

Mercer, J. E. 103

$$
\text { J. W. 28, } 35
$$

Mercier, C. 17, 213, 253

- Cardinal. 7

Meredith, C. iM. 18

Méric, H. de. 289

Merrifield, J. 181

Merrington, E. M. 16

Merritt, W. H. 165

Merz, J. T. 5, 7

Mesnil, F. 248

Messum, S. 183

Metcalfe. 4 C. C. 116

Metchnikoff, E. 288 
Metson, G. 63

Meycliar, L. 312

Meyer, B. F. 7, 14

Meysey-Thompson, R. F . 193

Miall, B. 188, 250

- I. C. $3,184,189$

Michaelis, D.M.L. 41

Michell, S. 56

Micholitsch, T. 276

Middleton, E.C. 91

G.A.T. $49,51,59,64$ R, E. 51,57

Midgley, I.. 300

Miers, Sir H. A. 164

Milburn, T. 212

Miles, A. 232, 261, 263

Mill, H. R. 175,179

$$
\text { J. S. } 6,13
$$

Millais, J.G. 192, 193

Millar, A. 69,219 J. B. 31 W.J. $73,82,180$

Millard, C. K. 288

Miller, H.C. 253

- J. 239,240

- J. S. 77

$$
\text { R. } 280
$$

Milligan, F. M. 219 Sir W. 274

Millington, J. P. 3

Millis, C. T. 25,77 G. P. 283

Milne, J. 33,167 J. J. 32 J. S. 232 R. 300 R. M. 22, 41 T. 299 W. P. 27, 28

Milner, H. B. 168

Milroy, J. A. 135 M. F. W. 302 T. H. 135

Milson, F. 151

Minchin, G. M. 41, 42, 47 W.C. 250

Minett, E. P. 229

Minikin, R. C. R. 54

Minto, W. 13

Miremont, C.de. 161,180

Mitchell, A. 9 C. A. $128,133,137,138,141$, $148,235,238,297$ C. F. 61,65 F. S. 69 G. A. 61,65 J. 71
Mitchell, P. 232

- P.C. 184, 195

- W. 16

Mivart, St. G. 2

Moggridge, J. T. 189

Molesworth, Sir G. L. 46, 50 H. B. 62 W. H. 110

Molinari, E. 137

Moll, A. 279, 290

Monahąn, A. 7 A.J. 14

Monckton, C. C. F. 121

Monro, T.K. 242

Montagu, Lord. 80

Montel, A. 68

Monteverde, R. D. 312

Moodie, A. R. $\mathbf{2 7 4}$

Moor, C. G. 229, 233, 235

- S.A. 202

Monre, A. S. 301

B. 135, 195, 226

- E. C.S. 54

- F. 189

- G. E. 11

- H. 96,143

- Sir J.W. 162

- N. 232

- S. B. 79

- T. 77

— T.S. 129

c-Sir W. 236

Moorhead, T. G . 224

Mordin, R. 120

More, C. G. 79

Moreton. H. W. 115

Morgan, A. P. 93 C. Llovd 16, 19, 187, 195 .

G. T. 131 J. D. 118

- J.J. 156, 157

Morison, A. B. 254

C. G. T. 211

J.R. 264,266

- R. 260

Morley, A. $\quad 39,43,44$, , 81 H. F. 126

Morrell, R. S. 141

Morrice, G. C. 27

Morris, C. 181 F. O. 189

Sir H. 222, 248

H. J. 283

I. H. 33,48

Sir M. 284

T.N. 218 


\section{Name Index.}

Morrow, J. 89

Morse, H. W. 126

Morten, H. 294

Mortimer, F. J. 308 G. 155 J. D. 263

Morton, A. S. 271 E. R. 105 W. C. 222

Moses, O. St. J. 276

Moss, C. E. 203, 206 H. 84

Mosso, A. 259

Mott, Sir F. W. 18, 253

Mottelay, P, F. 3

Moulinier, T. 255

Moullin, C. W. M. 248, 266, 267

Moulton, Lord. 2

Moussu, G. 217

Mowat, H. 105

Moynihan, Sir B. G. A. 266

Mudge, G. P. 184, 200

Mueller, F. 205

Muir, J. 104 M. M.P. $124,126,133$ R. 229,288

Sir T. 27

Muirhead, I. B. 271 J. H. 11 W. A. 236

Mulhall, M. G. 38

Mukerji, N. G. 211

Mumford, E. E. R. 18

Mummery, J. H. 282 J. P. L. 257, 262, 266

Munby, A. E. 64, 130

Mundella, V.A. 1

Munro, J. 86, 110

- R. D. 84 R.W. 219

Muratet, L. 246

Murdoch, W. H. F. 110, 115

Murphy, J. K. 242, 247, 264, 280, 285

- Sir S. F. 234

Murray, A.J. 71

- D.A. 28. 29, G. R. 254

- H. M. 243

- Sir J. 183

- J. A. 213, 218, 220

- J.E. 120

R. W. 265, 267

Murrell, W. 238, 285

Muscio, B. 17

Muter, J. 132

Myddleton. 3
Myers, C. S. 17,19

- J.E. 125

Nabarro, D. 248

Naegeli, C. 196

Nall, S. 276

Nankivell, A. T. 233, 285

Nash, J. T. C. 195

Nasmith, J. 298, 301

Nave, .J. 204

Nayler, W. A. 33, 41

Naylor, C. H. 99 T. E. 304 W. 151

Neale, R. E. 110, 111

Neave, G. B. 131

Neilson, R. M. 89

Neligan, A. R. 236

Nernst, W. 126

Nettlefold, J. S. 68

Neuburger, M. 232

Neumann, E. 282

Neville, H. A. D. 213 S. 113

Newbigin, M. 1. 175, 176, 178 M. T. 193

Newby, E. J. 91

Newcombe, S. 160

Newell, A. G. 245

Newham, H. B. G. 259

Newland, C. B. 19 H. O. 219

Newlands, B. E. R. 138

- J.A.R. 138

Newman, E. W. 311

- Sir G. 234,279 L. F. 213

Newsham, J. C. 209, 211, 212, 214, 216

Newsholme, Sir A. 233, 245, 250

Newsome, H. F. V. 58

Newth, G. S. 124, 130, 132

Newton, Sir I. 24, T. 77

Nicholls, Capt. 182 A. E. 181 H. A. A. 211

Nicholson, H. A. 170 R, T. 80 W. 143

Nicol, G. 71

Nicoll, M. 19

Nielson, T. 49

Nietzki, R. 147

Nisbet, D. T. 300 H. 299,300 J. 209

Nixon, R. C. J. 34 
Noble, Sir A. 158

Norie, J. W. 182

Normandy, F. 124

North, N. 300

Norton, F. 278

Northcliffe, Viscount. 80

Norton, G. 308

Norwell, A. 41

Nottage, W. H. 121

Notter, J. L. 233

Nowell, W. S. 283

Noyer, J. 151

Nunn, A. W. 292 J. A. 296 T. P. 22,26

Nutt, P. 91

Nuttall, G. H. F. 189, 229, 245

Oberst einer, Prof. 223

O'Callaghan, M. A. 216

O'Connor, F. W. 259 H. 59,145

O'Dea, J. J. 26, 36. 37

O'Donahue, T. A. 51, 171

O'Donoghue, C. H. 186

Ogden, C. K. 9

Ogg, A. 99

Ogley, D. H . 60, 107, 117

Okey, T. 302

Okill, J . 88

Oldfield, C. 277

Oldham, F. 124.

Oliver, C. E. 69

D. 200,206

F. W. 55, 195, 200

G. 211

Sir T. 238, 259

Ombrédanne, Prof . 264

Onodi, A. 270, 274

Onslow, M. W. 135, 203

Oppenheimer, C. 128, 238

Oram, Sir H. J. 86

Orford, H. 102, 308

Ormandy, W. R. 144

Ormerod, F. 297

Ormsby, M. T. M. 51

Orr, A. J. 73

- J. 21]

J. B. 295

M. A. 161

Orrin, H. C. 222, 261

Orton, G. H. 289

Orthmann, E. G. 275

Orwin, C.S. 214

Osborn, G. 26

Osborne, F. C. 94 T. B. 135

Oschwald, U. A. 115
Oscroft, P. W. 130

O'Shea, L. T. 124

Osler, Sir W. 243

Osmond, F. 156

Ostertag, R. 235

Ostwald, W. 126, 130, 132

Otabe, S. 250

O'Toole, I. 46

Oulton, L. 114

Outram, J. F. 63

Overbeck-Wright, A. W. 25s

Overend, W. 250

Owen, E. 265, 266

- H. 182 W. D. 121

Owens, F. W. 180

Page, C. M. 264

J. M. 29 W. 5

Paget, S. 232

Paine, A. 249

Painton, E. T. 114

Paisseau, G. 245

Pakes, W. C. C. 233

Pallin, W. A. 230

Palmer, A. R. 107, 110, 115

— J. H. 35

- M. D. 287

T. F. 302 W. S. 9

Pamely, C. 74

Panton, A. 26 P. N. 240

Pappenheim, A. 241

Paramore, R. H. 275

Park, J. 51, 54, 155, 156, 166, 169 W. E. 93

Parker, C.A. 273

_ G. 232

- G. W. 42, 101, 160

- J. 99,172

M. A. 132

— P. A. M. 54

T. J. $7,184,186$

W. N. 186

Parkes, F. 289

L.C. 233 O. 70

Parkinson, B. R. 146

- S. 40, 101 T. W. F. 175

Parr, A. 76 G. D. A. $110,114,115,173$

Parry, E. J. 141, 142, 235

- L. A. 259

Parson, J. 53

Parsons, F. G. 222 
Parsons, H. de B. 84 H. F. 234 J. H. 16, 102, 269, 270, 271 J. J. 290 S. J. 154

Part, G. M. 168

Partington, J. R. 25, 99, 130, 151

Partridge, W. 124, 229, 235

Partsch, J. 178

Passmore, A.C. 62, 65

Pasteur, 4

Patchell, W. H. 173

Paterson, A. M. 222, 223, 224

- D. 299 G. W. L. 112, 116, 173

W. E. 38

Paton, D. M. 288

- D. N. 226, 240, 295 H. 304

Patrick, G. T. W. 7

Pattison, J. T. 155

Paul. C. N. 284 I. H. 137 M. E. 228,279 N. M. 9,10

Pavlov, I. P. 286

Pavy, F. W. 258

Pawson, H. C. 211

Payne, .T. F. 232 W. H. 4

Paynter, J. E. 33

Peacey, E. 296

Peacock, D. H. 3

Peake, A. H. 53

- R. J. 301

Pear, T. H. 253

Pearce, E. K. 189 J. G. 310 W. J. 69

Pearmain, T.H. 235

Pearn, F. 311 S. 311

Pearse, A. W. 217

Pearson, 182

- C. Y. 261 J. C. 77 J. H. 62 K. $3,43,44,45,49,54,195$ M. 134 M. G. 263

N. 10,16

S. V. 250

Peattie, J. 84

Peddie, A. 46 R. A. 2, 304

Pedley, R. D. 282

Peel, R. 172
Peel, T. 81

Pelly, S. A. 170

Pembrey, M. S. 226, 240, 293

Pendlebury, C. 36

Pendred, V. 83

Pendry, H. W. 120

Penhallow, D. P. 264

Penlake, R. 308

Penlington, W. A. G. 216

Penman, D. 173

Pennington, A. S. 191

Penrose, H. E. 107, 121

Penzer, N. M. 219

Percival, A. S. 25, 101, 272 G. A. 117 J. 212, 213, 214, 220

Perkin, A. G. 147

— F. M. 46, 124, 130, 133, 144 H. 173 W. H. 41, 124, 125, 129, 181

Perol, P. 244

Perrin, J. 103

Perrott, A. D. 34

Perry, 3 S. W. 53

J. 25, 28, 45, 82

Peters, O. H. 256

Petherbridge, F.R. 213

Petit, G. 142

Pettigrew, W. F. 83

Pfeffer, W. 203

Philip, A. 119 A. J. 304, 305 J. C. 127

Philipson, J. 65

Phillimore, J. 80

Phillips, C. D. F. 293

- H.J. 156

- Sir J. 275

— J. A. 169

L. P. 246 W. 204

Philpott, T. V. 214

Piaggio, H. T. H. 29

Picard, H. K. 155

Pickard, J. A. 156

Pickering, W. H. 160

Pickerill, H. D. 256

H. P. 282

Pickford, A. G. 32

Pickworth, C. N. 37

- P.C.N. 311

Pidduck, F. B. 107

Pigg, J. J. 308

Piggot, H. E. 35

Piggott, H. 177

Pilcher, R. B. 124, 137 
Pilkington, W. 51

Pillsbury, W. B. 7, 16

Pilon, H. 105

Pinches, H. J. 261

Pinkerton, P. 33

R. H. $31,41,42$

Pintner, R. 17

Piper, C. W. 308

Pippard, A. J. S. 93

Pirie, G. 41

Pite, B. 62

Pitfield, R. L. 230

Planck, M. 99

Playfair, E. 232, 252

Plimmer, R. H. A. 135

Plomer, H. R. 305

Plotinus. 9

Plucknett, F. 302

Plues, M. 205, 206

Plummer, H. C. 160

Pogson, F. L. 9

Poincaré, H. 2

Poland, J. 232, 268

Politzer, A. 274.

Pollard, A. F. C. 54 A. W. 305 H. 158

Polleyn, F. 299

Pollock, C. E. 247 W. 88

Pomponazzi, P. 6

Poole, B. W. 302

- H. E. 111 .J. 120

W. H. 286

Pope, F. G. 131 T. H. 137 Sir W. J. 164

Popplewell, W. C. 44, 51, 74, 14:3

Porritt, B. D. 142

Porter, A. 191

- A. E. 235

A. W. 40,106

B. C. 180

C. 234,237

C. T. 82

J. 217

W. G. 273, 274

Poschl, V. 128

Possnett, V. 304

Potter, M. C. 201, 213

S. O. L. 222

T. 66

Potts, H. E. 128, 142

W. A. 280

Poulsen, A. 66

Poulton, E. B. 189, 195, 196
Powell, A. R. 134

Power, F. D. 171

Sir D'A . 247, 261

Powles, H. H. P. 72, 85

Poynting, J. H. 96, 98, 176

Poynton, F. J. 249, 255

Poyser, A. W. 106, 107

Pràeger, R. L. 200

Prain, Sir D. 206

Prasad, G. 29

Pratt, A. 206 - H. B. 95 H. K. 82,85

Prausnitz, C. 274

Preece, Sir W. H. 120

W. L. 120

Prendergast, M. 70

Prentice, H. R. 280

Prescott, J , 40

Preston, H. 124

T. 35, 99, 101

Price, E. A. 36

- F. W. 255

J. A. P. 242

T. S. 130,131

W. 76

W. A. 115

Prichard, A. H. 286

Prideaux, E. B. R. 127, 134 R. M . 297

Priestley, E. 297 J. 3,4

Priestman, H. 297, 298

Primrose, H. S. 75 J. S. G. $75,154,155$

Pringle, A. 309 J. H. 263

Pringle-Pattison, A. S. 7

Pritchard, E. 279 J. L. 93

Probyn-Williams, R. J. 263

Procter, H. R. 149 R. A. 160,161

Prost, E. 133

Prothero, R. E. 215

Protheroe, E. 185

Proud, E. D. 311

Pryde, J. 38

Przibram, H. 223

Pull, E. 76, 85

Pullen, W. W. F. 33, 43, 45, 73, 82, 85

Punnett, M . 36 R. C. 189,195

Puppe, J. 73

Purchase, W. R. 63

Purday, H. F.P. 88 
Purington, C. W. 312

Purves, A. 157

Purvis, J. E. 234

Putsch, A. 144

Pycraft, W. P. 192

Pye. 264

Pye-Smith, P. H. 242

Quain, Sir R. 222, 243

Quatrefages, A. de. 197

Quiggin, A. H. 197

Quilter, J. H. 300

Quincke, H. 265

Radasch, H. E. 223

Radcliffe, J. W. 301

Radcliffe-Crocker, H. 284

Radford, E. M. 22 W. 294

Radhakrishnan, S. 7

Raffety, C. W. 105

Raikes, H. P. 59

Rainy, H. 244

Rambaut, A. A. 162

Rambousek, J. 238

Ramsay, Sir A. C. 169 A. M. 269

A. R. J. 147 Sir W. 3, 100, 126

Ramsbottom, A. 243, 255

Ramsey, A. S. 40, 42, 101

Rand, B. 13

Randau, P. 78

Randles, W. N. 309

Rankin, D. J. 165

- R. 116 W. 264

Rankine, W. J. M. 43, 49, 73, 82, 90

Raphael, F. C. 115

Rappoport, S. 8

Rastall, R. H. 165, 166, 168, 214

Rat, J. N. 246

Rausenberger, F. 158

Ravenhill, A. 234

Rawling, L. B. 224, 265

Rawlley, T. C. 297

Rawson, C. 147

Raxworthy, H. C. 272

Rayleigh, Lord. 96, 99, 103, 105

Raymond, J. 4

Raymond-Barker, E. 114

Rayner, H. 298

- M. C. 200

Raynes, F. W . 59, 60

Rea, J. T. 63

R. L. 262

Read, C. 13, 197

C. S. 253

H. H. 164
Réal, P. 263

Reaney, M. J. 19

Redding, J. M. 290

Redfern, J. B. 117

Redgrave, G. R. 66

Redgrove, H.S. 127

Redmayne, Sir R. A. S. 171, 172

Redwood, Sir B. 144 I. I. 144

Reed, F.R.C. 166, 169

H. L. 35

S. J. 89

T. 86

Reeks, H. C. 295

Reepen, H. B. 197

Regan, C. T. 192

Rehling, M. M. 201

Reid, Sir A. 247

C. 168

G. 59

Sir G. A. 195

J. A. 62

Reiser, F. 157

- N. 301, 302

Renisen, I. 124, 130

Rendle, A. B. 200

Rennie. 4 J. 185,200

Renwick, W. G. 65

Revis, C. 139

Rew, Sir R. H. 139, 218

Reynolds, E. S. 234 O. 21

S. H. 191

W. D. 45

Rhead, E. L. 153, 157

Rhodes, H. J. 304 J.E. W. 168 W. G. 113

Riach, M. A. S. 93

Ribot, T. 16, 20

Richards, C. H. 30

P. A. E. 134 W. A. 154

Richardson, A. 70 C. A. 10 H. 177 J. 82,88 L. F. 54 O. W. 104, 105

S. S. 107

W. 147

W. G. 266

Richmond, H. D. 216

Richter, V. 131

Rickaby, J. 10, 11

Ricketts, T. F. 246 
Name Index.

Ricks, G. 65

Rideal, E. K. 57, 128, 129, 155

- S. 57, 138, 139

Rider, J. H. 118

Ridgeway, Sir W. 193

Ridgway, A. C. 311

Ridley, H. N. 206, 219

Riemer, J. 172

Riesz, M. 23

Rignano, E. 2

Riley, J. W. 65

W. J. 62

Rimmer, E. J. 64, 85

Rings, F . 67

Rintoul, W. R. 98

Ripley, W.Z. 197

Ripper, W. 82

Ritchie, A. E. 169

D. G. 8

E. G. 49

J. $195,229,240$

L. C. P. 268

W. T. 254, 255

Rivers, W. C. 250 W. H. R. 20, 251, 253

Riviere, C. 250, 289

Rivington, 62

Rixon, C. H. L. 252

Robb, A. A. 104

Robert, B. I. 251

Roberts, C. 93

C. H. 275

C. W. 86

F. 226

F. T. 243

G. H. 214

J. 110

M. E. 302

R. D. 166

T. 301

W. M. 41

Roberts-Austen, Sir W. C. 153

Robertson, A. W . 240

D. 113

F. D. S. 213

G. M. 253

J. 46

J. B. 114

J. M. 8

L. S. 85

N. 289

P. W. 133

W. 234, 235, 237

W. F. 254

W. G. A. 234, 238

Robin, A. 289

Robinson, A. 221
Robinson, A. H. 267

- F. F. 36

G. D. 277

- G. R. 216

H. 56

H. C. 76

H. P. 308

J. L. 41, 183

W. 124, 213

Rohson, A. G. 73, 76

Sir A. W. M. 24.8, 256, 266

J. H. 47

W. A. 91

Roepke, Dr. 249, 288

Roesler, E. 87

Rogers, A. G. L. 214

C. C. 208

F. H. 80

Sir L. 245, 246

R.A. P. 11, 33

W. M. 206

Roget, F. F. 226

Rohland, P. 128

Rohr, M. von. 102

Rolfe-Martin, A. B. 121

Rolleston, G. 224

Sir H. D. 239, 241, 256

J. D. 246

Romanes, G. J . 19, 195

Romer, F. 263

Römer, P. H. 280

Ronaldson, J. H. 165

Rood, O. N. 102

Roper, A. G. 195

Roscoe, Sir H. E. 102, 124, 126, 130

Rose, E. M. 88 Sir T. K. 155

W. 261

W. N. 25

Rosemberg, P. 77

Rosenberg, E. 110 F. 33

Rosenhain. W. 149,156

Ross, E. H. 189

F. W. F. 248

G. R. T. 10

J. S. 263,283

- P. 26

- Sir R. 245, 246

Rossetti, G. A. 46

Roth, P. B. 268

Rothery, G. C. 69

Rothwell, C. F. S. 299

- F. 251

Rounthwaite, H. M. 86

Routh, E. J . 40, 41

Rowarth, E. 47 
Name Index.

Rowe, E. 65

Rowland, A. F. 252

Rowlands, R. P. 261

Rownson, 46

Roxburgh, W. 157

Royds, R. 82

Royle, H. M. 146

Rubencamp, R. 142

Rudd, J. H. 65 W. A. 48

Ruff, F. 90

Ruge, A. 14

Rugg, W. G. $180,181,182$

Ruggiero, G. de. 8

Ruhe, A. 10

Ruhmer, E. 121

Russ, C. 247 S. 105

Russell, A. 113, 114

- A. E. 244

- B. 10, 14, 22

— E. J. 213, 220

E.S. 186

H. 189

I. 178

J. C. 176

J. W. 31

L. J. 14

R. 248

T. H. 205

W. 255

Ruston, A. G. 143, 215

Rutherford, 219

A. H. 226

Sir E. 105

Rutley, F. 164, 168

Rutter, W. P. 219

Ryan, J. C. 236

Rye, E. C. 189

Ryland, F. 12,16

S.Y.K. 83

Saberton, C. 290

Sabine, M. H. 90

Sachs, J . von. 199, 201

Sackur, O. 127

Sadler, H. 160 W. 216

Sadtler, S. S. 132

Sage, A. R. 62

Sahli, H. 289

Sahni, B. 200

Sainsbury, H. 293

Saker, D. G. 216

Saleeby, C. W. 248

Salisbury, E. J. 199

- R.D. 166,176

Salmon, G. 33
Salmon, P. R. 308

W.G. 51

Salomons, Sir D. 116

Salter, C. 140, 144, 146, 209 C. T. C. 138 W.M. 8

Salvadori, G. 16

Sampson, R. A. 160

Samson, C. G. 62

Samuel, A. M. 192

Sand, H. J. S. 147

Sandeman, E. A. 150

Sanders, C. F. 7

Sanderson, F. W . 42, 107

Sandiford, P. 19

Sandon, F. 25

Sands, D. L. 115

Sanford, P. G. 150

Sankey, H. R. 82, 88

Sargeant, E. W. 56 F. P. 125

Sargent, A. J . 177 P. 244, 264

Satterly, J. 96, 99, 10\%

Saundby, R . 244, 256, 257, 259

Saunders, B. 78 E. 189

- J. T. 223

Sauvage, E. 83

Savage, Sir G. 253

W. G. 235

Savill, T. D. 244

Savin, J. 117

Savoia, H. 157

Sawyer, J. E. H. 258

Saxelby, F. M. 25

Saxl, A. 268

Sayers, H. M. 118

Scales, T. S. 196

Scarlett, R. H. 99

Schafer, Sir F. A. S. 222, 223, 226

Scharf, R. F. 185, 193

Schaub, E. L. 20

Scheithauer, W. 144

Schenck, H. 201

Scherer, R. 139

Schiaparelli, G. 159

Schidrowitz, P. 142

Schiller, F.C. S. 14

Schimper, A. F. W. 208

Schindler, K. 67

Schlick, M. 104

Schmidt, $H$. 138 O. 193,195

Schmieden, V. 261

Schnabel, C. 153

Schoeller, W. R. 134 
Schofield, A. T. 251, 253, 290

Schönland, S. 196

Schooling, W. 214

Schopenhauer, A. 12

Schorlemmer, C. 124,

Schott, G. A. 106, 107

Schottelius, M. 230

Schryver, S. B. 135

Schubert, A. 77

Schultz, F. 284 G. 147

Schulze, F. 17

Schuster, Sir A. 3, 96, 98, 101, 102

- E. 194

Schutzenberger, Prof. 128

Schwartz, Dr. von. 171

Schwarz, E. H. L. 167,169

Schweizer, V. 142

Schwendener, S. 196

Scorer, A. G. 190

Scott, A. 126

$$
\text { A. A. H. } 67
$$

C. A. 33

D. G. 201

D. H. $170,184,202,203$

H. H. 244

J. F. 145

L. 214

R. F. 27

R. H. 162

S. R. 265

T. B. 243

W. 58,296

W. A. 65

Mitchell, F. 69

Scripture, E. W. 17

Seabrook. A. H. 144

Séailles, G. A. 7

Searle, A. B. $65,66,128,145,149$ 150

G. F.C. 44, 103

Seaton, A. E. 86

- E. C. 245

Sedgwick, A. 186

Seeligmann, T. 142

Sencert, I.. 264

Sennett, R. 86

Senter, G. 127,130

Sequeira, J. H. 284

Seth, J. 8, 12

Sessions, H. 217

Seward, A. C. 2, 170, 195

Sewell, T. 110, 112

Sewill, H. 283

$$
\text { J.S. } 283
$$

Sexton, A. H. 67, 73, 133, 134, 143 $153,154,155,157$
Sexton, M. J. 85

Seymour, A. 148

Shakespear, G. A. 96

Shanahan, E. W. 218

Shand, A. F. 16

Share-Jones, J. T. 295

Sharp, D. 190

- J. 57,157

- P. 298

Sharpe, E. M. B. 190

Shaw, A. H. 58

- B. 75

— C. W. 294

H. 93

J. H. 87

N. 209

- S. 150

- T.R. 73, 76

- W.J. 121

- Sir W. N. 97, 100, 163

Mackenzie, J.A. 249

Shelley, C. P.B. 76

Shennan, T. 239

Shenstone, W. A. 130

Shenton, E. W. H. 267

Shepherd, E.C.M. 80

- J.W. 133

Sheppard, S. E. 127

Shera, A. G. 288

Sherborn, C. D. 185

Sherlock, E. B. 253

Sherren, J. 285

Sherrin, G. C. 80

Sherrington, C. S. 226,233

Sherwood, G. 215

Shield, W. $\mathbf{5 4}$

Shipley, Sir A. E. 3, 185, 186, 190, 191,196

Shone, I. 59

Shonk, A. 302

Shore, A. 121

- L. F. 225

Short, A. R. 226, 242, 244, 261

Showell, P. G. 180

Shuckard, W. E. 190

Shuttleworth, G. E. 280

Sibley, W.K. 284

Siddons, A. W. $26,31,32,37,98$

Sidgwick, A. 14

- H. 8,12

Silberstein, L. 23, 24, 101, 102, 104

Silk, A. E. 54

- J.F.W. 263

Sillem, C. 191

Sim, J. 172

T.R. 205

Simmonds, C. 138 


\section{Name Index.}

Simmons, A. T. 97, 176, 177

- W. H. 141

Simms, F. W. 51

Simon, T. 280

Simpson, F. M. 5

W. J. 236,246

Sindall, R. W. 148

Sivewright, Sir J. 120

Skelton, R. A. and Co. 67

Skinner, M. L. 278

W.R. 172

Slack, J. E. 4 f

Slade, J. H. 42

Slater, A. $\quad 158,215$ J. A. 313

Slaughter, J. W. 19

Sleeper, M. B. 121

Slessor, H. H. 10

Slingo, Sir W. 107

Sloan, S. 276

Slosson, E. E. 104, 122

Smart, E. 174

— E. H. 32

Smeaton. 4

Smiles, S. 3

Smith, A. C. $\quad 257$

— A. H. 282

B. 36,376

C. $26,32,33$

C. A. $44,82,88$

C. F. 113, 115

D. 311

D. W. 180

E. 280

E. A. $155,156,261,283$

E. C. B. 56,84

E. M. 19

Sir F. 295

F. 264

F. J. 234, 238, 244

F. J. J. 72

G. 185

G. E. 197,253

G. F. H. 165

G. S. G. 229, 245, 259

G. W. 185

H. G. 164, 205

H. H. 219,220

H. J.S. 21

J. C. 69,142

J. H. 26, 32, 35, 36, 99, 129,

214

- J.S. K. 256, 268

- L. F. 264

P. C. 252

P. H.P. 242

R. E. B. 308
Smith, R.H. 28, 38, 46, 82

- S. 151

- S.P. 112,113

- S.W. 153

- T. A. 73

- T.B. 145

- T.G. 88

- T.S. 311

W. 302

W. G. 197

W.H. 48,89

- W. J. 213, 244

Smyth, W. H. 159

Smythe, J. A. 155

R. H. 295, 296

Snaith, G.L. 179

Snell, Sir J. F. C. 73

Snowball, T. 270

Snowman, J. 244

Soddy, F. 2, 103, 105

Sohn, C. E. 135,286

Solereder, H. 203

Sollas, H. 167

Solms-Laubach, G. $\quad \mathbf{3 7 0}$

Solomon, H. G. 115 M. 117

Solomons, B. 275

Somerscales, A. N. $\quad 86,87$

Somerville, W. 211

Sommerville, D. 234

- D. M.Y. 34

Sonder, O. W. 205

Sorapure, V. E. 244

Sorley, W.R. 6, 8, 12, 13

Sornay, P. de. 220

Sorsbie, R. F. 166

Sothern. J. W. M. 87, 89, 143

-R. M. 87

Sourdille, Dr. 273

Souster, E. G. W. 311

South, R. 190

Southall, W. 292

Southcombe, J.E. 141

Southerns, L. 98

Southward, J. 305

Souttar, H. S. 251

Soxhlet, D.H. $\quad 147$

Spackman, C. 66

Spaight, J. M. 91

Spanton, J. H. 48

Sparrow, F. W. 308

Spencer, A. S. 67

H. $3,4,11,12,16,20,811$

- J. F. $12 \%, 130$

- L. J. 164

C. G. 264

W. G. 261 
Spencer, Browne, H. 262

Spielmann, P. E. 131

Spiers, F. S. 196

Spikes, W. H. 73

Spitta, E. J. 196, 309

Spon. 90

Spooner, H. J. $\quad 48,80,88,151$

Sprague, E. H. 25, 41, 44, 49, 50, 55

- J.T. 119

Sprawson, C. A. 236, 289

Sprigge, S. S. 232

Springett, B. H. 82

Squire, J. E. 243

- Sir P. W. 223, 292

Stace, W. T. 8

Stacey, W. F. 163

Staig, R. A. 186

Stainton, H. T. 190

Stallo, J. B. 98

Standage, H. C. 139,149

Stanford, R. V. 131

Stanley, H. 73,98

- R. 121

Stansbie, J. H. 78, 153

Stanton, W. F. 45

Stark, A. C. 291

Starling, E. H. 226, 227, 286

- S.G. 97, 107, 110

Startin, J. 284,

Staveley, E. F. 190

Stead, J. F. 156

Stebbing, E. P. 209

- F.C. 181

L. S. 11

T.R.R. 191

Stedman, T. L. 243

Steel, J.H. 296

Steele, J.C. 243

- J.E. 71

W. J. 41

Steenbeck, W. H. 313

Steinheil, A. 102

Stelfox, S. H. 40

Stenhouse, E. 176

Step, E. 191, 205, 206, 209

Stephen, D.J. 8

G.A. 305

Sir L. 8

Stephens, H. 211 J. W. W. 248

Stephenson, C. $\mathbf{3 0 0}$ G. 63

Stephensons. 3

Stern, H. A. 25

Sternberg, G. M. 288

Steven, E. M. 279
Stevens, F. H. $31, \mathbf{3 4}, \mathbf{3 6}, 120$

- H. R. 291, 292

- H. P. 142,148 T. G. 275

W. M. 244

Stevenson, Sir T. 234

W. W. 209, 214

Stewart, A. M. 97

A. W. 124, 128, 131, 234

B. 51,98

D. 286

G. 85

G. N. 227

H. L. 8

I. 294

J. 305

- J. M'K. 11

- Sir J.P. 251

133

Stieglitz, J. 133

Still, A. 110

- G. F. 280

Stirling, W. 160

Stobbs, T . 46, 153

Stock, C. H. 62

Stockbridge, F. P. 18

Stockl, A. 8

Stockman, R $\quad 249$

Strock, H. B. 139, 141, 151, 234

Stoddart. 86 W. H. B. 254

Stokes, Sir G. G. 96,101

- R. 155

R. S. G. 165

Stone, G. 171 G. de H. 79

H. 209

Stoneman, B. 201

Stoney, J. 29

Stopes, M. C. 144, 170, 201

Stonford-Taylor, G, 288

Storey, F. W. 201

Storring, C. 18

Story-Maskelyne, N. 164

Stout, G. F. 16,18

Strachan, H. 237

Strachey, Sir R . 206

Strange, W. L. 55

Strangeway. 295

Strangeways, T. S. P. 229

Strasburger, E. 201

Stratford, E. Wingfield - . 17

Straton, C. R. 187

Stratton, G. M. 18

Stretton, C. E. 83

Strickland, F. 80 


\section{Name Index.}

Stromeyer, C. E. 85

Strong, C. A. 16 T. B. 2

Struben, A. M. A. 183

Strutt, E. G. 214

Stuart, A. H. 24, 72

Low, W. 273

Sturch, F. 65

Sturge, M. D. 251

Sturridge, E. 282, 283

Sturrock, W. D. 234

Sturt, H. 14

Sudborough, J. J. 131

Suddards, F. 300

Suess, E. 167

Suffit, C. $\quad 246$

Sutting, E. R. 150

Suggate, A. 50

Sully, J. 16, 19, 20

Summer, P. H. 95

Sumners, A. I. 145,165

Supino, G. 88

Suplee, H. H. 89

Sutcliffe, G. L. 66

J. A. L. 141

Sutherland, G. A. 255, 281, 286

- W. D. 238 W. G. 291

Sutton, F. 134

- Sir J. B. 232, 260, 267, 275

Svedberg, T. 128

Swaine, A. T. 167 W. 101

Swainston, C. M. 181, 182

Swallow, M. G.S. 89

Swan, K. R. 1

Swanton, E. W. 190, 204

Swanwick, F. T. 35

Swanzy. 270

Swayne. J. G. 277 W. C. 277

Sweet, H. 13

Swietochowski, G. De. 285

Swift, H. B. 119

Swinburne, J. 82

Swinhoe, C. 189,190

Swintos, A. J. 91

Svienham, Iord. 158

Sykes, W. J. 138

Sylvester, C. 94, 112, 114, 118

J. J. 21

Sym, W. G. 269, 270, 271

Syme, S. G. 273

W.S. 273

Symington, J. 222

Symmers, W. St. C. 230

Symonds, M. 302
Taggart, W.S. 298, 301, 302

Tailfer, L. $\mathbf{3 0 0}$

Tait, J. $181,182,227$

$\longrightarrow$ P. G. 7, 21, 22, 23, 41

Talbot, F. A. $71,95,144,309$

Tancock, E. O. 160

Tanner, A. F. 219 H. 212

Tansley, A. G. 18

Tanzi, E. 254

Tarleton, F. A. 24, 42

Tatlow, .J. 4

Tayler, A. J. W. $52,74,82,88,209$

Taylor, A. 234

- A.E. 11,12

- A.S. 238

A. T. 83

E. G. R. 177

E. H. 222,261

Sir F. 243

F. G. 29

F. N. $50,57,59$

G. $75,163,179$

- G. G.S. 289

- G. S. 288

- H.G. 73

- H.S. 128,143

- J. 132,281

- J. E. 40

- J. T. 299,308

- S. 103

- T. 46

- W. 308

- W. T. 115

- W. W. 126,128

Teago, F. J. 109

Teed, P. L. 130

Teetgen, A. B. 219

Telford. 4

Terry, C. W. 65 H. L. 142

Thatcher, E. 77

Thearle, S. J.P. 71

Theobald, F. V. $190,214,248$

Thesing, C. 184

Thibierge, G. 247

Thilly, F. 8

Thiselton-Dyer, Sir W. T. 205, 206

Thoday, D. 201

Thoinot, L. H. 230

Thole, F.B. 123, 127, 131, 133

Thomälen, A. 110

Thomas, E. M. 201

- G. H. 91

- H. H. 169

- J. 132

J. B. 71 
Thomas, P. 134

W.N. 51

Thompson, A. B. 169

A. W. H. 30

C. J. S. 292

D'A. W. 187

H. 76,295

H. G. 4

H. S. 206

J.S. 4

R.F. M . 193

R. L. 178

S. P. 4, 28, 101, 108, 110,

$112,270,308$

T. 110

Sir W.H. 286

Thomsen, C. F. 158

- J. 128

Thomson, A. 224, 261, 270

A. L. 192

G. 59

G. H. 17

G. P. 93

G. S. 216

H. C. 251

H. H. 250

H. T. 263

J. 96,281 ,

J. A. $2,4,5,184,185,187$,

$191,194,195,196$

J. A. K. 8

J. B. 22

J. H. 144

- Sir J. J. 98, 104, 108, 128

M. 196

- S. 243

Sir St. C. 273

W. 219

Thorburn, A. 192, 193

Thorn, W. H. 84

- W.T. 87

Thorne, L. T. 255 P.C.L. 137

W. B. 255

Thornley, T. 298, 301

Thornton, A. $\quad 40,134$

- J. 176, 184, 227

Thorp, E. L. 300 J. 305

Thorpe, J.F. 147 Sir T. E. $\quad 4,122,126,133,137$ W. H. 50

Threlfall, H. 51

Thresh, J. C. 235

Thrift, W. E. 101

Thurston, A. P. 93

C. B. 177
Thursfield, J. H. 280

$$
\text { M. } 239
$$

Tibbetts, T. M. 232

Tibbles, W. 139,286

Tidy, H. L. 243

Tiffany, F. 209

Tilden, Sir W. A. $122,124,126$

Tilley, H. 273

Tillyard, R. J. 190

Timberg, R. 287

Timiriazeff, C.A. 203

Tims, H. W. M. 282

Tinel, J. 251

Tinker, F. S. 249

Tinkler, C. K. 137, 144

Tinney, W. H. 173

Tirard, N. I.C. 285

Tisdale, C. W. W. 216

Titchener, E. B. $\quad 7,12,17,18$

Titherley, A. W. 131

Tod. 86, 87

F. H. 274

Todd, A. H. 262, 281

- J. 182,219 T. W. 244

Toderovich, G. 312

Todhunter, I. $29,34,36,44$

Tognoli, E: 133

Tolkowsky, M. 101

Tomes, C. S. 282, 283

- Sir J. 283

Tomkinson, C. W. 215

Tompkins, A. E. 87

Tonge, J. 145, 172

Toovey, T. W. 217

Topham, J. 313

W. H. 25

Topley, W. W. 240, 307

Torr, C. 71

Torrens, J . 244

Torrey, J. 142

Torrilhon, G. L. 142

Townsend, C. F. 308 F. 207 J.S. 104

Tozer, H.F. 175

Traill, T. W. 85

Traube, M.R. 18

Travis. 53

Tredgold, A. F. 254

Treiber, T. 75

Treves, Sir F. 222, 261

Trewman, H. F. 118

Triggs, H. I. 68

Trimble, C.J. A. 25

Trinks, W. 82

Trotman, S. R. $\quad 149,300$ 


\section{Name Index.}

Trotter, A. P. 60

L. B. C. 255

W. 20

Trouessart, F. L. 230

Truscott, S. J. 165,174

Tubby, A. H. 261, 268

Tubeuf, C. von. 213

Tuck, G. L. 246

Tucker, R. 21

- T. G. 13

Tuckey, C. L. 290 C.. $0.33,41$

Tudsbery, J. H. T. 57

Tunzelmann, G. W. de. 108

Turck, H. 13

Turnbull, A. 2, 261

— W. 299

Turner, A. L. $\quad 4,273,274$

C. C. 91

D. 105,290

G. C. 23,25

H. 298

H. H. 104, 160, 161

H. W. 111

L. B. 121

P. 224, 261, 267

T. $153,154,157$

Sir W. 4

W. 262

- W. E.S. 128,129

Tutt, J. W. 190

Tutton, A. E. H. 164

Tweedy, E. H. 277

Twelvetrees, W. N. 62, 67

Twining, F. W. 251

Twiss, D. F. 131

Twort, F. W. 296

Tyler, F. A. 124

Tyndall, J. \$, 168

Ugarte, J. P. 219

Upcott, H. 263

Underwood, A. B. G. 282

- A. S. 282, 283

Unstead, J. F. 175, 177

Unwin, A. H. 209

- P.W. 32

R. 68

W. C. $38,48,55$

Urquhart, J. W. 116, 117

Urwick, E. J. 12

Ushorne, P. O. G. 50

Usherwood, T.S. 25

Usill, G. W. 51

Valentin, W. G. 124

Valentine, C. W. 18

- E.J. 171

Vallack, A. S. 263
Vallery-Radot, R. 4

Van Hall, C. J. J. 219

Van Liew, C. C. 18

Van 't Hoff, J. H. 126, 127

Varisco, B. 11

- P. 16

Vassall, A. 98

Vaughan, D. T. G. 198

Vendelmans, H. 220

Venn, J. 14

Verdon, W. 255

Vermuyden. 3

Vernon, A. 215

H. M. 195

- Harcourt, L. F. $50,55,59$

Vickerman, C. 298

Villa, G. 17

Villamil, R. De. $42,92,103$

Villavecchia, V. 137

Ville, G. 220

Vinall, J. W. T. $\quad 179$

Vincent, C. 151

- H. 246

- R. 279

S. 227

Vines, S. H. 199, 201

Vittoz, R. 252

Vogel, E. 308

- H. 307

Vogt, J. H.L. 165

Voit, E. 102

Vries, D. De. 75

- H. D. 194

Vulpius, O. 281

Wabner, R. 173

Waddington, V. 287

Wade, C. F. 85

- J. 131 W. L. 95

Wadia, D. N. 169

Wadmore, J. M. 127

Waele, A. de. 141

Waggett, E. B. 274

Wagner, E. 235

$$
\text { P.A. } 174
$$

R. 137

Wagstaff, C. J. L. 103

Wahl, A. 147

Wakefield, S. 298

Wake, R. 65

Waldo, F. 163

Walford, E. W. 80

Walkden, S. L. 93

Walker, A. H. 235

C. 156

C. E. 17

E. W. A.

241 
Walker, G. T. 108

G. W. 167

J. $101,125,128,130$

J. W. T. 266

L. 302

L. J. 8

M. 112

N. 284

S. F. $85,116,117,173$

W. J. 92, 94

W. M. 151

Tisdale, C. W. 216

Wall, E.J. 308

Wallace, A. R. 3, 167, 193, 196

- C. 265

- Sir C.S. 266

- J. 52,94

- J. S. $279,281,282,286$

Wall W.M. 55

Wallas, G. 20

Waller, A. D. 227

H. E. 289

Walley, J. T. 39, 236

Wallis, B.C. $175,177,178$ C. E. 282

F. 111

Sir F.C. 266

Budge, Sir E. A. 231

209

Tayler, A. J. $52,74,82,88$,

Walmsley, R. M. 111 T. 222

Walsh, D. 284, 289 J. J. 232

Walshan, H. 250, 289

Walsingham, Lord. 190

Walston, Sir C. 12

Walter, A. F. 182 K. 299

Walters, F. B. 31

W. R. 250, 251

Walton, A. J. 263 T. 71

Wang, C. Y. 155,169

Wanhill, C. F. 232

Wanklyn, W. 246

Wansbrough, W. D. 29, 83, 84, 85

Warburton, C. 190

Ward, E. 266

- F. 185

H. 121

H. M. 207, 209, 213

J. $10,17,196$

- S. 12

Warden, A. A. 232, 289

Wardt, R. G. de. 119

Waring, E. J. 292
Waring, H. J. 262

Warington, R. 220

Warming, E. 201, 203

Warn, R.H. 77

Warnes, A.R. 145

Warrell, C. 220

Warren, A. G. 82

— E.J. 308

R. 261

W. H. 50

Warwick, F. J. 291

Washbourn, J. W. 245

Washburn, M. F. 12

Wasmann, E. 196

Watkins, A. 308

Watson, B. P. 275, 276, 277

$\longrightarrow$ D. 246,247

- D.C. 244

- E.R. 127

- G.N. 23

- G.W. 80

- H.S. 59

- H.W. 100

J. $48,66,78,213$

- J. K. 247, 278, 294

— T. H. 71

W. W. 98, 217, 300

Watt. 4

$$
\text { W. } 98,217,300
$$

A. $119,141,148,149$

-_ Sir. G. 219

H. J. 17, 103

Watts. 126

F. 20,212

- H.C. 93

- W. M. 102, 207

W.W. 167

Weatherburn, C. E. 24

Weatherhead, R. 161

Webb, A. D. 38

C.C.J. 8

— E. 17

- H.J. 212

- J. C. 290

- S. 5

- T.W. 160

- W. 68

- W. M. 191

—_Johnson, A. E. 246

Webber, F. 313

W.C. 65

- W. H. Y. 146

Weber, A. 8

C. O. 142

- Sir H. 259, 289

Webster, A. D . 209, 210

Weeks-Shaw, C. 294

Weigall, A. G. 212 
Name Index.

Weininger, $O .18$

Weisbach, J. 56,74

Weismann, A. 196

Weiss, F. E. 213 R. 240

Welby, F.A. 3, 226, 227

Wellington, R. H. 238

Wells, G. C. 51

$\longrightarrow$ G. J 88

- H. G. 187

- P. A. 65

S. H. 40,48

Welton, J. 14

Wenyon, C. M. 259

Werner, L. 270

Wertheim, E. 276

West, C. E. 265, 269

- F. W. 53

G. 309

G. S. 204

M. 19

S. 256

Westaway, F. W. 2

Westcott, G. J. B. 28 W. W. 288, 292

Westell, W. P. 185, 192, 193, 201

Westermarck, E. 11

Westinghouse, G. 3

Westland, A. 278

Weston, F. E. 133, 140

- H.C. 147

Whale, G. 95 H. L. 265, 269

Whall, C. W. 150

W. B. $181,182,183$

Wharton, Sir W.J.L. 183

Wheatley, O. 66

Wheeler. 242

- O. 308

- R. V. 144

Sir W. I. de C. 262

Wheen, C. W. 54

Whellens, W. H. 210

Whetham, W. C. D. 96, 108, 128

Whewell, W. 21

Whinyates, L. 125

Whipham, T. R. C. 281

Whitaker, J.R. 221, 224

Whitby, G. S. 142

White, B. 155

C. P. 267

C. G. 91

G. M. 60

G. T. 73

H. A. 155

H. G. 117, 120

H. J. 71
White, J.R. 267

- J.W. 207

- R. P. 256, 281

- T. H. 80

- Sir W. H. 291,293

W. H. 98, 257

W. L. 60

Whitehead, A. N. 2, 8, 22, 27, 30, 32

\section{S. E. 146}

Whitelaw, J. 51

Whitelegge, Sir A. 234

Whiteley, R. L. 126, 130

Whitelocke, R. H. A. 267

Whitfield, A. 284

Whiting, A. J. 244

Whitla, J. A. 292

Sir W. 243, 285, 291

Whitney, W. D. 13

Whittaker, C. M. 148

- C. R. 198, 221, 222, 224, 227,

260,261

— E. T. 23, 41, 102

- T. 8,12

W. E. de B. 80

Whitwam, J. H. 302

Whymner, R. 139

Wibberley, T. 212

Wickham, H. A. 220

- L. 289

Widdowson, T. W. 282, 283

Widgery, A. G. 11

Wight, .J. T. 42

Wigley, T. B. 78

Wilcockson, W. H. 165

Wilcox, E. V. 235

Wilda, H. 74, 89

Wildgoose, A. 73

Wilkes, W. H. 182

Wilkinson, M. E. 302 W. T. 305

Willcocks, Sir W. 55

Williams, A. 307

- G. 182, 264

H. E. 132

- H.W. 305

- J. 83

- L. 243

- M. M. 212

- M. V. 11

- P.W. 274

- R. J.P. 263

W. 296

Ellis, C. 65

Williamson, A. P. W. 181, 182

B. 29,42

H. 52,258 
Williamson, J. 51,67

J.G. 311 R. T. 252

Willis, J. C. 207,212 M. 200 S. J. 121

Willoughby, E.F. 216, 234 W. G. 246

Willows, R. S. 98, 128

Wilmore, A. 178

Wilson, E. 118 F.H. 172 F. J. 126 H. 78 H. A. 98,104 H. M. 137 H.R. 53 H. W. 2.58, 260 J. 196,217 J. C. 31 N. J. 114 O. . 190 R. M. 244, 310 R. MeN. 255 S. 119 T. S. 255 Barker, Sir D. 181, 182

Wimperis, H. E. $80,89,94$, Winchester, C. 92

Windelband, W. 14

Windle, Sir B. C. A. 224

Wingfield, H. 252 H. E. 290 Stratford, E. 17

Wingrave, W. 274

Winn, W, 210

Winterbottom, J. 302

Witkowski. 282

Witthaus, R. A. 125

Wodehouse, E. 11

Wohlgemuth, A. 17

Wolf, A. 14

Wolff, C. E. 83 H. W. 212, 215 Eisner, A. 251, 288

Wollaston, T. V. 191

Wolstenholme, J. 22, 37

Wood, A. 103

$$
\text { C. A. } 176
$$

F. 52,59

Sir H. T. 5

J. 213

J. K. 148

J. T. 149

L. E. 112

P. W. 30

T. B. $139,213,217,218$
Wood, W. Q. 263

Wood-Jones, F 191

Woodall, H. 146

Woodburn, W. 36

Woodeock, W. H. 66

Woodhead, Sir G. S. 230, 240 S. A. 213 T. W. 201

Woodhouse, T. 297, 299, 300, 302

Woodnutt, W. E. 216

Woodroffe, J . F . 220

Woodruff, H. A. 218

Woods, H. 170

- R. J. 44, 45

Woodward, B. B. 191

C. .J. 38

H. B. $167,168,169$

W. H. 5

Woodwark, A. S. 243, 294

Woolf, C. H. 101

Woollard, L. 71

Woolaston, T. R. 73

Woollatt, G. H. 130

Wootton, A. C. 291 W. O. 165

Wordingham, C. H. 111

Workman, W. P. 31, 36, 37, 38

Worster-Drought, C. 245

Worth, C. A. 271

Worthington, A. M. 42

Wraight, E. A. 156

Wrapson, J. P. 38

Wren, H. 132

Wrench, G. T. 277, 278

Wrey, C. 212

Wright, A. C. $69,136,141,147$

$\longrightarrow$ Sir A. E. $197,230,246,288$

A. W. O. 253

C. O. 48

C. R. A. 141

G. F. 168,197

H. 245,246

H. E. 138

H. T. 311

J. 115

J. F. 27

K. M. 201

I. 102,197

M. R. 98,99

R. S. 102

W. 222

W. B. 168

Wrightson, J. 212

Sir T. 274

Wryde, J. S. 71

Wu Lien-Teh. 246

Wundt, W. M. 12, 17, 18, 20 
Name Index.

Wurtz, Prof. 128

Wyatt, H. 80

Wylie, A. M. 172

$$
\text { J. G. 252, } 267
$$

J. A. 248

Xydis, C. 51

Yarr, Sir M. 270

Yates, R. F . 77, 130

Yealland, L. R. 253

Yeaman, C. H. 111

Yearsley, M. 188, 274

Yeo, I. B. 285, 287

Yonge, E. S. 273, 274

Yorke, J. P. 98

Youatt, W. 217

Young, A. 27

A. P. 111, 118

A. W. 44

C. 63

C. A. 161

E. 177

E. W. 50

F. 80
Young, G. C. 23

H. 279

J. 228

J. E. 115

— J. W. A. 22

M. 281

R. B. 174

S. 128

W. H. 23, 26,

W. J. 296.

Younger, E. G. 254

Youngson, P. 84, 87

Yule, G. U. 38 .

Zaehnsdorf, J. W. 305

Zander, E. 287

Zeeman, P. 102

Zeidler, J. 117

Zeller, E. 8

Zerr, G. 142, 148

Ziehen, T. 18

Zimmern, A. 244

Zimmer, G. F. 74

Zittel, K. A . von . 167, 170 


\section{SUBJECT INDEX.}

Abdomen, Diseases of the, $\mathbf{2 5 8}$

- Surgery of the, 265

Accumulators, Electric, 116

Acetylene, 59, 143

Acids, 150

Acoustics for Musicians, 103

Adhesives, 139

Aerated Waters, 137

Aerial Navigation, 94

Aero Engines, 94

Aerofoils, 93

Aeronauties, 91 et seq.

Aeroplanes, 91 et seq.

- Design and Construction, 93

Aesthetics, 12

Afforestation, 208 et seq.

Agglutinants, 139

Agriculture, 211 et seq.

Aireraft, 91 et seq.

Air Gas, 59

Airscrews, 93

Airships, 95

Air Sickness, 255

Alcohol, 137

Alcoholometric Tables, 126

Algæ, 203

Algebra, 25, 26, 27

Alkalies, 150

Alloys, Non-Ferrous, 154

Alternating Current (Electrical Engineering), $112,113,114$

Aluminium, 155

Ammonia, 145, 151

Amputations, 266

Anaesthetics, 262, 282, 283

Analysis :

Air, 100

Chemical, 132 et seq., 213

Food, 235

Gas, 146

Metallurgical, 156

Spectrum, 102

Water, 234

Analytical Chemistry, 132

Anatomy, 221 et seq.

- Dental, 282

- Veterinary, 295

Ancient Lights, Questions affecting, 62
Animal Biology, 186

- Geography, 193

- Husbandry, 215

- Life, 187

- Mind, 19

- Portraiture, 185

- World, 185

Animals, Anatomy of, 224

Animate Nature, The system of, 2

Anthracite, 144

Anthropology, 197

Antimony, 131, 155

Antisepsis, 263

Ants, 187, 189

Appendicitis, 265, 266

Arbitration (Building), 63

Arc Lamps, 59, 117

Arches, 49, 50

Archimedes, Method and Works of, 22

Architecture, 4, 48, 58, 61, 62, 70, 71

Arithmetic, 21, 36

Armature Construction, 111

Arsenic, Organic Compounds of, 131

Arthritis, 249

Artificial Lighting, 59

Artillery, 158

Art Needlework, 302

Ashestos and the Asbestos Industry, 165

Asepsis and Antisepsis, 263

Asphalt, 145, 169

Assaying, 156

Astronomy, 159 et seq.

- Nautical, 180

Atlases, Astronomical, 161

- Geological, 168

Atmosphere, The, 162

- Gases of, 100

Atolls, 191

Atomic Theory, 126, 128

Atoms, 103

Aviation, 91 et seq .

Aviators, Reference Books for, 94

Axial Fans, 60

Bacteriology, 214, 229, 230

Balloons, 95

Bandaging and Dressing (Surgical), 263 264 
Banket, The, 174

Basket Making, 302

Batrachians, 192

Batteries, Electric, 115, 116, 118

Bees and Bee-Keeping, 187 et seq., 216,217

Beeswax, 217

Beetles, 188

Bells, Electric, 117

Benzol, 146

Bequerel Rays, The, 105

Beri-beri, 245

Biographies of Men of Science, 2

Biological Chemistry, 134

Biology, 10, 184 et seq.

Birds, 192

Bitumen, 145, 169

Bladder, Diseases of the, 258

Blast Furnace Practice, 157

Blasting, 172

Bleaching, 299, 300

Blood and Blood Pressure, 241

- Diseases of, 254

Blowpipe Analysis, 132

Boat Building, 64

Boiler Chemistry, 137

Boilers, 72, 84, 85

Books and Book-Binding, 305

Boot and Shoe Manufacture, 302

Boring, 57, 172

Botany, 198 et seq., 212

Brain, 'The, 227, 252, 265

Brakes, for Electric Tramway Cars, 118

Brassfounding, 157

Bread Making, 139

Brewing, 137

Bricks and Brickmaking, 65

Bridges, 49, 50

Briquetting, 144

Bronzing, Gilding, etc., 69

Builders, Mechanies for, 42

Builders' Quantities, 62, 63

Building Construction, 61 et seq.

- Law, 63

- Materials, 64

- Stones, 169

Butter and Cheese Making, 216

Butterflies, 187 et seq.

Cabinet-making, 64, 65

Cables, Electric, 114

Cacao, Cultivation and Curing of, 219

Caisson Sickness, 259

Calcareous Cements, 66

Calculus, 27, 28, 29

Camels, notes on for Veterinary Surgeons, 296
Canal Engineering, 53

Cancer, 248, 267, 276

Candles, Manufacture of, 140

Cane Sugar, 218

Carbon Compounds, 130

Carbons, for Electric Lighting, Manufacture of, 117

Carpentry, 64

Carpets, 302

Carving, Wood, 64, 65

Casein, 139

Cast Iron, 154

Catalysis, 128

Cataract Fxtraction, 270

Caterpillar, Life of the, 188

Cattle and Cattle Breeding, 216, 217

Celluloid, 151, 152

Cellulose, 135

Cement, 66

Centrifugal Fans, 60

- Pumps, 56

Ceramics and Ceramic Industries, 65, 149

Cerebro-Spinal Fever, 245

Channels, Design of for Irrigation, 55

Charts (Navigation), 182

Chemical Calculations, 125

- Crystallography, 164

- Engineering, 136

- Fertilisers, 220

- Physiology, 227

Chemicals, Manufacture of, by Electrolysis, 129

Chemistry, 122 et seq., 213

Chemists, Famous, 122

Child Study, 18

Children, Diseases and Hygiene, 270 et seq.

China Grass, 297

Chlorine and Chlorine Products, 151

Chloroform, 263

Chocolate, 139

Cholera, 245

Cinematography, 309

Civil Engineering, 49 et seq.

Clays and Clay Industries, 65, 149

Climate, 162

Climatology, 236

Climatotherapy, 289

Clinical Medicine, 243

Clock Repairing, 78

Clouds, 162

Coach Building, 65

Coal and Coal Mining, 144, 165, 169, 170,172

Coal Fields (Kent; Scotland), 169

- Tar, 145

Coast Erosion and Protection, 55 
Cob and Pisè Work, 65

Cocoa, 139, 219

Coconut Cultivation and Planting, 218,219

Coffee, Cultivation of, 219

Coils, Induction, 115, 116

Coins, History of, 4

Cold Storage, 82

Colliery and Field Surveying, 51

- Working and Management, 172

Colloids, 128

Colour, in Relation to Chemical Constitution, 127

- Blindness, 271

- Spectra, 102

Columns and Struts, 49

Comets, 160

Commerce, History of, 4

Commercial Engineering, 73

- Geography, 177

Compass (Magnetic) in Aircraft, 94

Compass Work, 181

Compressed Air (Mining), 172

- Air Power Transmission, 74

Concrete, 66

- Roads and their Construction, 52

Conifers, 208, 210

Conjunctiva, Diseases of the, 270

Constipation, 257

Constitutional Diseases, 248

Consumption, 249, 250, 251

Continuous Current Electrical Engineering, 112, 114

Copper, 154, 155

Coral and Atolls, 191

Cordage Fibres, 297

Corrosion and Protection of Metals, 67

- of Iron and Steel, The, 153

Cosmogomy, Problems of, 160

Costing, 311

Cotton, 218, 219, 297

-Doubling, 298

- Manufacture, 301

- Spinning, 298, 301,302

- Waste, 298

— Weaving, 298, 299

Cranes, their construction, 74

Crayfish, The, 191

Creation, Story of, 194

Creative Chemistry, 122

- Evolution, 9

Crops, Field, 218

Crystallography, 164

Currency, History of, 4

Current: (Flectrical Engineering), 112 113

Cyanide Process for Extraction of Gold, 174
Cyanogen Compounds, Chemistry of, 132

Cycles, Motor. 80

- Electric Lighting for, 118

Cytology, 196

Dairying, 215

Dams, Construction of, 54

Decoration, House, 68

Decorative Design, 48

Deformities and their Surgical treatment, 268

Dentistry, 282, 283

Dermatology (Skin Diseases), 284

Design, Machine, 47 et seq.

- Textile, 300

- of Structures, 44

Diamonds, 101, 173

Diathermy, in Medicine and Surgery, 290

Dictionaries of Technical Terms in Fnglish and other Languages, 312, 313 (See also "Terms.")

Dietetics, 286

Digestive System, Diseases of the, 256

Diphtheria, 245

Dirigibles, 95

Discoveries:-

Astronomical, 160

Chemical, 122, 129

Geographical, 175

Twentieth Century, 4

Diseases (various), 244 et seq.

Disinfectants, 139

Diving, 71

Dock Engineering, 54

Domestic Sanitation, 58, 59

Doubling, 297, 298

Drainage, 56 et seq.

Draughtsmanship, 47 et seq.

Dreams, 19

Drilling, 75, 76

Drugs, 139, 235, 293

Drying Machinery, etc., 136

Dust Destructors, 60

Dyestuffs and Dyeing, 146, 299

Dynamics, 40, 128

Dynamo, 111, 112

Dynamometers, 72

Dysentery, 245

Ear, Diseases of, 273, 274

Earth, The, 167, 176

Earthenware, 150

Earthquakes, 167

Earthworms and their allies, 190

Eclipses, 160 


\section{Subject Index.}

Economic Geography, 177

- Geology, 169

- Mineralogy, 164

Education, History of, 4

Egyptian Irrigation, 55

Elasticity of Materials, 43

- Mathematical Theory of, 41, 44

Electric Furnaces, 155

Electrical Engineering, 109 et seq.

Electricity, 104 et seq.

- Medical, 290

- Applied to Mining, 173

Electro-Chemistry, 128

Electrolysis, 12 $\mathrm{r}$

Electromagnetism, 106-108

Electro-Metallurgy, 155

Electrons, 103

Electro Plating, 118, 119

Electro-Physiology, 227

Electrotherapy, 283, 289

Electrotyping, 304

Elementary Science, 1

Embossing, 304

Embroidery, 302

Embryology, 222

Emery, 75

Enamelling on Metal, 78

Endogenetic Structures, 167

Energy, Conservation of, 98

- Thermal Measurement of, 99

Engine Design, Graphic Methods of, 47

Engines :

Aero, 94

Diesel, 88

Internal Combustion, $\mathbf{8 7} \mathbf{- 8 9}$

Marine, 85, 86

Steam, 81, 82

Engineering:

Agricultural, 215

Chemical, 136

Civil, 49 et seq.

Electrical, 109 et seq.

Gas, 145

Mechanical, 72 et seq .

Engineers, Geology for, 166

English Poor Relief, Early History of, 5

Engraving, 304, 306

Entomology, 187 et seq.

Epidemics, 236

Epilepsy, 252

Estimating, 50, 62, 63, 89, 311

Fthics, 11

Euclid, 34

Eugenics, 195

Erolution, 9, 10, 103, 193
Examination Guides on Navigation, 181

Examination Papers (Mathematics), 22

Exogenetic Structures, 167

Experimental Chemistry, 123, 124

- Psychology, 17

Explosives and their Manufacture, 150

Eye, Diseases and Injuries of, 269271

Fans, Centrifugal and Axial, 60

Farming, 211, 212

Farm Tractors, 215

Fats, 139

Feeding of Animals and Crops, 217, 218

Fermentation, 137

Ferments, 128

Ferns, 204

Fertilisers, 220

Fevers, 244 et seq.

Fibres, Textile, 297

Field Crops, 218

Field and Colliery Surveying, 51

Files and Filing, 75

Filters and Filter Presses, 136

Finishing of 'Textile Fabrics, 299, 300

Fiords, 167

Fire Protection in Buildings, 68

Fishes and Fisheries, 191

Fitting, Electric, 116

Flax, 218, 297

- Spinning, 298

Flight, Theory and Practice of, 91, 92

Flora, 205

Flour and Bread Making, 139

Fluids, Mechanics of, 42

Fly, The, 188, 189

- in relation to Disease, 259

Foods, 139, 286

- Analysis and Inspection, 235

Forensic Medicine, 237, 238

Foreshores, Maintenance of, 55

Forestry, 208 et seq.

Forging, 77, 78, 154

Formulæ (Engineering), 50

Fortification, 158

Fossils, 170

Foundations for Machinery, 72, 73

Foundry Work, 74, 157

Fractures and their Treatment, 268

Frog, The, 192

Frozen Meat Trade, History of, 4

Fuels, 142

Fungi, 204

Fungoid Diseases of Plants, etc., 212 
Furnaces, Electric, 155

Furniture Making, 64

Gall Bladder, Diseases of the, 256

Galvanized Iron, 153

Gas, 100, 104, 143, 146

- Engineering, 145

- Manufacture, 145

Gauges, 46

Gearing, 73, 83

Gelatine, 139

Gem-Stones, 165

General Science, 1

Generators, Electric, 111, 112

Genetics, 193

Genito-Urinary System, Diseases of the, 257

Geodesy, 50, 51

Geodynamies, 167

Geographical Distribution of Animals, 193

- - Plants, 203

Geography, 175 et seq.

Geology, 105, 166 et seq., 214

Geometrical Drawing, 48

Geometry, 29 et seq.

Geophysical Investigations, 1

Gilding, Bronzing, etc., 69

Girders, 44, 49, 50

Glands :

Anatomy of, 223

Diseases of, 254

Glass and Glass Manufacture, 149

- Blowing, Methods of, 130

Glaucoma, 271

Glazing, Colour, 69

Gloves and the Glove Trade, 303

Glow Worm, The, 188

Glues, 64, 139

Glycerine, 140

Gold and Gold Mining, 154, 155, 165 , 173

Goldsmiths' Work, 78

Gonorrhea, 246

Gout, 249

Graining and Marbling, 68

Grape Vine, Cultivation of, 219

Graphic Arts, 304

Graphics, 33

Grasses, 206, 207, 212

Grasshopper, Life of the, 188

Gravitation, 104

Grinding Machinery, 76

Gums, 141

Gun-Shot Wounds, 264

Guns, Theory of the Recoil of, 158

Gutta Percha, 142
Gynæcology, 231, 275 et seq.

Gyroscope, 45

Gyrostatics, 45

Hæmatology, 241

Hand-Lettering, 48

Harbour Engineering, 53, 54

Hat Manufacturing, Chemistry of, 302

Head, Surgery of, 265

Headache, 252

Heart, Diseases of the, 254

- Surgery of, 265

Heat, 39,99

- Engines, 81-83

- Treatment of Metals, 157

Heating of Buildings, 60

Hemp, Fabrics, Manufacture of, 300

- Spinning, 298

Herbals, 198 et seq., 219

Heredity, 193, 228

Hernia, 266

High Explosives, 150

- Temperatures, 99

Histology, 223, 239

History, Natural, 185

- of Science, Education, Learning, Commerce, etc., 4

Hoisting Machinery, 74

Hops, 219

Horology, 78

Horse, The, 193

- Anatomy, Diseases, etc., of, 295, 296

Horse-Shoeing, 296

Hospitals, Isolation, 234

Housecraft Science, 1

House Decoration, 68

Human Geography, 179

Hydraulic Motors, 56

Hydraulies, 43, 53

Hydrodynamies, 42

Hydrogen, Chemistry and Manufacture of, 130

Hydrographic Surveying, 183

Hydrology, Medical, 289

Hydrostatics, 39, 41, 42

Hygíene, 58, 232, 236

- of Children, 279

- Veterinary, 296

Hypnotism, 290

Ice Age, 167, 168

Ice-making, 82

Ideas (Scientific) of To-day, 1

Igneous Rocks, 168

Illumination, $59,116,117$

Immunisation, Therapeutic, 287, 288 
Incandescent Flectric Lamps, 116, 117

India Rubber, 142

Indicators (Chemical), Theory and Use of, 134

Induction Coils, 115, 116

Industrial Chemistry, 136 et seq.

- Engineering, 73

- Organisation, 310, 311

- Training, 1

Industry, History of, 5

- and Science, 1, 2

Infant Feeding and Hygiene, 279

Infectious Diseases, 244 et seq.

Inflammation, Pathology of, 240, 241

Ingots and Ingot Moulds, 157

Injectors, Steam, 84, 85

Ink Manufacture, 148

Inorganic Chemistry, 124, 129

Insanity, 253

Insecticides, 152

Insectivorous Plants, 198

Insects, 187

Installation, Electrical, 116

Instruments :

Electrical, 115

Engineering, 49, 51, 75

Optical, 101, 102

Insulation of Electrical Machines, 111, 114

Internal Combustion Engines, 87

International Language and Science, 1

Intestines, Diseases of the, $\mathbf{2 5 7}$

Introduction to Science, 2

Inventions, 4, 72, 122

Ionization, 104, 105

Iron and Steel, 153

- Construction, 67

Ironfounding, $\mathbf{1 5}$ \%

Ironwork, Strains in, 49

Irrigation, 55

Island Life, 167

Jsolation Hospitals, 234

Japanning, Metal, 78

Jena Glass, 149

Joinery, 64, 65

Jute : its manufacture, 297, 300

- Spinning, 298

- Weaving, 299

Kidneys, Diseases of the, 257

Kinetic Theory of Gases, 100

Laboratories, Chemical, 130

Laboratory Work and Arts, 130

Lace and Lace Making, 302
Lacquering and Bronzing Brass Ware, 78

Land Forms, 167

- Reclamation, 55

- Surveying, 50 et seq.

Language (International) and Science, 1

- History of, 12,13

Lantern, Use of in Scientific Demonstrations, 102

- Slide Making, 308

Laryngology, 273, 274

Lathes and Lathe Work, 75, 76

Law, Mining, 171

- Sanitary, 237

-, Science of, 1

Laying-off, 70,71

Lead, 154, 155, 165

Lead (Sheet), Weights and Measurements of, 45

Leather Manufacture, 148

- Work, 302

Lecithin and Allied Substances, 131

Levelling, 51

Life, Origin of, 193

- and Science, 2, 184

Lifting and Conveying, 74

Light, 100, 101

Lighthouses and Lightships, 71

Lighting, Artificial, 59, 60, 116, 117, 118

Lightning Conductors, 106, $10 \gamma$

Limes, 66

Linen Manufacture, 300

- Weaving, 299

Liquid Fuels, 143

- Steel, 153

Liquids, Motions of, 103

- Viscosity of, 127

Lithography, 304

Liver, Diseases of the, 256

Locomotive Engineering, 83

- System, Diseases of, 267

Logarithms, 36, 37

Logic, 13

Lubricants and Lubrication, 74, 139, 140,144

Lunar Theory, Treatise on, 160

Lungs, Diseases of, 255,256

- Surgery of, 265

Lymphatic System, Diseases of, 254

Machine Drawing, Design, \&c., 47 et seq., 109

Machines, Theory of, 43

Magnesium, Organometallic, 132

Magnetic Compass in Aircraft, 94

Magnetism, 106-108, 162, 181 
Magnetos, 118

Malarial Diseases, 245

Mammals, 193

Man, 2, 197

Management, Scientific and Works, 310,311

Manganese Ores, 165

Manures, 220

Map Work, 176

Maps, Astronomical, 161

- Geological, 168

Marble and Marble Working, 65, 66

Margarine, 139

Marine Engines, 85-87

- Meteorology, 162

- Signalling, 182

- Surveying, 183

Masonry, 49, 50, 65

Massage and Movement Cures, 287

Materia Medica, 291 et seq.

Mathematics, 21 et seq.

- (Mining), 171

Matter, Properties of, 103

Measurements :

Electrical, 115

Mechanics, 45

Meat Inspection, 235, 236

Mechanical Dentistry, 283

- Engineering, 72 et seq.

Mechanics, 39 et seq.

Medical Geography, 236

- Jurisprudence, 232, 237

- Students, Chemistry for, 125

Medicine, 231 et seq.

- Veterinary, 295, 296

Mediæval Thought and Science, 1

Mendelism, 195, 196

Mensuration, 33

Mental Development, 18

- Disorders, 253

- Tests, 17

Mesopotamia, Irrigation of, $\mathbf{5 5}$

Metallography, 156

Metallurgy, 153 et seq.

Metallurgical Dentistry, 283

Metal Work (Turning, Welding, etc.), 76 et seq.

Metals, 153

- in Aircraft Construction, 93

- Corrosion of, 67

- Heat Treatment of, 157

Metaphysics, 8

Meteorology, 162 et seq.

Meters, Electricity, 115

Method and Science, 2

Metric System, 45, 46

Mica Mining, 173
Microscopy, 196, 197

- Dental, 282

Midwifery, 277, 278

Military Engineering, 158

- Geography, 179

- Ophthalmology, 270

- Sanitation, 233

- Surgery, 264

Milk and Milk Testing, 215, 216, 235

Milling Machines and Practíce, 75, 76

Mind, The, 15, 16, 17

- Animal, 19

Mine Drainage, 56

- Surveying, 50 et seq.

Mineral Oils, 143

- Waters, 137, 287

- Waxes, 144

Minera logy, 164, 165

Mining, 171 et seq.

- Geology, 169

Model Drawing, 48

Molecular Association, 128

- Physics, 103, 104

Mollusca, Life of the, 191

Moon. The, 160

Morphology :

Animal, 185

Plant, 201

Mosses, 204

Moths, British, 188, 189, 190

Motor Car, Electrical Application to, 118

_ - Engineering, 79, 80

- Cycles, 80, 118

Motors, 56, 88, 111, 112

Mould, Vegetable, 190

Municipal Engineering, 57, 58

Muscles, Action of, 227

Mycology, Technical, 138

Nation, The, and Science, 2

Natural History, 185

Nature Study, 184

Nautical Astronomy, 180

- Tables and Terms, 181

Naval Architecture, 70, 71

Navigation, 180 et seq.

- Aerial, 94

Neck, Surgery of, 265

Needlework, Art, 302

Nerves and Nervous System, 227

- Disorders of, 252

Neurasthenia, 252

Neurology, 223

Nickel, 155

Nitro-Explosives, 150

Non-Ferrous Metals and Alloys, 154 
Nose, Diseases of, 273,274

Nucleic Acids, 134

Nursing, 263, 276, 294

Obstetrics, 275 et seq.

- Veterinary, 295

Occupational Diseases, 259

Oceanography, 182

Oil and Oil Fields, 139, 169

- Engineering, 74

- Motors, 88

- Tank Steamers, 71

Operative Surgery, 261

Ophthalmology, 269 et seq.

Ophthalmoscopy, 270

Optic Nerve, Diseases of, 270

Optics, 100, 101

Ordnance Survey Maps, 176

Ore Deposits, 169

- Dressing, 174

Organic Chemistry, 124, 130

Organism, The, Science and Philosophy of, 9

Origin of Life, 193

- Species, 194

Ornamental Stones, 66

Orthopædic Surgery, 267

Osmotic Pressure, 127

Osteology, 223

Otology, 273, 274

Oxy-Acetylene Welding, 77

Ozone, 129

Paint and Painting, 68, 141

Palæobotany, 170

Palæontology, 170

Paper and Paper Making, 148, 305

Paralysis, Ocular, 271

Parasites, Diseases due to, 248

Patent Laws, 1, 2

Pathology, 239 et seq.

- Surgical, 262

Pattern Making, 74, 75

Pearls, 190, 191

Peat, 146

Pedagogy, History of , 4

Per-acids and their Salts, 130

Peritoneum, Diseases of the, 257

Permanent Way, Railways and Tramways, 52

Petrol Air Gas, 59

Petroleum, 143

Petrology, 168

Pharmacology, 292, 293

Pharmacopœias, 291, 292

Pharmacy, 291 et seq.

Philosophy, 6 et seq.
Photo-Chemistry, 127

- Flectricity, 307

Photographs, Telegraphic Transmission of, 119,121

Photography, 307

Photomicrography , 196, 308, 309

Physical Chemistry, 127

- Geography, 176

Physics, 96 et seq.

Physiography, 175

Physiological Chemistry, 134

- Psychology, 17

Physiology, 225, et seq.

- Dental, 282

- Plant, 201

- Veterinary, 295

Pigments, 141

Pistols, Automatic, 158

Pitch, Manufacture of, 145

Plant Constituents, 135

- Disease and Pests, 212

Plants and Plant Life, 198 et seq.

- Poisonous, 212

Plague, 231, 246

Plating, Electro, 118, 110

Platinum Metals, 165

Plumbing, 57, 58

Plywood, Manufacture and use of, 64

Pneumatics, 39, 40, 42

Poisonous Plants, 212

Poisons and Poisoning, 238

Polyphase Currents, 110

Pond Life, 187

Poor Relief, Early History of, 5

Popular Science, 1

Portable Steam Engines, 82

Portland Cement, 66

Post-Mortem Examination, 239

Pottery, 65, 149

Poultry Farming, 216, 217

Power Plant, Electric, 111

- Transmission, 73, 74

Precious Metals, The, 155

- Stones, 165

Prescribing, 286

Preserved Foods, Manufacture of, 139

Printing, 304, 305,

- Inks, 148

- Telegraph System, The

Baudôt, 120

- Textile, 299

Producer Gas, 143

Progress, Origin and Growth of, 9

Projection, Optical, 102

Propellers for Aircraft, 93

- Marine, 70, 85, 86

Proteids, Chemistry of, 227 
Proteins, Chemical Constitution of, 135

- The Vegetable, 135

Psychiatry, 253

Psycho-Analysis, 19

- Therapeutics, 290

Psychological Medicine, 242

Psychology, 15, et seq.

Public Health, 232, 234, 237

Pumps and Pumping, 56

Punjab Rivers and Works, 55

Pyrometry, 99

Qualitative Chemical Analysis, 133

Quantitative Chemical Analysis, 133

Quantities, Builders, 62, 63

Quarrying, 171

Quaternions, 23

Radiation, 105

Radio-Activity, 104, 105

- Telegraphy, 120, 121

Radium, 105

- Therapeutics, 289

Railways :

Electric, 117, 118

Permanent Way, 52

Signalling, 52, 53

Surveying, 51

Tube, 53

Rain, Work of, 168

Rams, Hydraulic, 56

Rare Earth Industry, 152

- Earths, 129, 130

Rationalism, History of English, 4

Reagents, Chemical, 132, 133

Rectum, Diseases of, 257

- Surgery of, 265,266

Refraction of the Eye, 271

Refractory Materials, 150, 169

Refrigeration, 82

Refuse Disposal, 60

Re-inforced Concrete, 66, 67

Relativity, 104

Repairs, Building, 62, 63

Reptiles, 192

Resins, 141

Respiratory System, Diseases of the, 255

Rheumatism, 249

Rhinology, 273, 274

Rifle and Rifle Shooting, 158

River Development, 176

- Engineering, 53

Rivers, 176

- as Sources of Water Supply, 57

- Work of, 168
Road Making, 52

Rock Asphalts, 169

Rocks, 168

Röntgen Rays, 105

— in Medical Work, 289

Roofing Tiles, 65

Royal Society of Arts, History of, 5

Rubber and Rubber Planting, 142, $218-220$

Salt, 150

Salvarsan, 288

Sands, 65

- Refractory, 169

Sanitation, 57, 232 et seq.

Saw Mills, 77

Scenery, Scientific Study of, 169

Sciatica, 252

Screw-cutting, 75, 76 .

Scumbling, 69

Seamanship, 180 et seq.

Sea Sickness, 252

Seasons, Biology of the, $\mathbf{1 8 4}$

Sea Water Distillation, 124

Seaweeds, 203, 204

Secretions, Internal, 227

Seismology, 167

Serum Therapy, 287, 288

Sewerage, 57 et seq.

Sex, 193, 228

Sextent, The, 180

Sexual Physiology, 228

Shaft-Sinking, 172

Shale Oils, 144

Shales, 65

Sheet Lead, Weights and Measurements of, 45

- Metal Work, 77

Shell Shock, 252

Shells, 191

Ships and Shipbuilding, 70,71

Shore Protection, 55

Signalling, Marine, 182

- Railway, 52, 53

Silica and the Silicates, 149

Silk Dyeing, 299

- Industry, 297

- Manufacture,300, 301

- Spinning, 298

Silver, Metallurgy of, 154, 155

Silversmiths' Work, 78

Sizing, Materials used in, 68

- Yarn and Warp, 299

Skin Diseases, 284,

Slide Rule, 36

Small-Pox, 231, 246

Smithing, 77,78 
Smoke Prevention, 142

Soap and Soap Manufacture, 139-141

Soap Bubbles, 100

Social Psychology, 20

Socialism, History of, 5

Sociology, 20

Soils, 169, 220

Solar System, 160

Soldering, 77

Sound, 102, 103

Space and Time, Theory of, 104

Species, Origin of, 194

Spectacles, Prescribing of, 272

Spectroscope, The, 132

Spectroscopy, 102, 127

Spices, 219

Spiders, 187 , et seq.

Spinal Cord, Diseases of, 252

Spinning, 297, 298

- Machine, 301

Sprue, and its treatment, 236, 258

Stable Sanitation, 58

Staffordshire Potteries, History of, 150

Stained Glass Work, 150

Staining, 68

Stars, 160, 161, 181

Statics, 40

Stationary Steam Engines, 82

Stationery, 305

Statistics (Mathematics), 38

Steam Boilers, Construction and Management, 84, 85

Steam Engines, 43, 81, 82, 83

- Heating, 60

Steamships, 70

Steel, 153

- and Iron Construction, 67

- Ships, 71

Stencils and Stencilling, 68

Stereochemistry, 128

Stereotyping, 304

Stoichiometry, 128

Stomach, Diseases of the, 256

Stone, Artificial and Masonry, 65

- Mining and Quarrying, 171

Stratigraphy, 168

Straw and String Work, 302

Strength of Materials, 43

Stresses and Thrusts, 49

Structures, Theory and Design of, 44, 49

Struts and Columns, 49

Submarine Telegraph, 120

Submarines, 71

Submerged Forests, 168

Sugar; its manufacture, etc., 138, 218
Sulphate of Ammonia, 151

Sun, The, 160,161

Superheating on Locomotives, 83

Surface Tension and Surface Energy, 128

Surgery, 260 et seq.

- Dental, 282

- Veterinary, 295

Surgical Anatomy, 221

Surveying :

Hydrographic, 183

Land and Mine, 50 et seq.

Marine, 183

Sweetmeats, Manufacture of, 139

Switchboards, (Electric), 111

Synthesis, Essays in Scientific, 2

Syphilis, 246, 247

Tacheometer Surveying, 51

Tanning, 148

Tapestry Weaving, 302

Tars, 144, 145

Tea, Cultivation of, 218, 219

Teaching of Scientific Method, 1

Technical Electricity, 109, 110

Technical Terms, see "Terms."

Teeth, Anatomy, etc., of, 282, 283

Telegraphy, 119-121

Telephony, 119-121

Telephotography, 307, 308

Temperatures, High, 99

Terms :-

Aeronautics, 94

Architecture, 61, 62

Biology, 184

Botany, 200

Building Trades, 61, 62

Mechanical Engineering, 72

Medical, 242, 243

Nautical, 181

Optics, 101

Textile, 302

Wireless Telegraphy, 121

and Dictionaries of, in English and other Ianguages, 312,313

Terrestrial Magnetism, 162

Testing, Electrical Engineering, 114, 115

- of Chemical Reagents, 132

Tetanus, 246

Textile Machinery, 301

Textiles, 297 et seq.

Theodolite Surveying, 51

Theology and Science, 2

Therapeutics, 285 et seq.

- Dental, 283

- Gynæcological, 276 
Therapeutics, Ophthalmic, 271

- Surgical, 262

- Veterinary, 296

Thermo-Chemistry, 127, 128

Thermodynamics, 99,127

Thermo-Therapy, 289

Throat, Diseases of, 273, 274

Thrusts and Stresses, 49

Thyroid Therapy, 289

Ticks, 187

Tidal Lands, 55

Tides, 160, 176, 182

Tiles, 65

Timber, 208 et seq.

Time and Space, Theory of, 104

Tin, Metallurgy of, 155

- Ores, 165,169

- Plate Industry, The, 154

Tobacco, 219

Tools, Machine, 76, 75

Topographical Geology, 169

Tow Spinning, 298

Town Planning, 68

Toxicology, 232, 237, 238

- Veterinary, 296

Traction, Electric, 117

Tractors, Farm, 215

Trade Unionism, History of, 5

Tramways, Electric, 117, 118

- Permanent Way, 52

Transformers, 113

Transmission, Electrical Engineering, 114

Trees, 208 et seq.

Trigonometry, 34, 35

Tropical Hygiene, 236

- Medicine, 258

Tube Railways, Setting out of, 53

-Wells, 55

Tuberculin, 288, 289

Tuberculosis, 249, 288, 289

Tumours, 267

Tungsten Ores, 165

Turbines, 56, 89

Turning, Metal, 76

Typhoid Fever, 246

Typography, 304

Urinary Surgery, 266

Urine, Examination of, 239

Utilitarianism, History of English, 4.

Vaccination, 231, 246, 288

Valency, Theory and Studies in, 127

Valuation, Mine, 171

Valves and Valve Gearing, 83

Varnishes and Varnishing, 68, 69, 141
Vectors, 23, 113

Vegetable Mould, 190

Venereal Diseases, 246, 247

Ventilation, 60, 172

- of Electrical Machinery, 110

Veterinary, 295, 296

Vinegar, Manufacture and Examination of, 138

Viscosity of Liquids, 127

Vitalism, History and Theory of, 9

Volcanoes, 167

Volumetric Analysis, 133, 134

War, Nervous Disorders Caused by, 252

War and Science, 2

War Ships, 70

War Surgery, 264

Warp Sizing, 299

Wasps, 187, 189

Waste Products, Ctilisation of, 15 I

Watch Repairing, 78

Water, 137, 168

- Analysis, 234

- Hammer in Hydraulic Pipe Lines, 54

- Power, 54, 56

- Purification, 57

- Supply, 53 et seq.

Waterworks, 56, 57

Waxes, 139, 144

Weather, 162

Weaving, 298, 299, 302

Weights and Calculations (Mechanics) 45

Welding, etc., 77,119

Well Sinking, 57

Wells, Tube, 55

Whales, 193

Wheat, 218, 219

Wireless Telegraphy and Telephony, 120,121

Wire-rope Ways, 74

Wiring, Electric, 116

Women, Diseases of, 275

Wood Products, 151

- Pulp, 148

Woodwork and Allied Trades, 64

Wood Working Machinery, 77

Woollen Industry, 297

- Manufacture, 301

- Spinning, 298

Worsted Industry, 297

- Manufacture, 300, 301

- Spinning, 298

X-Rays, 104, 105, 164 
X-Rays Diagnosis (Surgical), 262

- Therapy, 289

- Treatment of Skin Diseases, 284

Yarns, Sizing of, 299

- Technical Testing of, 300

- Woollen and Worsted, Manufacture of, 300, 301
Yellow Fever, 248

Zinc, and its Alloys, 155

- Industry, 155

- Organometallic compounds of, 132

- Oxide, 69

Joology, 185, 214

Zoophytes, British, 191 
ff

$[+\cdots+?$

$$
\text { (n) }
$$

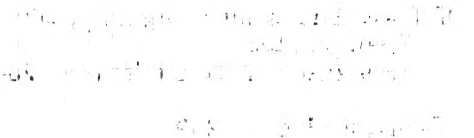


Z

7407

G7B8

1921

cop. 3
British Science Guild

A catalogue of British scientific and technical books

\section{PLEASE DO NOT REMOVE \\ CARDS OR SLIPS FROM THIS POCKET}

UNIVERSITY OF TORONTO LIBRARY 
